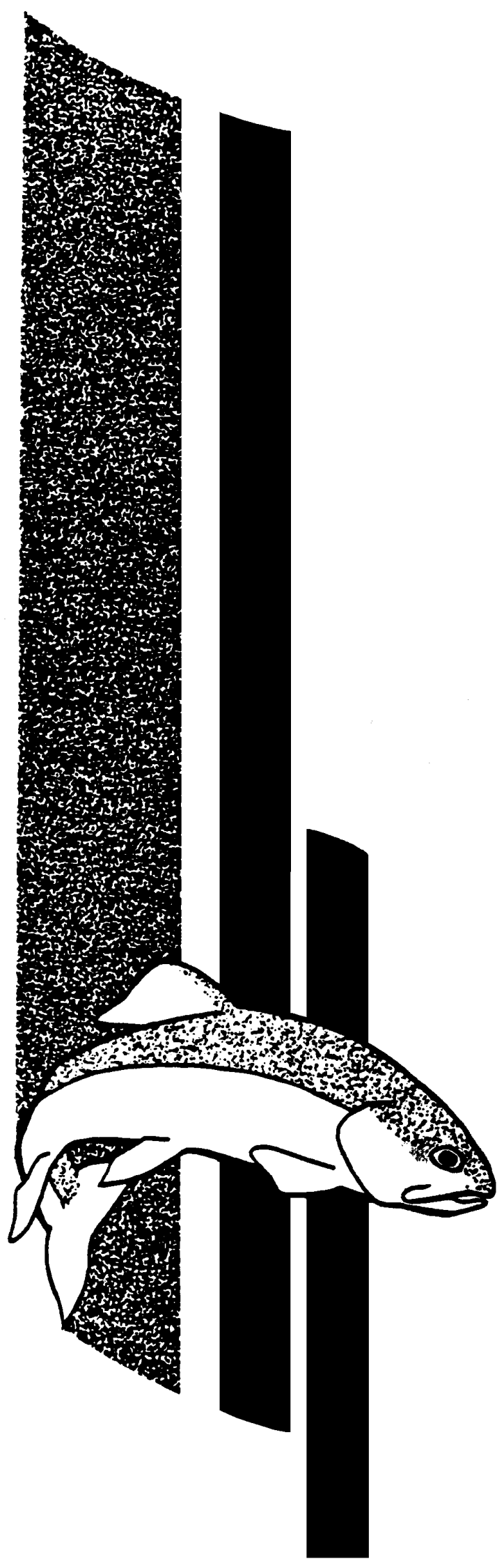

\title{
KOOTENAY LAKE \\ FERTILIZATION EXPERIMENT, YEAR 15 (NORTH ARM) AND YEAR 3 (SOUTH ARM) (2006) REPORT
}

\section{by}

E.U. Schindler, D. Sebastian,

G.F. Andrusak, H. Andrusak, L. Vidmanic, J. Stockner, F. Pick, L.M. Ley

P.B. Hamilton, M. Bassett and K.I. Ashley

Fisheries Project Report No. RD 126 2009

Fish and Wildlife Science and Allocation Ministry of Environment

Province of British Columbia

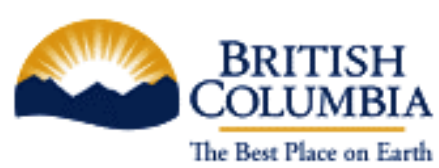

Major Funding by

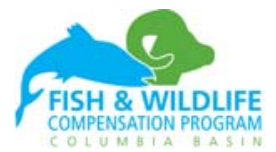

Fish and Wildlife Compensation Program Columbia Basin

and

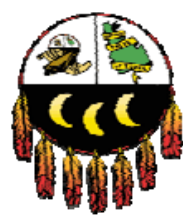

Kootenai Tribe of Idaho 
Fisheries Project Reports frequently contain preliminary data, and conclusions based on these may be subject to change. Reports may be cited in publications but their manuscript status (MS) must be noted. Please note that the presentation summaries in the report are as provided by the authors, and have received minimal editing. Please obtain the individual author's permission before citing their work. 


\title{
KOOTENAY LAKE FERTILIZATION EXPERIMENT, YEAR 15 (NORTH ARM) AND YEAR 3 (SOUTH ARM) (2006) REPORT
}

\author{
by \\ E.U. Schindler ${ }^{1}$, D. Sebastian ${ }^{2}$ \\ G.F. Andrusak ${ }^{3}$, H. Andrusak ${ }^{3}$, L. Vidmanic ${ }^{4}$, \\ J. Stockner ${ }^{5}$, F.Pick ${ }^{6}$, L. M. Ley ${ }^{6}$, P.B. Hamilton ${ }^{7}$, \\ M. Bassett ${ }^{1}$ and K.I. Ashley ${ }^{8}$
}

1 Fish and Wildlife Science and Allocation Section, Ministry of Environment, Province of BC, 401-333 Victoria St., Nelson, BC, V1L 4K3

2 Aquatic Ecosystem Science Section, Biodiversity Branch Ministry of Environment, Province of BC PO Box 9338 STN PROV GOVT, Victoria, BC, V8W 9M2

3 Redfish Consulting Ltd., 5244 Hwy 3A, Nelson, BC, V1L 6N6

4 Limno-Lab Ltd., 506-2260 W.10 ${ }^{\text {th }}$ Ave., Vancouver, BC V6K 2H8

5 Eco-Logic Ltd., 2614 Mathers Avenue, West Vancouver, BC, V7V 2J4

6 Ottawa-Carleton Institute of Biology, Department of Biology, University of Ottawa, Ottawa, ON, K1N 6N5

7 Research Division, Canadian Museum of Nature, P.O. Box 3443, Station D, Ottawa, ON, K1P 6P4.

8 Department of Civil Engineering, 2324 Main Mall, University of British Columbia, Vancouver, BC, V6T 1W5. 



\section{ACKNOWLEDGEMENTS}

Funding for the fifteenth year (2006) of the Kootenay Lake North Arm Fertilization Experiment was provided by the Fish and Wildlife Compensation Program - Columbia Basin) and Ministry of Environment. Funding for the third year (2006) of the Kootenay Lake South Arm Fertilization Experiment was provided by the Kootenai Tribe of Idaho and Ministry of Environment. Thanks to the British Columbia Conservation Foundation for administering a portion of the funding provided by the Kootenai Tribe of Idaho.

The Fish and Wildlife Compensation Program - Columbia Basin is a joint initiative between BC Hydro, BC Ministry of Environment and Fisheries and Oceans Canada. The program was established to conserve and enhance fish and wildlife compensation populations affected by BC Hydro dams in the Canadian portion of the Columbia River Basin.

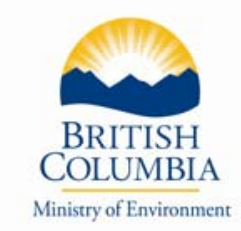

The ministry's vision is a clean, healthy and naturally diverse environment that enriches people's lives, now and in the future.

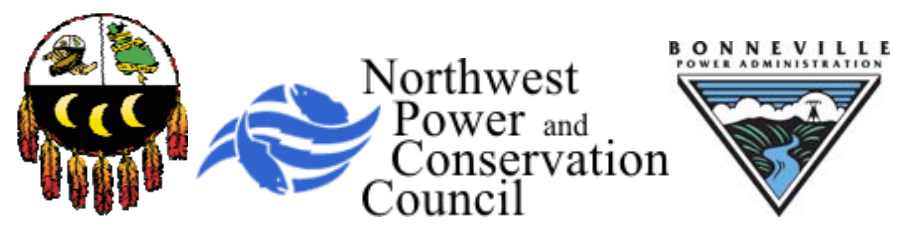

The Kootenai Tribe of Idaho receives funding from the Bonneville Power Administration through the Northwest Power and Conservation Council's Columbia Basin Fish and Wildlife Program. 


\begin{abstract}
This report summarizes results from the fifteenth year (2006) of nutrient additions to the North Arm of Kootenay Lake and three years of nutrient additions to the South Arm. Experimental fertilization of the lake has been conducted using an adaptive management approach in an effort to restore lake productivity lost as a result of nutrient uptake in upstream reservoirs. The primary objective of the experiment is to restore kokanee (Oncorhynchus nerka) populations, which are the main food source for Gerrard rainbow trout (Oncorhynchus mykiss) and bull trout (Salvelinus confluentus).
\end{abstract}

The quantity of agricultural grade liquid fertilizer (10-34-0, ammonium polyphosphate and 28-0-0, urea ammonium nitrate) added to the North Arm in 2006 was 44.7 tonnes of $\mathrm{P}$ and 248.4 tonnes of $\mathrm{N}$. The total fertilizer load added to the South Arm was 257 tonnes of nitrogen; no $\mathrm{P}$ was added.

Kootenay Lake has an area of $395 \mathrm{~km}^{2}$, a maximum depth of $150 \mathrm{~m}$, a mean depth of 94 $\mathrm{m}$, and a water renewal time of approximately two years. Kootenay Lake is a monomictic lake, generally mixing from late fall to early spring and stratifying during the summer. Surface water temperatures generally exceed $20{ }^{\circ} \mathrm{C}$ for only a few weeks in July.

Results of oxygen profiles were similar to previous years with the lake being well oxygenated from the surface to the bottom depths at all stations. Similar to past years, Secchi disc measurements at all stations in 2006 indicate a typical seasonal pattern of decreasing depths associated with the spring phytoplankton bloom, followed by increasing depths as the bloom gradually decreases by the late summer and fall.

Total phosphorus (TP) ranged from $2-7 \mu \mathrm{g} / \mathrm{L}$ and tended to decrease as summer advanced. Over the sampling season dissolved inorganic nitrogen (DIN) concentrations decreased, with the decline corresponding to nitrate (the dominant component of DIN) being utilized by phytoplankton during summer stratification.

Owing to the importance of epilimnetic nitrate that is required for optimal phytoplankton growth discrete depth water sampling occurred in 2006 to measure more accurately changes in the nitrate concentrations. As expected there was a seasonal decline in nitrate concentrations, thus supporting the strategy of increasing the nitrogen loading in both arms. These in-season changes emphasize the need for an adaptive management approach to ensure the nitrogen to phosphorus (N:P) ratio does not decrease below 15:1 (weight:weight) during the fertilizer application period.

Phytoplankton composition determined from the integrated samples $(0-20 \mathrm{~m})$ was dominated by diatoms, followed by cryptophytes and chrysophytes. The contribution of cryptophytes to total biomass was higher in 2006 than in 2005. Cryptophytes, considered being edible biomass for zooplankton and Daphnia spp., increased in 2006.

Phytoplankton in the discrete depth samples (2, 5, 10, 15 and 20m) demonstrated a clear north to south gradient in average phytoplankton density and biomass among the three

Kootenay Lake Fertilization Experiment, Year 15 (North Arm) and Year 3 (South Arm) ii (2006) Report 
stations sampled, with highest values at the North Arm station (KLF 2) and lowest values in the most southern station in the South Arm (KLF 7). Populations were dominated by flagellates at all stations and depths in June and July, then dominated by diatoms in August and September in the North and South arms of the lake. There were no large bluegreen (cyanobacteria) populations in either arm of the lake in 2006.

Seasonal average zooplankton abundance and biomass in both the main body of the lake and in the West Arm increased in 2006 compared to 2005. Zooplankton density was numerically dominated by copepods and biomass was dominated by Daphnia spp.

The annual average mysid biomass data at deep stations indicated that the North Arm of Kootenay Lake was more productive than the South Arm in 2006. Mysid densities increased through the summer and declined in the winter; mean whole lake values remain within prefertilization densities.

Kokanee escapement to Meadow Creek declined in 2006 to approximately 400,000 spawners. The Lardeau River escapement also declined with approximately 100,000 spawners. Escapement in the South Arm tributaries in 2006 was similar to 2005 with virtually no spawners.

The mean size of female and male kokanee from Meadow Creek was larger than the past three years $(24.9 \mathrm{~cm}$ and $25.2 \mathrm{~cm}$, respectively) and larger than the long term average $(25.2 \mathrm{~cm})$. This is indicative of a density dependent growth response as a decline in in-lake abundance and returning spawners occurred.

.Spring hydroacoustic estimates indicated low densities of South Arm kokanee with most of the North Arm fry remaining at the most northernly stations. By the fall, the distribution of kokanee from the North Arm to the South Arm was fairly uniform, a normal occurrence in Kootenay Lake. Fall hydroacoustic estimates in 2006 increased to approximately 22 million kokanee.

The relationship between the number of fry produced from Meadow Creek and the number of fry estimated in the fall hydroacoustic survey were similar, a trend that has occurred during most study years.

Results of the 2006 fertilization experiments indicate that the trophic level response has been positive. Nutrient additions to the North and South arms have resulted in sufficient phytoplankton biomass suitable for Daphnia spp growth. Daphnia biomass and pelagic kokanee numbers size and biomass increased, all indicative of successful trophic level responses to nutrients.

Kootenay Lake Fertilization Experiment, Year 15 (North Arm) and Year 3 (South Arm) iii (2006) Report 


\section{TABLE OF CONTENTS}

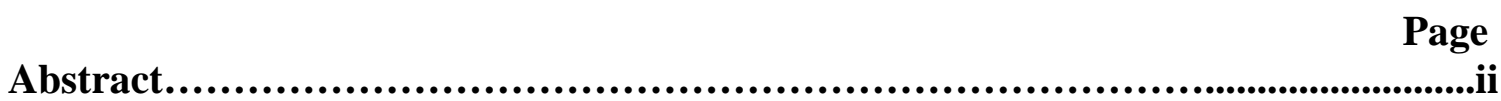

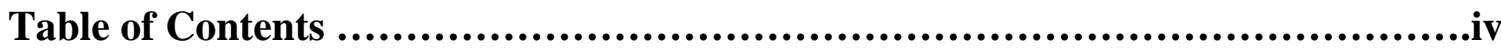

List of Figures .........................................................................

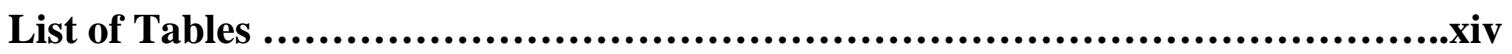

Chapter 1 - Introduction ........................................................1

Chapter 2 - Fertilizer Loading in Kootenay Lake Year 15 (North Arm) and Year 3 (South Arm) (2006) ................................................................19

Chapter 3 - Physical and Chemical Limnology of Kootenay Lake in Response to Experimental Fertilization, Year 15 (North Arm) and Year 3 (South Arm) (2006)

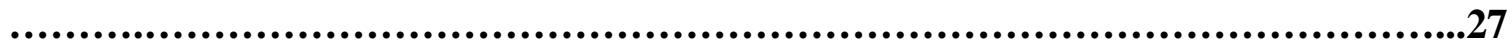

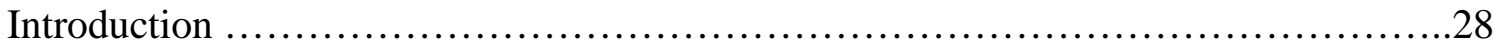

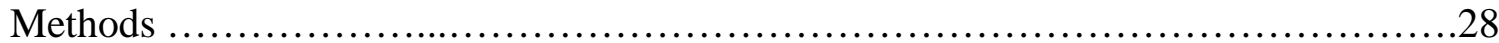

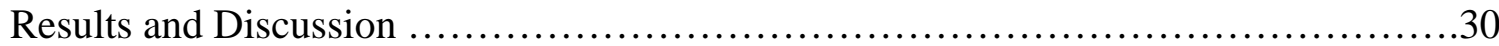

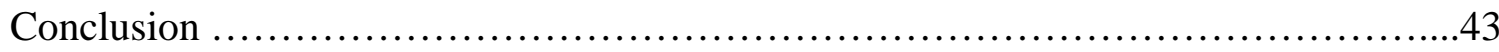

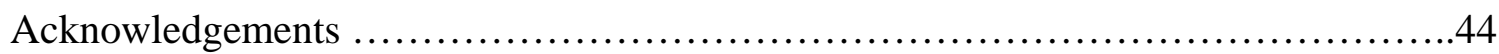

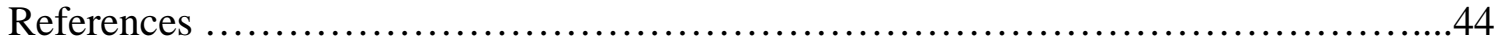

Chapter 4 - Phytoplankton Biomass, Composition and Size Distribution of Kootenay Lake, BC following Experimental Fertilization, Year 15 (North Arm) and Year 3 (South Arm) (2006) .........................................................79

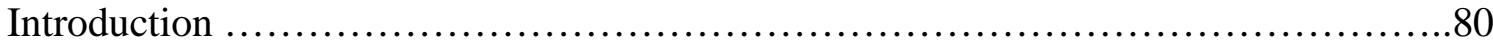

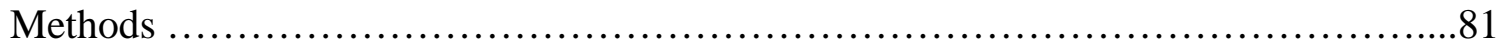

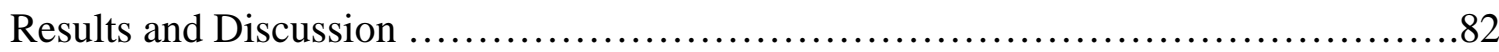

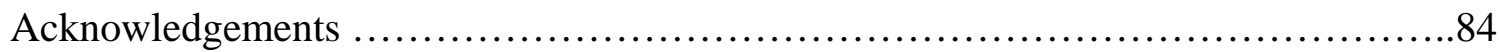

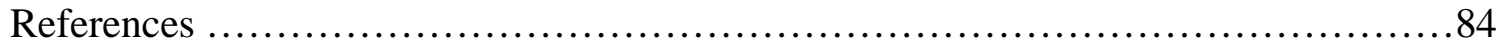

Chapter 5 - Phytoplankton Vertical Distribution Patterns in Kootenay Lake - 2006

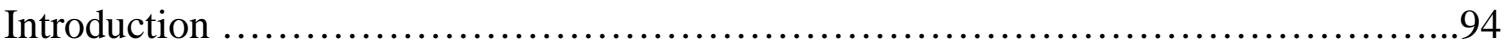

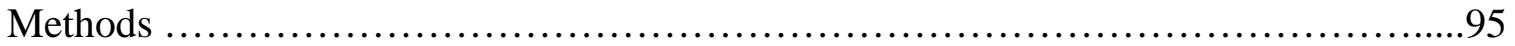

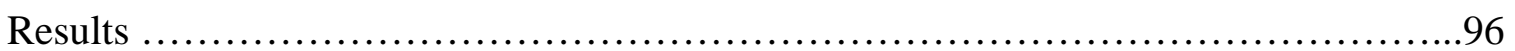

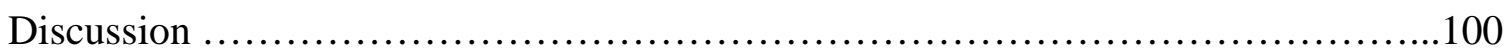

Summary and Conclusions ....................................................

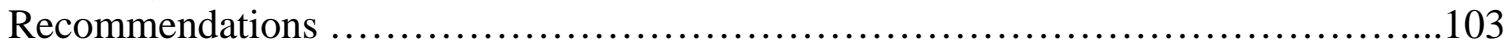

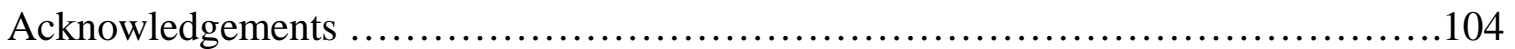

Kootenay Lake Fertilization Experiment, Year 15 (North Arm) and Year 3 (South Arm) iv (2006) Report 
References cited .104

Chapter 6 - Response of Zooplankton and Mysis Relicta to Experimental Fertilization, Year 15 (North Arm) and Year 3 (South Arm) (2006) ................117

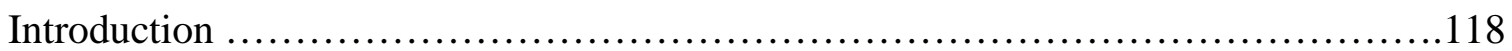

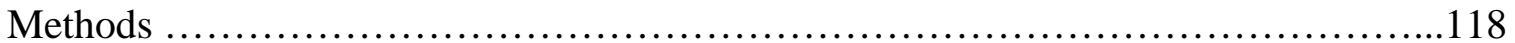

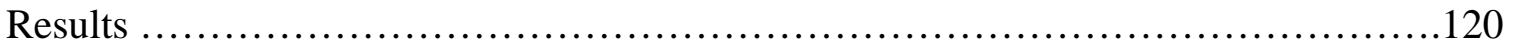

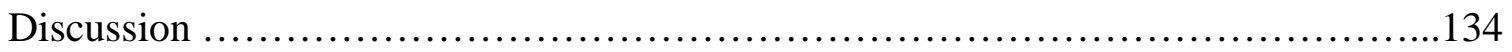

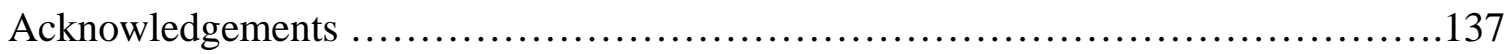

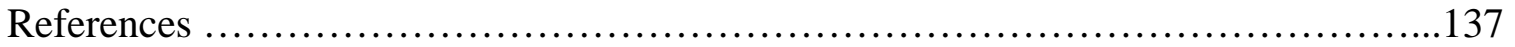

Chapter 7 - Response of Kokanee to Experimental Fertilization of the North Arm of Kootenay Lake in 2006. ...........................................................................173

Introduction and Background ................................................. 174

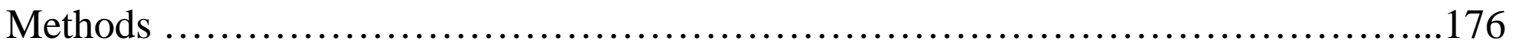

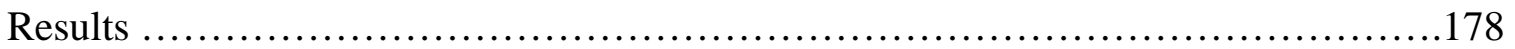

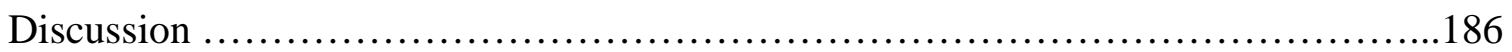

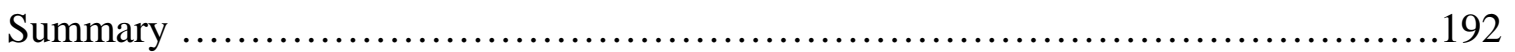

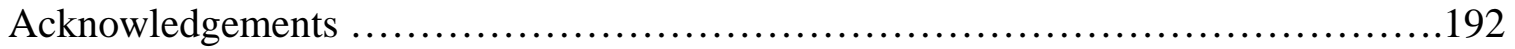

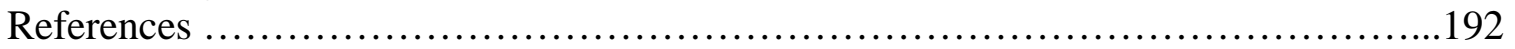

Chapter 8 - Status of Kokanee in the South Arm of Kootenay Lake as a result of Experimental Fertilization -2006 ............................................213

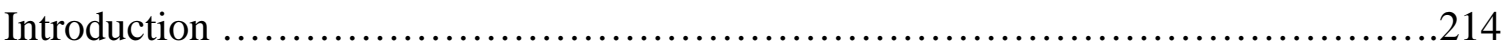

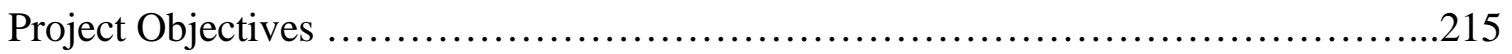

Background ..............................................................215

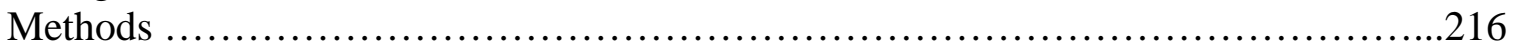

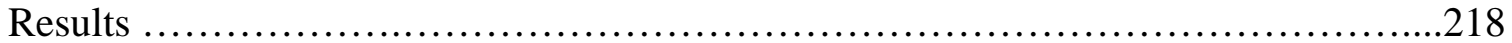

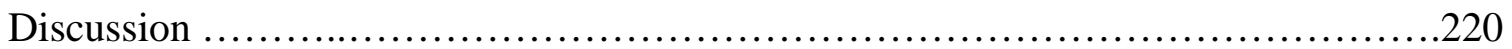

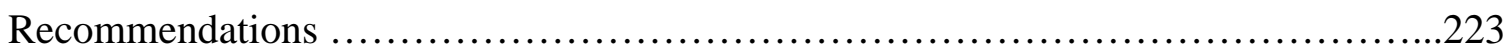

Acknowledgements ..........................................................223

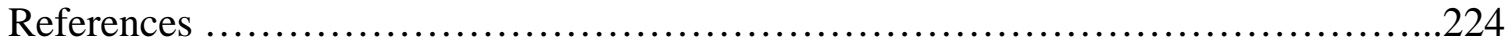

Kootenay Lake Fertilization Experiment, Year 15 (North Arm) and Year 3 (South Arm) 


\section{LIST OF FIGURES}

Figure 1.1. Kootenay Lake, British Columbia, sampling stations. ..................18

Figure 2.1. Kootenay Lake nutrient loading in 2006 with weekly distributions of: a) phosphorus loading to the North Arm, b) nitrogen loading to the North Arm, c) the N:P ratio (wt:wt) of fertilizer dispensed, and d) the combined nutrient loading of fertilizer in tonnes per week. .24

Figure 2.2. Kootenay Lake South Arm nutrient loading in 2006 with weekly distributions of nitrogen to the South Arm, a) $\mathrm{mg} / \mathrm{m}^{2} /$ week and b) tonnes of fertilizer per week. ...........................................25

Figure 3.1. Temperature $\left({ }^{\circ} \mathrm{C}\right)$ profiles at station KLF 1 for February-April and JuneNovember, 2006. ...............................................46

Figure 3.2. Temperature $\left({ }^{\circ} \mathrm{C}\right)$ profiles at station KLF 2 for February-April and JuneNovember, 2006.

Figure 3.3. Temperature $\left({ }^{\circ} \mathrm{C}\right)$ profiles at station KLF 3 for February-April and JuneNovember, 2006. .48

Figure 3.4. Temperature $\left({ }^{\circ} \mathrm{C}\right)$ profiles at station KLF 4 for February-April and JuneNovember, 2006.

Figure 3.5. Temperature $\left({ }^{\circ} \mathrm{C}\right)$ profiles at station KLF 5 for February-April and JuneNovember, 2006. .50

Figure 3.6. Temperature $\left({ }^{\circ} \mathrm{C}\right)$ profiles at station KLF 6 for February-April and JuneNovember, 2006. .51

Figure 3.7. Temperature $\left({ }^{\circ} \mathrm{C}\right)$ profiles at station KLF 7 for February-April and JuneNovember, 2006................................................52

Figure 3.8. Temperature $\left({ }^{\circ} \mathrm{C}\right)$ profiles at station KLF 8 for February-April and JuneNovember, 2006. .53

Figure 3.9. Secchi disk depth at KLF 1-4 in the North Arm (upper), KLF 5-7 in the South Arm and KLF 8 in the West Arm (lower) from April-November, 2006. . .54

Figure 3.10. Turbidity (NTU) from 0-20 m at KLF 1-4 in the North Arm (upper), KLF 5-7 in the South Arm and KLF 8 in the West Arm (lower) from AprilNovember, 2006. .55

Kootenay Lake Fertilization Experiment, Year 15 (North Arm) and Year 3 (South Arm) vi (2006) Report 
Figure 3.11. Turbidity (NTU) from $>50 \mathrm{~m}$ at KLF 1-4 in the North Arm (upper) and KLF 5-7 in the South Arm (lower) from May-October, 2006. ...........56

Figure 3.12. Conductivity ( $\mu \mathrm{S} / \mathrm{cm}$ ) from $0-20 \mathrm{~m}$ at KLF 1-4 in the North Arm (upper), KLF 5-7 in the South Arm and KLF 8 in the West Arm (lower) from April-November, 2006. Conductivity was not analyzed from KLF 4 in June, July and September 2006. .57

Figure 3.13. Conductivity $(\mu \mathrm{S} / \mathrm{cm})$ from $>50 \mathrm{~m}$ at KLF $1-4$ in the North Arm (upper) and KLF 5-7 in the South Arm (lower) from May-October 2006. Conductivity was not analyzed from KLF 4 in June, July and September. .58

Figure 3.14. Total phosphorus (TP) from 0-20 m at KLF 1-4 in the North Arm (upper), KLF 5-7 in the South Arm and KLF 8 in the West Arm (lower) from April-November, 2006. .59

Figure 3.15. Total phosphorus from $>50 \mathrm{~m}$ at KLF 1-4 in the North Arm (upper) and KLF 5-7 in the South Arm (lower) from May-October, 2006. 60

Figure 3.16. Total dissolved phosphorus (TDP) from 0-20 m at KLF 1-4 in the North Arm (upper), KLF 5-7 in the South Arm and KLF 8 in the West Arm (lower) from April-November, 2006.

Figure 3.17. Total dissolved phosphorus (TDP) from $>50 \mathrm{~m}$ at KLF 1-4 in the North Arm (upper) and KLF 5-7 in the South Arm (lower) from May-October 2006.

Figure 3.18. Total nitrogen (TN) from 0-20 m at KLF 1-4 in the North Arm (upper), KLF 5-7 in the South Arm and KLF 8 in the West Arm (lower) from April-November, 2006. The result from November at KLF 5 was not plotted as it was an outlier. 63

Figure 3.19. Total nitrogen (TN) from $>50 \mathrm{~m}$ at KLF 1-4 in the North Arm (upper) and KLF 5-7 in the South Arm (lower) from May-October, 2006. ...........64

Figure 3.20. Dissolved inorganic nitrogen (DIN) from 0-20 $\mathrm{m}$ at KLF 1-4 in the North Arm (upper), KLF 5-7 in the South Arm and KLF 8 in the West Arm (lower) from April-November, 2006.

Figure 3.21. Dissolved inorganic nitrogen (DIN) from $>50 \mathrm{~m}$ at KLF 1-4 in the North Arm (upper) and KLF 5-7 in the South Arm (lower) from May-October, 2006. 66

Kootenay Lake Fertilization Experiment, Year 15 (North Arm) and Year 3 (South Arm) vii (2006) Report 
Figure 3.22. Silica from 0-20 m at KLF 1-4 in the North Arm (upper), KLF 5-7 in the South Arm and KLF 8 in the West Arm (lower) from April-November, 2006. Silica was not analyzed in August at KLF 5.

Figure 3.23. Silica measurements from $>50 \mathrm{~m}$ at KLF 1-4 in the North Arm (upper) and KLF 5-7 in the South Arm (lower) from May-September, 2005. Silica was not analyzed at KLF 5 in August. ..68

Figure 3.24. $\mathrm{pH}$ measurements from 0-20 m at KLF 1-4 in the North Arm (upper), KLF 5-7 in the South Arm and KLF 8 in the West Arm (lower) from AprilNovember, 2006.

Figure 3.25. $\mathrm{pH}$ from $>50 \mathrm{~m}$ at KLF $1-4$ in the North Arm (upper) and KLF 5-7 in the South Arm (lower) from May-September, 2006. 70

Figure 3.26. Alkalinity from 0-20 m at KLF 1-4 in the North Arm (upper), KLF 5-7 in the South Arm and KLF 8 in the West Arm (lower) from AprilNovember, 2006. .71

Figure 3.27. Alkalinity from $>50 \mathrm{~m}$ at KLF 1-4 in the North Arm (upper) and KLF 5-7 in the South Arm (lower) from May-October, 2006. No sample was taken at KLF1 in May. .72

Figure 3.28. Total organic carbon (TOC) from 0-20 m at KLF 1-4 in the North Arm (upper), KLF 5-7 in the South Arm and KLF 8 in the West Arm (lower) from April-November, 2006. .73

Figure 3.29. Total organic carbon (TOC) from $>50 \mathrm{~m}$ at KLF 1-4 in the North Arm (upper) and KLF 5-7 in the South Arm (lower) from May-October, 2006.

Figure 3.30. Chlorophyll $a$ from 0-20 m at KLF 1-4 in the North Arm (upper), KLF 57 in the South Arm and KLF 8 in the West Arm (lower) from AprilNovember, 2006. .75

Figure 3.31. Discrete depth profiles of total dissolved phosphorus (TDP) in the epilimnion of Kootenay Lake, June-September, 2006. .76

Figure 3.32. Discrete depth profiles of dissolved inorganic nitrogen (DIN) in the epilimnion of Kootenay Lake, June-September, 2006. .76

Figure 3.33. Discrete depth profiles of Chlorophyll $a$ in the epilimnion of Kootenay Lake, June-August, 2006. All September results were removed as errors were detected in the analysis. .77

Kootenay Lake Fertilization Experiment, Year 15 (North Arm) and Year 3 (South Arm) viii (2006) Report 
Figure 4.1. Total algal biomass, along the North South transect of Kootenay Lake, from April through November of 2006. Stations KLF 1 through KLF 7. Station KLF 8 is located in the West Arm.

Figure 4.2A. Seasonal algal biomass, by algal division, for station KLF 2 in the North Arm in 2006. Lines correspond to divisions as indicated in the legend. "Others" correspond to chlorophytes and occasional pyrrhophytes (dinoflagellates). .88

Figure 4.2B. Seasonal algal biomass, by algal division, for station KLF 6 in theSouth Arm in 2006. Lines correspond to divisions as indicated in the legend. "Others" correspond to chlorophytes and occasional pyrrhophytes (dinoflagellates). 89

Figure 4.3. Seasonal biomass of netplankton $(>64 \mu \mathrm{m})$ at stations KLF 2 (dark histograms) and KLF 6 (light histograms).........................90

Figure 4.4. Seasonal biomass of nanoplankton $(2-20 \mu \mathrm{m})$ at stations KLF 2 (dark histograms) and KLF 6 (light histograms). .91

Figure 4.5. Summer average biomass of Kootenay Lake since 1992. Fertilized station KLF 2 in the North Arm compared to old "reference" station KLF 6 in the South Arm. Note that $\mathrm{N}$ additions began in the South Arm in 2004. ......92

Figure 5.1. Kootenay Lake station KLF 2 vertical profile of abundance (cells/mL) and biomass $\left(\mathrm{mm}^{3} / \mathrm{L}\right), 2006$. 110

Figure 5.2. Phytoplankton abundance (cells $/ \mathrm{mL}$ ) and biomass $\left(\mathrm{mm}^{3} / \mathrm{L}\right), \quad \mathrm{KLF} 2$ Kootenay Lake, 2006. .........................................111

Figure 5.3. Kootenay Lake station KLF 6 vertical profile of abundance (cells/mL) and biovolume $\left(\mathrm{mm}^{3} / \mathrm{L}\right), 2006$.

Figure 5.4. Phytoplankton abundance and biomass by class, KLF 6, Kootenay Lake, 2006. 113

Figure 5.5. Kootenay Lake station KLF 7 vertical profile of abundance (cells/mL) and biomass $\left(\mathrm{mm}^{3} / \mathrm{L}\right), 2006$.

Figure 5.6. Phytoplankton abundance and biomass by class, KLF 7, Kootenay Lake, 2006. 115

Figure 5.7. Phytoplankton average abundance and biomass in vertical profiles, Kootenay Lake, 2004-2006. ..................................116

Kootenay Lake Fertilization Experiment, Year 15 (North Arm) and Year 3 (South Arm) ix (2006) Report 
Figure 6.1. Zooplankton density 1972- 2006. (Note: 1972-1990 from mid-lake station, near current station KLF 5 and 1992-2006 whole-lake average). .........140

Figure 6.2. Seasonal composition of zooplankton as a percentage of average density in the North, South and West Arms of Kootenay Lake, 1997-2006.

Figure 6.3. Density of calanoid and cyclopoid zooplankton in Kootenay Lake - North Arm, 1997-2006. 142

Figure 6.4. Density of calanoid and cyclopoid zooplankton in Kootenay Lake - South Arm and West Arm, 1997-2006. 143

Figure 6.5. Zooplankton density in Kootenay Lake, 1997-2006. 144

Figure 6.6. Seasonal average zooplankton density in Kootenay Lake, 1997-2006. ..145

Figure 6.7. Zooplankton biomass in Kootenay Lake, 1997-2006. 146

Figure 6.8. Seasonal average zooplankton biomass in Kootenay Lake, 1997-2006. 147

Figure 6.9. Seasonal composition of zooplankton as a percentage of average biomass in the North, South and West Arms of Kootenay Lake, 1997-2006. .....148

Figure 6.10. Density of cladoceran and copepod zooplankton in the North Arm of Kootenay Lake, 1997-2006.

Figure 6.11. Density of cladoceran and copepod zooplankton in the South and West arms of Kootenay Lake, 1997-2006.

Figure 6.12. Biomass of cladoceran and copepod zooplankton in the North Arm of Kootenay Lake, 1997-2006. 151

Figure 6.13. Biomass of cladoceran and copepod zooplankton in the South and West arms of Kootenay Lake. 152

Figure 6.14. Proportion of gravid females of two species of Copepoda found in Kootenay Lake in 2006. .153

Figure 6.15. Number of eggs per gravid female in two species of Copepoda found in Kootenay Lake in 2006. .154

Figure 6.16. Proportion of gravid females of two species of Cladocera found in Kootenay Lake in 2006. 155

Kootenay Lake Fertilization Experiment, Year 15 (North Arm) and Year 3 (South Arm) $\mathrm{X}$ (2006) Report 
Figure 6.17. Number of eggs per gravid female in two species of Cladocera found in Kootenay Lake in 2006. 156

Figure 6.18. Seasonal average zooplankton density (top) and Daphnia density (bottom) in some BC Lakes.

Figure 6.19. Seasonal average zooplankton biomass (top) and Daphnia biomass (bottom) in some BC lakes. 158

Figure 6.20. Daphnia density (top) and biomass (bottom) as a percentage of total zooplankton density and biomass in some BC lakes. 159

Figure 6.21. Annual average density of M. relicta in Kootenay Lake from 1972 to 2006. 160

Figure 6.22. Annual average density (top) and biomass (bottom) of M. relicta in the North and South arms of Kootenay Lake. 161

Figure 6.23. Seasonal average density of $M$. relicta at pelagic and near-shore stations in Kootenay Lake, 1999-2006. 162

Figure 6.24. Density of developmental stages of M. relicta at shallow sites in the North Arm of Kootenay Lake, 1999-2006. Note: the scale is different for station KLF 3. 163

Figure 6.25. Density of developmental stages of M. relicta at shallow sites in the South and West arms of Kootenay Lake, 1999-2006. Note: The scale is different for station KLF 8. 164

Figure 6.26. Density of developmental stages of $M$. relicta at deep sites in the North Arm of Kootenay Lake 1999,-2006. Note: the scale for station KLF 1 is different. 165

Figure 6.27. Density of developmental stages of M. relicta at deep sites in the South and West arms of Kootenay Lake, 1999-2006.Note: the scale for station KLF 8 is different. 166

Figure 6.28. Seasonal average biomass of $M$. relicta at pelagic and near-shore stations in Kootenay Lake, 1999-2006.

Figure 6.29. Biomass of developmental stages of M. relicta at shallow sites in the North Arm of Kootenay Lake, 1999-2006. Note: the scale is different for station KLF 1.........................................................168

Kootenay Lake Fertilization Experiment, Year 15 (North Arm) and Year 3 (South Arm) xi (2006) Report 
Figure 6.30. Biomass of developmental stages of $M$. relicta at shallow sites in the South and West arms of Kootenay Lake, 1999-2006.Note: the scales for stations KLF 5 and KLF 8 are different. 169

Figure 6.31. Biomass of developmental stages of $M$. relicta at deep sites in the North Arm of Kootenay Lake, 1999-2006.Note: the scale for station KLF 1 is different. 170

Figure 6.32. Biomass of developmental stages of $M$. relicta at deep sites in the South and West arms of Kootenay Lake, 1999-2006.Note: The graph for station 8 has a different scale. 171

Figure 6.33. Annual average density (top) and biomass (bottom) of M. relicta in some BC Lakes.

Figure 7.1. North Arm of Kootenay Lake kokanee escapements to Meadow Creek. (Note: 1964-1968 data from Acara 1970). .196

Figure 7.2. North Arm of Kootenay Lake kokanee escapements to Lardeau River 1964 2006. (Note: 1964-1968 data from Acara 1970). 196

Figure 7.3. Mean length $(\mathrm{cm})$ of Meadow Creek female and male kokanee spawners and fecundity, 1969-2006. Dotted horizontal line illustrates 39-year average fecundity of 259. 197

Figure 7.4. Kokanee fry production estimates from the Meadow Creek system and that portion from the spawning channel, 1968-2005. 198

Figure 7.5. Scatter plot of Meadow Creek spawning channel egg deposition vs. fry production for years where data was available 1968-2006.

Figure 7.6. Kokanee length-frequency distributions by scale age for trawl-caught fish in Kootenay Lake and returning spawners to Meadow Creek in September 2005 and 2006. 199

Figure 7.7. Comparisons of trends in kokanee mean length-at-age from trawl captures and Meadow Creek spawner samples. 200

Figure 7.8. Response of in-lake kokanee populations (all ages) to nutrient enrichment, based on acoustic surveys. Error bars represent 95\% confidence limits. .201

Figure 7.9. Kokanee abundance estimates for age 0 and ages 1-3 kokanee in Kootenay Lake based on fall acoustic sampling 1992-2006. .201

Kootenay Lake Fertilization Experiment, Year 15 (North Arm) and Year 3 (South Arm) xii (2006) Report 
Figure 7.10. Relationship between numbers of kokanee fry produced from the Meadow Creek spawning channel and estimated numbers of fall fry determined by hydroacoustics. 202

Figure 7.11. Comparison of kokanee density in North and South Arms of Kootenay Lake based on annual acoustic monitoring, 1985-2006. 202

Figure 7.12 Longitudinal density distribution for age 0 and ages 1-3 kokanee in Kootenay Lake during a) October 2004 b) September 2005 and c) September 2006. 203

Figure 7.13 Biomass estimates (kg/ha) for all ages of Kootenay Lake kokanee from trawl and hydroacoustic surveys and known weights of spawners. Dotted line indicateds commencement of fertilization; trendline shown as solid line. .204

Figure 7.14. Kokanee fry-to-adult survival based on Meadow Creek Spawning Channel data. .205

Figure 7.15. Recruit-spawner relationship for Lardeau River and Meadow Creek (19712006). Dotted line represents replacement level of 1.0. 206

Figure 8.1. Kootenay Lake, Kootenai/y River and tributary streams. .227

Figure 8.2. Longitudinal density distributions of age $0+$ kokanee in early summer and fall sampling in Kootneay Lake based on acoustic surveys in 2004-06. 228

Figure 8.3. Response of fall In-lake kokanee population (all ages) to nutrient enrichment in the North Arm. ............................................................229

Figure 8.4. Trends in fall kokanee abundance by age for Kootenay Lake, 1985-2006.

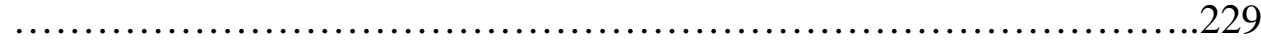

Figure 8.5. Comparison of kokanee density in North and South Arms of Kootenay Lake based on annual fall acoustic monitoring, 1985-2006. .230

Figure 8.6. North Arm of Kootenay Lake kokanee escapements to Meadow Creek 1964-2006. Note: 1964-1968 data from Acara, unpublished MS. 231

Figure 8.7. North Arm of Kootenay Lake kokanee escapements to Lardeau River 19642006. Note: 1964-1968 data from Acara, unpublished MS. 231

Kootenay Lake Fertilization Experiment, Year 15 (North Arm) and Year 3 (South Arm) xiii (2006) Report 


\section{LIST OF TABLES}

Table 1.1. Kootenay Lake Participants, Activities and Affiliation for 2006 studies. ...15

Table 1.2 Sampling activities, Kootenay Lake, 2006............................17

Table 2.1. Kootenay Lake nutrient loading of fertilizer during 2006 - liquid ammonium polyphosphate (10-34-0) and liquid urea-ammonium nitrate (28-0-0). .....22

Table 2.2. Total tonnes of phosphorus and nitrogen dispensed into the North Arm of

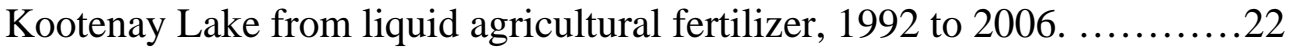

Table 2.3. Kootenay Lake South Arm nutrient loading of fertilizer during 2006 - liquid urea ammonium nitrate $(28-0-0)$.....................................23

Table 3.1. Kootenay Lake Fertilization Program limnological sampling sites. ........29

Table 3.2. Seasonal mean ( \pm standard deviation), maximum, and minimum temperatures in the West Arm (KLF 8) taken at 0-35 m depths, 2006. ......31

Table 3.3. Average Secchi depth (m) in spring (April-June), summer (July-September), and fall (October - November) for the North and South arms of Kootenay Lake, 1997-2006*. 32

Table 3.4. Average turbidity (NTU) from 0-30 $\mathrm{m}$ in spring (April-June), summer (JulySeptember), and fall (October-November) for the North and South arms of Kootenay Lake, 1997-2006*. .33

Table 3.5. Average conductivity $(\mu \mathrm{S} / \mathrm{cm})$ from $0-30 \mathrm{~m}$ in spring (April-June), summer (July-September), and fall (October - November) for the North and South arms of Kootenay Lake, 1997-2006*. . .34

Table 3.6. Average total phosphorus (TP; $\mu \mathrm{g} / \mathrm{L}$ ) from $0-30 \mathrm{~m}$ in spring (April-June), summer (July-September), and fall (October - November) for the North and South arms of Kootenay Lake, 1997-2006*. .35

Table 3.7. Average total dissolved phosphorus (TDP; $\mu \mathrm{g} / \mathrm{L}$ ) from $0-30 \mathrm{~m}$ in spring (April-June), summer (July-September), and fall (October-November) for the North and South arms of Kootenay Lake, 1997-2006*................36

Table 3.8. Average total nitrogen (TN; $\mu \mathrm{g} / \mathrm{L})$ from $0-30 \mathrm{~m}$ in spring (April-June), summer (July-September), and fall (October-November) for the North and South arms of Kootenay Lake, 1997-2006*.

Kootenay Lake Fertilization Experiment, Year 15 (North Arm) and Year 3 (South Arm) xiv (2006) Report 
Table 3.9. Average dissolved inorganic nitrogen (DIN; $\mu \mathrm{g} / \mathrm{L}$ ) from $0-30 \mathrm{~m}$ in spring (April-June), summer (July-September), and fall (October-November) for the North and South arms of Kootenay Lake, 1997-2006*.................38

Table 3.10. Average silica (mg/L) from $0-30 \mathrm{~m}$ in spring (April-June), summer (JulySeptember), and fall (October-November) for the North and South arms of Kootenay Lake, 1997-2006*. .39

Table 3.11. Average alkalinity ( $\mathrm{mg} \mathrm{CaCO}_{3} / \mathrm{L}$ ) from $0-30 \mathrm{~m}$ in spring (April-June), summer (July-September), and fall (October-November) for the North and South arms of Kootenay Lake, 1997-2006*. 40

Table 3.12. Average total organic carbon (TOC; $\mathrm{mg} / \mathrm{L}$ ) from $0-30 \mathrm{~m}$ in spring (AprilJune), summer (July-September), and fall (October-November) for the North and South arms of Kootenay Lake, 1997-2006*.

Table 3.13. Average chlorophyll $a$ (Chl $a$; $\mu \mathrm{g} / \mathrm{L}$ ) from $0-20 \mathrm{~m}$ in spring (April-June), summer (July-September), and fall (October- November) for the North and South arms of Kootenay Lake, 1997-2006*.

Table 4.1. Biomass averages (mg. $\left.\mathrm{m}^{3}\right)$ at the station 2 (KLF 2) in the North Arm and at station 6 (KLF 6) in the South Arm from 1992 to 2006. Enhancement is the effect of fertilization during the summer (ratio of Stn 2 over Stn 6) although starting in $2004 \mathrm{~N}$ has been added to the South Arm. .86

Table 5.1. Average vertical profile station abundance and biomass for Kootenay Lake in 2004, 2005, and 2006. .98

Table 5.2. Peak phytoplankton abundance and biomass in 2004, 2005, and 2006 in the epilimnion of Kootenay Lake at selected stations with major contributing groups. 100

Table 6.1. List of zooplankton species identified in Kootenay Lake, 1997-2006. ....121

Table 6.2. Seasonal average density of zooplankton in the North, South, and West arms of Kootenay Lake during 1997-2006. Values are seasonal averages, calculated for samples collected April-October 1997-2002 and April-November 20032006. Density is in units of individuals/L. Values from Arrow Lakes Reservoir, Okanagan Lake and Alouette Lake are shown for comparison. .123

Table 6.3. Seasonal average biomass of zooplankton in North, South, and West arms of Kootenay Lake in 1997-2006. Values are seasonal averages, calculated for samples collected April-October 1997-2002 and April-November 2003 and 2006. Biomass is in units of $\mu \mathrm{g} / \mathrm{L}$. Data from Arrow, Okanagan and Alouette lakes are shown for comparison. ......................................125

Kootenay Lake Fertilization Experiment, Year 15 (North Arm) and Year 3 (South Arm) $\quad$ XV (2006) Report 
Table 6.4. Monthly average density and biomass of zooplankton in the North, South and West arms of Kootenay Lake in 2006. Density is in units of individuals/L, and biomass is in units of $\mu \mathrm{g} / \mathrm{L}$. 128

Table 6.5. Fecundity data for Leptodiaptomus ashlandi in the North, South and West arms of Kootenay Lake in 1997-2006. Values are seasonal averages, calculated for samples collected April-October 1997-2002 and AprilNovember 2003 and 2006.

Table 6.6. $\quad$ Fecundity data for Diacyclops bicuspidatus thomasi in the North, South and West arms of Kootenay Lake in 1997-2006. Values are seasonal averages, calculated for samples collected April-October 1997-2002 and AprilNovember 2003-2006. 130

Table 6.7. Fecundity data for Daphnia spp. in the North, South and West arms of Kootenay Lake in 1997-2006. Values are seasonal averages, calculated for samples collected April-October 1997-2002 and April-November 2003-2006.

Table 6.8. Fecundity data for Bosmina longirostris in the North, South and West arms of Kootenay Lake in 1997-2006. Values are seasonal averages, calculated for samples collected April-October 1997-2002 and April-November 2003-2006.

Table 6.9. Annual average density and biomass of Mysis relicta in the North, South and West arms of Kootenay Lake, 1997-2006. Values are for deep sites only, calculated for samples collected between January and December 1997-2005 and February to November 2006. Data from Arrow Lakes Reservoir and Okanagan Lake are shown for comparison. 133

Table 7.1. Species composition from standard trawl surveys in Kootenay Lake during 1985-2006. 180

Table 7.2. Summary of kokanee trawl catches by age for Kootenay Lake 1985-2006.

Table 7.3. Kokanee catch statistics from the September 2006 trawl surveys.

Table 7.4. Size statistics from trawl captured kokanee September 2006.

Table 8.1. Peak counts of kokanee spawners during August to September 2006 stream surveys, South Arm (BC) of Kootenay Lake and tributaries of Kootenai River, Idaho 218

Kootenay Lake Fertilization Experiment, Year 15 (North Arm) and Year 3 (South Arm) xvi (2006) Report 
Table 8.2. Development of redds and egg deposition for October 2006 kokanee eyed-egg plants in tributary streams, South Arm (BC) of Kootenay Lake and Kootenai River, Idaho. 219

Table 8.3. $\quad$ Predicted escapement levels to BC and Idaho streams resulting from eyed-egg plants 2003-2006. Biostandards of 25\% egg-to-fry survival rates and 5\% fry-to-adult survival rates were used. .222

Kootenay Lake Fertilization Experiment, Year 15 (North Arm) and Year 3 (South Arm) xvii (2006) Report 
Kootenay Lake Fertilization Experiment, Year 15 (North Arm) and Year 3 (South Arm) $\quad$ xviii (2006) Report 


\section{CHAPTER 1}

INTRODUCTION

TROPHIC LEVEL RESPONSES TO NORTH ARM (YEAR 15) AND SOUTH ARM (YEAR 3) KOOTENAY LAKE EXPERIMENTAL FERTILIZATION

by

Harvey Andrusak

Redfish Consulting Ltd

Nelson, BC

Kootenay Lake Fertilization Experiment, Year 15 (North Arm) and Year 3 (South Arm) 


\section{Introduction}

Aquatic ecosystem restoration through addition of phosphorus and or nitrogen has become a successful management practice during the last two decades in British Columbia. Nutrient loss in large waterbodies is frequently linked to upstream hydroelectric development with newly formed reservoirs retaining key nutrients that previously contributed to downstream systems (Stockner 2003; Perrin et al. 2006). Kootenay Lake has been the focus of experimental nutrient additions in a long-term effort to offset the impact of ultra-oligotrophication caused by numerous human activities within the watershed. This report describes trophic level responses to 15 years of nutrient additions to the North Arm of Kootenay Lake and three years of results from nutrient additions to the South Arm of Kootenay Lake.

Nearly three decades ago Daley et al. (1981) identified that nutrient impoverishment in Kootenay Lake was the result of key nutrient uptake by newly formed upstream reservoirs and correctly predicted that the lake would become ultra-oligotrophic by the mid 1980s. The consequences of this change in lake productivity became all too apparent by the late 1980s. Kokanee (Oncorhynchus nerka) numbers fell at an alarming rate and by 1991 there were $<0.25$ million adults compared to numbers typically $>1$ million. A large-scale fertilization experiment was initiated in 1992 in an attempt to reverse the significant kokanee decline that top predators are so reliant upon (Ashley et al. 1997). A good understanding of this bottom-up approach to increasing fish production is essential and therefore, each trophic level is monitored annually. The 2006 production responses to nutrient additions in two widely separated parts of the lake are compared with previous years’ results.

The notion of reversing the ultra-oligotrophic status of Kootenay Lake was initially met with some public and scientist concern and skepticism. However, the federal government (DFO) had long used lake fertilization in British Columbia (Hyatt and Stockner 1985; Stockner and MacIsaac 1996) and, the literature was fairly supportive with a number of formal publications on nutrient additions to various lakes elsewhere in Canada, USA, Sweden and Scotland (Ashley et el. 1999; Hyatt et al. 2004). Sockeye enhancement work through lake fertilization undertaken by DFO in the late 1960s has proven quite successful (Stockner 1981; Stockner 1987; Stockner 2003; Hyatt et al. 2004). A recent publication by Maxwell et al. (2006) addresses the benefit-cost of fertilizing Chilko Lake and concludes that biological and economic changes were positive. The DFO fertilization projects and their published results as well as other literature provided strong evidence that nutrient additions could be safely and effectively applied to the North Arm of Kootenay Lake. During the last 15 years there have also been a number of studies conducted by the province on other BC lakes and reservoirs that have been fertilized (Ashley and Stockner 2003; Wilson 2003; Hyatt et al. 2004; Perrin et al. 2006).

Gerrard rainbow trout (Oncorhynchus mykiss) are the primary focus of the Kootenay Lake sport fishery since these fish can reach trophy sizes of $~ 10-14 \mathrm{~kg}$ due to their highly piscivorous foraging behavior on kokanee (Andrusak and Parkinson 1984). The impetus for nutrient addition had been to ensure the sustainability of these top predators as well as

Kootenay Lake Fertilization Experiment, Year 15 (North Arm) and Year 3 (South Arm) 
the highly regarded bull trout (Salvelinus confluentus). In the late 1980s, kokanee numbers declined to such low levels there was concern about the future of the entire lake's assemblage of predators that were so reliant on kokanee. Thus, the fertilization program is actually aimed at the entire fish community in Kootenay Lake, not solely kokanee and rainbow trout. The 1992 plan that was implemented was simple: add nutrients $(\mathrm{P}$ and $\mathrm{N})$ equal to pre-impoundment levels to stimulate primary and secondary production that would be beneficial to planktivorous fish, especially kokanee. After only four years this bottom-up approach had been highly successful in rebuilding the North Arm kokanee population (Ashley et al. 1997; Schindler et al. 2006, 2007a,b).

Paradoxically, despite successful restoration of North Arm kokanee the number of spawners in South Arm streams continued to decline and by the early 2000s there were virtually none observed (Andrusak and Fleck 2006). Similarly, kokanee from Kootenay Lake that spawn in northern Idaho streams were also very low in number. In recognition of the virtual total loss of spawning kokanee in Idaho, the Kootenai Tribe of Idaho (KTOI), the State of Idaho (Idaho Department of Fish and Game - IDFG) and the provincial Ministry of Environment (MOE) collaborated to secure Bonneville Power Authority (BPA) funding for experimental nutrient addition to the South Arm in an attempt to restore South Arm kokanee abundance (Anders et al. 2003). This project began late in 2004 but was fully implemented for the entire growing seasons of 2005 and 2006.

Meanwhile, the same process that reduced Kootenay Lake productivity was responsible for the decline in Kootenai River productivity in Idaho and Montana. This river is nutrient poor due to nutrient uptake in the Koocanusa Reservoir located upstream at Libby, Montana (BPA 2005). Substantial declines in abundance of most Kootenai River fish species have been documented (Paragamian 2002). In the early 2000s, the KTOI and IDFG proposed to add nutrients to the river similar to stream and river restoration projects carried out in British Columbia (Slaney et al. 2003; Ashley and Stockner 2003). After extensive reviews (BPA 2005) and public hearings the KTOI was permitted in 2005 by the USA Environmental Protection Agency (EPA) to add liquid nitrogen and phosphorus to the Kootenai River for up to five years to replace lost nutrients (S. Ireland, Project Manager, KTOI, Bonners Ferry, Idaho, pers. comm. 2006). Results of this work are not reported here but it should be noted that this project, as well as others in Idaho, are ultimately all aimed at restoring Kootenay Lake fish populations and their habitat.

\section{Study Area}

Kootenay Lake is located in the upper Columbia River drainage of Southeast British Columbia (Fig. 1.1). It lies in a north-south direction between the Selkirk and Purcell Mountain ranges. The main lake is $107 \mathrm{~km}$ long, approximately $4 \mathrm{~km}$ wide with a mean depth of $94 \mathrm{~m}$ and a maximum of $154 \mathrm{~m}$ (Daley et al. 1981). The lake is fed by two major river systems: the Lardeau/Duncan system at the north end and the Kootenay/i River that originates in $\mathrm{BC}$ and flows through parts of Montana and Idaho before entering the lake's south end. The outlet of the main lake, at Balfour, BC, is the upper end of the West Arm. At this outlet, a sill lies at a depth of approximately $8 \mathrm{~m}$ producing a distinct boundary between the main lake and the West Arm. The West Arm is about $40 \mathrm{~km}$ long

Kootenay Lake Fertilization Experiment, Year 15 (North Arm) and Year 3 (South Arm) 
with a mean depth of only $13 \mathrm{~m}$. It is physically and limnologically different from the main lake, comprised of a series of shallow basins interconnected by narrow riverine sections. The West Arm of Kootenay Lake flows in a westerly direction becoming the lower Kootenay River, which flows into the Columbia River at Castlegar, BC. The entire West Arm has an annual mean retention time of about 5-6 days (Martin and Northcote 1991). The main basin of the lake has a retention time of 1.8 years (Daley et al 1981). A more detailed description of the limnology of Kootenay Lake can be found in Northcote (1973), Daley et al. (1981), Ashley et al. (1999), and Northcote et al. (1999).

\section{Background}

Kootenay Lake has a long history of scientific investigation dating back to the late 1940s. Dr. P.A. Larkin and some of his students conducted a general limnological investigation on Kootenay Lake in 1948-1949 (Larkin 1950). This pioneer work provided some excellent baseline data that have been particularly useful in understanding the lake prior to the eutrophication that began in the 1950s (Northcote 1973). One of Dr. Larkin's students (E.H. Vernon) studied Kootenay Lake kokanee and determined there were three races of kokanee that reside in the lake (Vernon 1957). T.G. Northcote was another of Dr. Larkin's students and Northcote has published several papers that documented limnological changes in Kootenay Lake (Northcote 1972, 1991; Northcote et. al. 1999). Northcote (1973) provided an excellent summary of the early anthropogenic impacts on Kootenay Lake and chronicles eutrophication of the lake. It is clear from the data Northcote presented that huge quantities of fertilizer (primarily phosphorus) from Cominco's fertilizer plant located in Kimberley, BC, were responsible for eutrophication during the late 1950s and throughout the 1960s (Northcote 1973). Blue-green algae blooms, even in the early 1970s, were particularly prominent in the South Arm of Kootenay Lake.

Introduction of the opossum shrimp Mysis relicta into Kootenay Lake in 1949 resulted in a major ecological impact due to their competition for zooplankton with kokanee (Northcote 1991). The objective of this introduction was to provide an intermediate macrozooplanktor for the Gerrard rainbow trout (Northcote 1991). Successful introduction of these shrimp was not confirmed until 1964 when they were observed drifting through the outlet of the lake (Sparrow et al. 1964). As it turned out these trout utilize mysids on a very limited basis (Andrusak and Parkinson 1984). Contrary to the intention of improving the fish populations in the lake it is widely viewed today that this introduction has been detrimental especially to kokanee since mysids and kokanee both prey upon cladocerans, especially Daphnia sp. (Northcote 1991). Lasenby et al. (1996) documented the growth and food habits of Mysis in Kootenay Lake confirming that they do prefer Daphnia sp. Most researchers believe Mysis have been at least partially responsible for the decline of kokanee in the main lake (Martin and Northcote 1991), but the larger issue of decreased lake productivity almost certainly overshadows the mysid impact (Daley et al. 1981).

In an unexpected turn of events West Arm kokanee have been the primary beneficiaries of the mysid introduction largely due to the unique flow features of the upper West Arm

Kootenay Lake Fertilization Experiment, Year 15 (North Arm) and Year 3 (South Arm) 4 (2006) Report 
(Northcote 1973). Mysids in the vicinity of the outlet move to the surface at night where they are caught up in the current and displaced over the sill thereby becoming highly vulnerable to kokanee predation (Thurber Consultants 1981). Martin and Northcote (1991) concluded that main lake kokanee have not benefited to any appreciable degree from the mysid introduction. Some researchers, including Ashley et al. (1997) and Walters et al. (1991), suggest that mysids may have been partially responsible for the dramatic decline in main lake kokanee stocks in the 1980s.

Hydroelectric development has had an irreversible impact on Kootenay Lake's fish habitat. The two major inflowing systems - Kootenay and Duncan rivers - and the outlet (lower Kootenay River) have all been dammed. Historically, the initial dam (Corra Linn) affecting the lake was constructed on the Kootenay River downstream of Nelson in the early 1930s. This dam results in the potential storage of about $2 \mathrm{~m}$ on the main lake but it has had more of an effect on the West Arm due to the extent and length of time of drawdown (Andrusak and Andrusak 2007).

The Duncan Dam was built on the Duncan River in the mid-1960s approximately $12 \mathrm{~km}$ upstream of the north end of the lake. This dam eliminated hundreds of kilometres of spawning habitat used by kokanee, rainbow trout, bull trout and numerous other species. There was blockage to, and elimination of, spawning habitat for more than a million kokanee, a loss of a spawning run of Gerrard-size rainbow trout (numbers unknown), and blockage to spawning habitat for possibly a few thousand bull trout. It also resulted in retention of nutrients, the impact of which has been much greater than initially predicted (Larkin 1998). A little known fact about Kootenay Lake research was that at the time of the construction of Duncan Dam, a major research program was funded by BC Hydro. This work was directed toward kokanee population assessments at Meadow Creek and the Lardeau River, and toward in-lake kokanee population estimates. Considerable limnological sampling was conducted from 1965-1970. Unfortunately, there was little documentation of this work other than the kokanee assessment work at Meadow Creek and the zooplankton assessment by Zyblut (1970).

The majority of the lake's inflow originates in the upper Kootenay River watershed that starts in the East Kootenay and flows south into Montana before turning west into Idaho then north into Kootenay Lake. The Libby Dam was built on the Kootenay River in the mid 1970s about $300 \mathrm{~km}$ upstream of the South Arm of Kootenay Lake. The Kootenay River watershed contributes nearly $80 \%$ of the total inflow to Kootenay Lake. (Northcote 1972). Daley et al. (1981) documented the enormous impact that the Libby Dam has had on Kootenay Lake as a result of nutrient retention. Recent work in the late 1990s in Idaho has also revealed major problems with burbot and sturgeon spawning success as a result of the Libby Dam altering the hydrological regime of the Kootenay River (C. Spence. Fisheries Biologist. Nelson, BC, pers. comm., 2006). Nutrients stripped out of the system by the Koocanusa Reservoir behind the Libby Dam is most likely the cause of reduced river productivity in the Idaho portion of the river and this has prompted a major restoration program involving nutrient additions (Holderman and Hardy 2004; BPA 2005).

Kootenay Lake Fertilization Experiment, Year 15 (North Arm) and Year 3 (South Arm) 
During the 1950s and 1960s, the Cominco Ltd. fertilizer plant at Kimberley, BC, discharged tonnes of fertilizer into the St. Mary's River that flows into the Kootenay River and then Kootenay Lake. As a consequence Kootenay Lake productivity during this era increased substantially. The lake's N:P ratio was about 14:1 prior to the fertilizer plant commencing operations in 1953 but changed to about 5:1 by 1962 and remained at that level until 1972 (Daley et al. 1981). Blue-green algae blooms were evident during the summers and Zyblut (1970) noted that zooplankton numbers had risen threefold compared to data collected by Larkin (1950). In retrospect the kokanee populations in the 1960s were probably at historically high levels but no estimates of escapement were made prior to 1964. In 1964, Bull (1965) estimated over 4 million kokanee spawned in the Lardeau-Duncan system, probably reflecting the highly productive state of the lake at that time. The Meadow Creek spawning channel was built in 1967 as partial compensation for construction of the Duncan Dam. A very good data base has been established since 1967 on Meadow Creek kokanee spawner numbers, size, fecundity and fry production.

With Kootenay Lake moving towards eutrophication by the early 1970s public pressure and governments forced Cominco to control their fertilizer discharge. Pollution abatement was well in hand by 1973, which coincidentally was when the Libby Dam was completed. The level of impact of these two events was not foreseen by many. However, the federal government was prompted to launch a major limnological investigation in the mid 1970s led by Dr. Ralph Daley of Environment Canada, Inland Waters Directorate. A multi-disciplinary team investigated the physical and chemical limnology from 19761999 and their study concluded that cessation of phosphorus discharge and nutrient retention behind hydroelectric dams on the two major inflow rivers (Kootenay and Duncan) were the primary reasons for the lake again becoming oligotrophic (Daley et al. 1981; Ashley et al. 1999). In fact, nutrient input to the lake declined below pre-dam conditions and the lake underwent a gradual decline in productivity through to the 1990s as the lake became ultra-oligotrophic. The observed reduction in nutrients, especially phosphorus, led to phytoplankton biomass decline followed by decreases in kokanee. Kokanee escapements to Meadow Creek reflected these changes all too well. In general the late 1960s and early 1970s was a period of kokanee abundance followed by the 1980s when numbers began to decline until a record lows of $<0.25$ million were recorded in 1990 and 1991. At the same time the South Arm kokanee population had virtually disappeared.

By 1990 it was quite apparent that lake productivity had decreased so much that the kokanee population was at risk and on the brink of collapse. It was very obvious to most that the Gerrard rainbow population was also in jeopardy given their reliance on kokanee. The desire to restore the lakes' productivity to the pre-dam/pre-fertilizer plant level was largely driven by public demand to retain the lake's highly popular and regionally significant sport fisheries. In response to these dire circumstances and public concern the provincial government organized a workshop held at the University of British Columbia in February, 1991, to contemplate all options including the merits of experimentally fertilizing a portion of the lake in an attempt to halt the lake productivity decline. Korman et al. (1990) describes various alternatives that were contemplated. A Kootenay

Kootenay Lake Fertilization Experiment, Year 15 (North Arm) and Year 3 (South Arm) 
Lake Fertilization Response Model was developed to understand what would happen if the lake was fertilized to pre-impoundment and pre-cultural enrichment levels (Walters et al. 1991). The model predicted that fertilization would likely be unsuccessful and that mysids, not kokanee, would be the most likely beneficiaries.

Provincial fisheries managers, faced with the dilemma of the model's prediction but no viable alternative decided to proceed with an experimental fertilization of a portion of the North Arm of Kootenay Lake for a five-year period. Due to the inherent uncertainty of the experiment, an intensive monitoring program of all trophic levels was launched in 1992 by a multi-disciplinary group of scientists to track the physical and biological responses to experimental addition of $\mathrm{P}$ and $\mathrm{N}$. Results of this experiment have been reported in a series of technical reports (Ashley et al. 1999; Wright et al. 2002a,,b; Schindler et al. 2006, 2007a,b) and the response by North Arm kokanee has been very positive. Briefly, after only four years of fertilizer addition, kokanee escapements to the North Arm's Lardeau River and Meadow Creek systems were once again over 1 million, comparable to spawner numbers of the 1960s and 1970s (Ashley et al. 1999). As part of the experiment and also due to some who were doubtful of the apparent trophic responses, the nutrient loadings were reduced from 1997-1999 by nearly 50\% to determine if fertilization was the sole reason for the striking increase in kokanee numbers. The results of reduced fertilizer loads were swift and equally dramatic. The 2000-2002 Meadow Creek kokanee numbers fell to $<0.4$ million, size decreased while at the same time fry-to-adult survival rates declined. As a consequence the fertilizer-loading rate was increased in 2000 and by 2001 the load was increased to the original 1992 level. Once again kokanee numbers increased in 2003 and 2004 to $\sim 1$ million. The biological responses to Kootenay Lake fertilization have been documented in a series of technical reports similar to this one as well as some in more formal publications (Ashley et al. 1997; Ashley et al. in Murphy and Munawar 1999).

During the peak of lake productivity in the late 1960s the lake arguably supported a highly productive and the most intensive inland sport fishery in the province that had an estimated net worth of $\$ 5.8$ million (Pearse and Laub 1969). At that time, and due to the lake,s close proximity to Idaho and Washington, foreign anglers represented nearly $50 \%$ of the total angling effort. Much of the fishing at that time was directed at kokanee and burbot that concentrated at the lake's outlet. However, overall what attracts anglers to Kootenay Lake is the trophy-sized Gerrard rainbow trout. Even at the turn of the century rainbow trout $>15 \mathrm{~kg}$ were highly sought by local anglers (Northcote 1973; Irvine 1978) and this fishery persists to this day. Rainbow trout fishing occurs year round with most fishing gear comprised of surface trolled plugs or bucktail flies that mimic kokanee. The fishery was closely monitored for several decades until the 1990s with the most recent catch statistics summarized by Andrusak (1987) and Redfish Consulting Ltd. (2003). It is believed that the exploitation rate for these trout is very high (e.g., 63\% - Andrusak 1981). Until recently the only known spawning area for these unique-sized trout is at the outlet area of Trout Lake where the Lardeau River forms and then flows south into Kootenay Lake after joining the Duncan River. For this reason the Gerrard rainbow trout spawning run has been monitored annually since 1957 and there is a good correlation between catch and escapement (Andrusak and Andrusak 2006). In the face of intensive

Kootenay Lake Fertilization Experiment, Year 15 (North Arm) and Year 3 (South Arm) 7 (2006) Report 
fishing pressure this trout population today is sustainable primarily because of their high fecundity, an abundance of kokanee and a very high rate of catch-and-release (Andrusak and Andrusak 2006).

Interestingly, during the last three years a number of large trout have also been observed spawning just downstream of the Duncan Dam. Numbers of fish are difficult to determine but it appears there may be 50-100 (L. Porto, DFO Habitat Biologist, Nelson, BC, pers. comm., YEAR). Research is underway to determine their origin since they may be Gerrard rainbow trout that have been induced to spawn due to warm(er) water releases from the Duncan Dam. Alternatively these fish may be remnants of the original Duncan River spawning run that disappeared after the dam was completed.

The lake supports at least two other rainbow trout populations. Cartwright (1961) described the West Arm population that grows up to $4 \mathrm{~kg}$ but seldom preys upon kokanee. These trout provide excellent fly fishing opportunities during the summer months. Recently an updated assessment of this fishery by Andrusak (2006) suggests that this fishery is comprised of several stocks including some fish that spawn in a few Kootenai River tributaries in Northern Idaho. Growth rates of these fish today are far lower than those measured in 1966 with this decrease attributed to the change in lake productivity. A lesser known rainbow trout population inhabits the South Arm of Kootenay Lake. These trout also provide good fishing opportunities during the summer and fall (Andrusak 1987; 2006).

Bull trout appear to be abundant in Kootenay Lake and they are also a popular sport fish that are caught using the same methods as rainbow trout fishing, i.e., trolling plugs and spoons but usually at much greater depths. These fish occasionally exceed $7 \mathrm{~kg}$ but most are 3-4 kg. In recent years these fish have become an important alternative sport species especially during the late winter months when rainbow trout catchability is low.

Historically there were three strains of kokanee in Kootenay Lake with each arm supporting separate populations (Vernon 1957). The main lake continues to provide small but abundant numbers for summer time anglers. The West Arm kokanee population was the center of attention during the 1970s when the lake was highly productive. This fishery peaked in the 1970s with annual catches close to 100,000 fish but with the decline of this population in the late 1980s there has been much less fishing for them despite the recovery evident in the late 1990s. A combination of some over-fishing due to a mixed stock fishery and the severe decline in lake productivity has relegated this once famous fishery to a modest, seasonal fishery with a small annual catch quota of about 5,000.

White sturgeon (Acipencer transmontanus) that inhabit the Kootenay River at the south end of the lake once supported a low-level sport fishery. However, these fish have been severely threatened due to impacts of the Libby Dam and the fishery has been closed for well over two decades due to conservation concerns. Research currently underway has confirmed that this population is in decline due to poor spawning success and limited recruitment. A recovery strategy that includes juvenile hatchery production in Idaho has been initiated and the success of this program is now being monitored (C. Spence, Fisheries Biologist, BC Ministry of Environment, Nelson, BC, pers. comm., WHEN).

Kootenay Lake Fertilization Experiment, Year 15 (North Arm) and Year 3 (South Arm) 
A highly intensive fishery occurred for burbot (Lota lota) at the outlet area near Balfour, BC, during the 1960s and 1970s. This fishery was examined by Martin (1976) for possible overfishing. Martin (1976) concluded that overfishing was not excessive but more conservative regulations were required. Very restrictive regulations were imposed on this fishery but the population collapsed by the early 1980s and has not recovered despite a total closure that has remained in effect for over twenty years. Lake and river assessment work during the last five years has failed to identify any appreciable numbers of burbot anywhere in the lake (C. Spence, Fisheries Biologist, BC Ministry of Environment, Nelson, BC, pers. comm., 2006).

This report summarizes results of the 2006 monitoring program that tracks trophic level responses to experimental fertilization of the North Arm and South Arm of Kootenay Lake.

\section{Objective of the Kootenay Lake Experimental Fertilization Program}

Since the beginning of experimental fertilization in 1992 in the North Arm of Kootenay Lake, the specific objective of this program has been to rebuild the kokanee population by increasing lake productivity to the level that existed prior to 1950. The primary goal of this fertilization program has been to ensure sufficient forage, specifically kokanee, for the lake's piscivores. Commencing in 2004 this program was expanded to include the South Arm in an effort to restore South Arm kokanee in BC and Idaho.

The scientific basis and direction of the experimental fertilization program on Kootenay Lake originated with Dr. K. Ashley who was the senior research biologist for the Ministry of Environment at the beginning of the project. Eva Schindler, limnologist for the Ministry of Environment located in Nelson, BC, is the biologist responsible for all aspects of the monitoring program as well as for determining the weekly amounts of fertilizer applied to the lake. A large number of scientists, fisheries biologists and administrative personnel participated in the 2006 Kootenay Lake Fertilization Program. A list of the 2006 participants and their primary function is shown in Table 1.1.

\section{Acknowledgements}

Thanks to the Kootenai Tribe of Idaho for providing the funds and the British Columbia Conservation Foundation for administering the funds for this report.

\section{References}

Anders, P., H. Andrusak, K. Ashley, and J. Hammond. 2003. Kokanee and Ecosystem Restoration in South Arm Kootenay Lake and the Arrow Lakes Reservoir, British Columbia. Pre-implementation Report and Work Plan prepared for the Kootenai Tribe of Idaho and the British Columbia Ministry of Water, Land and Air Protection. S. P. Cramer and Associates, Moscow, ID. 47 pp.

Kootenay Lake Fertilization Experiment, Year 15 (North Arm) and Year 3 (South Arm) 
Andrusak, H. 1981. Kootenay Lake Sport Fishery Statistics 1978-80. B.C. Ministry of Environment, Fish and Wildlife Branch, Fisheries Technical Circular No. 53. 1981. Ministry of Environment.

Andrusak, H. 1987. Kootenay Lake Sport Fishery 1984-86, unpublished M.S., Fisheries Branch, Nelson, BC. Report No. KO-19 31 p.

Andrusak, H., and E.A. Parkinson. 1984. Food habits of Gerrard stock rainbow trout in Kootenay Lake, British Columbia. B.C. Ministry of Environment, Fish and Wildlife Branch, Fisheries Technical Circular No. 60.

Andrusak, H., and G.F. Andrusak. 2007. Observations, Preliminary Analysis and Comparisons Between Shore- and Stream-Spawning Kokanee (Oncorhynchus nerka) in the West Arm of Kootenay Lake 2007. Redfish Consulting Ltd., Contract Report for the Department of Fisheries and Oceans, Nelson, BC.

Andrusak, H., and C. Brown,. 1987. Kootenay Lake Fisheries Management Plan 198789. B.C. Ministry of Environment, 56 pp.

Andrusak, H., D. Sebastian, G. Scholten and P. Woodruff. 2006. Response of Kokanee and Gerrard Rainbow Trout to Experimental Fertilization of the North Arm of Kootenay Lake, 2002 and 2003 Pages 157 - 181 in Schindler et al. Kootenay Lake Fertilization Experiment, Years 11 and 12 (2002 and 2003). Fisheries Project Report No. RD 114, Ministry of Environment, Province of British Columbia.

Andrusak, H., and L. Fleck. 2007. Status of Kokanee in the South Arm of Kootenay Lake Prior to Experimental Fertilization. Pages 251-272. In Schindler et al. Kootenay Lake Fertilization Experiment, Year 13 (North Arm) and Year 1 (South Arm) (2004) Report. Fisheries Project Report No. RD 117, Ministry of Environment, Province of British Columbia.

Andrusak, H., and G. F. Andrusak. 2006. Analysis of Gerrard rainbow trout size, age, fecundity and growth data. Final report submitted to the BC Ministry of Water, Land, and Air Protection, by Redfish Consulting Limited. Nelson, BC.

Andrusak, G. F. 2006. West Arm Kootenay Lake Rainbow Trout Stock Status and Their Recreational Fishing Potential. Redfish Consulting Ltd., Contract Report for the Habitat Conservation Trust Fund.

Andrusak, H. 2006. A Review and Status Report of South Arm Kootenay Lake and Kooetnai/y River Adfluvial Rainbow Trout. Redfish Consulting Ltd., Contract Report for the Kootenai Tribe of Idaho.

Kootenay Lake Fertilization Experiment, Year 15 (North Arm) and Year 3 (South Arm) 
Ashley, Ken, Lisa C. Thompson, David C. Lasenby, Laurie McEachern, Karen E. Smokorowski and Dale Sebastian. 1997. Restoration of an Interior Lake Ecosystem: the Kootenay Lake Fertilization Experiment. Water Qual. Res. J. Canada 32:295-323.

Ashley, K., L.C. Thompson, D. Sebastian, D.C. Lasenby, K.E. Smokorowski, and H. Andrusak. 1999. Restoration of Kokanee Salmon in Kootenay Lake, a Large Intermontane Lake, by Controlled Seasonal Application of Limiting Nutrients. Pages 127 - 169 in Murphy, T.P. and M. Munawar, editors. Aquatic Restoration in Canada Backhuys Publishers, Leiden.

Ashley, K., L.C. Thompson, D. P Lombard,. Y-R.Yang,. F.R. Pick, ???Hamilton, D.B. Lasenby, K.E. Smokorowski, L. McEachern, P.B.,Sebastian D. C and George Scholten. 1999 Kootenay Lake Fertilization Experiment- Year 5 (1996/97) Report. Fisheries Project Report No. 65 Province of BC, Ministry of Fisheries, Fisheries Management Branch.

Bonneville Power Authority. 2005. Kootenai River Ecosystems Preliminary Assessment DOE/EA-1518. Bonneville Power Authority, Portland, Oregon.

Bull, C.J. 1965. Enumeration of kokanee salmon populations on the Lardeau-Duncan River system 1964. British Columbia Fish and Wildlife Branch, Fisheries Management Report. 46. 12 p.

Cartwright, J.W. 1961. Investigations of the Rainbow Trout of Kootenay Lake, British Columbia, with Special Reference to the Lardeau River. BC. Fish and Wildlife Branch, Managaement Publication 7. 46p.

Daley, R.J., E.C. Carmack, C.B.J. Gray, C.H. Pharo, S. Jasper, and R.C. Wiegand. 1981. The effects of upstream impoundments on Kootenay Lake, B.C. Canada Inland Waters Directorate, Research Institute, Scientific Series, West Vancouver, British Columbia.

Holderman, C., and R. Hardy, eds. 2004. Kootenai River Ecosystem Project: An ecosystem approach to evaluate and rehabilitate a degraded, large riverine ecosystem. Kootenai Tribe of Idaho, Project 94-49. Annual Report to the Bonneville Power Administration, Portland, OR.

Hyatt, K. D., D.J. McQueen, K.S. Shortreed and D.P. Rankin 2004. Sockeye Salmon (Oncorhynchus nerka) Nursery Lake Fertilization: Review and Summary of Results. Environ. Rev. 12 133-162 (2004). NRC Research Press Web Site @ http://er.nrc.ca/ November 102004.

Irvine, James R. 1978. The Gerrard rainbow trout of Kootenay Lake, British Columbia A discussion of their life history with management, research and enhancement recommendations. BC Fisheries Management Report No. 72. March, 1978.

Kootenay Lake Fertilization Experiment, Year 15 (North Arm) and Year 3 (South Arm) 
Korman, J., C.J. Perrin and R.C. Wiegand 1990. Feasibility of fertilization of Kootenay Lake, North Arm. B.C. Ministry of Environment Volume????: 108 pp

Larkin, P.A. 1950. Summary of investigation conducted by the Fisheries Research Group, attached to the British Columbia Game Department, in 1949. Annual Report of the British Columbia Game Commission for 1949, pp 55-61.

Larkin, G.A. 1998. Kootenay Lake phosphorus loading from the Kootenay and Duncan rivers. Report prepared for the Columbia Basin Fish and Wildlife Compensation Program, 26 p.

Lasenby, D.C., K.E. Smokorowski, and L.J. McEachern 1996. Distribution, abundance, growth, life history and feeding habits of Mysis relicta in Kootenay Lake, BC following experimental fertilization Year 4 (1994/95). Contract Report for BC Ministry of Environment, Lands and Parks, Fisheries Branch.

Martin, A.D. 1976. Kootenay Lake Burbot Fishery. Internal Report. Ministry of Environment, Nelson, BC.

Martin, A.D., and T.G. Northcote 1991. Kootenay Lake; An Inappropriate Model for Mysis relicta Introduction in North Temperate Lakes. American Fisheries Society Symposium 9:23-29.

Maxwell, Marla Rae, Randell M. Peterman, Michael J. Bradford and Eraland A. MacIsaac. 2006. A Bayesian Analysis of Biological Uncertainty for a Whole-Lake Fertilization Experiment for Sockeye Salmon in Chilko Lake, British Columbia, and Implications for the Benefit-Cost Ratio. North American Journal of Fisheries Management Volume 26 (2) p. 418-429. 2006.

Northcote, T.G. 1973. Some Impacts of Man on Kootenay Lake and Its Salmonids. Great Lakes Fisheries Commission Tech. Rep. 25.

Northcote, T.G. 1991. Success, Problems and Control of Introduced Mysid Populations in Lakes and Reservoirs. American Fisheries Society Symposium 9:5-16.

Northcote, T.G., D.B. Fillion, S.P. Salter and G.L. Ennis. 1999. Interactions of Nutrients and Turbidity in the Control of Phytoplankton in Kootenay Lake, British Columbia, Canada, 1964 to 1966. Misc. Fisheries Project Report No. 1. Province of British Columbia.

Paragamian, V.L. 2002. Changes in the species composition of the fish community in a reach of the Kootenai River, Idaho after construction of Libby Dam. Journal of Freshwater Ecology 17(3): 375-383. 
Pearse, P.H., and M.E. Laub 1969.The value of Kootenay Lake sport fishery. BC Fish and Wildlife Branch, Study Report No. 3, Economics of Wildlife and Recreation. 58p.

Perrin, C.J., M.L.Rosenau, T. Broke Stables and K.I. Ashley 2006. Restoration of a Montane Reservoir Fishery via Biomanipulation and Nutrient Addition. North American Journal of Fisheries Management Volume 26 (2) p. 391-407. 2006.

Schindler, E.U., K.I. Ashley, R. Rae, L. Vidmanic, H. Andrusak, D. Sebastian, G. Scholten, P. Woodruff, F. Pick, L.M. Ley and P.B. Hamilton. 2006. Kootenay Lake Fertilization Experiment, (Years 11 and 12) (2002 and 2003). Fisheries Project Report No. RD 114. 2006. Ministry of Environment, Province of British Columbia.

Schindler, E.U., R. Rae, K.I. Ashley, L. Vidmanic, D. Sebastian, H. Andrusak, G. Scholten, P. Woodruff, J. Stockner, F. Pick, L.M. Ley, P.B. Hamilton, G.F. Andrusak and L. Fleck. 2007a. Kootenay Lake Fertilization Experiment, Year 13 (North Arm) and Year 1 (South Arm) (2004) Report. Fisheries Project Report No. RD 117, Ministry of Environment, Province of British Columbia.

Schindler, E.U., H. Andrusak, K.I. Ashley, G.F. Andrusak, L. Vidmanic, D. Sebastian, G. Scholten, P. Woodruff, J. Stockner, F. Pick, L.M. Ley and P.B. Hamilton. 2007b. Kootenay Lake Fertilization Experiment, Year 14 (North Arm) and Year 2 (South Arm) (2005) Report. Fisheries Project Report No. RD 122, Ministry of Environment, Province of British Columbia.

Sparrow, R. A. H., P.A. Larkin and R. A. Rutherglen 1964. Successful introduction of Mysis relicta Loven into Kootenay Lake, British Columbia. Journal of the Fisheries Research Board of Canada 21 (5):1325-1327.

Stockner, J.G., and E.A. MacIsaac. 1996. British Columbia lake enrichment programme; two decades of habitat enhancement for sockeye salmon. Regulated Rivers: Reservoir Management: 12:547-561.

Stockner, J. editor. 2003. Nutrients in salmonid ecosystems: Sustaining production and biodiversity. American Fisheries Society Symposium 34. American Fisheries Society, Bethesda, MD.

Walters, C.J., J. Digisi, J. Post and J. Sawada. 1991. Kootenay Lake Fertilization Response Model. Fisheries Management Report No. 98, Ministry of Environment, Province of British Columbia.

Wilson, G., Ashley, K., McCusker, M., Land, R., Stockner, J., Dolecki, D., Scholten, G., and D. Sebastian. 2003. The Alouette Reservoir Fertilization Project: Years 2000 and 2001 Experiment, Whole Reservoir Fertilization. Fisheries Project Report No. RD 99.

Kootenay Lake Fertilization Experiment, Year 15 (North Arm) and Year 3 (South Arm) 
Wright, M. E., K. I. Ashley, F. R. Pick, L. M. Ley, P. B. Hamilton, L. C. Thompson, L. Vidmanic and H. Andrusak. Kootenay Lake Fertilization Experiment Year 8 (1999/2000) Report. 2002a. British Columbia Ministry of Water, Land and Air Protection. Technical Report No. 102. 140 pp.

Wright, M. E., K. I. Ashley, H. Andrusak, H. Manson, R. Lindsay, R.J. Hammond, F. R. Pick, L.M. Ley, P.B. Hamilton, S. L. Harris, L.C. Thompson, L. Vidmanic, D. Sebastian, G. Scholten, M. Young and D. Miller. Kootenay Lake Fertilization Experiment Year 9 (2000/2001) Report. 2002b. British Columbia Ministry of Water, Land and Air Protection. Technical Report No. 105. 194 pp..

Zyblut, E.R. 1970. Long-Term Changes in the Limnology and Macrozooplankton of a Large British Columbia Lake. Journal of the Fisheries Research Board of Canada 27: 1239-1250. 
Table 1.1. Kootenay Lake Participants, Activities and Affiliation for 2006 studies.

\begin{tabular}{|c|c|c|}
\hline Contribution & Personnel & Affiliation \\
\hline Fertilizer schedule, loading & Eva Schindler & Ministry of Environment \\
\hline Fertilizer application & $\begin{array}{l}\text { George Veale } \\
\text { Western Pacific } \\
\text { Marine } \\
\end{array}$ & $\begin{array}{l}\text { G. Veale Holdings Ltd. } \\
\text { Western Pacific Marine }\end{array}$ \\
\hline $\begin{array}{l}\text { Physical limnology, water } \\
\text { chemistry, phytoplankton, } \\
\text { zooplankton, mysid sampling }\end{array}$ & $\begin{array}{l}\text { Don Miller } \\
\text { Mike Lindsay } \\
\text { Eva Schindler } \\
\end{array}$ & $\begin{array}{l}\text { Kootenay Wildlife Services Ltd. } \\
\text { Ministry of Environment } \\
\text { Ministry of Environment }\end{array}$ \\
\hline $\begin{array}{l}\text { Physical limnology, water } \\
\text { sampling analysis }\end{array}$ & $\begin{array}{l}\text { Greg Andrusak } \\
\text { Eva Schindler } \\
\text { Marley Bassett }\end{array}$ & $\begin{array}{l}\text { Redfish Consulting Ltd. } \\
\text { Ministry of Environment } \\
\text { Ministry of Environment }\end{array}$ \\
\hline Primary production sampling & $\begin{array}{l}\text { Shannon Harris } \\
\text { Les Fleck } \\
\text { Greg Andrusak }\end{array}$ & $\begin{array}{l}\text { Ministry of Environment } \\
\text { Crystal Springs Consulting (BCCF) } \\
\text { Redfish Consulting Ltd. (BCCF) }\end{array}$ \\
\hline Primary productivity analysis & Shannon Harris & Ministry of Environment \\
\hline $\begin{array}{l}\text { Phytoplankton analysis and } \\
\text { ecology }\end{array}$ & $\begin{array}{l}\text { Dr. Frances Pick } \\
\text { Linda Ley } \\
\text { Paul Hamilton } \\
\text { Dr. John Stockner }\end{array}$ & $\begin{array}{l}\text { Biology Department, University of Ottawa } \\
\text { Canadian Museum of Nature } \\
\text { Canadian Museum of Nature } \\
\text { Eco-Logic Ltd. }\end{array}$ \\
\hline $\begin{array}{l}\text { Zooplankton and mysid } \\
\text { analysis and biology }\end{array}$ & Dr. Lidija Vidmanic & Limno-Lab Ltd. \\
\hline Kokanee acoustic sampling & $\begin{array}{l}\text { Dale Sebastian } \\
\text { George Scholten } \\
\text { Patricia Woodruff }\end{array}$ & $\begin{array}{l}\text { Ministry of Environment } \\
\text { Ministry of Environment } \\
\text { British Columbia Conservation Foundation } \\
\text { (BCCF) }\end{array}$ \\
\hline Kokanee trawling & $\begin{array}{l}\text { Don Miller } \\
\text { Mike Lindsay }\end{array}$ & $\begin{array}{l}\text { Kootenay Wildlife Services Ltd. } \\
\text { Kootenay Wildlife Services Ltd. }\end{array}$ \\
\hline $\begin{array}{l}\text { Meadow Creek kokanee fry } \\
\text { enumeration }\end{array}$ & $\begin{array}{l}\text { John Bell } \\
\text { Murray Pearson }\end{array}$ & $\begin{array}{l}\text { Ministry of Environment } \\
\text { Ministry of Environment }\end{array}$ \\
\hline $\begin{array}{l}\text { Meadow Creek adult kokanee } \\
\text { enumeration }\end{array}$ & $\begin{array}{l}\text { John Bell } \\
\text { Murray Pearson }\end{array}$ & $\begin{array}{l}\text { Ministry of Environment } \\
\text { Ministry of Environment }\end{array}$ \\
\hline $\begin{array}{l}\text { South Arm adult kokanee } \\
\text { enumeration }\end{array}$ & Les Fleck & Crystal Springs Contracting (BCCF) \\
\hline $\begin{array}{l}\text { South Arm kokanee eyed egg } \\
\text { plants }\end{array}$ & $\begin{array}{l}\text { Les Fleck } \\
\text { John Bell } \\
\text { Gary Munro } \\
\text { Murray Pearson } \\
\text { Eva Schindler } \\
\text { Owen Schoenberger } \\
\text { Greg Andrusak } \\
\end{array}$ & $\begin{array}{l}\text { Crystal Springs Contracting (BCCF) } \\
\text { Ministry of Environment } \\
\text { Ministry of Environment } \\
\text { Ministry of Environment } \\
\text { Ministry of Environment } \\
\text { Freshwater Fisheries Society of BC } \\
\text { Redfish Consulting Ltd. (BCCF) }\end{array}$ \\
\hline $\begin{array}{l}\text { Kokanee and rainbow trout } \\
\text { analysis and biology }\end{array}$ & $\begin{array}{l}\text { Dale Sebastian } \\
\text { Harvey Andrusak }\end{array}$ & $\begin{array}{l}\text { Ministry of Environment } \\
\text { Redfish Consulting Ltd. }\end{array}$ \\
\hline Regional support, logistics & $\begin{array}{l}\text { John Bell } \\
\text { Jeff Burrows }\end{array}$ & $\begin{array}{l}\text { Ministry of Environment } \\
\text { Ministry of Environment }\end{array}$ \\
\hline
\end{tabular}

Kootenay Lake Fertilization Experiment, Year 15 (North Arm) and Year 3 (South Arm) 


\begin{tabular}{|c|c|c|}
\hline FWCP Steering Committee & $\begin{array}{l}\text { Wayne Stetski } \\
\text { Ted Down } \\
\text { Kevin Conlin } \\
\text { Gary Birch } \\
\text { Bruce MacDonald } \\
\text { Richard Spilker } \\
\text { Greg Mustard } \\
\text { Joe Nicholas } \\
\text { Byron Louis }\end{array}$ & $\begin{array}{l}\text { Ministry of Environment } \\
\text { Ministry of Environment } \\
\text { BC Hydro } \\
\text { BC Hydro } \\
\text { Fisheries and Oceans Canada } \\
\text { Public Representative } \\
\text { Public Representative } \\
\text { First Nations Respresentative } \\
\text { First Nations Representative }\end{array}$ \\
\hline $\begin{array}{l}\text { Project co-ordination and } \\
\text { scientific liaison }\end{array}$ & Eva Schindler & Ministry of Environment \\
\hline Administration & $\begin{array}{l}\text { Maureen DeHaan } \\
\text { Beth Woodbridge } \\
\text { Sue Ireland } \\
\text { Charlie Holderman } \\
\text { Melinda } \\
\text { Woznesensky } \\
\text { Deborah McNicol } \\
\text { Theresa Hall }\end{array}$ & $\begin{array}{l}\text { FWCP } \\
\text { FWCP } \\
\text { Kootenai Tribe of Idaho } \\
\text { Kootenai Tribe of Idaho } \\
\text { British Columbia Conservation Foundation } \\
\text { British Columbia Conservation Foundation } \\
\text { Corporate Services Division }\end{array}$ \\
\hline Editorial comments & $\begin{array}{l}\text { Rowena Rae } \\
\text { Eva Schindler } \\
\text { Harvey Andrusak }\end{array}$ & $\begin{array}{l}\text { Sumac Writing and Editing } \\
\text { Ministry of Environment } \\
\text { Redfish Consulting Ltd. }\end{array}$ \\
\hline
\end{tabular}

FWCP - Fish and Wildife Compensation Program - Columbia Basin 
Table 1.2 Sampling Activities - Kootenay Lake, 2006.

\begin{tabular}{|c|c|c|}
\hline Parameter sampled & Sampling frequency & Sampling technique \\
\hline $\begin{array}{l}\text { Temperature, dissolved oxygen, } \\
\text { turbidity }\end{array}$ & Monthly, April to November & $\begin{array}{l}\text { SeaBird profile from surface to bottom at } \\
\text { stations KLF 1-8. }\end{array}$ \\
\hline Transparency & Monthly, April to November & $\begin{array}{l}\text { Secchi disk (without viewing chamber) at } \\
\text { stations KLF 1-8. }\end{array}$ \\
\hline $\begin{array}{l}\text { Water chemistry: } \\
\text { TDS, specific cond., pH, silica, } \\
\text { alkalinity and nutrients (TP, TDP, } \\
\left.\text { LL, SRP, } \mathrm{NO}_{3}+\mathrm{NO}_{2}, \mathrm{NH}_{3}\right) \\
\text { Total metals }\end{array}$ & Monthly, April to November & $\begin{array}{l}\text { (a) Integrated sampling tube at } 0-20 \mathrm{~m} \\
\text { plus a bottle sample } 5 \mathrm{~m} \text { off the bottom at } \\
\text { stations KLF1-8 (bottom sample collected } \\
\text { May to October at stations KLF 1-7). } \\
\text { (b) June and September samples at } 0-20 \\
\text { m integrated and } 5 \mathrm{~m} \text { off the bottom at } \\
\text { stations KLF 1-8 }\end{array}$ \\
\hline $\begin{array}{l}\text { Discrete } \mathrm{N} \text { and } \mathrm{P} \\
\left(\mathrm{NO}_{3}^{-}+\mathrm{NO}_{2}^{-}\right) \text {, ammonia, SRP, TP, } \\
\text { and TDP. }\end{array}$ & Monthly, June to September & $\begin{array}{l}\text { Bottle samples at } 2 \mathrm{~m}, 5 \mathrm{~m}, 10 \mathrm{~m}, 15 \mathrm{~m} \\
\text { and } 20 \mathrm{~m} \text { at stations KLF 2, } 6 \text { and } 7\end{array}$ \\
\hline $\begin{array}{l}\text { Chlorophyll a (not corrected for } \\
\text { phaeophytin) }\end{array}$ & $\begin{array}{l}\text { Monthly, April to November } \\
\text { Monthly, June to September }\end{array}$ & $\begin{array}{l}\text { Integrated sampling tube } 0-20 \mathrm{~m} \text { at station } \\
\text { KLF 1-8. } \\
\text { Discrete samples at } 2 \mathrm{~m}, 5 \mathrm{~m}, 10 \mathrm{~m}, 15 \mathrm{~m} \\
\text { and } 20 \mathrm{~m} \text { at stations KLF 2, } 6 \text { and } 7 \text {. }\end{array}$ \\
\hline Phytoplankton & Monthly, April to November & $\begin{array}{l}\text { Integrated sampling tube at } 0-20 \mathrm{~m} \text { at } \\
\text { stations KLF 1-8. }\end{array}$ \\
\hline Discrete phytoplankton & Monthly, June to September & $\begin{array}{l}\text { Bottle samples at } 2 \mathrm{~m}, 5 \mathrm{~m}, 10 \mathrm{~m}, 15 \mathrm{~m} \\
\text { and } 20 \mathrm{~m} \text { at stations KLF 2, } 6 \text { and } 7 .\end{array}$ \\
\hline Primary Production & Monthly, June to September & Sampled at stations KLF 2 and KLF 6 \\
\hline Macrozooplankton & Monthly, April to November & $\begin{array}{l}3 \text { oblique Clarke-Bumpus net hauls (- } \\
\text { approximately } 3 \text { minutes each) from } 40- \\
\text { 0m at stations KLF 1-8 (150 } \mu \mathrm{m} \text { net } \\
\text { mesh). }\end{array}$ \\
\hline Mysids & $\begin{array}{l}\text { Monthly, April to December } \\
\text { 2005, January and March } \\
\text { 2006. }\end{array}$ & $\begin{array}{l}3 \text { replicate hauls with mysid net, two deep } \\
\text { and one shallow at stations KLF 1-8. }\end{array}$ \\
\hline Kokanee acoustic sampling & June and September & $\begin{array}{l}\text { Standard MoE Simrad and Biosonics } \\
\text { hydroacoustic procedures at } 18 \text { transects. }\end{array}$ \\
\hline Kokanee trawling & $\begin{array}{l}\text { June and September trawl } \\
\text { series }\end{array}$ & $\begin{array}{l}\text { Standard trawl series using oblique hauls } \\
\text { at } 18 \text { transects. }\end{array}$ \\
\hline Kokanee adult enumeration & $\begin{array}{l}\text { Fall spawning period at } \\
\text { Meadow Creek, the Lardeau } \\
\text { River, and selected streams } \\
\text { tributary to Kootenay Lake }\end{array}$ & $\begin{array}{l}\text { Standard MoE, Kootenay Region } \\
\text { procedures. }\end{array}$ \\
\hline $\begin{array}{l}\text { South Arm kokanee eyed egg } \\
\text { plants }\end{array}$ & $\begin{array}{l}\text { Fall eyed egg plants on select } \\
\text { South Arm tributaries }\end{array}$ & $\begin{array}{l}\text { Standard MoE, Kootenay Region } \\
\text { procedures. }\end{array}$ \\
\hline Kokanee fry enumeration & $\begin{array}{l}\text { Spring monitoring at Meadow } \\
\text { Creek Spawning Channel }\end{array}$ & $\begin{array}{l}\text { Standard MoE, Kootenay Region } \\
\text { procedures. }\end{array}$ \\
\hline
\end{tabular}




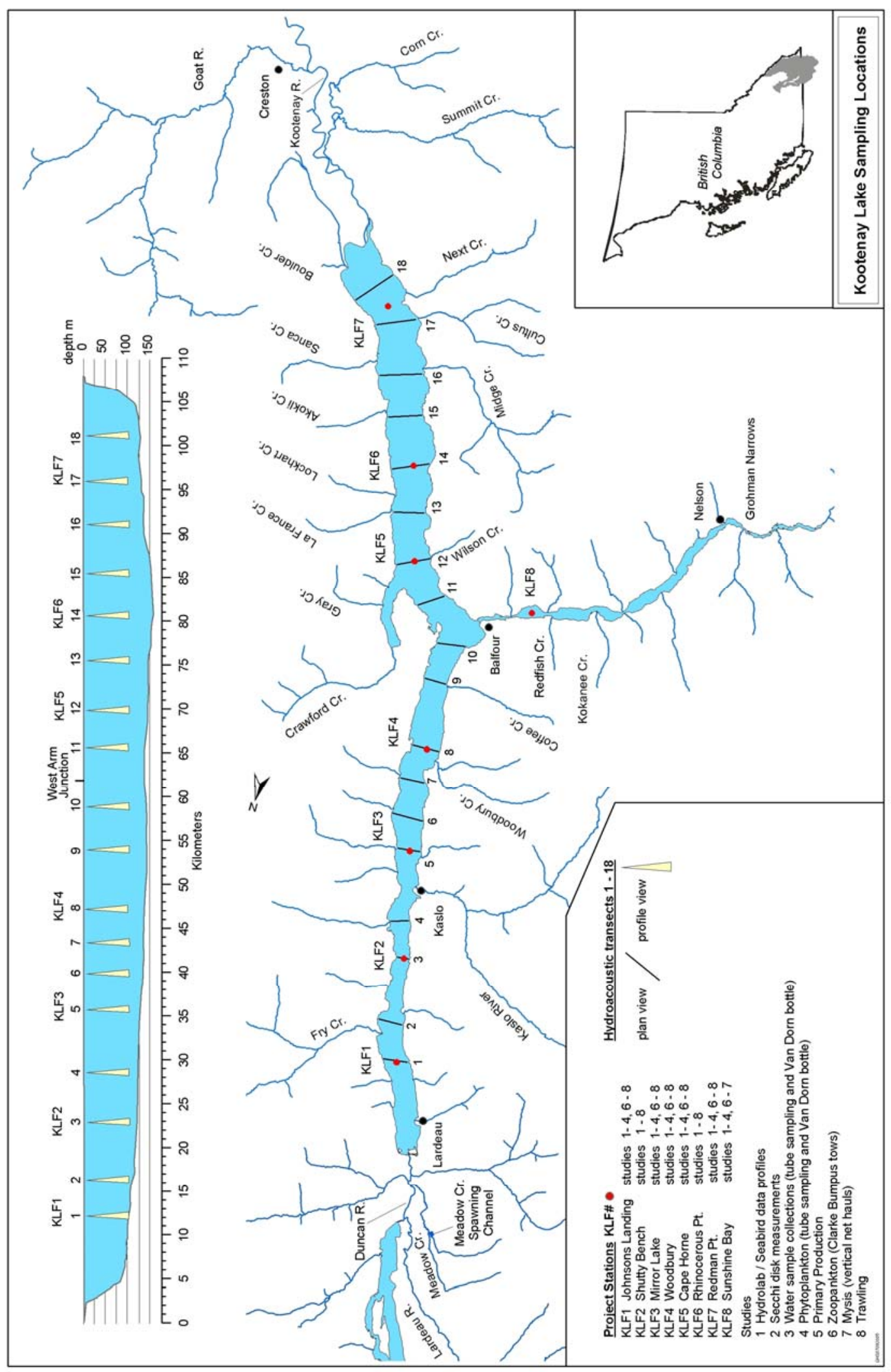

Figure 1.1 Kootenay Lake, British Columbia, sampling stations sites.

Kootenay Lake Fertilization Experiment, Year 15 (North Arm) and Year 3 (South Arm) 18 (2006) Report 


\title{
CHAPTER 2
}

FERTILIZER LOADING IN KOOTENAY LAKE, YEAR 15 (NORTH ARM) AND YEAR 3 (SOUTH ARM) (2006)

by

\author{
Eva U. Schindler \\ Ministry of Environment \\ Nelson, BC \\ and \\ Ken I. Ashley \\ Department of Civil Engineering, UBC \\ Vancouver, BC
}

Kootenay Lake Fertilization Experiment, Year 15 (North Arm) and Year 3 (South Arm) 


\section{Fertilizer type}

An agricultural grade liquid fertilizer blend of ammonium polyphosphate (10-34-0, N$\mathrm{P}_{2} \mathrm{O}_{5}-\mathrm{K}_{2} \mathrm{O}$; \% by weight) and urea-ammonium nitrate $\left(28-0-0, \quad \mathrm{~N}-\mathrm{P}_{2} \mathrm{O}_{5}-\mathrm{K}_{2} \mathrm{O}\right.$; \% by weight) was used for the fertilization experiment in the North Arm of Kootenay Lake. The total quantity of added fertilizer in 2006 was 44.6 tonnes of phosphorus and 248.7 tonnes of nitrogen. The nitrogen to phosphorus (N:P) ratio of the fertilizer varied throughout the season with a range from $0.67: 1$ in the spring to 11.8 in the late summer (Table 2.1). The amounts phosphorus and nitrogen added from 1992 to 2006 are listed in Table 2.2.

In 2003, an analysis of the nutrient gradient had compared the North Arm with the South Arm. The results indicated that there was no phosphorus gradient, but a decreasing nitrogen gradient was present from the North Arm to the South Arm. Therefore, a decision was made to add nitrogen alone to the South Arm during 2004 and 2005 and a similar decision was made for 2006. An agricultural grade of liquid urea-ammonium nitrate (28-0-0, N- $\mathrm{P}_{2} \mathrm{O}_{5}-\mathrm{K}_{2} \mathrm{O}$; \% by weight) was added to the South Arm once per week from June $12^{\text {th }}$ to September $10^{\text {th }}$ in 2006 , except for July $17^{\text {th }}$ where fertilizer additions did not occur due to logistical issues.

\section{Fertilizer application}

The nutrients were applied to the North Arm using a tug and barge, as in previous years. The barge was fitted with two tanks capable of carrying a total of 76 tonnes of fertilizer. The applications for the North Arm occurred at weekly intervals. Fertilizer was pumped through a flow meter before being discharged at the stern of the tug into the prop wash from the propeller (Ashley et al. 1999). The fertilizer is required to mix in with the prop wash as it is slightly heavier than water - the mixing ensure the nutrients are available in the photic zone of the lake. The area of application in the North Arm was between two kilometres north of transect 1 and four kilometres south of transect 2, a distance of $10 \mathrm{~km}$ (see Fig. 1.1 in Chapter 1 of this report).

The nutrients for the South Arm experiment were dispensed from the Western Pacific Marine/Ministry of Transportation and Highways MV Balfour ferry in 2006. Two fertilizer trucks each carrying 35 tonnes of fertilizer drove on to the ferry and the nutrients would be dispensed into the lake from the trucks to two dispensing bars located at the stern of the vessel into the prop wash of the ferry to ensure proper mixing. The area of application in the South Arm was between transects 12 and 15, a distance of $12.5 \mathrm{~km}$ (see Fig. 1.1 in Chapter 1 of this report). The method of application of fertilizer in the South Arm was similar to the North Arm where the load was distributed equally with one half released on the departing trip and one half on the return trip.

\section{Seasonal loading and timing}

The loading and timing of nutrient additions in the North Arm were designed to simulate the loading during spring freshet (pre-dam) conditions. Weekly loading rates of 
phosphorus decreased during the summer while nitrogen rates increased. This loading schedule was conducted as in previous years to adaptively manage for nitrogen consumption in the water column as the season progressed (Table 2.1, Fig 2.1). The total load of fertilizer distributed in 2006 in the North Arm was 44.7 tonnes of phosphorus and 248.7 tonnes of nitrogen.

Nitrogen additions to the South Arm of Kootenay Lake were maintained at a similar rate each week (Table 2.3, Fig. 2.2). The total load of fertilizer distributed in 2006 in the South Arm was 257 tonnes of nitrogen (276 tonnes was initially planned).

\section{Acknowledgements}

The Fish and Wildlife Compensation Program - Columbia Basin provided funding for the North Arm project and the Kootenai Tribe of Idaho provided funding for the South Arm project. Thanks to G. Veale Holdings Ltd for fertilizer dispensing in the North Arm and Western Pacific Marine (MV Balfour ferry) for fertilizer dispensing in the South Arm. Thanks to Greg Andrusak and Les Fleck for assisting with dispensing on the South Arm project. Thanks to the British Columbia Conservation Foundation for administering a portion of the Kootenai Tribe of Idaho funds.

\section{References}

Ashley, K., L.C. Thompson, D. Sebastian, D. C. Lasenby, K.E. Smokorowski, and H. Andrusak. 1999. Restoration of Kokanee salmon in Kootenay Lake, a large intermontane lake, by controlled seasonal application of limiting nutrients. Pages 127169 In: Murphy and Munawar, editors. Aquatic Restoration in Canada. 
Table 2.1. Kootenay Lake nutrient loading of fertilizer during 2006 - liquid ammonium polyphosphate (10-34-0) and liquid urea-ammonium nitrate (28-0-0).

\begin{tabular}{|c|c|c|c|c|c|c|c|c|}
\hline \multirow[b]{2}{*}{ Week } & \multirow[b]{2}{*}{ Date } & \multicolumn{3}{|c|}{ Phosphorus } & \multicolumn{3}{|c|}{ Nitrogen } & \multirow[b]{2}{*}{$\begin{array}{c}\mathrm{N}: \mathrm{P} \text { ratio } \\
\mathrm{wt}^{\mathrm{w}} \mathrm{wt}^{2}\end{array}$} \\
\hline & & $\begin{array}{l}\mathrm{Load} \\
\mathrm{mg} / \mathrm{m}^{2}\end{array}$ & $\begin{array}{l}\text { Amount } \\
\text { kgs }\end{array}$ & $\begin{array}{l}\text { 10-34-0 } \\
\text { Tonnes }\end{array}$ & $\begin{array}{l}\text { Load } \\
\mathrm{mg} / \mathrm{m}^{2}\end{array}$ & $\begin{array}{c}\text { Amount } \\
\text { kgs }\end{array}$ & $\begin{array}{c}\text { 28-0-0 } \\
\text { Tonnes }{ }^{1}\end{array}$ & \\
\hline 1 & Apr 23 & 7.5 & 1,307 & 8.8 & 5.1 & 880 & 0.0 & 0.67 \\
\hline 2 & Apr 30 & 7.5 & 1,307 & 8.8 & 5.1 & 880 & 0.0 & 0.67 \\
\hline 3 & May 07 & 12.8 & 2,227 & 15.0 & 8.6 & 1,500 & 0.0 & 0.67 \\
\hline 4 & May 14 & 16.2 & 2,821 & 19.0 & 10.9 & 1,900 & 0.0 & 0.67 \\
\hline 5 & May 21 & 18.7 & 3,252 & 21.9 & 56.4 & 9,792 & 27.2 & 3.0 \\
\hline 6 & May 28 & 22.5 & 3,905 & 26.3 & 68.0 & 11,814 & 32.8 & 3.0 \\
\hline 7 & Jun 04 & 22.5 & 3,905 & 26.3 & 68.0 & 11,814 & 32.8 & 3.0 \\
\hline 8 & Jun 11 & 18.7 & 3,252 & 21.9 & 84.5 & 14,678 & 44.6 & 4.5 \\
\hline 9 & Jun 18 & 15.0 & 2,598 & 17.5 & 67.6 & 11,746 & 35.7 & 4.5 \\
\hline 10 & Jun 25 & 12.8 & 2,227 & 15.0 & 79.6 & 13,820 & 44.0 & 6.2 \\
\hline 11 & Jul 02 & 0.0 & 0 & 0.0 & 0.0 & 0 & 0.0 & 0.0 \\
\hline 12 & Jul 09 & 13.7 & 2,376 & 16.0 & 106.0 & 18,400 & 60.0 & 7.7 \\
\hline 13 & Jul 16 & 14.2 & 2,465 & 16.6 & 104.7 & 18,180 & 59.0 & 7.4 \\
\hline 14 & Jul 23 & 13.7 & 2,376 & 16.0 & 105.5 & 18,316 & 59.7 & 7.7 \\
\hline 15 & Jul 30 & 9.8 & 1,707 & 11.5 & 110.6 & 19,210 & 64.5 & 11.3 \\
\hline 16 & Aug 06 & 9.8 & 1,707 & 11.5 & 110.6 & 19,210 & 64.5 & 11.3 \\
\hline 17 & Aug 13 & 4.7 & 817 & 5.5 & 55.6 & 9,650 & 32.5 & 11.8 \\
\hline 18 & Aug 20 & 4.7 & 817 & 5.5 & 55.6 & 9,650 & 32.5 & 11.8 \\
\hline 19 & Aug 27 & 9.4 & 1,633 & 11.0 & 111.2 & 19,300 & 65.0 & 11.8 \\
\hline 20 & Sep 03 & 9.4 & 1,633 & 11.0 & 111.1 & 19,294 & 65.0 & 11.8 \\
\hline 21 & Sep 11 & 13.7 & 2,376 & 16.0 & 106.0 & 18,400 & 60.0 & 7.7 \\
\hline
\end{tabular}

Table 2.2. Total tonnes of phosphorus and nitrogen dispensed into the North Arm of Kootenay Lake from liquid agricultural fertilizer, 1992 to 2006.

\begin{tabular}{ccc}
\hline Year & $\begin{array}{c}\text { Phosphorus } \\
\text { Tonnes }\end{array}$ & $\begin{array}{c}\text { Nitrogen } \\
\text { Tonnes }\end{array}$ \\
\hline $1992-1996$ & 47.1 & 206.7 \\
1997 & 29.5 & 111.6 \\
1998 & 22.9 & 92.9 \\
1999 & 22.9 & 92.9 \\
2000 & 29.5 & 111.6 \\
2001 & 47.1 & 206.7 \\
2002 & 47.1 & 206.7 \\
2003 & 47.1 & 240.8 \\
2004 & 37.6 & 243.5 \\
2005 & 44.1 & 246.9 \\
2006 & 44.7 & 248.4 \\
\hline
\end{tabular}


Table 2.3. Kootenay Lake South Arm nutrient loading of fertilizer during 2006 liquid urea ammonium nitrate (28-0-0).

\begin{tabular}{ccccc}
\hline \multirow{2}{*}{ Week } & Date & $\begin{array}{c}\text { Noad } \\
\mathrm{mg} / \mathrm{m}^{2}\end{array}$ & $\begin{array}{c}\text { Amount } \\
\text { kgs }\end{array}$ & $\begin{array}{c}\text { Fertilizer } \\
\text { 28-0-0 } \\
\text { Tonnes }\end{array}$ \\
\hline 1 & Jun 12 & 93.3 & 21,280 & 76.0 \\
2 & Jun 19 & 86.8 & 19,793 & 70.7 \\
3 & Jun 26 & 86.3 & 19,687 & 70.3 \\
4 & Jul 03 & 86.2 & 19,662 & 70.2 \\
5 & Jul 10 & 85.8 & 19,580 & 69.9 \\
6 & Jul 17 & 0.0 & 0 & 0.0 \\
7 & Jul 24 & 85.0 & 19,393 & 69.3 \\
8 & Jul 31 & 86.2 & 19,673 & 70.3 \\
9 & Aug 07 & 86.2 & 19,653 & 70.2 \\
10 & Aug 14 & 86.1 & 19,639 & 70.9 \\
11 & Aug 21 & 87.0 & 19,855 & 70.3 \\
12 & Aug 28 & 86.3 & 19,695 & 70.4 \\
13 & Sep 04 & 86.5 & 19,726 & 70.4 \\
\hline 14 & Sep 11 & 86.4 & 19,701 & \\
\hline
\end{tabular}

1 Tonnes refers to the amount of fertilizer added. 


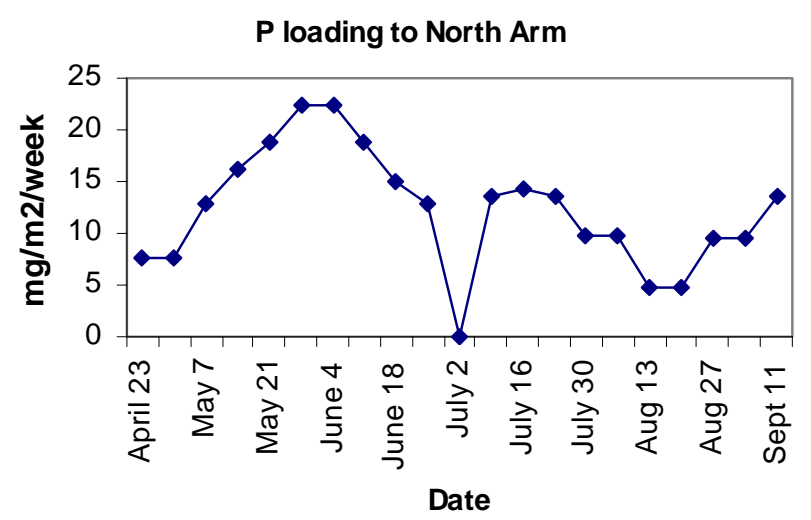

a)

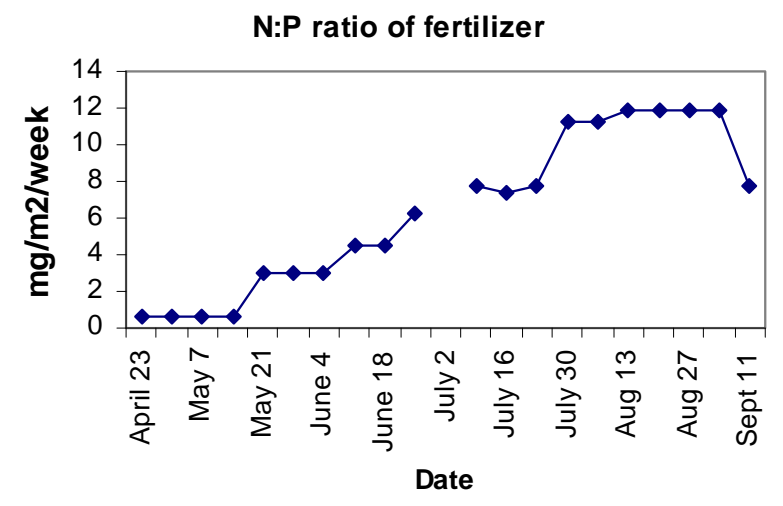

c)

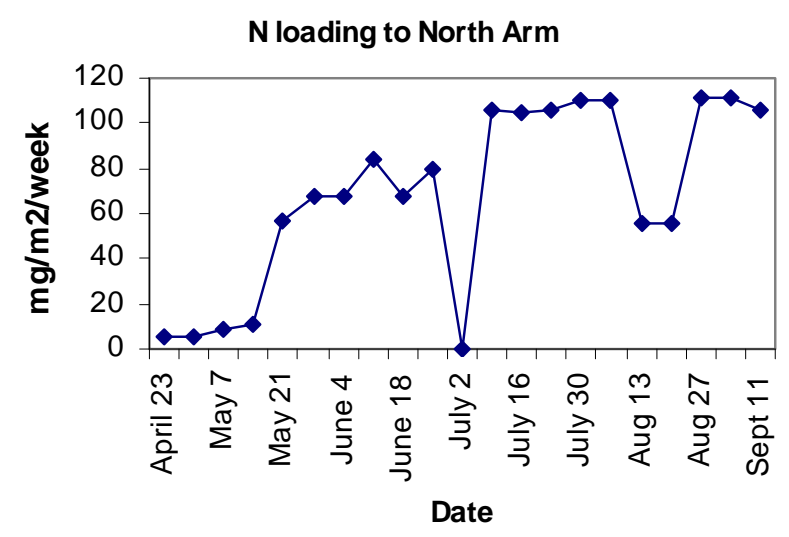

b)

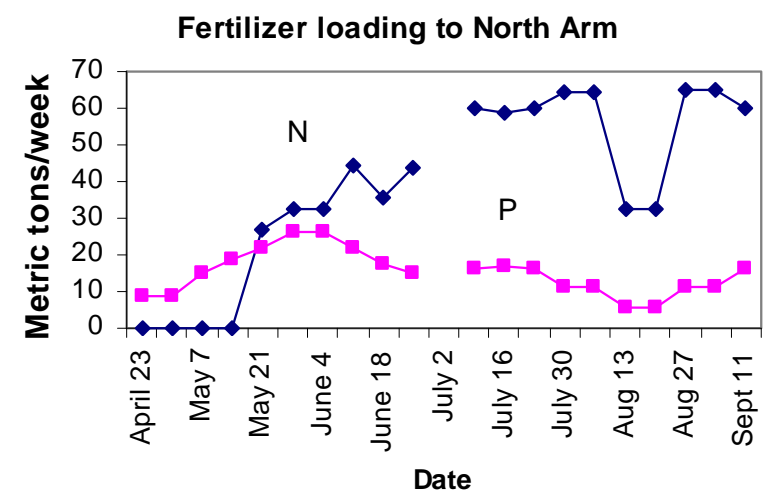

d)

Figure 2.1. Kootenay Lake nutrient loading in 2006 with weekly distributions of: a) phosphorus loading to the North Arm, b) nitrogen loading to the North Arm, c) the N:P ratio (wt:wt) of fertilizer dispensed, and d) the combined nutrient loading of fertilizer in tonnes per week. 

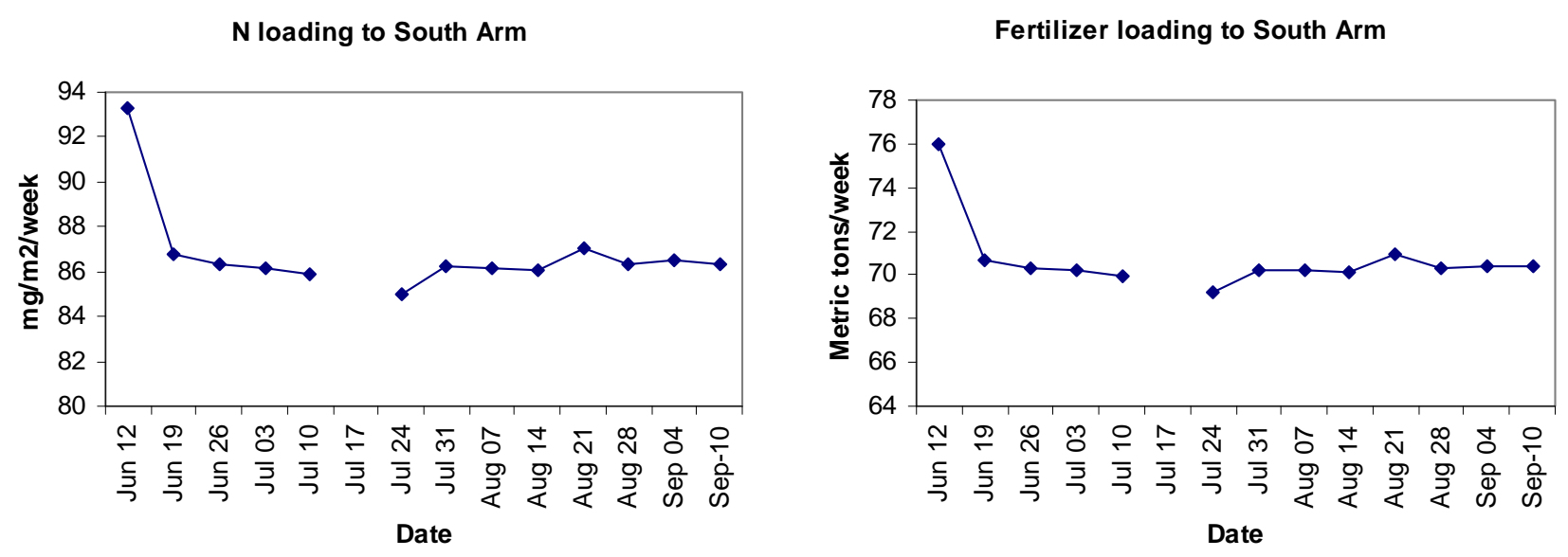

a)

b)

Figure 2.2. Kootenay Lake South Arm nutrient loading in 2006 with weekly distributions of nitrogen to the South Arm, a) $\mathrm{mg} / \mathrm{m}^{2} /$ week and b) tonnes of fertilizer per week.

Kootenay Lake Fertilization Experiment, Year 15 (North Arm) and Year 3 (South Arm) 
Kootenay Lake Fertilization Experiment, Year 15 (North Arm) and Year 3 (South Arm) 


\title{
CHAPTER 3
}

PHYSICAL AND CHEMICAL LIMNOLOGY OF KOOTENAY LAKE IN RESPONSE TO EXPERIMENTAL FERTILIZATION, YEAR 15 (NORTH ARM) AND YEAR 3 (SOUTH ARM) (2006)

\author{
by \\ Greg F. Andrusak \\ Redfish Consulting Ltd. \\ Nelson, BC \\ and \\ Eva U. Schindler \\ Ministry of Environment \\ Nelson, BC \\ and \\ Marley Bassett \\ Ministry of Environment \\ Nelson, BC
}




\section{Introduction}

Kootenay Lake experimental fertilization was initiated to stimulate a "bottom up" response within the lakes' trophic food chain and ultimately lead to the recovery of its fish populations. Lake fertilization has been used as a technique for enhancing and restoring primary and secondary productivity within many large lake systems throughout British Columbia and Alaska (Stockner and MacIsaac 1996, Mazumder and Edmundson 2002, Perrin et al. 2006). Monitoring the physical and chemical limnological processes within the lake are important metrics for the response of nutrient addition.

Nutrient losses, resulting from upstream hydro-electric impoundment in the late 60s and early 70s, caused Kootenay Lake to enter a phase of trophic depression (Ney 1996) which nearly caused the collapse of a keystone species, kokanee (Oncorhynchus nerka). Although stimulating primary productivity was expected to be the initial response, the main purpose of the experimental fertilization program was to recover declining kokanee and rainbow trout (Oncorhynchus mykiss) populations in Kootenay Lake (Ashley et al. 1997). Liquid nitrogen (N; as 28-0-0, N-P-K) and phosphorus (P; as 10-34-0) have been added to the North Arm of the lake during the growing season, annually, since 1992 (Schindler et al. 2007). As well, starting in 2004, nitrogen ( $\mathrm{N}$; as 28-0-0) has been added annually to the South Arm of the lake. In 2006, a total of 44.7 tonnes of phosphorus and 248.4 tonnes of nitrogen were dispensed into the North Arm, while 257.3 tonnes of nitrogen was added to the South Arm.

This report summarizes the physical and chemical limnology data collected on the North, South and West arms of Kootenay Lake in 2006. The physical limnology data include temperature, Secchi depth, turbidity, and conductivity. The chemical limnology data include phosphorus, nitrogen, silica, $\mathrm{pH}$, alkalinity, total organic carbon, and chlorophyll a. Seasonal averages from previous years are shown in the tables and discussed in relation to 2006 but are not included in graphs. Data from previous years can be found in earlier Kootenay Lake Fertilization Experiment annual reports (Wright et al. 2002; Schindler et al. 2006, 2007a, b).

\section{Methods}

Physical and chemical data were collected at pre-established Kootenay Lake Fertilization (KLF) sampling sites simultaneously with the collection of phytoplankton and zooplankton samples (Figure 1.1). Monthly sampling was conducted in January and from March to November for physical parameters and from April to November for chemical and biological samples. Physical, chemical, and biological data were collected for all eight stations in the lake (KLF 1-8) (Table 3.1).

Kootenay Lake Fertilization Experiment, Year 15 (North Arm) and Year 3 (South Arm) 28

(2006) Report 
Table 3.1. Kootenay Lake Fertilization Program limnological sampling sites.

\begin{tabular}{cclc}
\hline Site ID & EMS site no. & \multicolumn{1}{c}{ Site name } & Depth (m) \\
\hline KLF 1 & E216949 & Kootenay Lake at Johnson's Landing & 100 \\
KLF 2 & E216950 & Kootenay Lake at Kembell Creek & 120 \\
KLF 3 & E216951 & Kootenay Lake at Bjerkeness Creek & 120 \\
KLF 4 & E216952 & Kootenay Lake at Hendricks Creek & 135 \\
KLF 5 & E216953 & Kootenay Lake at Crawford Bay & 140 \\
KLF 6 & E216954 & Kootenay Lake at Rhinoceros Point & 150 \\
KLF 7 & E218832 & Kootenay Lake at Redman Point & 125 \\
KLF 8 & E252949 & Kootenay Lake - West Arm & 35 \\
\hline
\end{tabular}

\section{Physical Limnology}

Temperature and oxygen profiles were obtained using a SeaBird, SBE 19-plus profiler. At all stations, the profiler logged information every 10 centimetres from the surface to 5 $\mathrm{m}$ off the bottom.The Seabird probe also recorded oxygen, specific conductance and turbidity. These data are not shown in graphs or tables but are mentioned in the text. Conductivity analysis was also conducted by the water chemistry lab, and these data are graphed. Water transparency was measured at each station using a standard $20-\mathrm{cm}$ Secchi disk.

\section{Chemical Limnology}

Water samples were collected at KLF 1-7 over the course of the sampling season from both the epilimnion and the hypolimnion. Epilimnion samples were obtained from April to November using a 2.54-cm (inside diameter) tube sampler to collect an integrated water sample from $0-20 \mathrm{~m}$. The hypolimnion samples were obtained from May to October with a Van Dorn sampling bottle from a depth of $5 \mathrm{~m}$ off the bottom. A 0-20 m integrated sample was also collected at KLF 8 in the West Arm. The epilimnion integrated depth was changed from previous years because $20 \mathrm{~m}$ is more representative of the epilimnetic layer. The 30-m depth used previously sometimes penetrated the thermocline during the summer months. Also, the $20-\mathrm{m}$ depth is the same as the depth used to collect integrated samples for phytoplankton taxonomy.

Water samples were shipped within $24 \mathrm{~h}$ of collection to Maxxam Analytics, Inc. in Burnaby, B.C. Samples were analyzed for turbidity, conductivity, orthophosphate (OP), total phosphorus (TP), total dissolved phosphorus (TDP), total nitrogen (TN), dissolved inorganic nitrogen (DIN), silica, alkalinity, total organic carbon (TOC), and chlorophyll $a$ (Chl a) (epilimnion only). Prior to shipping to the lab, Chl $a$ samples were prepared by filtering a portion of the water sample through a filter with $0.45-\mu \mathrm{m}$ pore size. At the lab, the filters were placed in centrifuge tubes with $90 \%$ buffered acetone and were sonicated to rupture the algal cells and homogenize the filters. Chl $a$ concentrations were then calculated from formulae using the absorbance of the supernatant at specific wavelengths.

Kootenay Lake Fertilization Experiment, Year 15 (North Arm) and Year 3 (South Arm) 29 (2006) Report 
Additional water samples were taken at discrete depths in the epilimnion using a Van Dorn sampling bottle. Samples were obtained from depths of 2, 5, 10, 15, and $20 \mathrm{~m}$ for analysis at the lab (as above) of OP, TP, TDP, DIN, and Chl $a$ (Chl $a$ samples were collected for depths of 2-15 m). Samples were taken monthly from June to September at stations KLF 2, 6 and 7.

In this report, average measurements of integrated samples from the spring, summer, and fall of 1997 to 2006 are given for the North Arm (average of KLF 2 and 4) and the South Arm (average of KLF 6 and 7) of Kootenay Lake. Data from KLF 1, 3, 5 and 8 were not collected from 1997 to 2003 and, therefore, are not included in the long-term averages. Results from KLF 1, 3, 5 and 8 are presented in the figures at the end of this report. Detailed data and analysis for the 1997 to 2005 sampling seasons are available in previous annual reports. All data are on file at the BC Ministry of Environment office in Nelson, B.C.

\section{Results and Discussion}

\section{Physical Limnology}

\section{Temperature}

Kootenay Lake, a warm monomictic lake, is generally isothermal from late fall to early spring and stratified during the summer (Wetzel 2001). With the exception of the West Arm (KLF 8), this monomictic pattern was evident from the monthly temperature profiles for both the North and South arms in 2006 (Figs 3.1-3.8). However, the morphology of the West Arm of Kootenay Lake is very different from the main basin of the lake, with physical and chemical limnology similar to that of the epilimnion of the main lake (Daley et al. 1981). Throughout the winter and early spring (December-April), the lake was essentially isothermal, $3-6^{\circ} \mathrm{C}$ from surface to bottom. However, as early as April, surface temperatures were reaching $8-9^{\circ} \mathrm{C}$ at KLF 1 and KLF 8 in 2006. By late spring and early summer (June-July) a general warming trend was evident with surface temperatures reaching $10-20^{\circ} \mathrm{C}$ for both the North and South arms, developing a thermocline at 20 to $30 \mathrm{~m}$, which continued until October. Fall turnover was beginning to develop by November with an apparent deepening of the thermocline.

A maximum surface temperature of $20.8^{\circ} \mathrm{C}$ was recorded in July in the North Arm (KLF 4) and in the South Arm (KLF 6) when the lake was highly stratified. During the same time, hypolimnetic temperatures remained $4-6^{\circ} \mathrm{C}$ throughout both of these arms. Although the West Arm remained isothermal throughout the year, due to its riverine morphology, a maximum surface temperature of $19.8^{\circ} \mathrm{C}$ was recorded in August in 2006 (Table 3.2).

Kootenay Lake Fertilization Experiment, Year 15 (North Arm) and Year 3 (South Arm) 
Table 3.2. Seasonal mean ( \pm standard deviation), maximum, and minimum temperatures in the West Arm (KLF 8) taken at 0-35 m depths, 2006.

\begin{tabular}{ccccc}
\hline Season & Mean & +SD & Maximum & Minimum \\
\hline Winter & 4.4 & 0.5 & 6.2 & 4.0 \\
Spring & 8.3 & 2.5 & 11.2 & 5.2 \\
Summer & 16.5 & 1.8 & 19.8 & 14.0 \\
Fall & 12.5 & 2.6 & 15.5 & 10.2 \\
\hline
\end{tabular}

Spatial and temporal differences in stratification between the North and the South arms exist due to variation in temperature and discharge regimes from the Duncan/Lardeau and Kootenay rivers which are controlled by upstream reservoirs. Surface flow inputs are probably the most important sources affecting water quality conditions of this large lake system (Northcote et al. 1999). The Kootenay and Duncan rivers comprise 56\% and 21\% of the total inflow to Kootenay Lake, respectively (Binsted and Ashley 2006). Moreover, differences in the thermal structure of the North and South arms are also caused by many complex interactions of surface-driven processes (wind and heat exchange) and internal wave dynamics within Kootenay Lake (Northcote et al. 1999).

\section{Dissolved Oxygen}

Results of oxygen profiles were similar to previous years. Kootenay Lake is well oxygenated from the surface to the bottom depths at each station (data on file at the Ministry of Environment).

\section{Secchi Depth}

In 2006, Secchi depths varied seasonally from summer to winter from $4.3 \mathrm{~m}$ to $14.9 \mathrm{~m}$ in the North Arm, $2.7 \mathrm{~m}$ to $14.9 \mathrm{~m}$ in the South Arm, and $3.6 \mathrm{~m}$ to $12.5 \mathrm{~m}$ in the West Arm (Fig 3.9). Secchi measurements evaluate the transparency of water to light and can serve as a general indicator of productivity (Wetzel 2001). Similar to past years, Secchi disc measurements at all stations on Kootenay Lake in 2006 indicate a typical seasonal pattern of decreasing depths associated with the spring phytoplankton bloom, followed by increasing depths as the bloom gradually abates by the late summer and fall.

Since 1997, average Secchi depths have shown a gradual increase in transparency for the spring and fall seasons in both the North and South arms (Table 3.3). On the other hand, average Secchi depths have remained relatively consistent throughout the summer since 1997. In general, many dynamic and complex interactions can account for the annual variation in Secchi depths within Kootenay Lake.

Kootenay Lake Fertilization Experiment, Year 15 (North Arm) and Year 3 (South Arm) 
Table 3.3. Average Secchi depth (m) in spring (April-June), summer (JulySeptember), and fall (October - November) for the North and South arms of Kootenay Lake, 1997-2006*.

\begin{tabular}{ccccccc}
\hline \multirow{2}{*}{ Year } & \multicolumn{3}{c}{$\begin{array}{c}\text { North Arm } \\
\text { KLF 2 \& 4 }\end{array}$} & & \multicolumn{3}{c}{$\begin{array}{c}\text { South Arm } \\
\text { KLF 6 \& 7 }\end{array}$} \\
\cline { 2 - 7 } & Spring & Summer & Fall & Spring & Summer & Fall \\
\hline 1997 & 4.8 & 5.6 & 8.4 & 3.1 & 5.1 & 7.6 \\
1998 & 6.6 & 7.6 & 6.7 & 5.2 & 7.5 & 7.5 \\
1999 & 7.3 & 5.2 & 9.0 & 6.2 & 5.6 & 8.2 \\
2000 & 6.4 & 6.0 & 7.3 & 6.4 & 6.5 & 9.6 \\
2001 & 8.0 & 6.5 & 10.1 & 7.2 & 7.4 & 8.7 \\
2002 & 9.4 & 5.8 & 7.9 & 6.6 & 5.5 & 4.7 \\
2003 & 8.8 & 6.4 & 7.7 & 7.7 & 6.0 & 9.1 \\
2004 & 9.1 & 6.4 & 8.1 & 6.8 & 7.0 & 9.8 \\
2005 & 9.0 & 6.3 & 9.2 & 8.5 & 6.8 & 10.1 \\
2006 & 9.6 & 5.9 & 11.4 & 7.3 & 6.5 & 11.5 \\
\hline${ }^{*}$ Prior to 2003, fall data were for October only. & & & & &
\end{tabular}

\section{Turbidity}

Turbidity $(0-20 \mathrm{~m})$, a measure of suspended particles, indicated a general increase during the spring following the freshet and then a decline through the summer and into the fall in 2006 (Fig 3.10). This trend, similar to that demonstrated by the Secchi disc measurements, was more evident in the South Arm compared to the North Arm in 2006. Turbidity in the South Arm peaked by June compared to the peak in the North Arm which occurred by July. However, a high of 1.7 NTU was measured in the North Arm (KLF 1) in July, while a high of 1.3 NTU was recorded in the South Arm in June (KLF 6 \& 7). Hypolimnetic sampling indicated that turbidity was fairly consistent throughout the year , ranging from 0.2-0.4 NTU for both the North and South arms of Kootenay Lake in 2006 (Fig 3.11).

In the period 1997-2006, average turbidity values ranged from 0.29-0.99 NTU in the North Arm and 0.25-1.80 NTU in the South Arm (Table 3.4). The increase in inorganic particulates is most likely associated with freshet conditions occurring annually from May to July. In addition, turbidity tends to be higher in reservoirs than in natural lakes (Wetzel 2001), major tributary flow regimes regulated by upstream dams have a substantial impact upon turbidity trends in Kootenay Lake.

Kootenay Lake Fertilization Experiment, Year 15 (North Arm) and Year 3 (South Arm) 32 (2006) Report 
Table 3.4. Average turbidity (NTU) from $0-30 \mathrm{~m}$ in spring (April-June), summer (July-September), and fall (October-November) for the North and South arms of Kootenay Lake, 1997-2006*.

\begin{tabular}{ccccccc}
\hline \multirow{2}{*}{ Year } & \multicolumn{3}{c}{$\begin{array}{c}\text { North Arm } \\
\text { KLF 2 \& 4 }\end{array}$} & \multicolumn{3}{c}{$\begin{array}{c}\text { South Arm } \\
\text { KLF 6 \& 7 }\end{array}$} \\
\cline { 2 - 7 } & Spring & Summer & Fall & Spring & Summer & Fall \\
\hline 1997 & 0.65 & 0.65 & 0.36 & 1.80 & 0.66 & 0.43 \\
1998 & 0.46 & 0.72 & 0.44 & 0.74 & 0.39 & 0.25 \\
1999 & 0.61 & 0.72 & 0.39 & 0.83 & 0.57 & 0.36 \\
2000 & 0.42 & 0.47 & 0.55 & 0.69 & 0.41 & 0.25 \\
2001 & 0.29 & 0.60 & 0.35 & 0.29 & 0.40 & 0.36 \\
2002 & 0.61 & 0.99 & 0.42 & 0.96 & 0.73 & 0.48 \\
2003 & 0.35 & 0.62 & 0.41 & 0.50 & 0.66 & 0.42 \\
2004 & 0.33 & 0.74 & 0.35 & 0.37 & 0.73 & 0.31 \\
2005 & 0.42 & 0.62 & 0.25 & 0.35 & 0.64 & 0.27 \\
2006 & 0.50 & 0.80 & 0.33 & 0.80 & 0.75 & 0.23 \\
\hline *Prior to 2003, fall data were for October only. The 2004-2006 data were collected from 0-20 m.
\end{tabular}

\section{Conductivity}

Conductivity or specific conductance, is a measure of resistance of a solution to electrical flow (Wetzel 2001). Results from integrated samples $(0-20 \mathrm{~m})$ ranged from 122-167 $\mu \mathrm{mhos} / \mathrm{cm}$ in the North Arm, from 143-188 $\mu \mathrm{mhos} / \mathrm{cm}$ in the South Arm, and from 141$167 \mu \mathrm{S} / \mathrm{cm}$ in the West Arm in 2006 (Figure 3.12). Hypolimnetic conductivity samples (May-October) were less variable ranging from 173-186 $\mu \mathrm{S} / \mathrm{cm}$ in the North Arm and 171-195 $\mu$ S/cm in the South Arm (Figure 3.13).

In the period 1997-2006, average conductivity values ranged from 92-163 $\mu \mathrm{mhos} / \mathrm{cm}$ in the North Arm and 133-183 $\mu \mathrm{mhos} / \mathrm{cm}$ in the South Arm over the various seasons measured (Table 3.4). Interestingly, the pattern of the South Arm having higher conductivity compared to the North Arm is consistent to that reported in Northcote et al. (1999) and Daley et al. (1981), while the West Arm water was considered intermediate. Importantly, the differences between the North and South arms are attributed to the specific geology of the two major basins that flow into Kootenay Lake.

Kootenay Lake Fertilization Experiment, Year 15 (North Arm) and Year 3 (South Arm) 
Table 3.5. Average conductivity $(\mu \mathrm{S} / \mathrm{cm})$ from $0-30 \mathrm{~m}$ in spring (April-June), summer (July-September), and fall (October - November) for the North and South arms of Kootenay Lake, 1997-2006*.

\begin{tabular}{ccccccc}
\hline \multirow{2}{*}{ Year } & \multicolumn{3}{c}{$\begin{array}{c}\text { North Arm } \\
\text { KLF 2 \& 4 }\end{array}$} & \multicolumn{3}{c}{$\begin{array}{c}\text { South Arm } \\
\text { KLF 6 \& 7 }\end{array}$} \\
\cline { 2 - 7 } & Spring & Summer & Fall & Spring & Summer & Fall \\
\hline 1997 & 163 & 143 & 152 & 165 & 161 & 173 \\
1998 & 153 & 146 & 148 & 164 & 169 & 176 \\
1999 & 162 & 135 & 106 & 183 & 144 & 133 \\
2000 & 92 & 132 & 134 & 146 & 153 & 159 \\
2001 & & 142 & 134 & & 162 & 167 \\
2002 & 155 & 125 & 127 & 151 & 157 & 150 \\
2003 & 154 & 135 & 127 & 159 & 153 & 153 \\
2004 & 147 & 140 & 144 & 148 & 169 & 169 \\
2005 & 155 & 133 & 156 & 164 & 178 & 180 \\
2006 & 152 & 136 & 156 & 163 & 178 & 183 \\
\hline *Prior to 2003, fall data were for October only. The 2004-2006 data were collected from 0-20 m.
\end{tabular}

\section{Chemical Limnology}

\section{Integrated Sampling}

\section{Phosphorus}

Total phosphorus (TP) samples, composed of mainly organic particulate phosphorus, taken at 0-20 m ranged from 2-5 $\mu \mathrm{g} / \mathrm{L}$ in the North Arm, 2-7 $\mu \mathrm{g} / \mathrm{L}$ in the South Arm, and $2-5 \mu \mathrm{g} / \mathrm{L}$ in the West Arm (Figure 3.14). Overall, the South Arm stations indicated higher TP concentrations compared to the North and West arms. No seasonal trend in epilimnetic TP was apparent in any of the arms in Kootenay Lake in 2006. Similarly, hypolimnetic samples (May-October) remained consistent, ranging from 2-4 $\mu \mathrm{g} / \mathrm{L}$ in the North Arm and 2-5 $\mu \mathrm{g} / \mathrm{L}$ in the South arm (Fig 3.15).

Kootenay Lake, an oligotrophic to oligo-mesotrophic lake, is generally considered a fairly unproductive lake with an average TP ranging from 3-10 $\mu \mathrm{g} / \mathrm{L}$ (Wetzel 2001). With a few exceptions since 1997, TP measurements generally have not exceeded $10 \mu \mathrm{g} / \mathrm{L}$ (Table 3.6). In fact, TP has gradually declined in both the North and South arms of Kootenay Lake over this 10 year period. This occurrence is most likely associated with the biological uptake of phosphorus, which is the least abundant nutrient and most commonly limits productivity. In addition to the inputs from artificial nutrient addition, the Duncan/Lardeau and Kootenay rivers are the most important sources of total phosphorus to Kootenay Lake. Binsted and Ashley (2006) have given a detailed overview of phosphorus loadings to Kootenay Lake from these two major rivers.

Kootenay Lake Fertilization Experiment, Year 15 (North Arm) and Year 3 (South Arm) 34 (2006) Report 
Table 3.6. Average total phosphorus (TP; $\mu \mathrm{g} / \mathrm{L}$ ) from $0-30 \mathrm{~m}$ in spring (April-June), summer (July-September), and fall (October - November) for the North and South arms of Kootenay Lake, 1997-2006*.

\begin{tabular}{ccccccc}
\hline \multirow{2}{*}{ Year } & \multicolumn{3}{c}{$\begin{array}{c}\text { North Arm } \\
\text { KLF 2 \& 4 }\end{array}$} & \multicolumn{3}{c}{$\begin{array}{c}\text { South Arm } \\
\text { KLF 6 \& 7 }\end{array}$} \\
\cline { 2 - 7 } & Spring & Summer & Fall & Spring & Summer & Fall \\
\hline 1997 & 14.0 & 10.5 & 5.0 & 22.2 & 8.8 & 6.0 \\
1998 & 4.3 & 7.0 & 4.5 & 5.0 & 6.8 & 5.5 \\
1999 & 4.8 & 5.5 & 4.5 & 6.2 & 5.3 & 6.5 \\
2000 & 5.0 & 10.0 & 7.5 & 5.8 & 9.2 & 7.5 \\
2001 & 7.7 & 6.0 & 3.0 & 3.5 & 4.8 & 2.5 \\
2002 & 6.3 & 3.8 & 5.5 & 7.8 & 5.2 & 3.5 \\
2003 & 3.5 & 5.0 & 7.8 & 4.3 & 4.5 & 4.0 \\
2004 & 3.5 & 3.0 & 5.5 & 2.7 & 3.3 & 5.8 \\
2005 & 3.8 & 2.8 & 2.0 & 3.0 & 2.7 & 2.0 \\
2006 & 3.2 & 3.0 & 2.0 & 2.8 & 3.2 & 2.3 \\
\hline *rior to 2003, fall data were for October only. The 2004-2006 data were collected from 0-20 m.
\end{tabular}

Total dissolved phosphorus (TDP) from samples taken at 0-20 m ranged from 2-7 $\mu \mathrm{g} / \mathrm{L}$ in the North Arm, 2-5 $\mu \mathrm{g} / \mathrm{L}$ in the South Arm, and 2-3 $\mu \mathrm{g} / \mathrm{L}$ in the West Arm (Fig 3.16). Except for a measurement of $7 \mu \mathrm{g} / \mathrm{L}$ in November (KLF4), both the North and South arms had remarkably similar trends in seasonal TDP. This trend of higher TDP ( 5 $\mu \mathrm{g} / \mathrm{L})$ values in the early spring, followed by a sharp decline is most likely associated with the rapid biological utilization of TDP coinciding with spring algal production in the epilimnion.. Hypolimnetic TDP (May-October) ranged from 2-6 $\mu \mathrm{g} / \mathrm{L}$ in both the North and South arms (Fig 3.17).

In a seasonal comparison since1997, epilimnetic TDP has remained consistently low, ranging from 2-8 $\mu \mathrm{g} / \mathrm{L}$ (Table 3.7). In addition, due to the oligotrophic nature of Kootenay Lake, little variation in phosphorus concentration occured between comparable seasons. Overall, TP and TDP concentrations are low in Kootenay Lake as result of the limited availability and its rapid biological utilization.

Kootenay Lake Fertilization Experiment, Year 15 (North Arm) and Year 3 (South Arm) 35 (2006) Report 
Table 3.7. Average total dissolved phosphorus (TDP; $\mu \mathrm{g} / \mathrm{L}$ ) from 0-30 $\mathrm{m}$ in spring (April-June), summer (July-September), and fall (October-November) for the North and South arms of Kootenay Lake, 1997-2006*.

\begin{tabular}{ccccccc}
\hline \multirow{2}{*}{ Year } & \multicolumn{3}{c}{$\begin{array}{c}\text { North Arm } \\
\text { KLF 2 \& 4 }\end{array}$} & \multicolumn{3}{c}{$\begin{array}{c}\text { South Arm } \\
\text { KLF 6 \& 7 }\end{array}$} \\
\cline { 2 - 7 } & Spring & Summer & Fall & Spring & Summer & Fall \\
\hline 1997 & 4.3 & 3.5 & 4.0 & 8.0 & 4.3 & 3.0 \\
1998 & 2.7 & 2.0 & 2.0 & 3.3 & 2.0 & 2.0 \\
1999 & 2.8 & 2.3 & 2.5 & 3.0 & 2.3 & 2.5 \\
2000 & 2.0 & 3.5 & 4.0 & 2.5 & 5.0 & 4.5 \\
2001 & 3.5 & 2.0 & 2.0 & 2.2 & 2.7 & 2.5 \\
2002 & 4.0 & 2.8 & 4.0 & 4.0 & 4.0 & 3.0 \\
2003 & 2.8 & 2.5 & 3.5 & 3.2 & 3.3 & 4.8 \\
2004 & 2.2 & 2.2 & 4.8 & 2.0 & 3.0 & 2.8 \\
2005 & 2.5 & 2.2 & 2.5 & 2.3 & 2.3 & 2.0 \\
2006 & 2.5 & 2.5 & 3.2 & 2.8 & 2.5 & 2.0 \\
\hline *rior to 2003, fall data were for October only. The 2004-2006 data were collected from 0-20 m.
\end{tabular}

\section{Nitrogen}

The nitrogen cycle within freshwaters is highly complex and occurs through various forms of fixation, assimilation, and reduction (Wetzel 2001). In fresh water, complex biochemical processes utilize nitrogen in many forms consisting of dissolved molecular $\mathrm{N}_{2}$, ammonia nitrogen, nitrite, nitrate, and organic nitrogen.

Total nitrogen (TN) from samples taken at 0-20 m ranged from 120-270 $\mu \mathrm{g} / \mathrm{L}$ in all three arms (North, South, and West) of Kootenay Lake in 2006 (Fig 3.18). Moreover, all three arms indicated a similar trend of declining TN from spring to fall followed by an increase in early winter. The pattern of declining $\mathrm{TN}$ from spring to fall reflects biological utilization of nitrogen through the growing season, most evident within the epilimnion of the lake. For both the North and South arms, hypolimnetic TN samples ranged from 210$290 \mu \mathrm{g} / \mathrm{L}$ in Kootenay Lake in 2006 (Fig. 3.19). Within both arms, most stations showed slight declines in hypolimnetic TN from May to August followed by a slight increase from August to September. However, TN concentrations at KLF 2 and KLF 7 continued to decline into late summer and fall.

In comparison, average seasonal TN values have ranged from 125-343 $\mu \mathrm{g} / \mathrm{L}$ in the North Arm and 90-235 $\mu \mathrm{g} / \mathrm{L}$ in the South Arm since1997 (Table 3.8). Seasonal averages in 2006 were higher compared to 2005, with the exception of the North Arm summer average $(142 \mu \mathrm{g} / \mathrm{L})$ which was the lowest recorded since 1997.

Kootenay Lake Fertilization Experiment, Year 15 (North Arm) and Year 3 (South Arm) 36 (2006) Report 
Table 3.8. Average total nitrogen ( $\mathrm{TN} ; \mu \mathrm{g} / \mathrm{L})$ from $0-30 \mathrm{~m}$ in spring (April-June), summer (July-September), and fall (October-November) for the North and South arms of Kootenay Lake, 1997-2006*.

\begin{tabular}{ccccccc}
\hline \multirow{2}{*}{ Year } & \multicolumn{3}{c}{$\begin{array}{c}\text { North Arm } \\
\text { KLF 2 \& 4 }\end{array}$} & \multicolumn{3}{c}{$\begin{array}{c}\text { South Arm } \\
\text { KLF 6 \& 7 }\end{array}$} \\
\cline { 2 - 7 } & Spring & Summer & Fall & Spring & Summer & Fall \\
\hline 1997 & 218 & 143 & 130 & 212 & 130 & 125 \\
1998 & 225 & 192 & 135 & 227 & 187 & 150 \\
1999 & 220 & 190 & 275 & 228 & 180 & 220 \\
2000 & 213 & & & 177 & & \\
2001 & 343 & 167 & 145 & 215 & 163 & 105 \\
2002 & 200 & 177 & 175 & 210 & 180 & 235 \\
2003 & 182 & 302 & 125 & 177 & 155 & 90 \\
2004 & 180 & 148 & 148 & 167 & 127 & 178 \\
2005 & 180 & 152 & 145 & 163 & 130 & 145 \\
2006 & 223 & 142 & 163 & 232 & 153 & 180 \\
\hline *Prior to 2003, fall data were for October only. The 2004-2006 data were collected from 0-20 m.
\end{tabular}

Dissolved inorganic nitrogen (DIN), consisting of nitrate, nitrite, and ammonia, are the most common inorganic forms of nitrogen in freshwater. In the absence of anthropogenic sources, concentrations are usually low because ammonia is quickly converted to nitrite and then to nitrate by nitrifying bacteria (Wetzel 2001). Moreover, nitrate and ammonia levels can be severely reduced or depleted by photosynthetic assimilation and can be considered a growth limiting nutrient under certain conditions.

Dissolved inorganic nitrogen (DIN) from samples taken at 0-20 m ranged from 30-153 $\mu \mathrm{g} / \mathrm{L}$ in the North Arm, 44-160 $\mu \mathrm{g} / \mathrm{L}$ in the South Arm, and 37-148 $\mu \mathrm{g} / \mathrm{L}$ in the West Arm (Fig 3.20).

Similar to TN, all three arms indicated a similar trend of declining DIN from spring to fall followed by an increase in early winter. This pattern coincides with the seasonal growth of phytoplankton and biological utilization of nitrogen in the epilimnion. Hypolimnetic DIN samples remained stable throughout the season, ranging from 159-237 $\mu \mathrm{g} / \mathrm{L}$ for both arms (Fig 3.21).

In comparison, the range of DIN concentrations have been 32-157 $\mu \mathrm{g} / \mathrm{L}$ in the North Arm and 32-145 $\mu \mathrm{g} / \mathrm{L}$ in the South Arm since 1997 (Table 3.9). A general pattern of declining DIN concentrations from spring to summer is evident. Importantly, this pattern coincides with the natural influx of nutrients associated with freshet conditions and the anthropogenic influx of nutrients from lake fertilization. Variability in the spring concentrations of DIN can be directly attributed to climatic influences such as; precipitation, snow pack and seasonal timing of the run-off.

Kootenay Lake Fertilization Experiment, Year 15 (North Arm) and Year 3 (South Arm) 37 (2006) Report 
Table 3.9. $\quad$ Average dissolved inorganic nitrogen (DIN; $\mu \mathrm{g} / \mathrm{L}$ ) from $0-30 \mathrm{~m}$ in spring (April-June), summer (July-September), and fall (October-November) for the North and South arms of Kootenay Lake, 1997-2006*.

\begin{tabular}{ccccccc}
\hline \multirow{2}{*}{ Year } & \multicolumn{3}{c}{$\begin{array}{c}\text { North Arm } \\
\text { KLF 2 \& 4 }\end{array}$} & \multicolumn{3}{c}{$\begin{array}{c}\text { South Arm } \\
\text { KLF 6 \& 7 }\end{array}$} \\
\cline { 2 - 7 } & Spring & Summer & Fall & Spring & Summer & Fall \\
\hline 1997 & 118 & 89 & 70 & 113 & 64 & 62 \\
1998 & 120 & 75 & 32 & 123 & 83 & 86 \\
1999 & 147 & 94 & 90 & 130 & 80 & 77 \\
2000 & 174 & 96 & 71 & 173 & 68 & 68 \\
2001 & 157 & 82 & 69 & 145 & 83 & 57 \\
2002 & 133 & 75 & 58 & 108 & 44 & 57 \\
2003 & 108 & 50 & 67 & 114 & 71 & 63 \\
2004 & 118 & 53 & 58 & 100 & 42 & 83 \\
2005 & 109 & 42 & 78 & 113 & 32 & 85 \\
2006 & 117 & 60 & 89 & 118 & 82 & 100 \\
\hline *rior to 2003, fall data were for October only. The 2004-2006 data were collected from 0-20 m. & &
\end{tabular}

Note: data for spring 2000 in this table in previous reports was calculated incorrectly.

\section{Silica}

Silica is an integral structural component in diatomaceous algae and is considered a major factor influencing algal production in many lakes (Wetzel 2001). Moreover, silica can have a strong influence on the succession and productivity of algal communities in lakes and streams. As a result, silica can be considered a limiting factor in diatom production when its availability is low. Silica occurs primarily in two major forms: dissolved silicic acid and particulate silica.

Dissolved reactive silica from samples taken at 0-20 m ranged from 2.1-7.8 $\mathrm{mg} / \mathrm{L}$ in the North Arm and 2.7-8.6 mg/L for both the South and West arms (Fig 3.22). Declining silica concentrations from spring to summer-fall were observed for all three arms of Kootenay Lake in 2006. This pattern is associated with the biological utilization of silica during the diatom bloom that generally peaks by late spring. Hypolimnetic silica was highest in May and then remained fairly constant for the remainder of the season in the North and South arms. Results ranged from 4.6-9.3 mg/L and 6.4-9.9 mg/L, in the North and South arms, respectively (Fig 3.23).

In general, silica tends to display little variation in natural waters around the world compared to other inorganic constituents (Wetzel 2001). Since 1997, silica concentrations on Kootenay Lake have tended to be fairly constant in both arms while displaying a declining seasonal trend from spring to fall (Table 3.10).

Kootenay Lake Fertilization Experiment, Year 15 (North Arm) and Year 3 (South Arm) 38 (2006) Report 
Table 3.10. Average silica (mg/L) from 0-30 $\mathrm{m}$ in spring (April-June), summer (JulySeptember), and fall (October-November) for the North and South arms of Kootenay Lake, 1997-2006*.

\begin{tabular}{ccccccc}
\hline \multirow{2}{*}{ Year } & \multicolumn{3}{c}{$\begin{array}{c}\text { North Arm } \\
\text { KLF 2 \& 4 }\end{array}$} & \multicolumn{3}{c}{$\begin{array}{c}\text { South Arm } \\
\text { KLF 6 \& 7 }\end{array}$} \\
\cline { 2 - 7 } & Spring & Summer & Fall & Spring & Summer & Fall \\
\hline 1997 & 4.8 & 4.0 & 3.5 & 6.8 & 5.1 & 4.3 \\
1998 & 4.9 & 4.2 & 3.5 & 6.3 & 5.3 & 4.7 \\
1999 & 5.1 & 5.0 & 4.2 & 6.1 & 4.1 & 4.9 \\
2000 & 5.4 & 4.4 & 3.3 & 6.4 & 5.4 & 4.3 \\
2001 & 5.4 & 3.4 & 2.2 & 5.5 & 4.6 & 3.5 \\
2002 & 5.2 & 3.5 & 4.0 & 6.0 & 4.2 & 4.7 \\
2003 & 5.3 & 3.3 & 3.2 & 5.6 & 4.5 & 4.0 \\
2004 & 4.8 & 4.2 & 3.7 & 5.7 & 4.7 & 5.0 \\
2005 & 6.2 & 4.6 & 5.8 & 6.6 & 4.5 & 6.3 \\
2006 & 6.7 & 4.5 & 4.1 & 7.5 & 5.8 & 4.6 \\
\hline *rior to 2003, fall data were for October only. The 2004-2006 data were collected from 0-20 m.
\end{tabular}

\section{Alkalinity and $\mathrm{pH}$}

Alkalinity and $\mathrm{pH}$ are measures of the buffering capacity and acidity, respectively, of natural waters often associated with limnological processes. Alkalinity, which differs from an alkaline $\mathrm{pH}$, is the buffering capacity of lake water to resist $\mathrm{pH}$ changes and involves the inorganic carbon components in most fresh waters (Wetzel 2001). Moreover natural waters have a wide variation in acidity and alkalinity, often regulating many chemical processes.

In 2006, $\mathrm{pH}$ indicated slightly alkaline conditions, ranging from 7.2-8.2 for all stations sampled on Kootenay Lake in 2006. The epilimnetic $(0-20 \mathrm{~m})$ results decreased from April to May and then increased through the summer (Fig 3.24). The hypolimnetic (>50 $\mathrm{m}$ ) results increased from spring to summer (Fig. 3.25).

Alkalinity from samples taken at $0-20 \mathrm{~m}$ ranged from $51.5-74.4 \mathrm{mg} \mathrm{CaCO}_{3} / \mathrm{L}$ in the North Arm, 59-86.8 $\mathrm{mg} \mathrm{CaCO}_{3} / \mathrm{L}$ in the South Arm, and 58.2-71.2 $\mathrm{mg} \mathrm{CaCO}_{3} / \mathrm{L}$ in the West Arm (Fig 3.26). No distinct pattern was observed throughout the sampling period from April-November. In the hypolimnion, alkalinity was fairly consistent through the sampling season, ranging from 73.1-79 $\mathrm{mg} \mathrm{CaCO}_{3} / \mathrm{L}$ in the North Arm and 76.9-99.7 $\mathrm{mg}$ $\mathrm{CaCO}_{3} / \mathrm{L}$ in the South Arm (Fig 3.27).

In the period 1997-2006, alkalinity has remained stable, ranging from a low in 2002 (53 mg $\left.\mathrm{CaCO}_{3} / \mathrm{L}\right)$ in the North Arm to a high in the South Arm in $2006(80 \mathrm{mg} \mathrm{CaCO} / \mathrm{L}$, Table 3.11). The South Arm has remained more alkaline compared to the North Arm, most likely as a result of the geology of the Kootenay River basin.

Kootenay Lake Fertilization Experiment, Year 15 (North Arm) and Year 3 (South Arm) 39 (2006) Report 
Table 3.11. Average alkalinity ( $\mathrm{mg} \mathrm{CaCO}_{3} / \mathrm{L}$ ) from $0-30 \mathrm{~m}$ in spring (April-June), summer (July-September), and fall (October-November) for the North and South arms of Kootenay Lake, 1997-2006*.

\begin{tabular}{ccccccc}
\hline \multirow{2}{*}{ Year } & \multicolumn{3}{c}{$\begin{array}{c}\text { North Arm } \\
\text { KLF 2 \& 4 }\end{array}$} & \multicolumn{3}{c}{$\begin{array}{c}\text { South Arm } \\
\text { KLF 6 \& 7 }\end{array}$} \\
\cline { 2 - 7 } & Spring & Summer & Fall & Spring & Summer & Fall \\
\hline 1997 & 64 & 55 & 57 & 67 & 63 & 67 \\
1998 & 65 & & & 67 & & \\
1999 & & & & & & \\
2000 & 62 & 58 & 57 & 63 & 66 & 70 \\
2001 & & 63 & 59 & & 72 & 72 \\
2002 & 68 & 53 & 58 & 66 & 67 & 69 \\
2003 & 67 & 61 & 59 & 68 & 68 & 70 \\
2004 & 64 & 59 & 60 & 66 & 70 & 70 \\
2005 & 67 & 61 & 67 & 71 & 79 & 77 \\
2006 & 65 & 58 & 67 & 67 & 77 & 80 \\
\hline *rior to 2003, fall data were for October only. The 2004-2006 data were collected from 0-20 m.
\end{tabular}

\section{Total Organic Carbon}

Total organic carbon (TOC) includes both dissolved and particulate organic carbon (Wetzel 2001). Dissolved carbon dioxide and bicarbonate are the major sources of carbon for photosynthesis in freshwater systems. Utilization of inorganic carbon provides the foundation for much of the organic productivity in an ecosystem.

Total organic carbon from 0-20 m samples ranged from 0.5-2.6 mg/L in the North Arm, from 0.9-3.9 mg/L in the South Arm, and from 1-2.3 mg/L in the West Arm (Figure 3.28). The North Arm results peaked in June, decreased through October and increased in November. The South Arm TOC also peaked in June, except for the result from station KL 5 which peaked in July, and declined through the remainder of the sampling season until early winter. The TOC profile in the West Arm (KLF 8) followed a similar pattern to the South Arm stations, increasing during the summer and declining by the fall. In the hypolimnion, TOC ranged from 0.6-4.8 mg/L for both the North and South arms (Figure 3.29). In general, the South Arm displayed higher variation in TOC concentrations but trends were similar between the epilimnetic and hypolimnetic sampling regimes.

Since 1997, TOC averaged 0.6-1.8 mg/L in the North Arm and 0.9-2.1 mg/L in the South Arm (Table 3.12). Although these values are at the low end of the range (TOC of 1-30 $\mathrm{mg} / \mathrm{L}$ ) in natural waters, they are consistent with oligotrophic systems (Wetzel 2001). Phytoplankton productivity and small allochthonous inputs are most likely the primary sources of organic carbon to Kootenay Lake.

Kootenay Lake Fertilization Experiment, Year 15 (North Arm) and Year 3 (South Arm) 40 (2006) Report 
Table 3.12. Average total organic carbon (TOC; $\mathrm{mg} / \mathrm{L}$ ) from $0-30 \mathrm{~m}$ in spring (AprilJune), summer (July-September), and fall (October-November) for the North and South arms of Kootenay Lake, 1997-2006*

\begin{tabular}{ccccccc}
\hline \multirow{2}{*}{ Year } & \multicolumn{3}{c}{$\begin{array}{c}\text { North Arm } \\
\text { KLF 2 \& 4 }\end{array}$} & \multicolumn{3}{c}{$\begin{array}{c}\text { South Arm } \\
\text { KLF 6 \& 7 }\end{array}$} \\
\cline { 2 - 7 } & Spring & Summer & Fall & Spring & Summer & Fall \\
\hline 1997 & 0.8 & 1.4 & 0.6 & 1.4 & 1.6 & 0.9 \\
1998 & 1.1 & 1.5 & 1.2 & 1.5 & 1.8 & 1.5 \\
1999 & 1.8 & 1.3 & 1.3 & 1.8 & 1.7 & 1.6 \\
2000 & 1.0 & 1.1 & 1.1 & 1.3 & 1.3 & 1.2 \\
2001 & 1.0 & 1.2 & 1.1 & 1.0 & 1.4 & 1.0 \\
2002 & 1.2 & 1.2 & 1.2 & 1.6 & 1.9 & 1.6 \\
2003 & 1.4 & 1.6 & 1.4 & 1.6 & 1.5 & 1.7 \\
2004 & 1.0 & 1.2 & 1.4 & 1.3 & 1.5 & 1.1 \\
2005 & 0.9 & 1.1 & 1.2 & 1.1 & 1.7 & 0.9 \\
2006 & 1.3 & 1.1 & 1.7 & 1.9 & 2.1 & 1.8 \\
\hline *Prior to 2003, fall data were for October only. The 2004-2006 data were collected from 0-20 m.
\end{tabular}

\section{Chlorophyll a}

Chlorophyll $a$ (chl $a$ ), a photosynthetic pigment, is a primary characteristic of all algae. Concentrations of this pigment are often associated with a lake's algal biomass and are representative of its overall productivity. Importantly, chlorophyll concentrations are highly variable because of many dynamic physical and chemical processes within lake systems.

Chl $a$ ranged from 0.5-7.5 $\mu \mathrm{g} / \mathrm{L}$ in the North Arm, 0.5-4.5 $\mu \mathrm{g} / \mathrm{L}$ in the South Arm, and 0.5-4.3 $\mu \mathrm{g} / \mathrm{L}$ in the West Arm in 2006 (Figure 3.30). The peak of $7.5 \mu \mathrm{g} / \mathrm{L}$ in the North Arm occurred in August at station KLF 1. Although the South Arm demonstrated more variability between stations, a general trend of increasing chlorophyll concentrations was evident from spring to summer for all stations. In contrast to 2005, the lake did not demonstrate a fall peak in chlorophyll concentrations in 2006, often associated with fall turnover. As well, this data coincides with the integrated phytoplankton results (see Fig 4.1 in Chapter 4 of this report).

From 1997-2006, average Chl $a$ concentrations have ranged from 1-4.1 $\mu \mathrm{g} / \mathrm{L}$ in the North Arm and 0.8-4.8 $\mu \mathrm{g} / \mathrm{L}$ in the South Arm (Table 3.13). Notably, summer chlorophyll $a$ concentrations have steadily increased for the North Arm in 2001 through 2006 compared to the 1997 through 2000 which was the period where nutrient additions decreased. Summer chlorophyll $a$ concentrations in the South Arm slightly increased during 2004 through 2006 compared to previous years, except in 2002. This slight increase is due to the addition of nutrients which commenced in 2004.

Kootenay Lake Fertilization Experiment, Year 15 (North Arm) and Year 3 (South Arm) 41 (2006) Report 
Table 3.13. Average chlorophyll $a$ (Chl $a$; $\mu \mathrm{g} / \mathrm{L})$ from $0-20 \mathrm{~m}$ in spring (April-June), summer (July-September), and fall (October- November) for the North and South arms of Kootenay Lake, 1997-2006*.

\begin{tabular}{ccccccc}
\hline \multirow{2}{*}{ Year } & \multicolumn{3}{c}{$\begin{array}{c}\text { North Arm } \\
\text { KLF 2 \& 4 }\end{array}$} & \multicolumn{3}{c}{$\begin{array}{c}\text { South Arm } \\
\text { KLF 6 \& 7 }\end{array}$} \\
\cline { 2 - 7 } & Spring & Summer & Fall & Spring & Summer & Fall \\
\hline 1997 & 4.1 & 1.7 & 2.2 & 2.4 & 1.9 & 4.3 \\
1998 & 2.0 & 1.5 & 1.0 & 2.3 & 1.6 & 1.1 \\
1999 & 2.6 & 1.8 & 1.6 & 3.5 & 1.7 & 2.1 \\
2000 & 3.5 & 1.5 & 1.1 & 1.1 & 1.2 & 1.1 \\
2001 & 2.8 & 2.6 & 1.1 & 2.2 & 1.7 & 0.8 \\
2002 & 3.2 & 3.5 & 4.1 & 2.4 & 3.8 & 4.8 \\
2003 & 1.6 & 3.2 & 1.7 & 1.2 & 1.8 & 1.4 \\
2004 & 2.0 & 3.0 & 2.4 & 1.7 & 2.6 & 2.4 \\
2005 & 1.4 & 2.5 & 1.4 & 1.2 & 2.7 & 1.2 \\
2006 & 1.4 & 3.3 & 2.3 & 1.4 & 3.0 & 1.7 \\
\hline *Prior to 2003, fall data were for October only. The 2004-2006 data were collected from 0-20 m.
\end{tabular}

\section{Discrete Sampling}

Discrete sampling was reduced from seven stations to three stations (KLF 2, KLF 6 and KLF 7) on Kootenay Lake in 2006. Despite this, sampling occurred from June through to September, 2006 and remained at 2, 5, 10, 15 and 20 meter depths.

\section{Total Dissolved Phosphorus}

Epilimnetic TDP, on average, was higher in the North Arm (KLF 2) compared to the South Arm (KLF 6 and KLF 7, Fig 3.31). The North Arm experienced a peak in TDP in June with $4 \mu \mathrm{g} / \mathrm{L}$ at $10 \mathrm{~m}$ and September with $5 \mu \mathrm{g} / \mathrm{L}$ at $5 \mathrm{~m}$ (Fig 3.31). In comparison, the South Arm experienced a peak of $4 \mu \mathrm{g} / \mathrm{L}$ in September at $2 \mathrm{~m}$. All stations experienced an increase in TDP $(>2 \mu \mathrm{g} / \mathrm{L})$ in the upper $5 \mathrm{~m}$ of the epilimnion in September. However, during the growing season (June-August), both arms tended to remain at or near the detection limit of $2 \mu \mathrm{g} / \mathrm{L}$. Variability in TDP concentrations declined as depth increased in all stations in 2006.

\section{Dissolved Inorganic Nitrogen}

Discrete sampling demonstrated a depletion of DIN in the upper (2, 5 and $10 \mathrm{~m}$ ) epilimnion throughout the growing season at all stations in 2006 (Fig 3.32). This is a result of the rapid assimilation of DIN by algae in the trophogenic zone (Wetzel 2001). The DIN concentrations increased with depth at all stations. In the North Arm, DIN was highest in June and September and declined in July and August at 2 and $5 \mathrm{~m}$. In the South Arm, DIN was highest in September at station KLF 6 and June at station KLF 7.

Kootenay Lake Fertilization Experiment, Year 15 (North Arm) and Year 3 (South Arm) 42 (2006) Report 


\section{Chlorophyll a}

Discrete chl $a$ concentrations were highest in July and August for both the North and South arm stations on Kootenay Lake in 2006 (Fig 3.33). Chl $a$ concentrations in the North Arm peaked in August at $7.5 \mu \mathrm{g} / \mathrm{L}$ for KLF 2 while the South Arm peaked with 4.8

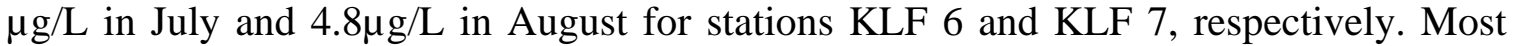
stations indicated a general pattern of declining chl $a$ with increasing depth, particularly beyond 10 meters in depth. These results coincide with the discrete phytoplankton biomass results (see Chapter 5 in this report).

The peak chl $a$ concentrations coincide with the peak phytoplankton biomass which was dominated by Chryso-cryptophytes and Bacillariophytes (diatoms) in Kootenay Lake in 2006 (see Chapter 5 in this report).

\section{Conclusion}

Kootenay Lake is considered an oligotrophic to mesotrophic system, with total phosphorus concentrations ranging between 2-7 $\mu \mathrm{g} / \mathrm{L}$. Observed differences within the lake and between stations was evident in 2006, most likely a result of major differences in surface flow inputs and timing. Surface flow inputs, primarily from the Lardeau/Duncan and Kootenay Rivers' are the most important nutrient sources affecting water quality conditions on Kootenay Lake (Northcote et al. 1999; Binsted and Ashley 2006). Spring algal blooms, evident from chl $a$ measurements, began in May and peaked in July-August as the lake was thermally stratifying. Dissolved nitrogen profiles indicate a rapid assimilation by algae within the epilimnion but remained above values often associated with nitrogen limitation. Other chemical limnology factors (alkalinity and silica) were not considered limiting to primary productivity in 2006.

South Arm fertilization has indicated a response, with chl $a$ concentrations supporting an upward trend in summer concentrations since nutrient additions commenced in 2004. Chl $a$ results on the South Arm were similar to results on the North Arm in 2006. However, these results are confounded by many other factors manifesting themselves on Kootenay Lake such as; var-Q sturgeon flows (Montana), Kootenai River fertilization (Idaho) and natural variability in phosphorus inputs. Overall, Kootenay Lake is still considered a fairly unproductive system that is regulated for its hydro-electric capacity. As a result of these major anthropogenic perturbations, Kootenay Lake receives limited available ambient phosphorus (Northcote 1973; Ashley et al. 1997, Pieters et al. 2003). Therefore, stimulating "bottom up" responses through nutrient addition is vital in restoring lower trophic assemblages and sustaining fish populations in Kootenay Lake.

Kootenay Lake Fertilization Experiment, Year 15 (North Arm) and Year 3 (South Arm) 


\section{Acknowledgements}

Thanks to Kootenay Wildlife Services Ltd for sample collection. Funding was provided by the Fish and Wildlife Compensation Program - Columbia Basin for the 0-20 m integrated samples and SeaBird profiles at stations (KLF 2, 4, 6 and 7) and the Kootenai Tribe of Idaho (KTOI) provided funding for the 0-20 m integrated samples and SeaBird profiles at stations (KLF 1, 3, 5 and 8) and all of the discrete depth profiles.

\section{References}

Ashley, K., L.C. Thompson, P. Warburton, J.-R. Yang, F.R. Pick, P.B. Hamilton, D.B. Lasenby, K.E. Smokorowski, L. McEachern, D. Sebastian, and G. Scholten. 1997. Kootenay Lake Fertilization Experiment- Year 4 (1995/96) Report. Fisheries Project Report No. 58, Province of BC, Ministry of Environment, Lands and Parks Fisheries Branch.

Binsted, G.A., and K.I. Ashley. 2006. Phosphorus Loading to Kootenay Lake from the Kootenay and Duncan rivers and Experimental Fertilization Program. Prepared for the British Columbia Conservation Foundation.

Mazumder, A., and J.A. Edmundson. 2002. Impact of fertilization and stocking on trophic interactions and growth of juvenile sockeye salmon (Oncorhynchus nerka). Can. J. Fish. Aquat. Sci Vol 59, 2002.

Ney, J.J. 1996. Oligotrophication and its discontents: effects of reduced nutrient loading on reservoir fisheries. Pages 285-295 in L.E. Miranda and D.R. DeVries, editors. Multidimensional approaches to reservoir fisheries management. American Fisheries Society, Symposium 16, Bethesda, Maryland.

Northcote, T.G. 1973. Some Impacts of Man on Kootenay Lake and Its Salmonids. Great Lakes Fisheries Commission Tech. Rep. 25.

Northcote, T.G., D.B. Fillion, S.P. Salter, and G.L. Ennis 1999. Interactions of Nutrients and Turbidity in the Control of Phytoplankton in Kootenay Lake British Columbia, Canada, 1964 to 1966. Misc. Fisheries Project Report No. 1, Province of British Columbia.

Perrin, C.J., M.L. Rosenau, T.B. Stables, and K.I. Ashley. 2006. Restoration of a montane reservoir fishery via biomanipulation and nutrient addition. North Am. J. Fish. Manag. 26:391-407.

Pieters, R., L. Vidmanic, S. Harris, J. Stockner, H. Andrusak, M. Young, K. Ashley, B. Lindsay, G. Lawrence, K. Hall, A. Eskooch, D. Sebastian, G. Scholten, and P.E. Woodruff. 2003. Arrow Reservoir Fertilization Experiment - Year 3 (2001/2002) Report. Fisheries Project Report No. RD 103. Ministry of Water, Land and Air Protection, Province of British Columbia.

Kootenay Lake Fertilization Experiment, Year 15 (North Arm) and Year 3 (South Arm) 44 (2006) Report 
Schindler, E. U., K. I. Ashley, R. Rae, L. Vidmanic, H. Andrusak, D. Sebastian, G. Scholten, P. Woodruff, F. Pick, L. M. Ley and P. B. Hamilton. 2006. Kootenay Lake Fertilization Experiment, Years 11 and 12 (2002 and 2003). Fisheries Report No. 114, Ministry of Environment, Province of British Columbia.

Schindler, E.U., R. Rae, K.I. Ashley, L. Vidmanic, D. Sebastian, H. Andrusak, G. Scholten, P. Woodruff, J. Stockner, F. Pick, L.M. Ley, P.B. Hamilton, G.F. Andrusak and L. Fleck. 2007a. Kootenay Lake Fertilization Experiment, Year 13 (North Arm) and Year 1 (South Arm) (2004) Report. Fisheries Project Report No. RD 117, Ministry of Environment, Province of British Columbia.

Schindler, E.U., H. Andrusak, K.I. Ashley, G.F. Andrusak, L. Vidmanic, D. Sebastian, G. Scholten, P. Woodruff, J. Stockner, F. Pick, L.M. Ley and P.B. Hamilton. 2007b. Kootenay Lake Fertilization Experiment, Year 14 (North Arm) and Year 2 (South Arm) (2005) Report. Fisheries Project Report No. RD 122, Ministry of Environment, Province of British Columbia.

Stockner, J.G. and E.A. MacIssaac. 1996. British Columbia lake enrichment program: two decades of habitat enhancement for sockeye salmon. Regulated Rivers: Research and Management 12:547-561.

Wetzel, R.G. 2001. Limnology. $3^{\text {rd }}$ Ed, Academic Press, San Diego.

Wright, M.E., K.I. Ashley, H. Andrusak, H. Manson, R. Lindsay, R.J. Hammond, F.R. Pick, L.M. Ley, P.B. Hamilton, S.L. Harris, L.C. Thompson, L. Vidmanic, D. Sebastian, G. Scholten, M. Yong and D. Miller. 2002. Kootenay Lake Fertilization Experiment Year 9 (2000/2001) Report, Fisheries Project Report No. 105, Ministry of Water, Land and Air Protection, Province of British Columbia.

Kootenay Lake Fertilization Experiment, Year 15 (North Arm) and Year 3 (South Arm) 45 (2006) Report 

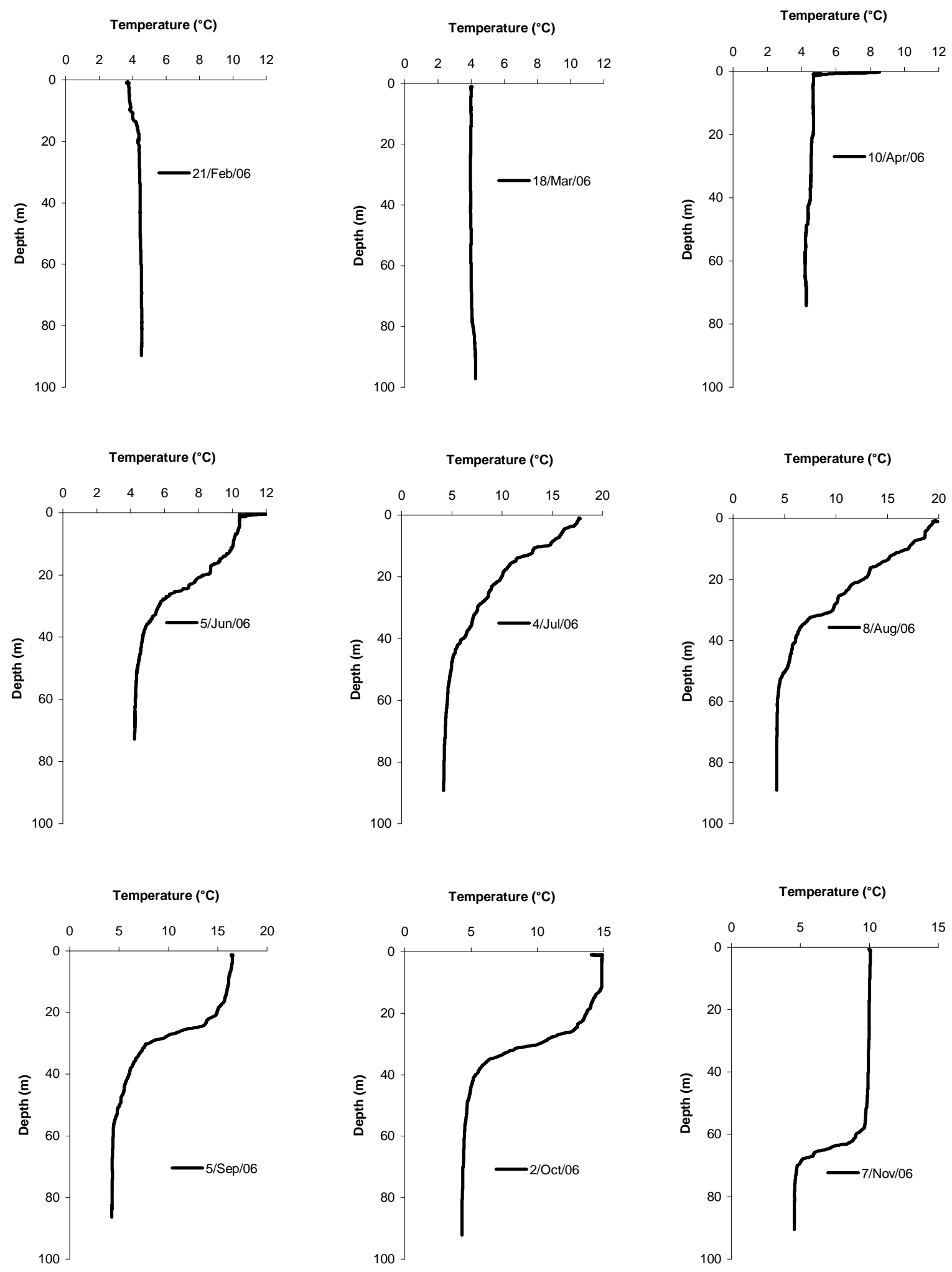

Figure 3.1. Temperature $\left({ }^{\circ} \mathrm{C}\right)$ profiles at station KLF 1 for February-April and JuneNovember, 2006.

Kootenay Lake Fertilization Experiment, Year 15 (North Arm) and Year 3 (South Arm) 46 (2006) Report 

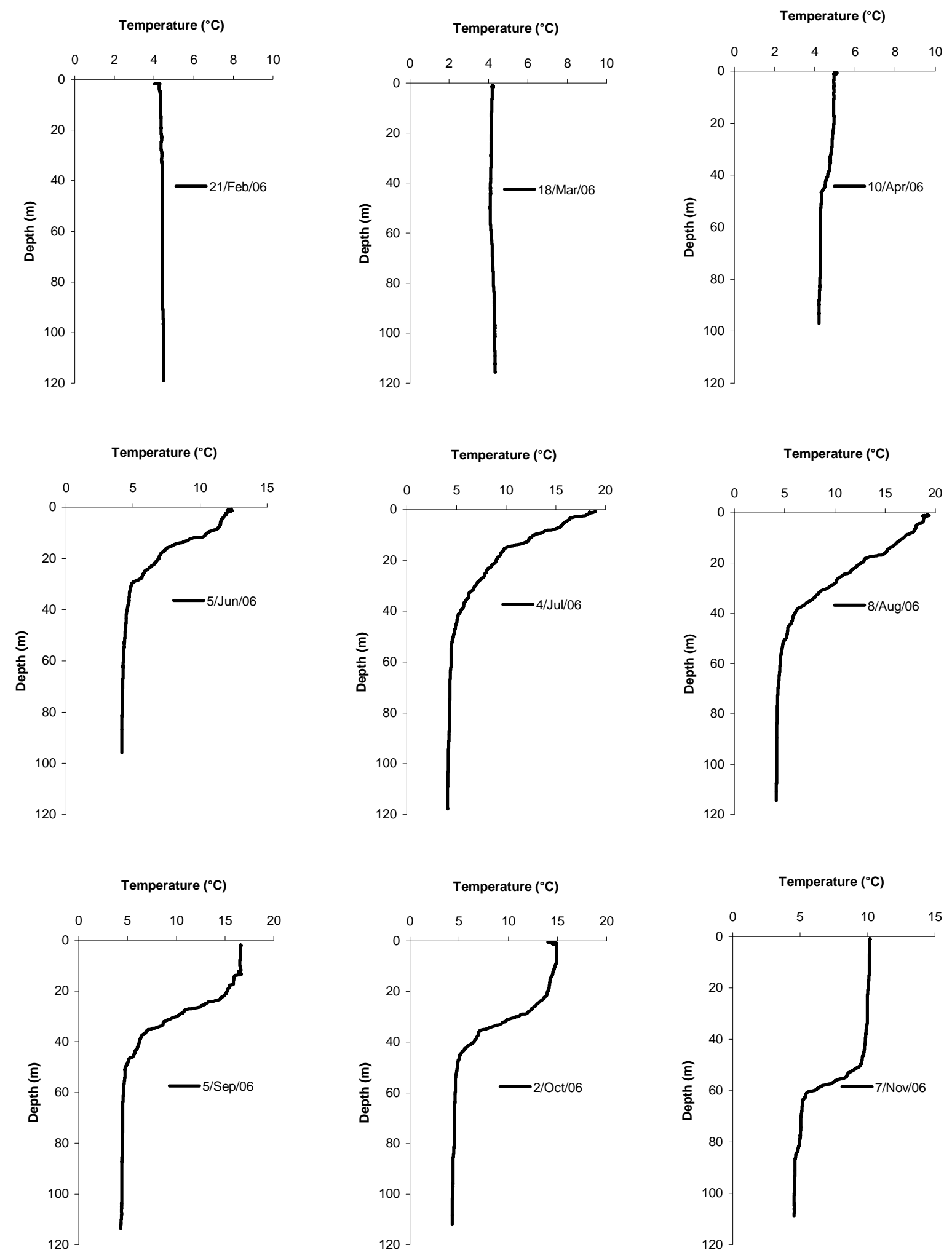

Figure 3.2. Temperature $\left({ }^{\circ} \mathrm{C}\right)$ profiles at station KLF 2 for February-April and JuneNovember, 2006.

Kootenay Lake Fertilization Experiment, Year 15 (North Arm) and Year 3 (South Arm) 47 (2006) Report 

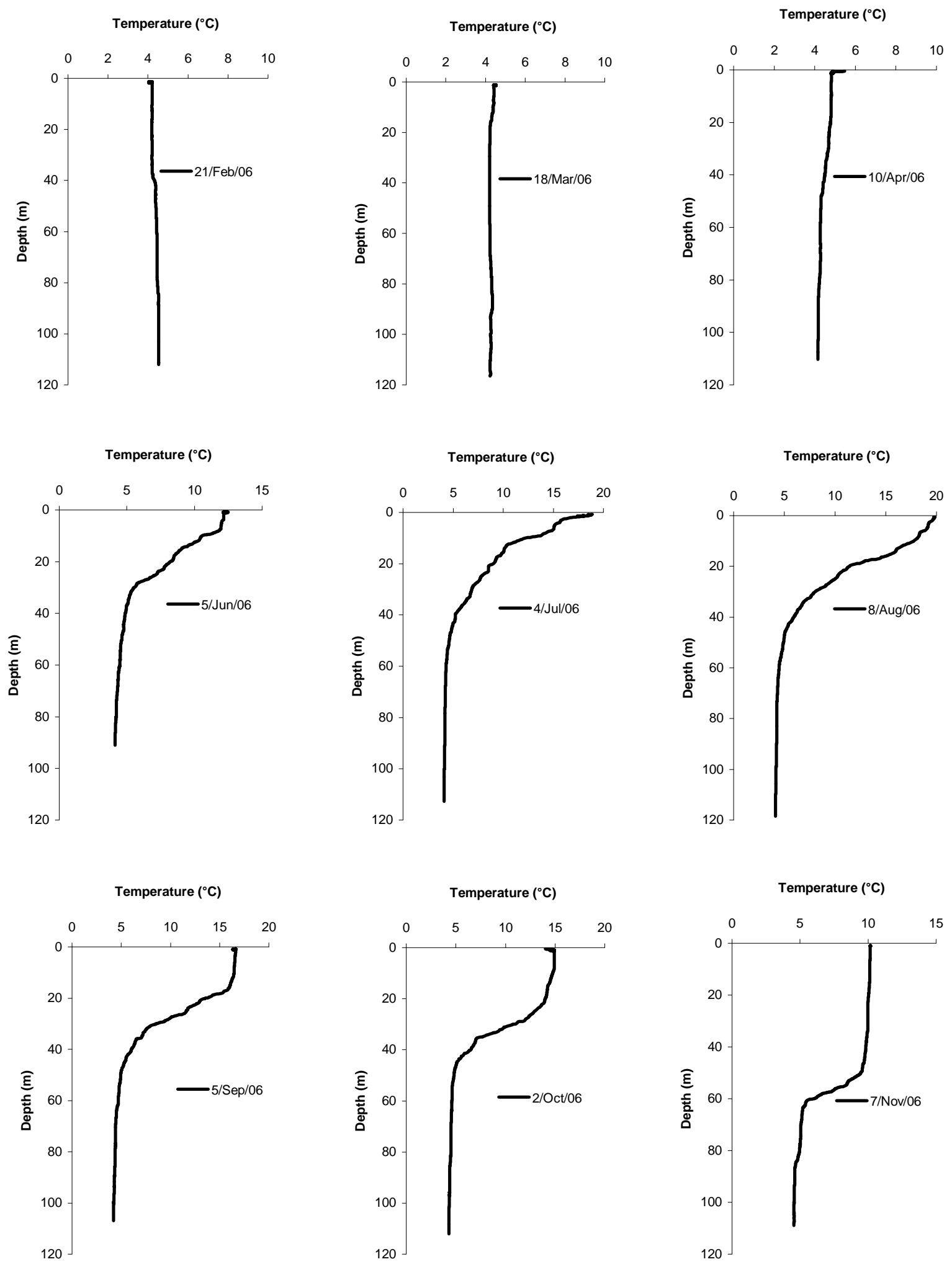

Figure 3.3. Temperature $\left({ }^{\circ} \mathrm{C}\right)$ profiles at station KLF 3 for February-April and JuneNovember, 2006.

Kootenay Lake Fertilization Experiment, Year 15 (North Arm) and Year 3 (South Arm) 48 (2006) Report 

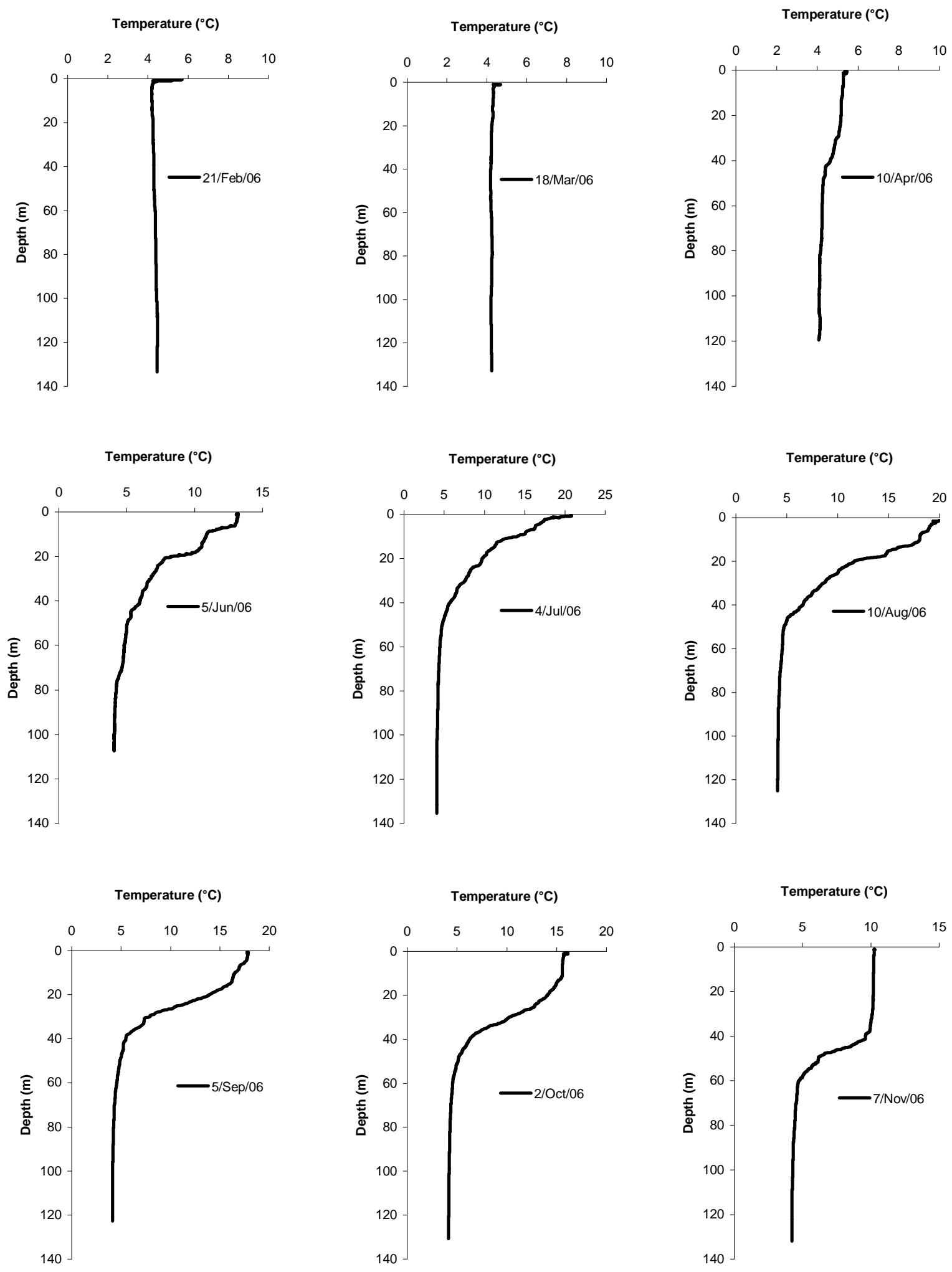

Figure 3.4. Temperature $\left({ }^{\circ} \mathrm{C}\right)$ profiles at station KLF 4 for February-April and JuneNovember, 2006.

Kootenay Lake Fertilization Experiment, Year 15 (North Arm) and Year 3 (South Arm) 49 (2006) Report 

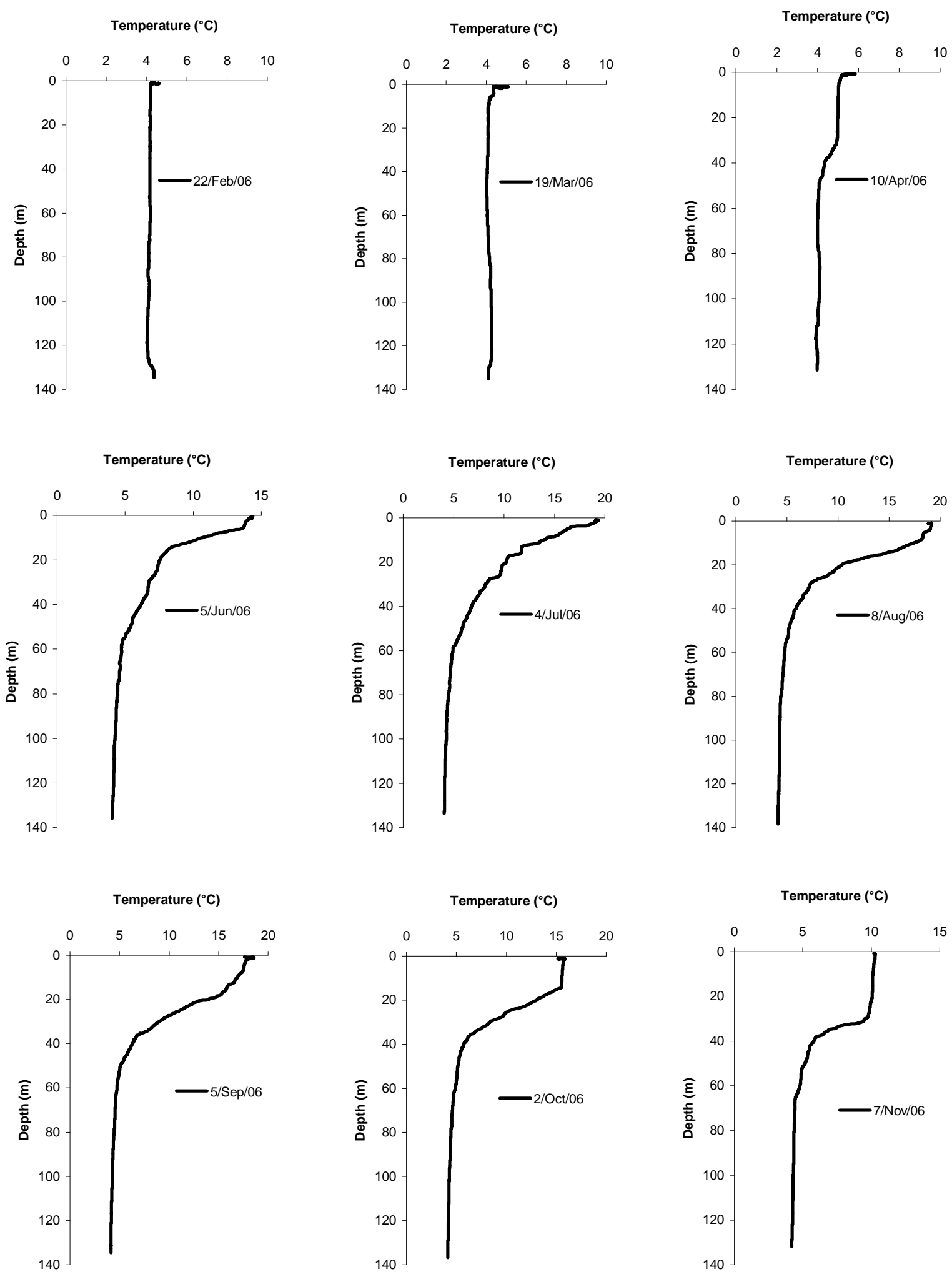

Figure 3.5. Temperature $\left({ }^{\circ} \mathrm{C}\right)$ profiles at station KLF 5 for February-April and JuneNovember, 2006.

Kootenay Lake Fertilization Experiment, Year 15 (North Arm) and Year 3 (South Arm) 50 (2006) Report 

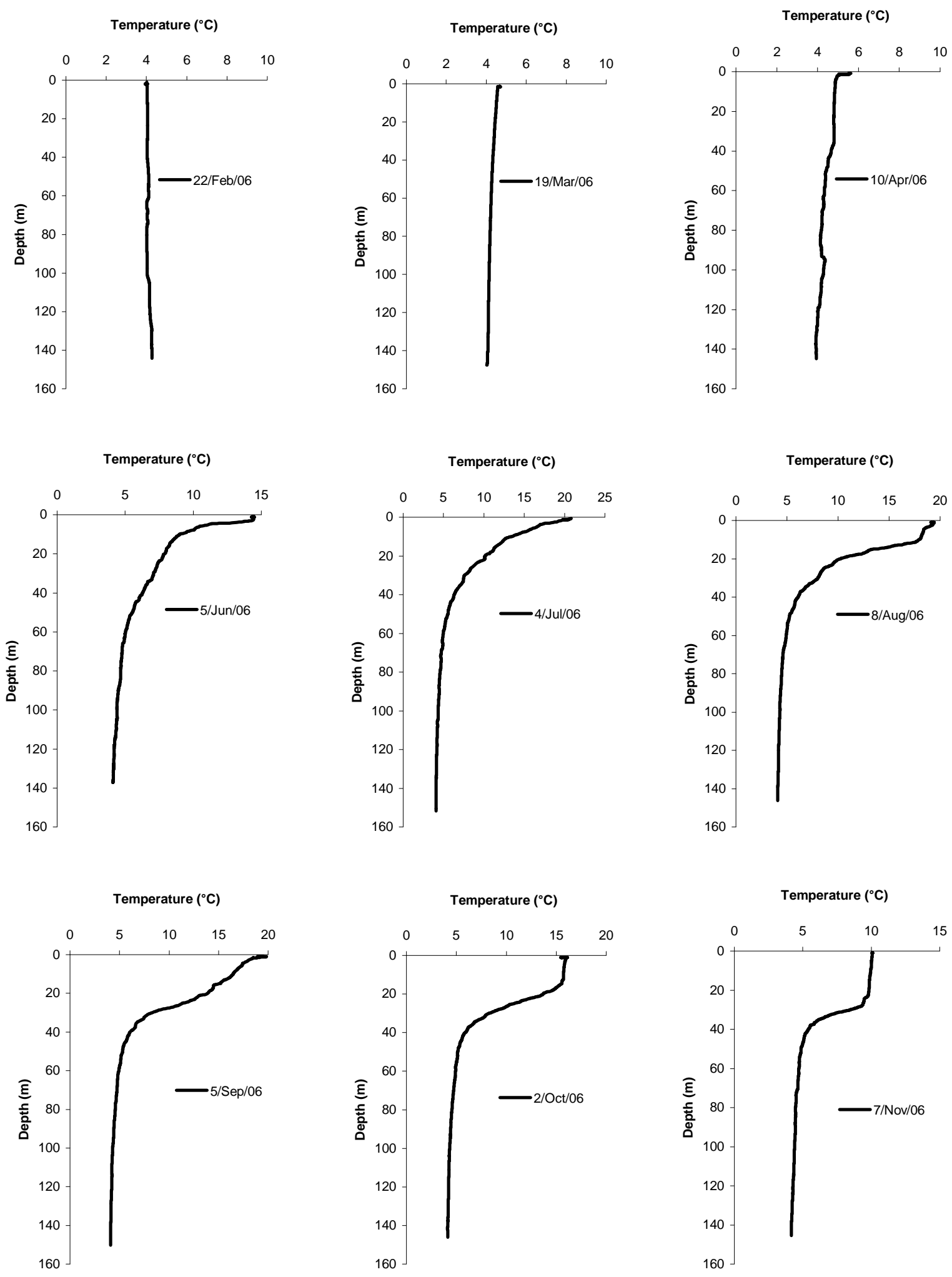

Figure 3.6. Temperature $\left({ }^{\circ} \mathrm{C}\right)$ profiles at station KLF 6 for February-April and JuneNovember, 2006.

Kootenay Lake Fertilization Experiment, Year 15 (North Arm) and Year 3 (South Arm) 

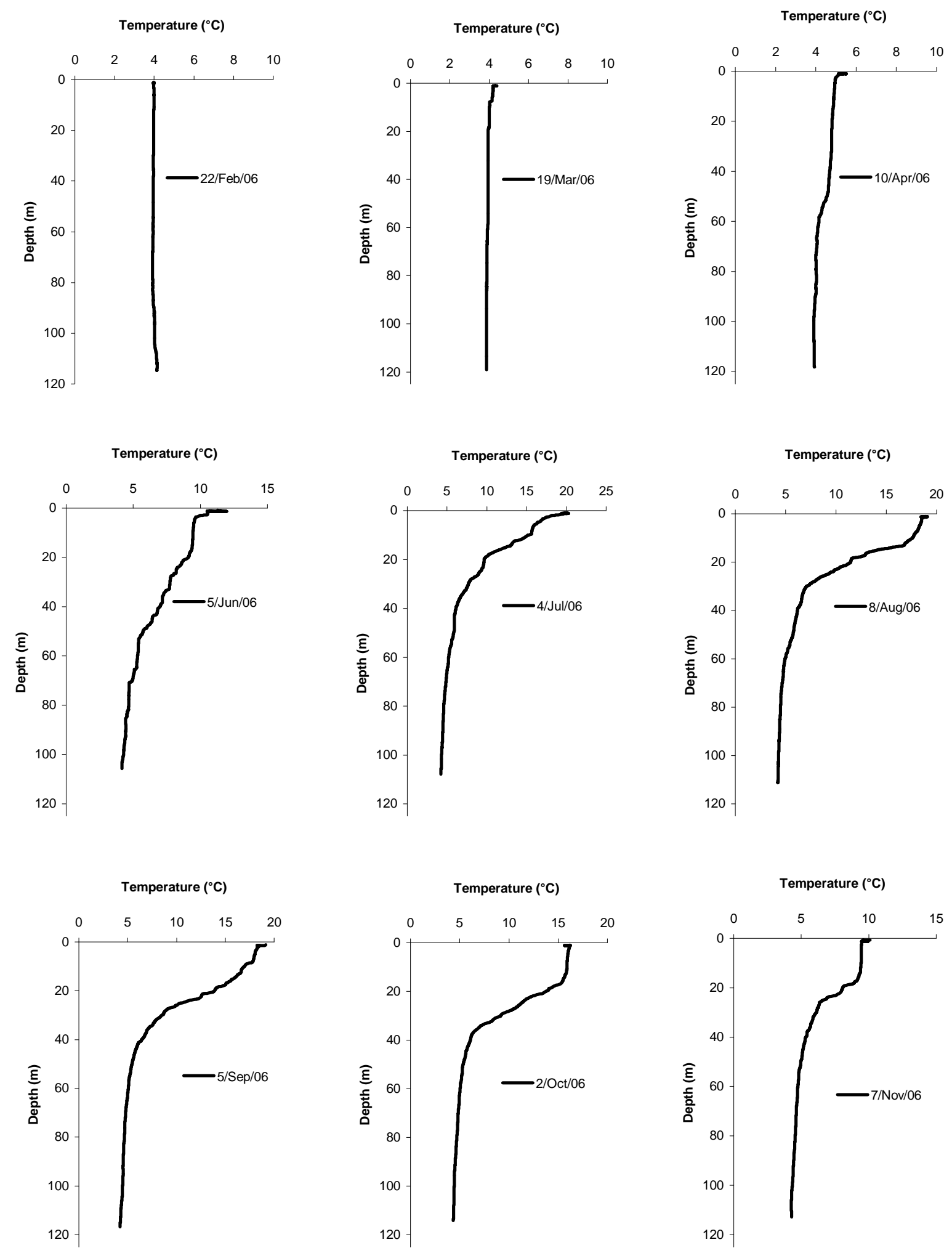

Figure 3.7. Temperature $\left({ }^{\circ} \mathrm{C}\right)$ profiles at station KLF 7 for February-April and JuneNovember, 2006.

Kootenay Lake Fertilization Experiment, Year 15 (North Arm) and Year 3 (South Arm) 52 (2006) Report 

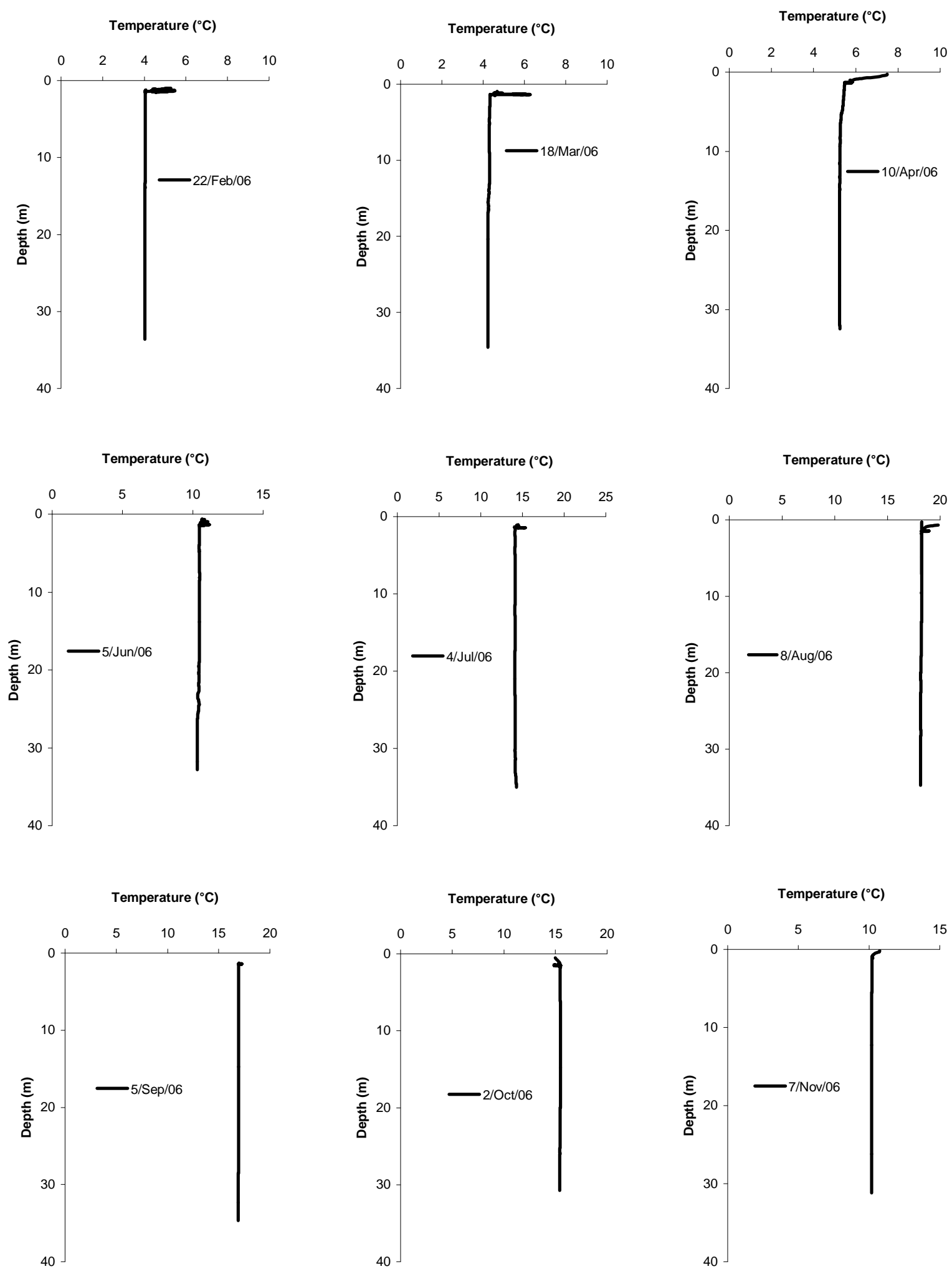

Figure 3.8. Temperature $\left({ }^{\circ} \mathrm{C}\right)$ profiles at station KLF 8 for February-April and JuneNovember, 2006.

Kootenay Lake Fertilization Experiment, Year 15 (North Arm) and Year 3 (South Arm) 

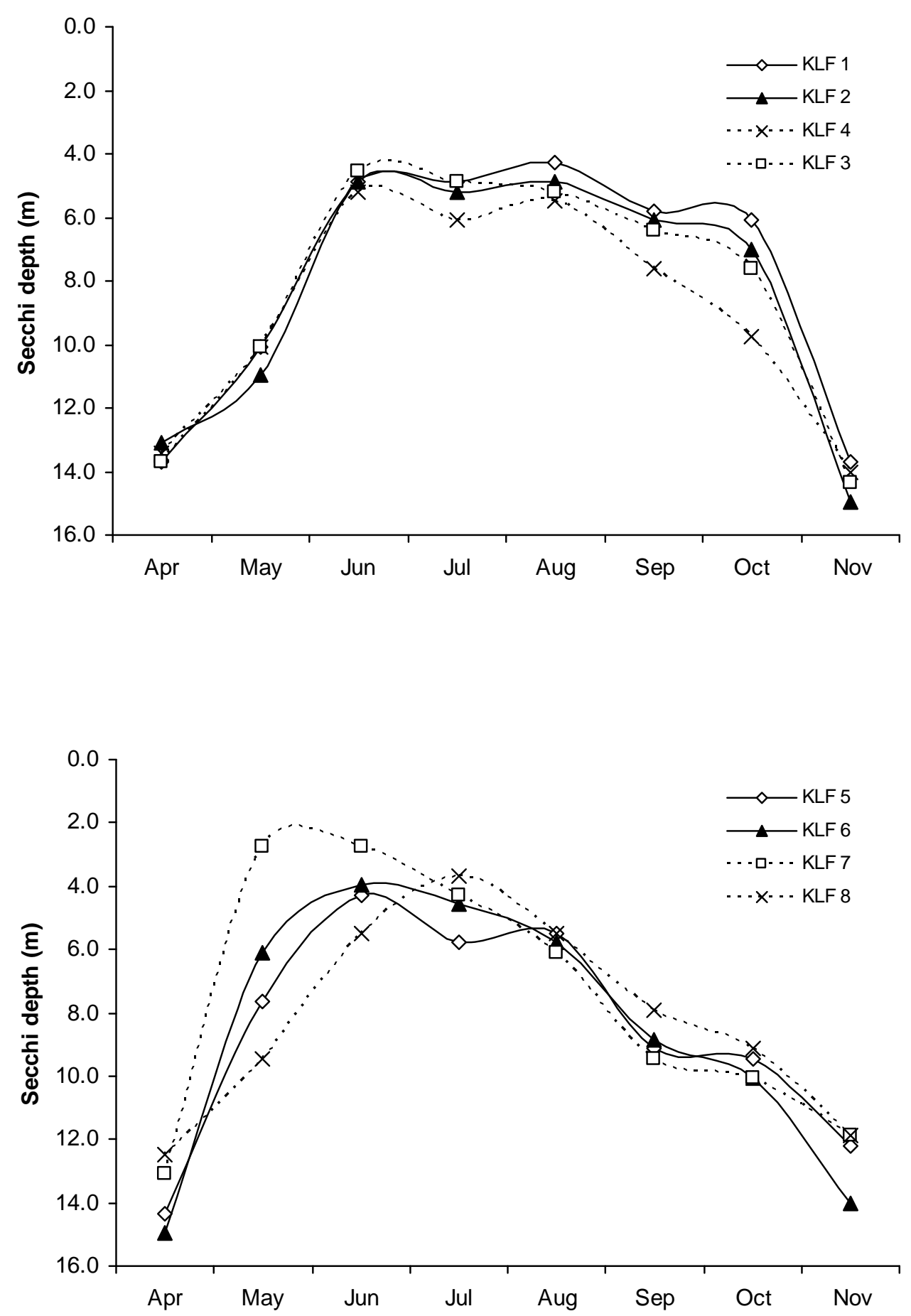

Figure 3.9. Secchi disk depth at KLF 1-4 in the North Arm (upper), KLF 5-7 in the South Arm and KLF 8 in the West Arm (lower) from April-November, 2006.

Kootenay Lake Fertilization Experiment, Year 15 (North Arm) and Year 3 (South Arm) 54 (2006) Report 

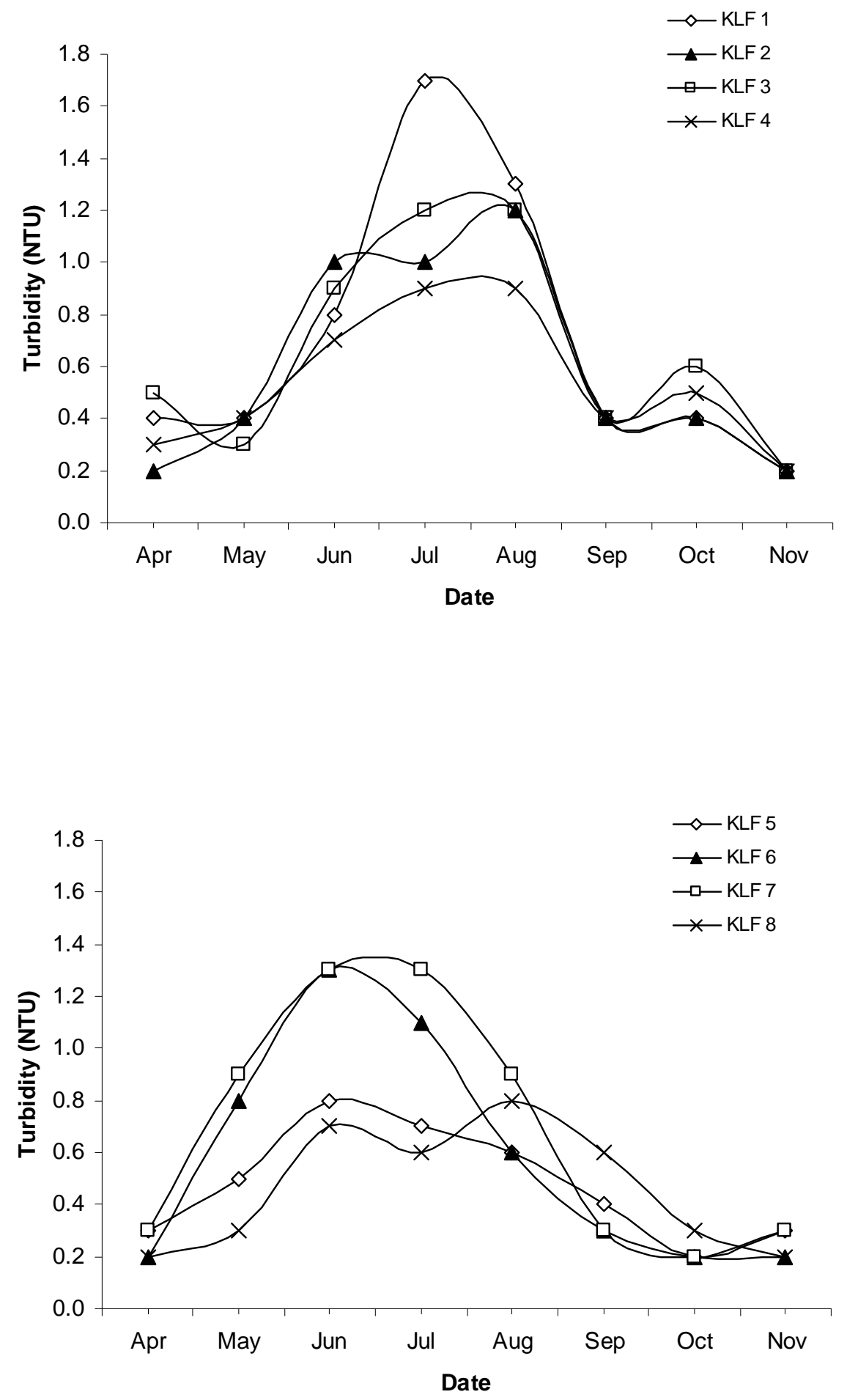

Figure 3.10. Turbidity (NTU) from 0-20 m at KLF 1-4 in the North Arm (upper), KLF 5-7 in the South Arm and KLF 8 in the West Arm (lower) from AprilNovember, 2006.

Kootenay Lake Fertilization Experiment, Year 15 (North Arm) and Year 3 (South Arm) 55 (2006) Report 

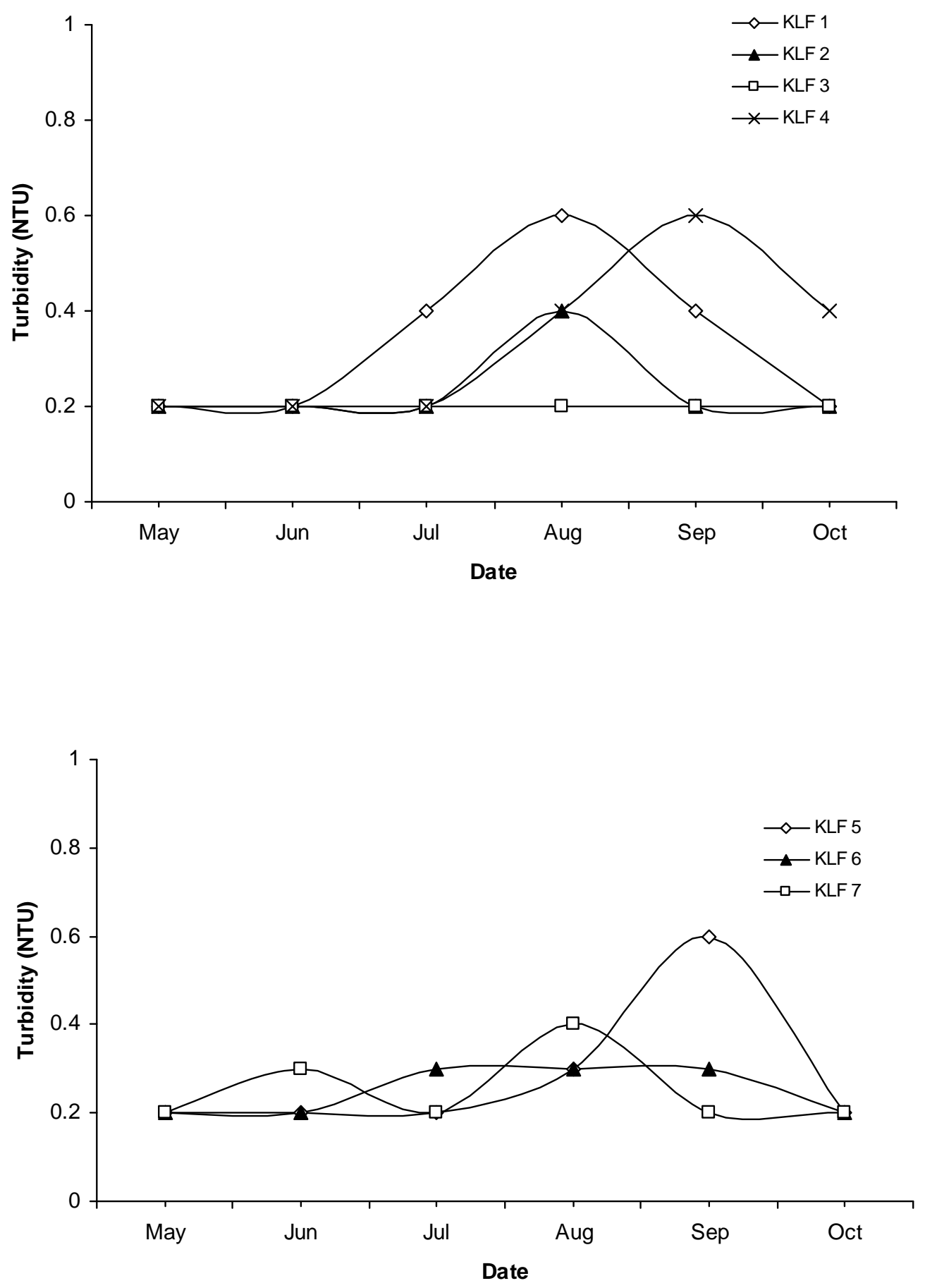

Figure 3.11. Turbidity (NTU) from $>50 \mathrm{~m}$ at KLF 1-4 in the North Arm (upper) and KLF 5-7 in the South Arm (lower) from May-October, 2006.

Kootenay Lake Fertilization Experiment, Year 15 (North Arm) and Year 3 (South Arm) 56 (2006) Report 

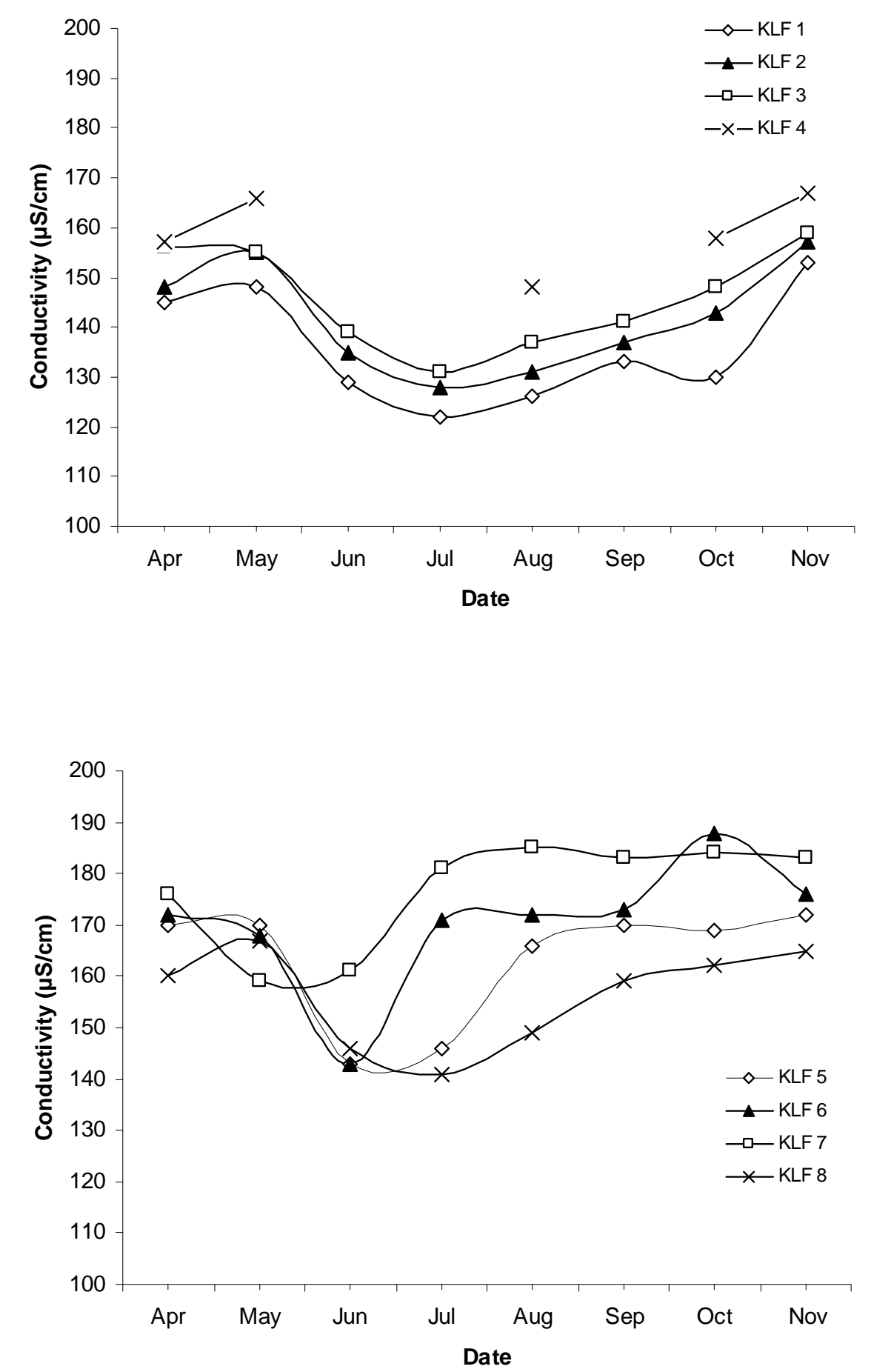

Figure 3.12. Conductivity $(\mu \mathrm{S} / \mathrm{cm})$ from $0-20 \mathrm{~m}$ at KLF 1-4 in the North Arm (upper), KLF 5-7 in the South Arm and KLF 8 in the West Arm (lower) from April-November, 2006. Conductivity was not analyzed from KLF 4 in June, July and September 2006.

Kootenay Lake Fertilization Experiment, Year 15 (North Arm) and Year 3 (South Arm) 57 (2006) Report 

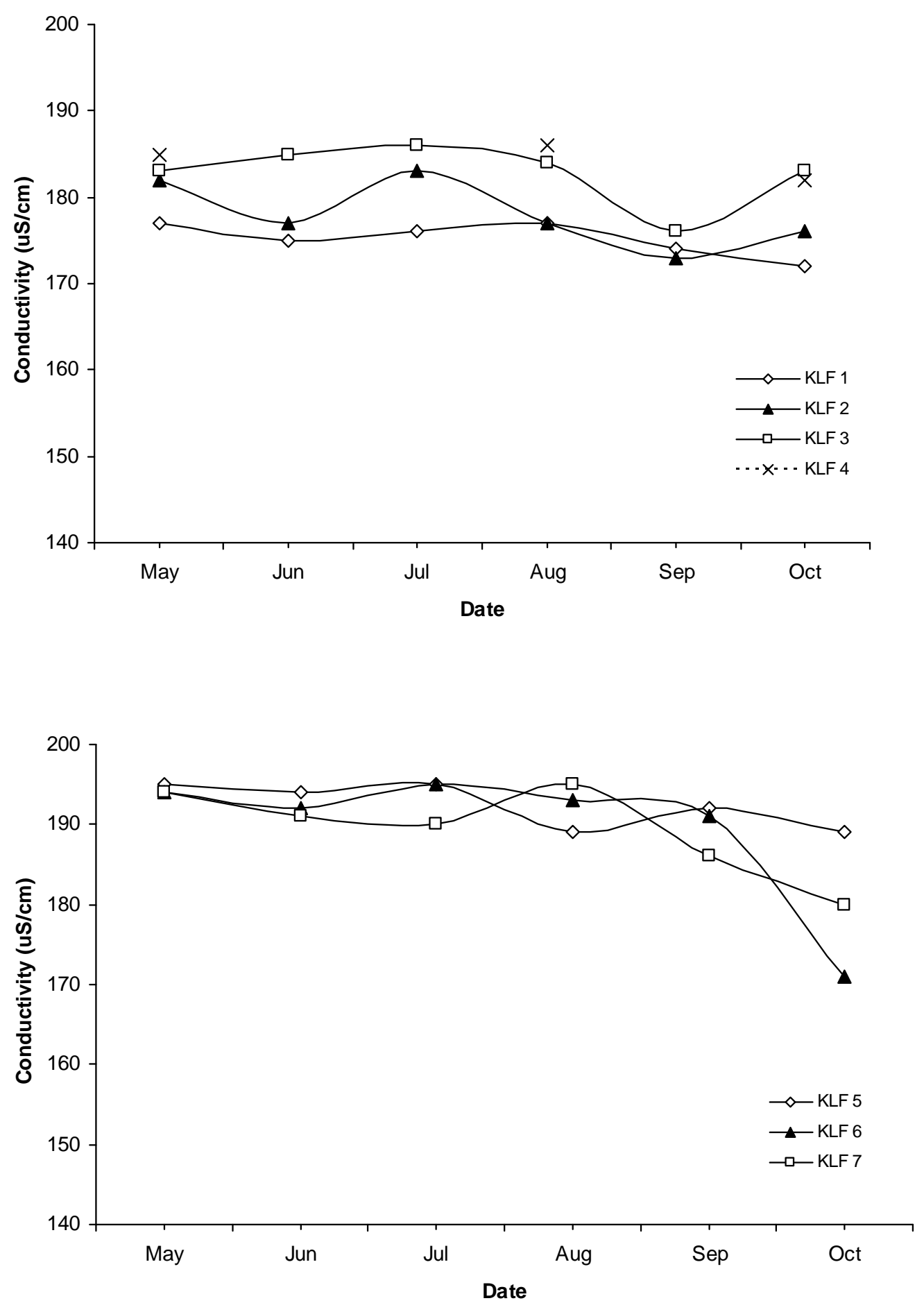

Figure 3.13. Conductivity $(\mu \mathrm{S} / \mathrm{cm})$ from $>50 \mathrm{~m}$ at KLF 1-4 in the North Arm (upper) and KLF 5-7 in the South Arm (lower) from May-October 2006. Conductivity was not analyzed from KLF 4 in June, July and September.

Kootenay Lake Fertilization Experiment, Year 15 (North Arm) and Year 3 (South Arm) 

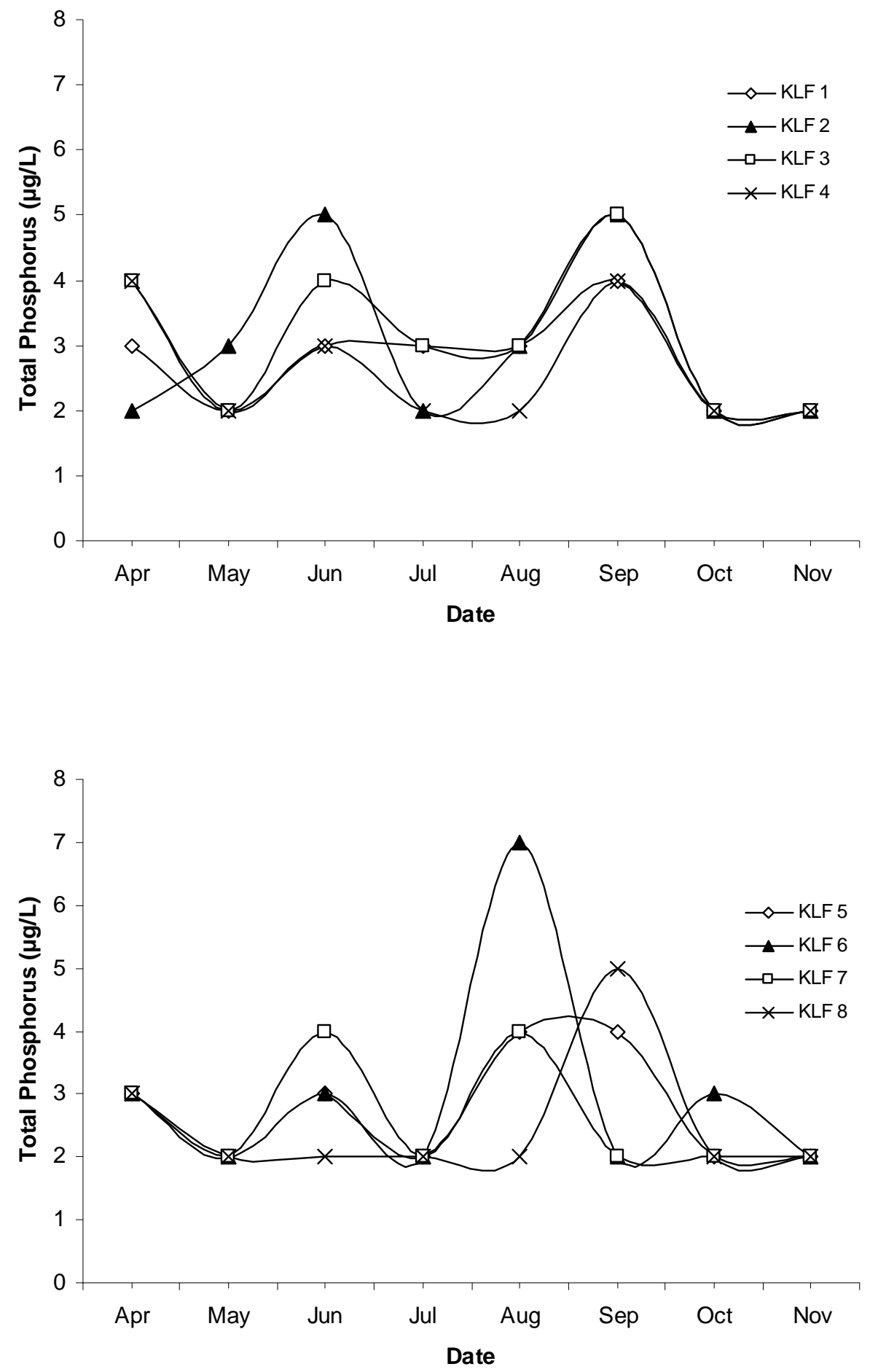

Figure 3.14. Total phosphorus (TP) from 0-20 m at KLF 1-4 in the North Arm (upper), KLF 5-7 in the South Arm and KLF 8 in the West Arm (lower) from April-November, 2006.

Kootenay Lake Fertilization Experiment, Year 15 (North Arm) and Year 3 (South Arm) 59 (2006) Report 

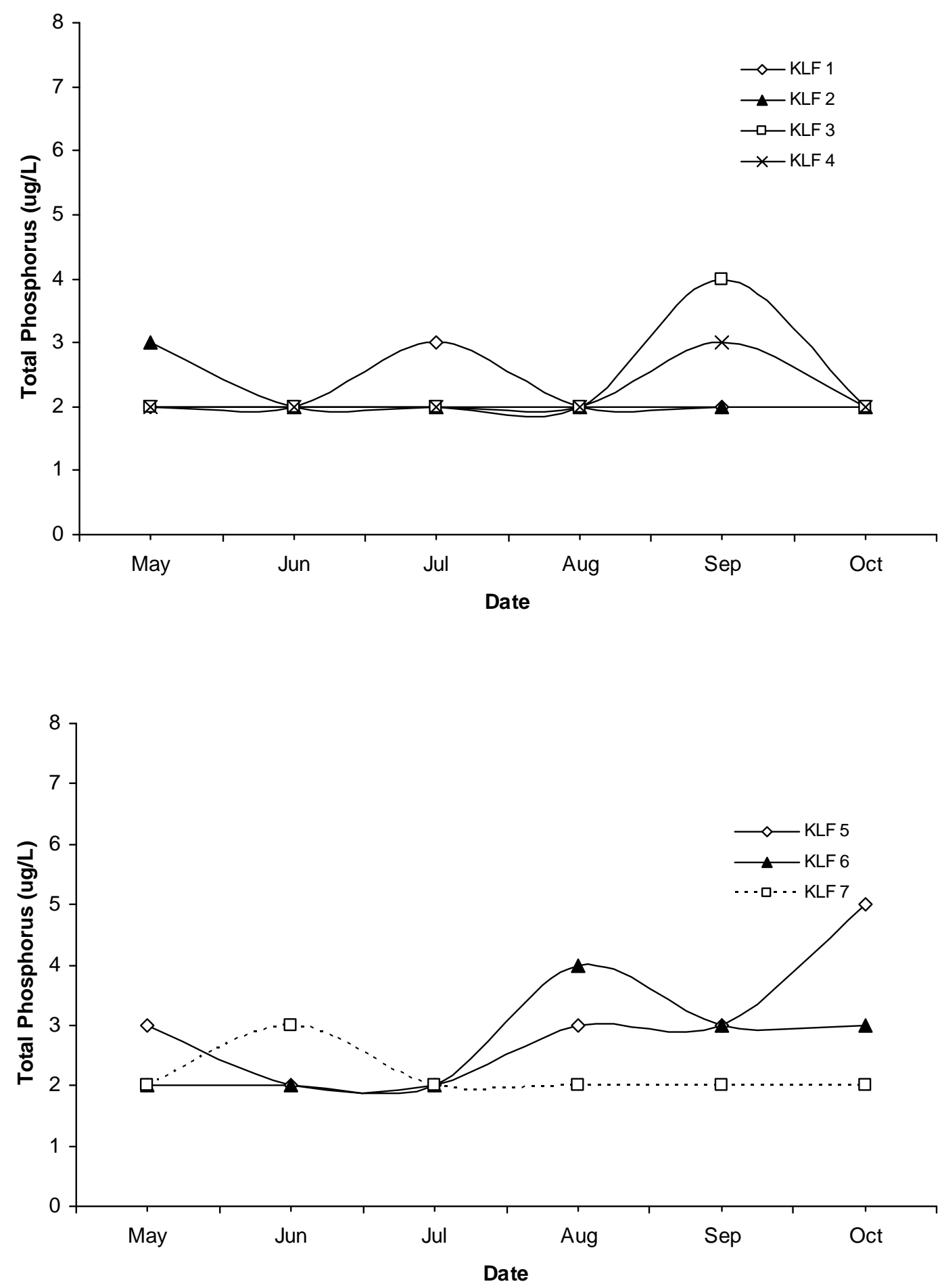

Figure 3.15. Total phosphorus from $>50 \mathrm{~m}$ at KLF 1-4 in the North Arm (upper) and KLF 5-7 in the South Arm (lower) from May-October, 2006.

Kootenay Lake Fertilization Experiment, Year 15 (North Arm) and Year 3 (South Arm) 60 (2006) Report 

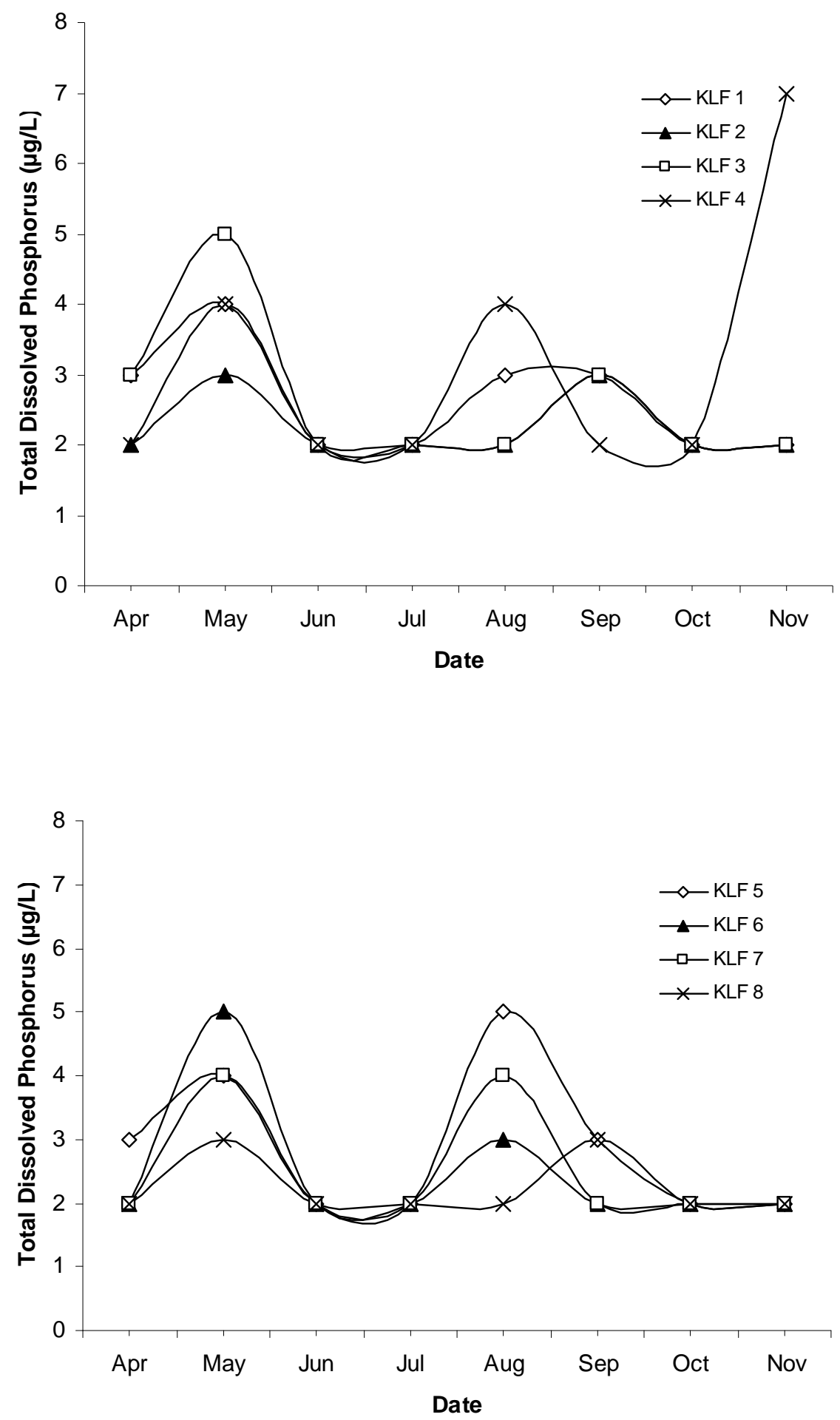

Figure 3.16. Total dissolved phosphorus (TDP) from 0-20 m at KLF 1-4 in the North Arm (upper), KLF 5-7 in the South Arm and KLF 8 in the West Arm (lower) from April-November, 2006.

Kootenay Lake Fertilization Experiment, Year 15 (North Arm) and Year 3 (South Arm) 61 (2006) Report 

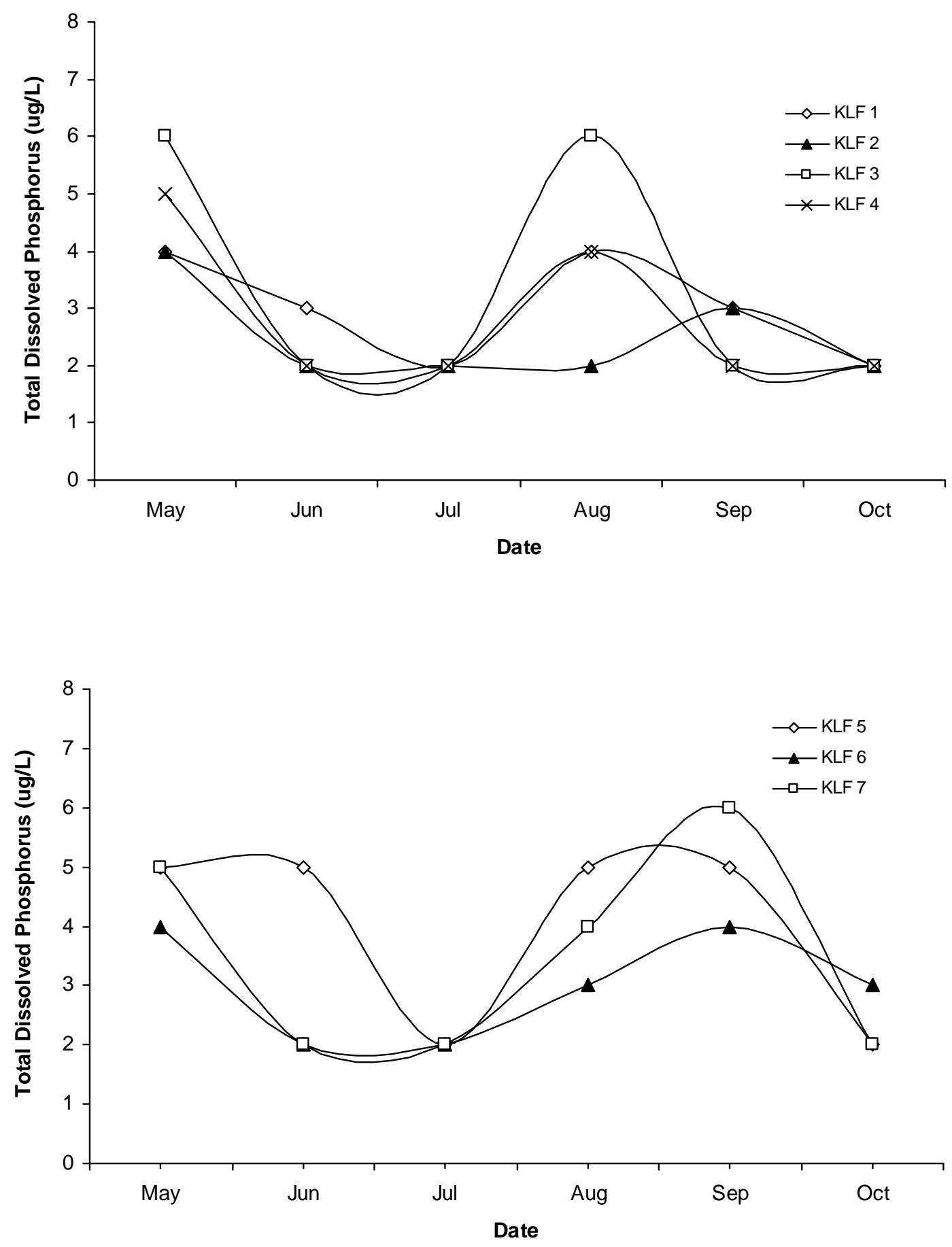

Figure 3.17. Total dissolved phosphorus (TDP) from $>50 \mathrm{~m}$ at KLF 1-4 in the North Arm (upper) and KLF 5-7 in the South Arm (lower) from May-October 2006.

Kootenay Lake Fertilization Experiment, Year 15 (North Arm) and Year 3 (South Arm) 62 (2006) Report 

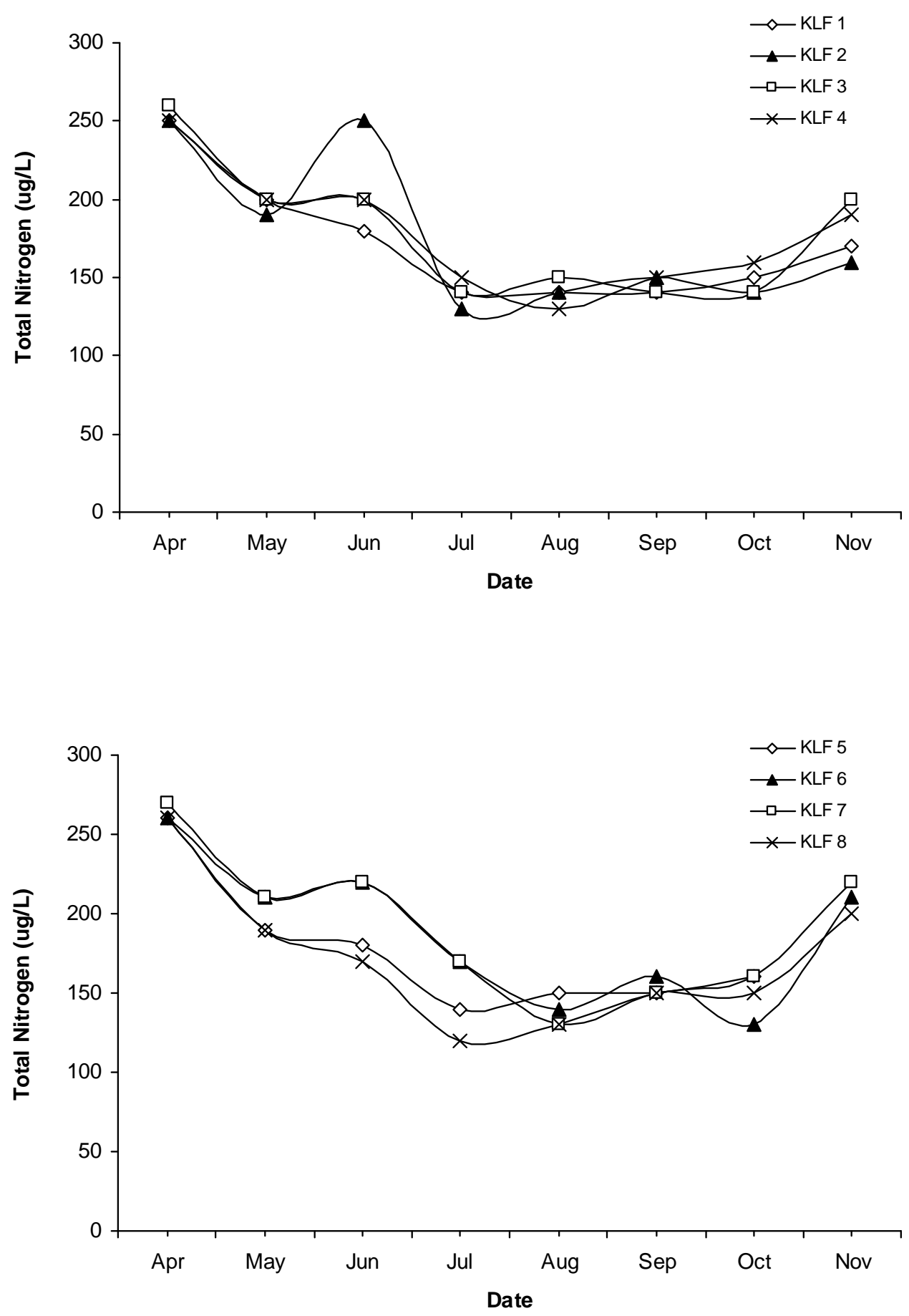

Figure 3.18. Total nitrogen (TN) from 0-20 m at KLF 1-4 in the North Arm (upper), KLF 5-7 in the South Arm and KLF 8 in the West Arm (lower) from April-November, 2006. The result from November at KLF 5 was not plotted as it was an outlier.

Kootenay Lake Fertilization Experiment, Year 15 (North Arm) and Year 3 (South Arm) 

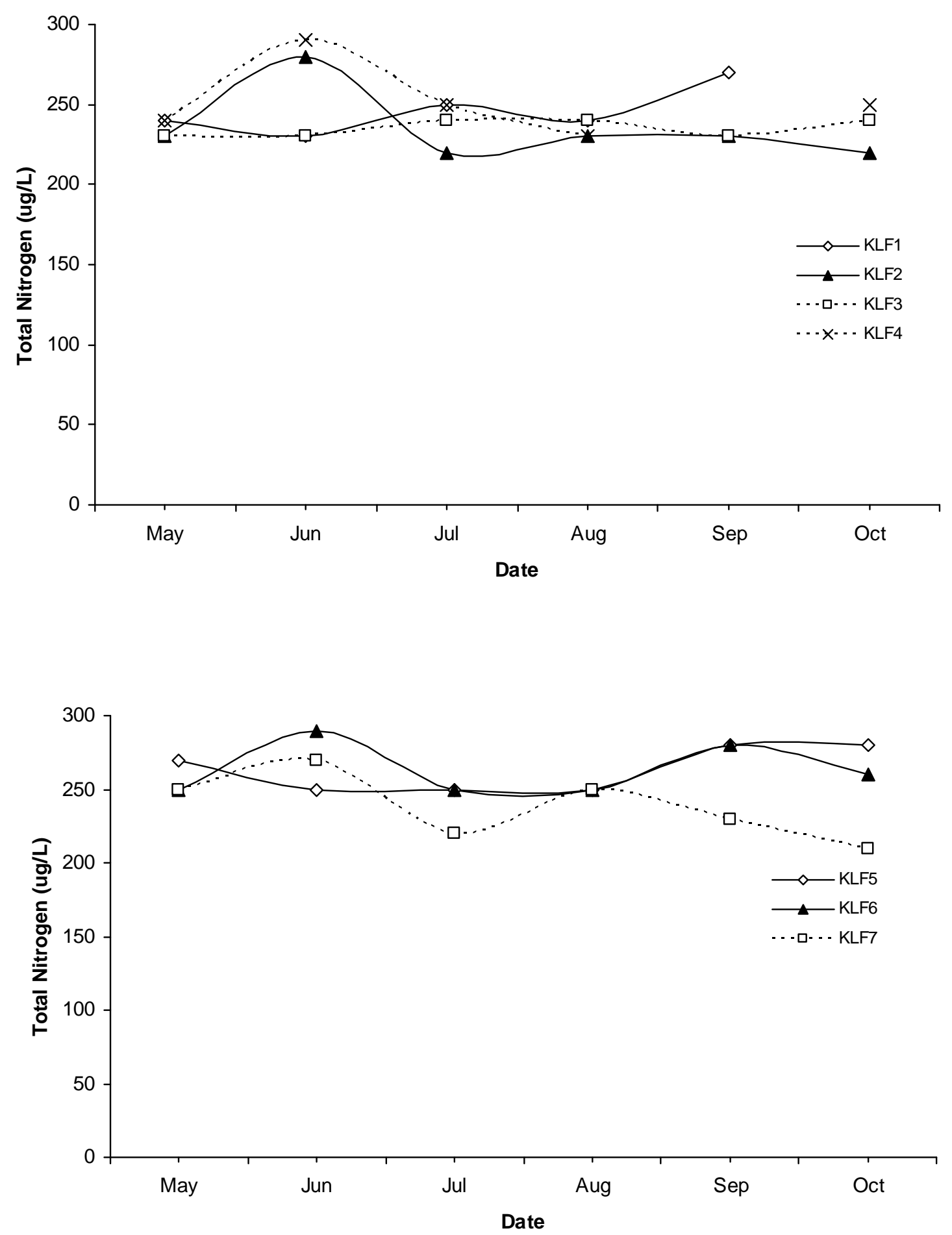

Figure 3.19. Total nitrogen (TN) from $>50 \mathrm{~m}$ at KLF 1-4 in the North Arm (upper) and KLF 5-7 in the South Arm (lower) from May-October, 2006.

Kootenay Lake Fertilization Experiment, Year 15 (North Arm) and Year 3 (South Arm) 64 (2006) Report 

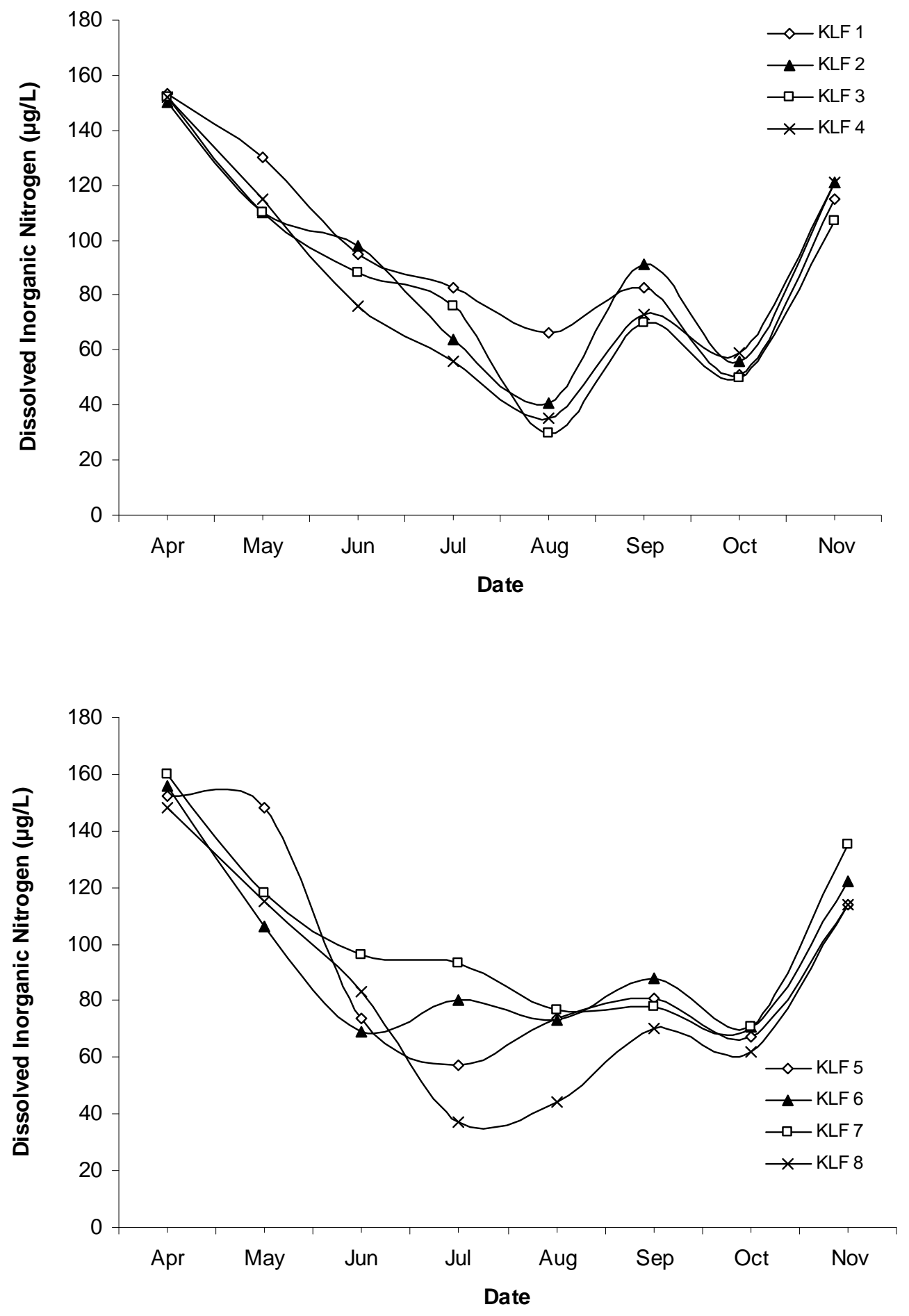

Figure 3.20. Dissolved inorganic nitrogen (DIN) from 0-20 $\mathrm{m}$ at KLF 1-4 in the North Arm (upper), KLF 5-7 in the South Arm and KLF 8 in the West Arm (lower) from April-November, 2006.

Kootenay Lake Fertilization Experiment, Year 15 (North Arm) and Year 3 (South Arm) 65 (2006) Report 

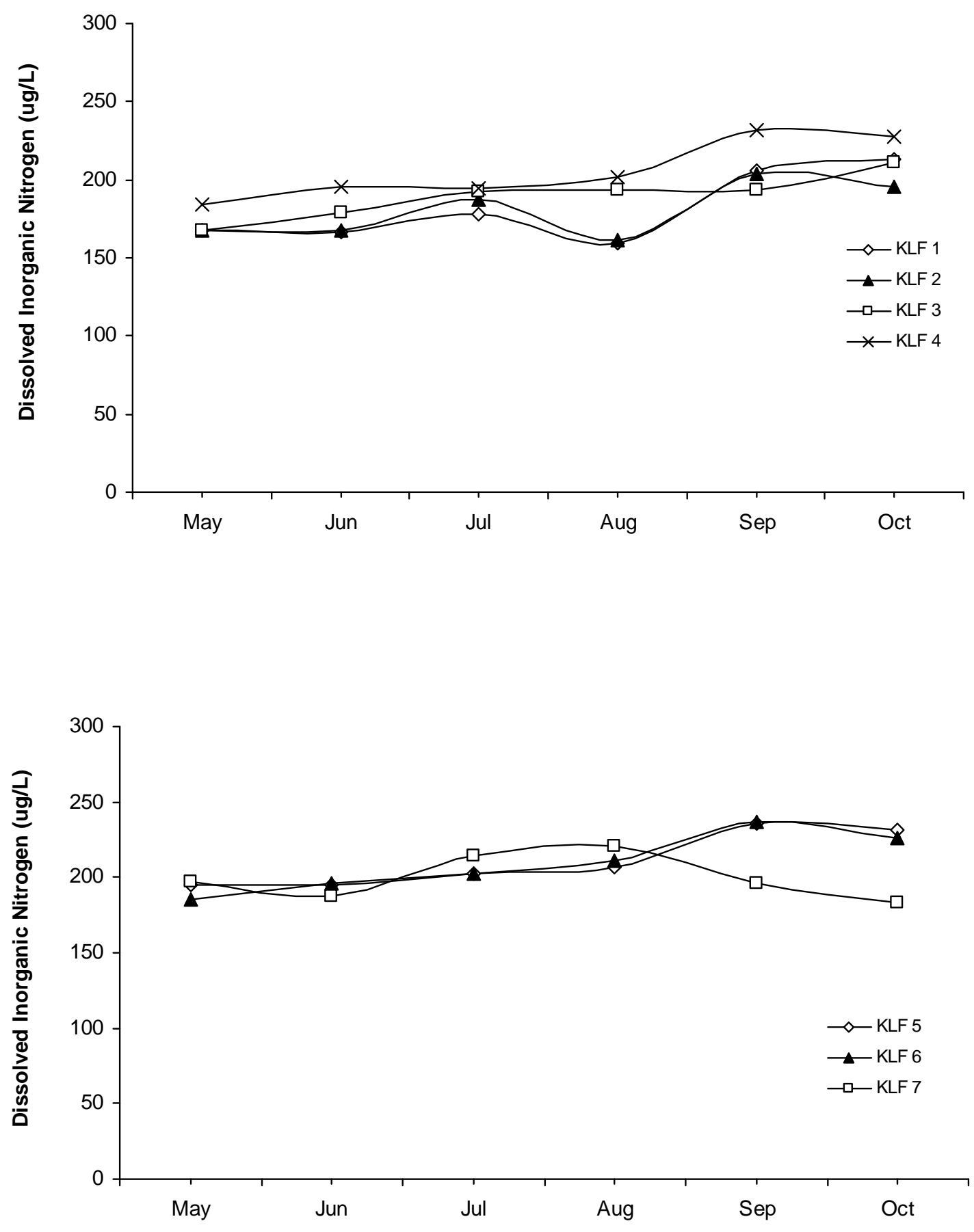

Figure 3.21. Dissolved inorganic nitrogen (DIN) from $>50 \mathrm{~m}$ at KLF 1-4 in the North Arm (upper) and KLF 5-7 in the South Arm (lower) from May-October, 2006.

Kootenay Lake Fertilization Experiment, Year 15 (North Arm) and Year 3 (South Arm) 66 (2006) Report 

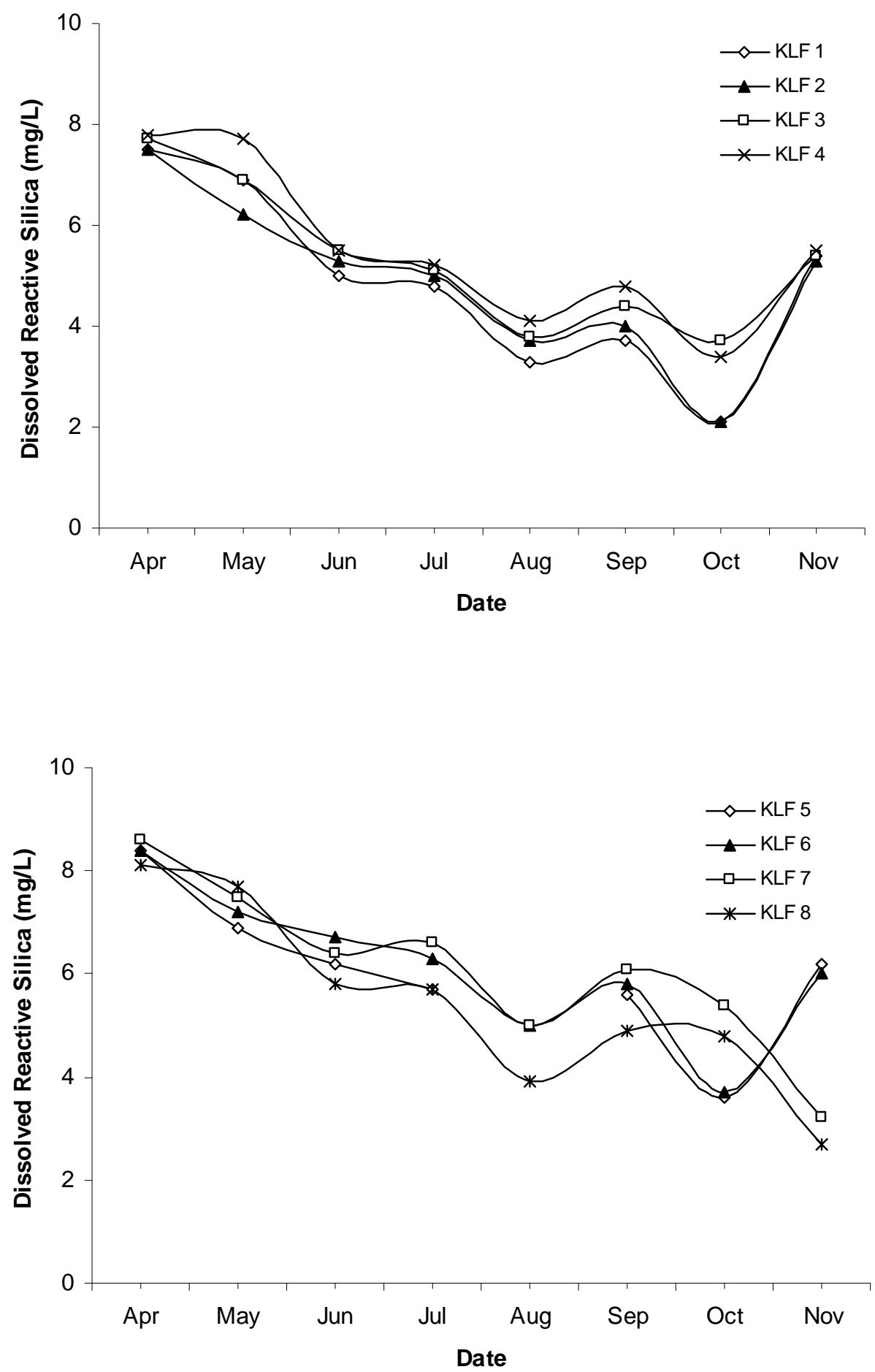

Figure 3.22. Silica from 0-20 $\mathrm{m}$ at KLF 1-4 in the North Arm (upper), KLF 5-7 in the South Arm and KLF 8 in the West Arm (lower) from April-November, 2006. Silica was not analyzed in August at KLF 5.

Kootenay Lake Fertilization Experiment, Year 15 (North Arm) and Year 3 (South Arm) 67 (2006) Report 

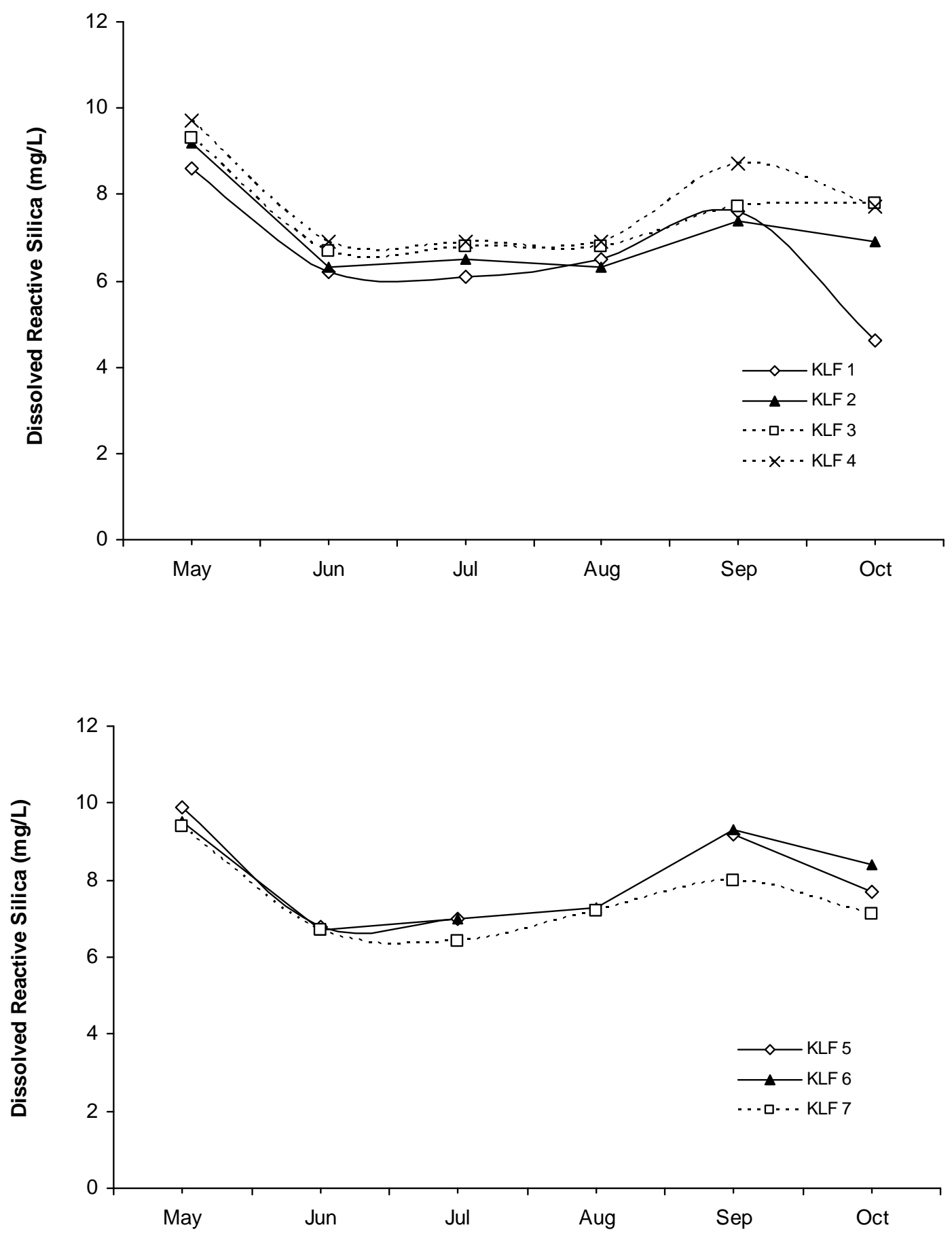

Figure 3.23. Silica measurements from $>50 \mathrm{~m}$ at KLF 1-4 in the North Arm (upper) and KLF 5-7 in the South Arm (lower) from May-September, 2005. Silica was not analyzed at KLF 5 in August.

Kootenay Lake Fertilization Experiment, Year 15 (North Arm) and Year 3 (South Arm) 68 (2006) Report 

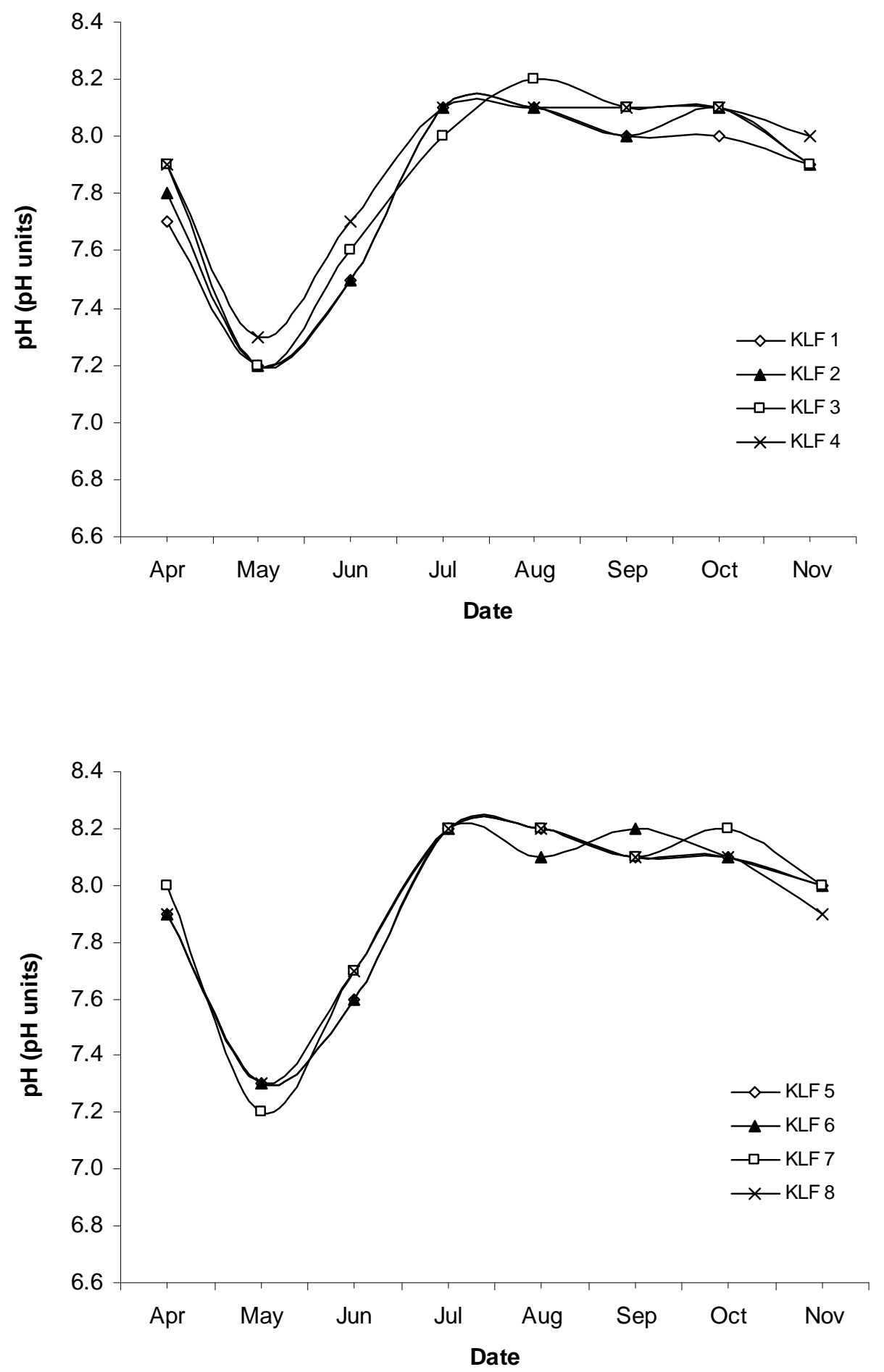

Figure 3.24. $\mathrm{pH}$ measurements from 0-20 m at KLF 1-4 in the North Arm (upper), KLF 5-7 in the South Arm and KLF 8 in the West Arm (lower) from AprilNovember, 2006.

Kootenay Lake Fertilization Experiment, Year 15 (North Arm) and Year 3 (South Arm) 69 (2006) Report 

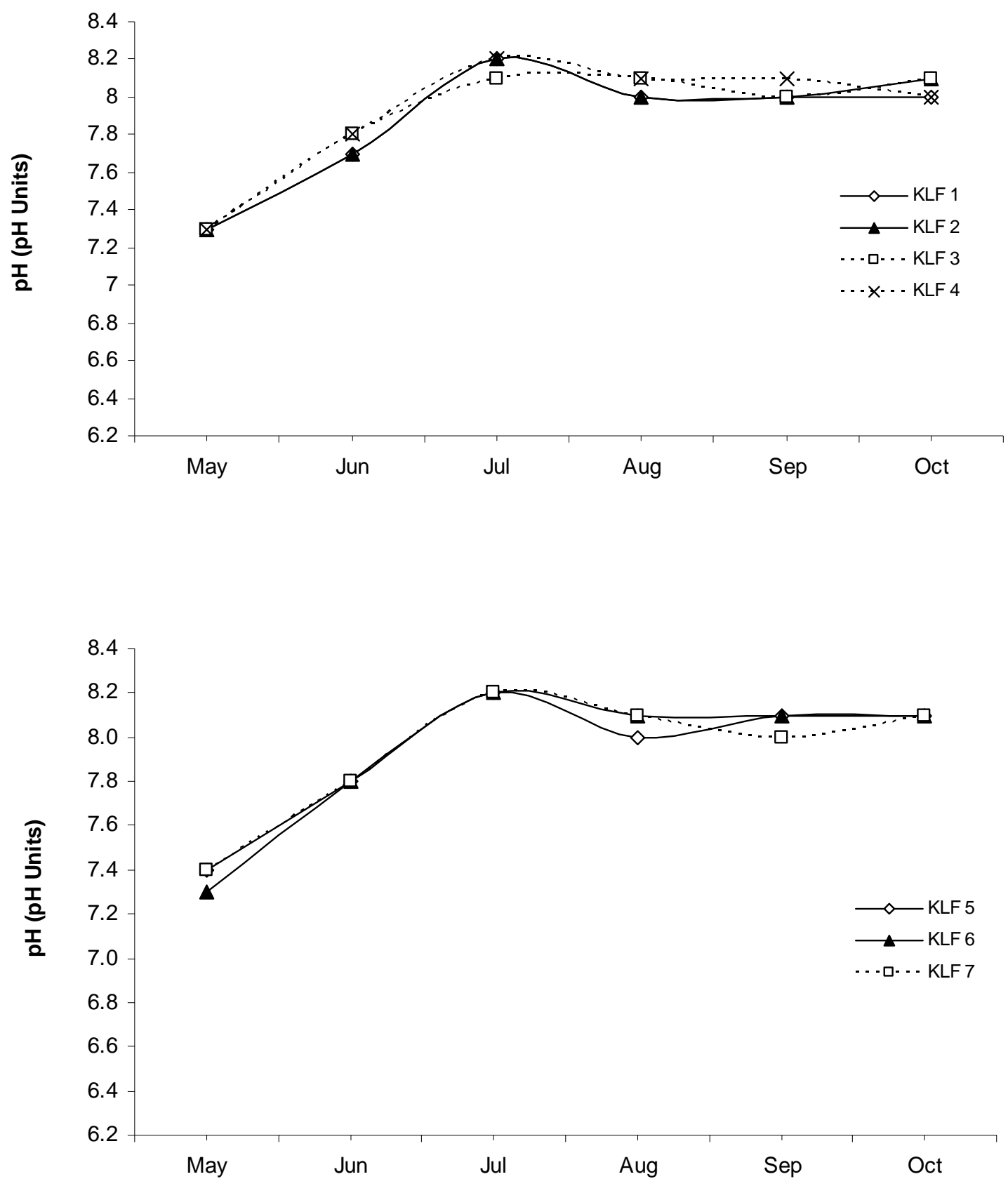

Figure 3.25. $\mathrm{pH}$ from $>50 \mathrm{~m}$ at KLF 1-4 in the North Arm (upper) and KLF 5-7 in the South Arm (lower) from May-September, 2006.

Kootenay Lake Fertilization Experiment, Year 15 (North Arm) and Year 3 (South Arm) 70 (2006) Report 

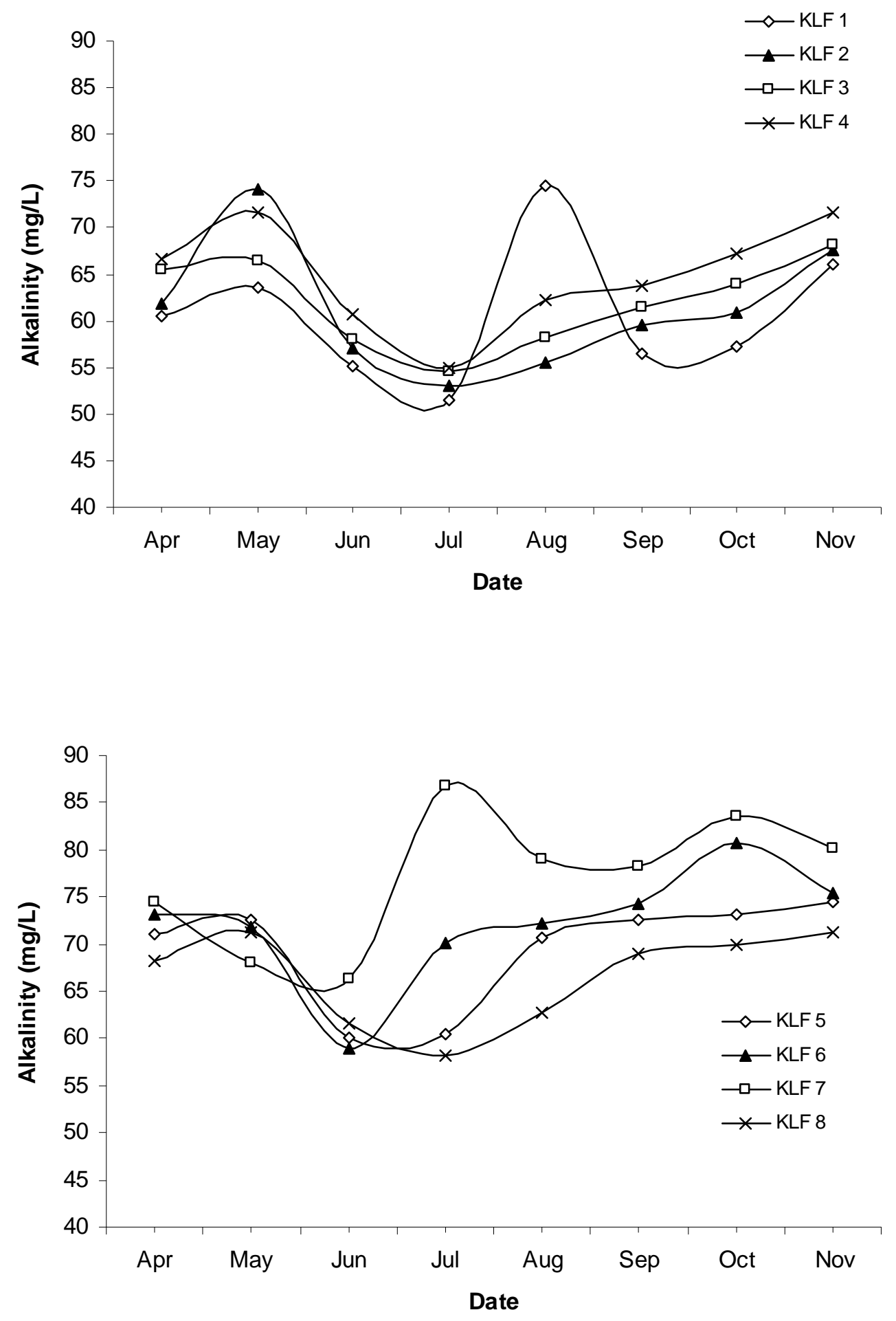

Figure 3.26. Alkalinity from 0-20 $\mathrm{m}$ at KLF 1-4 in the North Arm (upper), KLF 5-7 in the South Arm and KLF 8 in the West Arm (lower) from AprilNovember, 2006.

Kootenay Lake Fertilization Experiment, Year 15 (North Arm) and Year 3 (South Arm) 

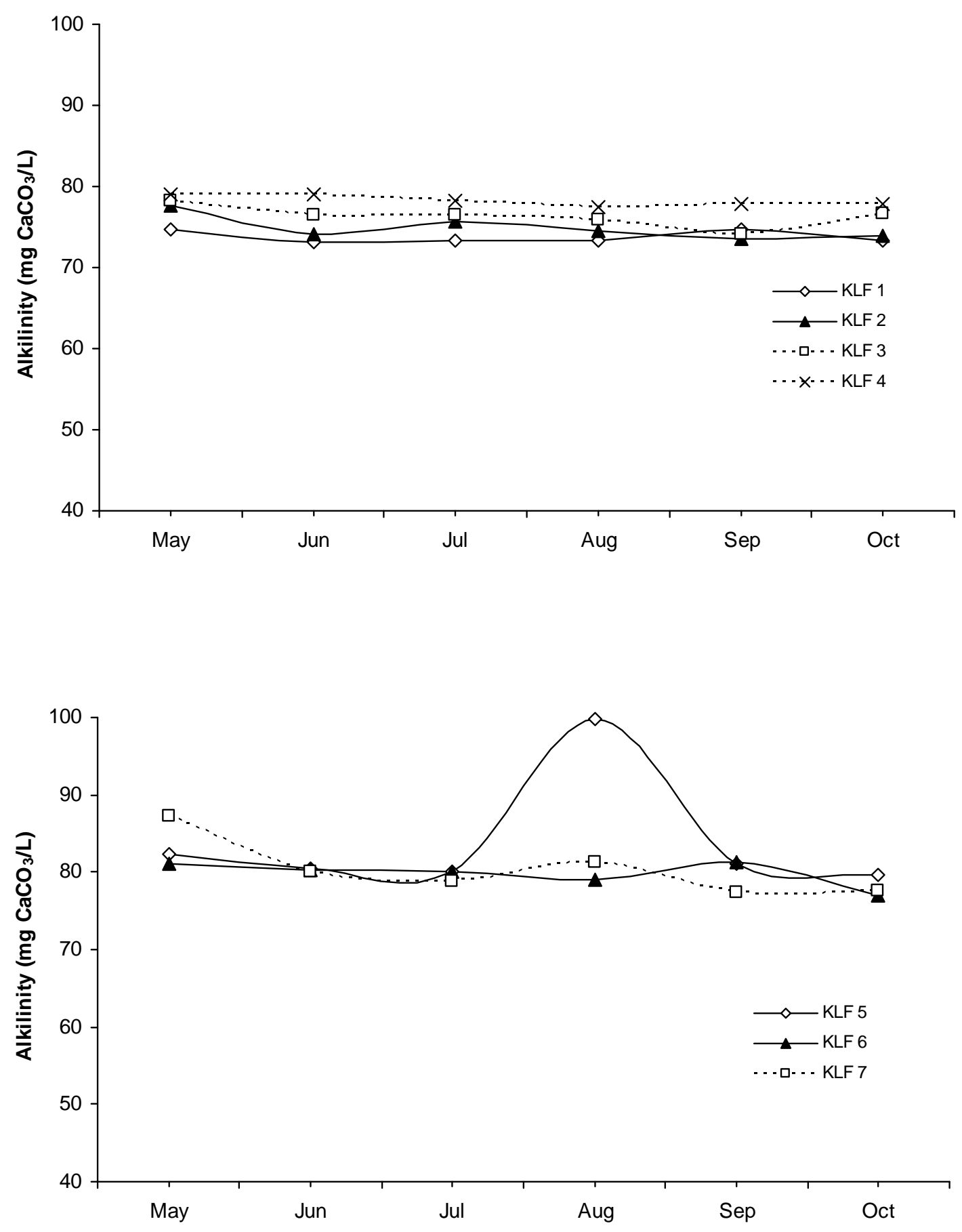

Figure 3.27. Alkalinity from $>50 \mathrm{~m}$ at KLF 1-4 in the North Arm (upper) and KLF 5-7 in the South Arm (lower) from May-October, 2006. No sample was taken at KLF1 in May.

Kootenay Lake Fertilization Experiment, Year 15 (North Arm) and Year 3 (South Arm) 72 (2006) Report 

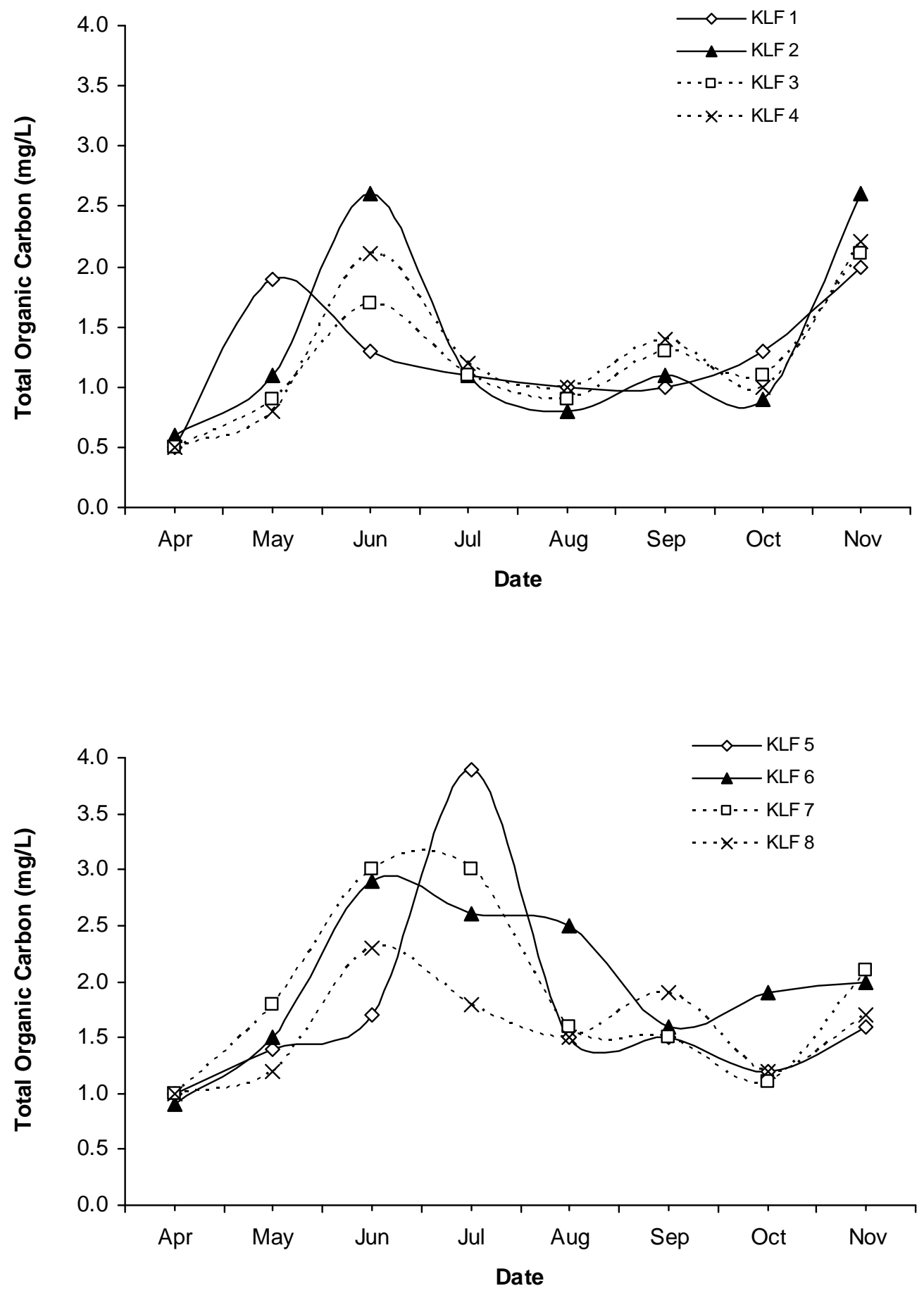

Figure 3.28. Total organic carbon (TOC) from 0-20 m at KLF 1-4 in the North Arm (upper), KLF 5-7 in the South Arm and KLF 8 in the West Arm (lower) from April-November, 2006.

Kootenay Lake Fertilization Experiment, Year 15 (North Arm) and Year 3 (South Arm) 73 (2006) Report 

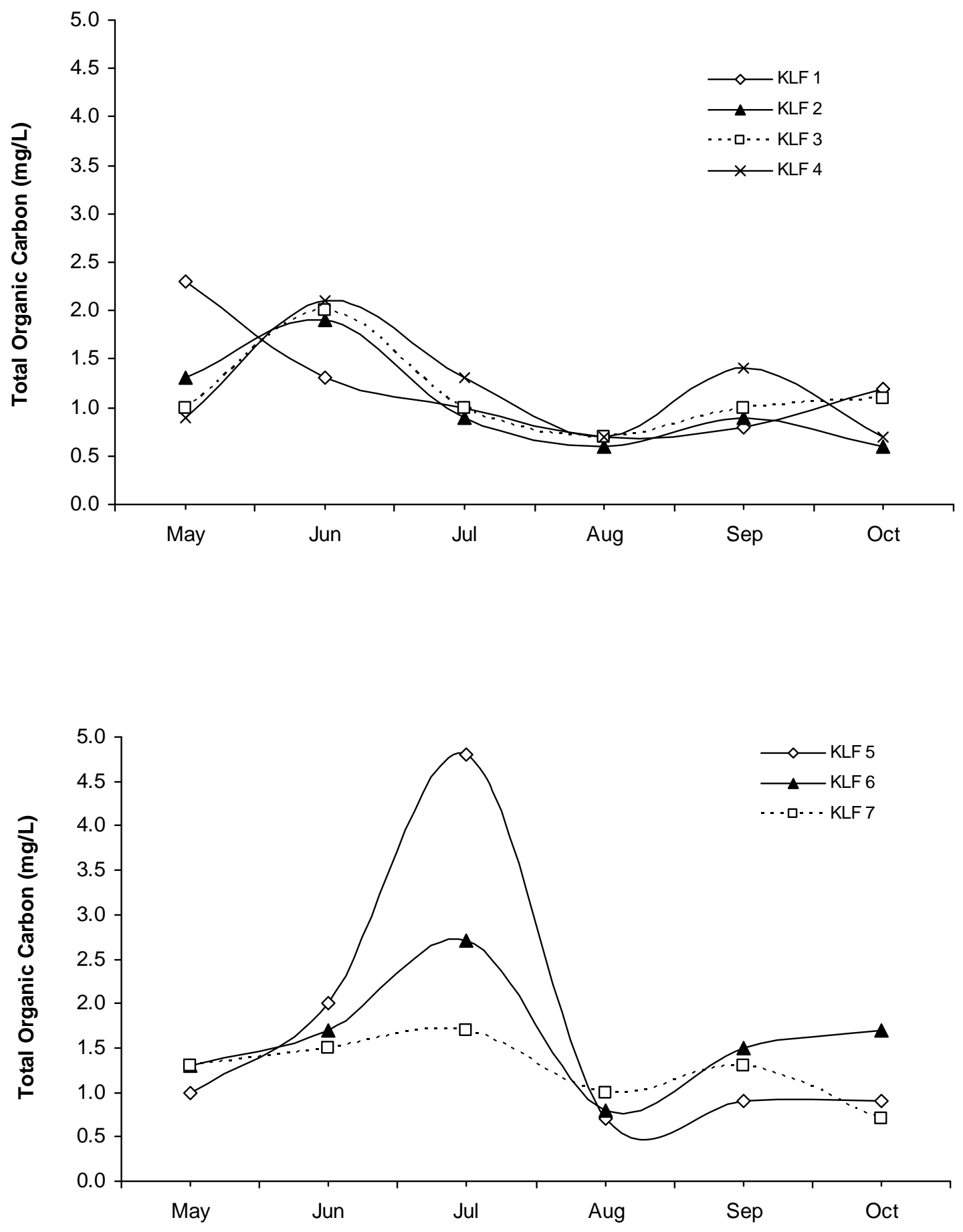

Figure 3.29. Total organic carbon (TOC) from $>50 \mathrm{~m}$ at KLF 1-4 in the North Arm (upper) and KLF 5-7 in the South Arm (lower) from May-October, 2006.

Kootenay Lake Fertilization Experiment, Year 15 (North Arm) and Year 3 (South Arm) 74 (2006) Report 

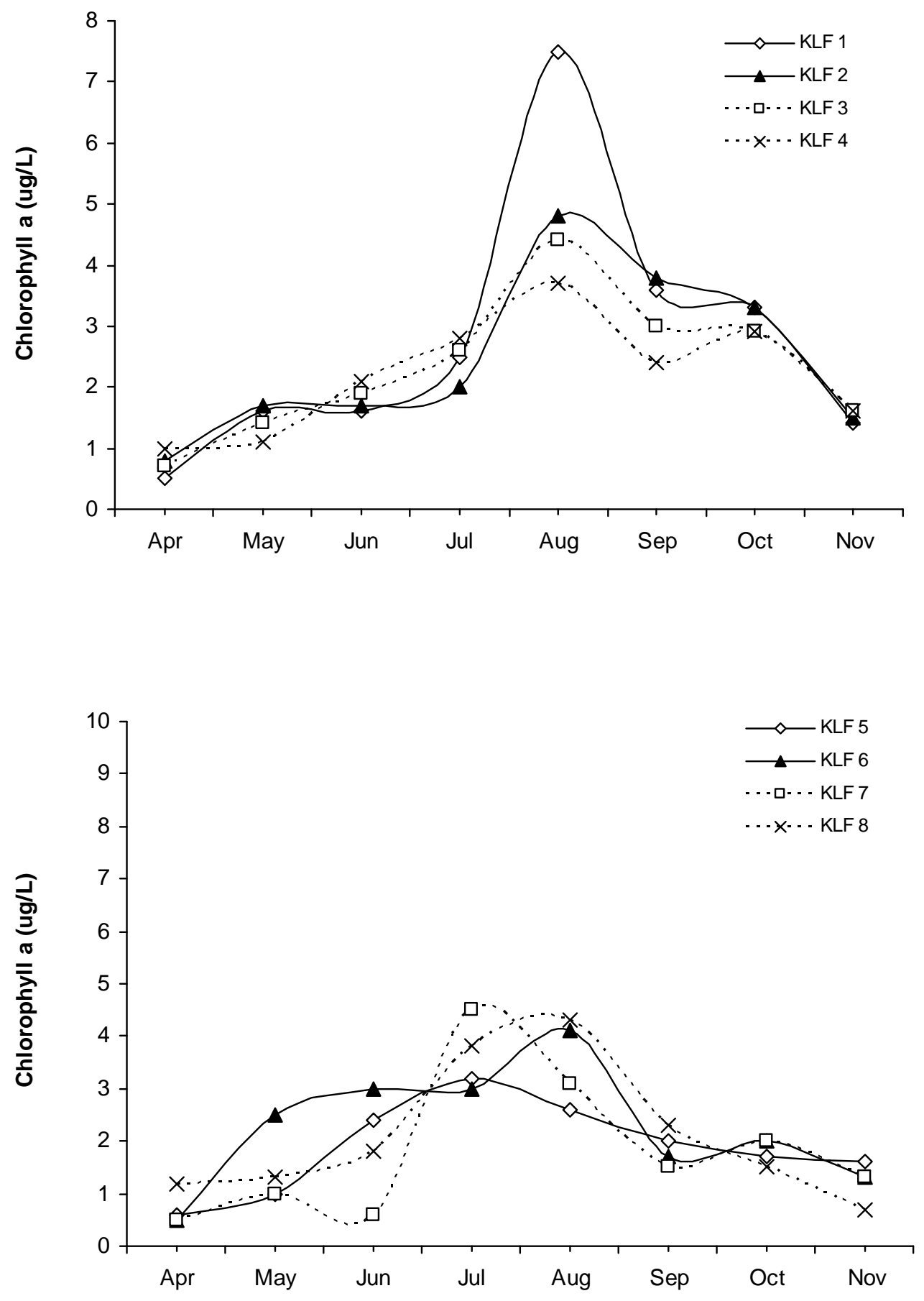

Figure 3.30. Chlorophyll $a$ from 0-20 m at KLF 1-4 in the North Arm (upper), KLF 57 in the South Arm and KLF 8 in the West Arm (lower) from AprilNovember, 2006.

Kootenay Lake Fertilization Experiment, Year 15 (North Arm) and Year 3 (South Arm) 75 (2006) Report 

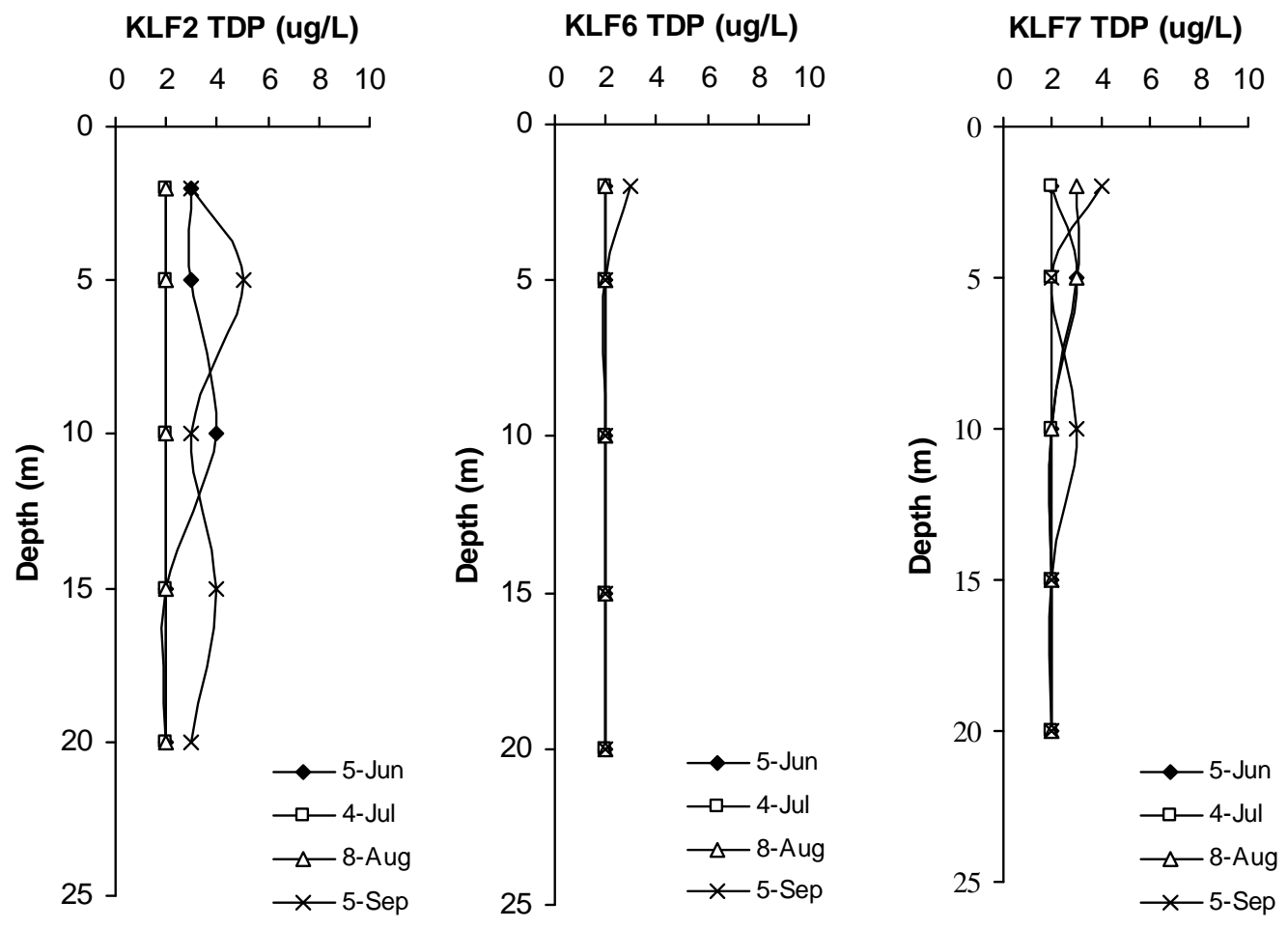

Figure 3.31. Discrete depth profiles of total dissolved phosphorus (TDP) in the epilimnion of Kootenay Lake, June-September, 2006.
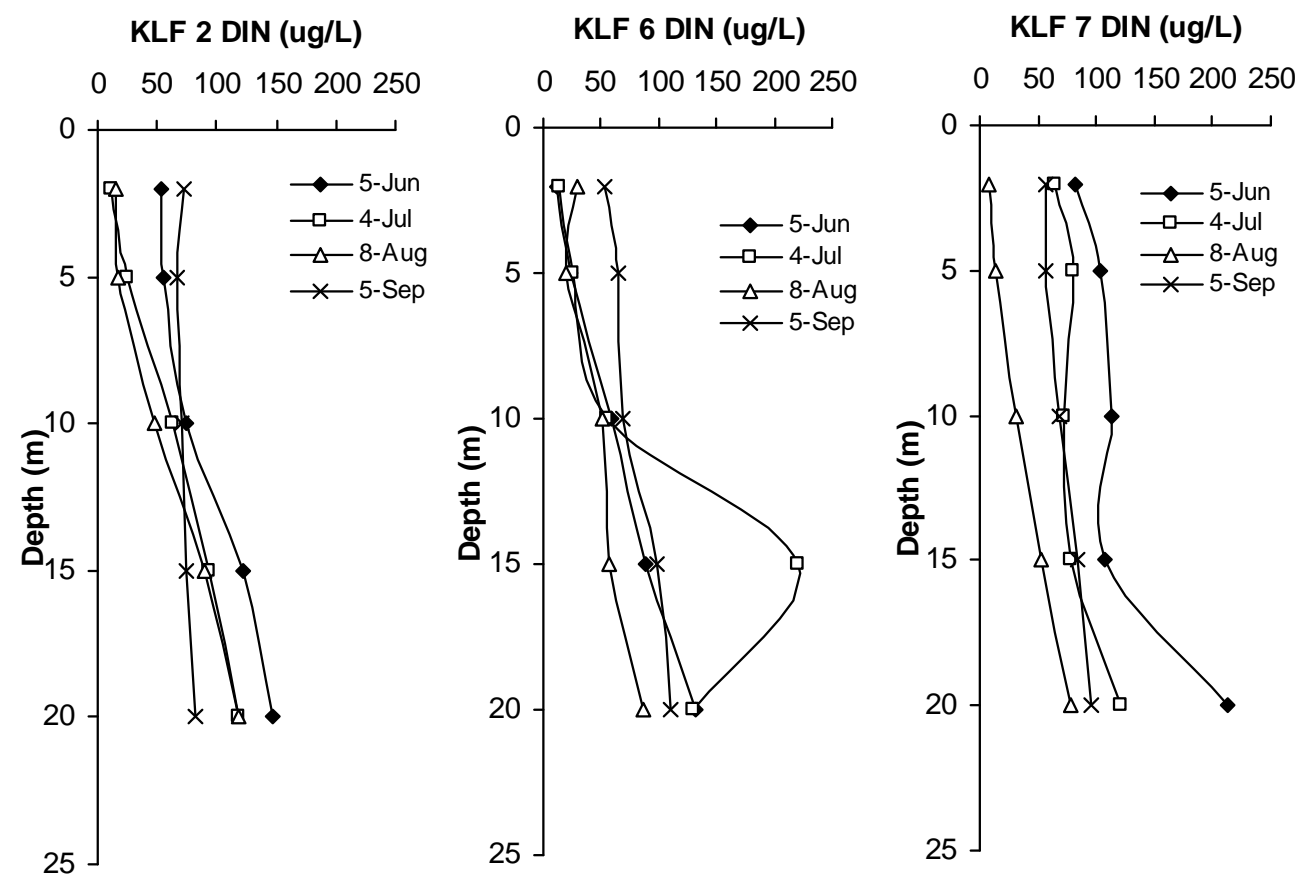

Figure 3.32. Discrete depth profiles of dissolved inorganic nitrogen (DIN) in the epilimnion of Kootenay Lake, June-September, 2006.

Kootenay Lake Fertilization Experiment, Year 15 (North Arm) and Year 3 (South Arm) 76 (2006) Report 

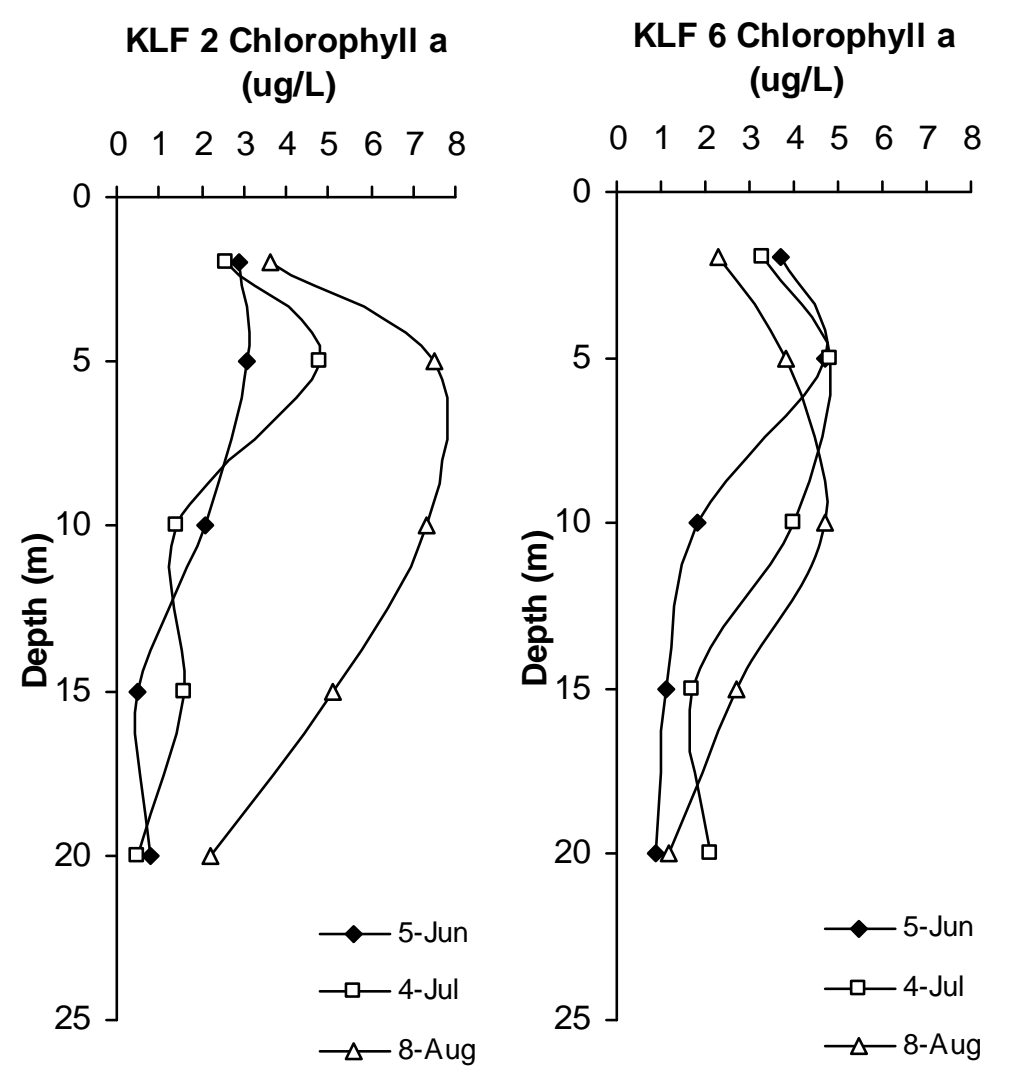
KLF 7 Chlorophyll a (ug/L)

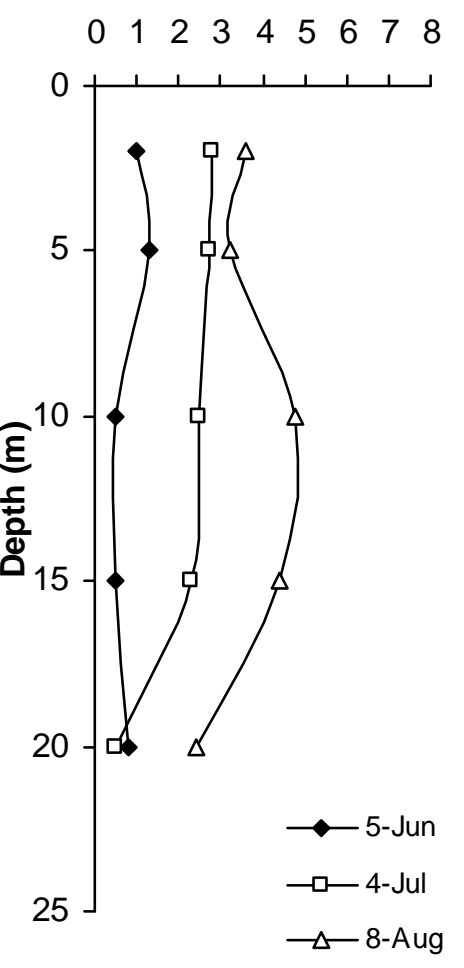

Figure 3.33. Discrete depth profiles of Chlorophyll $a$ in the epilimnion of Kootenay Lake, June-August, 2006. All September results were removed as errors were detected in the analysis.

Kootenay Lake Fertilization Experiment, Year 15 (North Arm) and Year 3 (South Arm) 77 (2006) Report 
Kootenay Lake Fertilization Experiment, Year 15 (North Arm) and Year 3 (South Arm)

(2006) Report 


\title{
CHAPTER 4
}

\section{PHYTOPLANKTON BIOMASS, COMPOSITION \\ AND SIZE DISTRIBUTION OF KOOTENAY LAKE, B.C., \\ FOLLOWING EXPERIMENTAL FERTILIZATION \\ YEAR 15 (NORTH ARM) AND YEAR 3 (SOUTH ARM) (2006)}

by

Frances R. Pick

Ottawa-Carleton Institute of Biology

Department of Biology

University of Ottawa

Ottawa, Ont.

K1N 6N5

and

\author{
Linda M. Ley \\ Paul B. Hamilton \\ Research Division \\ Canadian Museum of Nature \\ P.O. Box 3443, Station "D" \\ Ottawa, Ont. \\ K1P 6P4
}




\section{Introduction}

Kootenay Lake, a large $\left(390 \mathrm{~km}^{2}\right)$ fjord lake in South-Eastern British Columbia, has been continuously fertilized since 1992 in an effort to rehabilitate declining populations of kokanee salmon (Oncorhynchus nerka) (Ashley et al. 1997, 1999). From 1992 to 1996 the fertilization treatment to the North Arm used 47.1 tonnes of agricultural grade phosphorus fertilizer from spring to early fall. A further five-year adaptive management period of experimental fertilization was initiated in 1997 to document trophic level responses to changing loading rates of nitrogen and phosphorus. In 1997, fertilizer loading was lowered to 29.5 tonnes of phosphorus and this load was further reduced to 22.9 tonnes of phosphorus in each year of 1998 and 1999. In the $9^{\text {th }}$ year of fertilization (2000) the load was increased back to 29.5 tonnes of phosphorus as it was in 1997 and in the $10^{\text {th }}-12^{\text {th }}$ year $(2003)$ the load was further increased back to 47.1 tonnes as during 1992-96. In 2004, 38 tonnes of phosphorus and 244 tonnes of nitrogen were added to the North Arm. In addition, in 2004, the South Arm was fertilized for the first time during August (Aug 1-Sept 10 ${ }^{\text {th }}$ ) with a weekly addition of nitrogen (28-0-0). In 2005, the total load of fertilizer distributed in 2005 in the North Arm was 44.1 tonnes of phosphorus and 246.9 tonnes of nitrogen, dispensed weekly from April 24th to September $5^{\text {th }}$; N was added to the South Arm as an agricultural grade of 28-0-0 urea-ammonium nitrate formulation, twice per week from June $5^{\text {th }}$ to September $5^{\text {th }}$ (except weeks of July $17^{\text {th }}$, July $31^{\text {st }}$, and September $4^{\text {th }}$ ) for a total load similar to the North Arm (234 tonnes of N). In 2006, 44.6 tonnes of $\mathrm{P}$ and 248.4 tonnes of $\mathrm{N}$ were added to the North Arm and 257.3 tonnes of $\mathrm{N}$ to the South Arm. In 2006, nitrogen was added at weekly intervals (see Chapter 2 of this report).

The rationale for the fertilization programme was that the lake had been suffering from an "oligotrophication" due to the construction of dams on both major tributaries (Duncan and Kootenay Rivers) and consequent reductions in anthropogenic nutrient loading. The historical record on the phytoplankton community dating from the early 1970s through the early 80 s indicated subtle changes in species composition towards more oligotrophic taxa even though total algal biomass did not decline significantly during the same period (Daley and Pick 1990). With fertilization, an increase in primary production and algal biomass was anticipated to trigger an increase in cladoceran biomass for consumption by young of the year kokanee salmon (Walters et al. 1991). Other lakes in British Columbia have undergone artificial fertilization with apparently positive effects on fish production (Stockner and MacIssac 1996).

This report is an analysis of the changes, induced by fertilization, to the phytoplankton community of Kootenay Lake during 2006, the $15^{\text {th }}$ year of fertilization in the North Arm and the third year of fertilization with nitrogen in the South Arm. The data from the 2006 sampling are presented with a comparison to 1992-2005 data. As in 2003 - 2005 in addition to the standard stations KLF 2, 4, 6 and 7, the stations KLF 1, 3, 5 and 8 (located in the West Arm of Kootenay, where water exits the lake) were also sampled.

Kootenay Lake Fertilization Experiment, Year 15 (North Arm) and Year 3 (South Arm) 


\section{Methods}

Water samples were collected monthly from April to November, integrating a $0-20 \mathrm{~m}$ water column, in keeping with the historical sampling procedure, at seven stations along the length of the North Arm and into the South Arm and at one station in the West Arm (station KLF 8).

Subsamples of integrated samples were preserved for phytoplankton analysis using Lugol's iodine solution. Enumerations were made on settled material (Utermöhl 1938, Lund et al. 1958), using a Leitz Dialux 22 light microscope. Aliquots of 5 - $15 \mathrm{ml}$ were settled overnight (16 hours) in $26 \mathrm{~mm}$ diameter sedimentation chambers. For each sample, a minimum of 300-350 phytoplankton cells was counted along randomly selected transects to ensure an 85-90\% counting accuracy (Lund et al. 1958). The length of each transect equalled the diameter of the chamber. Cell counts and dimensions were recorded on a computerized counter (Hamilton 1990) to facilitate the calculations of the parameters describing phytoplankton community structure. For counting purposes cells were assigned to one of three magnifications: 400X, 200X and 100X, depending on their size and nature. The cells were consistently identified and enumerated at the assigned magnification.

The estimations of total algal biomass, and size and division distribution were derived from the enumerations. Algal biomass was determined from estimations of the volume of each algal taxon. One of seven pre-selected shapes (sphere, cone, double cone, ellipsoid, parallelepiped, half parallelepiped and rod) was assigned to each species (Hamilton 1990). The dimensions were measured on 3-10 individuals per species. The summation of the individual cell volumes: the biovolume was converted to biomass ( $\mathrm{mg}^{-\mathrm{m}^{-3}}$ ) assuming a density of 1 (Utermöhl 1958).

Taxa were assigned to specific size classes based on the mean of their longest dimension. Accordingly, total biomass was partitioned into six size classes: the picoplankton $(<2.1 \mu \mathrm{m})$, the ultraplankton $(>2-10 \mu \mathrm{m})$, the nanoplankton $(10.1-20 \mu \mathrm{m})$, the microplankton (20.1-64 $\mu \mathrm{m})$ and the net plankton $(>64 \mu \mathrm{m})$. For the purposes of reporting here, nanoplankton are considered to encompass $2-20 \mu \mathrm{m}$ in diameter cells, which is considered the most edible fraction for zooplankton. In contrast the net plankton is considered the least edible size fraction. Picoplankton, which can be very abundant in oligotrophic BC lakes, is a size fraction difficult to enumerate accurately by conventional light microscopy and needs to be examined by epifluorescence microscopy.

Total biomass was further separated into seven main divisions: Cyanobacteria, Chlorophyta, Chrysophyta, Cryptophyta, Pyrrhophyta, diatoms, and Euglenophyta and Xanthophyta. The latter division was not recorded in Kootenay Lake and euglenophytes were extremely rare.

A species list for all phytoplankton enumerated is given in Appendix II along with the codes used for these species; the list of "associated taxa" refers to algae observed in the samples but not present in the enumerated transects (Appendix II is available in a hard

Kootenay Lake Fertilization Experiment, Year 15 (North Arm) and Year 3 (South Arm) 
copy report with the Fish and Wildlife Compensation Program, Nelson, BC). The count sheets of the raw data are provided in Appendix III for each sample (Appendix III is available in a hard copy report with the Fish and Wildlife Compensation Program, Nelson, BC). Linda Ley conducted the enumerations using the same technique as in previous years using the same computer program (Hamilton 1990).

\section{Results and Discussion}

\section{Monthly transects}

Total phytoplankton biomass was low in April with lower concentrations in the North Arm stations (KLF 1-4 average $0.07 \mathrm{~g} \mathrm{~m}^{-3}$ ) compared to the South Arm stations (KLF 5-7 average $0.12 \mathrm{~g} \mathrm{~m}^{-3}$ ) (Fig. 4.1). Cryptophytes (Cryptomonas spp. and Rhodomonas renamed Plagioselmus) were dominant.

The low biomass in April was followed by a rise in biomass in May at all stations. The May rise in the North Arm was due to further increases in cryptophytes and in the case of the South Arm additionally some centric diatoms (Cyclotella. sp).

Biomass continued to rise through early June because of increases in pennate diatoms namely Synedra spp. and some Asterionella. In July algal biomass was highest at KLF 5 and KLF 6 in the South Arm from increases in Fragilaria (particularly at KLF 6), Tabellaria and some Cyclotella.

Algal biomass was highest across the lake in August when the pattern was one of very high biomass in the North Arm (KLF $1 \& 2>1 \mathrm{~g} / \mathrm{m}^{3}$ ) declining into the South Arm (Fig. 4.1). During August pennate diatoms Fragilaria crotonensis and Tabellaria contributed the greatest biomass $(\sim 70 \%)$ in the North Arm, whereas in the South Arm these same taxa were less dominant $(\sim 50 \%)$.

A North-South decline in biomass was also observed in September and October when pennate diatom biomass was declining. Small centric diatoms were relatively more numerous in September, whereas cryptomonads resumed numerical dominance in October at all stations. During November biomass was uniformly at its lowest point (Fig. 4.1).

\section{Taxonomic composition at the division level}

Diatoms (Bacillariophyta) dominated the biomass of Kootenay Lake regardless of the sampling date or station, comprising on average depending on the station between $80 \%$ (station KLF 2) and 65\% (station KLF 6) of the total algal biomass. As is typically observed in other years, large pennate diatoms tend to dominate the maximum biomass periods but in 2006 this occurred in July - August rather than the typical spring period (mid to late June is typically when Kootenay Lake has a diatom maximum). Later in the summer a variety of centric species of the genus Cyclotella become more abundant but in 2006 they were rarely ever dominant in terms of biomass.

Kootenay Lake Fertilization Experiment, Year 15 (North Arm) and Year 3 (South Arm) 82 
Following diatoms, the next most important division was the Cryptophyta followed by the Chrysophyta and finally Cyanobacteria or "others" (comprised of Chlorophyta and Pyrrhophyta) (Fig. 4.2A and B). Cryptophyta were typically most dominant in the spring (April through June Fig. 4.2A and B). As was observed in 2005, on average the contribution of cryptophytes to total biomass was greater in the South Arm than in the North Arm (31\% vs. 18\%); overall the cryptophyte biomass was higher in 2006 than in 2005. Cryptophytes are considered the most nutritional algae for zooplankton growth along with chlorophytes so an increase in cryptophyte biomass should have positive impacts on zooplankton production.

Chrysophyta comprised the third major algal division in Kootenay Lake and chrysophyte biomass was slightly higher in the South Arm as well as the contribution of chrysophytes to total biomass $(2.8 \%$ vs. $1.3 \%$ in North Arm) but chrysophyte biomass was lower in 2006 than 2005.

\section{Size distribution}

Large pennate diatoms tend to dominate biomass in Kootenay probably as a result of significant deep vertical mixing and silica availability. As a result, the size distribution of algal biomass tends to be dominated by the larger fractions (Fig. 4.3). Netplankton with a maximum linear dimension greater than $64 \mu \mathrm{m}$ was a significant fraction of the total biomass ranging from 35 to $42 \%$ on an annual basis depending on the station and varied from 3 to $79 \%$ seasonally. As such the effect of season tends to override the effect of station or fertilisation on the size distribution of biomass. In the North Arm there was a large increase in net plankton in August and October (Fig. 4.3). The average contribution of netplankton to the total biomass was greater in the North Arm (42\%) than in the South Arm during 2006 (35\%) in contrast to 2005 when less of a difference was observed.

Nanoplankton plankton biomass $(2-20 \mu \mathrm{m})$ was higher in the South Arm in the spring (May and June) while the North Arm nanoplankton was higher later in the year (August, September, October) (Fig.4.4).

\section{Comparison with the previous years of fertilization}

In the year 2006, the average biomass was higher in the North relative to the South Arm (Table 4.1), the summer biomass (June, July, August) was higher in the $\mathrm{N}+\mathrm{P}$ fertilized

North Arm versus the N-fertilized South Arm (Fig. 4.5) with 0.62 vs. $0.47 \mathrm{~g} \mathrm{~m}^{-3}$ total algal biomass.

Considering the levels of fertilizer added to the North Arm in 2006, algal biomass was not as high as in previous years with similar fertilizer additions, or more significantly, the enhancement relative to the South Arm was not particularly high at 1.26 (Table 4.1). Daphnia spp. were abundant in 2006, therefore a grazing effect could explain the decreased phytoplankton biomass. The highest summer enhancement was recorded in 2001 at 3.04 (Table 4.1). While differences in the enhancement ratios could in part be due

Kootenay Lake Fertilization Experiment, Year 15 (North Arm) and Year 3 (South Arm) 83 
to the timing of sampling with respect to blooms, they may also reflect differences in the physical regime of the lake between years as there is a strong climate effect on the year to year variation in algal biomass (Fig. 4.5).

The addition of nitrogen to the South Arm did not result in a significant increase in summer biomass relative to the natural variation observed over the 10 years when the South Arm was not treated (2006 Stn KLF 6 summer average $0.47 \mathrm{~g} \mathrm{~m}^{-3}$ vs. the average of 1993-2003 of $0.59 \mathrm{~g} \mathrm{~m}^{-3}$ ). The fact that the North Arm was on average higher points to the overall importance of $\mathrm{P}$ in limiting algal biomass in Kootenay Lake.

\section{Acknowledgements}

Thanks to Kootenay Wildlife Services Ltd for sample collection. Funding was provided by the Fish and Wildlife Compensation Program - Columbia Basin for stations KLF 2, 4, 6 and 7. Funding was provided by the Kootenai Tribe of Idaho for stations KLF 1, 3, 5 and 8.

\section{References}

Ashley, K., L. C. Thompson, D. C. Lasenby, L. McEachern, K. E. Smokorowski and Dale Sebastian. 1997. Restoration of an interior lake ecosystem: the Kootenay Lake fertilization experiment. Water Qual. Res. J. Canada 32: 295-323.

Ashley, Ken, Lisa C. Thompson, Dale Sebastian, David C. Lasenby, Karen E. Smokorowski and Harvey Andrusak. 1999. Restoration of Kokanee salmon in Kootenay Lake, a large intermontane lake, by controlled seasonal application of limiting nutrients. Aquatic Restoration in Canada, (Ed.) T. Murphy \& $\mathrm{M}$. Munawar. Backhuys Publishers, Leiden, The Netherlands.

Daley, R.D. \& F.R. Pick. 1990. Phytoplankton biomass and composition of Kootenay Lake, British Columbia, following reductions in phosphorus loading. Verh. Internat. Verein. Limnol. 24: 314-318.

Hamilton, P.B. 1990. The revised edition of a computerized plankton counter for plankton, periphyton and sediment diatom analyses. Hydrobiologia 194: 23-30.

Kalff, J. 2000. Limnology. Prentice-Hall.

Lund, J.W.G., C. Kipling \& E.D. Le Cren. 1958. The inverted microscope method of estimating algal numbers and the statistical basis of estimations by counting. Hydrobiologia 11: 143-170.

Pick, F.R. \& D.R.S. Lean. 1987. The role of macronutrients (C, N, P) in controlling cyanobacterial dominance in temperate lakes. New Zealand J. Mar. Freshwat. Res. 21: 425-434.

Kootenay Lake Fertilization Experiment, Year 15 (North Arm) and Year 3 (South Arm) 
Reynolds, C. S. 1984. The ecology of freshwater phytoplankton. Cambridge University Press, Cambridge, U.K. 384 pp.

Stockner, J.G. and E.A. MacIssac. 1996. British Columbia lake enrichment programme: two decades of habitat enhancement for sockeye salmon. Regulated Rivers: Research and Management 12: 547-561.

Utermöhl, H. 1938. Zur vervollkommnung der quantitativen phytoplankton methodik. Mitt. Int. Verein. Limnol. 9: 1-39.

Walters, C.J., J. Digisi, J. Post \& J. Sawada. 1991. Kootenay Lake Fertilization Response Model. Fisheries Management report No. 98, Ministry of the Environment, Province of British Columbia. $36 \mathrm{pp}$. 
Table 4.1. Biomass averages (mg. $\mathrm{m}^{3}$ ) at the station 2 (KLF 2) in the North Arm and at station 6 (KLF 6) in the South Arm from 1992 to 2006. Enhancement is the effect of fertilization during the summer (ratio of Stn 2 over Stn 6) although starting in $2004 \mathrm{~N}$ has been added to the South Arm.

\begin{tabular}{|c|c|c|c|c|c|}
\hline & & $\begin{array}{l}1 \\
\text { Oct.) } \\
-14)\end{array}$ & $\begin{array}{l}\text { Summ } \\
\text { (Jun. } \\
\text { (n=3 }\end{array}$ & & $\begin{array}{l}\text { Summer } \\
\text { Enhancement }\end{array}$ \\
\hline & $\operatorname{Stn} 2$ & $\operatorname{Stn} 6$ & $\operatorname{Stn} 2$ & $\operatorname{Stn} 6$ & Ratio \\
\hline 1992 & 445 & 359 & 534 & 473 & 1.13 \\
\hline 1993 & 658 & 364 & 1091 & 455 & 2.40 \\
\hline 1994 & 900 & 477 & 1183 & 557 & 2.12 \\
\hline 1995 & 1366 & 800 & 1556 & 945 & 1.65 \\
\hline 1996 & 1867 & 813 & 2483 & 1040 & 2.39 \\
\hline 1997 & 626 & 337 & 1081 & 519 & 2.08 \\
\hline 1998 & 436 & 323 & 516 & 462 & 1.12 \\
\hline 1999 & 405 & 340 & 501 & 397 & 1.26 \\
\hline 2000 & 500 & 316 & 419 & 395 & 1.06 \\
\hline 2001 & 1011 & 438 & 1016 & 334 & 3.04 \\
\hline 2002 & 572 & 875 & 881 & 1085 & 0.82 \\
\hline 2003 & 509 & 276 & 720 & 340 & 2.12 \\
\hline 2004 & 217 & 287 & 224 & 336 & 0.67 \\
\hline 2005 & 439 & 429 & 624 & 469 & 1.33 \\
\hline 2006 & 464 & 317 & 589 & 469 & 1.26 \\
\hline
\end{tabular}




\section{Kootenay Lake \\ Phytoplankton Biomass 2006}

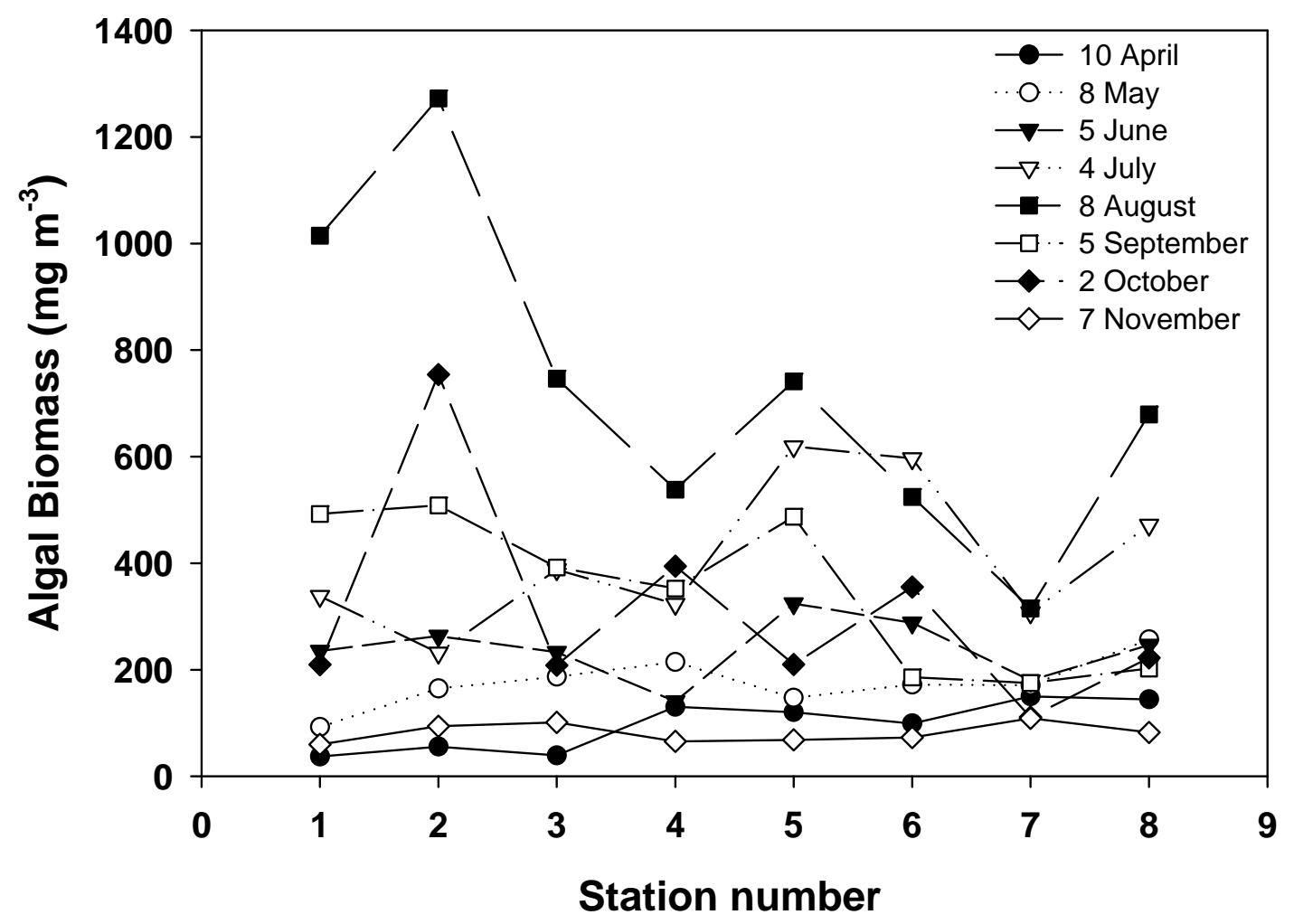

Figure 4.1. Total algal biomass, along the North South transect of Kootenay Lake, from April through November of 2006. Stations KLF 1 through KLF 7. Station KLF 8 is located in the West Arm. 


\section{Kootenay Lake 2006 Station 2 Phytoplankton composition}

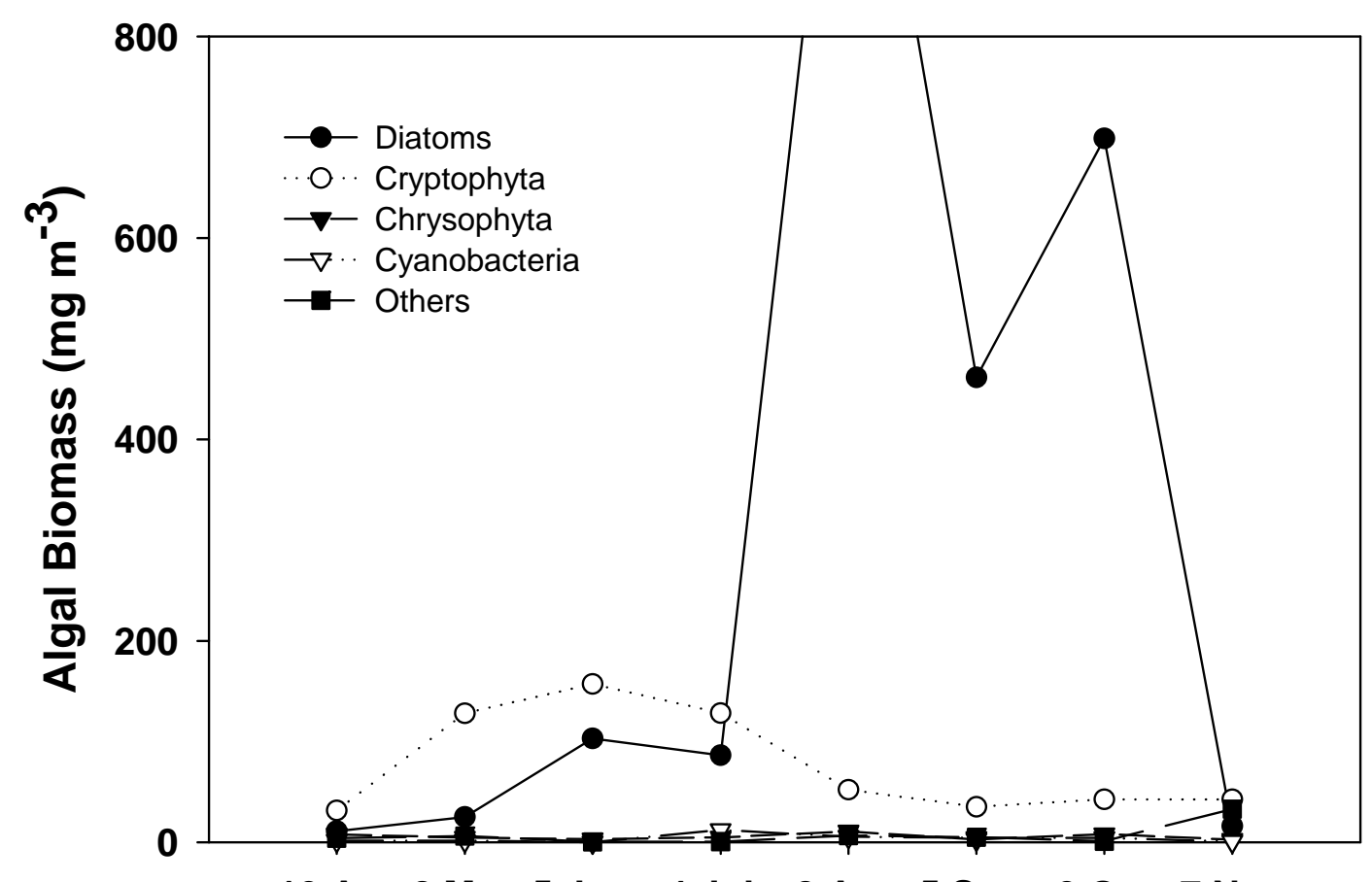

10 Apr 8 May 5 June 4 July 8 Aug 5 Sept 2 Oct 7 Nov

2006

Figure 4.2A. Seasonal algal biomass, by algal division, for station KLF 2 in the North Arm in 2006. Lines correspond to divisions as indicated in the legend. "Others" correspond to chlorophytes and occasional pyrrhophytes (dinoflagellates). 


\section{Kootenay Lake 2006 \\ Station 6 Phytoplankton composition}

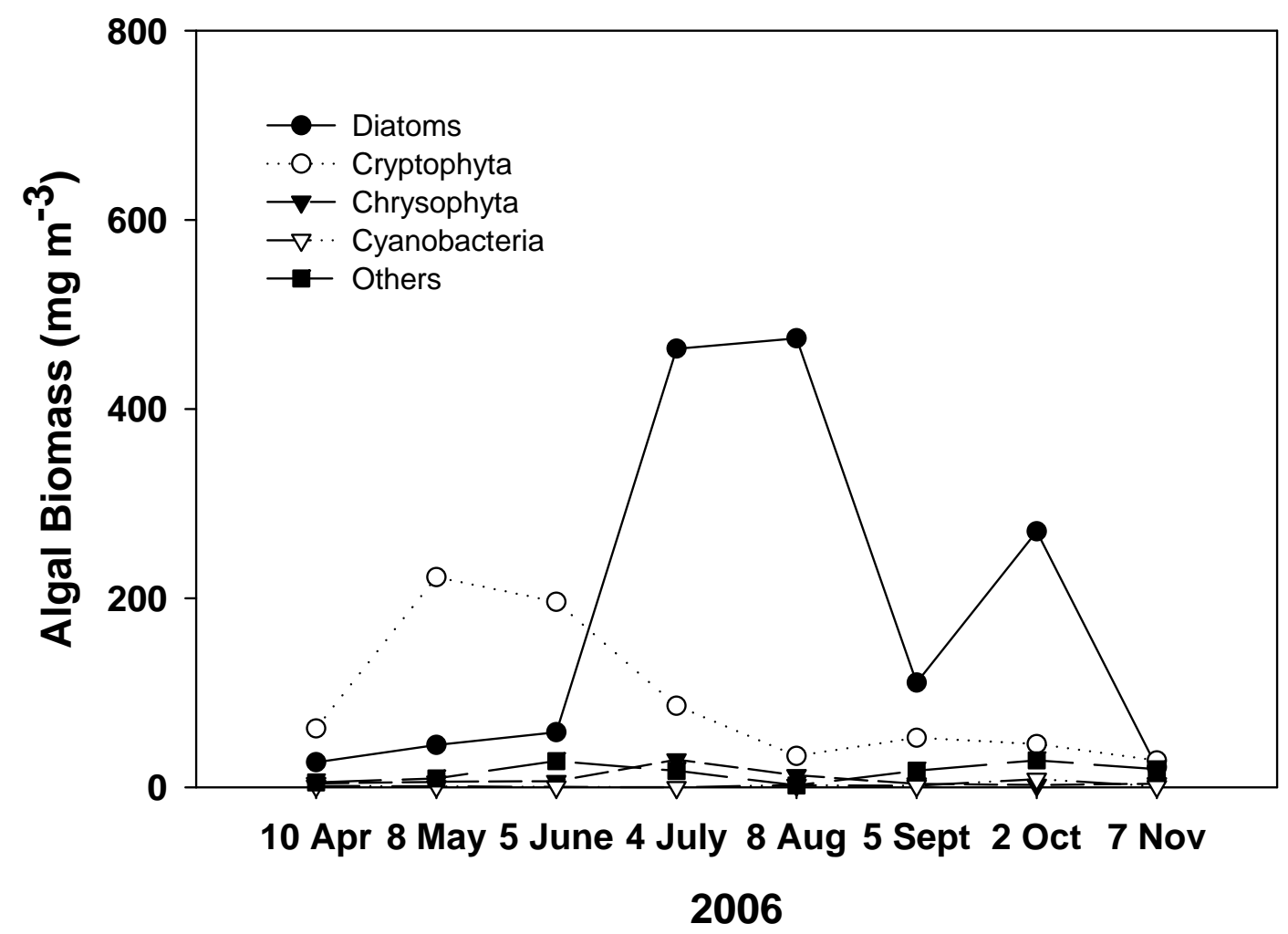

Figure 4.2B. Seasonal algal biomass, by algal division, for station KLF 6 in theSouth Arm in 2006. Lines correspond to divisions as indicated in the legend. "Others" correspond to chlorophytes and occasional pyrrhophytes (dinoflagellates). 


\section{Kootenay Lake 2006}

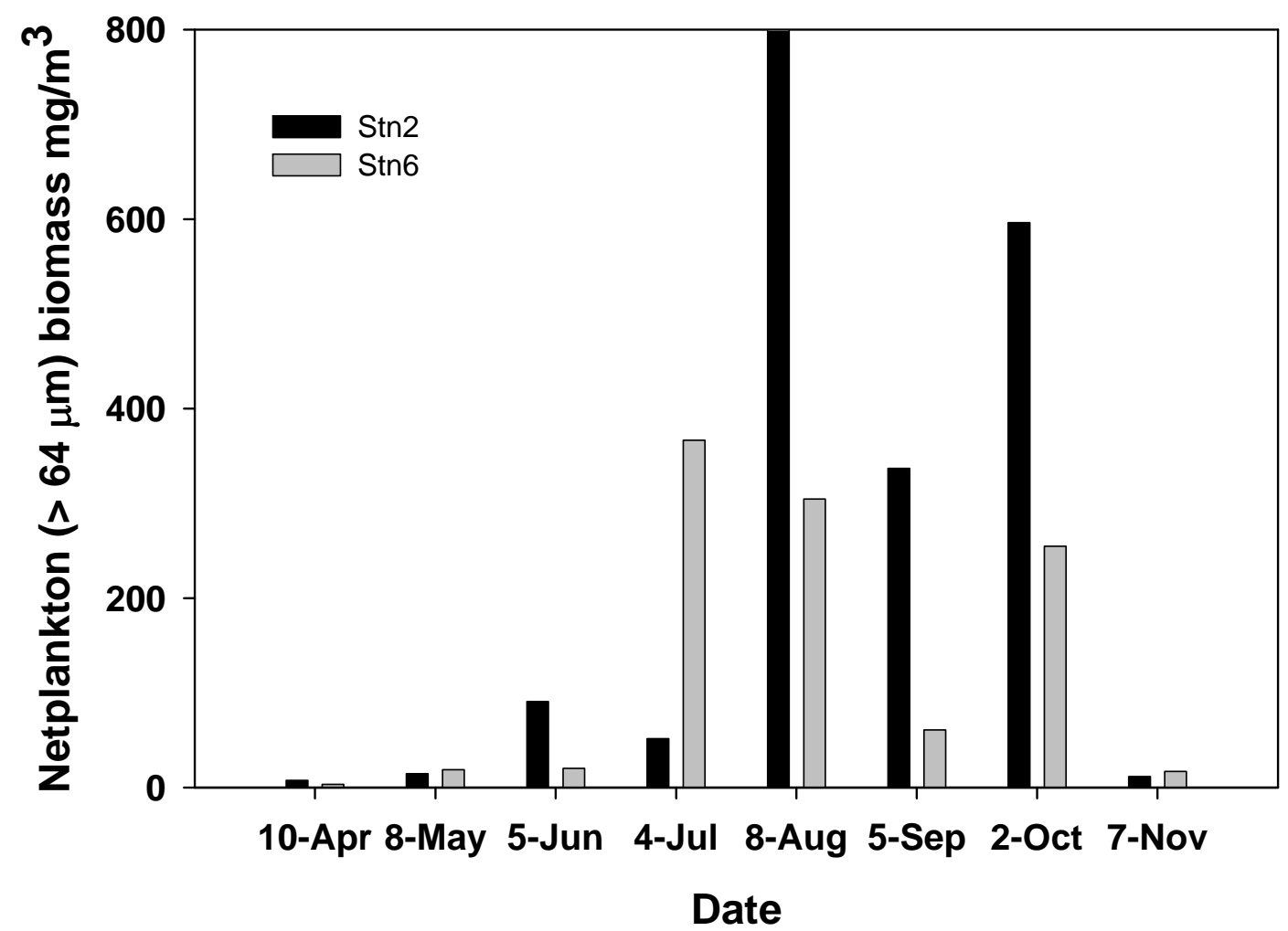

Figure 4.3. Seasonal biomass of netplankton $(>64 \mu \mathrm{m})$ at stations KLF 2 (dark histograms) and KLF 6 (light histograms). 
Kootenay Lake 2006

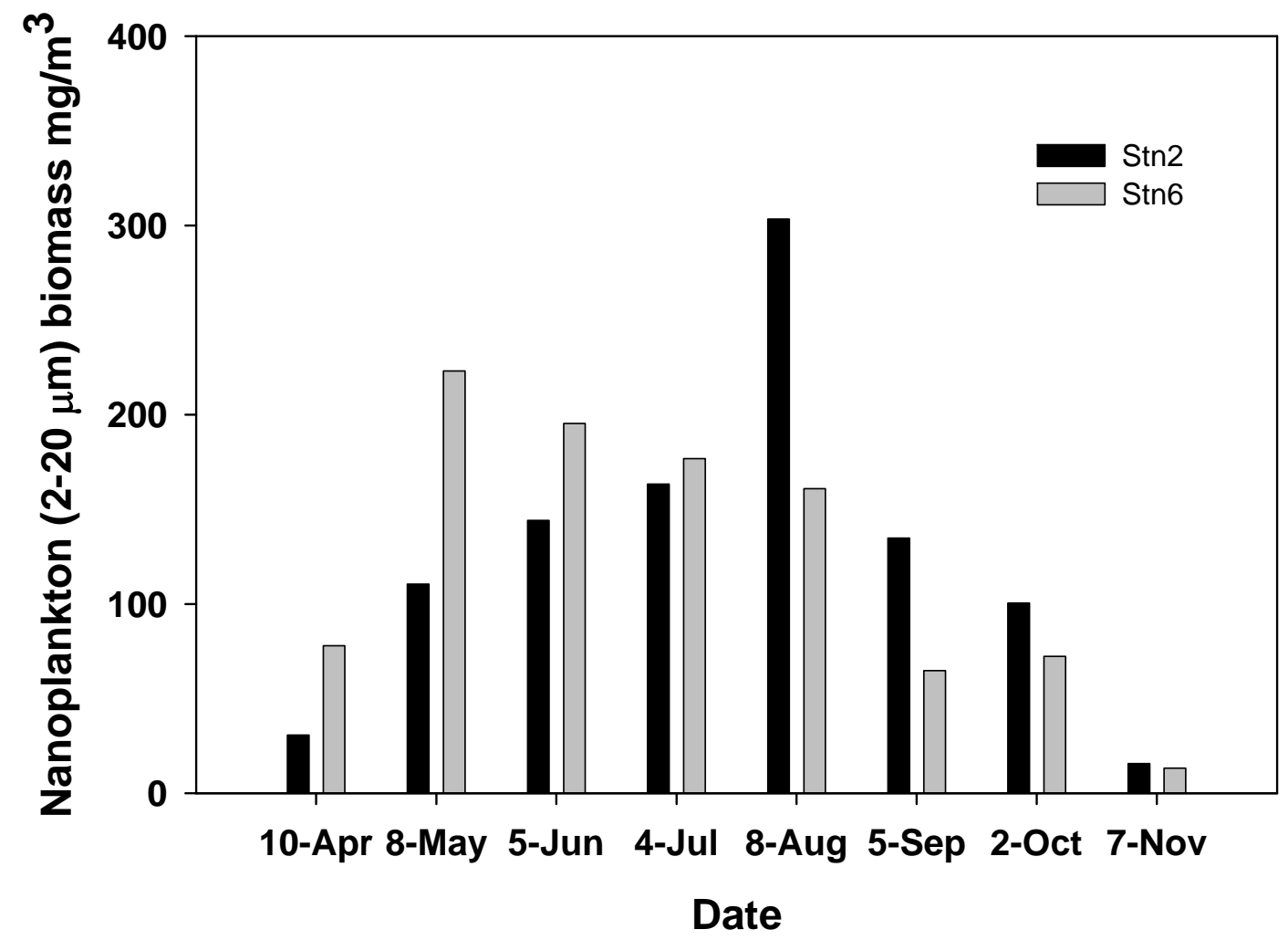

Figure 4.4. Seasonal biomass of nanoplankton $(2-20 \mu \mathrm{m})$ at stations KLF 2 (dark histograms) and KLF 6 (light histograms). 


\section{Kootenay Lake Summer average (Jun. - Aug.)}

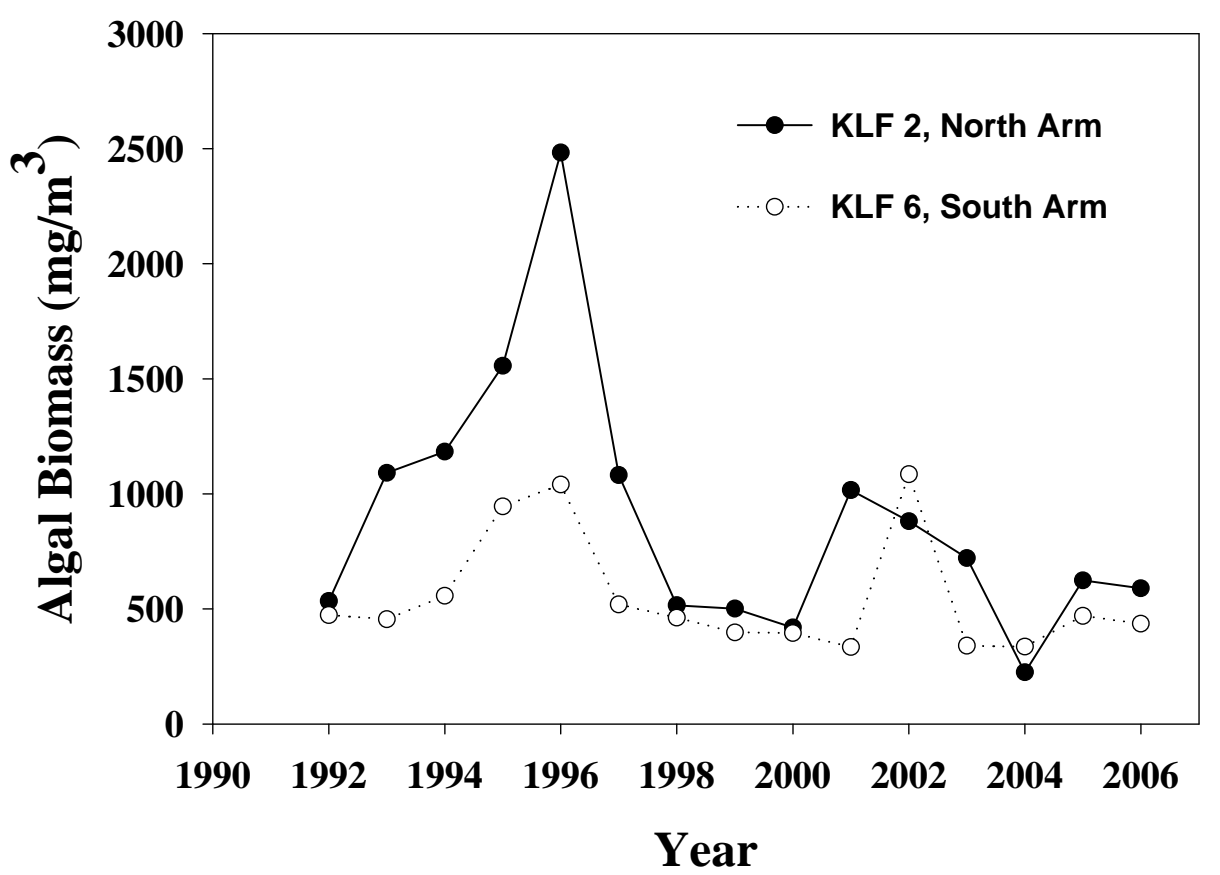

Figure 4.5. Summer average biomass of Kootenay Lake since 1992. Fertilized station KLF 2 in the North Arm compared to old "reference" station KLF 6 in the South Arm. Note that N additions began in the South Arm in 2004. 


\title{
CHAPTER 5
}

PHYTOPLANKTON VERTICAL DISTRIBUTION PATTERNS IN KOOTENAY LAKE - 2006

by

\author{
Dr. John Stockner \\ Eco-Logic Ltd. \\ Vancouver, BC
}




\section{Introduction}

Investigations of Kootenay Lake began in the mid-1960s when some effects of eutrophication were noted (Northcote 1973, Northcote et al. 2005). Even earlier, in the mid-1950's, residents were concerned about poor water quality, but it was not until the summer of 1958 that widespread algal blooms first appeared and quickly became annual summer occurrences throughout the 1960s and early 1970s (Ennis 1975). Beginning in 1953, effluent discharges to the Kootenay River from a phosphorus fertilizer plant (Cominco) entered the South Arm of Kootenay Lake (Fig. 1.1 in Chapter 1). In some years, soluble reactive phosphate (SRP) loads to the lake were estimated to be >6-7-fold higher than values measured before the fertilizer plant began operation (Binsted and Ashley 2006). In 1969, pollution control facilities at the fertilizer plant were improved and phosphorus inputs from the Kootenay River greatly declined; by 1974, the phosphorus inputs had finally stopped. After construction of the Duncan Dam in 1967, phosphorus loading from the Duncan River, the primary inflow to the North Arm of Kootenay Lake, declined from pre-dam values of about 60 tonnes SRP to current values of about 12-15 tonnes (Binsted and Ashley 2006). The construction of Libby Dam in 1973 on the Kootenay River in Montana further reduced phosphorus inputs to the lake by as much as 10-fold from pre-dam values (Daley et at. 1981, Perrin and Korman 1997, Binsted and Ashley 2006). During the 1980s and early 1990s, the lake began to shown acute signs of nutrient deprivation or oligotrophication (Ashley et al. 1997, Stockner et al. 2000). Nutrient supplementation (fertilization) was implemented in the early 1990s to reverse the adverse effects of oligotrophication on what was then considered, and still remains, a world-class fishery for both kokanee and rainbow trout (Ashley et al. 1997).

Kootenay Lake is basically a diatom-dominated lake, and this major group, common in all oligotrophic lakes during spring and fall periods, has responded positively to the historic changes in nutrient loading (Ennis 1975, Pick et al. 1999), including the most recent years of lake fertilization that began in 1992 (Daley and Pick 1990, Ashley et al. 1997, Northcote et al. 2005). The spring increase is usually dominated by Fragilaria spp., especially F. crotonensis, as well as Asterionella formosa and Cyclotella spp., and later in the season by Tabellaria fenestrata. However, with nutrient supplementation, the response of these large diatoms has been protracted to include summer dominance as well. In recent years, the Chryso-Cryptophyceae, notably Cryptomonas spp., Rhodomonas minuta, and Chrysochromulina sp., have also responded positively to nutrient addition. Blue-greens (Cyanophyceae) have declined in abundance in both arms, most notably in the South Arm with the start of nitrogen-only fertilization in 2005 and 2006. Currently in the South Arm, the contribution of blue-greens to both total phytoplankton abundance and biomass has been negligible.

\section{Study Purpose}

In 2006, the fourth year of a Kootenay Lake discrete-depth phytoplankton sampling program, sampling was done for a four-month period, June to September (the primary growing season), and only at three lake stations, KLF 2 in the North Arm and KLF 6 and 7 in the South Arm. This report summarizes the 2006 results in the context of previous 
more intensive vertical profile studies completed in 2004 and 2005 (Schindler, 2007a, 2007b), with a short commentary on any notable changes in phytoplankton abundance, biomass, and species composition among stations and depths and between North and South arms.

\section{Methods}

\section{Study Site}

Kootenay Lake has three arms: the small West Arm lake outlet and the larger North and South arms, of which the latter two received nutrient additions in 2006. The North Arm received both $\mathrm{N}$ and $\mathrm{P}$ additions at a prescribed $\mathrm{N}: \mathrm{P}$ ratio, while the South Arm received an $\mathrm{N}$-only addition to augment low dissolved $\mathrm{N}$ levels that are typically found in the South Arm (see Chapter 2 in this report). The N-only addition attempts to avert an Nlimited condition and associated increases in $\mathrm{N}_{2}$-fixing colonial blue-greens (Cyanophyceae), which create inedible carbon sinks.

\section{Sampling}

Vertical discrete-depth profiles were obtained monthly from June to September using a Van Dorn water sampler. Samples were taken from 2, 5, 10, 15, and $20 \mathrm{~m}$ depths at stations KLF 2 in the North Arm and KLF 6 and 7 in the South Arm of Kootenay Lake (see Fig. 1.1 in Chapter 1 of this report). Each phytoplankton sample was preserved in acid Lugol's iodine preservative and couriered to Eco-Logic Ltd., West Vancouver, for enumeration.

\section{Enumeration}

Phytoplankton enumeration was usually done within 15 days of receiving the samples. Prior to quantitative enumeration, the samples were gently shaken for 60 seconds, carefully poured into $25 \mathrm{~mL}$ settling chambers, and allowed to settle for a minimum of 68 hours. Counts were done using a Carl Zeiss inverted phase-contrast plankton microscope. Counting followed a two-step process: 1 . Micro-phytoplankton $(20-200 \mu \mathrm{m})$, e.g., diatoms, dinoflagellates, and filamentous blue-greens, within 5-10 random fields were enumerated at $250 \mathrm{X}$ magnification, and 2. Smaller phytoplankton (excluding microphytoplankton) within or touching a $10-15 \mathrm{~mm}$ transect line were counted at $1560 \mathrm{X}$ magnification. This high magnification scan permitted quantitative enumeration of some minute autotrophic picoplankton cells (0.2-2.0 $\mu \mathrm{m}$ [Class Cyanophyceae], and small auto-, mixo-, and heterotrophic nano-flagellates $(2.0-20.0 \mu \mathrm{m})$ [Classes Chrysophyceae and Cryptophyceae]. In total, about 175-225 cells were enumerated from each sample to ensure statistical accuracy (Lund et al. 1958). The compendia of Prescott (1978) and Canter-Lund and Lund (1995) were used as the taxonomic references. The phytoplankton species and biomass list used for the computation of population and class biomass estimates for Kootenay Lake in 2006 appears in Appendix 1.

\section{Study Limitations}

Discrete-depth sampling in 2006 was done monthly from early June to early September at only three Kootenay Lake stations. Samples were not obtained in early May, midOctober, or November, so the spring and late fall phytoplankton communities are missing 
from the data set. Because spring and late fall are periods of deeper mixing (transition) in the lake, it is not possible to discuss a complete seasonal picture. Comments made about 'seasonal' changes in vertical distribution patterns relate solely to the summer stratified, or epilimnetic, growing season. The interpretations of population trends reported here are based on two key variables: abundance (cells $/ \mathrm{mL}$ ) and biomass (biomass) $\left(\mathrm{mm}^{3} / \mathrm{L}\right)$ of phytoplankton species and genera and their respective taxonomic classes. In remaining text the word biomass will be used exclusively instead of biovolume. I have attempted to provide a best interpretation of the seasonal trends without the support of additional data, e.g., chlorophyll, nutrients, primary production, zooplankton, etc.

\section{Results}

\section{Vertical Profiles, June 5-September 5, 2006}

\section{KLF 2}

The highest average cell abundance occurred in August, with an average density of $>13,000$ cells $/ \mathrm{mL}$ in the surface layer $(0-10 \mathrm{~m})$ and a peak density of $>16,000$ cells/mL at $5 \mathrm{~m}$, the largest peak noted at any station in 2006 (Fig. 5.1). The next highest densities were noted in September with peaks of $>8,000$ cells $/ \mathrm{mL}$ at 2 and $5 \mathrm{~m}$ depths. The July profile was highlighted by unusually low densities at most depths, with the exception of 5 $\mathrm{m}$ where a small peak $(>6,000$ cells $/ \mathrm{mL})$ occurred. June's profile showed the same pattern as noted in July, but population abundances were higher at all depths, notably in the surface layers with densities between 6,000-7,000 cells/mL at 2 and $5 \mathrm{~m}$ depths. Lowest densities across all months were always observed at 15 and $20 \mathrm{~m}$ depths. Flagellates were clearly dominant in June and co-dominant with diatoms in July, but by August and through to September diatoms were the dominant group at all depths with only minor contributions from other groups. The major contributors to density in August and September were the chain-forming Fragilaria crotonensis, Tabellaria fenestrata, and several species of Cyclotella.

Biomass profiles mirrored abundance profiles with remarkable clarity, with both the highest seasonal value $\left(2.3 \mathrm{~mm}^{3} / \mathrm{L}\right)$ in August at $5 \mathrm{~m}$ and the lowest at $20 \mathrm{~m}(<0.5$ $\mathrm{mm}^{3} / \mathrm{L}$ ) in August (Fig. 5.2) . Flagellates were the major contributors to biomass in June and July, but by August and September dominance had abruptly shifted to diatoms (Fig. 5.3) In June and July, the major flagellates were dominated by large Cryptomonas spp., followed by the smaller nano-flagellates Rhodomonas and Chroomonas spp. Major diatom contributors in August and September were Fragilaria crotonensis and Cyclotella spp. Dinoflagellates, Chlorophytes, and blue-greens (Cyanophyceae) were minor players and showed low and invariable populations through the season at all depths and dates.

\section{KLF 6}

In 2006, KLF 6, a station located mid-South Arm of the lake, had on average a lower phytoplankton density than occurred at KLF 2. The seasonal patterns of a flagellate to diatom shift noted at KLF 2 occurred at KLF 6 as well, but there was no July minimum observed at this station. Instead, a moderate abundance occurred in July, and a population 
maximum occurred in August with a peak at $2 \mathrm{~m}(>14,000$ cells $/ \mathrm{mL})$ (Fig. 5.3). The lowest average population abundance was noted at a depth of $20 \mathrm{~m}(2,000$ cells $/ \mathrm{mL})$ in July. In contrast to profiles from KLF 2, where lowest densities occurred in July, the lowest densities at KLF 6 occurred in September with values $<3,000$ cells $/ \mathrm{mL}$ at all depths. Diatoms and flagellates were the two major contributors to density at all dates and depths. A similar shift in major species occurred here with flagellates dominant in June and co-dominant with diatoms in July, but by August diatoms were major players, notably the species F crotonensis and Tabellaria fenestrata and secondarily Cyclotella spp. Other groups played only a small and insignificant role in their contribution to profile abundance patterns.

Biomass profiles at KLF 6 again very closely mirrored profiles of abundance and were on average highest in July and August, somewhat lower in June, and extremely low in September at all depths (Fig. 5.4). In June and July, flagellates were major contributors to biomass with Cryptomonas spp. the main contributors. Flagellates had a notable subsurface peak at $5 \mathrm{~m}\left(1.4 \mathrm{~mm}^{3} / \mathrm{L}\right)$ in June, attaining a more prominent 'mini-bloom' at $5 \mathrm{~m}\left(2.0 \mathrm{~mm}^{3} / \mathrm{L}\right)$ in July. By August, the Cryptomonas spp. bloom had dissipated and species composition had shifted to several species of diatoms that were now major contributors to biomass-F. crotonensis, Cyclotella spp., and Tabellaria fenestrata. The greatest average biomass profile occurred in August while the lowest was in September with nearly a two-fold decline in biomass in one month.

\section{KLF 7}

The lowest seasonal average phytoplankton abundance observed in the Kootenay Lake profiles in 2006 occurred at KLF 7, which is situated close to the inflow of the Kootenay River. In June, the profile was uniform, with very low and nearly equal abundance of all groups, except diatoms which were slightly more numerous at all depths. Abundance increased from an average of $<2,500$ cells/mL in June to about 4,000 in July but with little obvious subsurface peaks (Fig. 5.5). By August, maximum seasonal densities were achieved, averaging about 6,000 cells/mL in surface layers $(0-10 \mathrm{~m})$. September's profile was nearly identical to June's with low abundance at all depths, notably at $20 \mathrm{~m}$. Species succession was nearly identical to that at KLF 2 and 6, with a pronounced abundance of flagellates in July shifting to diatoms in August. There was a co-dominance of flagellates and diatoms in June and September, albeit at very low densities. The highest peak density $(<9,000$ cells $/ \mathrm{mL})$ occurred in August at $2 \mathrm{~m}$ depth, with diatoms comprising about $80 \%$ of the total, e.g., F. crotonensis, Cyclotella spp., and Tabellaria fenestrata.

As with previous stations, biomass profiles at KLF 7 were nearly identical to abundance profiles. The peak biomass value was in August at $2 \mathrm{~m}\left(<1.5 \mathrm{~mm}^{3} / \mathrm{L}\right)$ with diatoms the dominant contributors. The July biomass profile averaged about $0.6 \mathrm{~mm}^{3} / \mathrm{L}$, and diatoms and flagellates were both major contributors to the total (Fig. 5.6). By August, diatomsnotably F. crotonensis, Cyclotella spp., and Tabellaria fenestrata-were clearly the major species, contributing close to $80-85 \%$ to total biomass. Lowest average biomass values were in June $\left(<0.4 \mathrm{~mm}^{3} / \mathrm{L}\right)$ and September $\left(>0.5 \mathrm{~mm}^{3} / \mathrm{L}\right)$. 


\section{North - South Gradients}

In Kootenay Lake, the greatest phytoplankton densities usually occur at the upper North Arm stations, and their populations tend to increase rapidly in May/June after the start of nutrient application. Fertilization in some years seems to create a perceptible north to south gradient, occasionally in abundance but more frequently in biomass, that often can extend to the South Arm of the lake. The best example of this north-south gradient was seen in 2005 and to a limited extent (with only three stations) again in 2006, but the gradient was not prevalent in 2004, a low phytoplankton density year (Table 5.1).The most plausible explanation for the prevalence of the north-south phytoplankton gradient is that it is initiated in the North Arm in early summer by the added nutrients and attendant phytoplankton growth response within surface layer, and then advected southward with increased mortality from cell sinking and grazing (Daley et al. 1981, Carmack et al. 1986). In 2004 and 2005, the densities of phytoplankton at KLF 4 are greater than noted at KLF 3, likely due to surface layer mixing (forcing) and entrainment with stronger, northerly flowing South Arm surface and interflow currents in this midlake region (Ennis 1975, Ennis et al. 1983, Carmack et al. 1986).

Stations in the South Arm of the lake seldom show any south-north phytoplankton abundance or biomass gradient, and the station farthest south, KLF 7, has consistently shown the lowest phytoplankton population densities in the lake (Table 5.1, Figs. 5.7).

Table 5.1. Average vertical profile station abundance and biomass for Kootenay Lake in 2004, 2005, and 2006.

\begin{tabular}{lccc}
\hline Station & \multicolumn{3}{c}{ Abundance (cells/mL) } \\
\cline { 2 - 4 } & $\mathbf{2 0 0 4}$ & $\mathbf{2 0 0 5}$ & $\mathbf{2 0 0 6}$ \\
\hline KLF-1 & 6205 & 6375 & \\
KLF-2 & 4721 & 6062 & 5875 \\
KLF-3 & 4846 & 5094 & \\
KLF-4 & 5150 & 6003 & \\
KLF-5 & 4666 & 5684 & 4900 \\
KLF-6 & 5021 & 5255 & 3850 \\
KLF-7 & 3741 & & \\
& & $\mathbf{2 0 0 5}$ & $\mathbf{2 0 0 6}$ \\
& & 1.17 & \\
& $\mathbf{2 0 0 4}$ & 1.15 & 1.01 \\
KLF-1 & 0.88 & 1.01 & \\
KLF-2 & 0.75 & 0.96 & \\
KLF-3 & 0.69 & 0.95 & 0.90 \\
KLF-4 & 0.65 & 0.85 & 0.65 \\
KLF-5 & 0.74 & 0.91 & \\
KLF-6 & 0.80 & $\left.\mathbf{m m}^{\mathbf{3}} \mathbf{L}\right)$ \\
KLF-7 & 0.60 & & \\
\hline
\end{tabular}

Kootenay Lake Fertilization Experiment, Year 15 (North Arm) and Year 3 (South Arm) 


\section{Comparisons among Years - 2004, 2005, and 2006}

The average phytoplankton abundance in Kootenay Lake for all stations ( $\mathrm{n}=7)$ in 2004 and 2005 was 4,907 and 5,645 cells/mL, respectively. In $2006(\mathrm{n}=3)$, the average was 4,875 cells/mL, similar to the 2004 value. Average whole-lake biomass values were highest in 2005 at $1.01 \mathrm{~mm}^{3} / \mathrm{L}$, a value $>25 \%$ higher than observed in $2004\left(0.73 \mathrm{~mm}^{3} / \mathrm{L}\right)$ and $>15 \%$ higher than in $2006\left(0.85 \mathrm{~mm}^{3} / \mathrm{L}\right)$ (Table 5.1). The phytoplankton profiles were more intensively sampled in 2004 (7 stations, June-October) than in 2005 (7 stations, June-September) and especially 2006 (3 stations, June-September). Therefore, it is likely that the actual biomass averages were greater than reported, owing largely to the absence of October values in 2005 and 2006 (also fewer stations). October is a time of moderately high phytoplankton diatom densities, e.g., Tabellaria fenestrata, during autumnal mixing, (Pick et al. 1999). Though the profile values are likely conservative, results among years clearly point to 2005 as the year with the largest phytoplankton response and 2004 as one of low response (Table 5.1), with 2006 results, albeit from a limited number of stations, as a moderate response year.

There were noticeable shifts in the timing of phytoplankton abundance and biomass peaks among years, the most notable being the change of the yearly maximum peaks at KLF 2 from July in 2005 to August in 2006. Both peaks reached the greatest density ( $>15,000-16,000$ cells $/ \mathrm{mL}$ ) noted among stations and years (Table 5.2). There was also a major change in the phytoplankton groups that contributed to these record abundance peaks, and this is reflected in differences in biomass between years. In 2005, large bluegreens, Oscillatoria sp. were a significant contributor, while in 2006 it was almost exclusively diatoms and flagellates. This difference in species assemblages resulted in nearly a two-fold greater biomass in 2005 (Table 5.2). Another change occurred at KLF 6 where in 2006 the surface peak was much larger than in previous years and was also more prolonged, occurring again in August. There was also a compositional change, with the 2006 KLF 6 peak composed almost exclusively of diatoms and the 2005 peak composed of both blue-greens and diatoms (Table 5.2). One of the common features of these shifts is the conspicuous absence of blue-greens in both arms of the lake in 2006. As noted previously, the highest average station abundance and biomass among study years was usually in the North Arm at KLF 2 and the lowest was consistently at the South Arm station KLF 7 (Tables 5.1 and 5.2).

Kootenay Lake Fertilization Experiment, Year 15 (North Arm) and Year 3 (South Arm) 
Table 5.2. Peak phytoplankton abundance and biomass in 2004, 2005, and 2006 in the epilimnion of Kootenay Lake at selected stations with major contributing groups.

\begin{tabular}{|c|c|c|c|c|c|}
\hline Station & Year & $\begin{array}{c}\text { Peak } \\
\text { month(s) }\end{array}$ & $\begin{array}{l}\text { Abundance } \\
\text { (Cells/mL) }\end{array}$ & $\begin{array}{l}\text { Biomass } \\
\left(\mathrm{mm}^{3} / \mathrm{L}\right)\end{array}$ & Dominant groups \\
\hline \multirow[t]{3}{*}{$\begin{array}{c}\text { KLF } 2 \\
\text { (North } \\
\text { Arm) }\end{array}$} & 2004 & July/Aug. & $3-5,000$ & $0.3-0.6$ & $\begin{array}{c}\text { Diatoms, } \\
\text { Flagellates, Blue- } \\
\text { Greens }\end{array}$ \\
\hline & 2005 & July & 15,000 & 4.5 & $\begin{array}{c}\text { Flagellates, } \\
\text { Diatoms, Blue- } \\
\text { Greens }\end{array}$ \\
\hline & 2006 & Aug. & 16,000 & 2.6 & $\begin{array}{c}\text { Diatoms, } \\
\text { Flagellates. }\end{array}$ \\
\hline \multirow{3}{*}{$\begin{array}{c}\text { KLF 6 } \\
\text { (South } \\
\text { Arm) }\end{array}$} & 2004 & July & 9,000 & 1.3 & $\begin{array}{c}\text { Diatoms, } \\
\text { Flagellates. }\end{array}$ \\
\hline & 2005 & July & $8-9,000$ & 1.2 & $\begin{array}{l}\text { Diatoms, Blue- } \\
\text { Greens }\end{array}$ \\
\hline & 2006 & July/Aug. & 12,000 & 2.0 & Diatoms \\
\hline \multirow{3}{*}{$\begin{array}{c}\text { KLF } 7 \\
\text { (South } \\
\text { Arm) }\end{array}$} & 2004 & July/Aug. & 7,500 & 1.0 & $\begin{array}{c}\text { Diatoms, } \\
\text { Flagellates. }\end{array}$ \\
\hline & 2005 & Aug./Sept. & $7-8,000$ & 1.5 & $\begin{array}{c}\text { Diatoms, } \\
\text { Flagellates, Blue- } \\
\text { Greens }\end{array}$ \\
\hline & 2006 & Aug. & 7,000 & 1.2 & $\begin{array}{l}\text { Diatoms, } \\
\text { Flagellates. }\end{array}$ \\
\hline
\end{tabular}

Though there were discernable differences in both abundance and biomass profile patterns within the $20 \mathrm{~m}$ water column sampled during the four-month growing season in 2005 and 2006, there were three major shifts in community composition between years. The first was the greatly increased abundance of flagellates in both years-a trend most pronounced in 2006. The second was the increase in edible Cyclotella spp. in 2006 and decline in inedible Fragilaria spp. The third was the absence in 2006 of any significant populations of colonial blue-greens in both arms. The low population densities observed throughout the season at deeper depths (15-20 m) among all years and most dates and stations are likely attributable to several factors, including sinking of heavy colonial diatoms, zooplankton grazing mortality and sub-optimal growth conditions (low light). Finally, vertical distribution patterns examined in Kootenay Lake in all years have shown no prolonged sub-surface accumulation of phytoplankton (plates) at any station, depth, or date for any classes of the major phytoplankton groups.

\section{Discussion}

The early physical studies of Kootenay Lake reported initially by Daley et al. (1981) and later by Carmack et al. (1986) have shown that in spring and early summer the surface 
layers of Kootenay Lake's North and South arms are convected to mid-lake by moderately strong surface and interflow currents from the Duncan and Kootenay River inflows. They meet and mix in this sector, which is contiguous with the lake outlet, and then are advected to the West Arm outflow. This annual flushing of the surface layer or epilimnion is an annual feature of the lakes physics and is one of the key 'metrics' affecting phytoplankton and carbon (C) production dynamics. The flushing was especially apparent in the pre-dam era when freshet flows were not impeded by dams and could flush surface layers in weeks or months instead of in many months to a year, as in the present regulated conditions (Carmack et al. 1986).

Though sampling was limited to only three stations in 2006, phytoplankton vertical distribution in Kootenay Lake has shown more consistency both in species succession patterns and in shifts in abundance and biomass among stations and dates than seen in previous years. Perhaps the most unanticipated result from the 2006 profiles was the sharp reduction in phytoplankton abundance at KLF 2 in July, normally a station and month where populations are experiencing optimal conditions of light and nutrients (with supplementation), as was noted in the 2004 and 2005 profiles (Table 5.2). In contrast to results from KLF 2, phytoplankton populations in July at South Arm stations KLF 6 and 7 showed increasing abundance and biomass that peaked in August and then abruptly declined in September to the lowest levels of the season (Figs. 5.4 and 5.6). September is a time when in previous years, and at KLF 2 in 2006 as well, values were moderately high. I surmise that these changes may be related more to frequencies or duration of nutrient application (loads) than to climatic variability or nutrient limitation. The largest peak of both biomass and abundance occurred in July at KLF 2 in 2005 and again in August in 2006. The 2006 abundance peak was the largest concentration of phytoplankton $(>16,000$ cells $/ \mathrm{mL}$ ) yet to be counted during the three seasons of vertical profile sampling and was almost certainly related to nutrient supplementation.

The species composition in 2004 was primarily a mix of diatoms and blue-greens and was strongly biased toward inedible fractions within both groups. The abundance of flagellates in 2004 was considerably lower than in 2005 and 2006. Blue-greens were present in most counts in 2004, but in 2005 they were less numerous with a notable decline in colonial $\mathrm{N}_{2}$-fixing species., e.g., Anabaena. In 2006, blue-greens were very scarce with only a small population of Anabaena with heterocysts ( $\mathrm{N}_{2}$-fixing) at KLF 2 in September. One of the most striking features of the vertical profiles in 2005 was the marked increase of populations of Chryso- and Cryptophycean flagellates, especially Cryptomonas spp. In 2006, flagellate populations were even higher, and mini ‘blooms' of Cryptomonas, Rhodomonas, and Chroomonas were the major contributors. The flagellate species mix in Kootenay Lake in 2005 and 2006 was composed of highly edible species. These groups of small to moderate sized species $(10-35 \mu \mathrm{m})$ have been shown to transfer carbon rapidly and efficiently to cladoceran and copepod populations in several BC sockeye salmon nursery lakes (Stockner 1987, Shortreed and Stockner 1990, Stockner and Shortreed 1994, Stockner and MacIsaac 1996).

As noted previously, the large June and July production of edible flagellates in the 2005 profiles was to some extent balanced by the return of moderate populations of inedible 
diatoms. By August and September of 2005, both arms of Kootenay Lake supported moderate densities of Fragilaria crotonensis, F. acus, Diatoma elongatum, Tabellaria fenestrata, and Asterionella formosa, as well as moderate populations of edible Cyclotella species. Cyclotella spp. were the major species in historic (pre-1900) oligotrophic Kootenay Lake, and their resurgence in the past few years bodes well for a more efficient C-production and transfer ecosystem in the future (Ennis et al. 1983). The density of diatoms has always been highest within the zone of nutrient application, and their contribution to total phytoplankton biomass in the lake is well documented in earlier studies (Ennis 1975, Ennis et al. 1983, Daley et al. 1981; Rae et al. 1997, Pick et al. 1999, Northcote et al. 2005).

Reasons for the low Cyanophyte abundances in the South Arm are no doubt related to the high N-only additions of fertilizer to this arm in 2005 and 2006. Pico-cyanobacteria (Synechococcus sp., small Oscillatoria sp.) were ubiquitous at all depths and dates but showed low population densities. Finally, large populations of flagellates occurred in the North and South arms in 2005 and in 2006 following the start of nutrient application. This resurgence indicates that the $\mathrm{N}$ :P ratio in the fertilizer has been effective in shifting phytoplankton succession away from dominance by large colonial diatoms and bluegreens to populations of smaller edible species within more efficient microbial and nanoplankton based food webs. Such food webs are capable of rapidly transferring $C$ to higher trophic levels while simultaneously enhancing rates of nutrient recycling (Weisse 1990, Stockner 1988, Stockner and Shortreed 1991, 1994).

\section{Comparison with Arrow Lakes Reservoir}

It is informative to compare the species assemblages of Arrow Lakes Reservoir's upper basin with Kootenay Lake's north basin, both of which have received consistent yearly fertilizer applications. From year 2000 onward, Upper Arrow's diatom populations were composed of essentially the same dominant species as in the North Arm of Kootenay Lake. The populations in Arrow were larger and their colonial morphology more complex than observed in Kootenay (i.e., longer chain length, multiple star patterns, and larger colonies) and most were inedible.

Arrow Lakes Reservoir is basically a north-south input-output system, while Kootenay Lake has major river inputs in both North and South arms with a mid-lake outlet (West Arm). The water residence time of Kootenay Lake (average of 1.8 years) is much longer than in Arrow and sufficiently slow to allow settlement of heavier, colonial diatoms. Thus, flushing is no longer a major factor for phytoplankton mortality in Kootenay Lake as it once was (Daley et al. 1981). In addition, high density blooms in Kootenay Lake's fertilization zones are not as readily or as quickly dispersed as in Arrow Lakes Reservoir. In Arrow, the short water residence time (1-2 months) coupled with the strong Columbia River interflow creates the expected yearly north-south phytoplankton gradients (Pieters et al. 1998, 1999). But these Upper Arrow gradients are no longer as prevalent since the application method changed from ferry-crossing to north-south transects in 2005 and 2006. This change appears to have reduced the impact of the 'chemostat' effect in the fertilized Upper Arrow basin. Owing to the large number of cells per cluster in colonial

Kootenay Lake Fertilization Experiment, Year 15 (North Arm) and Year 3 (South Arm) 102 (2006) Report 
diatoms and the weight of their silica frustules, it is likely that a significant portion of the large inedible diatom populations are removed from the epilimnion of both systems by sinking - average rate of 1-2 m/day (Jackson et al. 1989)—especially in Kootenay Lake with its longer epilimnetic residence time.

\section{Summary and Conclusions}

The seasonal vertical distribution of phytoplankton in Kootenay Lake was first examined in 2003, then again in 2004 and 2005. In 2006, vertical distribution was examined from June to September at three stations. This report focuses on results from 2006, but when appropriate it compares and contrasts the findings with 2004 and 2005 results. The 2006 results have shown a clear north to south gradient in average phytoplankton density and biomass among the three stations sampled, with highest values at the North Arm station (KLF 2) and lowest values in the most southern station in the South Arm (KLF 7). In 2006, there was a diverse assemblage of populations composed of 20-25 species with a predominance of flagellates at all stations and depths in June and July, which then shifted to diatom dominance in August and September in both North and South arms of the lake. There were no large blue-green (cyanobacteria) populations in either arm of the lake in 2006. In 2005, using a whole-lake average ( $n=7$ stations), there was a $>20 \%$ increase in phytoplankton abundance and a $>30 \%$ increase in biomass as compared to 2004 populations. With limited sampling in 2006 ( $n=3$ stations), average densities were similar to 2005 values in the North Arm, but they were lower in the South Arm and comparable to 2004 densities._Phytoplankton biomass at KLF 6 in the South Arm was slightly higher in 2006 than in previous years, owing to greater numbers of diatoms, e.g., Fragilaria crotonensis and Cyclotella spp. Over the three years presented in this report, the largest phytoplankton populations were consistently found at North Arm stations that lie within the well established zone of fertilization. In June and July 2006, both arms of the lake had large populations of edible flagellates, e.g., Cryptomonas spp. and Rhodomonas sp., that were replaced in August and September by some large inedible diatoms-F. crotonensis and Tabellaria fenestrata-and several species of the edible diatom Cyclotella spp. The depth profiles across all years and stations showed that the majority of phytoplankton species were distributed in the epilimnion at 0-10 $\mathrm{m}$ and that among dates sampled there was a pattern of low population abundance at depths $>15 \mathrm{~m}$. There were no deep chlorophyll or phytoplankton population 'plates' found in any of the years of vertical profile sampling in Kootenay Lake.

\section{Recommendations}

- Vertical profiles should continue to be taken from three key stations (e.g., KLF 2, 4, and 6) and sampled five times per year (June, July, August, September, and October). The number of depths sampled should be increased to six, including the addition of a $30 \mathrm{~m}$ depth, e.g. 2, 5, 10, 15, 20 and $30 \mathrm{~m}$. The addition of a sample from $30 \mathrm{~m}$ would provide information on species-specific sinking rates of large colonial diatoms. 
- In August, September, and October an additional $30 \mathrm{~m}$ sample should be taken to assess the role of sinking on the fate of larger, inedible colonial diatom species, such as Asterionella, Fragilaria, and Tabellaria.

\section{Acknowledgements}

Funding was provided by the Kootenai Tribe of Idaho. Thanks to Don Miller of Kootenay Wildlife Services Ltd. for sample collection. Comments in draft review by Rowena Rae are most gratefully acknowledged. Thanks to the Fish and Wildlife Compensation program - Columbia Basin for administering the contract for this report.

\section{References Cited}

Ashley, K. + others. 1997. Restoration of an interior lake ecosystem: the Kootenay Lake fertilization experiment. Water Qual. Res. J. Canada 32: 295-323.

Binsted, G.A. and K. Ashley. 2006. Phosphorus loading to Kootenay Lake from the Kootenay and Duncan rivers and experimental fertilization program. Report prepared for B.C Conservation Foundation, Vancouver, BC.

Canter-Lund, H. and J.W.G. Lund. 1995. Freshwater Algae - Their Microscopic World Explored. BioPress Ltd., Bristol, UK, 360pp.

Carmack, E.C. + others. 1986. Mechanisms influencing the circulation and distribution of water mass in a medium residence-time lake. Limnol. Oceanogr. 31: 249-265.

Daley, R.J. and F.R Pick 1990. Phytoplankton biomass and composition of Kootenay Lake, British Columbia, following reductions in phosphorus loading. Verh. Internat. Verein. Limnol. 24: 314-318.

Daley, R.J. + others. 1981. The effects of upstream impoundments on the limnology of Kootenay Lake, BC. Nat. Water Res. Inst., Sci. Series No. 117, Vancouver, BC.

Ennis, G.L. 1975. Distribution and abundance of benthic algae along phosphate enriched Kootenay Lake, British Columbia. Verh. Int. Verein. Limnol. 19: 562-570.

Ennis, G.L., T.G. Northcote, and J.G. Stockner. 1983. Recent trophic changes in Kootenay Lake, British Columbia, as recorded by fossil diatoms. Can. J. Bot. 61: 1983-1992.

Jackson, L.J, J.G. Stockner, and P.J. Harrison. 1989. Contribution of Rhizosolenia eriensis and Cyclotella spp. to the deep chlorophyll maximum of Sproat Lake, British Columbia. Can. J. Fish. Aquat. Sci. 47: 128-135. 
Lund, J.G., C. Kipling, and E.D. LeCren. 1958. The inverted microscope method of estimating algal numbers and the statistical basis of estimations by counting. Hydrobiol. 11: 143-170.

Northcote, T.G. 1973. Some impacts of man on Kootenay Lake and its salmonids. Great Lakes Fish. Com. Tech. Rep. 25, Ann Arbor, Mich.

Northcote, T.G., F.R. Pick, D.B. Fillion, and S.P. Salter. 2005. Interaction of nutrients and turbidity in the control of phytoplankton in a large western Canadian lake prior to major watershed impoundments. Lake and Reservoir Management 21(3): 261-276.

Perrin, C.J. and J. Korman. 1997. A phosphorus budget and limnological description for Duncan Lake Reservoir, 1994-95. Report to BC Hydro, Kootenay Generation Area, Castlegar, BC, by Limnotek R. \& D. Vancouver, BC.

Pick, F.R., L. M. Ley, and P.B. Hamilton. 1999. Phytoplankton biomass, composition and size distribution of Kootenay Lake, B.C. following experimental fertilization. Report prepared for BCHydro/CBFWCP, Nelson, BC.

Pieters, R. + others. 1998. Arrow Reservoir limnology and trophic status-year 1 (1997/98) report. BC Min. of Env. Lands, and Parks, Fish. Project Rep. No RD 67.

Pieters, R. + others. 1999. Arrow Reservoir limnology and trophic status-year 2 (1998/99) report. BC Min. of Env. Lands, and Parks, Fish. Project Rep. No RD 72.

Prescott, GW. 1978. Freshwater Algae, 3rd Edition, W.C. Brown Co., Dubuque, Iowa.

Rae, R.M., F.R. Pick, P.B. Hamilton, and K.I. Ashley. 1997. Effects of fertilization on phytoplankton in Kootenay Lake, British Columbia. J. Lake \& Reservoir Manag. 13: 57-66.

Schindler, E. U., K. I. Ashley, R. Rae, L. Vidmanic, H. Andrusak, D. Sebastian, G. Scholten, P. Woodruff, F. Pick, L. M. Ley and P. B. Hamilton. 2006. Kootenay Lake Fertilization Experiment, Years 11 and 12 (2002 and 2003). Fisheries Report RD No. 114, Ministry of Environment, Province of British Columbia.

Schindler, E.U., R. Rae, K.I. Ashley, L. Vidmanic, D. Sebastian, H. Andrusak, G. Scholten, P. Woodruff, J. Stockner, F. Pick, L.M. Ley, P.B. Hamilton, G.F. Andrusak and L. Fleck. 2007. Kootenay Lake Fertilization Experiment, Year 13 (North Arm) and Year 1 (South Arm) (2004) Report. Fisheries Project Report No. RD 117, Ministry of Environment, Province of British Columbia. 
Schindler, E.U., H. Andrusak, K.I. Ashley, G.F. Andrusak, L. Vidmanic, D. Sebastian, G. Scholten, P. Woodruff, J. Stockner, F. Pick, L.M. Ley and P.B. Hamilton. 2007. Kootenay Lake Fertilization Experiment, Year 14 (North Arm) and Year 2 (South Arm) (2005) Report. Fisheries Project Report No. RD 122, Ministry of Environment, Province of British Columbia.

Shortreed, K.S. and J.G. Stockner. 1990. Effect of nutrient additions on lower trophic levels of an oligotrophic lake with a seasonal hypolimnetic chlorophyll maximum. Can. J. Fish. Aquat. Sci. 47: 262-273.

Stockner, J.G. 1987. Lake fertilization: The enrichment cycle and lake sockeye salmon (Oncorhynchus nerka) production. pp. 198-215. In: H.D. Smith, L. Margolis, and C.C. Woods [Eds.] Sockeye salmon (Oncorhynchus nerka) population biology and future management. Can. Spec. Publ. Fish. Aquat. Sci. 96, 486pp.

Stockner, J.G. 1988. Phototrophic picoplankton: an overview from marine and freshwater ecosystems. Limnol. Oceanogr. 33(4, part 2): 765-775.

Stockner, J.G. and E.A. MacIsaac. 1996. The British Columbia lake fertilization program: overview after two decades of salmon enhancement. Reg. Rivers. 12: 344-356.

Stockner, J.G. and K.S. Shortreed 1991. Phototrophic picoplankton: community composition, abundance and distribution across a gradient of oligotrophic British Columbia and Yukon Territory lakes. Int. Revue Ges. Hydrobiol. 76: 581-601.

Stockner, J.G. and K.S. Shortreed. 1994. Autotrophic picoplankton community dynamics in a pre-alpine lake in British Columbia, Canada. Hydrobiol. 274: 133142.

Stockner, J.G., E. Rydin, and P. Hyenstrand. 2000. Cultural oligotrophication: Causes and consequences for fisheries resources. Fisheries 25: (5) 7-14.

Weisse, T. 1990. Trophic interactions among heterotrophic microplankton, nanoplankton and bacteria in lake Constance (FRG). Hydrobiol. 191: 111-122. 
Appendix 1. Kootenay Lake phytoplankton species, codes, and biomass $\left(\mathrm{mm}^{3}\right)$, 2006.

\begin{tabular}{llll} 
Code & \multicolumn{1}{c}{ Class } & \multicolumn{1}{c}{ Bvol. } & \multicolumn{1}{c}{ Genus \& Species } \\
Bacillariophytes - diatoms & & \\
AM & Bacillariophyte & 80 & Achnanthes sp \\
AY & Bacillariophyte & 100 & Asterionella formosa var1 \\
AZ & Bacillariophyte & 120 & Asterionella formosa var2 \\
CP & Bacillariophyte & 200 & Cocconeis sp. \\
CU & Bacillariophyte & 500 & Cyclotella bodanica \\
CZ & Bacillariophyte & 350 & Cyclotella comta \\
CJ & Bacillariophyte & 350 & Ceratoneis sp. \\
CS & Bacillariophyte & 150 & Cyclotella stelligera \\
CW & Bacillariophyte & 50 & Cyclotella glomerata \\
CT & Bacillariophyte & 150 & Cyclotella sp \\
CM & Bacillariophyte & 500 & Cymbella sp. (large) \\
CO & Bacillariophyte & 250 & Cymbella sp. \\
DF & Bacillariophyte & 150 & Diatoma sp. \\
EV & Bacillariophyte & 250 & Eunotia sp. \\
FF & Bacillariophyte & 80 & Fragilaria construens \\
FC & Bacillariophyte & 120 & Fragilaria crotonensis \\
FG & Bacillariophyte & 100 & Fragilaria capucina \\
GG & Bacillariophyte & 750 & Gomphonema sp. \\
MD & Bacillariophyte & 350 & Aulicoseira distans \\
MI & Bacillariophyte & 200 & Aulicoseira italica \\
MJ & Bacillariophyte & 250 & Aulicoseira granulata \\
MZ & Bacillariophyte & 350 & Aulicoseira sp. \\
NV & Bacillariophyte & 500 & Navicula sp. \\
NZ & Bacillariophyte & 200 & Nitzschia sp. \\
RC & Bacillariophyte & 50 & Rhizosolenia sp. \\
SH & Bacillariophyte & 500 & Stephanodiscus hantschii. \\
SE & Bacillariophyte & 1500 & Stephanodiscus sp. \\
SN & Bacillariophyte & 100 & Fragilaria acus \\
SO & Bacillariophyte & 150 & Fragilaria angustissima \\
SU & Bacillariophyte & 1000 & Fragilaria ulna \\
SS & Bacillariophyte & 500 & Suriella \\
SR & Bacillariophyte & 250 & Fragilaria sp. \\
PI & Bacillariophyte & 2000 & Pinnularia sp. \\
TF & Bacillariophyte & 500 & Tabellaria fenestrata \\
TB & Bacillariophyte & 500 & Tabellaria flocculosa \\
DL & Bacillariophyte & 250 & Diploneis sp.
\end{tabular}

Chryso-Cryptophyte flagellates

BS Chryso-cryptophyte 200 Bitrichia sp.

CH Chryso-cryptophyte 250 Chilomonas sp.

XX Chryso-cryptophyte 20 Chromulina sp1 


$\begin{array}{llll}\text { CA } & \text { Chryso-cryptophyte } & 150 & \text { Chroomonas acuta } \\ \text { YO } & \text { Chryso-cryptophyte } & 500 & \text { Cryptomonas sp. } \\ \text { CC } & \text { Chryso-cryptophyte } & 75 & \text { Chrysochromulina sp. } \\ \text { DN } & \text { Chryso-cryptophyte } & 150 & \text { Dinobryon sp1 } \\ \text { DO } & \text { Chryso-cryptophyte } & 200 & \text { Dinobryon sp2 } \\ \text { KA } & \text { Chryso-cryptophyte } & 50 & \text { Kephyrion sp. } \\ \text { IS } & \text { Chryso-cryptophyte } & 200 & \text { Isthmochloron } \\ \text { MH } & \text { Chryso-cryptophyte } & 500 & \text { Mallomonas sp1 } \\ \text { MG } & \text { Chryso-cryptophyte } & 700 & \text { Mallomonas sp2 } \\ \text { SX } & \text { Chryso-cryptophyte } & 75 & \text { Stenokalyx } \\ \text { YZ } & \text { Chryso-cryptophyte } & 15 & \text { Small microflagellates } \\ \text { PT } & \text { Chryso-cryptophyte } & 100 & \text { Pseudokephrion sp. } \\ \text { PP } & \text { Chryso-cryptophyte } & 150 & \text { Pseudopedinella sp. } \\ \text { CI } & \text { Chryso-cryptophyte } & 75 & \text { Chrysoikos sp. } \\ \text { SY } & \text { Chryso-cryptophyte } & 700 & \text { Synura } \\ \text { RO } & \text { Chryso-cryptophyte } & 100 & \text { Rhodomonas sp. } \\ \text { CF } & \text { Chryso-cryptophyte } & 250 & \text { Chrysidiastrum }\end{array}$

\section{Dinophytes}

GY Dinophyte

GZ Dinophyte

CE Dinophyte

PJ Dinophyte

PK Dinophyte

\section{Chlorophytes}

XC Chlorophyte

CX Chlorophyte

CL Chlorophyte

CN Chlorophyte

CK Chlorophyte

XU Chlorophyte

DI Chlorophyte

LA Chlorophyte

EL Chlorophyte

EU Chlorophyte

GO Chlorophyte

OO Chlorophyte

SI Chlorophyte

SD Chlorophyte

QD Chlorophyte

UL Chlorophyte

CD Chlorophyte

MO Chlorophyte

NE Chlorophyte

ST Chlorophyte
500 Gymnodinium sp1

1500 Gymnodinium sp2

5000 Ceratium

350 Peridinium sp1

700 Peridinium sp2

\section{Ankistrodesmus sp.}

150 Coccomyxa sp.

500 Coelastrum sp.

500 Cosmarium sp.

200 Crucigenia sp.

700 Crucigeniella apiculata

900 Dichtyosphaerium

30 Langerheimia

250 Elakatothrix sp3

2500 Euglena

500 Gonium

500 Oocystis sp.

60 Scenedesmus sp.

1500 Staurodesmus sp.

250 Quadrigula

700 Ulothrix

150 Closteriopsis

200 Monoraphidium

350 Nephrocytium

1000 Staurastrum sp. 
$\begin{array}{ll}\text { PL } & \text { Chlorophyte } \\ \text { PA } & \text { Chlorophyte } \\ \text { PS } & \text { Chlorophyte } \\ \text { CB } & \text { Chlorophyte } \\ \text { KI } & \text { Chlorophyte } \\ \text { PE } & \text { Chlorophyte } \\ \text { PA } & \text { Chlorophyte } \\ \text { TE } & \text { Chlorophyte } \\ \text { VO } & \text { Chlorophyte } \\ \text { XI } & \text { Chlorophyte }\end{array}$

\section{Cyanophytes}

AC Cyanophyte

AH Cyanophyte

MS Cyanophyte

ZN Cyanophyte

ZO Cyanophyte
350 Planctonema sp.

1000 Planctosphaeria

100 Paulschultzia sp.

20 Chlorella

50 Kirchneriella sp.

1000 Pediastrum sp.

1500 Pandorina sp.

50 Tetraedron

4000 Volvox

700 Xanthidium

900 Anabaena circinalis

100 Aphanothecae sp.

20 Merismopedia sp.

20 Oscillatoria sp2

350 Oscillatoria limnetica 


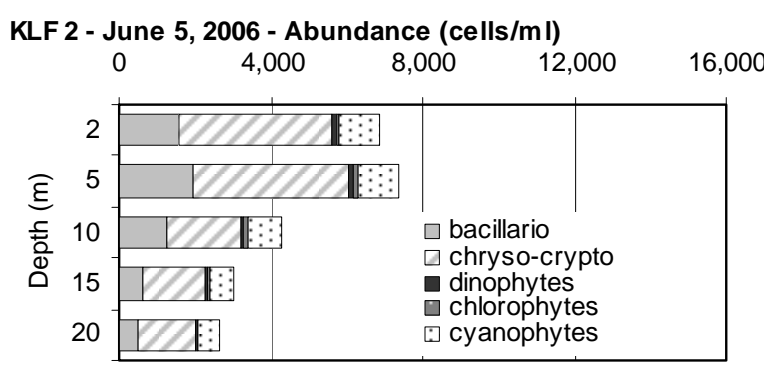

Biomass - (m m 3/L)

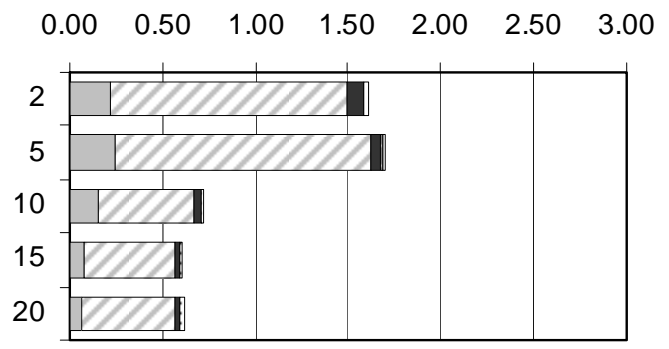

KLF 2- July 4, 2006
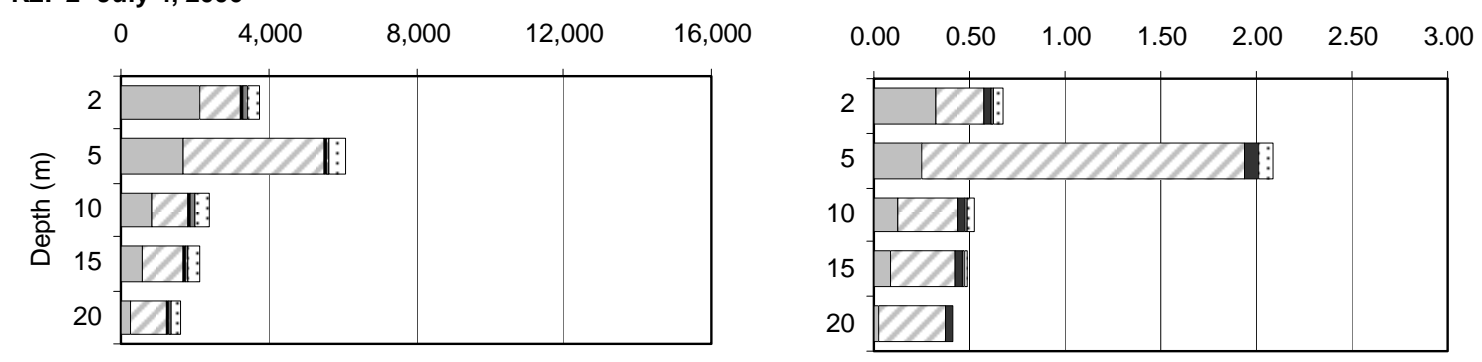

KLF 2 - Aug 8, 2006
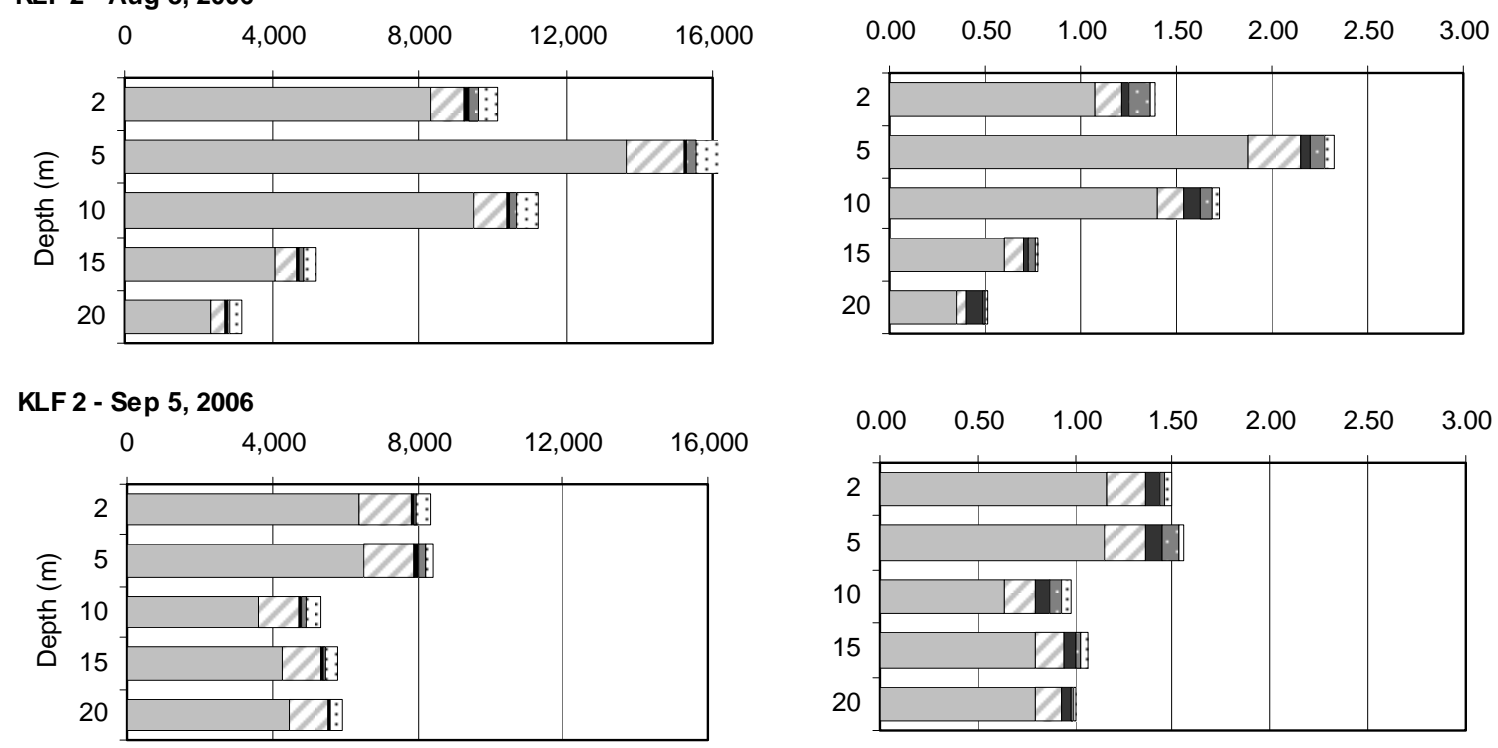

Figure 5.1. Kootenay Lake station KLF 2 vertical profile of abundance (cells/mL) and biomass $\left(\mathrm{mm}^{3} / \mathrm{L}\right), 2006$.

Kootenay Lake Fertilization Experiment, Year 15 (North Arm) and Year 3 (South Arm) 110 (2006) Report 
KLF 2 - 2006

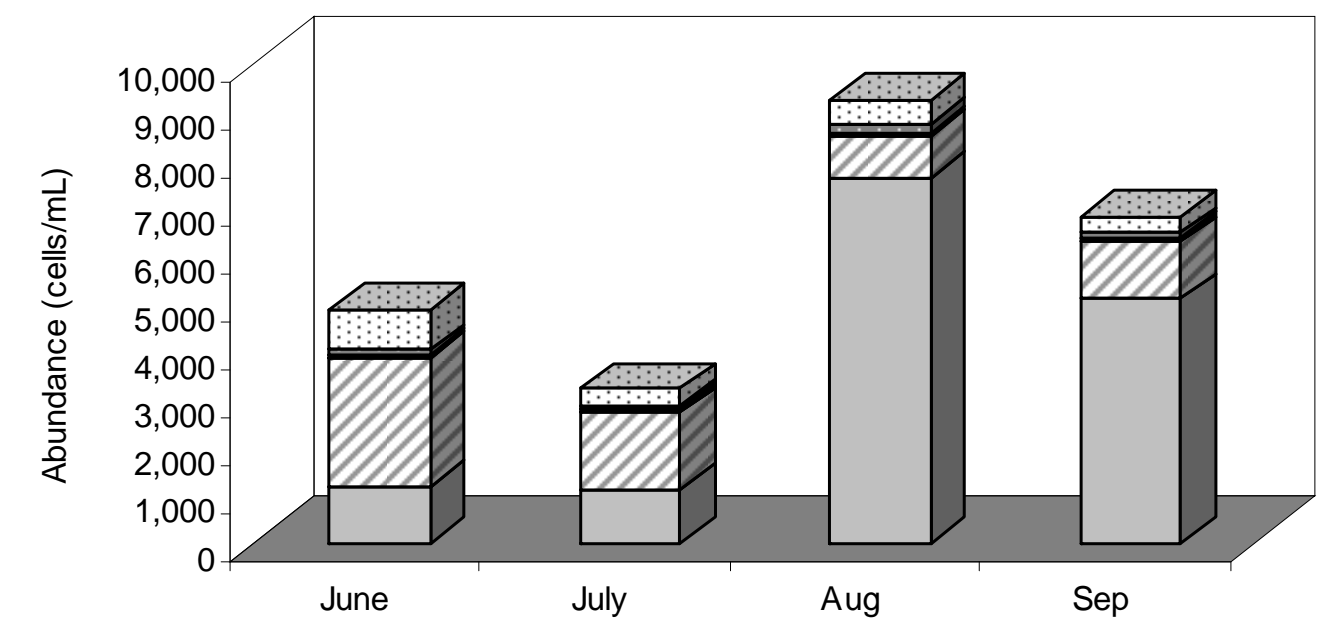

$\square$ bacillario $\square$ chryso-crypto $\square$ dinophytes $\square$ chlorophytes $\square$ cyanophytes

KLF 2 - 2006

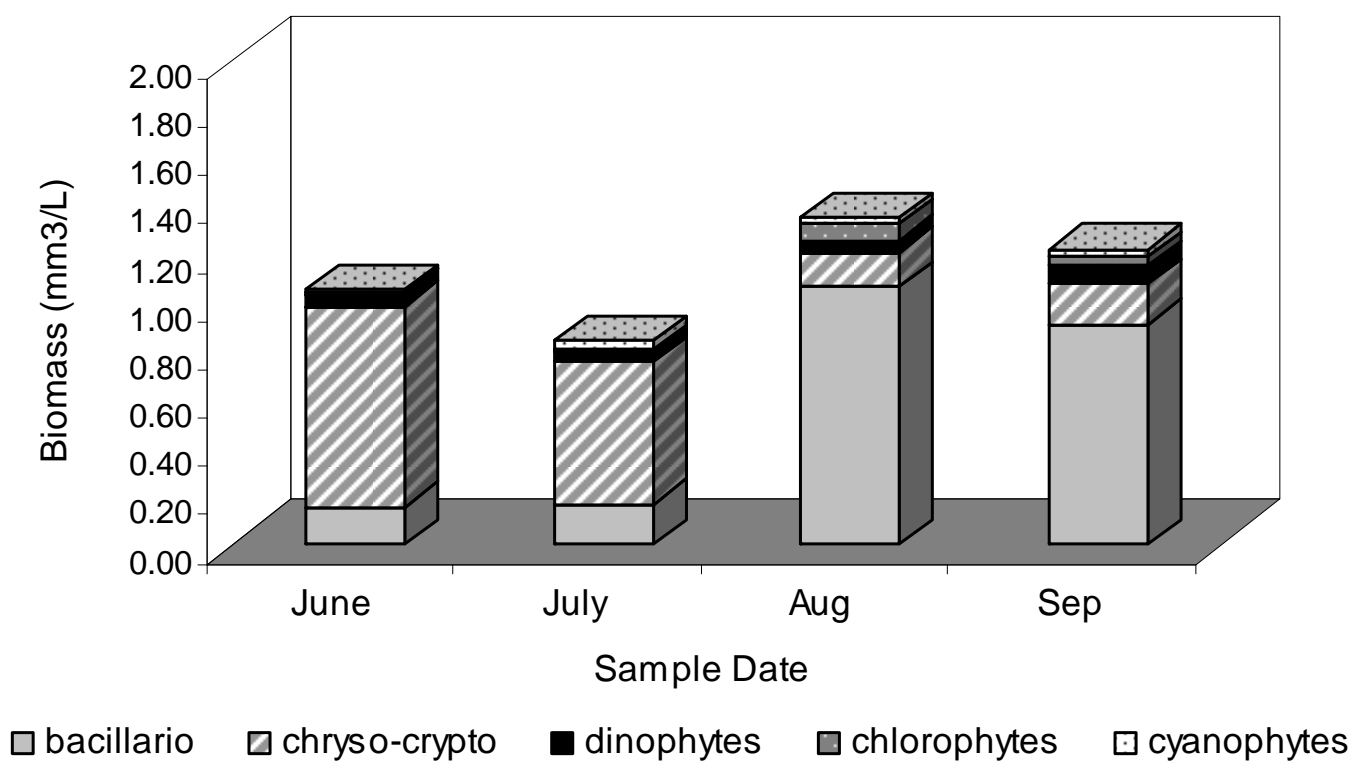

Figure 5.2. Phytoplankton abundance (cells $/ \mathrm{mL})$ and biomass $\left(\mathrm{mm}^{3} / \mathrm{L}\right), \mathrm{KLF} 2$ Kootenay Lake, 2006 
KLF 6 - June 5, 2006 - Abundance - (cells/mI)
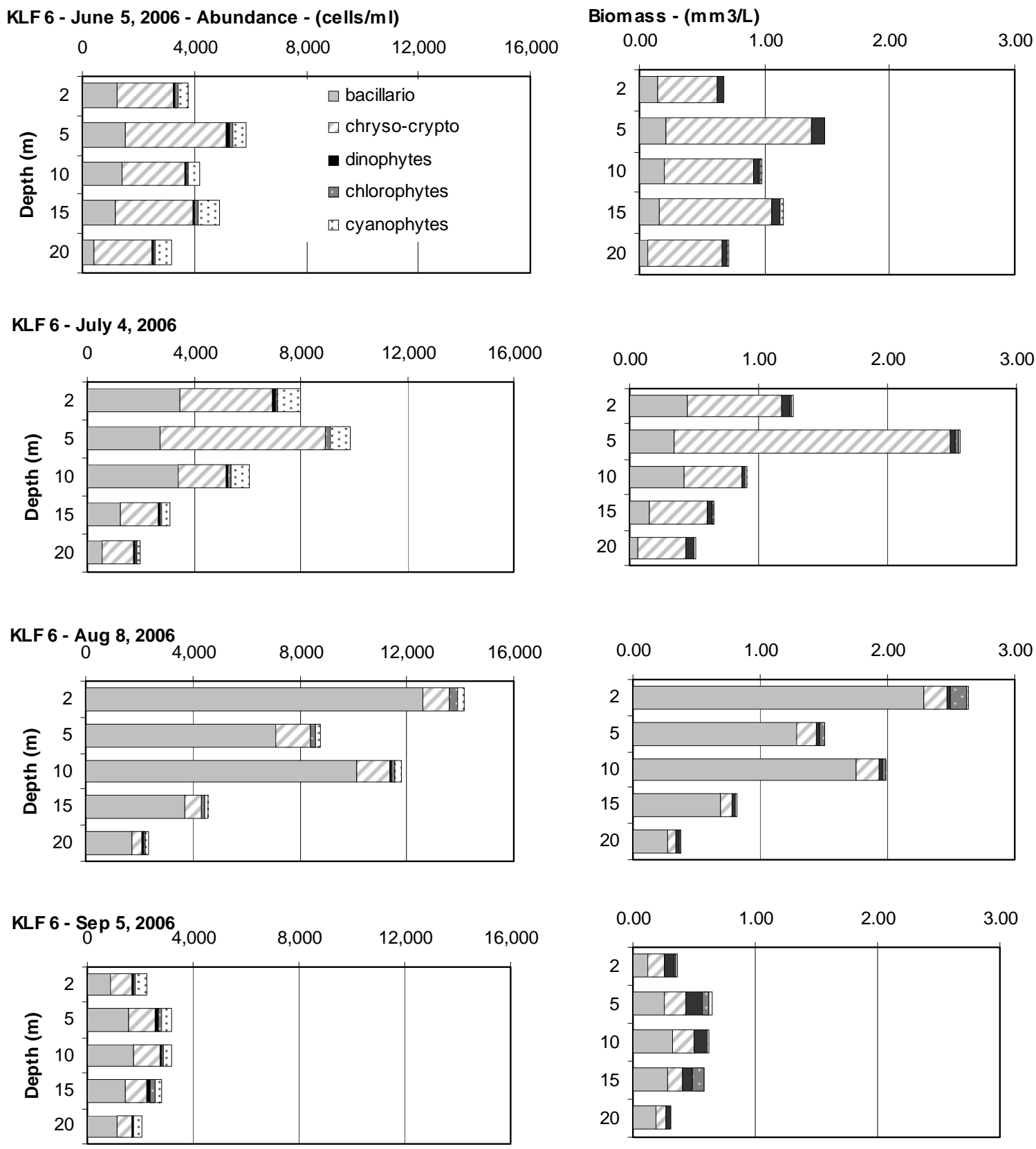

Figure 5.3. Kootenay Lake station KLF 6 vertical profile of abundance (cells/mL) and biovolume $\left(\mathrm{mm}^{3} / \mathrm{L}\right), 2006$. 


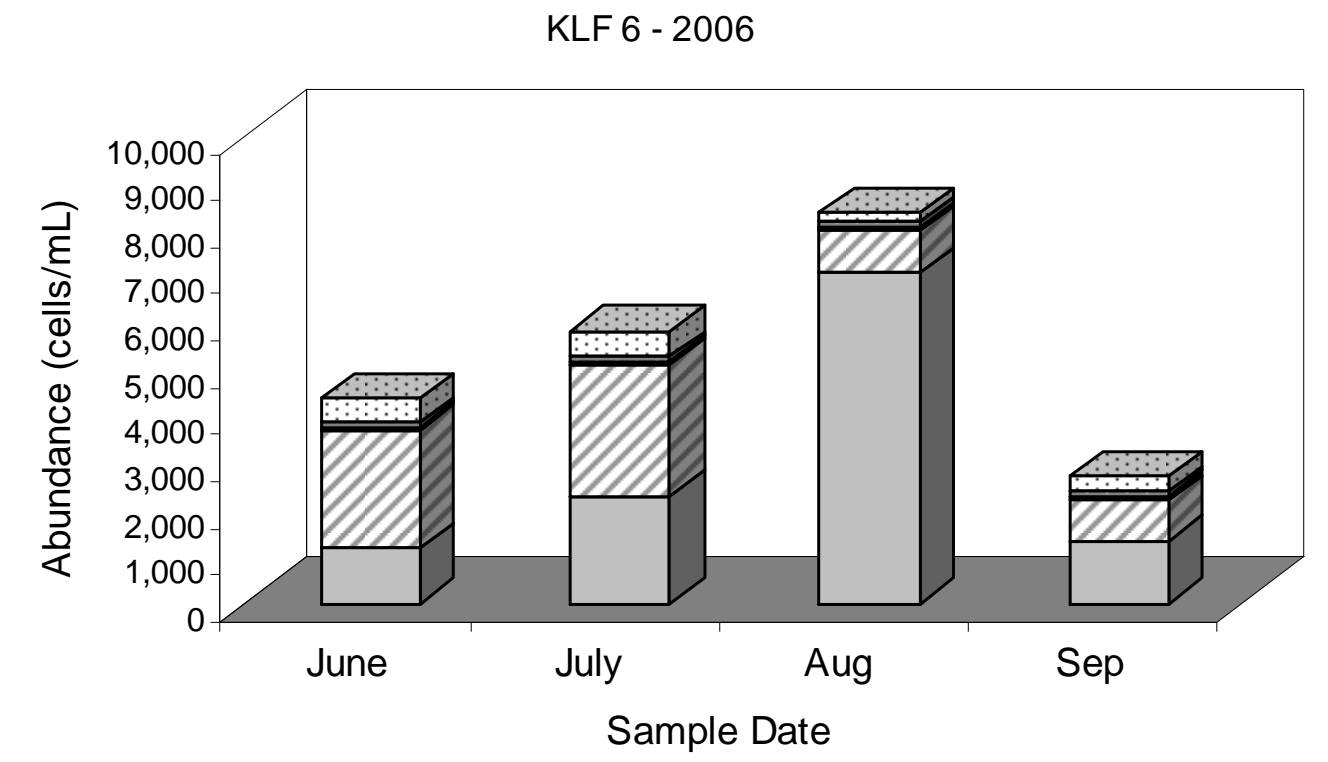

$\square$ bacillario $\square$ chryso-crypto $\square$ dinophytes $\square$ chlorophytes $\square$ cyanophytes

KLF $6-2006$

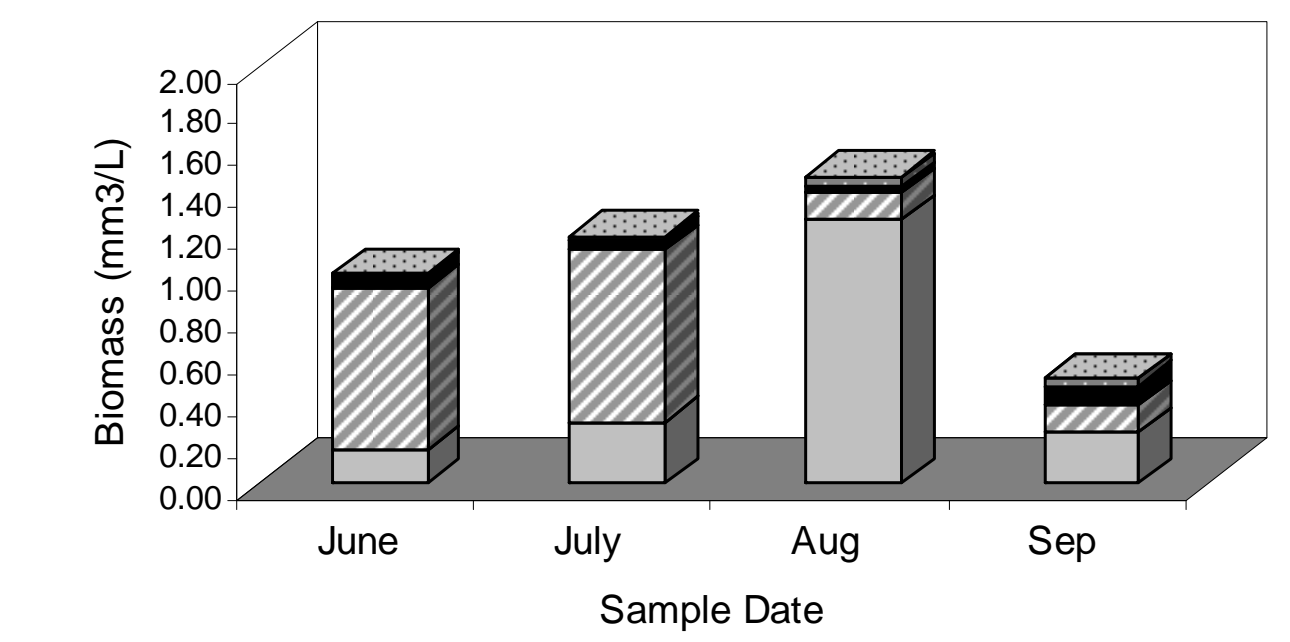

$\square$ bacillario $\square$ chryso-crypto $\square$ dinophytes $\square$ chlorophytes $\square$ cyanophytes

Figure 5.4. Phytoplankton abundance and biomass by class, KLF 6, Kootenay Lake, 2006. 
KLF 7 - June 5, 2006 - Abundance - (cells $/ \mathrm{ml}$ )

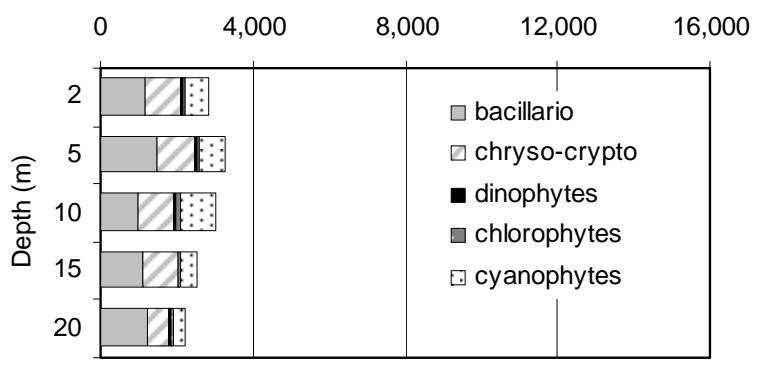

KLF 7 - July 4, 2006

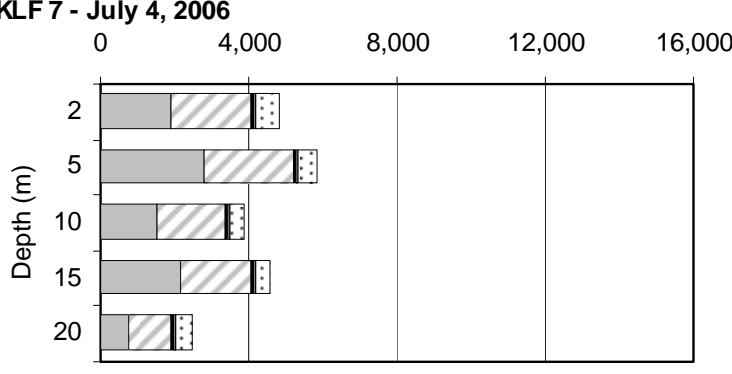

KLF 7 - Aug 8, 2006

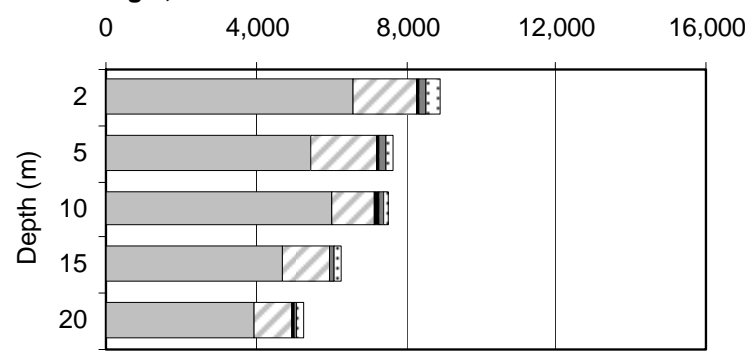

KLF 7 - Sep 5, 2006

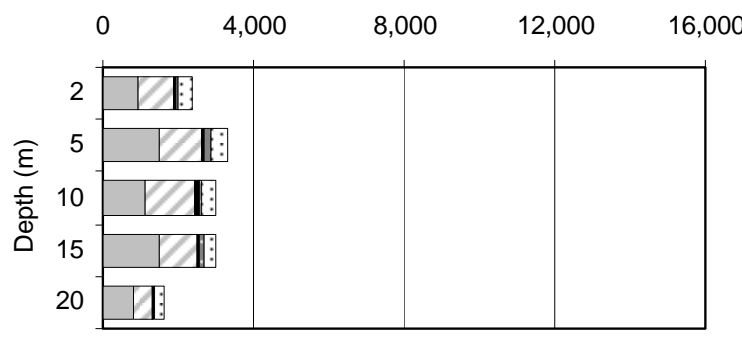

Biomass - (m m 3/L)
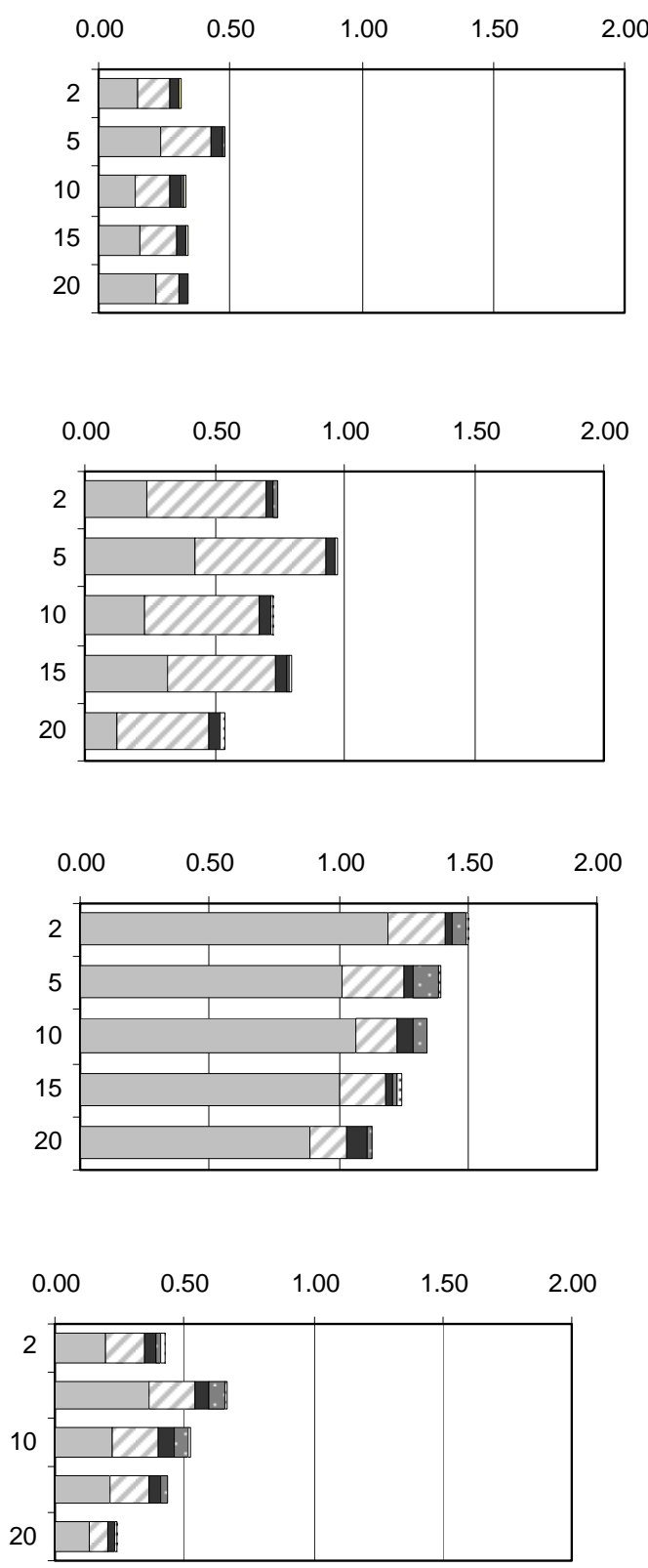

Figure 5.5. Kootenay Lake station KLF 7 vertical profile of abundance (cells $/ \mathrm{mL}$ ) and biomass $\left(\mathrm{mm}^{3} / \mathrm{L}\right), 2006$. 
KLF 7 - 2006

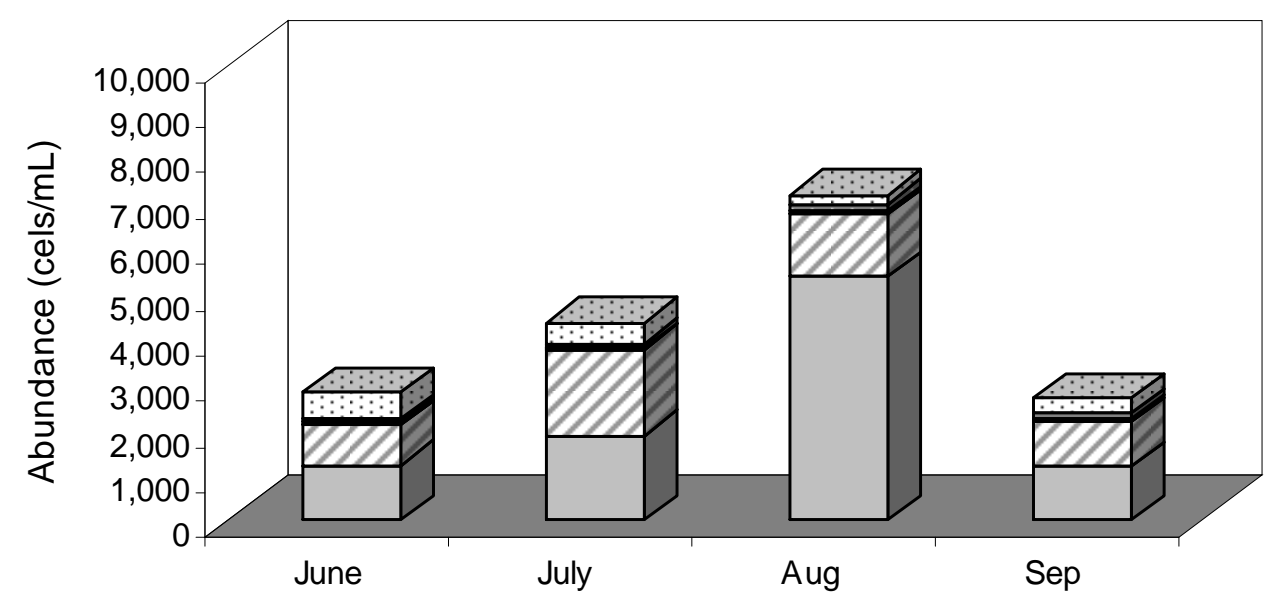

$\square$ bacillario $\square$ chryso-crypto $\square$ dinophytes $\square$ chlorophytes $\square$ cyanophytes

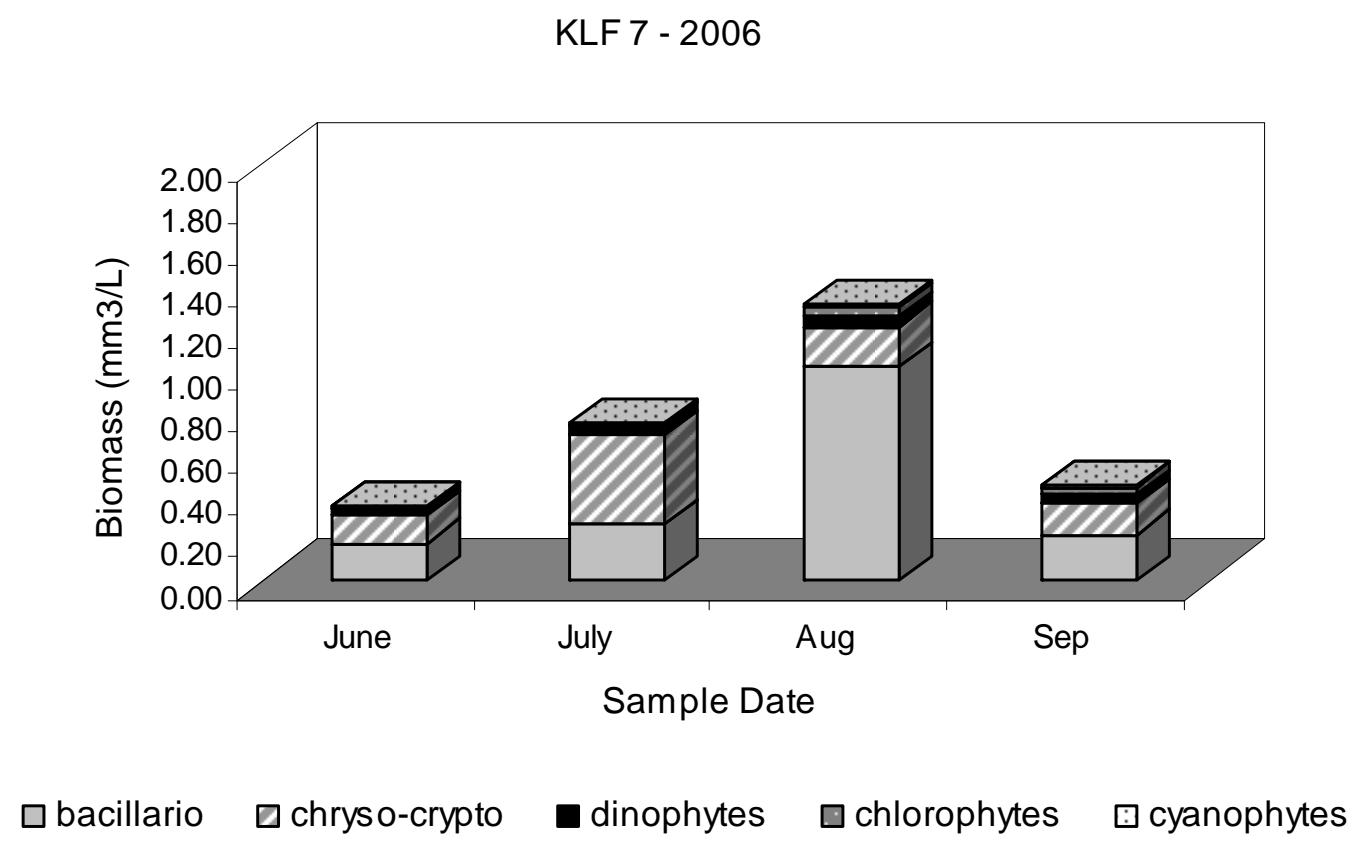

Figure 5.6. $\quad$ Phytoplankton abundance and biomass by class, KLF 7, Kootenay Lake, 2006. 

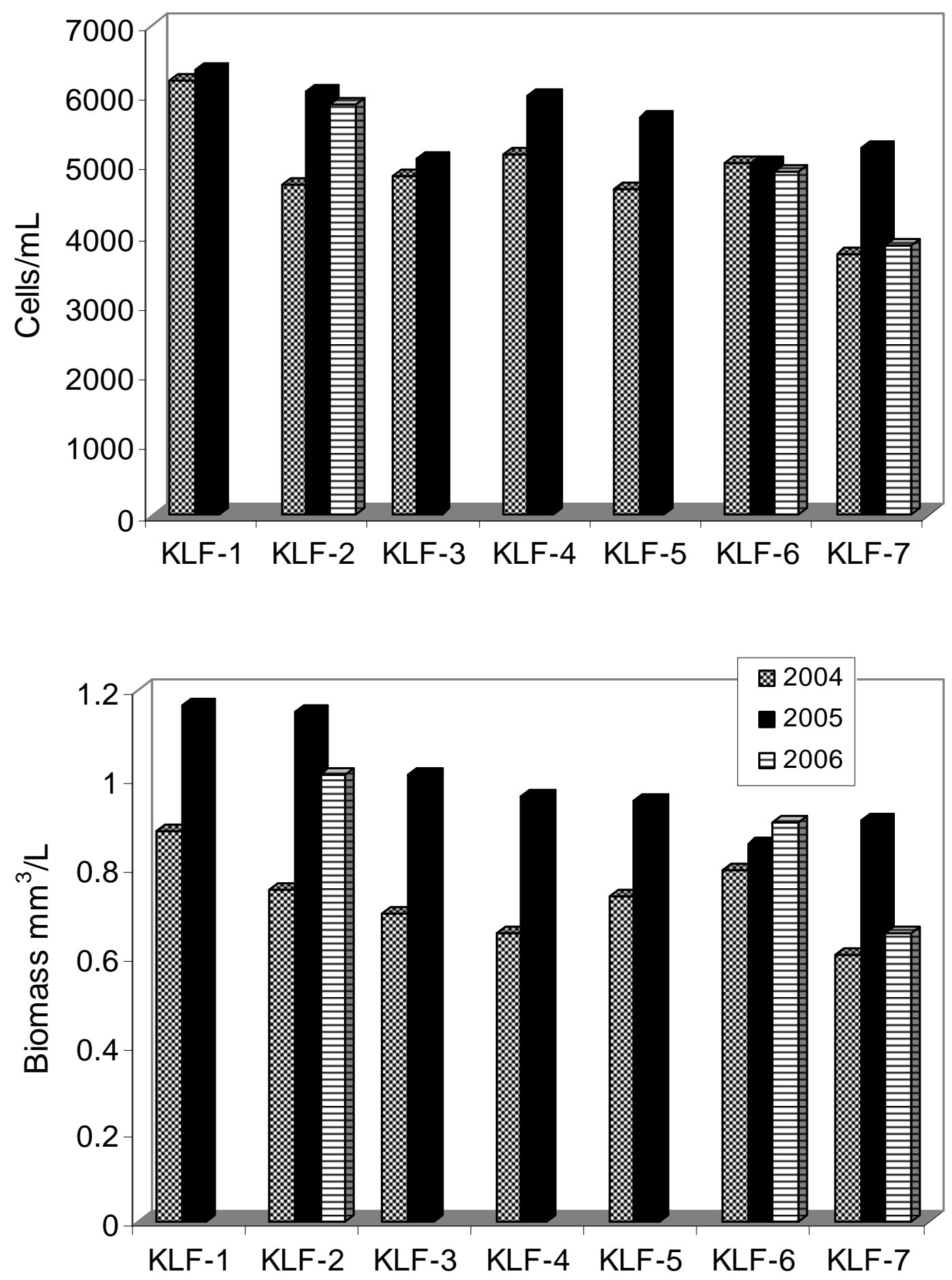

Figure 5.7. Phytoplankton average abundance and biomass in vertical profiles, Kootenay Lake, 2004-2006. 


\section{CHAPTER 6}

\section{RESPONSE OF ZOOPLANKTON AND MYSIS RELICTA TO EXPERIMENTAL}

FERTILIZATION, YEAR 15 (NORTH ARM) AND YEAR 3 (SOUTH ARM) (2006)

by

\section{Dr. Lidija Vidmanic}

Limno-Lab Ltd.

Vancouver, BC 


\section{Introduction}

Experimental fertilization of Kootenay Lake began in 1992, in an effort to restore the lake's productivity to natural levels. Kokanee salmon (Oncorhynchus nerka) abundance had declined to a historical low in 1991, and there was concern that the stock might collapse. An additional concern was that sport fish such as Gerrard rainbow trout (Oncorhynchus mykiss) and bull trout (Salvelinus confluentus) would decrease significantly, as kokanee are their main food source. Kokanee are planktivores that feed mainly on macrozooplankton such as Daphnia. The restoration experiment was further complicated by the presence of Mysis relicta, an exotic crustacean that competes with kokanee for zooplankton, particularly Daphnia. Mysis relicta was introduced into Kootenay Lake in 1949. The release of mysids interfered with established food webs and affected benthic, phytoplankton, zooplankton, and fish communities. Mysids feed on zooplankton and are in direct competition with kokanee for preferred zooplankton prey.

After four years of decreased nutrient addition (1997-2000), fertilizer loading was increased from 2001 onward to the level used during the first five years (1992-1996). Fertilizer was added to the surface waters near station KLF 2 in the North Arm, and in 2004, fertilization of the South Arm started near station KLF 5 (Chapter 2 in this report).

The study of zooplankton and mysids in Kootenay Lake started in 1992 as part of a multidisciplinary project to restore kokanee stocks by experimental fertilization of the North Arm. This report will focus on results from 1997 through 2006. Previous years' data are described in Ashley et al. 1996 and 1997, and in Thompson 1999.

\section{Methods}

\section{Zooplankton}

Sampling stations were established in 1992, numbered from north to south, with stations KLF 1-4 in the North Arm, and stations KLF 5-7 in the South Arm (see Fig 1.1 in Chapter 1 of this report). There were no sampling stations in the West Arm. From 1997 onward, zooplankton was sampled monthly from April through October at four stations: KLF 2, 4, 6, and 7. In 2003, a station in the West Arm was established (KLF 8) and samples were collected monthly from August to November. Samples were also collected from stations KLF 1, 3, and 5 during the same months.

In 2006, samples were collected from April 11 to November 03, using a Clarke-Bumpus sampler. At each of the stations (KLF 1-8), three replicate oblique tows were made. The net had 153- $\mu \mathrm{m}$ mesh and was raised from a depth of $40 \mathrm{~m}$ to $0 \mathrm{~m}$, at a boat speed of $1 \mathrm{~m} / \mathrm{s}$. Tow duration was $3 \mathrm{~min}$, with approximately 2,500 L of water filtered per tow. The exact volume sampled was estimated from the revolutions counted by the Clarke-Bumpus flow

Kootenay Lake Fertilization Experiment, Year 15 (North Arm) and Year 3 (South Arm) 
meter. The net and flow meter were calibrated before and after the sampling seasons in a flume at the Civil Engineering Department at the University of British Columbia.

Zooplankton samples were rinsed from the dolphin bucket through a $100-\mu \mathrm{m}$ filter to remove excess lake water and were then preserved in $70 \%$ ethanol. Zooplankton samples were analyzed for species density, biomass (estimated from empirical length-weight regressions, McCauley 1984), and fecundity. Samples were re-suspended in tap water filtered through a 74- $\mu \mathrm{m}$ mesh and sub-sampled using a four-chambered Folsom-type plankton splitter. Splits were placed in gridded plastic petri dishes and stained with Rose Bengal to facilitate viewing with a Wild M3B dissecting microscope (at up to $400 \mathrm{X}$ magnification). For each replicate, organisms were identified to species level and counted until up to 200 organisms of the predominant species were recorded. If 150 organisms were counted by the end of a split, a new split was not started. The length of 30 organisms of each species was measured, for use in biomass calculations, using a mouse cursor on a live television image of each organism. Lengths were converted to biomass ( $\mu g$ dry weight) using an empirical length-weight regression from McCauley (1984). The number of eggs carried by gravid females and the length of these individuals were recorded for use in fecundity estimates.

Rare species, e.g., Polyphemus pediculus, were counted and measured as "Other Cladocerans" or "Other Copepods" as appropriate. Zooplankton species were identified with reference to taxonomic keys (Pennak 1989; Wilson 1959; Brooks 1959; Sandercock and Scudder 1996).

\section{Mysis relicta}

Samples of mysids from Kootenay Lake were collected monthly from January to December from 1997 to 2004, February to December in 2005 and from February to November in 2006 at eight stations (KLF 1-4 in the North Arm, KLF 5-7 in the South Arm and station KLF 8 in the West Arm). Sampling was done at night, around the time of the new moon when possible, to decrease the chance of mysids seeing and avoiding the net. Three vertical hauls were done at each station, with the boat stationary, using a $1-\mathrm{m}^{2}$ square-mouthed net with $1,000 \mu \mathrm{m}$ primary mesh, $210 \mu \mathrm{m}$ terminal mesh, and $100 \mu \mathrm{m}$ bucket mesh. Two hauls were made in deep water ( 0.5 nautical miles from both west and east of lake centre) and one haul was made in shallow water near either the west or east shore. The West Arm station has a maximum depth of $35 \mathrm{~m}$, therefore two samples were collected from this depth and one from $25 \mathrm{~m}$. The net was raised from the lake bottom with a hydraulic winch at $0.3 \mathrm{~m} / \mathrm{s}$. The contents of the bucket were rinsed into a filter to remove excess lake water and were then preserved in $100 \%$ denaturated alcohol (85\% ethanol, 15\% methanol).

Samples were analyzed for density, biomass (estimated from an empirical length-weight regression; Lasenby 1977), life history stage, and maturity (Reynolds and DeGraeve 1972). Nine life history stages were identified: juvenile, immature male, mature male, breeding male, immature female, mature female, brooding female (brood pouch full of eggs or embryos), disturbed brood female (brood pouch not fully stocked with eggs, but at least one

Kootenay Lake Fertilization Experiment, Year 15 (North Arm) and Year 3 (South Arm) 
egg or embryo left to show that female had a brood), and spent female (brood pouch empty, no eggs or embryos remaining).

Samples were re-suspended in tap water filtered through a 74- $\mu \mathrm{m}$ mesh filter, placed in a plastic petri dish, and viewed with a Wild M3B dissecting microscope at up to $160 \mathrm{X}$ magnification. All mysids in each sample were counted and had their life history stage and maturity identified. The body length (tip of rostrum to base of telson) of up to 30 individuals of each stage and maturity was measured, for use in biomass calculations, using a mouse cursor on a live television image of each organism.

\section{Results}

\section{Zooplankton}

\section{Species Present}

The zooplankton population in Kootenay Lake has a diverse species assemblage. Twenty species of macrozooplankton were identified in the samples over the course of the study, with copepods such as Diaptomus ashlandi, Epishura nevadensis, and Cyclops bicuspidatus thomasi, and the cladocerans Daphnia galeata mendotae and Bosmina longirostris being the most numerous.

During the study period, four calanoid copepod species, Epischura nevadensis (Lillj.), Leptodiaptomus ashlandi (Marsh), Leptodiaptomus pribilofensis (Juday and Muttkowski) and Leptodiaptomus sicilisi (Forbes), were identified in samples from Kootenay Lake (Table 6.1). One cyclopoid copepod species, Diacyclops bicuspidatus thomasi (Forbes), was identified.

Fifteen cladoceran species were present in Kootenay Lake during the study period (Table 6.1). Seven species were present in samples in all nine years: Ceriodaphnia reticulata (Jurine), Daphnia galeata mendotae (Birge), Daphnia pulex (Leydig), Daphnia longispina (O.F.M.), Bosmina longirostris (O.F.M.), Leptodora kindti (Focke), and Diaphanosoma brachyurum (Liéven). Other rare species such as Scapholeberis mucronata (O.F.M.), Polyphemus pediculus (L.), Chydorus sphaericus (O.F.M.), Sida cristallina (O.F.M.), Alona affinis (Leydig), Acroperus harpae (Baird), and Graptoleberis testudinaria (Fischer) were observed sporadically. Daphnia spp. were not identified to species for density counts in any of the study years.

In all ten years, the zooplankton population composition has remained similar in both the North and South arms of Kootenay Lake. The predominant copepods in Kootenay Lake are L. ashlandi and D. bicuspidatus thomasi. The cladocerans D. brachiurum, Daphnia spp., and $B$. longirostris were common in all study years. 
Table 6.1. L List of zooplankton species identified in Kootenay Lake, 1997-2006.

\section{6}

Cladocera

Alona sp.

Alona affinis

Acroperus harpae

Bosmina longirostris

Ceriodaphnia reticulata

Chydorus sphaericus

Daphnia galeata mendotae

Daphnia pulex

Daphnia longispina

Diaphanosoma brachiurum

Graptoleberis testudinaria

Leptodora kindti

Polyphemus pediculus

Sida cristallina

Scapholeberis mucronata

\begin{tabular}{lllllllllll}
\multicolumn{1}{c}{} & & & & & & + & & + \\
& & & & & & & + & & + \\
& & & & & & & + & & \\
+ & + & + & + & + & + & + & + & + & + \\
+ & + & + & + & + & + & + & + & + & + \\
& + & + & + & & & + & + & + & + \\
+ & + & + & + & + & + & + & + & + & + \\
+ & + & + & + & + & + & + & + & + & + \\
+ & + & + & + & + & + & + & + & + & + \\
+ & + & + & + & + & + & + & + & + & + \\
& & & & & & & + & & \\
+ & + & + & + & + & + & + & + & + & + \\
+ & + & & & & & & & & \\
& & + & & & & & & &
\end{tabular}

\section{Copepoda}

Diacyclops bicuspidatus

Epischura nevadensis

Leptodiaptomus ashlandi

Leptodiaptomus pribilofensis

Leptodiaptomus sicilis

$\begin{array}{ccccccccccc}+ & + & + & + & + & + & + & + & + & + \\ + & + & + & + & + & + & + & + & + & + \\ + & + & + & + & + & + & + & + & + & + \\ & & & & & & & & & \\ & & & & & & & & & & \\ & & & & & & & & & \end{array}$

\section{Density and Biomass}

Zooplankton densities during the period of nutrient addition (1992-2006) have been consistently higher than during the period from 1973 to 1991, with the exception of some years such is 1972 and in the period from 1983 to 1986 (Fig. 6.1). The zooplankton populations in Kootenay Lake show a diverse species assemblage, with increasing population density in 2006 compared to the previous year. The zooplankton community in the North Arm was composed of 89\% copepods, 7\% Daphnia spp., and 4\% cladocerans other than Daphnia spp. in 2006 (Fig. 6.2). The proportion of cladocerans (including Daphnia spp.) varied from about 4-16\% from 1997 to 2006, except in 2001 when cladocerans composed $27 \%$ of the zooplankton community. Similarly, the South Arm population in the 2006 sampling season was made up of 90\% copepods, 6\% Daphnia spp., and 4\% cladocerans other than Daphnia spp. The proportion of cladocerans (including Daphnia spp.) over the course of the study fluctuated from 5\% to 18\% from 1997 to 2006. 
Kootenay Lake zooplankton density is numerically dominated by copepods, which include calanoids and cyclopoids. Both of these groups are widely distributed at the surface waters, are primarily planktonic, and are important components in food webs. During the study period 1997-2003, cyclopoids dominated the copepod community. However, during the summer and late fall in 2004, during the entire season in 2005 and in the summer 2006 calanoids were numerically dominant in both the North and South arms of Kootenay Lake (Figs. 6.3 and 6.4). Copepods were the most abundant zooplankton at each station from 1997 to 2006. They dominated during the entire sampling season, with populations peaking in July-August. In 2006 density peak occurred one month earlier in June in all three North, South and West Arms. The largest copepod population, averaging 54.26 individuals/L, was found in the South Arm, at station KLF 5, in July 2006. The dominant copepod in 2006 in the North Arm was D. bicuspidatus, with average densities of 10.29 individuals/L, L. ashlandi in the South Arm with 11.46 individuals/L, and in the West Arm both $D$. bicuspidatus and $L$. ashlani codominated with 9.20 individuals/L. Cladocerans were occasionally captured at the beginning of the sampling season in April and May, but significant populations did not develop until August in each study year.

Zooplankton density in the North Arm fluctuated from year to year during the study period (Fig. 6.5a, Table 6.2). However, with an increased fertilizer load in 2001, zooplankton density increased significantly in the following two years. The seasonal average zooplankton density (April to October) in the North Arm increased from 1999 to 2003. However, in 2004 and 2005 zooplankton density decreased. In 2006 seasonal average abundance increased to 24.80 individuals/L from 20.40 individuals/L in 2005 . Zooplankton abundance from 2001 to 2003 was the highest observed during the fertilization experiment and was higher than abundance observed in the early 1980s (Fig. 6.1). However, Daphnia spp. density during ten study years in the North Arm was less than 1 individual/L except in 2001 with 1.17 individuals/L, in 2003 with 2.22 individuals/L and in 2006 with 1.66 individuals/L (Fig. 6.6). The density of other cladocerans fluctuated during the course of the study with a significant increase in 2001 to 7.96 individuals/L from 0.62 individuals/ $\mathrm{L}$ in the previous year. In 2006, seasonal average abundance of cladocerans other than Daphnia was 1.03 individuals/L. (Fig. 6.5b, Table 6.2).

Zooplankton density during the ten years studied was lower in the South Arm than in the North Arm, except in 1997, 1999, and 2004 (Fig. 6.5a, Table 6.2). In the South Arm, the total zooplankton density had generally increasing trend from 1997 to 2003. In the next two years, a decrease of total zooplankton occurred in the South Arm followed by a slight increase in 2006. A similar pattern of density fluctuation of Copepoda and other Cladocera occurred during the study period (Fig. 6.5c, Table 6.2). Daphnia spp. density fluctuated in each successive year of the study. In 2006, the seasonal average density (April to November) of zooplankton in the South Arm was 24.28 individuals/L.

In the West Arm, the total zooplankton density, as well as densities of all copepods and Daphnia increased while Cladocera other than Daphnia decreased in 2006 compared to the previous year. The seasonal average density (April to November) of zooplankton in the West Arm was 24.67 individuals/L (Fig. 6.5a, Table 6.2). The zooplankton community in

Kootenay Lake Fertilization Experiment, Year 15 (North Arm) and Year 3 (South Arm) 122 (2006) Report 
2006 was composed of 85\% copepods, 5\% Daphnia spp., and 10\% cladocerans other than Daphnia spp (Fig. 6.2).

Table 6.2. Seasonal average density of zooplankton in the North, South, and West arms of Kootenay Lake during 1997-2006. Values are seasonal averages, calculated for samples collected April-October 1997-2002 and AprilNovember 2003-2006. Density is in units of individuals/L. Values from Arrow Lakes Reservoir, Okanagan Lake and Alouette Lake are shown for comparison.

\begin{tabular}{|c|c|c|c|c|c|c|c|c|c|c|c|}
\hline & Lake & 1997 & 1998 & 1999 & 2000 & 2001 & 2002 & 2003 & 2004 & 2005 & 2006 \\
\hline \multirow[t]{7}{*}{ Total Density } & Kootenay-North & 18.42 & 22.54 & 17.59 & 25.81 & 33.90 & 35.33 & 38.70 & 24.82 & 20.40 & 24.80 \\
\hline & Kootenay-South & 21.25 & 18.00 & 17.93 & 23.03 & 28.32 & 26.20 & 33.43 & 28.55 & 19.96 & 24.28 \\
\hline & Kootenay-West & & & & & & & 35.01 & 29.73 & 20.90 & 24.67 \\
\hline & Upper Arrow & 3.78 & 6.23 & 9.15 & 11.38 & 13.77 & 11.10 & 16.78 & 14.34 & 6.67 & 11.64 \\
\hline & Lower Arrow & 10.48 & 8.9 & 14.29 & 23.94 & 14.75 & 20.30 & 28.43 & 28.65 & 18.85 & 18.63 \\
\hline & Okanagan & 22.00 & 8.00 & 22.2 & 21.11 & 16.66 & 15.69 & 14.43 & 14.91 & 12.34 & \\
\hline & Alouette & & & & & & & & 5.90 & 4.20 & 11.50 \\
\hline \multirow[t]{6}{*}{ Copepod Density } & Koote & 17.58 & 20.50 & 16.74 & 24.86 & 24.77 & 32.99 & 32.61 & 23.38 & 18.41 & 22.11 \\
\hline & Kootenay-South & 18.82 & 15.92 & 17.04 & 19.29 & 23.31 & 23.32 & 29.42 & 26.50 & 17.12 & 21.96 \\
\hline & Kootenay-West & & & & & & & 28.06 & 26.81 & 17.89 & 20.83 \\
\hline & Upper Arrow & 2.30 & 4.39 & 6.99 & 10.04 & 11.25 & 10.11 & 12.47 & 13.38 & 6.06 & 9.84 \\
\hline & Lowe & 8.28 & 7.01 & 10.31 & 17.84 & 10.15 & 18.20 & 23.18 & 26.76 & 16.62 & 15.44 \\
\hline & Okanagan & 21.1 & 7.4 & 20.76 & 20.36 & 15.84 & 15.21 & 13.67 & 13.95 & 11.68 & \\
\hline Other Clad & Koote & 0.57 & 1.23 & 0.46 & 0.62 & 7.96 & 1.40 & 3.88 & 1.19 & 1.70 & 1.03 \\
\hline \multirow[t]{5}{*}{ Density* } & Kootenay-South & 1.68 & 1.11 & 0.49 & 2.32 & 4.23 & 2.03 & 2.81 & 1.64 & 2.21 & 0.85 \\
\hline & Kootenay-West & & & & & & & 4.38 & 1.99 & 1.90 & 1.31 \\
\hline & Upper Arrow & 0.63 & 0.92 & 0.63 & 0.55 & 1.71 & 0.76 & 3.80 & 0.85 & 0.51 & 1.20 \\
\hline & Lowel & 1.11 & 0.39 & 0.95 & 1.50 & 2.57 & 1.55 & 3.45 & 1.54 & 1.32 & 0.92 \\
\hline & Okanagan & 0.46 & 0.2 & 0.9 & 0.29 & 0.61 & 0.31 & 0.28 & 0.62 & 0.41 & \\
\hline Daphnia spp. & Koote & 0.27 & 0.81 & 0.39 & 0.33 & 1.17 & 0.94 & 2.22 & 0.25 & 0.28 & 1.66 \\
\hline \multirow[t]{6}{*}{ Density } & Kootenay-South & 0.75 & 0.97 & 0.39 & 1.43 & 0.78 & 0.85 & 1.20 & 0.41 & 0.63 & 1.48 \\
\hline & Kootenay-West & & & & & & & 2.56 & 0.92 & 1.10 & 2.53 \\
\hline & Upper Arrow & 0.15 & 0.92 & 1.53 & 0.8 & 0.81 & 0.23 & 0.48 & 0.11 & 0.09 & 0.61 \\
\hline & Lower Arrow & 1.06 & 1.50 & 3.04 & 4.6 & 2.03 & 0.55 & 1.80 & 0.34 & 0.92 & 2.26 \\
\hline & Okanagan & 0.25 & 0.11 & 0.54 & 0.47 & 0.21 & 0.17 & 0.48 & 0.34 & 0.25 & \\
\hline & Alouette & & & & & & & & 0.00 & 0.61 & 2.66 \\
\hline
\end{tabular}

*Values do not include Daphnia spp. density.

Zooplankton biomass had similar trends in both the North and South arms of Kootenay Lake. From 1997 to 2006, biomass fluctuated with highest values recorded in 2003 in both the North and South arms (Fig. 6.7a, Table 6.3). A similar trend was observed for copepods biomass. Daphnia biomass in the North Arm also reached the highest value in 2003 with $40.92 \mu \mathrm{g} / \mathrm{L}$, while in the South Arm Daphnia biomass reached its peak in 2006 with 35.42 $\mu \mathrm{g} / \mathrm{L}$ (Fig. 6.8). Cladocerans other than Daphnia had the highest biomass in 2001 in both North and South Arm. In 2006, biomass of total zooplankton, copepods and Daphnia 
increased in both the North and South arms, while cladocerans other than Daphnia decreased in comparison to the previous year. During the 2004 season, there was a significant decrease of Daphnia biomass, which was approximately seven times lower in the North Arm and approximately four times lower in the South Arm than in 2003 (Fig. 6.8, Table 6.3). In 2005 Daphnia biomass in the South Arms increased slightly, while at the same time decreased in the North Arm. In 2006 a significant increase of Daphnia biomass occurred with more than seven times higher in the North and more than three and a half times in the South Arm of Kootenay Lake. During 1997-2000 and 2004-2005, biomass was higher in the South Arm than in the North Arm for all categories except copepods (Fig. 6.7b, c, Table 6.3). In 2001 to 2003 and in 2006, biomass was higher in the North Arm than in the South Arm. In the North Arm, Daphnia spp. varied from $11 \%$ to $39 \%$ of the total zooplankton biomass from 1997 to 2005. During the same period, Daphnia spp. varied from $12 \%$ to $34 \%$ of the total zooplankton biomass in the South Arm (Fig. 6.9). In 2006 Daphnia biomass made up $49 \%$ and $48 \%$ of the total zooplankton biomass in the North and South Arm respectively. 
Table 6.3. Seasonal average biomass of zooplankton in North, South, and West arms of Kootenay Lake in 1997-2006. Values are seasonal averages, calculated for samples collected April-October 1997-2002 and April-November 2003 and 2006. Biomass is in units of $\mu \mathrm{g} / \mathrm{L}$. Data from Arrow, Okanagan and Alouette lakes are shown for comparison.

\begin{tabular}{|c|c|c|c|c|c|c|c|c|c|c|c|}
\hline & Lake & 1997 & 1998 & 1999 & 2000 & 2001 & 2002 & 2003 & 2004 & 2005 & 2006 \\
\hline \multirow{7}{*}{ Total Biomass } & Kootenay-North & 25.86 & 46.66 & 30.69 & 44.75 & 80.95 & 66.36 & 104.36 & 52.93 & 41.90 & 75.90 \\
\hline & Kootenay-South & 35.77 & 46.85 & 32.67 & 56.31 & 60.70 & 51.93 & 73.88 & 54.72 & 43.53 & 73.26 \\
\hline & Kootenay-West & & & & & & & 93.12 & 64.69 & 47.80 & 90.24 \\
\hline & Upper Arrow & 7.73 & 28.63 & 44.55 & 33.04 & 34.02 & 19.22 & 29.45 & 22.35 & 10.35 & 28.00 \\
\hline & Lowe & 30.56 & 47.89 & 71.57 & 107.41 & 55.97 & 37.26 & 71.58 & 55.74 & 37.17 & 78.02 \\
\hline & Okanagan & & & 59.79 & 58.02 & 43.19 & 35.28 & 42.00 & 39.94 & 26.12 & \\
\hline & Alouette & & & & & & & & 14.90 & 20.27 & 89.88 \\
\hline Copepod & oot & 21.49 & 31.62 & 24.60 & 36.98 & 41.67 & 48.18 & 51.26 & 43.42 & 33.20 & 36.61 \\
\hline \multirow[t]{5}{*}{ Biomass } & Kootenay-South & 25.09 & 26.23 & 24.55 & 31.71 & 39.06 & 33.96 & 45.80 & 44.01 & 28.51 & 35.92 \\
\hline & Kootenay-West & & & & & & & 42.96 & 42.53 & 27.77 & 29.61 \\
\hline & Upper Arrow & 4.41 & 7.85 & 12.4 & 17.01 & 19.53 & 14.45 & 18.24 & 19.14 & 8.50 & 14.96 \\
\hline & Lower Arrow & 11.46 & 10.85 & 17.56 & 27.03 & 18.32 & 24.70 & 31.47 & 46.56 & 20.53 & 21.79 \\
\hline & Okan & & & 41.9 & 41.8 & 34.8 & 28.92 & 27.00 & 26.02 & 20.18 & \\
\hline Other & oo & 1.31 & 3.34 & 1.22 & 2.23 & 18.94 & 3.56 & 12.17 & 3.44 & 3.42 & 2.03 \\
\hline Cladoceran & Kootenay-South & 2.61 & 4.48 & 1.69 & 5.33 & 9.94 & 6.09 & 6.43 & 4.34 & 4.88 & 1.92 \\
\hline \multirow[t]{4}{*}{ Biomass** } & Kootenay-West & & & & & & & 8.86 & 5.09 & 4.32 & 3.08 \\
\hline & Upper Arrow & 0.95 & 1.67 & 0.94 & 0.92 & 2.15 & 1.16 & 4.58 & 1.16 & 0.67 & 1.56 \\
\hline & Lower Arrow & 1.75 & 2.99 & 1.26 & 1.78 & 3.88 & 3.36 & 5.32 & 2.88 & 1.82 & 1.61 \\
\hline & Okanagan & & & 4.25 & 2.01 & 2.65 & 1.86 & 1.05 & 2.07 & 1.35 & \\
\hline Daphnia & Koote & 3.06 & 11.69 & 4.87 & 5.54 & 20.34 & 14.62 & 40.92 & 6.07 & 5.28 & 37.25 \\
\hline \multirow[t]{6}{*}{ Biomass } & Kootenay-South & 8.07 & 16.15 & 6.42 & 19.27 & 11.69 & 11.87 & 21.65 & 6.37 & 10.14 & 35.42 \\
\hline & Koote & & & & & & & 41.30 & 17.08 & 15.71 & 57.56 \\
\hline & Upper Arrow & 2.37 & 19.1 & 31.21 & 15.12 & 12.34 & 3.61 & 6.63 & 2.05 & 1.18 & 11.49 \\
\hline & Lower Arrow & 17.36 & 34.05 & 52.75 & 78.59 & 33.77 & 9.20 & 34.79 & 6.29 & 14.82 & 54.63 \\
\hline & Okanagan & & & 13.65 & 14.21 & 5.74 & 4.50 & 13.95 & 9.85 & 4.59 & \\
\hline & Alouette & & & & & & & & 0.03 & 11.29 & 58.41 \\
\hline
\end{tabular}

**Values do not include Daphnia spp. biomass.

During 2006, biomass of all categories, except Cladocera other than Daphnia, significantly increased in the West Arm. The seasonal average biomass (April to November) of zooplankton in the West Arm was $90.24 \mu \mathrm{g} / \mathrm{L}$ (Table 6.3). Daphnia biomass increased from a low of $15.71 \mu \mathrm{g} / \mathrm{L}$ in 2005 to $57.56 \mu \mathrm{g} / \mathrm{L}$ in 2006 (Fig. 6.8). The zooplankton biomass in 2006 was made up of 33\% copepods, 64\% Daphnia spp., and 3\% cladocerans other than Daphnia spp. (Fig. 6.9).

\section{Comparison of Kootenay Lake with other British Columbia large lakes and reservoirs}

Zooplankton density and biomass in Kootenay Lake did not show a steady increase across years (Tables 6.2 and 6.3). Total average density and biomass and Daphnia spp. average 
density and biomass fluctuated over the course of the years 1997-2006. Seasonal average zooplankton density in Kootenay Lake was higher than in either of the Arrow basins during each year of the study, except in 2000 and 2004 when zooplankton density in Lower Arrow increased to the level similar to Kootenay Lake (Fig. 6.18, Table 6.2) (Pieters et al. 2000, 2003, Schindler et al. 2007a). Total biomass in Kootenay Lake was less than the biomass in Lower Arrow during each year from 1998 to 2000 and less than the biomass in Upper Arrow only in 1999 (Fig. 6.18, Table 6.3). From 2001 onward the fertilizer load increased in Kootenay Lake which resulted in an increase of zooplankton biomass. From 2001 to 2003 zooplankton biomass was higher in Kootenay Lake than in Arrow Lakes Reservoir, and from 2004 to 2006 the biomass in all three Kootenay arms was similar to biomass in Lower Arrow and two to four fold higher than in Upper Arrow. These differences are due to the fluctuation in proportion of Daphnia spp. in total zooplankton density and biomass in these lakes, since individual Daphnia have a higher biomass than individuals of most other zooplankton species in these systems. This larger size results in an increase of zooplankton biomass in those years with favourable conditions for development of their population.

From 2001 to 2005, both zooplankton density and biomass were generally lower in Okanagan Lake than in Kootenay Lake, except in 2004 when Daphnia biomass in Okanagan Lake was higher (Andrusak et al. 2002, 2003, 2004). In Okanagan Lake, both density and biomass of most zooplankton categories showed a decreasing trend over the course of the study period. From 2000 onward (data for Okanagan Lake zooplankton 2006 are not available) zooplankton density in Kootenay Lake highly exceeded those values in Okanagan Lake (Fig. 6.18, Table 6.2) while Daphnia density and biomass in Okanagan Lake were lower than in Kootenay Lake only in 1998 and from 2001 to 2003 (Fig. 6.18, Table 6.2).

Seasonal average zooplankton density in Alouette Lake during the study period (data for Alouette Lake were available only from 2004 to 2006) were lower than in Kootenay Lake. Total zooplankton biomass was higher in Alouette than the North or South Arm but lower than the West Arm of Kootenay Lake in 2006 (Figs. 6.18, 6.19, Table 6.2).

In 2004 biomass of both total zooplankton and Daphnia in Alouette Lake was the lowest on record since Daphnia did not appear in the lake during the entire season (Alouette Lake limnology 2004-2006 technical report in preparation at the time of writing this report). In 2005 and 2006, Daphnia re-established in Alouette lake, and comprised 56$65 \%$ of the total zooplankton biomass. Daphnia density and biomass were higher then in the North Arm of Kootenay Lake in both years and higher than the biomass in the South Arm in 2006( Fig. 6.20). Daphnia density and biomass in the South Arm in 2005 and in the West Arm in 2005-2006 were similar to results in Alouette Lake.

From 1997 through 2006 the percentage of Daphnia density in total zooplankton in Kootenay Lake varied (Fig. 6.12). In the South Arm Daphnia density was between 1\% and $6 \%$ and biomass was between $11 \%$ and $48 \%$. In the North Arm Daphnia density fluctuated between $1 \%$ and $7 \%$ and biomass between $12 \%$ and $48 \%$. In the West Arm Daphnia density fluctuated between 3\% and 10\% and biomass between $26 \%$ and $64 \%$.

Kootenay Lake Fertilization Experiment, Year 15 (North Arm) and Year 3 (South Arm) 126 (2006) Report 
The highest percentage of Daphnia density and biomass in total zooplankton in Arrow Lakes Reservoir exceeded values compared to other lakes in the period from 1997 to 2001, while during 2002 to 2006, the proportion of Daphnia density and biomass varied between lakes. In 2006 despite the high proportion of Daphnia density in Alouette Lake, the proportion of Daphnia biomass did not exceed values in Lower Arrow (Fig. 6.20).

\section{Seasonal and Along-Lake Patterns}

In 2006, copepods were the predominant form of zooplankton, but cladocerans were present throughout the sampling period. Daphnia spp. was observed from May to the end of the sampling season. The seasonal development of zooplankton density did not differ in the North and South arms of Kootenay Lake in 2006. Total zooplankton density increased from the spring to the summer and decreased in the fall. Copepods dominated in density during the entire season, however Daphnia dominated by biomass in all three basins from August to November in 2006. Cladoceran abundance was low and the peak occurred in August in all three basins. Daphnia spp. density peaked in August in the West Arm, September in the North Arm and in October in the South Arm of Kootenay Lake. During 1997 and 1998 as well as in 2005, cladocerans and Daphnia spp. started to appear in July, which was earlier than other years. Conversely, 1999 was a late-season year, in which cladocerans and Daphnia spp. began to bloom in September. In 2000, the bloom of cladocerans started in August in the South Arm, while in the North Arm the season started in September. The years 2001, 2002, 2003, and 2004 were also late-season years with cladocerans and Daphnia blooming in August-September. In 2006 Daphnia appeared earlier than in previous years. In the South Arm Daphnia appeared in May in the North Arm in June and in the West Arm in July.

During 2006, peak total zooplankton densities occurred in June in the North and West Arms with 44.55 and 51.29 individuals/L, respectively and in July in the South Arm with 46.28 individuals/L (Table 6.4). The peak total zooplankton biomass occurred in September with $126.16 \mu \mathrm{g} / \mathrm{L}$ in the North Arm, in October with $155.25 \mu \mathrm{g} / \mathrm{L}$ in the South Arm, and with $221.03 \mu \mathrm{g} / \mathrm{L}$ in the West Arm. The peak Daphnia spp. biomass also occurred in September in the North Arm with $87.55 \mu \mathrm{g} / \mathrm{L}$, and in October in the South and West Arm with 137.31 $\mu \mathrm{g} / \mathrm{L}$ and $200.53 \mu \mathrm{g} / \mathrm{L}$ respectively (Table 6.4). During the September peak, Daphnia spp. made up a small proportion of zooplankton density. Due to the large body size of the adults, peak Daphnia biomass was $49 \%, 48 \%$, and $64 \%$ of the total biomass in the North, South, and West arms respectively.

During the ten years discussed in this report, peaks in density occurred at approximately the same time in the North and South arms. Similarly, biomass peaks in the North and South arms tended to coincide, or to be only a month apart. At times, there was a one to two month delay between the density and the biomass peaks. This delay was due to the increase in Daphnia and other cladoceran densities following the copepod density peak, as well as the large body size of individual cladocerans.

Kootenay Lake Fertilization Experiment, Year 15 (North Arm) and Year 3 (South Arm) 
Table 6.4. Monthly average density and biomass of zooplankton in the North, South and West arms of Kootenay Lake in 2006. Density is in units of individuals/L, and biomass is in units of $\mu \mathrm{g} / \mathrm{L}$.

\begin{tabular}{|c|c|c|c|c|c|c|c|c|c|}
\hline \multirow{2}{*}{$\frac{\text { Density }}{\text { North Arm }}$} & & April & May & June & July & Aug. & Sept. & Oct. & Nov. \\
\hline & Copepoda & 1.87 & 29.46 & 44.38 & 35.63 & 21.94 & 20.07 & 13.20 & 10.88 \\
\hline \multirow{3}{*}{ North Arm } & Daphnia & 0.00 & 0.00 & 0.05 & 0.13 & 3.87 & 4.15 & 3.21 & 1.91 \\
\hline & Other Cladocera* & $>0.01$ & 0.00 & 0.12 & 1.31 & 4.84 & 1.14 & 0.33 & 0.10 \\
\hline & Total Zooplankton & 1.88 & 29.46 & 44.55 & 37.07 & 30.65 & 25.35 & 16.74 & 12.90 \\
\hline \multirow[t]{4}{*}{ South Arm } & Copepoda & 4.94 & 32.85 & 44.63 & 42.83 & 18.16 & 15.32 & 11.02 & 7.81 \\
\hline & Daphnia & 0.00 & 0.04 & 0.00 & 0.76 & 3.46 & 2.39 & 4.48 & 0.73 \\
\hline & Other Cladocera* & $>0.01$ & 0.14 & 0.23 & 2.70 & 3.20 & 0.44 & 0.16 & 0.07 \\
\hline & Total Zooplankton & 4.95 & 33.02 & 44.86 & 46.28 & 24.82 & 18.15 & 15.65 & 8.61 \\
\hline \multirow[t]{4}{*}{ West Arm } & Copepoda & 3.38 & 29.29 & 50.98 & 37.35 & 17.02 & 11.13 & 11.46 & 6.01 \\
\hline & Daphnia & 0.00 & 0.00 & 0.00 & 0.60 & 8.54 & 4.14 & 5.79 & 1.17 \\
\hline & Other Cladocera* & 0.00 & 0.11 & 0.31 & 2.11 & 6.64 & 0.80 & 0.50 & 0.05 \\
\hline & Total Zooplankton & 3.38 & 29.40 & 51.29 & 40.05 & 32.19 & 16.07 & 17.75 & 7.23 \\
\hline
\end{tabular}

Biomass

\begin{tabular}{llrrrrrrrr}
\hline North Arm & Copepoda & 2.76 & 47.90 & 60.03 & 74.67 & 35.84 & 36.58 & 17.16 & 16.79 \\
& Daphnia & 0.00 & 0.00 & 0.42 & 1.72 & 75.40 & 87.55 & 81.88 & 51.18 \\
& Other Cladocera** & $>0.01$ & 0.00 & 0.15 & 2.23 & 10.52 & 2.03 & 0.53 & 0.23 \\
\cline { 3 - 8 } & Total Zooplankton & 2.76 & 47.90 & 60.60 & 78.62 & 121.76 & 126.16 & 99.57 & 68.20 \\
& & & & & & & & \\
South Arm & Copepoda & 8.44 & 56.33 & 62.63 & 66.57 & 31.48 & 29.15 & 17.62 & 12.12 \\
& Daphnia & 0.00 & 0.17 & 0.00 & 14.86 & 57.54 & 51.96 & 137.31 & 21.61 \\
& Other Cladocera** & 0.01 & 0.17 & 0.37 & 5.06 & 6.37 & 3.02 & 0.32 & 0.33 \\
\cline { 2 - 8 } & Total Zooplankton & 8.45 & 56.68 & 63.00 & 86.48 & 95.38 & 84.13 & 155.25 & 34.06 \\
& & & & & & & & \\
West Arm & & & & & & & & \\
& Copepoda & 5.03 & 36.01 & 67.45 & 54.50 & 24.96 & 19.49 & 19.35 & 10.06 \\
& Daphnia & 0.00 & 0.00 & 0.00 & 17.53 & 126.59 & 84.38 & 200.53 & 31.47 \\
& Other Cladocera** & 0.00 & 0.10 & 0.42 & 5.08 & 15.37 & 2.36 & 1.14 & 0.13 \\
\cline { 2 - 8 } & Total Zooplankton & 5.03 & 36.11 & 67.88 & 77.11 & 166.92 & 106.22 & 221.03 & 41.66 \\
\hline
\end{tabular}

*Values do not include Daphnia spp. density.

**Values do not include Daphnia spp. biomass.

The maximum zooplankton density in the main body of Kootenay Lake during 2006 was in July at station KLF 5, averaging 61.63 individuals/L, while in the West Arm the maximum zooplankton density was in June with 51.29 individuals/L (Figs. 6.10 and 6.11). Copepod densities peaked in June at most stations, while Cladocerans were occasionally captured in April-May (when sampling began), although significant populations did not develop until August (Figs. 6.10 and 6.11). Peak Daphnia densities along the lake were generally $12-35 \%$ of the total zooplankton density, with the highest seasonal densities at station KLF 1 in the main body of the lake, averaging 6.28 individuals/L in September, and in the West Arm with 8.53 individuals/L in August 2006. The highest Daphnia biomass in the main body of the lake was observed at station KLF 7 at $188.23 \mu \mathrm{g} / \mathrm{L}$ in October, while in the West Arm the highest Daphnia biomass was at 
$200.53 \mu \mathrm{g} / \mathrm{L}$, also recorded in October (Figs. 6.12 and 6.13). From August onward in previous years, biomass trends along the main body of the lake were largely driven by the development of Daphnia spp., since Daphnia made up the majority of zooplankton biomass. If zooplankton, particularly Daphnia, is available late in the growing season, it may allow fish and other predators to continue their growth into the fall. An increase in fish size prior to winter may lead to lower over-winter mortality (Johnson and Evans 1991; Miranda and Hubbard 1994).

\section{Zooplankton Fecundity}

Fecundity of the four most common zooplankton species, $L$ ashlandi, D. bicuspidatus thomasi, Daphnia spp., and B. longirostris, were studied during ten years, 1997-2006.

L. ashlandi females were gravid throughout the sampling period in 2006 (Fig. 6.14). The proportion of females that were gravid was highly variable, as in previous years, and was always below 0.6. From 1997 to 2002, there was a tendency for females to carry more eggs in the South Arm than in the North Arm, except in 1998. From 2003 onward the pattern changed and females from the North Arm had more eggs than those from the South Arm.

Table 6.5. $\quad$ Fecundity data for Leptodiaptomus ashlandi in the North, South and West arms of Kootenay Lake in 1997-2006. Values are seasonal averages, calculated for samples collected April-October 1997-2002 and AprilNovember 2003 and 2006.

\begin{tabular}{llrrrrrrrrrr}
\hline & Basin & 1997 & 1998 & 1999 & 2000 & 2001 & 2002 & 2003 & 2004 & 2005 & 2006 \\
\hline Proportion of Gravid & North Arm & 0.16 & 0.12 & 0.11 & 0.13 & 0.13 & 0.18 & 0.21 & 0.13 & 0.10 & 0.19 \\
Females & South Arm & 0.19 & 0.14 & 0.16 & 0.18 & 0.15 & 0.11 & 0.09 & 0.15 & 0.12 & 0.17 \\
& West Arm & & & & & & & 0.12 & 0.18 & 0.23 & 0.19 \\
\# Eggs per Gravid & North Arm & 13.83 & 13.21 & 17.78 & 14.71 & 13.33 & 10.16 & 11.91 & 13.68 & 11.59 & 13.56 \\
Female & South Arm & 14.53 & 12.49 & 18.56 & 16.90 & 13.97 & 11.96 & 10.56 & 11.16 & 9.92 & 12.32 \\
& West Arm & & & & & & & 10.31 & 9.86 & 10.04 & 14.21 \\
\# Eggs per Litre & North Arm & 1.04 & 1.34 & 1.08 & 0.77 & 3.61 & 1.96 & 2.74 & 2.31 & 1.15 & 3.39 \\
& South Arm & 2.22 & 1.65 & 1.13 & 2.19 & 3.42 & 1.08 & 1.85 & 1.74 & 0.91 & 3.33 \\
& West Arm & & & & & & & 1.2 & 1.35 & 1.32 & 2.83 \\
\# Eggs per Capita & North Arm & 0.29 & 0.24 & 0.23 & 0.25 & 0.31 & 0.15 & 0.3 & 0.19 & 0.17 & 0.31 \\
& South Arm & 0.46 & 0.26 & 0.23 & 0.45 & 0.24 & 0.12 & 0.12 & 0.25 & 0.14 & 0.24 \\
& West Arm & & & & & & & 0.2 & 0.11 & 0.25 & 0.28 \\
\hline
\end{tabular}

Leptodiaptomus. ashlandi females carried an average of 13.56, 12.32, and 14.21 eggs per gravid female in the North, South and West arms respectively (Fig. 6.15, Table 6.5). The number of eggs per water volume averaged 3.39 eggs/L in the North Arm, 3.33 eggs/L in the South Arm, and 2.83 eggs/L in the West Arm in 2006. The number of eggs per capita averaged 0.31, 0.24, and 0.28 eggs/individual in the North, South, and West arms respectively.

Diacyclops bicuspidatus thomasi females were gravid throughout the sampling period in 2006, with the proportion ranging from 0 to 0.42 (Fig. 6.14). From April to November, the proportion of gravid females averaged 0.16 in the North Arm, 0.16 in the South Arm, and 0.18 in the West Arm (Fig. 6.14, Table 6.6). The seasonal average number of eggs per 
gravid female was 15.44, 14.47, and 15.89 in the North, South and West arms respectively. During the sampling season, the number of eggs per litre of water averaged 3.59, 2.43, and 1.98 eggs/L, while the number of eggs per capita averaged $0.49,0.39$, and 0.54 eggs/individual in the North, South, and West arms respectively. The proportion of gravid females, number of eggs per gravid female, and number of eggs per capita were higher in the South Arm during 1997-2005 (except the number of eggs per gravid female in 2004), while in 2006 only the proportion of gravid females was higher in the South Arm. The number of eggs per water volume varied from year to year. In 2006 as in the previous year, gravid females carried more eggs in the West Arm than in either the North Arm or South Arm.

Table 6.6. $\quad$ Fecundity data for Diacyclops bicuspidatus thomasi in the North, South and West arms of Kootenay Lake in 1997-2006. Values are seasonal averages, calculated for samples collected April-October 1997-2002 and AprilNovember 2003-2006.

\begin{tabular}{llrrrrrrrrrr}
\hline & Basin & 1997 & 1998 & 1999 & 2000 & 2001 & 2002 & 2003 & 2004 & 2005 & 2006 \\
\hline Proportion of Gravid & North Arm & 0.28 & 0.09 & 0.12 & 0.11 & 0.12 & 0.13 & 0.14 & 0.14 & 0.16 & 0.16 \\
Females & South Arm & 0.26 & 0.16 & 0.16 & 0.13 & 0.13 & 0.20 & 0.15 & 0.13 & 0.19 & 0.16 \\
& West Arm & & & & & & & 0.15 & 0.12 & 0.15 & 0.18 \\
\# Eggs per Gravid & North Arm & 11.66 & 14.86 & 14.93 & 13.34 & 13.15 & 12.93 & 12.04 & 15.39 & 14.52 & 15.44 \\
Female & South Arm & 12.28 & 16.41 & 16.70 & 13.42 & 14.55 & 14.02 & 12.1 & 13.39 & 15.67 & 14.47 \\
& West Arm & & & & & & & 12.12 & 14.02 & 16.13 & 15.89 \\
\# Eggs per Litre & North Arm & 2.72 & 2.55 & 2.64 & 3.72 & 2.41 & 3.96 & 4.97 & 3.06 & 1.65 & 3.59 \\
& South Arm & 2.77 & 2.11 & 4.55 & 2.81 & 3.27 & 2.89 & 2.19 & 3.72 & 2.36 & 2.43 \\
& West Arm & & & & & & & 3.66 & 3.41 & 1.65 & 1.98 \\
\# Eggs per Capita & North Arm & 0.42 & 0.28 & 0.35 & 0.36 & 0.32 & 0.34 & 0.27 & 0.33 & 0.28 & 0.49 \\
& South Arm & 0.47 & 0.39 & 0.57 & 0.38 & 0.47 & 0.53 & 0.26 & 0.36 & 0.76 & 0.39 \\
& West Arm & & & & & & & 0.22 & 0.3 & 0.61 & 0.54 \\
\hline & & & & & & & & & & & \\
\end{tabular}

Gravid females of Daphnia spp. were observed in samples from July to November in 2006. In 1997 and 1998, they were seen as early as June; in 1999, 2000, 2002, 2003, 2005 and 2006 they appeared in July; and in 2001 and 2004 they appeared in August. The proportion of gravid Daphnia spp. ranged from 0 to 0.8 in 2006 and averaged 0.12 in the North Arm, 0.15 in the South Arm and 0.19 in the West Arm (Fig. 6.16). The proportion of gravid females was considerably lower than in previous years. The seasonal average fecundity in 2006 was 2.28, 2.30, and 2.62 eggs per gravid female in the North, South, and West arms respectively, with a range of 1-5 eggs per gravid female. During the sampling season, the number of eggs per litre of water averaged $0.53,0.40$, and 0.74 (Fig. 6.17, Table 6.7), while the number of eggs per capita averaged $0.28,0.44$ and 0.67 in the North, South, and West arms respectively. Fecundity was slightly higher in the South then in the North Arm during the 2006 sampling season. 
Table 6.7. Fecundity data for Daphnia spp. in the North, South and West arms of Kootenay Lake in 1997-2006. Values are seasonal averages, calculated for samples collected April-October 1997-2002 and April-November 20032006.

\begin{tabular}{|c|c|c|c|c|c|c|c|c|c|c|c|}
\hline & Basin & 1997 & 1998 & 1999 & 2000 & 2001 & 2002 & 2003 & 2004 & 2005 & 2006 \\
\hline Proportion of Gravid & North Arm & 0.17 & 0.17 & 0.29 & 0.02 & 0.07 & 0.22 & 0.2 & 0.34 & 0.16 & 0.12 \\
\hline \multirow[t]{2}{*}{ Females } & South Arm & 0.12 & 0.22 & 0.16 & 0.04 & 0.09 & 0.18 & 0.21 & 0.23 & 0.16 & 0.15 \\
\hline & West Arm & & & & & & & 0.23 & 0.26 & 0.06 & 0.19 \\
\hline Gravid & North Arm & 2.19 & 2.17 & 2.71 & 1.75 & 1.71 & 2.78 & 2.61 & 2.98 & 2.43 & 2.28 \\
\hline \multirow[t]{2}{*}{ Female } & Sou & 2.24 & 2.41 & 2.42 & 2.24 & 1.83 & 2.14 & 2.1 & 2.93 & 2.58 & 2.30 \\
\hline & & & & & & & & 3.18 & 2.96 & 28 & 2.62 \\
\hline \multirow[t]{3}{*}{ \# Eggs per Litre } & $\mathrm{rm}$ & 0.1 & 0.37 & 0.11 & 0.02 & 0.17 & 0.49 & 0.95 & 0.24 & 14 & 0.53 \\
\hline & Arm & 0.15 & 0.48 & 0.07 & 0.11 & 0.14 & 0.28 & 0.52 & 0.14 & .15 & 0.40 \\
\hline & & & & & & & & 0.69 & 0.72 & 0.18 & 0.74 \\
\hline \multirow[t]{3}{*}{ \# Eggs per Capita } & North Arm & 0.41 & 0.36 & 1.05 & 0.04 & 0.13 & 0.78 & 0.55 & 1.19 & 0.37 & 0.28 \\
\hline & Arm & 0.26 & 0.71 & 0.6 & 0.14 & 0.17 & 0.48 & 0.47 & 0.68 & 0.50 & 0.44 \\
\hline & West Arm & & & & & & & 1.34 & 0.73 & 0.16 & 0.67 \\
\hline
\end{tabular}

Gravid females of $B$. longirostris were observed from May to November of the sampling season in 2006 (Fig. 6.14). In 1997 and 1998, gravid females were observed as early as April, but in other study years they did not appear until June-July. The proportion of gravid females averaged 0.25, 0.21, and 0.34 in the North, South, and West arms respectively in 2006 (Table 6.8). The number of eggs per gravid female was slightly higher in the North Arm as in previous years.

Table 6.8. Fecundity data for Bosmina longirostris in the North, South and West arms of Kootenay Lake in 1997-2006. Values are seasonal averages, calculated for samples collected April-October 1997-2002 and April-November 20032006.

\begin{tabular}{llrrrrrrrrrr}
\hline & Basin & 1997 & 1998 & 1999 & 2000 & 2001 & 2002 & 2003 & 2004 & 2005 & 2006 \\
\hline Proportion of Gravid & North Arm & 0.27 & 0.30 & 0.15 & 0.18 & 0.16 & 0.16 & 0.36 & 0.27 & 0.26 & 0.25 \\
Females & South Arm & 0.20 & 0.28 & 0.31 & 0.09 & 0.15 & 0.28 & 0.24 & 0.26 & 0.18 & 0.21 \\
& West Arm & & & & & & & 0.24 & 0.14 & 0.09 & 0.34 \\
\# Eggs per Gravid & North Arm & 2.43 & \multirow{2}{*}{3.26} & 2.25 & 1.75 & 1.52 & 1.52 & 1.92 & 2.53 & 2.39 & 1.75 \\
Female & South Arm & 2.14 & 2.50 & 2.13 & 1.56 & 1.45 & 1.67 & 1.56 & 1.94 & 1.69 & 1.53 \\
& West Arm & & & & & & & 1.33 & 1.86 & 1.14 & 1.52 \\
\# Eggs per Litre & North Arm & 0.17 & 0.48 & 0.02 & 0.02 & 0.22 & 0.14 & 1.15 & 0.4 & 0.39 & 0.37 \\
& South Arm & 0.39 & 0.20 & 0.10 & 0.06 & 0.15 & 0.15 & 0.9 & 0.15 & 0.33 & 0.24 \\
& West Arm & & & & & & & 0.82 & 0.45 & 0.10 & 0.46 \\
\# Eggs per Capita & North Arm & 0.57 & \multirow{2}{*}{1.02} & 0.31 & 0.27 & 0.29 & 0.25 & 0.72 & 0.78 & 0.65 & 0.45 \\
& South Arm & 0.47 & 0.70 & 0.62 & 0.14 & 0.26 & 0.41 & 0.37 & 0.21 & 0.26 & 0.35 \\
& West Arm & & & & & & & 0.32 & 0.27 & 0.10 & 0.52 \\
\hline
\end{tabular}

The seasonal averages were 1.75, 1.53, and 1.52 eggs per gravid female in 2006 in the North, South, and West arms respectively (Fig. 6.17). During the sampling season, the number of eggs per litre of water averaged $0.37,0.24$, and 0.46 , while the number of eggs per capita averaged $0.45,0.35$ and 0.52 in the North, South, and West arms respectively. All fecundity data in 2006 were higher in the North Arm. None of the fecundity measures were consistently higher in either the North Arm or South Arm over the ten-year period. 


\section{Mysis Relicta}

\section{Abundance and Biomass}

Seasonal average mysid densities during the fertilization experiment were well below the historical high values observed in the late 1970s and the mid-1980s (Fig. 6.21). However, the very erratic values observed during this period may have arisen due to sampling frequency and the methods used at that time. Samples were collected less regularly than during the current study, and the plankton net used had a finer mesh (Crozier and Duncan 1984). From 1992 onward, during the fertilization experiment, sampling of mysids began in January and continued until December, so all annual average values represent a twelvemonth period. In 2005, samples were not collected in February, so annual average values represent an eleven-month period, and in 2006 samples were collected during ten months, between February and November. During the course of the fertilization experiment, mysid densities were highest in 1992, declined over the four years from 1993 to 1996, but increased again from 1997 to 2001. In 2002 and 2003, densities decreased significantly by $50 \%$ as compared to 2001. In the next two years densities increased slightly followed by a decrease in 2006 (Fig. 6.21). The annual average of mysid densities at deep stations was higher in the South Arm than in the North Arm in 1993, 1994, 2001, and 2002. In 2003, 2005 and 2006 mysids were more abundant in the North Arm, while in 2004 the average mysid density was similar in the North and the South arms of the lake. In the West Arm, the mysid population was significantly less than in either the North or South arms during the period 2004-2006 (Fig. 6.22, Table 6.9).

As in previous years, densities were low in winter and spring, increased during the summer months, and declined in autumn (Smokorowski et al. 1997, Lasenby et al. 1998, Ashley et al. 1999, Wright et al. 2002a, 2002b, 2002c, Schindler et al. 2007b). Deep samples tended to have higher densities than near-shore samples. From 1997 to 2006, mysid densities at shallow sites in both the North and South arms were generally below 300 individuals $/ \mathrm{m}^{2}$ throughout the year (Fig. 6.23). At deep sites during July to October, densities were greater than 300 individuals $/ \mathrm{m}^{2}$ in five of the ten years (1999, 2000, 2001, 2004, and 2005) and less than 300 individuals $/ \mathrm{m}^{2}$ during the remainder of the year and in the other five years. From 1997 to 2006, there was a trend of higher mysid densities at the deep stations in the North Arm, except in 2001 and 2002 when densities were higher in the South Arm. During this same period, mysid densities at the shallow stations were at similar levels in both the North and South Arms, except in 1999 when density in the North Arm exceeded the number of mysids in the South Arm, and in 2000 when the density in the South Arm was greater than in the North Arm (Fig. 6.23).

During the ten year period discussed in this report, peak monthly values at shallow sites were usually recorded in June to July, mainly due to a higher number of juveniles (Figs. 6.24 and 6.25). At deep sites, there were usually two density peaks during the year, the first in May to June and the second in August to October, mainly due to a higher density of immature males and females (Figs. 6.26 and 6.27). In 2006, mysid density decreased at pelagic sites in both the North and the South Arm. At the near shore stations during the same time period a slight increase in mysid density in both basins was noted. The highest seasonal

Kootenay Lake Fertilization Experiment, Year 15 (North Arm) and Year 3 (South Arm) 132

(2006) Report 
mysid abundance in 2006 at a deep site was in August, at station KLF 1 in the North Arm, with 518 individuals $/ \mathrm{m}^{2}$ (mainly immature males and females) (Fig. 6.26). The highest seasonal abundance of mysids at a shallow site occurred in June, at station KLF 4, with 212 individuals $/ \mathrm{m}^{2}$ (mainly juveniles) (Fig. 6.24).

Table 6.9. Annual average density and biomass of Mysis relicta in the North, South and West arms of Kootenay Lake, 1997-2006. Values are for deep sites only, calculated for samples collected between January and December 1997-2005 and February to November 2006. Data from Arrow Lakes Reservoir and Okanagan Lake are shown for comparison.

\begin{tabular}{llrrrrrrrrrr}
\hline & Lake & 1997 & 1998 & 1999 & 2000 & 2001 & 2002 & 2003 & 2004 & 2005 & 2006 \\
\hline $\begin{array}{l}\text { Total Density } \\
\text { (individuals } / \mathrm{m}^{2} \text { ) }\end{array}$ & Kootenay-North Arm & 150 & 138 & 226 & 239 & 253 & 105 & 102 & 164 & 202 & 136 \\
& Kootenay-South Arm & 92 & 94 & 150 & 149 & 300 & 152 & 74 & 163 & 125 & 93 \\
& Kootenay-West Arm & & & & & & & & 9 & 8 & 19 \\
& Upper Arrow & 32 & 71 & 116 & 195 & 195 & 185 & 286 & 273 & 229 & 155 \\
& Lower Arrow & 63 & 99 & 134 & 223 & 259 & 158 & 101 & 121 & 89 & 199 \\
& Okanagan Lake & & & 184 & 310 & 338 & 201 & 237 & 389 & 356 & 257 \\
& & & & & & & & & & & \\
Total Biomass & Kootenay-North Arm & & & 1296 & 1239 & 1547 & 764 & 694 & 658 & 1014 & 932 \\
$\left(\mathrm{mg} / \mathrm{m}^{2}\right)$ & Kootenay-South Arm & & & 1143 & 940 & 1653 & 929 & 575 & 835 & 737 & 655 \\
& Kootenay-West Arm & & & & & & & & 37 & 16 & 33 \\
& Upper Arrow & 154 & 268 & 544 & 816 & 855 & 782 & 1560 & 1047 & 925 & 817 \\
& Lower Arrow & 263 & 450 & 712 & 1030 & 1063 & 598 & 597 & 590 & 470 & 757 \\
& Okanagan Lake & & & 2188 & 2266 & 3361 & 1385 & 2151 & 4129 & 2901 & 2942 \\
\hline
\end{tabular}

During the period 1999-2006, average mysid biomass was generally below 2,500 $\mathrm{mg} / \mathrm{m}^{2}$ at all stations (Fig. 6.28). Biomass was low in winter and spring, increased in summer and fall, and began to decline in December. In 2006, biomass was generally higher at the deep sites. From February to May 2006, mysid biomass was below $500 \mathrm{mg} / \mathrm{m}^{2}$ at deep sites and below $100 \mathrm{mg} / \mathrm{m}^{2}$ at shallow sites. From May onward, biomass increased but did not exceed 2,000 $\mathrm{mg} / \mathrm{m}^{2}$ at deep sites and $400 \mathrm{mg} / \mathrm{m}^{2}$ at shallow sites (Fig. 6.28).

From 1999 to 2001, mysid biomass frequently exceeded 2,000 mg/m² from September toward the end of the season. At the shallow sites, high peaks in biomass occasionally occurred, (eg. July 2000 when biomass exceeded 3,000 mg/m $\mathrm{m}^{2}$ at station KLF 5, in June 2002 when biomass exceeded 4,400 $\mathrm{mg} / \mathrm{m}^{2}$ at station $\mathrm{KLF} 1$ and 2,300 $\mathrm{mg} / \mathrm{m}^{2}$ at station KLF 5) (Figs. 6.29 and 6.30). At the deep sites of station KLF 1 in the North Arm and station KLF 7 in the South Arm, there was a tendency toward an increase of biomass from 1999 to 2001. From 2002 onward, biomass decreased at all deep sites (Figs. 6.31 and 6.32). Overall biomass was higher at deep stations than at shallow stations, because of the greater proportion of older (and therefore larger) individuals in deeper water. The highest biomass values at deep sites in 2006 were detected in August, at station KLF 1, with 4,152 mg/m² (mainly immature males and females), and at shallow sites in June, at station KLF 4, with $894 \mathrm{mg} / \mathrm{m}^{2}$ (mainly immature males and females).

Annual average density of mysids in the North Arm of Kootenay Lake from 1997 to 2000 was consistently higher than the density observed in Arrow Lakes Reservoir in those years 
(Fig. 6.33, Table 6.9). During the same time period mysid density in the South Arm fluctuated and had similar results to Arrow Lakes Reservoir. From 2002 onward mysid density in the North and South Arm of Kootenay Lake were lower than in Upper Arrow, and similar or higher than in Lower Arrow. Likewise, mysid biomass in Kootenay Lake was higher than in Arrow Lakes Reservoir from 1999 to 2002 (Fig. 6.33, Table 6.9). In 2003 mysid density and biomass in Upper Arrow had increased to the point where the density and biomass were twice of that in Kootenay Lake. From 2004 onward mysid biomass in Arrow Lakes Reservoir was similar or lower than biomass in Kootenay Lake. In Okanagan Lake, mysid density and biomass remained higher than in Kootenay Lake during the entire study period. Seasonal average biomass in Okanagan Lake exceeded values in Kootenay Lake two to three times, and in 2004 values were exceeded five times. Generally, annual average biomass in Kootenay Lake fluctuated between 500 and $1,500 \mathrm{mg} / \mathrm{m}^{2}$, while in Okanagan Lake annual average biomass was always between 1,500 and 4,000 mg/m² (Fig. 6.33).

\section{Life Stages and Fecundity}

The release of juveniles from females' brood pouches occurred in early spring and is reflected by a density increase in April of each year. By July, the juveniles have grown into the immature stage, so during the summer and fall, immature males and females dominate the mysid population. Brooding females and breeding males increase in density in the late fall as they reach maturity. The highest density of gravid females occurred during the winter.

The mysid population in Kootenay Lake has been composed of slightly more females than males. Density of developmental stages of M. relicta at deep sites is shown in Figs. 6.26 and 6.27. From February to April 2006, immature males, immature females, brooding females, and spent females were consistently present, similar to observations in previous years. From April to July, the majority of individuals were juveniles, with presence of both immature males and females. From July to September, the proportion of immature males and females increased as juvenile individuals progressed to the immature stage. From September to November immature and mature individuals were common.

The timing of progression through the developmental stages at the shallow sites in 2006 was similar to previous years (Figs. 6.24 and 6.25). From February to April, very few individuals of any stage were seen. From April to July, juveniles dominated the distribution. From July to September, the number of immature males and females increased, and from September to November, very few individuals of any stage were observed.

\section{Discussion}

Seasonal average zooplankton abundance and biomass in both the main body of the lake and in the West Arm increased in 2006. From 1997 to 2000, the fertilizer load was reduced relative to previous years, but in 2001 the fertilizer load was increased to the same level as at the beginning of the experiment. Although the grazeable nanoplankton and ultraplankton were not consistently enhanced in the fertilization zone in 2001, changes in the nutrient load caused increases in cladoceran density and biomass. The decline in the proportion of cladocerans in 2002 may have been due to a decrease in the 
biomass of grazeable phytoplankton (nanoplankton, $2-22 \mu \mathrm{m}$ ). As a result, zooplankton biomass may have declined and not been high enough to keep pace with the cropping rate imposed by the higher number of kokanee in the lake. However, the state of grazeable phytoplankton in 2003 increased in the fertilized North Arm of the lake, which was mirrored by increased zooplankton biomass, especially Daphnia biomass which increased more than two-fold. In 2004 and 2005, phytoplankton biomass in Kootenay Lake was the lowest recorded in the North Arm since 1992. The fertilization did not appear to enhance phytoplankton biomass in those years, which could be a reason for the substantial decrease in Daphnia as well as in other zooplankton abundance and biomass. With an increase in grazeable phytoplankton during 2006, conditions were more favourable for Daphnia, causing density to increase more than five times and biomass increase more than twice in comparison to the previous year.

During 1997 to 1998, zooplankton density and biomass fluctuated in both the North and South arms. During 1999 to 2001, total zooplankton biomass and density increased in both the North and South arms, while in 2002 only density in the North Arm continued to grow, and at the same time, density in the South Arm and biomass in both basins declined. Climatic conditions, changes in algal composition, or changes in Mysis relicta and kokanee abundance may have made conditions more favourable for Daphnia spp. and other cladocerans in Kootenay Lake in 1999 and 2000. These same factors, and potentially the increase of fertilizer load to the North Arm, may have made conditions more favourable in 2001. A bloom of small cladocerans in 2001 was a first reaction to the increase of the nutrient load, and in the following years, their density fluctuated but at a lower rate than during 2001. These changes have likely been due to a combination of nutrient load, predation, and climatic changes. Estimated kokanee abundance in Kootenay Lake for 2006 was 520 fish/ha, while mysid biomass was 932 and $655 \mathrm{mg} / \mathrm{m}^{2}$ in the North and South arms respectively. Consequently, the present state of zooplankton, and particularly Daphnia, consists of what has been left after they have been cropped by predators.

Kootenay Lake is at the more productive end of oligotrophic lakes. Changes in zooplankton density and biomass in 2006 suggest that the system has shifted towards more productive conditions compared to previous years (1997-2000) with decreased nutrient loads. Total zooplankton density in Kootenay Lake during the 2006 season was higher than those of Arrow Lakes Reservoir and Alouette Lake, while total zooplankton biomass was similar to Alouette or Lower Arrow. Total zooplankton biomass and biomass of copepods, cladocerans, and Daphnia were relatively stable in Kootenay Lake during the period of decreased nutrient loads. With the increased fertilizer load in 2001, the biomass of cladoceran zooplankton in Kootenay Lake increased significantly, exceeding the biomass in Arrow Lakes Reservoir and Okanagan Lake. In 2006, biomass of all categories in Kootenay Lake was similar to values in Arrow Lakes Reservoir, except for copepods biomass which were higher in Kootenay Lake.

A possible explanation for the lower Daphnia density and biomass in Kootenay Lake in the past, in comparison to Arrow Lakes Reservoir, is that in previous years there was higher predation pressure on zooplankton by greater mysid and kokanee densities in Kootenay Lake. Kootenay Lake contained approximately twice the density of $M$. relicta as Arrow 
Lakes Reservoir did between 1997 and 1999 (Wright 2000b). Since Daphnia is the preferred prey of both kokanee and mysids, predation may be suppressing the standing stock biomass of Daphnia in Kootenay Lake, despite potentially high zooplankton productivity. In addition to predation, other factors such as changes in the availability of grazeable algae may affect zooplankton biomass. Contrary to previous years, zooplankton densities and biomass in 2001-2006 followed the nutrient gradient with higher values in the fertilized section of Kootenay Lake. It seems that favourable growing conditions prevailed over predation by kokanee and $M$. relicta and allowed increased productivity of zooplankton in the fertilized part of the lake (Wright 2000a, 2000c).

There were no obvious trends in average fecundity of the more common species of Daphnia. Fish may be able to crop down the largest, most fecund females at such a high rate that very few large females are sampled, despite their presence in the lake. Kokanee in Kootenay Lake preferentially select the largest zooplankton, and the average zooplankton size in the diet samples is larger than the average size in the zooplankton samples (Thompson 1999). However, M. relicta preys upon all sizes of Daphnia spp. and does not appear to preferentially select larger individuals.

The annual average mysid biomass data at deep stations suggest that the North Arm of Kootenay Lake was more productive than the South Arm in 2006. During the study period from 1993 onward, mysid densities at deep stations have fluctuated along the length of the lake. From 1993 to 1996, mysid abundance decreased and gradually increased during the next five years from 1997 to 2001. During the following two years (2002-2003), a sharp decrease occurred, and in 2004, an increase was recorded. In 2005, an increasing trend continued in the North Arm, but both density and biomass decreased in the South Arm. In 2006 mysids decreased in both the North and South Arm of Kootenay Lake. Average mysid density was higher in the South Arm in 1993, 1994, 2001, and 2002. During the period 1995-2000 and again in 2003, 2005 and 2006, density was higher in the North Arm. In 2004, the average mysid density did not differ in the two basins. During the season, densities increased through the summer and declined in the winter. Mysid density and biomass were higher at the deep sites than at shallow near-shore sites. Near-shore samples contained mainly juveniles and immature males and females, while mature and breeding males and females were rare. From 1997 to 2005 (when winter sampling occurred), mysids were most actively breeding from December to March. During the breeding season, deep site samples contained a higher proportion of mature and breeding individuals than near-shore samples.

In comparison to other oligotrophic lakes in British Columbia, Kootenay Lake in the prefertilization period had a substantial mysid population. Since 1992, when the fertilization experiment started, mysid densities have increased, reaching a level similar to that of more productive years of the late 1970s and early 1980s. From 1993 onward, mysid data indicated that Kootenay Lake has been more productive than Arrow Lakes Reservoir, even with the commencement of fertilization in Arrow Lakes Reservoir in 1999. However, in 2002 and 2003, mysid densities in Kootenay Lake decreased sharply and were lower than in Arrow Lakes Reservoir. Fluctuations in the mysid population in 2004, 2005 and 2006, shifted the density and biomass in Kootenay Lake to numbers similar in Arrow Lakes Reservoir. Compared to Okanagan Lake, mysid densities and biomass were substantially lower in

Kootenay Lake Fertilization Experiment, Year 15 (North Arm) and Year 3 (South Arm) 136 (2006) Report 
Kootenay Lake despite the increased fertilizer load to Kootenay Lake in 2001 and mysid harvesting in Okanagan Lake from 1998 onward.

\section{Acknowledgements}

Thanks to Kootenay Wildlife Services Ltd for sample collection. Funding was provided by the Fish and Wildlife Compensation Program - Columbia Basin (stations KLF 2, 4, 6 and 7 for zooplankton and stations KLF 1-7 for Mysids). The Kootenai Tribe of Idaho funded stations KLF 1, 3, 5 and 8 for zooplankton and station KLF 8 for Mysids (from the Bonneville Power Administration).

\section{References}

Ashley, K.I., L.C. Thompson, L. Haywood-Farmer, J.-R. Yang, F.R. Pick, P.B. Hamilton, D.C. Lasenby, K.E. Smokorowski, L. McEachern, D. Sebastian, and G. Scholten. 1996. Kootenay Lake fertilization experiment-Year 3 (1994/95) report. Fisheries Project Report No. RD 49, Ministry of Environment, Lands and Parks, Province of British Columbia.

Ashley, K.I., L.C. Thompson, P. Warburton, J.-R. Yang, F.R. Pick, P.B. Hamilton, D.C. Lasenby, K.E. Smokorowski, L. McEachern, D. Sebastian, and G. Scholten. 1997. Kootenay Lake fertilization experiment-Year 4 (1995/96) report. Fisheries Project Report No. RD 58, Ministry of Environment, Lands and Parks, Province of British Columbia.

Andrusak, H., S. Matthews, I. McGregor, K. Ashley, G. Wilson, L. Vidmanic, J. Stockner, D. Sebastian, G. Scholten, P. Woodruff, D. Cassidy, J. Webster, K. Rood, and A. Kay. 2002. Okanagan Lake Action Plan-Year 6 (2001) with reference to results from 1996-2001. Fisheries Project Report No. RD 96. Biodiversity Branch, Ministry of Water, Land and Air Protection, Province of British Columbia

Andrusak, H., S. Matthews, I. McGregor, K. Ashley, G. Wilson, L. Vidmanic, J. Stockner, D. Sebastian, G. Scholten, P. Woodruff, D. Cassidy, J. Webster, A. Wilson, M. Gaboury, P. Slaney, G. Lawrence, W.K. Oldham, B. Jantz, and J. Mitchell. 2003. Okanagan Lake Action Plan-Year 7 (2002). Fisheries Project Report No. RD 106. Biodiversity Branch, Ministry of Water, Land and Air Protection, Province of British Columbia.

Andrusak, H., S. Matthews, I. McGregor, K. Ashley, R. Rae, A. Wilson, D. Sebastian, G. Scholten, P. Woodruff, L. Vidmanic, J. Stockner, G. Wilson, B. Jantz, J. Webster, H. Wright, C. Walters, J. Korman. 2004. Okanagan Lake Action Plan-Year 8 (2003). Fisheries Project Report No. RD 109. Biodiversity Branch, Ministry of Water, Land and Air Protection, Province of British Columbia. 
Brooks, J.L. 1959. Cladocera. Pp. 586-656 In Edmondson, W.T. (Ed.), Fresh-Water Biology, $2^{\text {nd }}$ Ed. John Wiley and Sons, New York.

Crozier, R.J., and W.F.A. Duncan. 1984. Kootenay Lake: 1984. British Columbia Ministry of Environment. 187 pp.

Johnson, T.B., and D.O. Evans. 1991. Behaviour, energetics, and associated mortality of young-of-the-year white perch (Morone americana) and yellow perch (Perca flavescens) under simulated winter conditions. Can. J. Fish. Aquat. Sci. 48: 672680.

Lasenby, D.C. 1977. The ecology of Mysis relicta in Kootenay Lake, British Columbia: final report 1976-1977. Manuscript.

Lasenby, D.C., L.J. McEachern, and M. Duffy. 1998. Distribution, abundance, growth, life history and feeding habits of Mysis relicta in Kootenay Lake, B.C. following experimental fertilization. Year 6 (1996-1997). Kootenay Lake Fertilization Project, Data Report, 1998, for the British Columbia Ministry of Environment, Lands and Parks, Fisheries Branch. 193 p.

McCauley, E. 1984. The estimation of the abundance and biomass of zooplankton in samples. Pp. 228-265 In Downing, J.A. and F.H. Rigler (Eds.), A Manual on Methods for the Assessment of Secondary Productivity in Fresh Waters. Blackwell Scientific Publications, Boston.

Miranda, L.E., and W.D. Hubbard. 1994. Winter survival of age-0 largemouth bass relative to size, predators, and shelter. N. Am. J. Fish. Manage. 14: 790-796.

Pennak, R.W. 1989. Fresh-Water Invertebrates of the United States: Protozoa to Mollusca, $3^{\text {rd }}$ Ed. John Wiley and Sons, New York. 628 pp.

Pieters, R., L.C. Thompson and, L. Vidmanic, M. Roushorne, J. Stockner, K. Hall, M. Young, M. Derham, S. Pond, K. Ashley, B. Lindsay, G. Lawrence, H. Andrusak, D. Sebastian, and G. Scholten. 2000. Arrow Lakes Reservoir fertilization experiment-Year 1 (1999/2000) report. Fisheries Project Report No. RD 82, Ministry of Environment, Lands and Parks, Province of British Columbia.

Pieters, R., L.C. Thompson, L. Vidmanic, S. Harris, J. Stockner, H. Andrusak, M. Young, K. Ashley, B. Lindsay, G. Lawrence, K. Hall, A. Eskooch, D. Sebastian, G. Scholten, and P.E. Woodruff. 2003. Arrow Reservoir fertilization experimentYear 2 (2000/2001) report. RD 87, Fisheries Branch, Ministry of Environment, Lands and Parks, Province of British Columbia.

Reynolds, J.B. and G.M. DeGraeve. 1972. Seasonal population characteristics of the opossum shrimp, Mysis relicta, in southeastern Lake Michigan, 1970-71. Proc. 15th Conf. Great Lakes Res. 1972: 117-131.

Kootenay Lake Fertilization Experiment, Year 15 (North Arm) and Year 3 (South Arm) 138 
Sandercock, G.A. and Scudder, G.G.E. 1996. Key to the Species of Freshwater Calanoid Copepods of British Columbia. Department of Zoology, UBC Vancouver, BC.

Schindler, E.U., L. Vidmanic, D. Sebastian, H. Andrusak, G. Scholten, P. Woodruff, J. Stockner, K.I. Ashley and G.F. Andrusak. 2007a. Arrow Lakes Reservoir Fertilization Experiment, Year 6 and 7 (2004 and 2005) Report. Fisheries Project Report No. RD 121, Ministry of Environment, Province of British Columbia.

Schindler, E.U., H. Andrusak, K.I. Ashley, G.F. Andrusak, L. Vidmanic, D. Sebastian, G. Scholten, P. Woodruff, J. Stockner, F. Pick, L.M. Ley and P.B. Hamilton. 2007b. Kootenay Lake Fertilization Experiment, Year 14 (North Arm) and Year 2 (South Arm) (2005) Report. Fisheries Project Report No. RD 122, Ministry of Environment, Province of British Columbia.

Smokorowski, K.E., D.C Lasenby, and L.J. McEachern. 1997. Mysis relicta in Kootenay Lake, B.C. following experimental fertilization (1995-96). Kootenay Lake Fertilization Project, Data Report, 1997, for the British Columbia Ministry of Environment, Lands and Parks, Fisheries Branch. 36 p.

Thompson, L.C. 1999. Abundance and production of zooplankton and kokanee salmon (Oncorhynchus nerka) in Kootenay Lake, British Columbia during artificial fertilization. Ph.D. thesis, Department of Zoology, University of British Columbia, Vancouver, British Columbia, 252 p.

Wilson, M.S. 1959. Free-living copepoda: Calanoida. Pp. 738-794 In Edmondson, W.T. (ed.) Fresh-Water Biology, $2^{\text {nd }}$ Ed., John Wiley and Sons, New York.

Wright, M.E., K.I. Ashley, H. Andrusak, H. Manson, R. Lindsay, R.J. Hammond, F.R. Pick, L.M. Ley, P.B. Hamilton, S.L. Harris, L.C. Thompson, L. Vidmanic, D. Sebastian, G. Scholten, M. Young, and D. Miller. 2002a. Kootenay Lake fertilization experiment-Year 9 (2000/01) report. Fisheries Project Report No. RD 105, Ministry of Water, Land and Air Protection, Province of British Columbia.

Wright, M.E., K.I. Ashley, R. Lindsay, R.J. Hammond, F.R. Pick, L.M. Ley, P.B. Hamilton, D.C. Lasenby, L.J. McEachern, M. Duffy, J.D. Whall, L.C. Thompson, D. Miller, L. Vidmanic, D. Sebastian, G. Scholten, and M. Young. 2002b. Kootenay Lake fertilization experiment-Year 7 (1998/99) report. Fisheries Project Report No. RD 98, Ministry of Water, Land and Air Protection, Province of British Columbia.

Wright, M.E., K.I. Ashley, R. Lindsay, R.J. Hammond, F.R. Pick, L.M. Ley, P.B. Hamilton, L.C. Thompson, L. Vidmanic, H. Andrusak, D. Sebastian, G. Scholten, M. Young, and D. Miller. 2002c. Kootenay Lake fertilization experiment-Year 8 (1999/2000) report. Fisheries Project Report No. RD 102, Ministry of Water, Land and Air Protection, Province of British Columbia.

Kootenay Lake Fertilization Experiment, Year 15 (North Arm) and Year 3 (South Arm) 139 


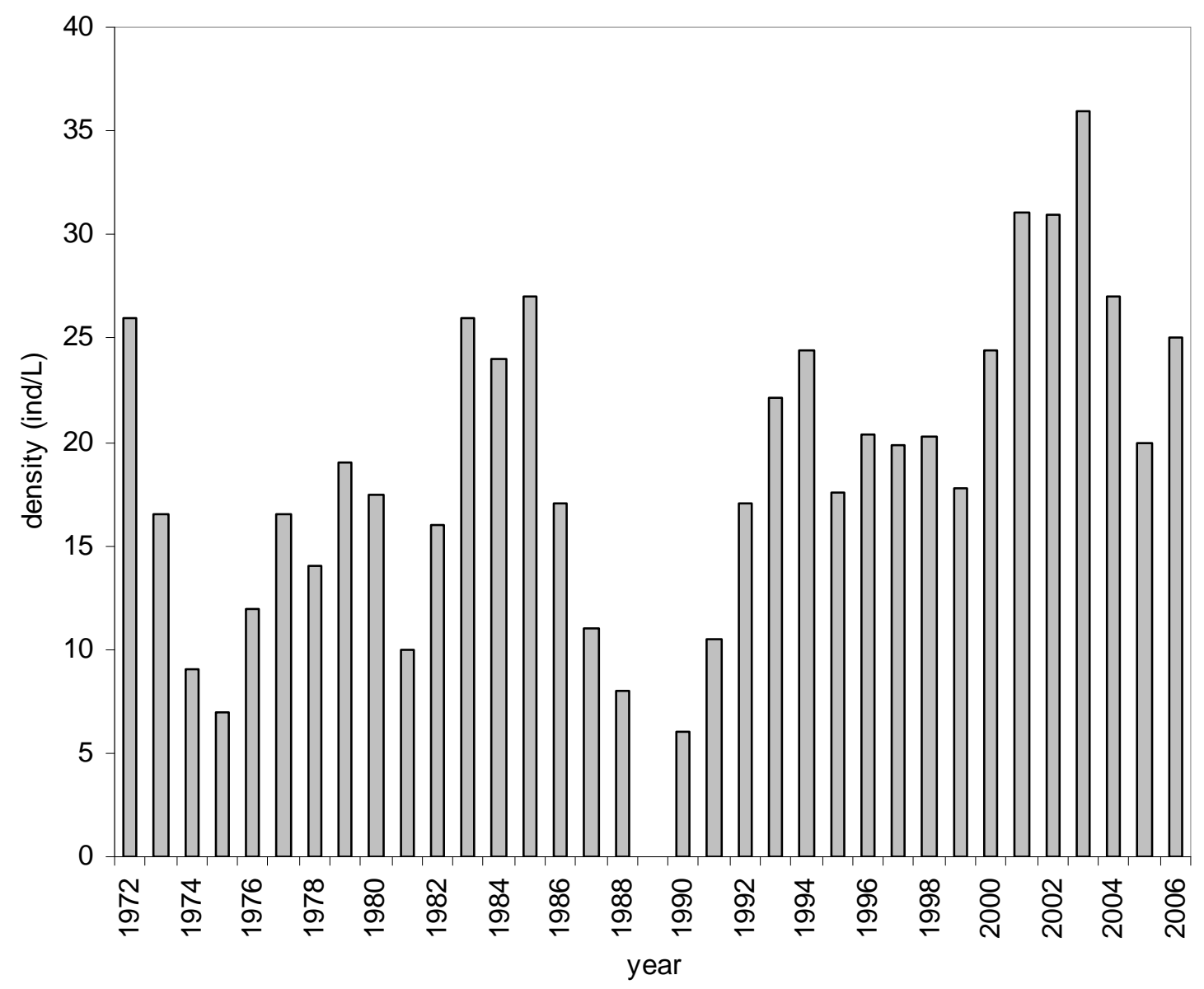

Figure 6.1. Zooplankton density 1972- 2006. (Note: 1972-1990 from mid-lake station, near current station KLF 5 and 1992-2006 whole-lake average). 

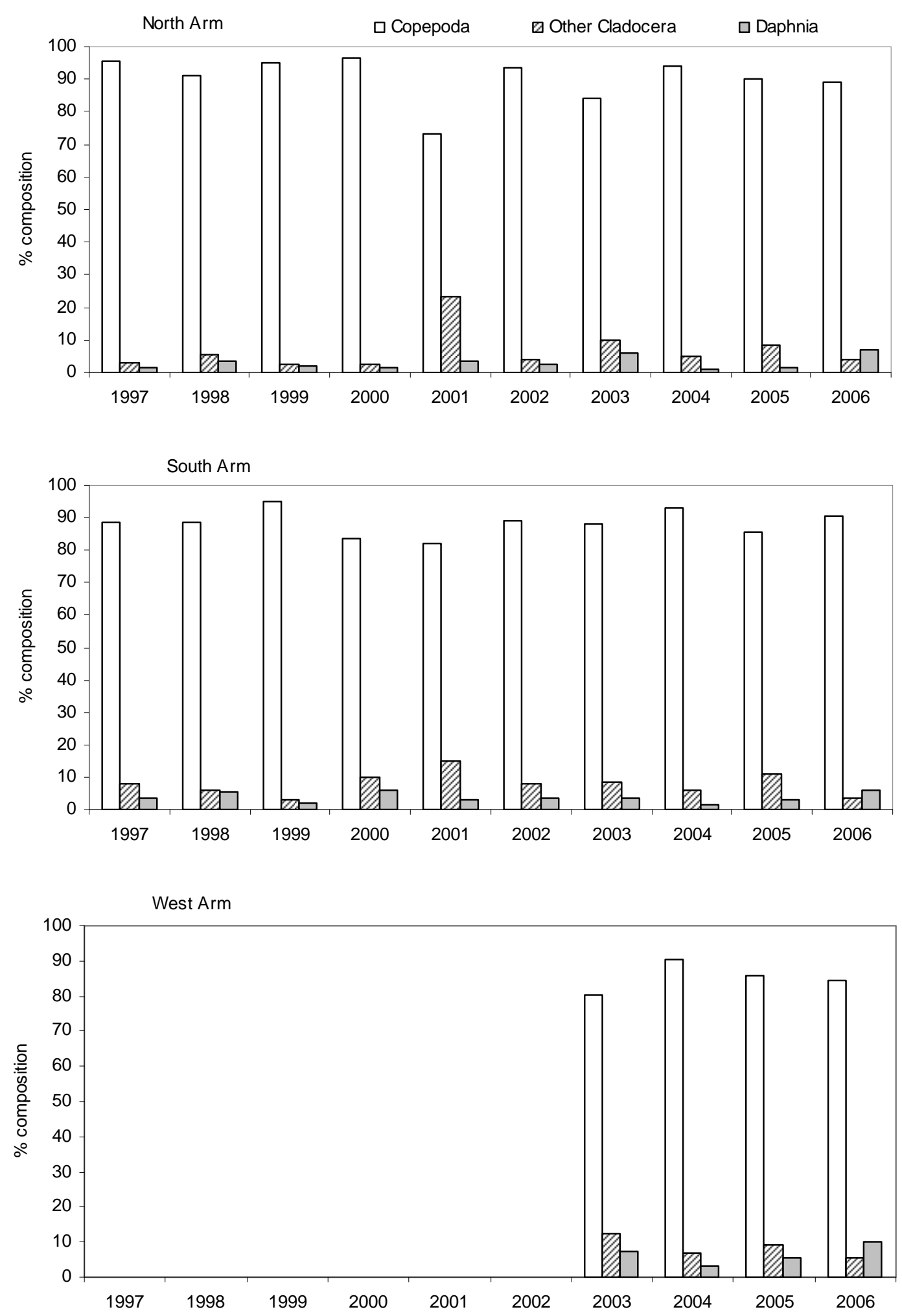

Figure 6.2. Seasonal composition of zooplankton as a percentage of average density in the North, South and West Arms of Kootenay Lake, 1997-2006. 

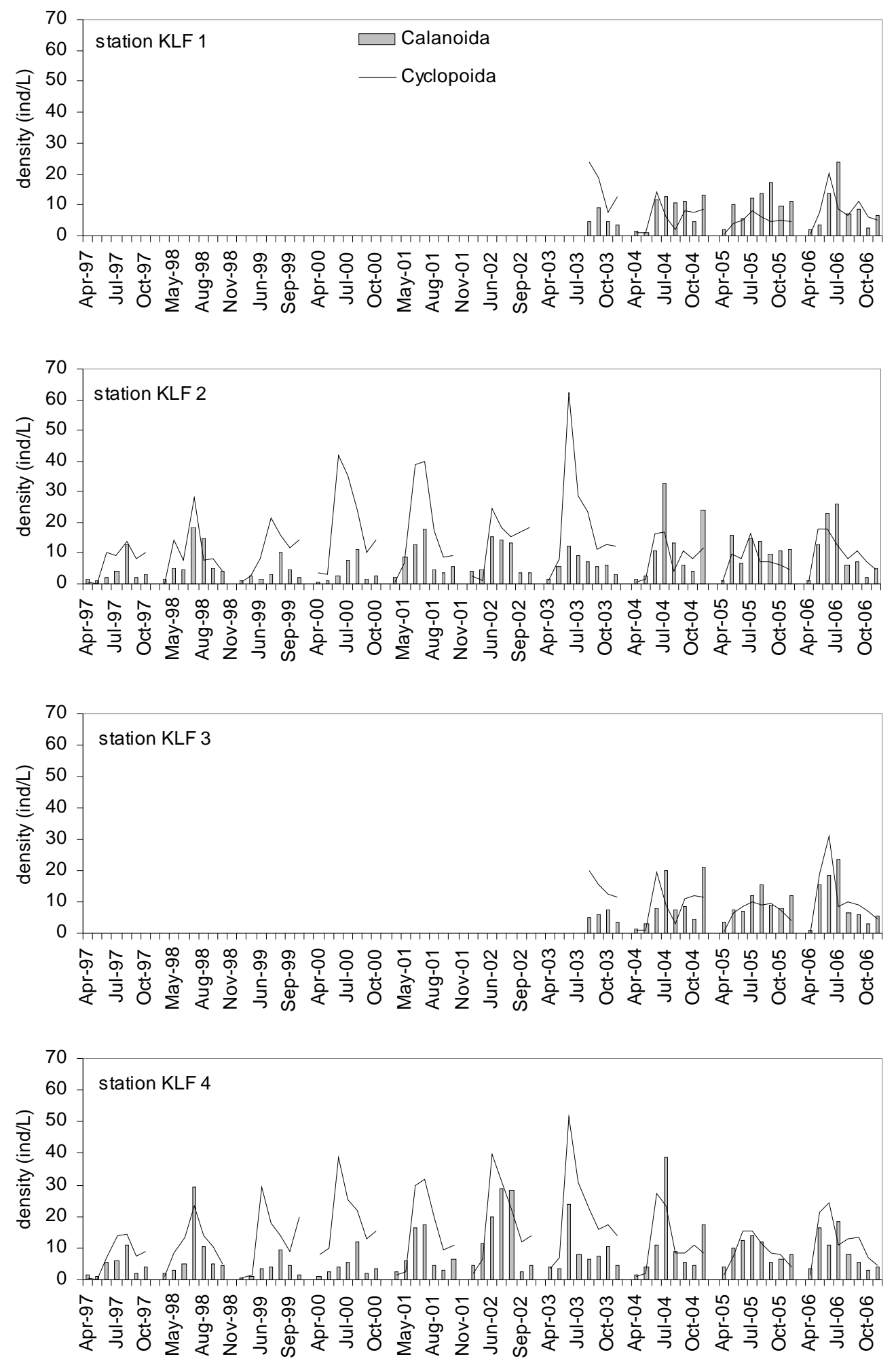

Figure 6.3. Density of calanoid and cyclopoid zooplankton in Kootenay Lake - North Arm, 1997-2006.

Kootenay Lake Fertilization Experiment, Year 15 (North Arm) and Year 3 (South Arm) 142 (2006) Report 

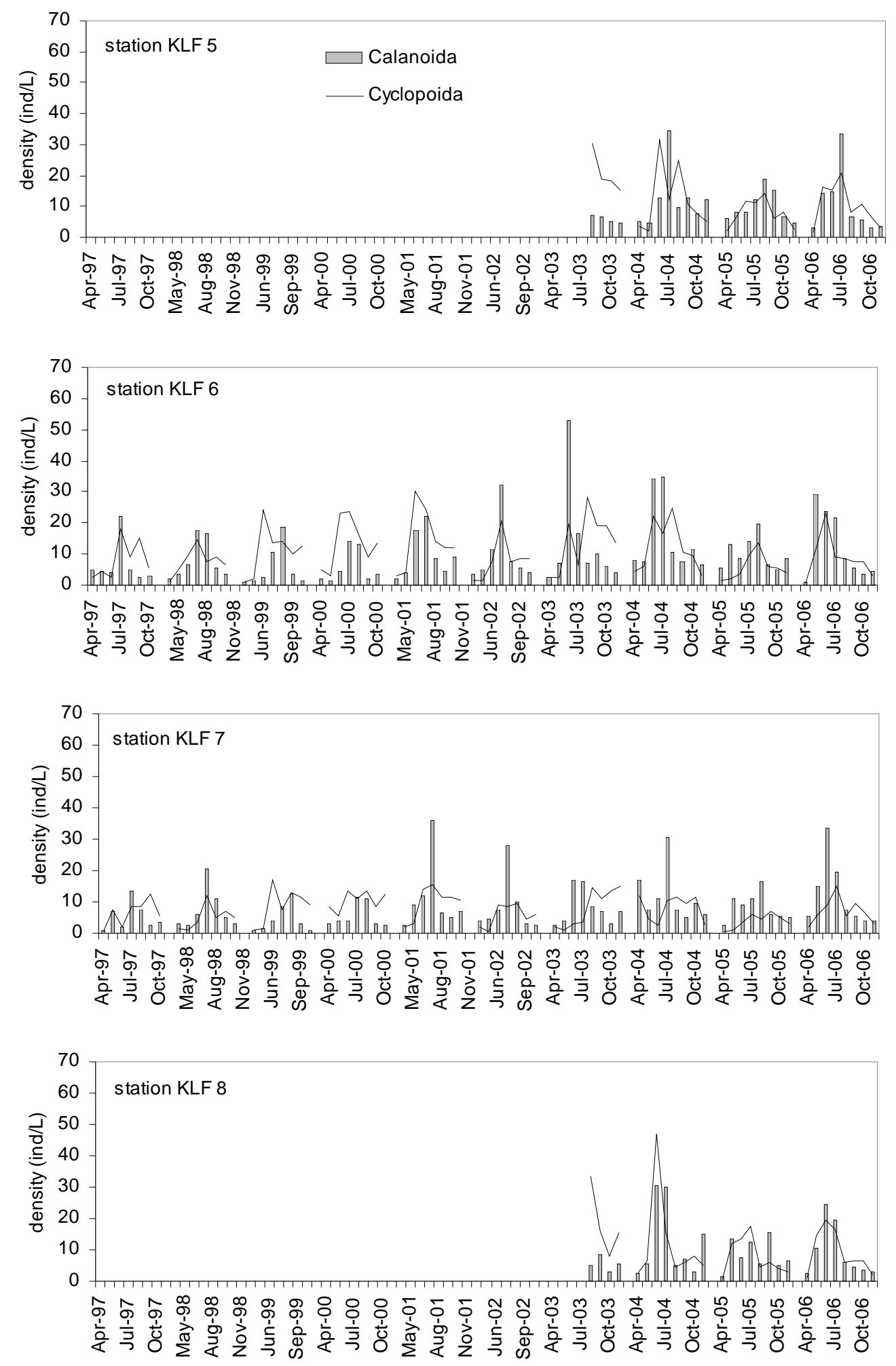

Figure 6.4. Density of calanoid and cyclopoid zooplankton in Kootenay Lake - South Arm and West Arm, 1997-2006.

Kootenay Lake Fertilization Experiment, Year 15 (North Arm) and Year 3 (South Arm) 


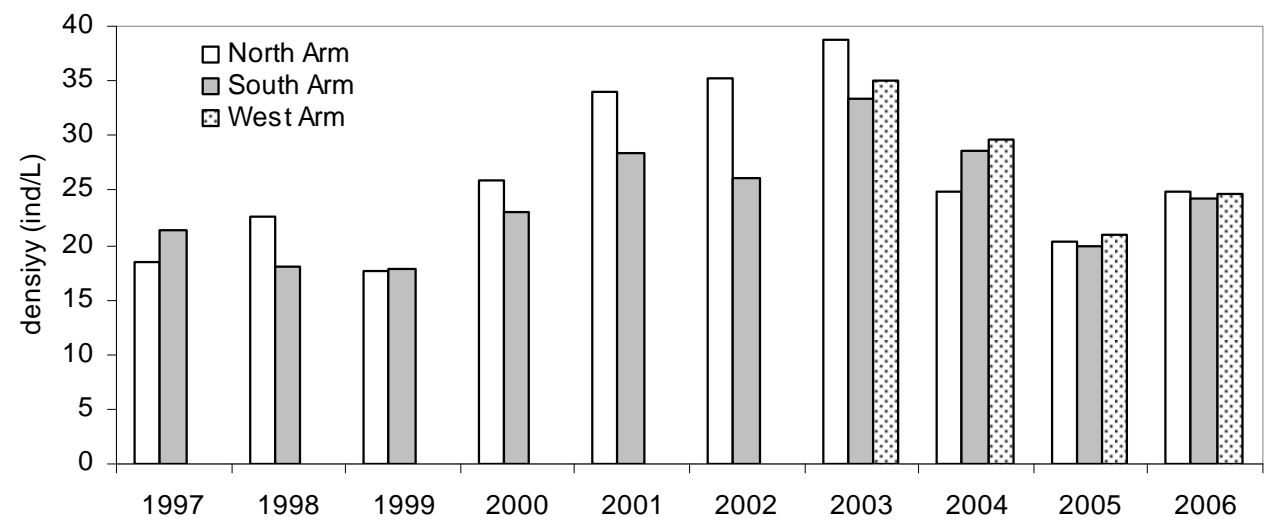

a.

Seasonal average density of total zooplankton in North, South, and West arms of Kootenay Lake, 1997-2006.

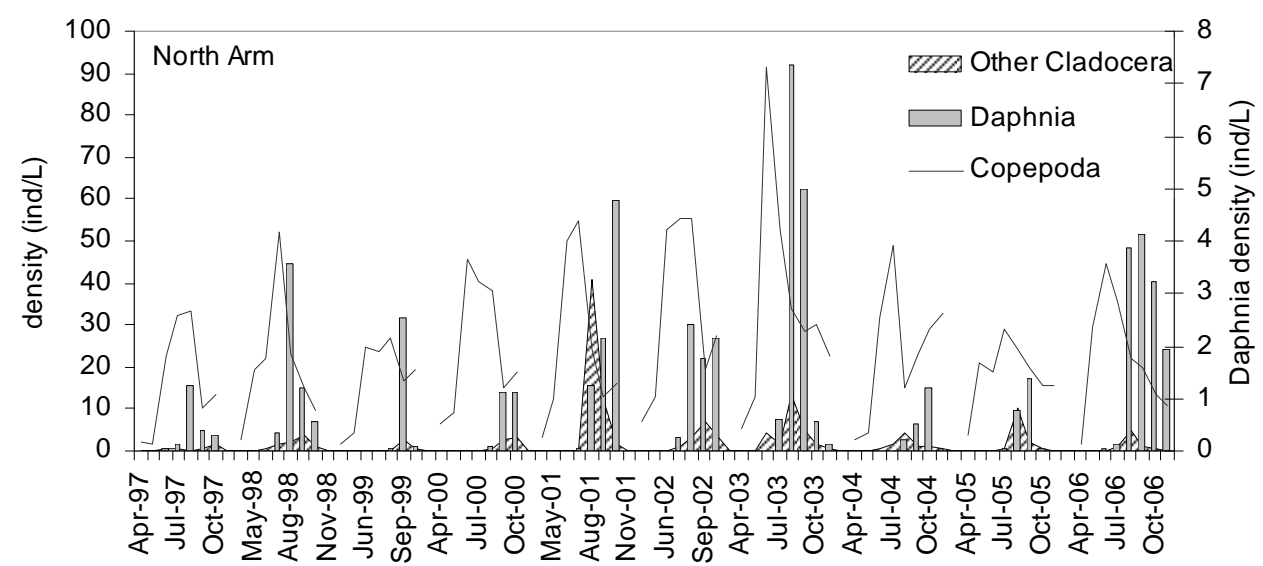

b. $\quad$ Seasonal density of zooplankton in North Arm of Kootenay Lake, 19972006.

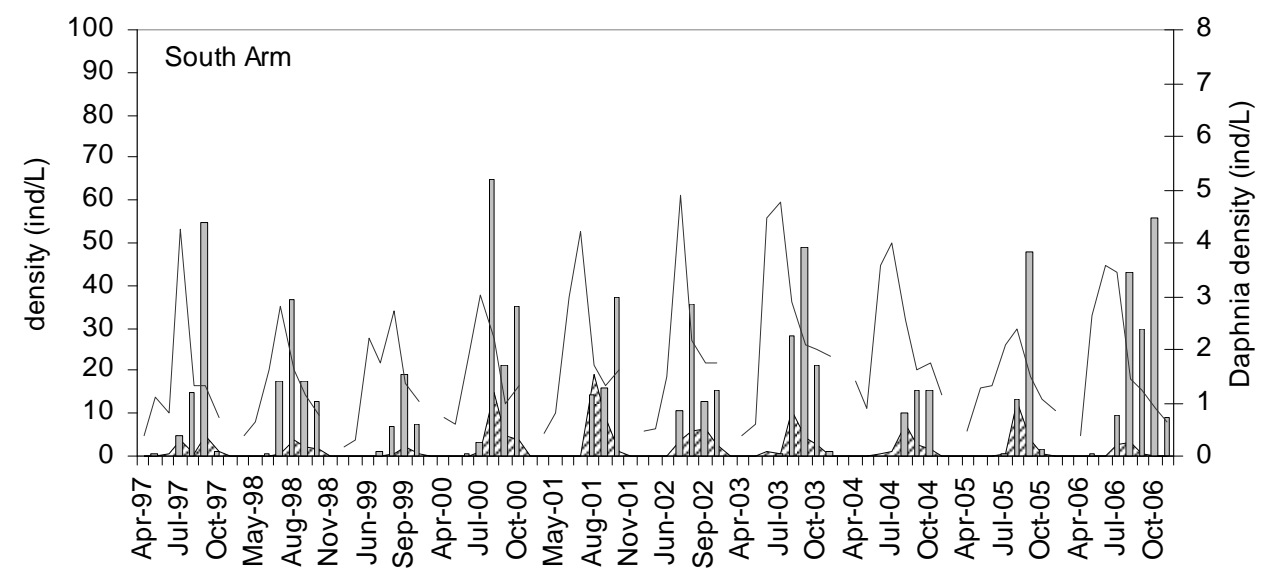

c. Seasonal density of zooplankton in South Arm of Kootenay Lake, 19972006.

Figure 6.5. Zooplankton density in Kootenay Lake, 1997-2006. 

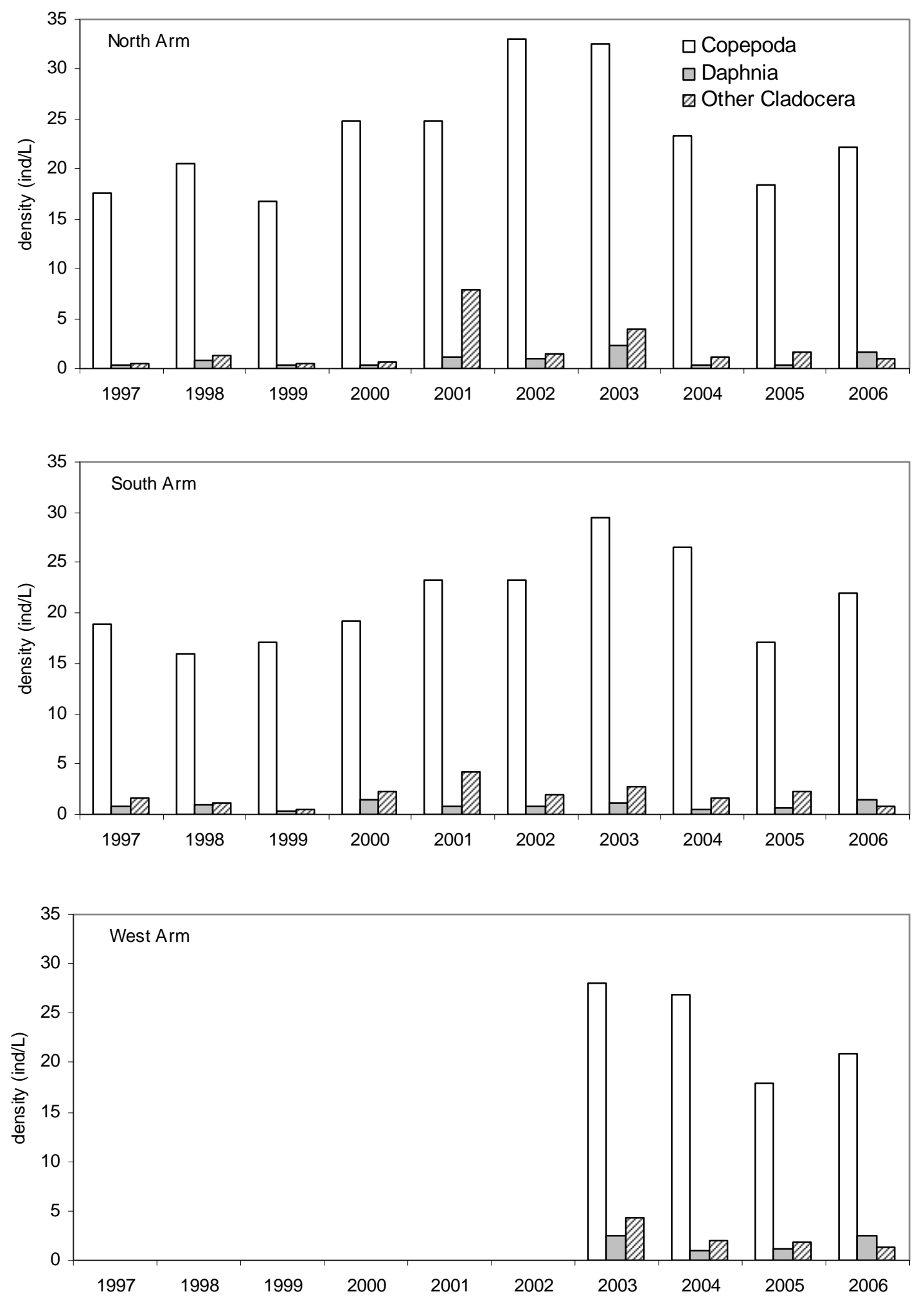

Figure 6.6. Seasonal average zooplankton density in Kootenay Lake, 1997-2006. 


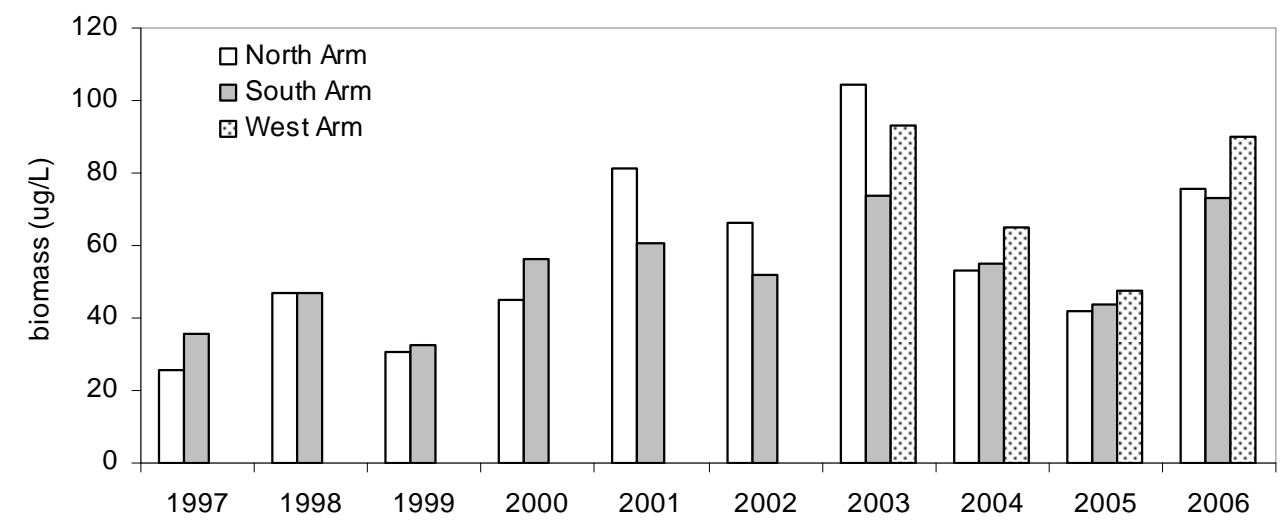

a.

Seasonal average biomass of zooplankton in North and South arms of Kootenay Lake, 1997-2006.

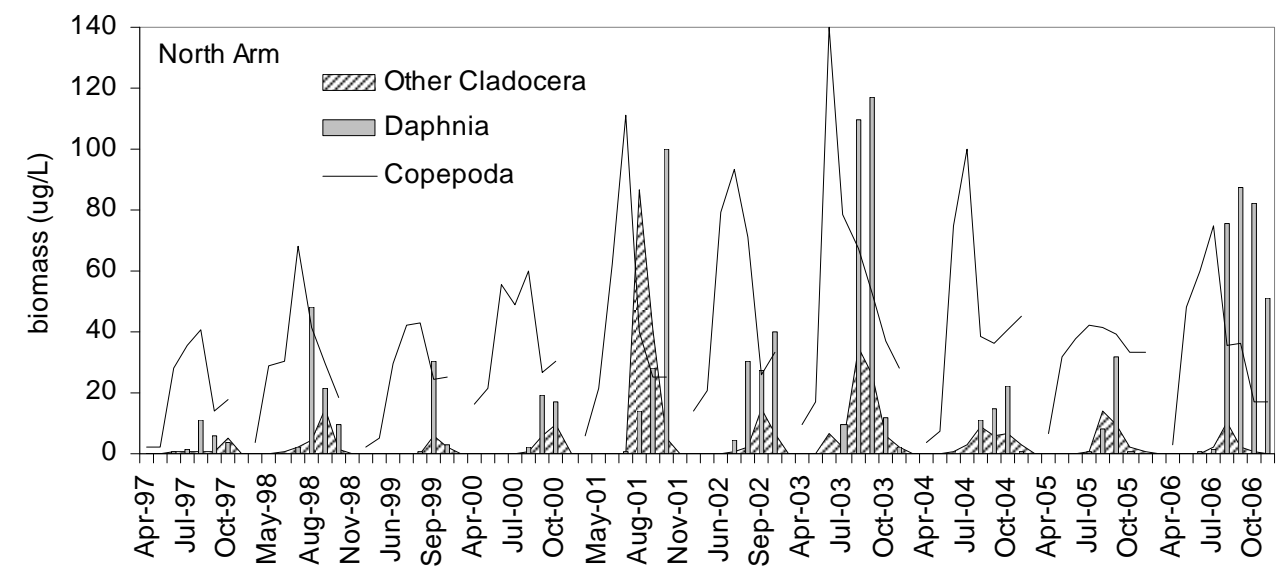

b. $\quad$ Seasonal biomass of zooplankton in North Arm of Kootenay Lake, 19972006.

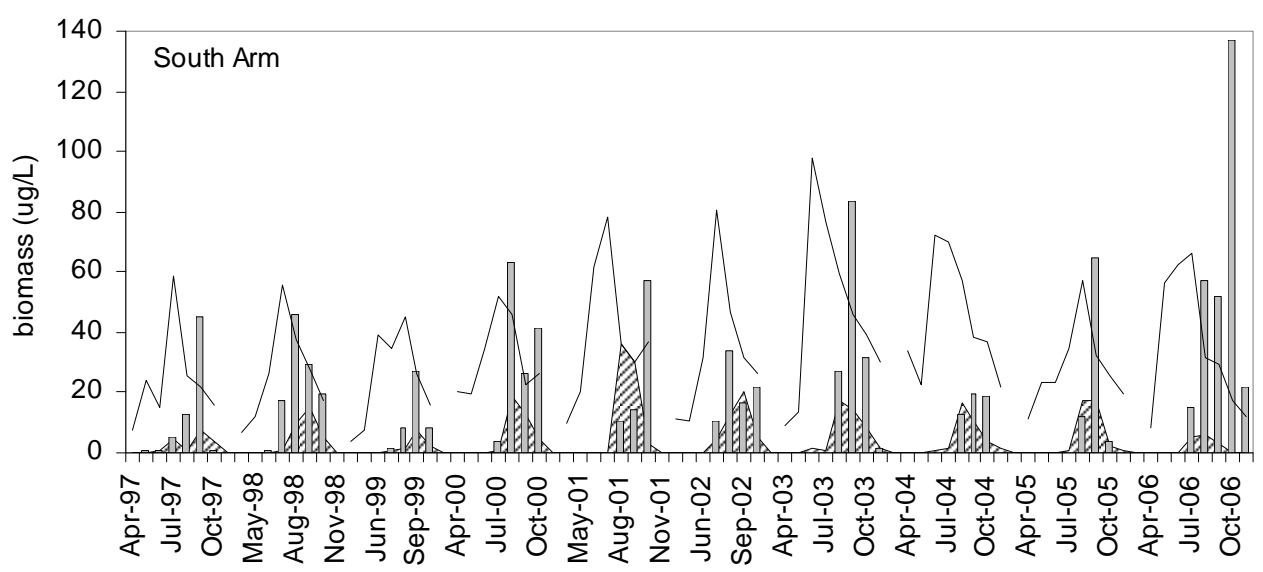

c. Seasonal biomass of zooplankton in South Arm of Kootenay Lake, 19972006.

Figure 6.7. Zooplankton biomass in Kootenay Lake, 1997-2006. 

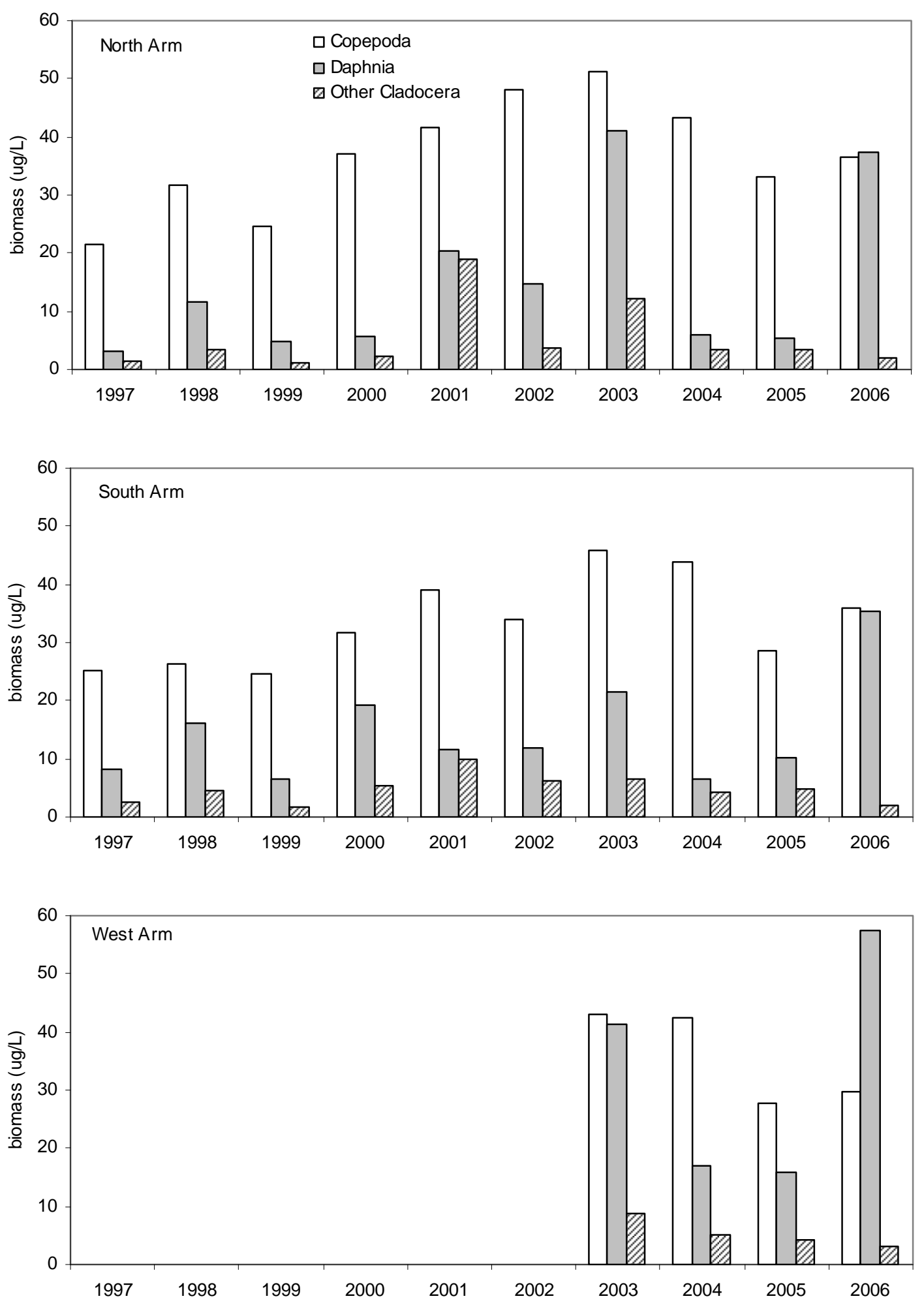

Figure 6.8. Seasonal average zooplankton biomass in Kootenay Lake, 1997-2006. 

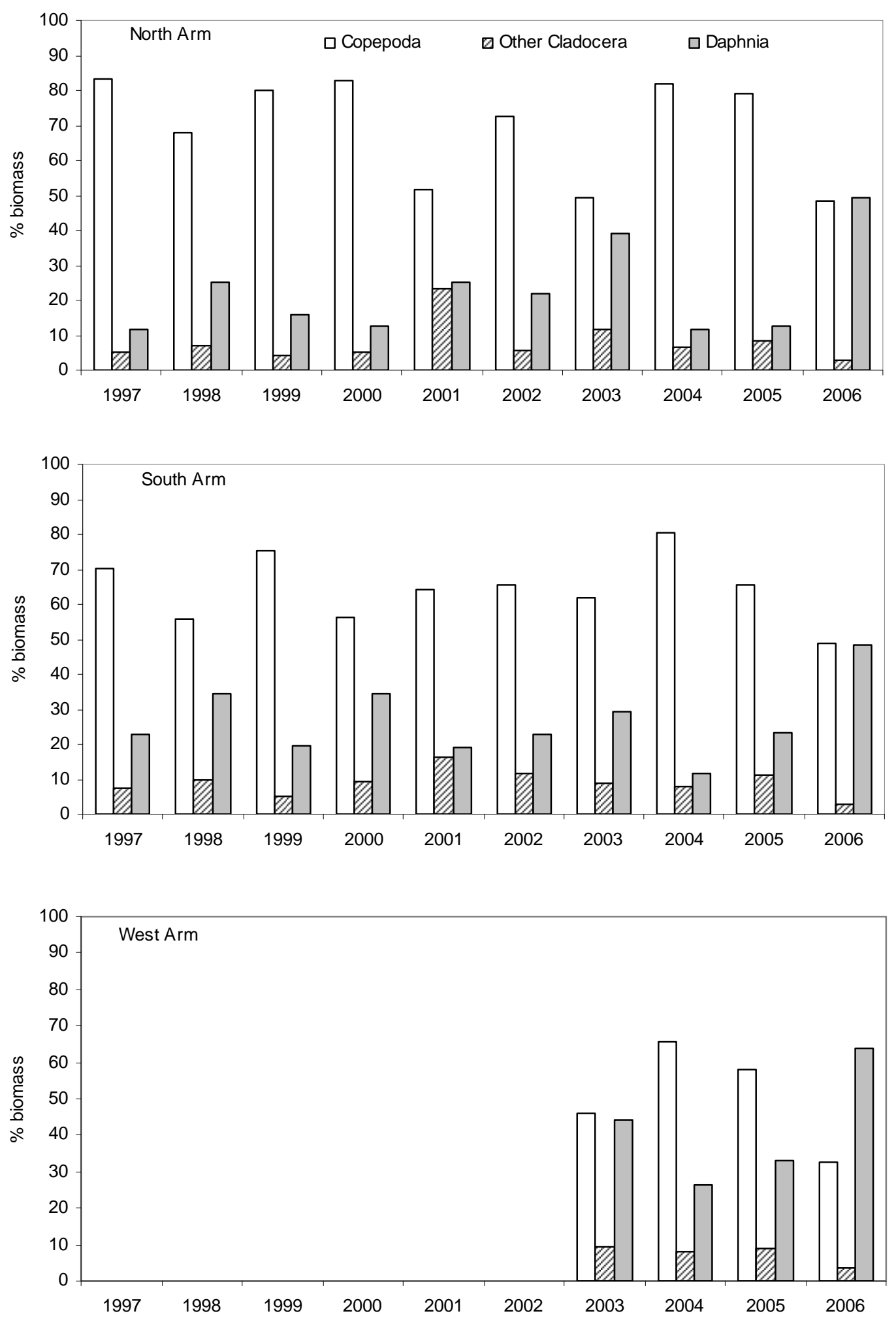

Figure 6.9. Seasonal composition of zooplankton as a percentage of average biomass in the North, South and West Arms of Kootenay Lake, 1997-2006. 

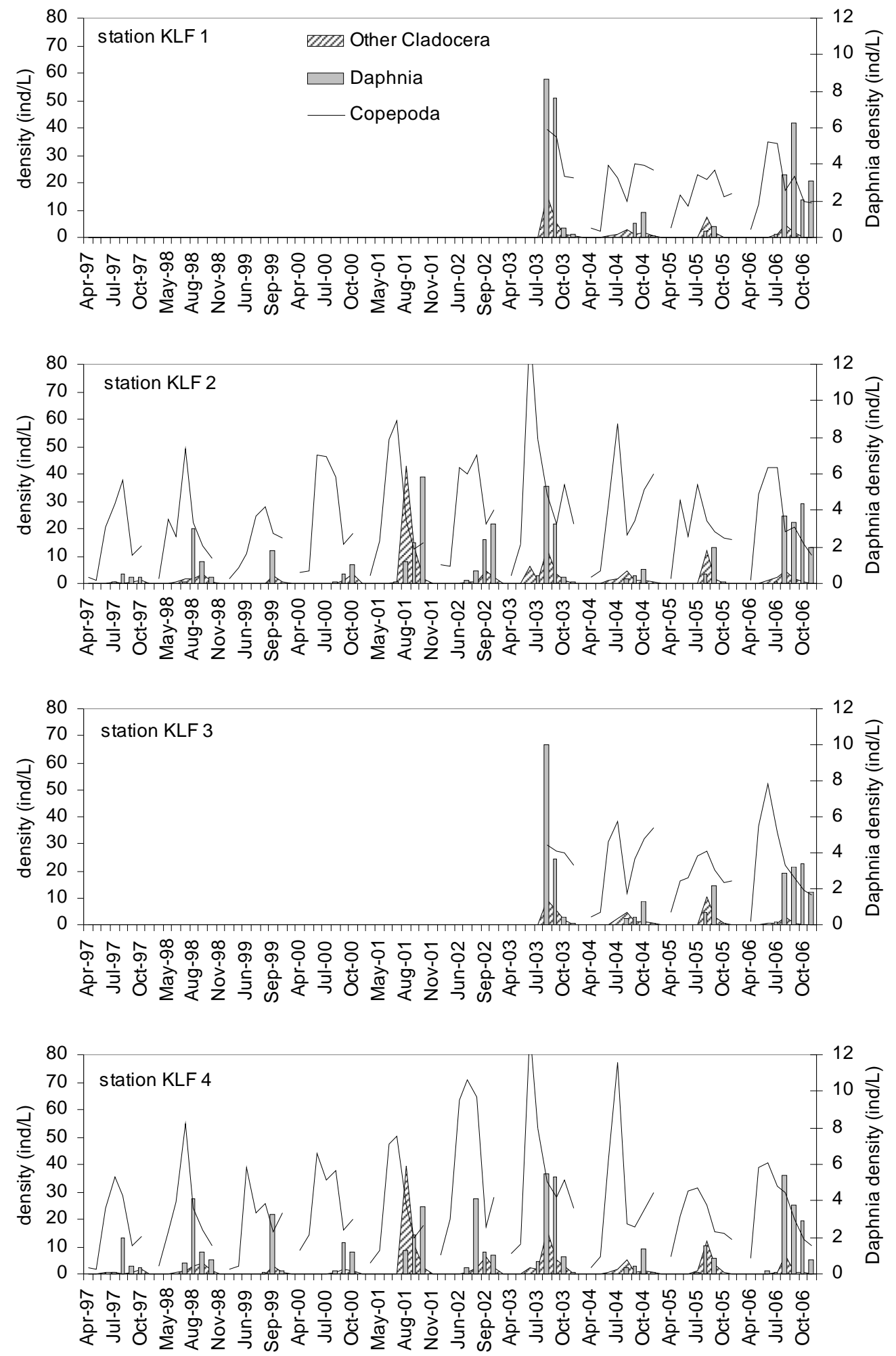

Figure 6.10. Density of cladoceran and copepod zooplankton in the North Arm of Kootenay Lake, 1997-2006. 

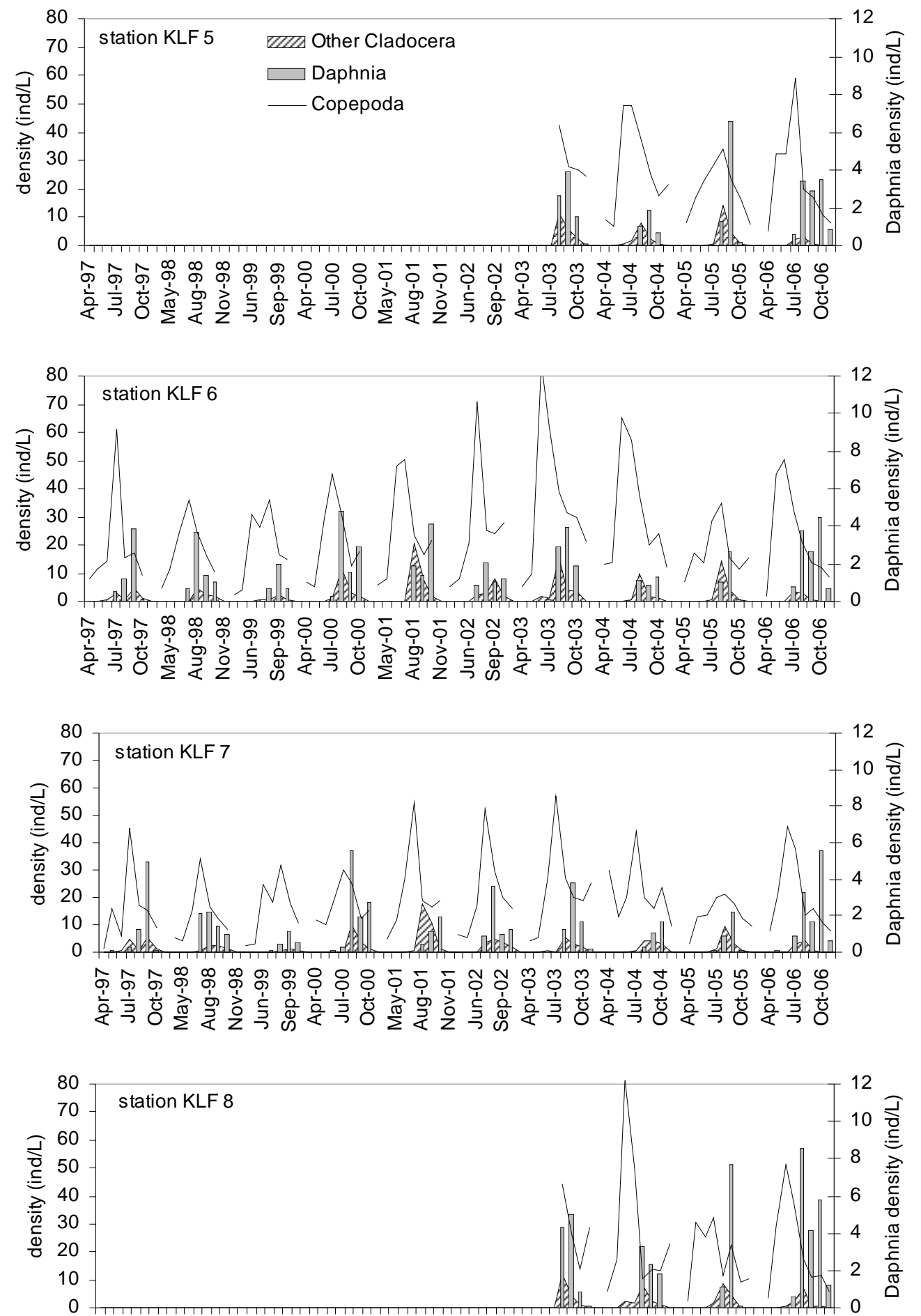

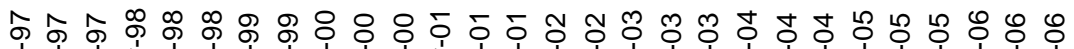

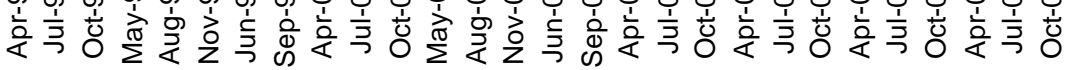

Figure 6.11. Density of cladoceran and copepod zooplankton in the South and West arms of Kootenay Lake, 1997-2006. 

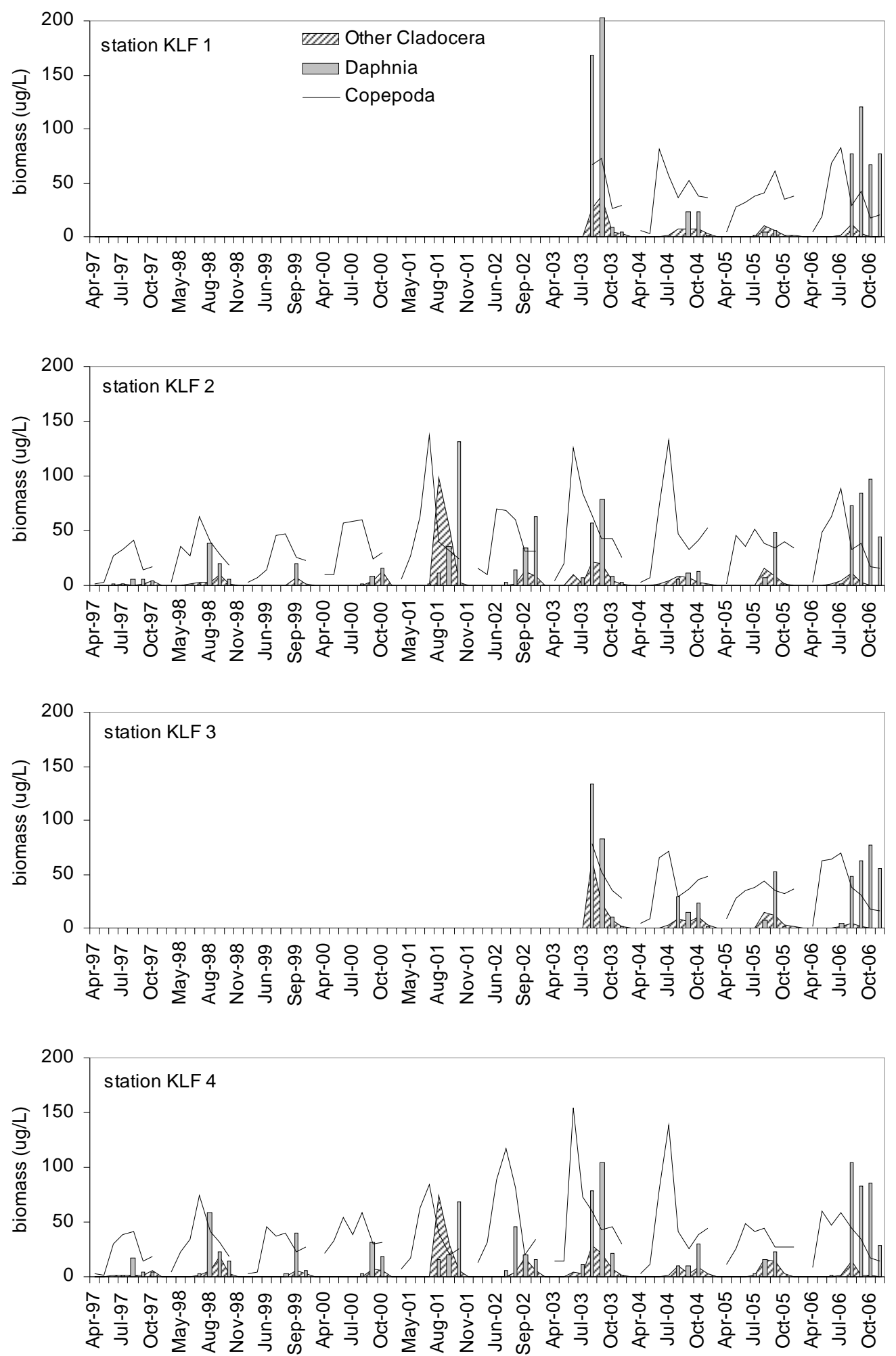

Figure 6.12. Biomass of cladoceran and copepod zooplankton in the North Arm of Kootenay Lake, 1997-2006.

Kootenay Lake Fertilization Experiment, Year 15 (North Arm) and Year 3 (South Arm) 

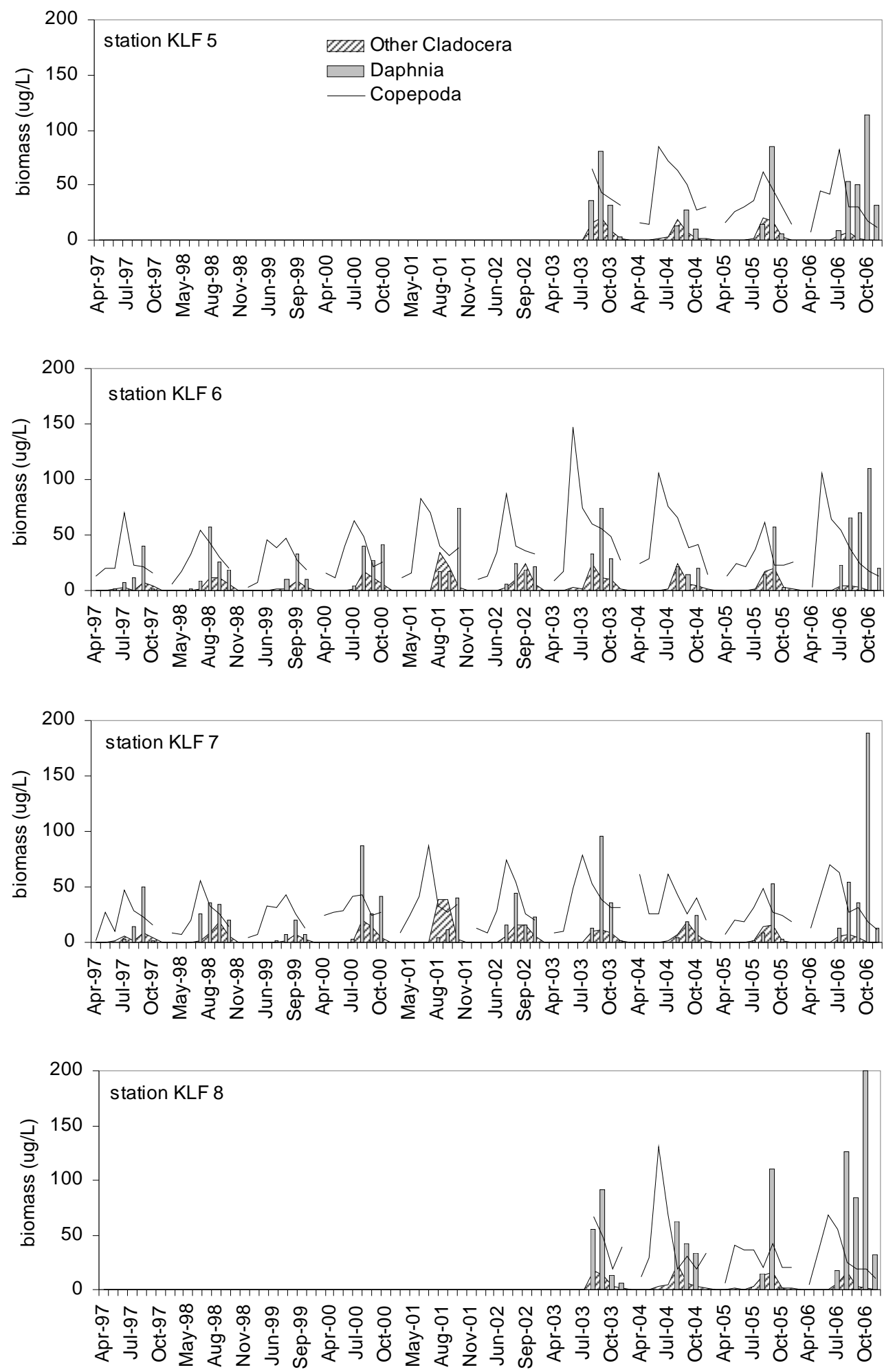

Figure 6.13. Biomass of cladoceran and copepod zooplankton in the South and West arms of Kootenay Lake. 

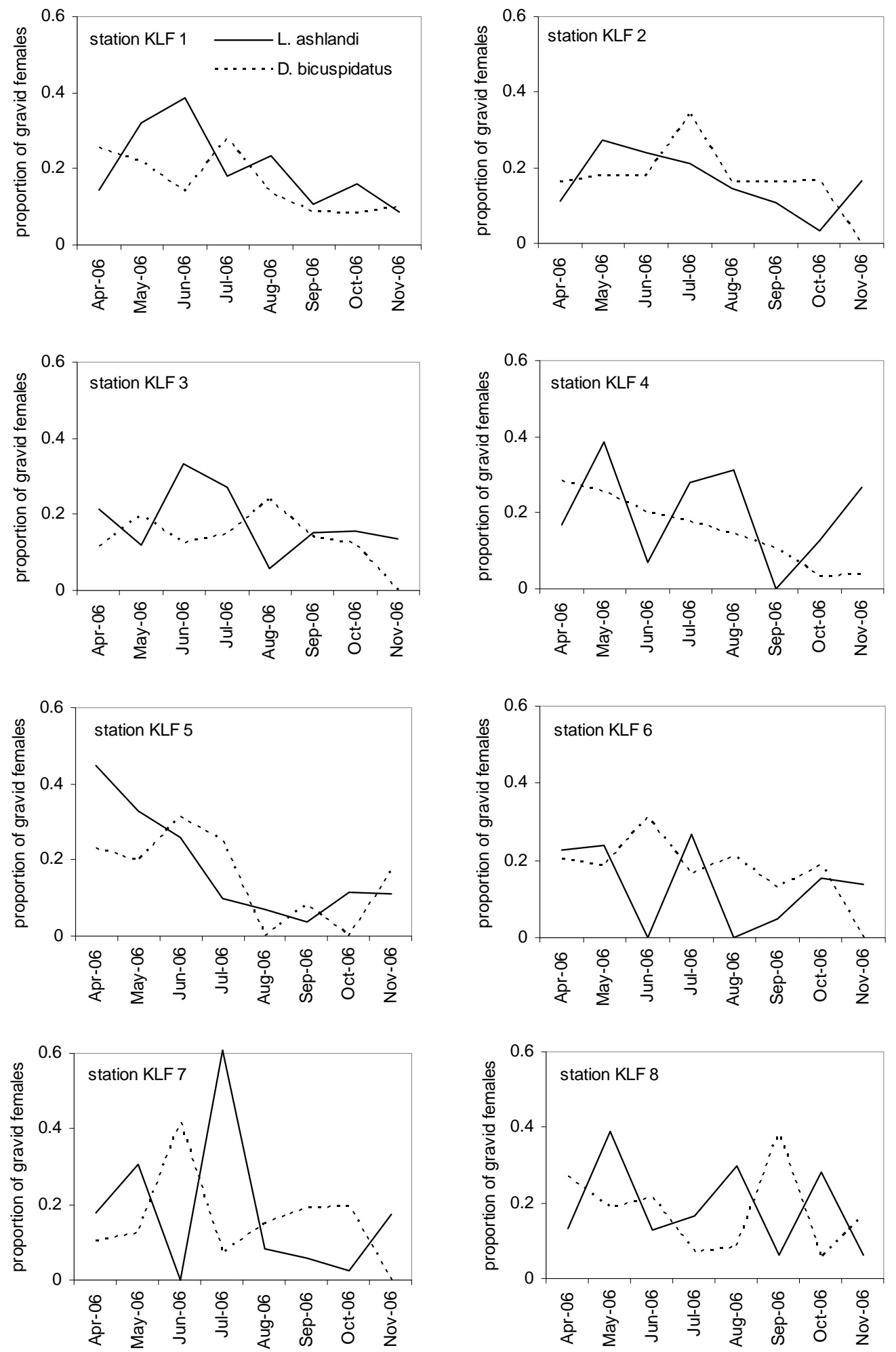

Figure 6.14. Proportion of gravid females of two species of Copepoda found in Kootenay Lake in 2006. 

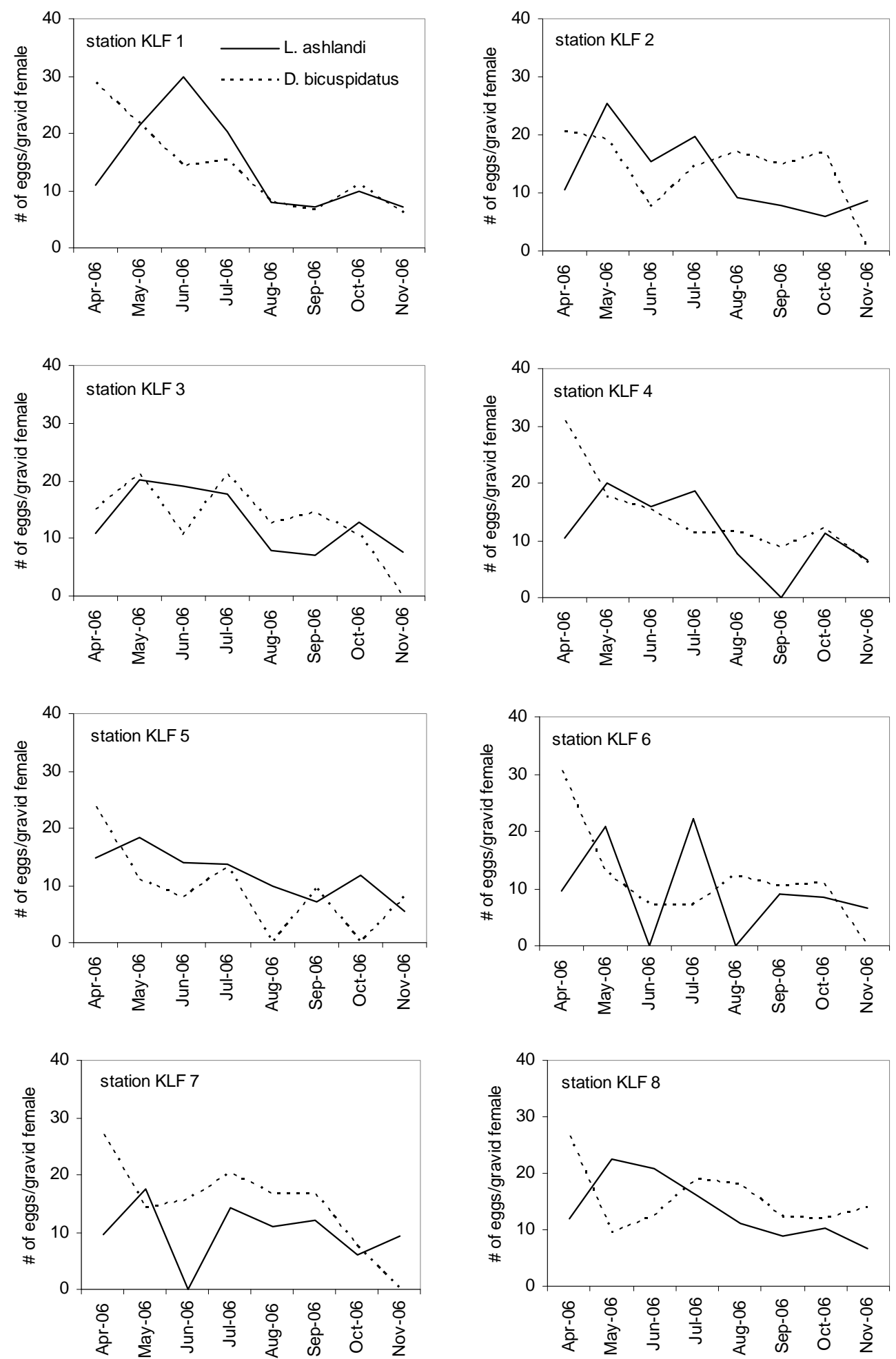

Figure 6.15. Number of eggs per gravid female in two species of Copepoda found in Kootenay Lake in 2006. 

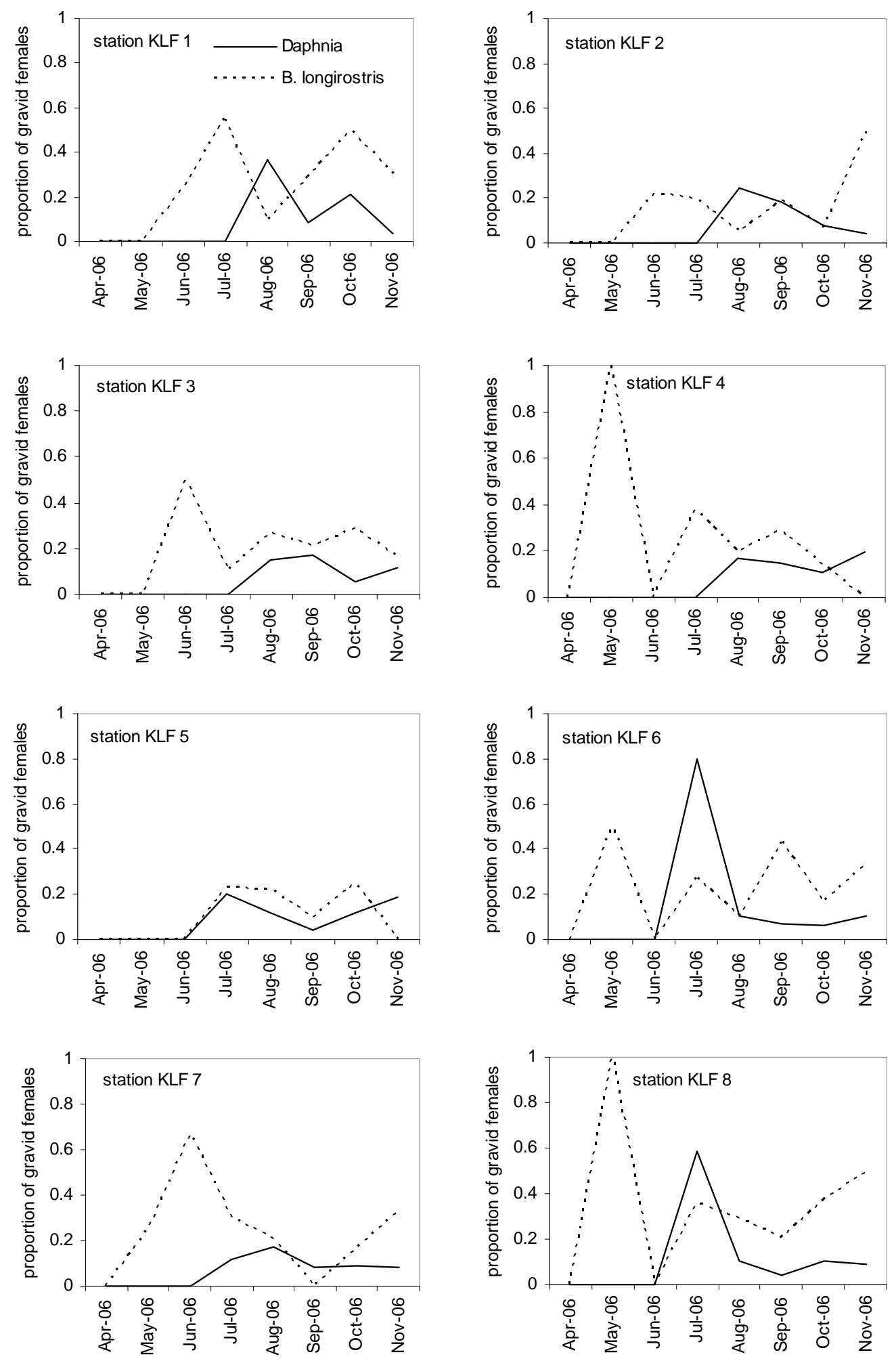

Figure 6.16. Proportion of gravid females of two species of Cladocera found in Kootenay Lake in 2006. 

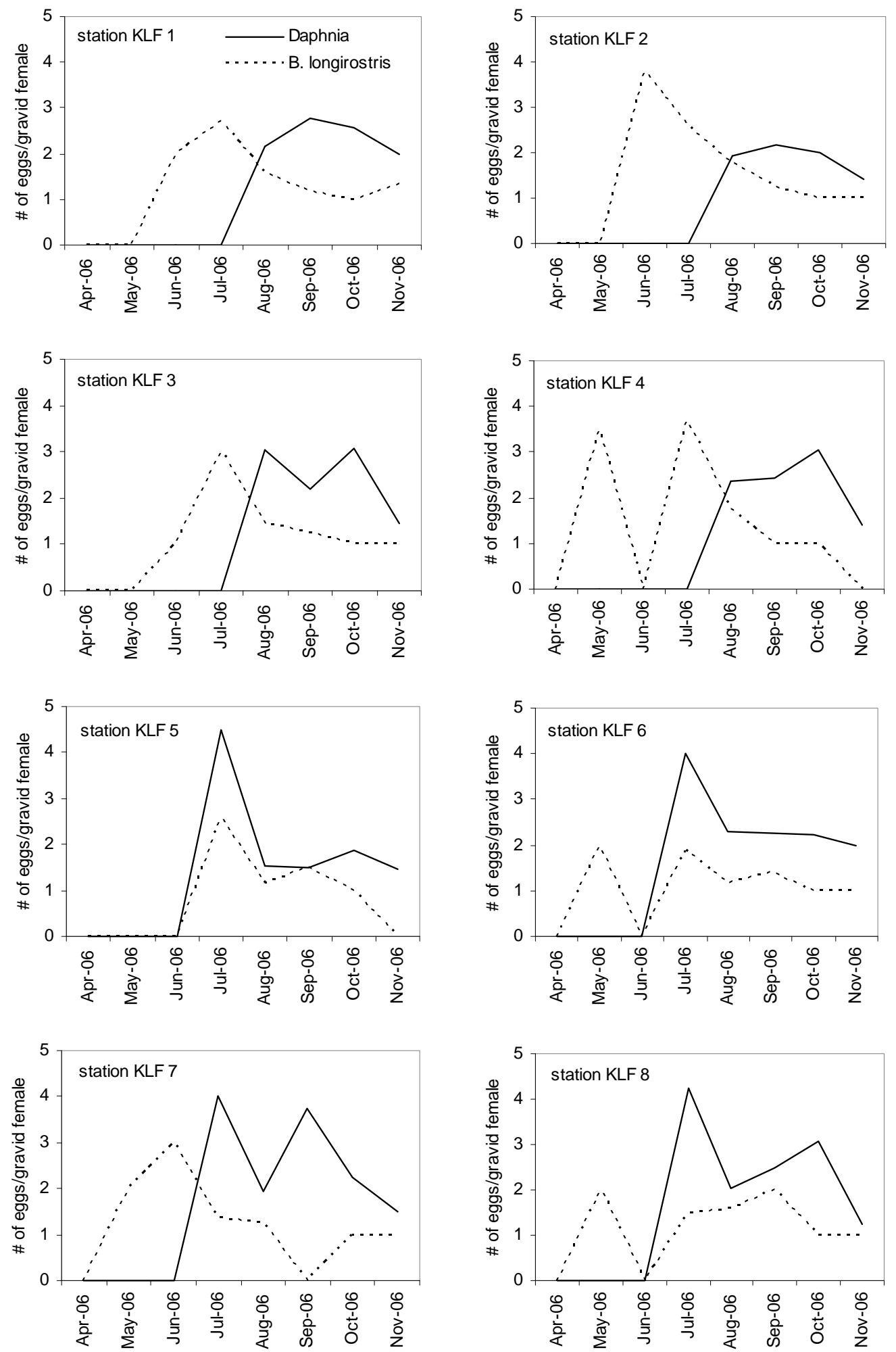

Figure 6.17. Number of eggs per gravid female in two species of Cladocera found in Kootenay Lake in 2006. 

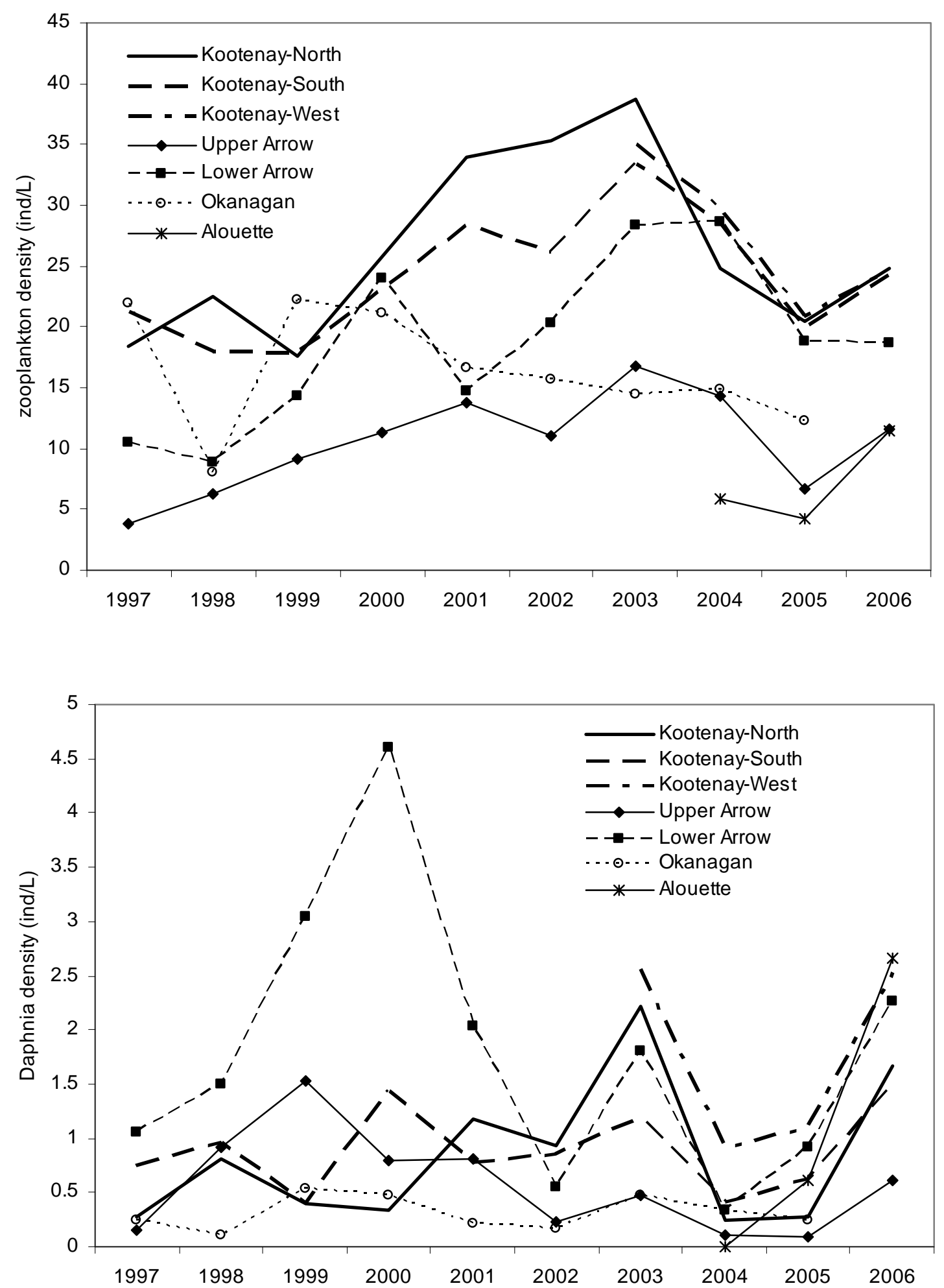

Figure 6.18. Seasonal average zooplankton density (top) and Daphnia density (bottom) in some BC Lakes. 

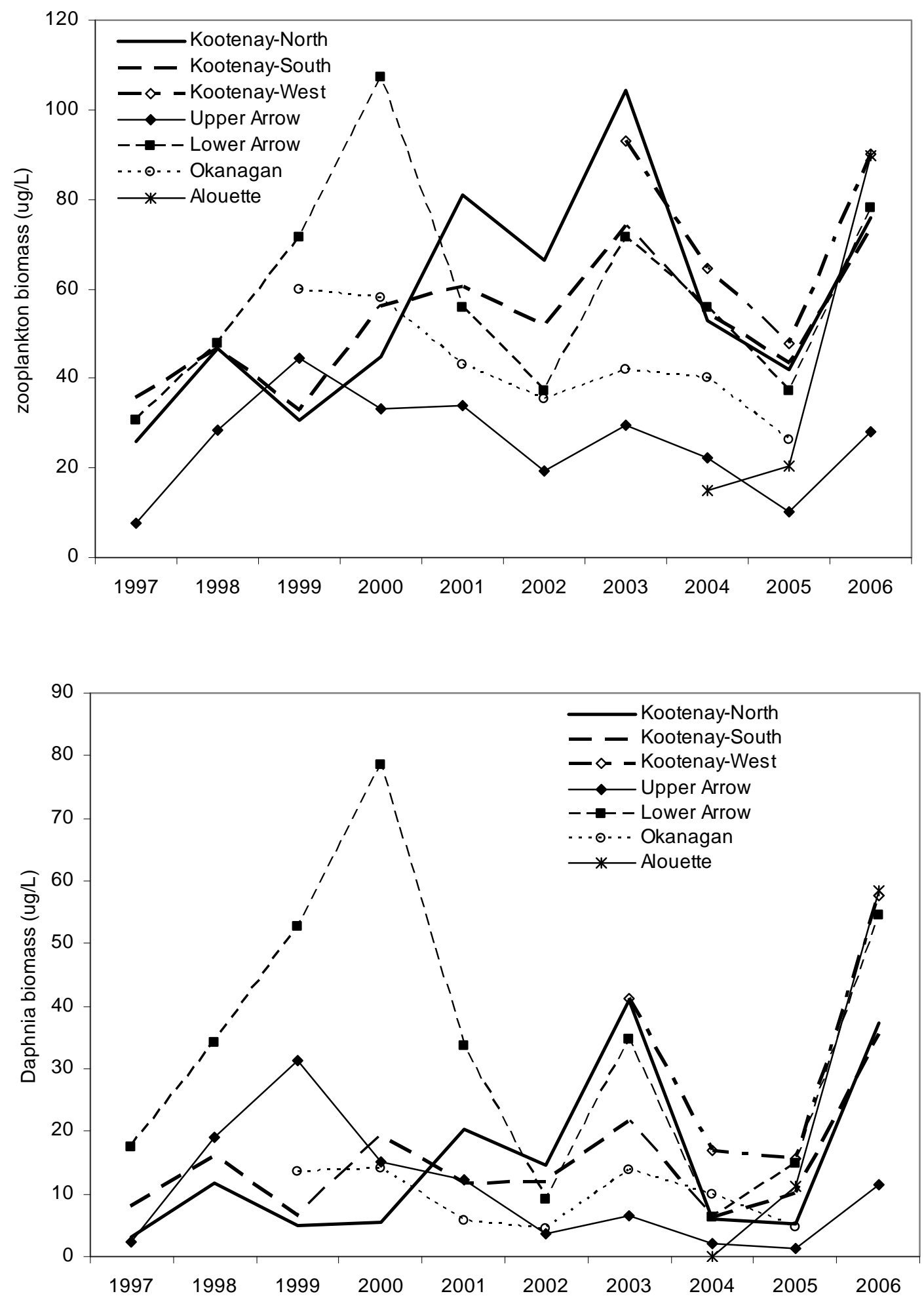

Figure 6.19. Seasonal average zooplankton biomass (top) and Daphnia biomass (bottom) in some BC lakes. 

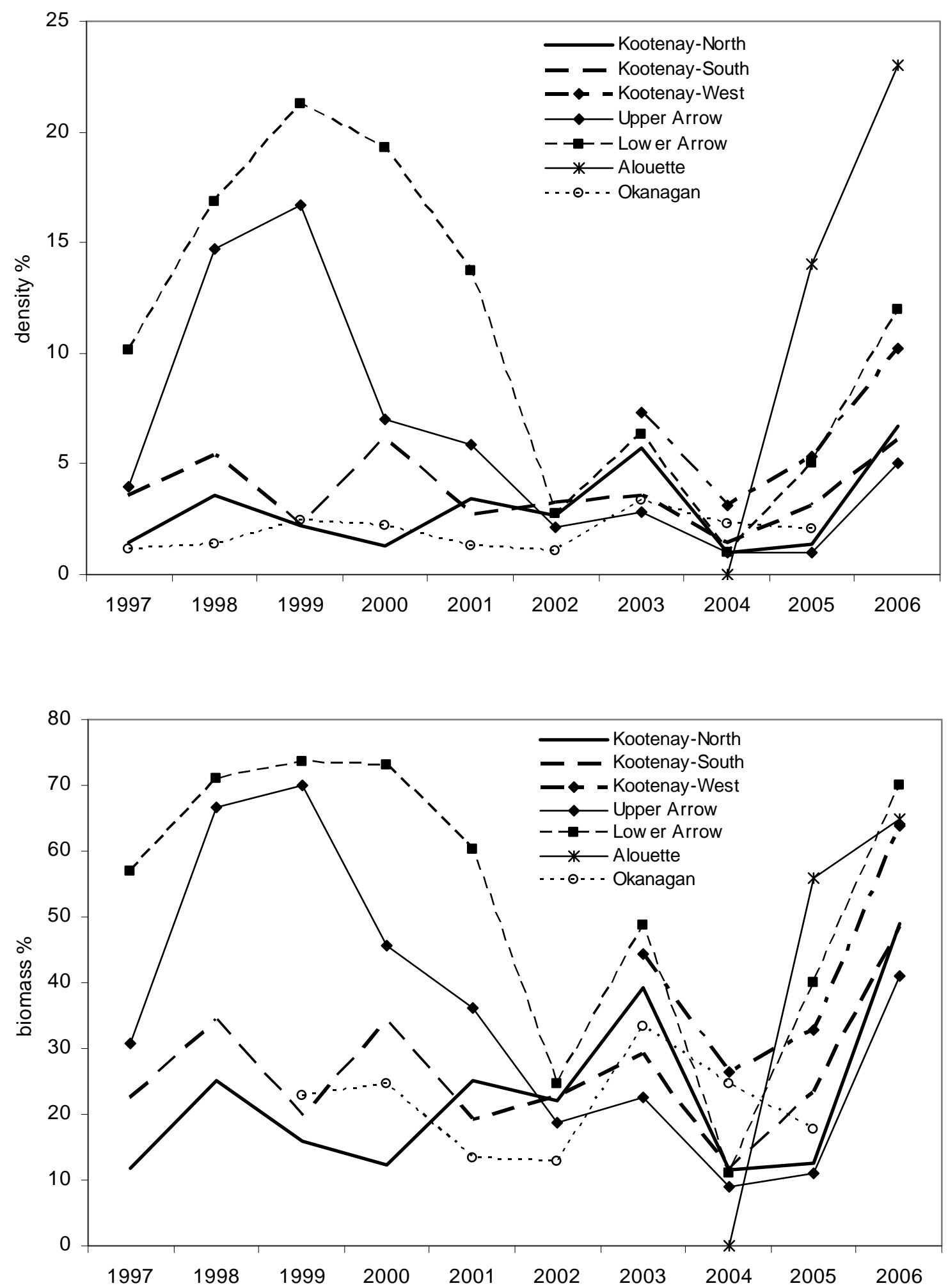

Figure 6.20. Daphnia density (top) and biomass (bottom) as a percentage of total zooplankton density and biomass in some BC lakes. 


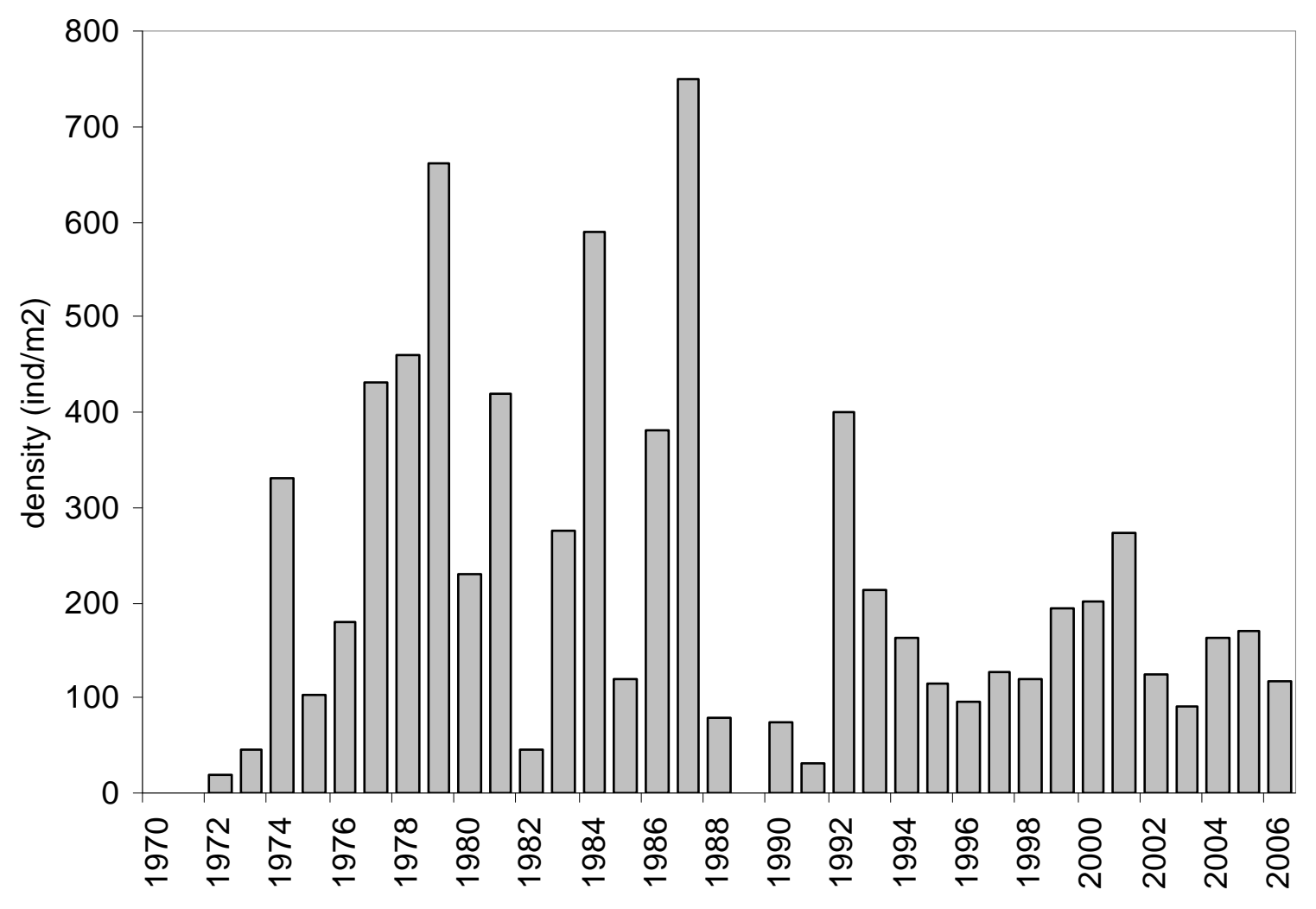

Figure 6.21. Annual average density of $M$. relicta in Kootenay Lake from 1972 to 2006. 

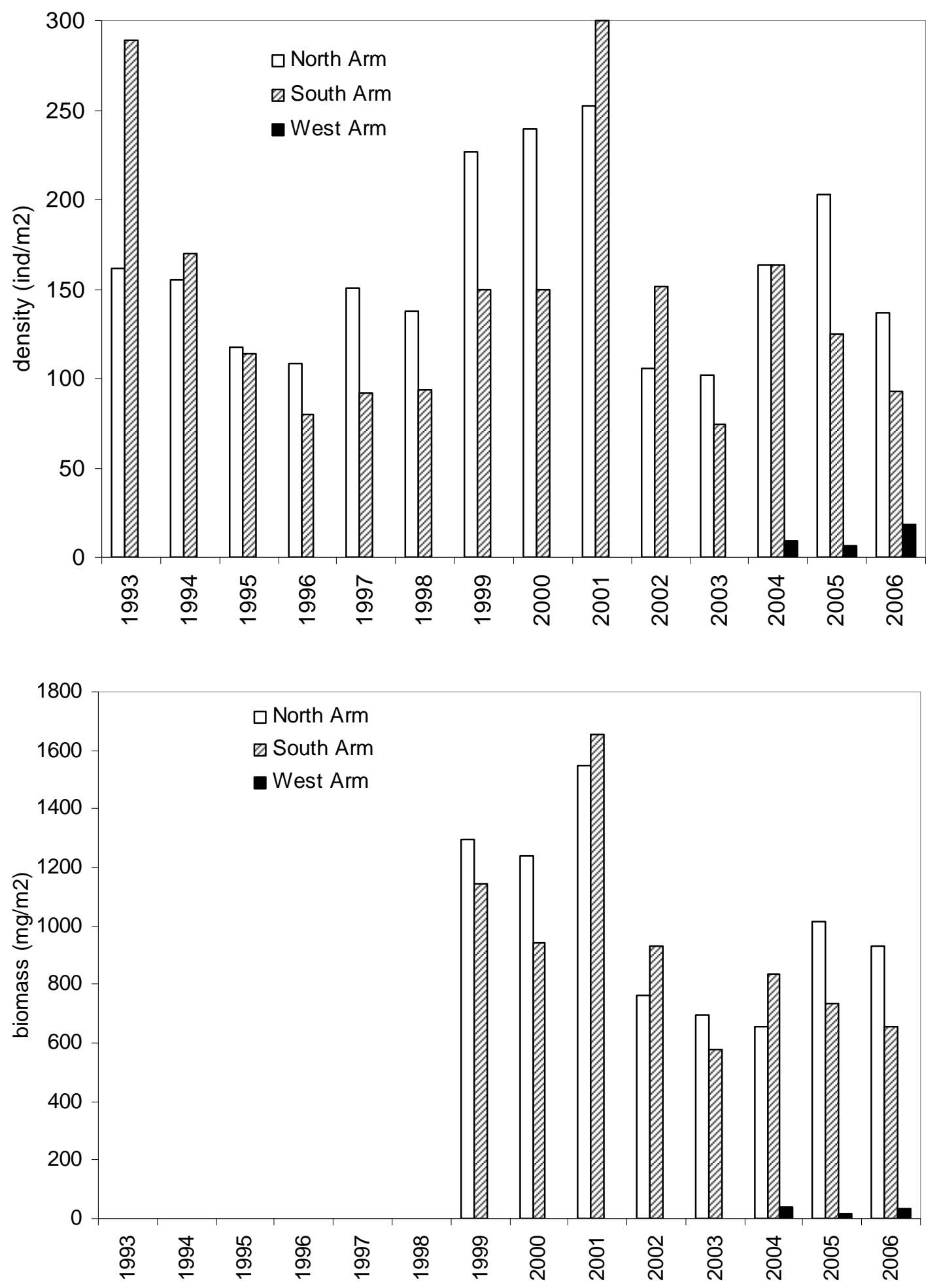

Figure 6.22. Annual average density (top) and biomass (bottom) of M. relicta in the North and South arms of Kootenay Lake. 

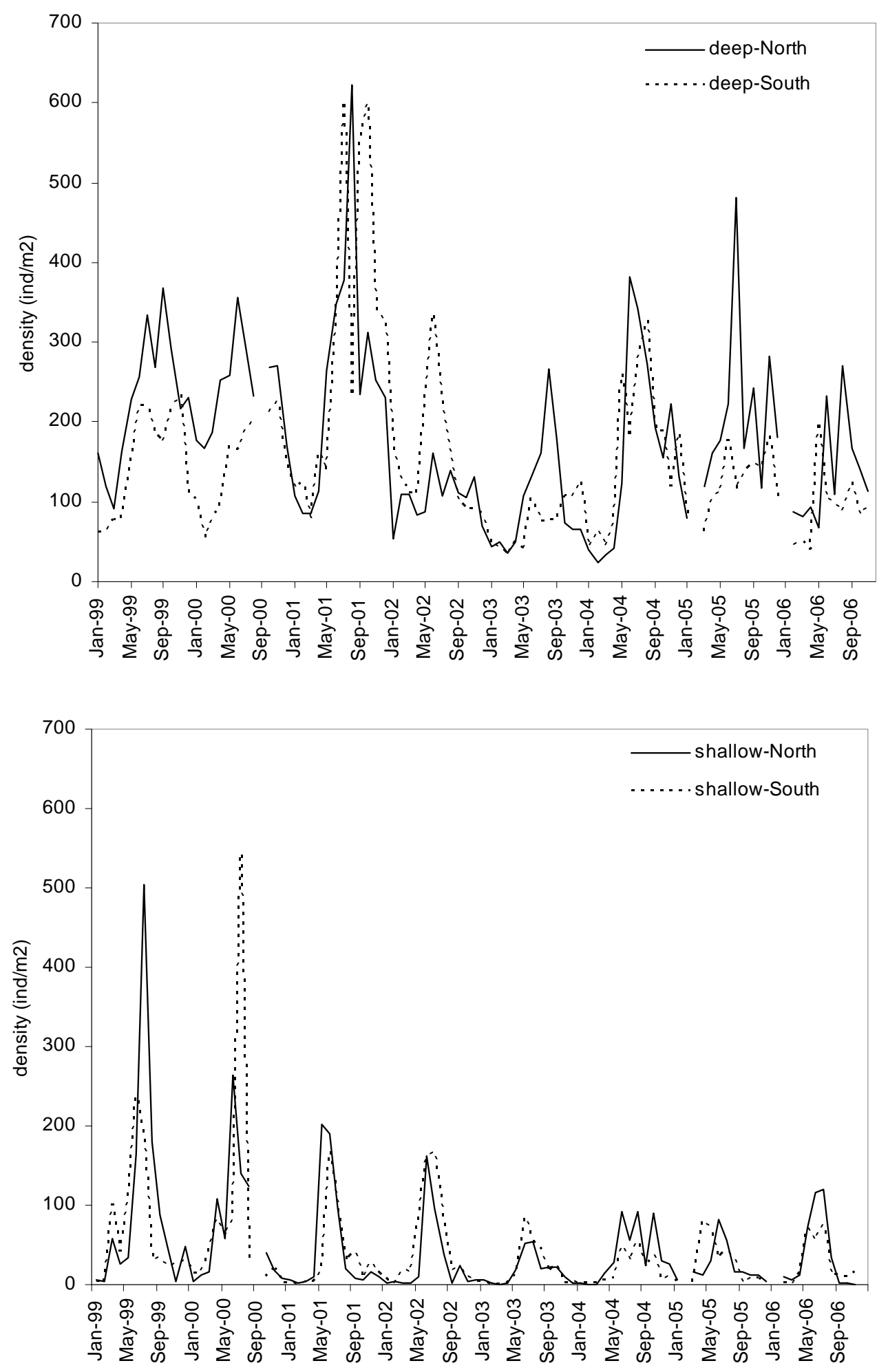

Figure 6.23. Seasonal average density of M. relicta at pelagic and near-shore stations in Kootenay Lake, 1999-2006. 

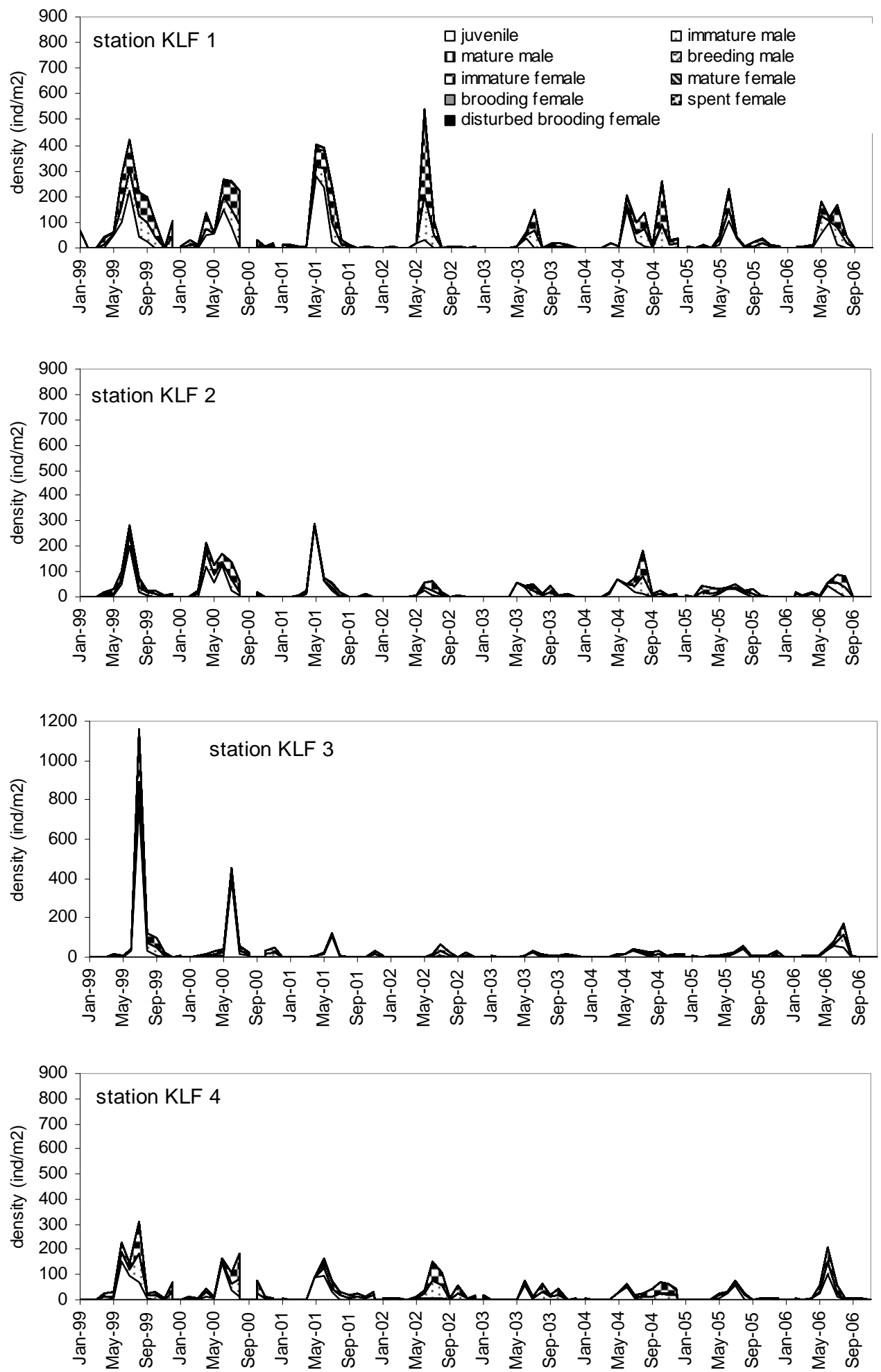

Figure 6.24. Density of developmental stages of $M$. relicta at shallow sites in the North Arm of Kootenay Lake, 1999-2006. Note: the scale is different for station KLF 3. 

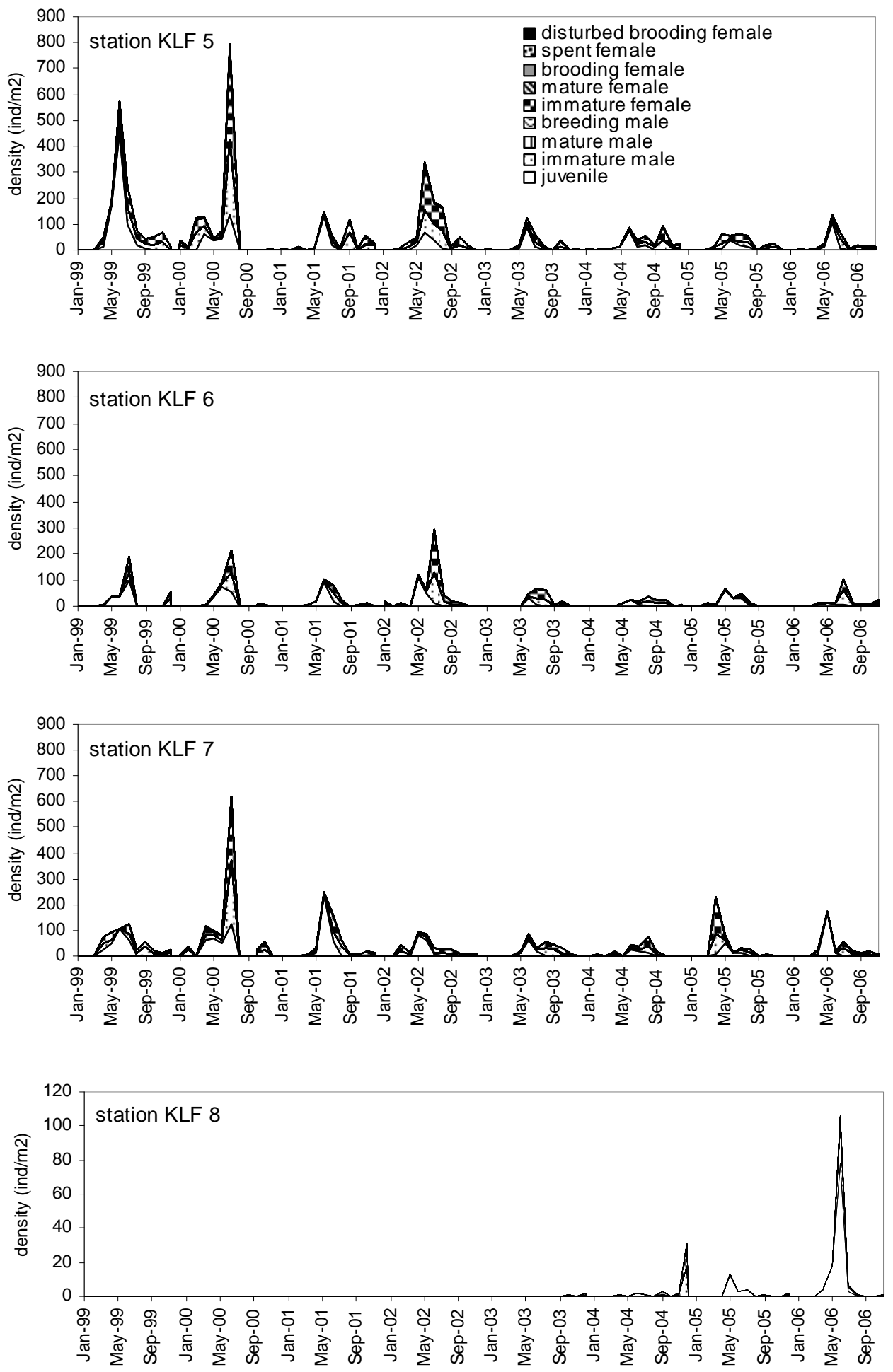

Figure 6.25. Density of developmental stages of $M$. relicta at shallow sites in the South and West arms of Kootenay Lake, 1999-2006. Note: The scale is different for station KLF 8. 

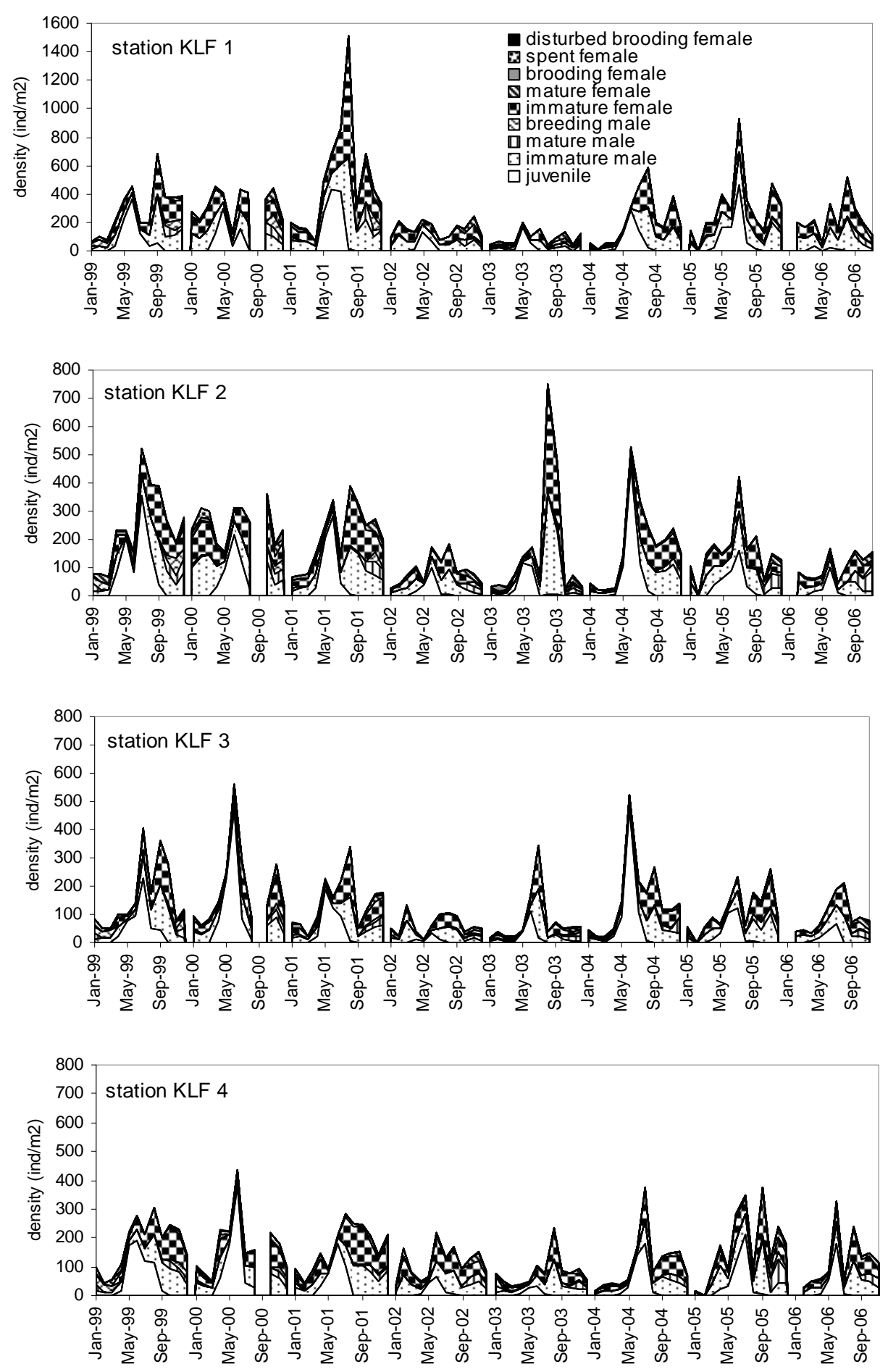

Figure 6.26. Density of developmental stages of $M$. relicta at deep sites in the North Arm of Kootenay Lake 1999,-2006. Note: the scale for station KLF 1 is different. 

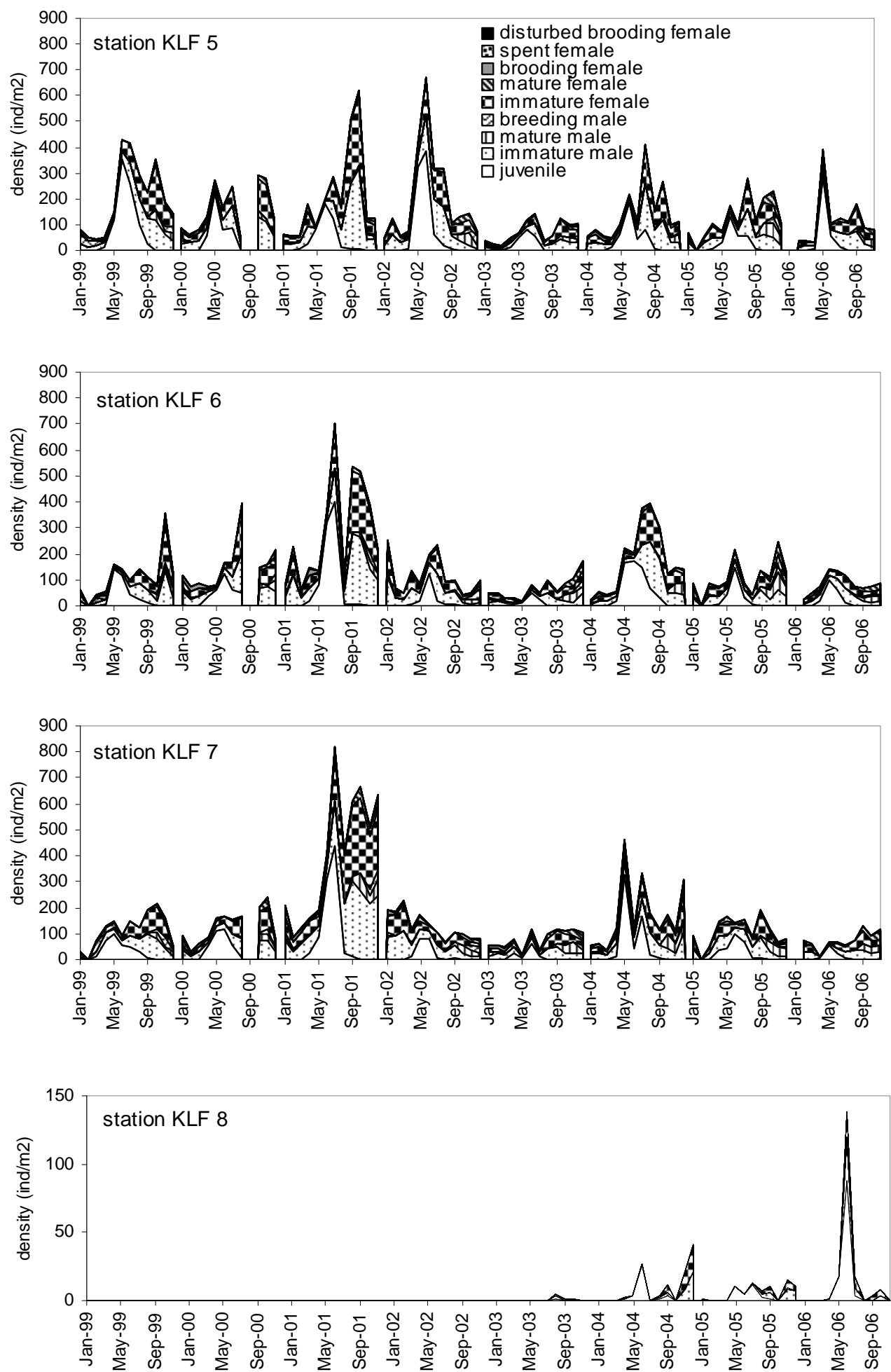

Figure 6.27. Density of developmental stages of $M$. relicta at deep sites in the South and West arms of Kootenay Lake, 1999-2006.Note: the scale for station KLF 8 is different.

Kootenay Lake Fertilization Experiment, Year 15 (North Arm) and Year 3 (South Arm) 166 (2006) Report 

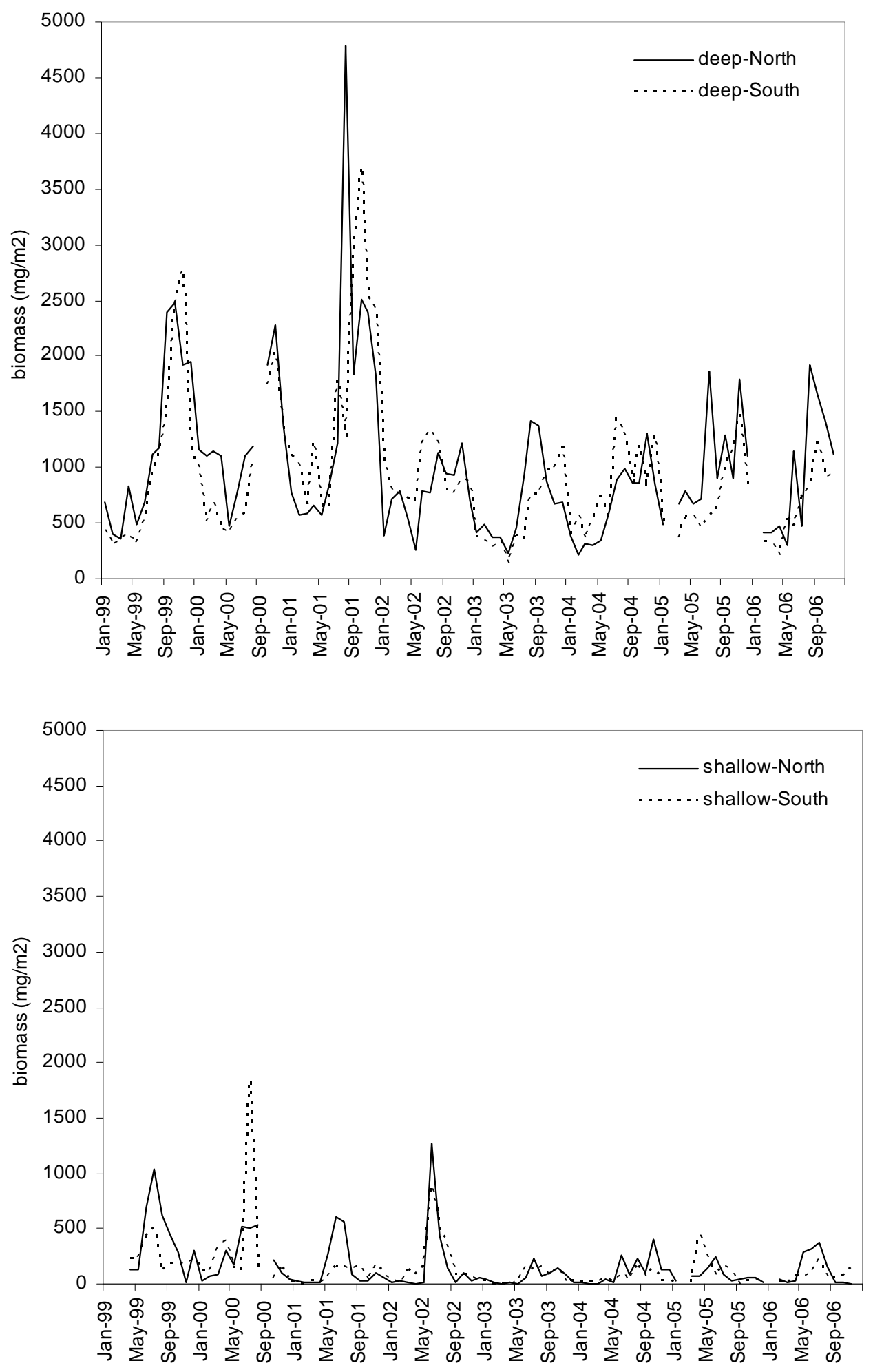

Figure 6.28. Seasonal average biomass of $M$. relicta at pelagic and near-shore stations in Kootenay Lake, 1999-2006.

Kootenay Lake Fertilization Experiment, Year 15 (North Arm) and Year 3 (South Arm) 167 (2006) Report 

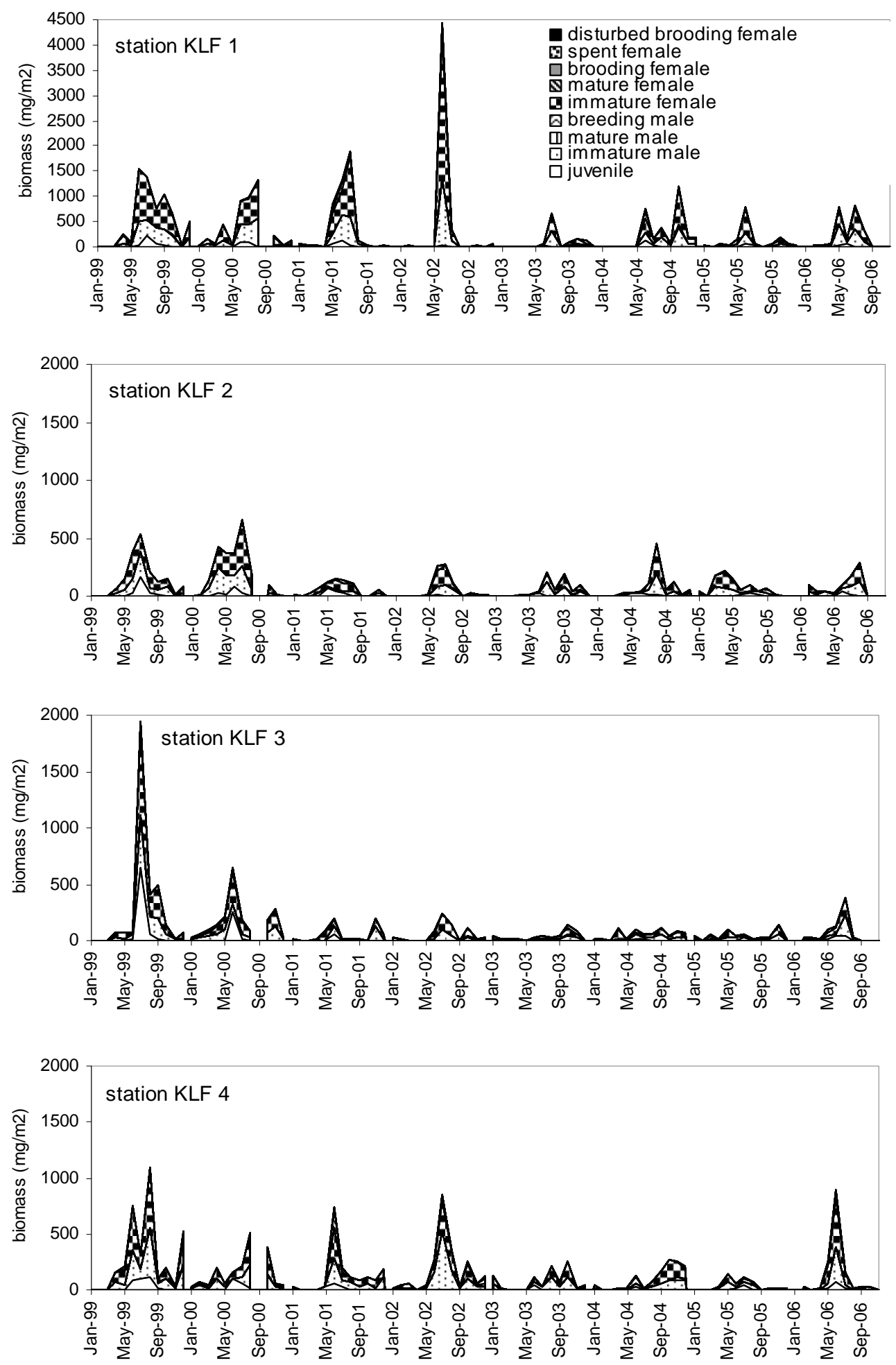

Figure 6.29. Biomass of developmental stages of $M$. relicta at shallow sites in the North Arm of Kootenay Lake, 1999-2006. Note: the scale is different for station KLF 1. 

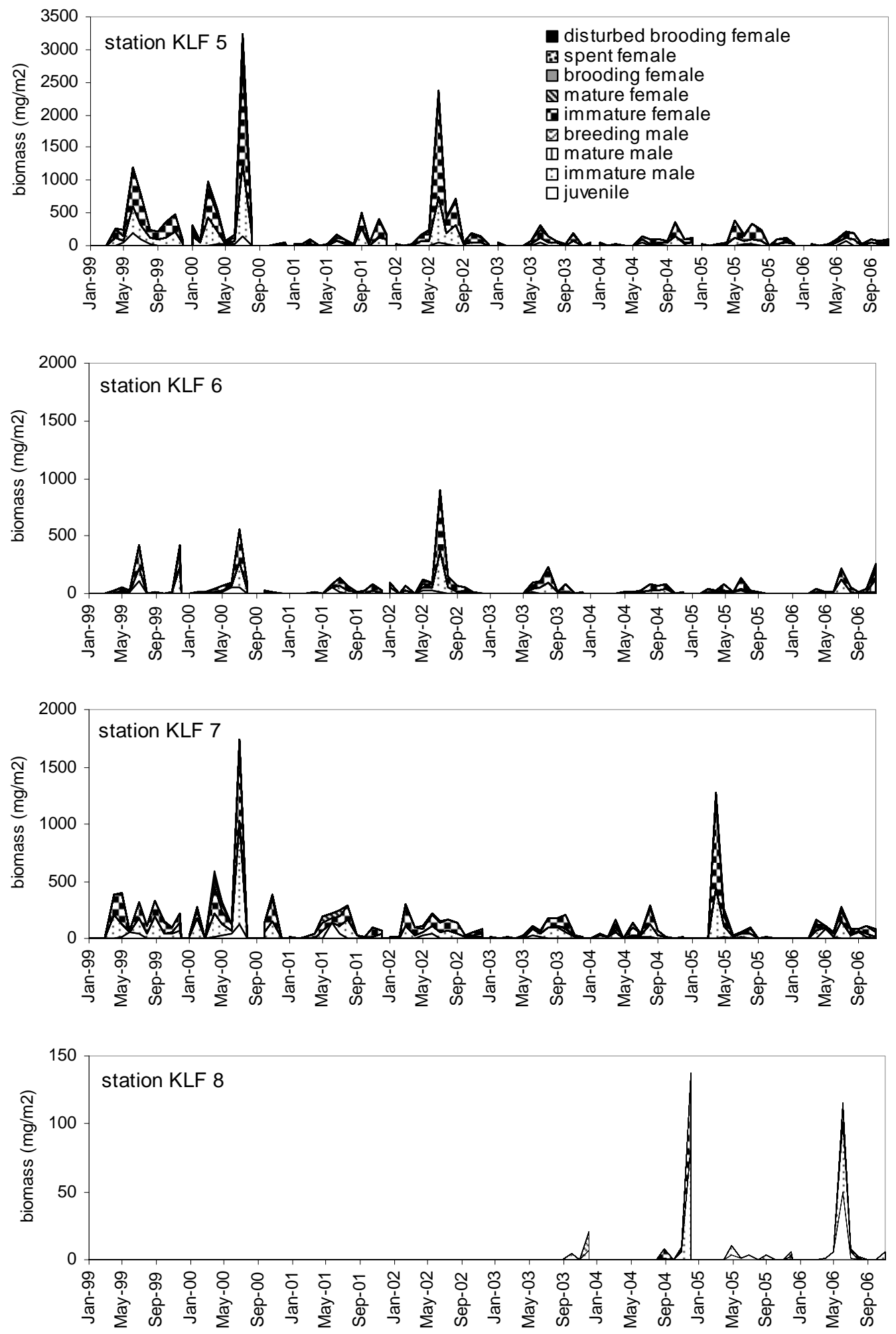

Figure 6.30. Biomass of developmental stages of $M$. relicta at shallow sites in the South and West arms of Kootenay Lake, 1999-2006.Note: the scales for stations KLF 5 and KLF 8 are different. 

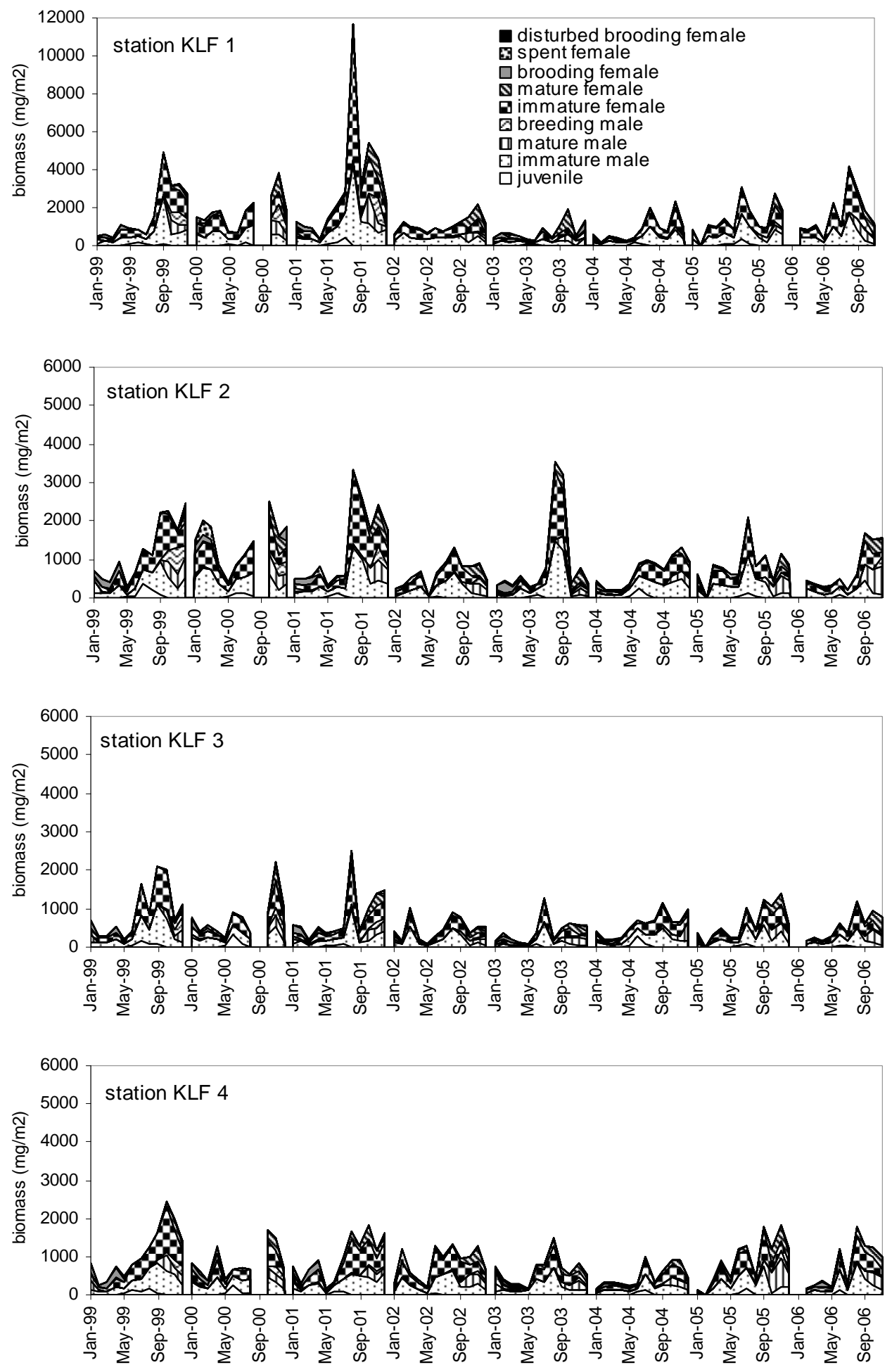

Figure 6.31. Biomass of developmental stages of $M$. relicta at deep sites in the North Arm of Kootenay Lake, 1999-2006.Note: the scale for station KLF 1 is different.

Kootenay Lake Fertilization Experiment, Year 15 (North Arm) and Year 3 (South Arm) 170 (2006) Report 

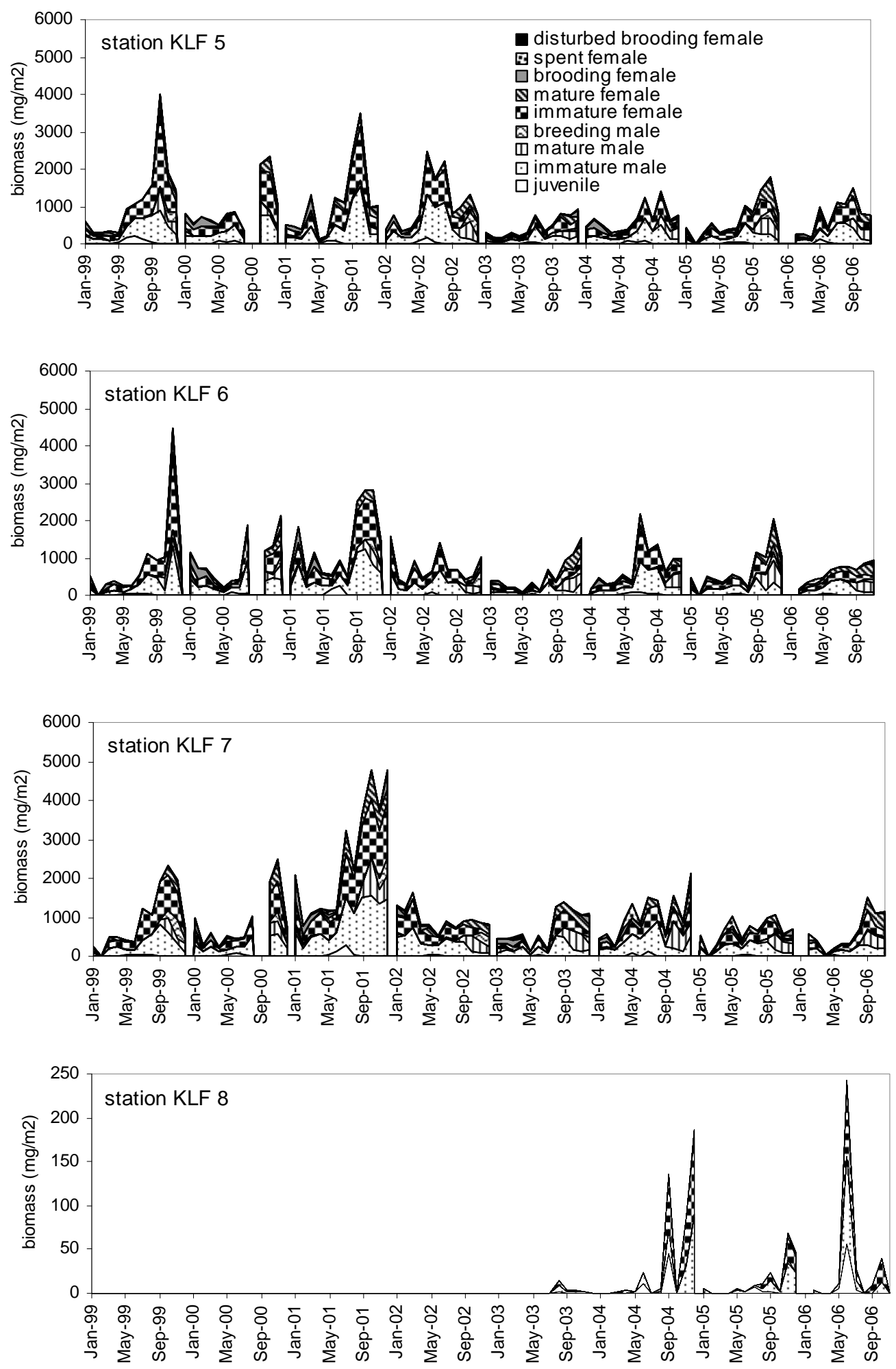

Figure 6.32. Biomass of developmental stages of $M$. relicta at deep sites in the South and West arms of Kootenay Lake, 1999-2006.Note: The graph for station 8 has a different scale.

Kootenay Lake Fertilization Experiment, Year 15 (North Arm) and Year 3 (South Arm) 

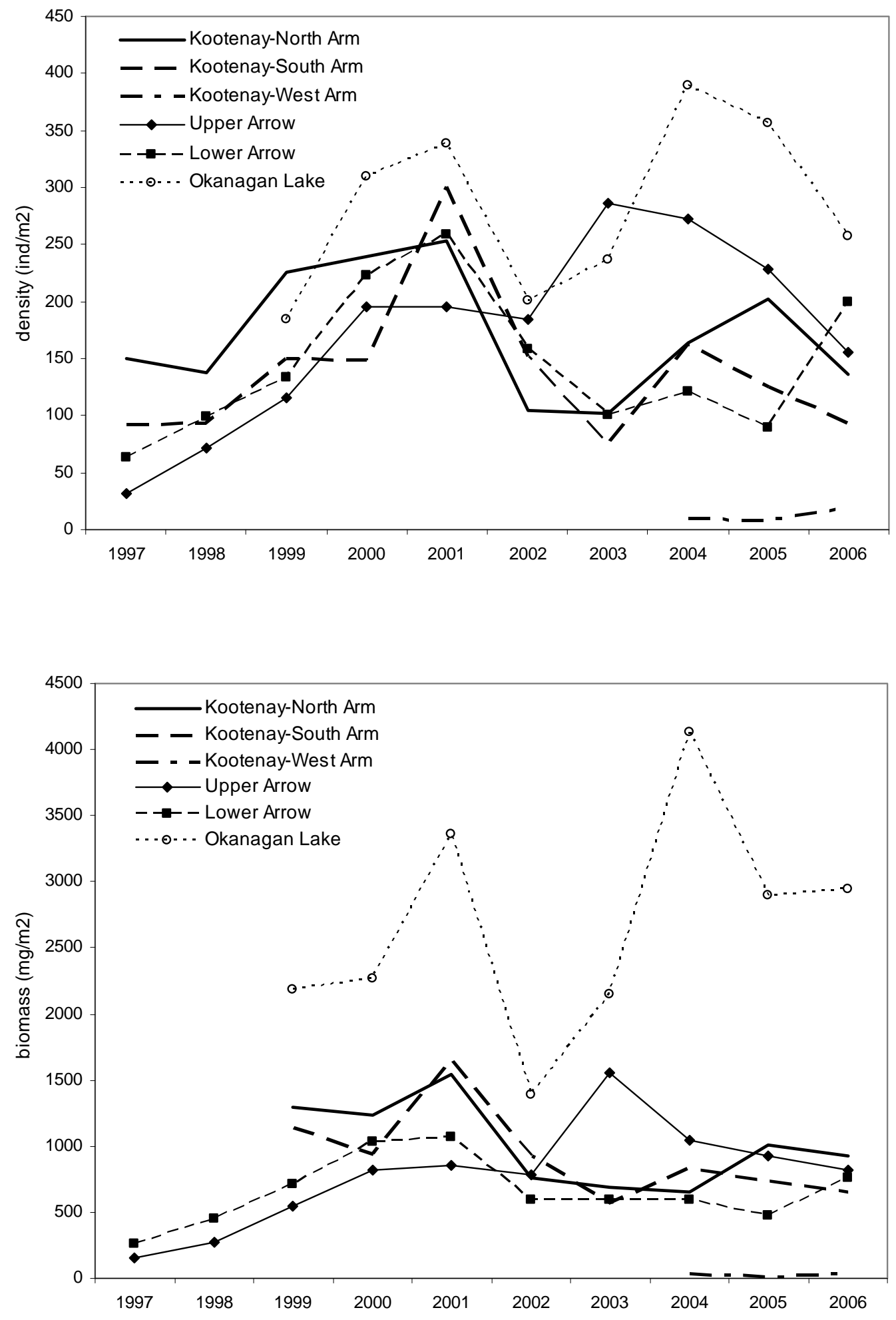

Figure 6.33. Annual average density (top) and biomass (bottom) of M. relicta in some BC Lakes. 


\title{
CHAPTER 7
}

\section{RESPONSE OF KOKANEE TO EXPERIMENTAL FERTILIZATION OF THE NORTH ARM OF KOOTENAY LAKE IN 2006}

\author{
by \\ Dale Sebastian \\ Ministry of Environment \\ Victoria, BC \\ and

\section{Harvey Andrusak} \\ Redfish Consulting Ltd. \\ Nelson, BC
}

and

\section{Greg F. Andrusak}

Redfish Consulting Ltd. Nelson, BC 


\section{Introduction and Background}

Changes to Kootenay Lakes' ecology have been dramatic during the last half century. Hydroelectric developments upstream of the lake during the 1960s and 1970s have been responsible for most of the alterations although unregulated discharge of phosphorus and other mining waste into the headwaters also had a significant influence on lake productivity during the 1960s and 1970s. Collectively these impacts caused major changes to sport fish populations that have been well documented in a series of publications (Northcote 1973; Daley et al. 1981; Ashley et al. 1997; Wright et al. 2002; Andrusak et al. 2006, Schindler et al. 2006a, 2007 a, b).

Kokanee (Oncorhynchus nerka) are the keystone species in Kootenay Lake with piscivores such as rainbow trout, bull trout, sturgeon, and burbot highly dependent on them. The relative abundance of kokanee in Kootenay Lake has been tracked since the early 1960s, likely making them the most studied kokanee population in British Columbia. Meadow Creek and the Lardeau River are the key spawning systems. Estimates of Meadow Creek escapements are used as an index of abundance for the main lake population. In the mid-1960s, a kokanee spawning channel with a capacity of 250,000 spawners was constructed on Meadow Creek as partial compensation for kokanee losses incurred due to construction of the Duncan Dam (Redfish Consulting Ltd. 1999). This channel commenced operation in 1967 and escapements and subsequent fry production estimates have been made annually since thus providing excellent time series data that can be used to track the major ecological changes that have taken place in Kootenay Lake. Meadow Creek has also been the primary kokanee egg collection site for the Province of British Columbia for nearly a century (Northcote 1973). The Meadow Creek stock has been planted in many systems throughout BC, including egg and fry plants in streams tributary to the South Arm of Kootenay Lake as well as some tributaries in Idaho (Andrusak and Fleck 2007).

In the 1950s and 1960s, Kootenay Lake had a very high level of productivity due to unregulated releases of phosphorus from a large mining operation located upstream of the lake (Northcote 1973). At that time, North Arm total escapement levels were high (1-3 million) as documented by Bull (1965) and Acara (1970). Meadow Creek spawner numbers were $<350,000$ in 1964 , the only year kokanee were enumerated before the Duncan Dam became operational. The Duncan Dam displaced all Duncan River kokanee starting in 1966 and many of these fish found their way into Meadow Creek where they spawned. Meadow Creek spawning channel production began in 1967, and escapement levels gradually increased over two cycles until the late 1970s when escapements exceeded 1 million. Two changes took place in the mid-1970s that dramatically impacted lake productivity. First, fertilizer loading to the lake began to decline with closure of Cominco's upstream fertilizer plant and secondly, Libby Dam became operational. While there were concerns about the impact of this dam on Kootenay Lake, the combined impact of reduced $\mathrm{P}$ loadings and nutrient retention in Koocanusa Reservoir was largely unforeseen. Daley et al. (1981) documented these changes, which resulted in a significant decline in lake productivity by 1980. Nutrient input to the lake declined below pre-dam conditions, and the lake underwent a gradual reduction in productivity through to the

Kootenay Lake Fertilization Experiment, Year 15 (North Arm) and Year 3 (South Arm) 174 (2006) Report 
early 1990s. Lagging slightly behind decreased productivity was a fall in kokanee numbers.

Main lake kokanee numbers began to decline in the mid-1980s (Andrusak 1987; Ashley et al. 1997). By the late 1980s there were virtually no South Arm kokanee while North Arm stock escapements decreased from a range of 0.5-4.1 million in the 1960s and 1970s to $0.3-0.5$ million in the late 1980s and early 1990s (Ashley et al. 1999; Andrusak and Fleck 2007). This decline led researchers to consider means of reversing the trend, especially since the highly valued Gerrard rainbow trout are dependent upon kokanee as their primary food source (Andrusak and Parkinson 1984).

The prospect of a complete collapse of kokanee in the main lake was interpreted to be a direct threat to the Gerrard rainbow trout population and was a concern to fishery managers and local anglers. In 1990, a series of meetings was conducted amongst fisheries researchers and managers to consider what, if anything could be done to reverse the downward trend. Korman et al. (1990) described various alternatives that were contemplated. Walters et al. (1991) developed a fertilization response model to determine what could possibly happen if a portion of the lake was fertilized to pre-impoundment and pre-cultural enrichment levels. The model predicted that fertilization was unlikely to be successful, because it was believed that the introduced Mysis relicta would respond more rapidly to increased food supply and out-compete the kokanee. Despite the models prediction, Provincial fisheries managers, faced with declining kokanee numbers and no other options, decided to proceed with a high risk a five-year experiment to fertilize a portion of the North Arm of the lake commencing in 1992.

The experiments primary objective was to restore the nutrient level to pre-dam conditions since the upstream reservoirs were serving as nutrient sinks (Binsted and Ashley 2006; Ashley et al. 1999). The response of North Arm kokanee to lake fertilization has been very positive. Kokanee escapements to the North Arm's Lardeau River and Meadow Creek systems have once again surpassed 1 million, comparable to escapement levels in the 1960s and 1970s (Ashley et al. 1999). As part of the experiment, there was a deliberate reduction in fertilizer loading from 1997-2000 to test the hypothesis that it was nutrient additions that had increased kokanee numbers through a bottom-up effect. Kokanee numbers declined in concert with reduced nutrient loading (Schindler et al. 2006a) and this prompted fisheries managers to increase the loading rate commencing in 2001.

Results of the Kootenay Lake experimental fertilization have been documented in a number of technical reports and other publications (e.g., Ashley et al. 1997; Wright et al. 2002; Schindler et al. 2006a, 2007a, b). A parallel program of nutrient addition to the nearby Upper Arrow Reservoir began in 1999 and provides the opportunity for some comparisons between these two large experimental programs (Schindler et al. 2006b).

This report documents the results of the North Arm kokanee response to 15 years (19922006) of consecutive nutrient addition, with emphasis on kokanee responses to different nutrient loadings. The specific objectives of this report are:

Kootenay Lake Fertilization Experiment, Year 15 (North Arm) and Year 3 (South Arm) 175 (2006) Report 
1. to summarize and analyze 2006 kokanee trawl and hydroacoustic data;

2. to summarize and interpret 2006 North and South Arm kokanee escapement data;

3. to demonstrate the apparent response of kokanee to various levels of experimental nutrient additions since 1992.

\section{Methods}

\section{North Arm Kokanee Escapement Estimates}

Meadow Creek kokanee data have been collected for over forty years and the methods have changed very little thus providing consistent time series information. Since the mid1960s, kokanee escapements to Meadow Creek have been determined by manually counting fish moving upstream into the channel using a permanent fish fence located at the lower end of the channel. At the peak of spawner migration, visual estimates are also made of kokanee numbers in Meadow Creek downstream of the channel. In years of high spawner numbers, some fish are passed upstream of the channel using a permanent fence located at the top end of the channel. Kokanee are sampled each year for length, age, sex ratio, and fecundity. Annual estimates of egg deposition are made, and fry out-migration from the channel is monitored each spring. Redfish Consulting Ltd. (1999) summarized the spawning channel methods and data from 1966-1998 as part of an evaluation of the channel's performance.

The methods used to conduct visual estimates of kokanee in lower Meadow Creek, Lardeau River, and Arrow Lakes Reservoir tributaries are described in detail by Redfish Consulting Ltd. (1999) and Sebastian et al. (2000). Due to the high cost of enumerating the Lardeau River, a single peak count estimate is conducted that is intended to provide only an order of magnitude estimate useful for understanding population trends. This estimate is supported by several days of visual ground truthing estimates and the peak of spawning is reasonably well known based on the daily count information of nearby Meadow Creek. None-the-less this data is not accurate enough to provide information for population estimates.

\section{Trawl and Hydroacoustic Sampling}

\section{Trawl}

The 2006 survey design and sampling techniques were similar to kokanee stock monitoring methods that have been conducted annually on Kootenay Lake since 1985 (Wright et al. 2002). Stepped-oblique trawls ensured a representative sample of fish was attained from each depth strata where fish were observed on the echosounder. The net was fished for 8 minutes at each consecutive 5-m depth layer, covering fish from 20-40$\mathrm{m}$ depth. Captured fish were kept on ice until they were processed the following morning. Species composition, fork length, weight, distinguishing marks (e.g., fin clips), scale code, and stage of maturity were recorded. Scales were taken from fish $>75 \mathrm{~mm}$ for

Kootenay Lake Fertilization Experiment, Year 15 (North Arm) and Year 3 (South Arm) 176 (2006) Report 
aging. Fish lengths were adjusted to an October 1 standard using empirical growth data from Rieman and Myers (1992) in Appendix 7.1.

Mid-water trawl samples provide the following information: species verification for the acoustic survey, indices of kokanee abundance, age structure, size-at-age, and the proportion of mature fish in the catch. Trawl gear used in 2006 consisted of a 5-m $\times 5-\mathrm{m}$ beam trawl, holding a 20-m long net of graduated mesh (6-92 mm stretched), towed at $0.80-0.95 \mathrm{~m} / \mathrm{s}$. The cable length and angle were used to estimate the trawl net depth, and a Global Positioning System (GPS) was used to estimate distances traveled for calculating sampled volumes.

\section{Hydroacoustics}

A complete nighttime survey of the limnetic habitat in Kootenay Lake was conducted during the new moon phase in September 2006. Acoustic survey data were collected at 18 transect locations evenly spaced along the length of the main lake, including both North and South Arms (see Chapter 1, Fig. 1.1). Surveys were conducted using a Simrad model EY200P operating at $70 \mathrm{kHz}$. The transducer was towed on a planer alongside the boat at a depth of $1 \mathrm{~m}$, and data were collected continuously along survey lines at 1-2 pings/s while cruising at $2 \mathrm{~m} / \mathrm{s}$. The data were converted to digital format and both stored on a PC computer and backed up on Sony digital audio tape (DAT). Navigation was by radar, GPS, and a 1:75,000 Canadian Hydrographics bathymetric chart. The Simrad system was calibrated in the field at the beginning of the survey. Field calibrations were conducted by collecting target strength data from a copper sphere suspended in the centre of the echosounder beam, $20 \mathrm{~m}$ from the transducer. The received signal level was adjusted to -39.1 decibels $(\mathrm{dB})$, which corresponds to the empirical strength of the sphere at $70 \mathrm{kHz}$. Echosounder specifications and field settings are presented in Appendix 7.2 and acoustic size classes and fork length equivalents in Appendix 7.3.

The Simrad survey data were digitized and then analyzed using the Hydroacoustic Data Acquisition System (HADAS) program, version 3.98, by Lindem (1991). The HADAS statistical analysis performed a function similar to manual counting to determine the number of targets per unit area by depth stratum. Habitat was stratified by 5-m depth layers and then further stratified into relatively homogeneous zones. Regression through origin of echo counts on areas sampled produced mean density and standard error values for each zone and depth stratum. A Monte Carlo Simulation procedure was used to combine all strata and develop maximum likelihood estimates and statistical bounds for each zone and for the combined zones using 30,000 iterations per run. Average fish densities by transect are shown in Appendix 7.4 and maximum likelihood population estimates and bounds are presented in Appendix 7.5. Fish size distribution was also estimated using a statistical de-convolution based on Craig and Forbes (1969). The resulting acoustic size distribution was used to proportion the fish population into two size classes representing age 0 fish and age $1-3$ fish, respectively.

Kootenay Lake Fertilization Experiment, Year 15 (North Arm) and Year 3 (South Arm) 


\section{Kokanee Biomass}

Biomass estimates for pelagic habitat were determined from acoustic abundance proportioned into age groups based on both trawl and acoustic surveys (Appendix 7.6). Mean weights at age from the trawl data were applied to the total estimated numbers of fish at each age to determine total biomass in the reservoir. Spawner biomass was estimated by applying the average weight of spawners measured at Meadow Creek Spawning Channel to the total estimated number of spawners from all tributaries. For years where no weights were available, individual weights were estimated from a length weight relation derived from previous Meadow Creek data on file (MoE). This number was then divided by the surface area of "pelagic habitat" to determine a biomass density (kg/ha).

\section{Results}

\section{Kokanee Escapements}

Following three consecutive years when escapements were $\sim 1$ million, Meadow Creek spawner numbers declined dramatically in 2006 to slightly less than 400,000, similar to the level of returns from 2000-2002 (Fig. 7.1). The 2006 spawner numbers were just slightly higher than their parental numbers in 2002. Similarly, the 2006 Lardeau River escapement estimate was nearly identical to the 2002 estimate (peak count only) of approximately 100,000. These numbers continue to be well below the estimates made in the late 1990s (Fig. 7.2). Lardeau River kokanee escapements do not appear to follow the same pattern as Meadow Creek. i.e. the Lardeau escapements continue to be comparatively low and the amplitude of peak counts has not increased as dramatically as observed at Meadow Creek.

\section{Spawner Size and Fecundity}

Meadow Creek kokanee are typically quite small and their mean size has been remarkably consistent over four decades ( $\mathrm{n}=38$ years), falling within a narrow size range from $20.0-27.0 \mathrm{~cm}$ with the mean size of females $(22.1 \mathrm{~cm})$ slightly smaller than of males $(22.3 \mathrm{~cm})$. The mean size of females in 2006 was $24.9 \mathrm{~cm}$ while the mean size of males was $25.2 \mathrm{~cm}$; these means were considerably larger than the previous three years and much larger than the 38-year average (Fig. 7.3). The largest mean size recorded was in 1993 when the females were $26.7 \mathrm{~cm}$ and males $27.1 \mathrm{~cm}$. The 2006 fecundity was 315 eggs/female or $22 \%$ higher than the long term average of 259 eggs/female.

\section{Meadow Creek Kokanee Fry Production}

The 2006 fry production estimate from the Meadow Creek spawning channel was about 17 million, lower than the 25 million in 2005 but comparable with other years in the 2000s (Fig. 7.4). Since the inception of lake fertilization fry production has increased substantially with all but one year exceeding 15 million (Fig. 7.4). This level of production is in contrast to the 1980s when total numbers seldom exceeded 7 million

Kootenay Lake Fertilization Experiment, Year 15 (North Arm) and Year 3 (South Arm) 178 (2006) Report 
(Fig. 7.4). Higher levels of fry production from the channel in the last decade reflect a combination of a) improved channel performance due to channel renovations and b) higher egg deposition resulting from increased escapement levels (Fig. 7.1). One would expect the relationship of fry production to egg deposition to reach some maximum or asymptote as the channel capacity is reached and superimposition reduces egg-to-fry survival. However a scatter plot of fry production vs. egg deposition shows a linear relationship indicating that the channel capacity has not yet been reached (Fig. 7.5).

\section{Trawl Catch Data}

\section{Total catch, composition, and age distribution}

The fall survey in 2006 was conducted at night time during September 19-26 ${ }^{\text {th }}$. As with previous trawl surveys catch was dominated (99.6\%) by kokanee (Table 7.1). All trawl surveys were conducted at night in the pelagic zone, so there is little doubt from the data in Table 7.1 which fish species occupy this area of the lake. i.e. the high percentage of kokanee fry re-affirms that the large majority of fish in the limnetic zone recorded by the acoustics survey are indeed kokanee. Total kokanee catch was far higher in 2006 than 2005 but still slightly lower than in other recent surveys. The vast majority of kokanee were captured in the fertilization zone at the north end of the lake. The majority (96.5\%) of the 754 kokanee caught in September 2006 were age 0+, with 2.8\% age 1+, 0.7\% age $2+$ and no age 3 fish captured (Table 7.2). Most age 3+ fish were already in the spawning streams at the time of the survey.

Kootenay Lake Fertilization Experiment, Year 15 (North Arm) and Year 3 (South Arm) 
Table 7.1. $\quad$ Species composition from standard trawl surveys in Kootenay Lake during 1985-2006.

\begin{tabular}{|c|c|c|c|c|c|c|c|c|c|}
\hline \multirow[b]{2}{*}{ Year } & \multirow[b]{2}{*}{ Month } & \multirow[b]{2}{*}{$\begin{array}{l}\text { No. of } \\
\text { Trawls }\end{array}$} & \multicolumn{6}{|c|}{ Number Caught by Species } & \multirow[b]{2}{*}{$\begin{array}{c}\text { Percent } \\
\text { Kokanee } \\
(\%)\end{array}$} \\
\hline & & & Kokanee & $\begin{array}{l}\text { Peamouth } \\
\text { Chub }\end{array}$ & Sucker & Whitefish & $\begin{array}{c}\text { Rainbow } \\
\text { trout }\end{array}$ & $\begin{array}{l}\text { Bull } \\
\text { trout }\end{array}$ & \\
\hline 1985 & 10 & 11 & 234 & 0 & 0 & 0 & 0 & 0 & 100.0 \\
\hline 1986 & 10 & 17 & 541 & 0 & 0 & 0 & 0 & 0 & 100.0 \\
\hline 1987 & 10 & 20 & 293 & 0 & 0 & 0 & 0 & 0 & 100.0 \\
\hline 1988 & 10 & 21 & 212 & 0 & 0 & 0 & 0 & 0 & 100.0 \\
\hline 1989 & 9 & 24 & 258 & 0 & 0 & 0 & 0 & 0 & 100.0 \\
\hline 1990 & 10 & 24 & 269 & 0 & 0 & 0 & 0 & 0 & 100.0 \\
\hline 1991 & 10 & 24 & 241 & 0 & 0 & 0 & 0 & 0 & 100.0 \\
\hline 1992 & 9 & 27 & 939 & 0 & 0 & 0 & 0 & 0 & 100.0 \\
\hline 1993 & 9 & 25 & 1064 & 0 & 0 & $1^{3}$ & 0 & 0 & 99.9 \\
\hline 1994 & 10 & 25 & 1366 & 0 & 0 & 0 & 0 & 0 & 100.0 \\
\hline 1995 & 9 & 30 & 2198 & 0 & $3^{1}$ & 0 & 0 & 1 & 99.8 \\
\hline 1996 & 9 & 29 & 1947 & 0 & $1^{1}$ & 0 & 0 & 0 & 99.9 \\
\hline 1997 & 9 & 18 & 676 & 1 & 0 & $2^{3}$ & 1 & 0 & 99.4 \\
\hline 1998 & 9 & 18 & 689 & 0 & 0 & 0 & 0 & 0 & 100.0 \\
\hline 1999 & 9 & 18 & 377 & 0 & 0 & 0 & 0 & 0 & 100.0 \\
\hline 2000 & 9 & 18 & 614 & 0 & 0 & $1^{3}$ & 0 & 0 & 99.8 \\
\hline 2001 & 9 & 18 & 692 & 0 & 0 & 0 & 1 & 0 & 99.9 \\
\hline 2002 & 9 & 21 & 667 & 0 & $1^{2}$ & 0 & 0 & 0 & 99.9 \\
\hline 2003 & 10 & 21 & 903 & 0 & 0 & $1^{4}$ & 0 & 0 & 99.9 \\
\hline 2004 & 9 & 20 & 827 & 0 & 0 & 0 & 1 & 0 & 99.9 \\
\hline 2005 & 9 & 19 & 250 & 0 & 0 & $1^{4}$ & 1 & 0 & 99.2 \\
\hline 2006 & 9 & 17 & 754 & 0 & 0 & 0 & 1 & 2 & 99.6 \\
\hline
\end{tabular}

${ }^{1}$ White sucker (Catostomus commersoni)

${ }^{2}$ Longnose sucker (Catostomus catostomus)

${ }^{3}$ Lake whitefish (Coregonus clupeaformis)

${ }^{4}$ Pygmy whitefish (Prosopium coulteri) 
Table 7.2. Summary of kokanee trawl catches by age for Kootenay Lake 1985-2006.

\begin{tabular}{clccrrrrr}
\hline Survey & Survey & No. of & No. of & \multicolumn{5}{c}{ Number of kokanee caught } \\
\cline { 5 - 8 } Year & Period & stations & trawls & age 0 & Age 1 & age $\mathbf{2}$ & age 3 & All ages \\
\hline 1985 & Oct 8 & 3 & 11 & 117 & 43 & 65 & 9 & 234 \\
1986 & Oct 7 & 3 & 17 & 465 & 26 & 41 & 9 & 541 \\
1987 & Oct 20 & 4 & 20 & 160 & 83 & 49 & 1 & 293 \\
1988 & Oct 4-7 & 4 & 21 & 113 & 56 & 43 & 0 & 212 \\
1989 & Sep 26-29 & 4 & 24 & 179 & 33 & 41 & 5 & 258 \\
1990 & Oct 16-18 & 4 & 24 & 210 & 32 & 21 & 6 & 269 \\
1991 & Oct 1-4 & 4 & 24 & 193 & 24 & 20 & 4 & 241 \\
1992 & Sep 21-26 & 6 & 27 & 794 & 43 & 100 & 2 & 939 \\
1993 & Sep 10-22 & 7 & 25 & 922 & 82 & 31 & 29 & 1064 \\
1994 & Oct 3-6 & 4 & 25 & 1191 & 115 & 59 & 1 & 1366 \\
1995 & Sep 24-27 & 6 & 30 & 1537 & 572 & 88 & 1 & 2198 \\
1996 & Sep 9-13 & 5 & 29 & 964 & 494 & 476 & 13 & 1947 \\
1997 & Aug 31-Sep 3 & 6 & 18 & 313 & 177 & 178 & 8 & 676 \\
1998 & Sep 17-21 & 6 & 18 & 348 & 71 & 253 & 17 & 689 \\
1999 & Sep 9-15 & 6 & 18 & 346 & 14 & 17 & 0 & 377 \\
2000 & Sep 25-29 & 6 & 18 & 599 & 5 & 10 & 0 & 614 \\
2001 & Sep 17-20 & 6 & 18 & 675 & 33 & 5 & 0 & 713 \\
2002 & Sep 11-14 & 7 & 21 & 595 & 67 & 4 & 1 & 667 \\
2003 & Oct 21-26 & 7 & 21 & 824 & 44 & 35 & 0 & 903 \\
2004 & Sep 15-18 & 7 & 20 & 699 & 69 & 52 & 7 & 827 \\
2005 & Sep 1-4 & 7 & 19 & 202 & 24 & 21 & 3 & 250 \\
2006 & Sep 19-26 & 6 & 17 & 728 & 22 & 4 & 0 & 754 \\
\hline & Total & & & $\mathbf{1 2 , 1 7 4}$ & $\mathbf{2 1 2 8}$ & $\mathbf{1 6 1 4}$ & $\mathbf{1 1 6}$ & $\mathbf{1 6 , 0 3 2}$ \\
& \% by age & & & $\mathbf{7 6 \%}$ & $\mathbf{1 3 \%}$ & $\mathbf{1 0 \%}$ & $\mathbf{1 \%}$ & \\
\hline
\end{tabular}

\section{Size and length-at-age}

Trawl and spawner sampling showed four modes at fork lengths of $58 \mathrm{~mm}, 128 \mathrm{~mm}, 221$ $\mathrm{mm} 251 \mathrm{~mm}$, which correspond to age groups $0-3$, respectively (Fig. 7.6b). There was some overlap in size of age 2 fish when compared with the size of the Meadow Creek spawners, so it is possible that a few spawners were age $2+$. As in previous years most kokanee were captured at the northern end of the lake (stations 1-4). Large numbers were also captured at station 7 while the central area (stations 5-6) had the lowest numbers (Table 7.3). The mean length-at-age increased for all age groups between 2005 and 2006 and even age $0+$ that rarely change in size increased slightly (Fig. 7.7).

Unlike 2005, the mean size of South Arm fish captured in 2006 was larger for all age groups than those same age groups caught in the North Arm (Table 7.4). 
Table 7.3. Kokanee catch statistics from the September 2006 trawl surveys.

\begin{tabular}{|c|c|c|c|c|c|c|c|c|}
\hline \multirow[t]{2}{*}{ Survey time } & \multirow[t]{2}{*}{ Section } & \multirow[t]{2}{*}{ Station } & \multirow[t]{2}{*}{ Hauls } & \multicolumn{5}{|c|}{ Number of fish caught } \\
\hline & & & & Age 0 & age 1 & age 2 & Age 3 & total \\
\hline \multirow[t]{8}{*}{ Sept 2006} & North Arm & 1 Johnson & 2 & 142 & 3 & 0 & & 145 \\
\hline & & 2 Shutty Bench & 2 & 186 & 6 & & & 192 \\
\hline & & 4 Woodbury Cr & 3 & 111 & 4 & & & 115 \\
\hline & South Arm & 5 Wilson Creek & 3 & 69 & 4 & 2 & & 75 \\
\hline & & 6 Rhinoceros Pt & 3 & 60 & 2 & 1 & & 63 \\
\hline & & 7 Redman Point & 3 & 160 & 3 & 1 & & 164 \\
\hline & & Both arms & & 728 & 22 & 4 & & 754 \\
\hline & & Proportion by age & & $97 \%$ & $3 \%$ & $<1 \%$ & & \\
\hline
\end{tabular}

Table 7.4. Size statistics from trawl captured kokanee September 2006.

\begin{tabular}{cllrrrr}
\hline Survey time & Basin & Station & age 0 & age 1 & age 2 & age 3 \\
\hline Sept 2006 & North Arm & Ave. length (mm) & 56 & 126 & & \\
& & Length range (mm) & $40-77$ & $101-158$ & & \\
& & 5.38 & 21.01 & & \\
& & Standard deviation & 439 & 13 & 0 & 0 \\
\cline { 3 - 7 } & Sample size (n) & 61 & 136 & 233 & \\
& South Arm & Ave. length (mm) & $47-77$ & $104-154$ & $227-235$ & \\
& & Length range (mm) & 7.73 & 24.60 & 4.44 & \\
& & Standard deviation & 289 & 4 & 0 \\
\hline
\end{tabular}

\section{Age-at-maturity}

Trawl caught kokanee provide the best opportunity for age analysis as distinct modes are evident for ages $0+$ and $1+$, while $2+$ and older fish can be verified by scale analysis (Fig. 7.6 a,b). The Meadow Creek spawner length frequency distributions have been superimposed on the frequency distribution of the 2005 and 2006 trawl-caught fish to illustrate that four age groups make up the majority of kokanee in Kootenay Lake. Analysis of the size-at-age data (Fig. 7.7) and the length-frequency distribution (Fig. 7.6) supports the assumption that the majority of kokanee that spawned in Meadow Creek in 2006 were age 3+. The overlap evident between ages 2+ and 3+ in 2005 (Fig. 7.6a) was not as pronounced in 2006 (Fig. 7.6b) but this overlap does suggest that some age 2+ fish might have also matured and spawned.

While the 2006 age-at-maturity of predominately age 3+ is consistent with other Kootenay Lake studies there have been some exceptions. Initially it was Vernon (1957) who reported that virtually $100 \%$ of North Arm kokanee matured at age 3+. Martin (1984) reaffirmed that most North Arm kokanee spawn at age 3+. However, Thompson (1999) observed a shift in age-at-maturity of Meadow Creek fish from 1993-1996. Although Thompson found the dominant age-at-maturity remained age 3+ from 19891992, a higher percentage (ranging from 15-42\%) of 2+ fish were evident from 19931996, as well as a greater contribution of 4+ fish. These results are not surprising given the significant changes to lake productivity that occurred at the time these cohorts were growing in Kootenay Lake. As growth slowed due to the unproductive state of the lake in

Kootenay Lake Fertilization Experiment, Year 15 (North Arm) and Year 3 (South Arm) 182 (2006) Report 
the late 1980s, some delay in maturation would be expected. The accelerated growth and earlier age of maturation noted by Thompson (1999) in the early 1990s was likely due to a combination of low kokanee densities and lake fertilization. The same growth response and shift in age-at-maturity was noted in Upper Arrow Reservoir kokanee soon after the fertilization operation began in 1999 (Pieters et al. 2000).

The age of Meadow Creek kokanee was re-examined from 2004 samples and the majority were determined to be age 3+ (J. Burrows, Senior Fisheries Biologist, Ministry of Environment, Nelson BC, pers. comm.) A return to a dominant age of 3+ at maturity would be expected due to the higher densities of kokanee in the lake and greater competition for food.

\section{Hydroacoustic Abundance Estimates}

The long term hydroacoustic surveys on Kootenay Lake provide considerable insight into changes that have taken place before and after lake fertilization. Nighttime surveys of the limnetic zone of the main lake portion of Kootenay Lake have been conducted in a standardized manner since 1991. As well, comparable manual echo counts date back to 1985. Initial surveys in the late 1980s and early 1990s, indicated total numbers were low, not exceeding 15 million (Fig. 7.8). Within two years of lake fertilization commencing in 1992 there was a sizeable increase in total numbers, surpassing 35 million by 1994. This increase was mainly due to rapid growth at the onset of fertilization (i.e., a classic density-growth response to favourable in-lake conditions), which resulted in a peak of both fecundity and total egg deposition in 1993 (Fig. 7.3). Most of the numerical increase in 1994 was observed in age 0+ fish, although ages 1-3+ fish had also increased slightly. Meadow Creek fry production remained high for three consecutive years (i.e., 19941996, Fig. 7.4) which led to increased numbers of ages 1-3+ fish after two years (i.e., 1996-1998) (Fig. 7.9). The higher numbers of ages 1-3+ fish correlate with a three-year period of lower growth and lower fecundity, suggesting that a combination of increased competition from ages 1-3 fish and decreased fertilization in the late 1990s led to smaller adults and reduced fry production (Figs.7.3, 7.4, 7.9). Reduced number of fry during 1997-2000 was followed by lower numbers of ages 1-3+ fish, again with a two-year lag time. Similar to 1992-1995, the relatively low numbers of ages 1-3 fish in 1999-2001 were consistent with a period of rapid growth and increase in spawner size and fecundity (Figs. 7.3, 7.9).

Total abundance increased substantially from 2001-2003 ranging from 25-35 million (Fig. 7.8). These increases were most likely due to the combined result of increased fry production (Fig. 7.4) and improved rearing conditions from increased fertilizer loadings that began in 2001. Following two lower years when numbers were $\sim 16$ million the 2006 estimate increased to 22 million. The 2006 estimate indicates an increase in fry and ages 1-3 from the low recorded in 2004. The reason(s) for the lower late summer fry estimates in 2004 and 2005 is not obvious since Meadow Creek fry production remained relatively high. The spawning channel produces the majority of fry for the North Arm and there is generally a good relationship between the fall fry acoustic estimates and Meadow Creek production (Fig. 7.10). This relationship $\left(\mathrm{R}^{2}=0.80\right)$ suggests that fry survival rates over

Kootenay Lake Fertilization Experiment, Year 15 (North Arm) and Year 3 (South Arm) 183 (2006) Report 
the summer period has been quite consistent from year to year. Note the obvious outlier(s) represented by the 2005 (and 2000) data in Figure 7.10 that suggests poor survival during summer 2005, a major departure from other years. The 2006 data again shows a strong relationship.

Prior to fertilization, kokanee densities in the South Arm tended to be higher during late summer than in the North Arm (Fig. 7.11). During the first seven years of fertilization, North Arm densities were higher than in the South Arm, presumably indicating that fertilization had changed the rearing conditions for kokanee. Commencing in 1999 this trend reversed under reduced fertilizer loadings (Fig. 7.8) but resumed in 2001 as fertilizer loading was increased. There was an immediate increase in North Arm numbers with the return to full fertilization by 2001, and then South Arm numbers increased and remained very high until 2004. North Arm numbers again were appreciably higher through 2006. As noted earlier, although fertilizer loading rates have remained at a high level through 2006, kokanee numbers in the lake declined during 2004 and 2005 but again increased in 2006 (Fig. 7.8).

Distribution of fry along the length of the lake in early summer (see Chapter 8) has usually been highly skewed to the north end since the majority are produced from Meadow Creek and the Lardeau River (Fig. 7.12). As the summer advances all age groups tend to disburse evenly throughout the lake as illustrated by the October 2004 and September 2006 data (Fig. 7.12a and c). The September 2005 pattern was unusual with all age groups highly concentrated at the north end of the lake (Fig. 7.12b). Presumably in 2005 there was ample food in the North Arm to attract all age groups, so movement of fish in a southward direction did not occur to the extent observed in most years.

\section{Kokanee Biomass Estimates}

Total kokanee biomass in the lake can be estimated using the mean weights and numbers determined from trawl and hydroacoustic surveys (see Appendix 7.6 for details). The calculated biomass was converted to $\mathrm{kg} / \mathrm{ha}$ based on known pelagic areas of the lake. Prior to fertilization (1985-1991) the average kokanee biomass density was $\sim 3.5 \mathrm{~kg} / \mathrm{ha}$. Since fertilization (1992-2006) the kokanee biomass densities has increased to an average of $\sim 9.6 \mathrm{~kg} / \mathrm{ha}$, close to a three-fold difference. These estimates generally track the fertilizer loading rates with about a two year lag time.

\section{Fry-to-Adult Survival Rates}

The biomass density estimates shown in Figure 7.13 provide good evidence of the positive impact of fertilization. Growth and survival in the lake also provides evidence of the impact of lake fertilization on kokanee. Relatively high fry-to-adult survival rates usually indicate low total numbers in the lake whereas low survival rates suggest high inlake abundance or unproductive growing conditions. Simple estimates of fry-to-adult survival rates have been determined using long-term data available from Meadow Creek. Clearly, there are some limitations on this methodology due to accuracy of the data (especially fry estimates), and a number of assumptions must be made. However, it is felt

Kootenay Lake Fertilization Experiment, Year 15 (North Arm) and Year 3 (South Arm) 184 (2006) Report 
that such estimates are valid because the data have been collected in a consistent fashion, using the same methods over a long period of time. Although the estimates may not be accurate in all years, the approach does provide a reliable long term trend. The assumptions made in determining survival rates include:

- $\quad$ one dominant age at spawning (i.e., age 3+);

- minimal harvest that does not appreciably influence escapement levels;

- natural stream egg-to-fry production of 5-10\% used for fry estimates above and below the Meadow Creek spawning channel.

Age data from the trawl samples and spawners support the assumption that the majority of fish mature at age 3+. Therefore, fry-to-adult survival rates have been calculated on the basis of age 3+ at time of spawning. It should be noted that even if these fish spawned as a mix of ages or at a dominant age (e.g., at age $2+$ ), the long-term trend of calculated fry-to-adult survival rates would illustrate the same general pattern.

In 2006 the spawners were primarily the progeny of parents from the spawning year 2002, although, as mentioned, some may have been age 2+ from the 2003-2007 cycle. In 2002, 0.35 million spawners returned to Meadow Creek and produced an estimated 18.3 million fry that resulted in a return of 0.37 million spawners. Therefore, the fry-to-adult survival rate for this cohort (2002-2006 cycle) was $2.0 \%$ (Fig. 7.14). This low survival rate does not equate to poor growing conditions in the lake. On the contrary, high spawner numbers that grew in the lake the preceding four years should result in lower fry-to-adult survival rates. The more important issue and one of the objectives of lake fertilization is to produce high spawner numbers which ensures an adequate food supply for large piscivores. The high survival rate calculated for 1994 was a result of fewer fish in the lake during 1989-1992, especially 1991, while the much lower rates from 20002002 were the result of very high spawner numbers during 1996-1999. The 2006 survival rate represents the lowest rate in three decades following very high spawner escapements from 2003-2005.

Survival rates in the four years prior to fertilization was $\sim 6.5 \%$ and reflects lower numbers growing in the lake during the late 1980s, while the survival rates have been < 4\% during the 2000s when kokanee abundance was much higher. It should be mentioned that the average survival rate since fertilization began has been $5 \%$, while some historic data from the 1970s indicate the survival rate was much higher at $\sim 12 \%$. The possible reasons for this large difference are discussed below.

\section{Recruit-Spawner Relationship}

The relationship between parents and offspring over a number of generations provides some valuable insights into how kokanee respond to coarse-scale changes in productivity. A generalized stock-recruitment relationship can be generated from the Meadow Creek spawning channel data based on 15 cycles of relatively consistent enumeration. This analysis assumes that the dominant age of spawners was 3+ and that the sport catch has

Kootenay Lake Fertilization Experiment, Year 15 (North Arm) and Year 3 (South Arm) 185 (2006) Report 
been minimal. The escapements to Meadow Creek during the last three years have exceeded their parental numbers thus replacement levels have been $>1.0$ (Fig. 7.15). This is in contrast to the 2000-2003 escapement years when replacement was not achieved (i.e., fewer recruits than spawning parents) owing to reduced fertilizer loadings in the late 1990s.

Lardeau River escapements for years when data are available (data on file, MOE, Nelson BC) also suggest that kokanee numbers increased throughout most of the 1990s. The cycles from 1994-2000 exceeded replacement levels, but the cycles from 2001-2003 did not achieve replacement, similar to the lack of replacement measured in Meadow Creek (Fig. 7.15). Lardeau River replacements have been achieved for the last three years. Caution is advised with this data interpretation since the Lardeau River estimate is a single count and, therefore, is subject to many sources of error.

\section{Discussion}

\section{Escapements}

Kootenay Lake experimental fertilization has now been underway for fifteen years and has evolved into a major restoration program. The long-term data set available for Meadow Creek kokanee escapements and fry production estimates provides an excellent opportunity to evaluate the numerical and biological responses of this pelagic species to fertilization. Since the mid-1960s, kokanee spawner numbers returning to Meadow Creek have been monitored as part of a long-term assessment of a spawning channel that was constructed on this system in 1967. Spawner numbers have been estimated as high as $\sim 1.4$ million and as low as $\sim 0.2$ million (Fig. 7.1). After only two years of fertilization that started in 1992 there was good evidence that kokanee were responding positively. Total in-lake abundance increased from 10 million to 35 million from 1992-1994. By 1996, escapements to Meadow Creek were $>1$ million, a level not experienced since the late 1970s. There was a decrease in spawner numbers in the early 2000s, but more recently (2003-2006) escapements have increased, exceeding 1 million in two of these years. Those increases were predicted based on high fry production from Meadow Creek during the early 2000s (Fig. 7.4) and from the 2002 and 2004 hydroacoustic surveys that indicated high abundance of ages 1-3 fish (Fig. 7.9). Low in-lake abundance acoustic estimates in 2004 and 2005, especially for the age 1-3 group in 2005, foretell lower escapements in 2006 and 2007. The 2006 survey indicates a strong 0+ cohort and some improvement in the age 1-3s and these data suggest that spawner numbers should again be starting to increase by 2008-09. Unlike Meadow Creek, the Lardeau River escapements have not shown large increases during the 2000s. Since lake growing conditions have greatly improved during the last two decades it is most likely that lower Lardeau River egg-to-fry survival rates account for the lack of significant increase to escapements.

Kootenay Lake Fertilization Experiment, Year 15 (North Arm) and Year 3 (South Arm) 186 (2006) Report 


\section{Biological Response to Lake Fertilization}

The biological response of kokanee to varying levels of nutrient additions can be seen by examining data shown in Figures 7.3 and 7.7. There have been two distinct increases in the size-at-age and fecundity data. Prior to fertilization, numbers of kokanee, mean size, and fecundity had all declined (Fig. 7.3). These changes triggered the fertilization experiment as it was quite evident that the decrease in lake productivity would otherwise be permanent (Daley et al. 1981; Ashley et al. 1997). Shortly after fertilization began, the mid-1990s mean size of adults increased, as did fecundity. These changes occurred due to low numbers of kokanee in the lake growing in an enriched system; by the late 1990s, spawner numbers were again $>1$ million. The lower mean sizes and fecundities recorded from 1996-1999 suggest a density-growth response due to large numbers of fish produced by the 1992-1996 spawners. In previous reports it was noted that increased fecundity and spawner length observed in 2000 and 2001 coincided with the decrease in total spawner abundance (Fig. 7.1), most likely because of reduced fertilizer loadings from 1997-2000. It was believed that the decrease in mean size and fecundity from 20032005 reflected a density-growth response as the whole lake population rebuilt following the increased fertilization that began in 2001. While this view is still held, the acoustic data shows an unexplained and certainly unexpected decrease in fry from 2003-2005 (Fig. 7.9). The 2006 fry estimate was much improved suggesting an in-lake survival problem for the 2004 and 2005 fry cohorts. In previous reports it was predicted that increased fish size and fecundity observed in the 1990s and 2000s would decline and stabilize close to the long-term average as the abundance of kokanee reached the lake's carrying capacity. While this prediction is still valid such stability has yet to occur since the 2004-2006 acoustic data and 2006 escapement data indicates some problems still exist with survival in the lake (see discussion below). Total in-lake abundance in 2004 and 2005 was comparatively low ( 16 million) although the estimate of about 22 million in 2006 and increased fry numbers does signal improvement.

Trawl caught kokanee provide an excellent size-at-age record of how each age group has responded to fertilization and variation in loading rates. Ashley et al. (1997) initially pointed out that growth of fry and 1+ fish has not changed appreciably since the fertilization experiment began (Fig. 7.7). This remains the case for fry with little size variation evident before and after fertilization (Fig. 7.7). Size data for age 1+ kokanee also does not show any real change before and after fertilization as a result of large natural variations in size that are fairly typical for age $1+$ kokanee in many BC lakes.

Lake fertilization and variation in the loading rates is definitely reflected in size and growth of the $2+$ and $3+$ fish. Growth rates for the older age kokanee (i.e. age 3+) increased in concert with the fertilization program for the spawner years 1991-1993 (Figs. 7.1, 7.3, 7.7), but then declined during 1994-1997, most likely reflecting intraspecific competition as total in-lake abundance of ages 1-3+ fish increased (Fig. 7.9). Growth rates for mature fish for year classes 1999 to 2001 increased probably because of lower total lake densities of ages 1-3+ fish and resulting decrease in the number of spawners during this period. From 2003 to 2005 the mature fish have been more abundant and have grown at a fairly constant rate. A change occurred again in 2006 with

Kootenay Lake Fertilization Experiment, Year 15 (North Arm) and Year 3 (South Arm) 187 (2006) Report 
the spawners much larger, females far more fecund but fewer of them. The acoustic data for 2004-2005 confirmed lower in-lake abundance that resulted in a much smaller 2006 escapement. The data predicts that 2007 escapements will be low or lower than 2006. The trawl and acoustics data combined with spawner size data demonstrates quite clearly that ages $2+$ and $3+$ fish in terms of growth appear to benefit the most from fertilization.

\section{In-Lake Abundance, Growth and Biomass}

Increased lake productivity due to fertilization provided instant, excellent growing conditions especially for ages $2+$ and $3+$ that, combined with low in-lake numbers, resulted in rapid growth and a doubling of average fecundity. These conditions led to record numbers of fall fry (>30 million) by 1994 (Fig. 7.9) and resulted in a dramatic increase in fry-to-adult survival which peaked at $>15 \%$ in 1994 . As the older age classes built up (1995-98) the spawner size, fecundity, and fry-to-adult survival rates all declined indicating a strong density-dependent response. This response was most likely heightened by a concurrent reduction in fertilization rates from 1997-2000 which contributed to a very rapid decline in population abundance by 1999 and 2000 (Figs 7.8, 7.9). Since 2001, full fertilization has continued and in-lake abundance again increased before inexplicably declining in 2004 and 2005. During this time estimated fry-to-adult survival rates increased as populations initially built from low levels under enriched conditions. The lower numbers in 2004 and 2005 led to a downturn in egg-to-fry survival in 2006 pointing to in-lake survival as a more probably cause than recruitment limitations. However, the phytoplankton and zooplankton data for these two years suggest there was ample food of good quality available (E. Schindler, Research Limnologist, MOE, Nelson $\mathrm{BC}$, pers. comm.), so some other factors must have been at play to account for the decrease in 2005 sub-adult kokanee numbers (Fig. 7.9). Predation is suspected and may have been more effective at reducing kokanee populations in 2005 since the kokanee remained aggregated in the North Arm fertilization zone into late summer, which is unusual. Caution must be used interpreting the egg-to-fry survival index since mortality can occur anytime over the three years prior to adult returns. The peaks in egg-to-fry survival occurred with a two to three year lag over changes (i.e. increases) in productivity since they were calculated from the adult return year.

As noted above, Kootenay Lake's kokanee fry-to-adult survival rates increased from 1992-1994, and this was most likely due to the beneficial influence of lake fertilization that commenced in 1992 (i.e., increased lake productivity including production of preferred zooplankton (Daphnia sp.) resulted in improved kokanee growth). This also occurred on Arrow Lakes Reservoir (Schindler et al. 2006b) when kokanee numbers were initially depressed. Wright et al. (2002) suggested cladocerans with high lipid content were available in higher densities and much later in the growing season under fertilized conditions. This would allow juvenile kokanee to enter the winter months at a relatively high maintenance level, thus allowing them to survive at higher rates than during pre-fertilization conditions. In support of this theory, Steinhart and Wurtsbaugh (2003) discussed the critical nature of lipid content when they measured juvenile kokanee mortality during the winter months in Stanley Lake, Utah. Clarke et al. (2004) examined Lake Pend Oreille kokanee and concluded that cladoceran consumption was lower than

Kootenay Lake Fertilization Experiment, Year 15 (North Arm) and Year 3 (South Arm) 188 (2006) Report 
before mysids had been introduced but that their lipid content was above starvation levels reported in the literature. The decline in Okanagan Lake's kokanee survival rates is suspected to be due to poor-quality phytoplankton (blue-greens) with low fatty acid content being consumed by cladocerans that are, in turn, eaten by juvenile kokanee (Andrusak et al. 2005b).

Scale analysis of the 2006 trawl data confirms that the majority of spawners were again age 3+ (Fig. 7.6, 7.7). In both 2005 and 2006 it is possible that some spawners were age $2+$ as suggested by the overlap in sizes between ages 2 and 3+ (Fig. 7.6). Increased growth can result in a shift to earlier maturation. Conversely during a period of declining lake growing conditions, such as occurred prior to fertilization and to a lesser extent during reduced fertilization, it is likely that kokanee will shift to older age at maturity. Grover (2005) found in Buck Lake (California) where kokanee numbers increased and growth decreased that size at maturity decreased followed by delay in maturation from age $2+$ to age $3+$.

Some anomalies exist with the kokanee data during the fertilization era. Total kokanee abundance in 2004 (Fig. 7.8) based on the acoustics survey was lower than expected at about 16 million, and this was attributed to lower fry production from Meadow Creek in spring 2004 (Fig. 7.4). The relationship between acoustic late summer fry abundance and Meadow Creek fry production has been quite strong (Fig. 7.10; $\mathrm{R}^{2}=0.80$ ). At the time the 2004 data were not considered unusual and could possibly be attributed to delayed density-dependence mortality (or inter-cohort density-dependence mortality) which has been proposed as the cause of sockeye cyclical patterns of dominance (Myers et al. 1997, Ricker 1997, Myers 2001). Levy and Wood (1992) referred to "brood interactions" which cause reduced survival in year class(es) that follow the dominant line. The most likely mechanism for this reduction is competition for food, in which the stronger year class consumes sufficient prey that this impacts the following year class. However when the 2005 acoustics data also indicated very poor summer survival of fry, despite good fry production, the 2005 data point was definitely considered a significant outlier (Fig. 7.10). Despite no obvious change in phytoplankton or zooplankton in 2005, almost 25 million fry produced from Meadow Creek were reduced to only half by the end of the summer, a far greater mortality than expected based on the relationship between Meadow Creek fry and fall fry estimates by hydroacoustics. The longitudinal distribution of fry in 2005 determined by the acoustic survey in September (Fig. 7.12b) was also very unusual, with the majority of fry found in the northern part of the lake. It is possible that these high fry densities in a small portion of the lake were subjected to unusually high predator mortality as mentioned previously. The 2006 acoustic survey showed an increase in fry numbers compared to 2004 and 2005 and there was again a good relationship between fry produced and the fall estimate (Figs. 7.4, 7.10). The 2004 and 2005 anomalies are difficult to explain but the impact of such lower than expected fall fry numbers will have major implications for future escapements unless some compensatory growth and survival occurs in 2007 and 2008.

The most convincing evidence of the beneficial effects of lake fertilization is in estimates of kokanee biomass. There has been nearly a three fold increase in kokanee biomass

Kootenay Lake Fertilization Experiment, Year 15 (North Arm) and Year 3 (South Arm) 189 (2006) Report 
since fertilization began (Fig. 7.13). This increase would likely have been even greater were it not for the deliberate reduction in loading rates in the late 1990s. From 1993-1998 biomass averaged $14.6 \mathrm{kgha}^{-1} \mathrm{yr}^{-1}$ but for the next 8 years it dropped slightly to 12.8 $\mathrm{kg}^{-1} \mathrm{ha}^{-1} \mathrm{yr}^{-1}$ with the decrease almost certainly due to reduced fertilizer loading rates from 1997-2000. Predation will also play a role in determining kokanee abundance and biomass levels.

\section{Meadow Creek Fry Production}

The long term data set for Meadow Creek indicates that fry production from the late 1960s through to the early 1990s was $<15$ million (Fig. 7.4). Fry production was especially low in the 1980s ranging from about 4-10 million . Fry production then increased from10-30 million in the 1990s and 2000s as a result of a combination of improved spawning channel performance (data on file, MOE, Nelson BC) and improved in-lake kokanee growth and survival. Meadow Creek fry-to-adult survival rates were comparatively quite high during the early 1970s (Fig.7.14). These cohorts would have grown in Kootenay Lake when nutrient levels were highly elevated as a result of phosphorus being released into Kootenay Lake from Cominco's fertilizer plant (Daley et al. 1981). The Duncan Dam became operational in 1967 and blocked very large numbers of spawning kokanee ( $>1$ million), resulting in limited spawning success. During the late 1960s and early 1970s, the lake would have been highly productive (Northcote 1973), but it likely received only one half the former numbers of kokanee due to the loss of Duncan River production. In addition, the Meadow Creek spawning channel did not produce large numbers of fry during its initial years of operation (late 1960s and 1970s) (Fig. 7.4). These conditions likely account for the estimated high fry-to-adult survival rates during that time. No fry production estimates were made during most of the 1980s, but in-lake survival rates were likely low during the late 1980s and early 1990s as evidenced by declining escapements (Fig. 7.1) reflecting the period of much reduced nutrient levels in the lake (Daley et al. 1981; Ashley et al. 1997). It is reasonable to conclude that lake fertilization has been primarily responsible for the increases in kokanee production at Meadow Creek since the mid-1990s.

The Meadow Creek spawning channel is obviously the key production centre for Kootenay Lake kokanee. Fry production has been as high as 28 million but generally in recent years it has produced 15-25 million. The relationship between egg deposition and fry production shown in Figure 7.5 appears to be linear suggesting that maximum fry production has not yet been achieved. Attaining maximum egg deposition may not be the most desirable management strategy in all years considering other factors including the demand for eggs elsewhere in the province. Experimentation with spawner numbers in the channel should continue in order to establish production limits of the channel and help establish what optimum levels of production might be over the longer term.

\section{Piscivore Response}

It is well known that Kootenay Lake Gerrard rainbow trout (and bull trout) rely heavily on kokanee (Andrusak and Parkinson 1984), and for this reason, the fertilization program

Kootenay Lake Fertilization Experiment, Year 15 (North Arm) and Year 3 (South Arm) 190 (2006) Report 
has been aimed at increasing kokanee numbers to ensure conservation of these top predators. Andrusak and Andrusak (2006) reported that the condition and growth of sport-caught rainbow trout in 2004 had vastly improved compared to data analyzed from the 1960s and 1980s. As well, rainbow trout angler success rates have been steadily improving during the 2000s, and spawner counts in the Lardeau River at Gerrard BC for the last three years have been well above the 41-year average (data on file, MOE, Nelson $\mathrm{BC}$ ). Anglers also report an increase in catch of bull trout, which is supported by the annual Kootenay Lake angler survey results (data on file, MOE, Nelson BC). Given all of these changes, it is quite possible that the predator populations have increased to the point where they are imposing significant predation on the kokanee, especially the older kokanee, and that predation may now regulate kokanee abundance as much as lake productivity. This "top down" effect by predators has been described by a number of authors (Carpenter et al. 2001, Hyatt et al. 2004, Perrin et al. 2006) and may partly explain why the acoustic data are predicting lower escapements in 2007.

\section{Lake Productivity}

Northcote (1973), Daley et al. (1981), and Ashley et al. in Murphy and Munawar (1999) have all described a number of major changes to Kootenay Lakes' productivity. During the last four decades there have been four significant perturbations affecting lake productivity: eutrophication during the 1960s, oligotrophication during the 1970s, ultraoligotrophication during the 1980s followed by a return to productive oligotrophy in the 1990s and 2000s. These events are illustrated quite well by analyzing the North Arm kokanee recruit-spawner relationships (Fig. 7.15). Through most of the 1970s, replacement levels were achieved when the lake was in a highly productive state but the spawning channel was producing comparatively low fry numbers. During this period, all of the kokanee year classes replaced themselves. The end of the 1970s to the late 1980s was a period when replacement levels were not attained, probably for two very different reasons. First, lake productivity began to decline by the late 1970s (Daley et al. 1981), largely due to the negative impacts of the Duncan and Libby dams (Larkin 1998). Second, spawning channel production was increasing, so in-lake competition kept fish size and fecundity below average (Fig. 7.4). In other words, kokanee production increased for a short period of time while lake productivity was declining.

The third productivity event occurred during the late 1980s and early 1990s when the lake became extremely unproductive and escapement levels fell to record lows with four successive kokanee cycles failing to replace themselves. The fourth event that is on-going due to lake fertilization has seen the swift recovery of kokanee with replacement easily accomplished for two consecutive cycles (1992-1999). Deliberate reduction of nutrient loading resulted in low escapements from 2000-2002 with these cohorts not replacing themselves. The recruit:spawner ratios for Meadow Creek from 2001-2003 were the lowest recorded since 1989, with the 2002 return the lowest on record since fertilization began (Fig. 7.14). The in-lake abundance estimates (Figs. 7.8, 7.10) indicated that increased numbers of age 1-3+ fish were present by 2001 and 2002 once the fertilizer loading was again increased. Escapements increased from 2003-2005 with replacement

Kootenay Lake Fertilization Experiment, Year 15 (North Arm) and Year 3 (South Arm) 191 (2006) Report 
levels exceptionally high. Escapements decreased in 2006 with replacement levels slightly above one.

\section{Summary}

The wealth of information gathered on Kootenay Lake over the course of the fertilization experiment points to a highly successful program. Kokanee biomass has increased, spawners have once again reached near record numbers, mysid numbers have remained constant if not slightly lower (see Chapter 6 in this report), and there is growing evidence that Gerrard rainbow trout are benefiting.

\section{Acknowledgements}

Funding was provided by the Fish and Wildlife Compensation Program - Columbia Basin. Thanks to Don Miller and Mike Lindsay of Kootenay Wildlife Services Ltd for conducting the trawl surveys and to George Scholten (MoE Victoria) and Patricia Woodruff (BCCF) for analyses of acoustic and trawl data.

\section{References}

Acara, A.H. 1970. The Meadow Creek Spawning Channel. Unpublished MS. Department of Recreation and Conservation, Fish and Wildlife Br., Victoria, BC.

Andrusak, H. 1987. Kootenay Lake Sport Fishery 1984-86. Unpublished MS, Fisheries Branch, Nelson, BC Report No. KO-19 31 pp.

Andrusak, H. and E.A. Parkinson. 1984. Food Habits of Gerrard Stock Rainbow Trout in Kootenay Lake, British Columbia. B.C. Ministry of Environment, Fish and Wildlife Branch, Fisheries Technical Circular No. 60.

Andrusak, H., S. Matthews, I. McGregor, K. Ashley, R. Rae, A. Wilson, J. Webster, G. Andrusak, L. Vidmanic, J. Stockner, D. Sebastian, G. Scholten, P. Woodruff, B. Jantz, D. Bennett, H. Wright R. Withler and S. Harris 2005. Okanagan Lake Action Plan Year 9 (2004) Report. Fisheries Project Report No. RD 111.Fisheries Management Branch, Ministry of Environment, Province of British Columbia.

Andrusak, H., and G.F. Andrusak. 2006. Analysis of Gerrard Rainbow Trout Size, Age, Fecundity and Growth Data. Contract report submitted to the BC Ministry of Water, Land, and Air Protection by Redfish Consulting Limited. Nelson, BC.

Andrusak, H., D. Sebastian, G. Scholten and P. Woodruff. 2006. Response of Kokanee and Gerrard Rainbow Trout to Experimental Fertilization of the North Arm of Kootenay Lake, 2002 and 2003. Pages 157 - 181. In Schindler et al., Kootenay Lake Fertilization Experiment, Years 11 and 12 (2002 and 2003), Fisheries Project Report No. RD 114, Ministry of Environment, Province of British Columbia.

Kootenay Lake Fertilization Experiment, Year 15 (North Arm) and Year 3 (South Arm) 
Andrusak, H. and L. Fleck. 2007. Status of Kokanee in the South Arm of Kootenay Lake Prior to Experimental Fertilization. Pages 251 - 272. In Schindler et al. Kootenay Lake Fertilization Experiment, Year 13 (north Arm) and Year 1 (South Arm) (2004) Report, Fisheries Project Report No. RD 117, Ministry of Environment, Province of British Columbia

Ashley, K., L.C. Thompson, D.C. Lasenby, L. McEachern, K.E. Smokorowski, and D. Sebastian. 1997. Restoration of an Interior Lake Ecosystem: The Kootenay Lake Fertilization Experiment. Water Qual. Res. J. Canada 32:295-323.

Ashley, K.I., L.C. Thompson, D. Lombard, J.R. Yang, F.R. Pick, P.B. Hamilton, G. Larkin, D.C. Lasenby, K.E. Smokorowski, D. Sebastian, and G. Scholten. 1999. Kootenay Lake Fertilization Experiment-Year 6 (1997/98) Report. Fisheries Project Report No. RD 65. Ministry of Fisheries, Province of British Columbia.

Binsted, G.A. and K.T. Ashley. 2006. Phosphorus Loading to Kootenay Lake from the Kootenay and Duncan Rivers and Experimental Fertilization Program, Report prepared for the British Columbia Conservation Foundation.

Bull, C.J. 1965. Enumeration of Kokanee Salmon Population on the Lardeau-Duncan River System, 1964. Fish and Wildlife Branch, Victoria, BC.

Carpenter, S.R., Cole, J.J, Hodson J.R., Kitchell, J.F., Pace, M.L., Bade, D., Cottingham, K.L., Essington, T.E, Houser, J.N., and Schindler, D.E. 2001 Trophic cascades, nutrients and lake productivity: whole lake experiments. Ecol. Monogr. 71:163186.

Clarke, L.R., P.S. Letizia, and D. H. Bennett. 2004. Autumn-to-Spring Energetic and Diet Changes among Kokanee from North Idaho Lakes with and without Mysis relicta. North American Journal of Fisheries Management 24(2):597-608.

Craig, R. E., and S. T. Forbes. 1969. Design of a Sonar for Fish Counting. Fisheridirektoratets Shrifter. Series Havundersokelser 15:210-219.

Daley, R.J., E.C. Carmack, C.B.J. Gray, C.H. Pharo, S. Jasper, and R.C. Wiegand. 1981. The Effects of Upstream Impoundments on Kootenay Lake, B.C. Canada Inland Waters Directorate, Research Institute, Scientific Series, West Vancouver, British Columbia.

Grover, M.C. 2005. Changes in Size and Age at Maturity in a Population of kokanee Oncorhynchus nerka during a Period of Declining Growth Conditions. Journal of Fish Biology (2005) 66, 122-134.

Hyatt, K.D., McQueen, D.J., Shortreed, K.S., and Rankin, D.P. 2004. Sockeye salmon (Oncorhynchus nerka) nursery lake fertilization: Review and summary of results. Environm. Rev. 12: 133-162(2004)

Korman, J., C.J. Perrin, and R.C. Wiegand. 1990. Feasibility of Fertilization of Kootenay Lake, North Arm. B.C. Ministry of Environment, 108 pp.

Levy, D.A., and Wood, C.C. 1992. Review of proposed mechanisms for sockeye salmon population cycles in the Fraser River. Bull. Math. Biol. 54:241-261.

Kootenay Lake Fertilization Experiment, Year 15 (North Arm) and Year 3 (South Arm) 193 (2006) Report 
Lindem, T. 1991. Hydroacoustic Data Acquisition System HADAS. Instruction Manual. Lindem Data Acquisition, Lda, Oslo, Norway. 32pp.

Love, R.H. 1977. Target Strength of an Individual Fish at any Aspect. J. Acoust. Soc. Am. 62(6):1397-1403.

Martin, A.D. 1984. An Investigation of the Decline in the West Arm Kokanee Fishery of Kootenay Lake, British Columbia, 1977-78. B.C. Fish and Wildlife Branch, Nelson, B.C. 24 pp.

Murphy, T.P. and M. Munawar. 1999. Aquatic Restoration in Canada. Backhuys Publishers, Leiden.

Myers, R.A. 2001. Stock and Recruitment: Generalizations about Maximum Reproductive Rate, Density Dependence, and Variability Using Meta-Analytic Approaches. ICES Journal of Marine Science, 58: 937-951

Myers, R.A, Bradford, M.J., Bridson, J.M., Mertz, G. 1997. Estimating Delayed DensityDependent Mortality in Sockeye Salmon (Oncorhynchus nerka): A Meta-Analytic Approach. Can. J. Fish. Aquat. Sci. 54: 2449-2462 (1997).

Northcote, T.G. 1973. Some Impacts of Man on Kootenay Lake and Its Salmonids. Great Lakes Fisheries Commission Tech. Rep. 25.

Perrin, C.J., M. L. Rosenau, T. B. Stables, and K. I. Ashley. 2006. Restoration of a Montane Reservoir Fishery via Biomanipulation and Nutrient Addition. North Am. J. Fish. Manag. 26:391-407.

Pieters, R., L.C. Thompson, L. Vidmanic, M. Roushorne, J. Stockner, K. Hall, M. Young, S. Pond, K. Ashley, B. Lindsay, G. Lawrence, H. Andrusak, D. Sebastian, and G. Scholten. 2000. Arrow Reservoir Fertilization Year 1 (1999/2000) Report. Fisheries Project Report No. RD 82. Province of BC Ministry of Environment, Lands and Parks.

Redfish Consulting Ltd. 1999. Performance Evaluation of Six Kokanee Spawning Channels in British Columbia. Ministry of Fisheries, Province of British Columbia, Victoria, BC.

Ricker, W.E. 1997. Cycles of abundance among Fraser River sockeye salmon. Canadian Journal of Fisheries and Aquatic Sciences, 54: 950-968

Rieman, B.E. and D.L. Myers. 1992. Influence of Fish Density and Relative Productivity on Growth of Kokanee in Ten Oligotrophic Lakes and Reservoirs in Idaho. Trans. Am. Fish. Soc. 121:178-191.

Schindler, E. U., K. I. Ashley, R. Rae, L. Vidmanic, H. Andrusak, D. Sebastian, G. Scholten, P. Woodruff, F. Pick, L. M. Ley and P. B. Hamilton. 2006a. Kootenay Lake Fertilization Experiment, Years 11 and 12 (2002 and 2003). Fisheries Report No. 114, Ministry of Environment, Province of British Columbia.

Schindler, E. U., D. Sebastian and H. Andrusak. 2006b. Arrow Lakes Reservoir Fertilization Experiment Summary Report - 1999 to 2004. Fisheries Report No. RD 116, Ministry of Environment, Province of British Columbia.

Kootenay Lake Fertilization Experiment, Year 15 (North Arm) and Year 3 (South Arm) 194 (2006) Report 
Schindler, E.U., R. Rae, K.I. Ashley, L. Vidmanic, D. Sebastian, H. Andrusak, G. Scholten, P. Woodruff, J. Stockner, F. Pick, L.M. Ley, P.B. Hamilton, G.F. Andrusak and L. Fleck. 2007a. Kootenay Lake Fertilization Experiment, Year 13 (North Arm) and Year 1 (South Arm) (2004) Report. Fisheries Project Report No. RD 117, Ministry of Environment, Province of British Columbia.

Schindler, E.U., H. Andrusak, K.I. Ashley, G.F. Andrusak, L. Vidmanic, D. Sebastian, G. Scholten, P. Woodruff, J. Stockner, F. Pick, L.M. Ley and P.B. Hamilton. 2007b. Kootenay Lake Fertilization Experiment, Year 14 (North Arm) and Year 2 (South Arm) (2005) Report. Fisheries Project Report No. RD 122, Ministry of Environment, Province of British Columbia.

Sebastian, D., Andrusak, H., Scholten, and L. Brescia. 2000. Arrow Reservoir Fish Summary. Stock Management Report 2000. Province of BC, Ministry of Fisheries for the Columbia Fish and Wildlife Compensation Program, BC Hydro and Ministry of Environment, Lands and Parks.

Steinhart, G.B. and W.A. Wurtsbaugh. 2003. Winter Ecology of Kokanee: Implications for Salmon Management. Transactions of the American Fisheries Society 132: 1076-1088.

Thompson, L.C. 1999. Abundance and Production of Zooplankton and Kokanee Salmon (Oncorhynchus nerka) in Kootenay Lake, British Columbia during Artificial Fertilization. PHD Thesis, University of British Columbia, Vancouver BC. 252 pp.

Vernon, E. H. 1957. Morphometric Comparison of Three Races of Kokanee (Oncorhynchus nerka) Within a Large British Columbia Lake. Journal of the Fisheries Research Board of Canada 27:1239-1250.

Walters, C.J., J. Digisi, J. Post, and J. Sawada. 1991. Kootenay Lake Fertilization Response Model. Fisheries Management Report No. 98, Ministry of Environment, Province of British Columbia.

Wright, M.E., K.I. Ashley, H. Andrusak, H. Manson R. Lindsay, R.J. Hammond, F.R. Pick, L.M. Ley, P.B. Hamilton, S.L. Harris, L.C. Thompson, , L. Vidmanic, D. Sebastian, G. Scholten, M. Young, and D. Miller. 2002. Kootenay Lake Fertilization Year 9 (2000/2001) Report. Fisheries Project Report No. RD 105 2002. Ministry of Water, Land and Air Protection, Province of British Columbia.

Kootenay Lake Fertilization Experiment, Year 15 (North Arm) and Year 3 (South Arm) 195 (2006) Report 


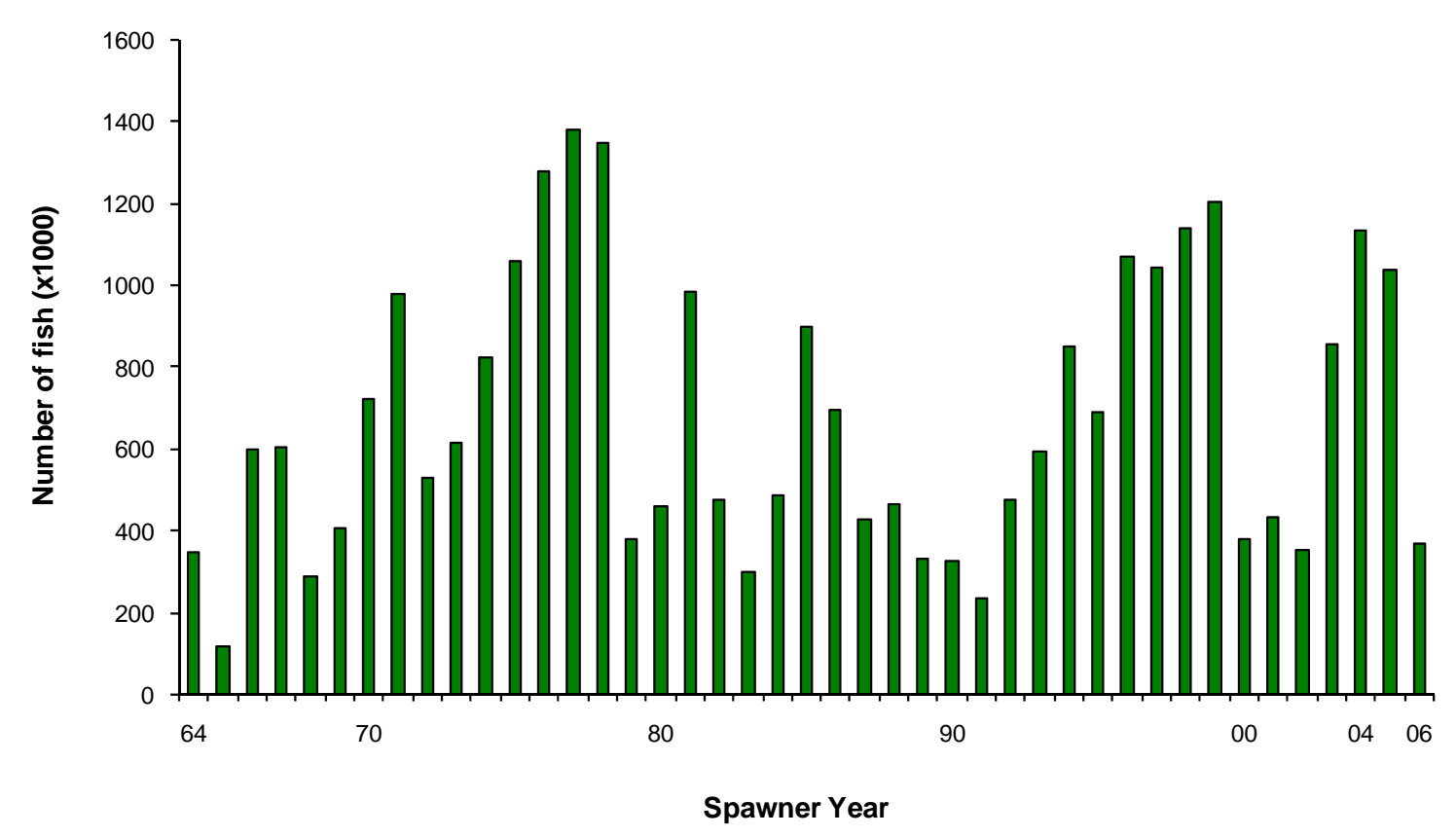

Figure 7.1. North Arm of Kootenay Lake kokanee escapements to Meadow Creek. (Note: 1964-1968 data from Acara 1970).

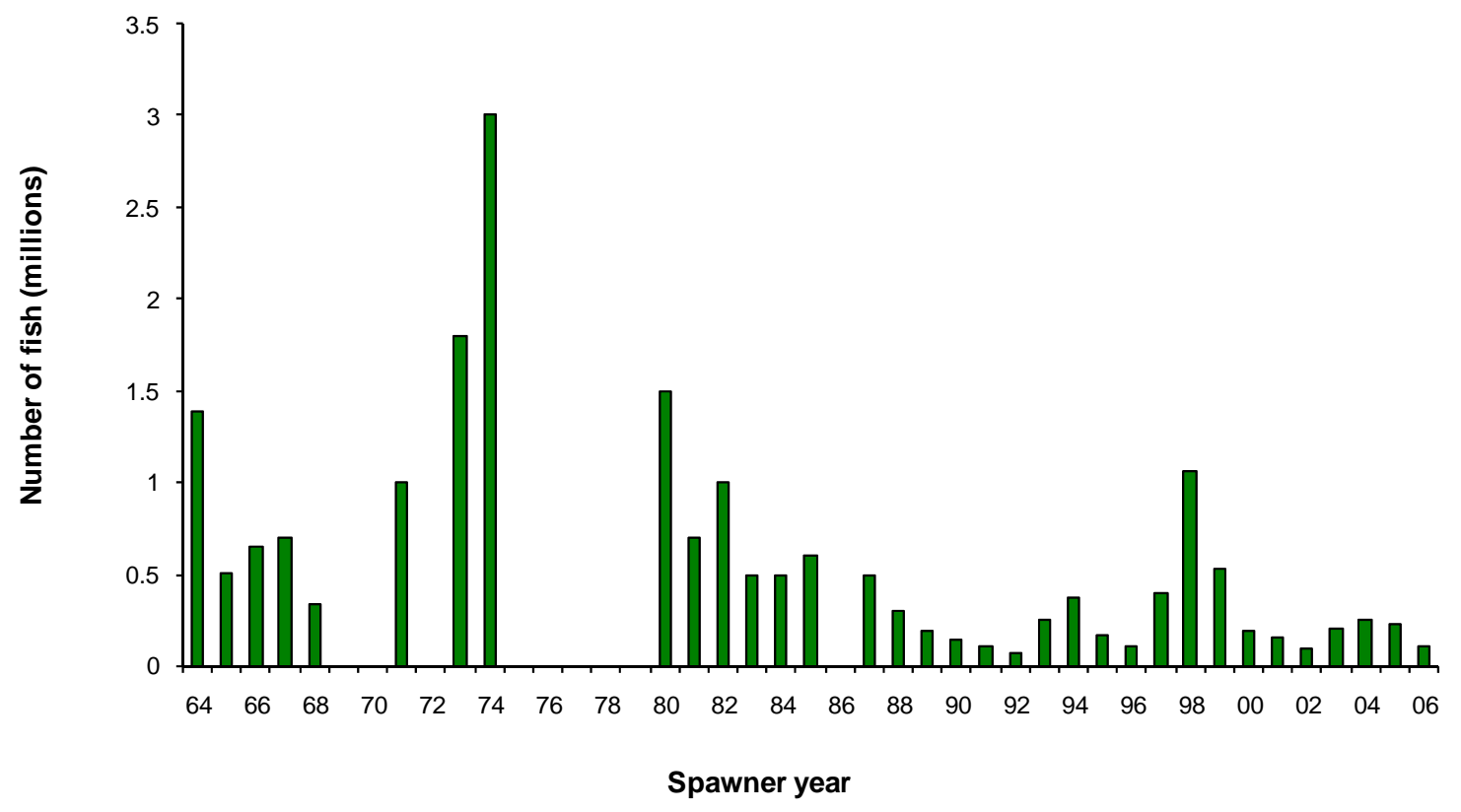

Figure 7.2. North Arm of Kootenay Lake kokanee escapements to Lardeau River 1964 2006. (Note: 1964-1968 data from Acara 1970).

Kootenay Lake Fertilization Experiment, Year 15 (North Arm) and Year 3 (South Arm) 196 (2006) Report 


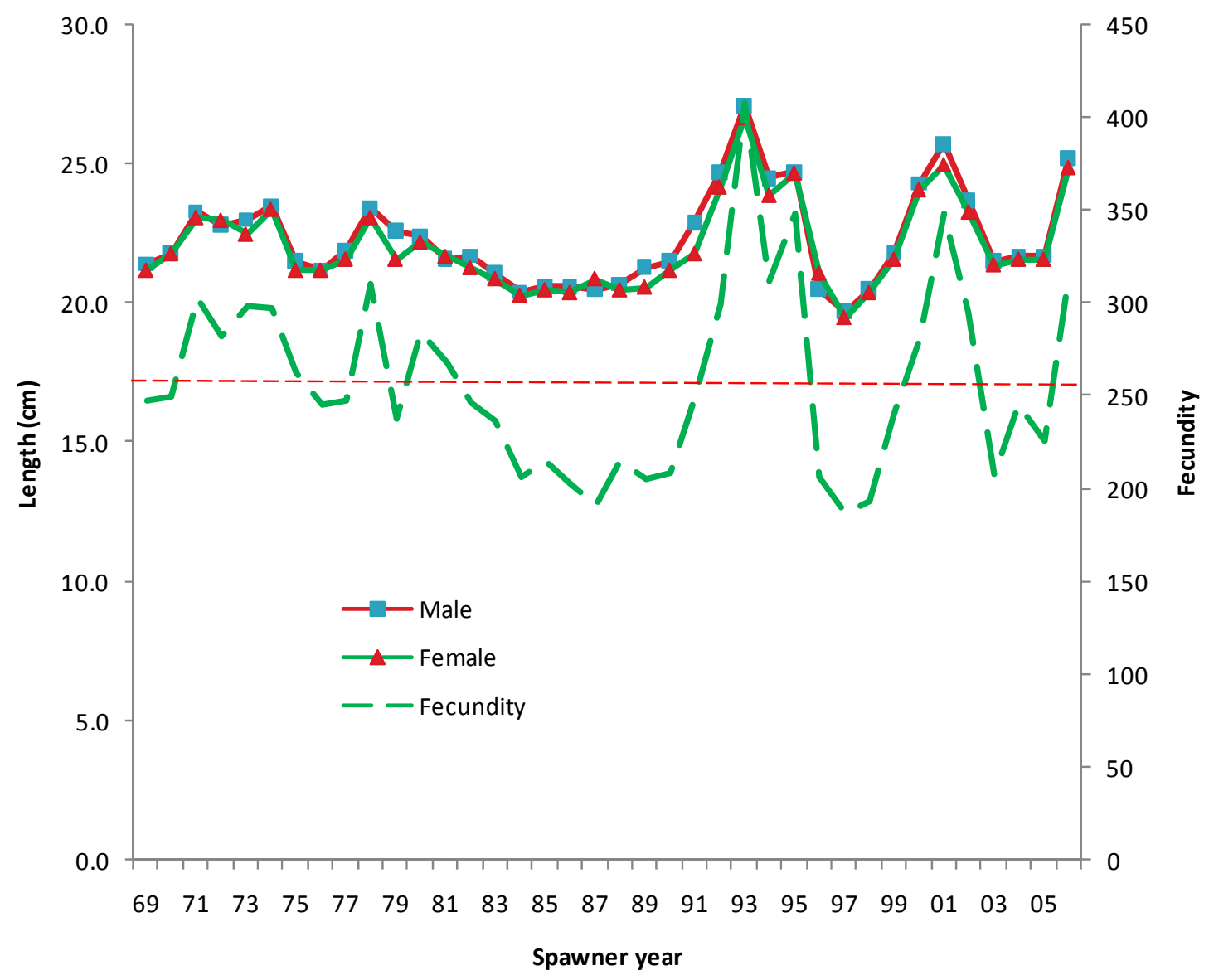

Figure 7.3. $\quad$ Mean length $(\mathrm{cm})$ of Meadow Creek female and male kokanee spawners and fecundity, 1969-2006. Dotted horizontal line illustrates 39-year average fecundity of 259. 


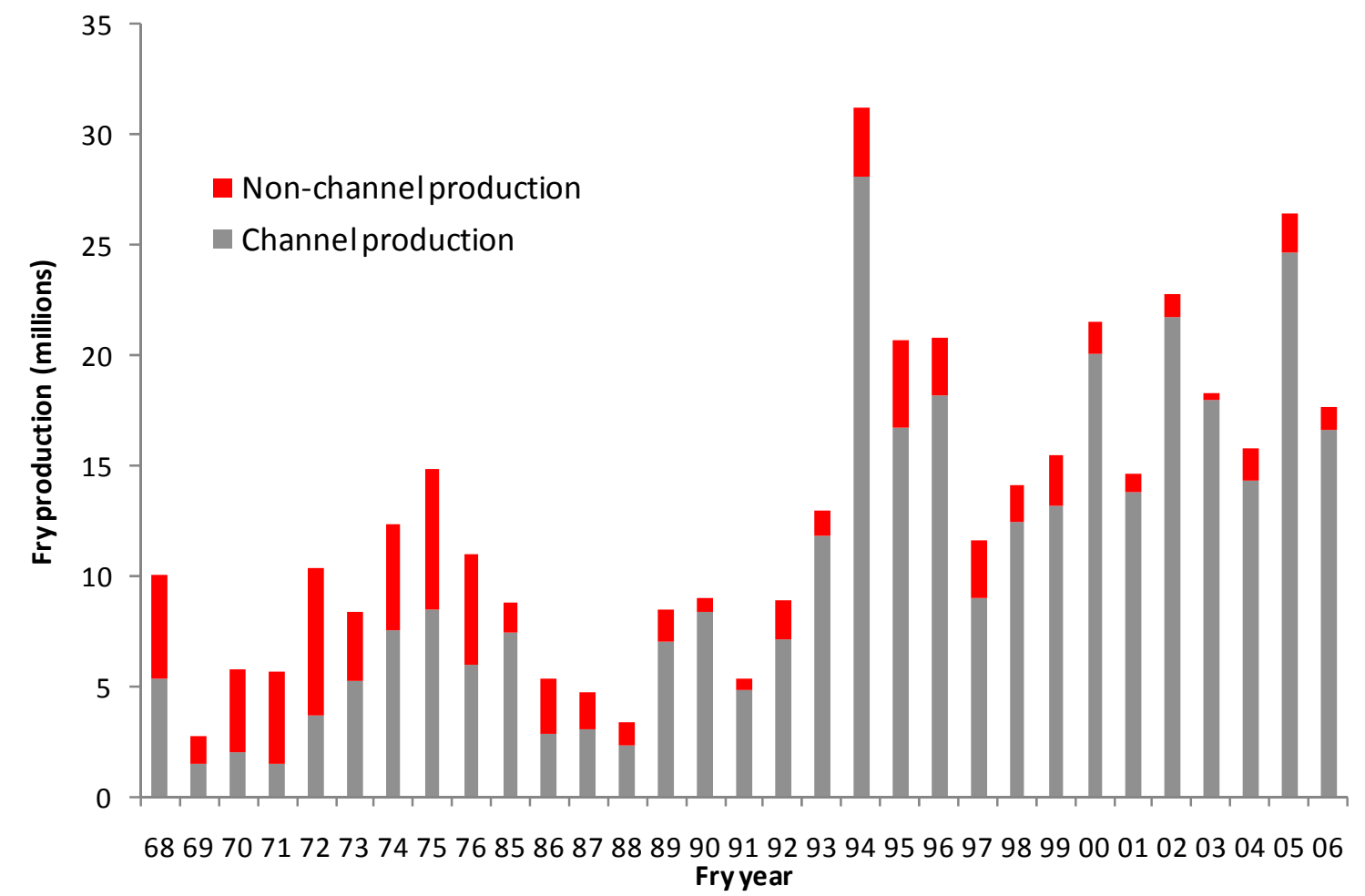

Figure 7.4. Kokanee fry production estimates from the Meadow Creek system and that portion from the spawning channel, 1968-2005.

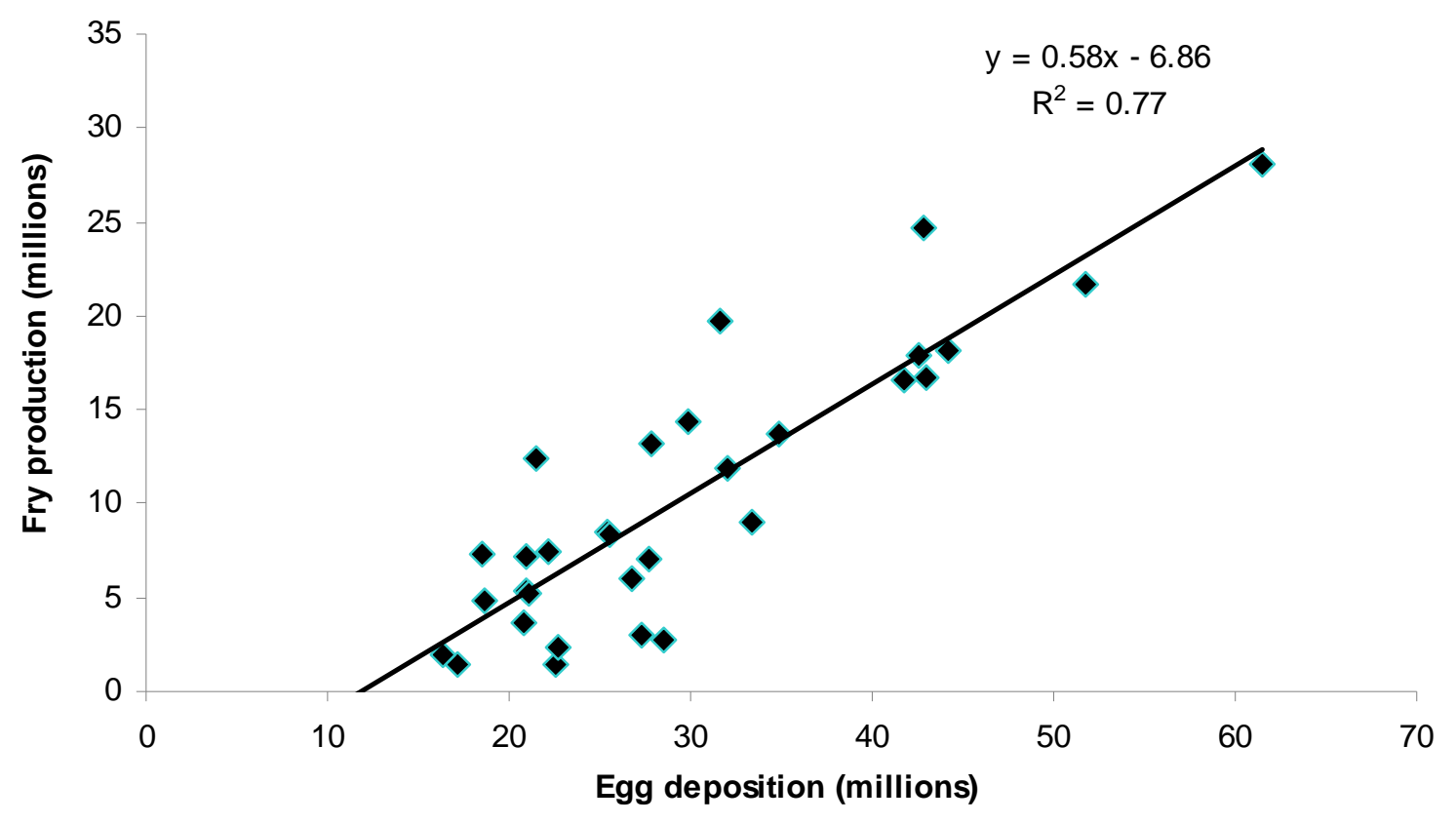

Figure 7.5. $\quad$ Scatter plot of Meadow Creek spawning channel egg deposition vs. fry production for years where data was available 1968-2006.

Kootenay Lake Fertilization Experiment, Year 15 (North Arm) and Year 3 (South Arm) 198 (2006) Report 

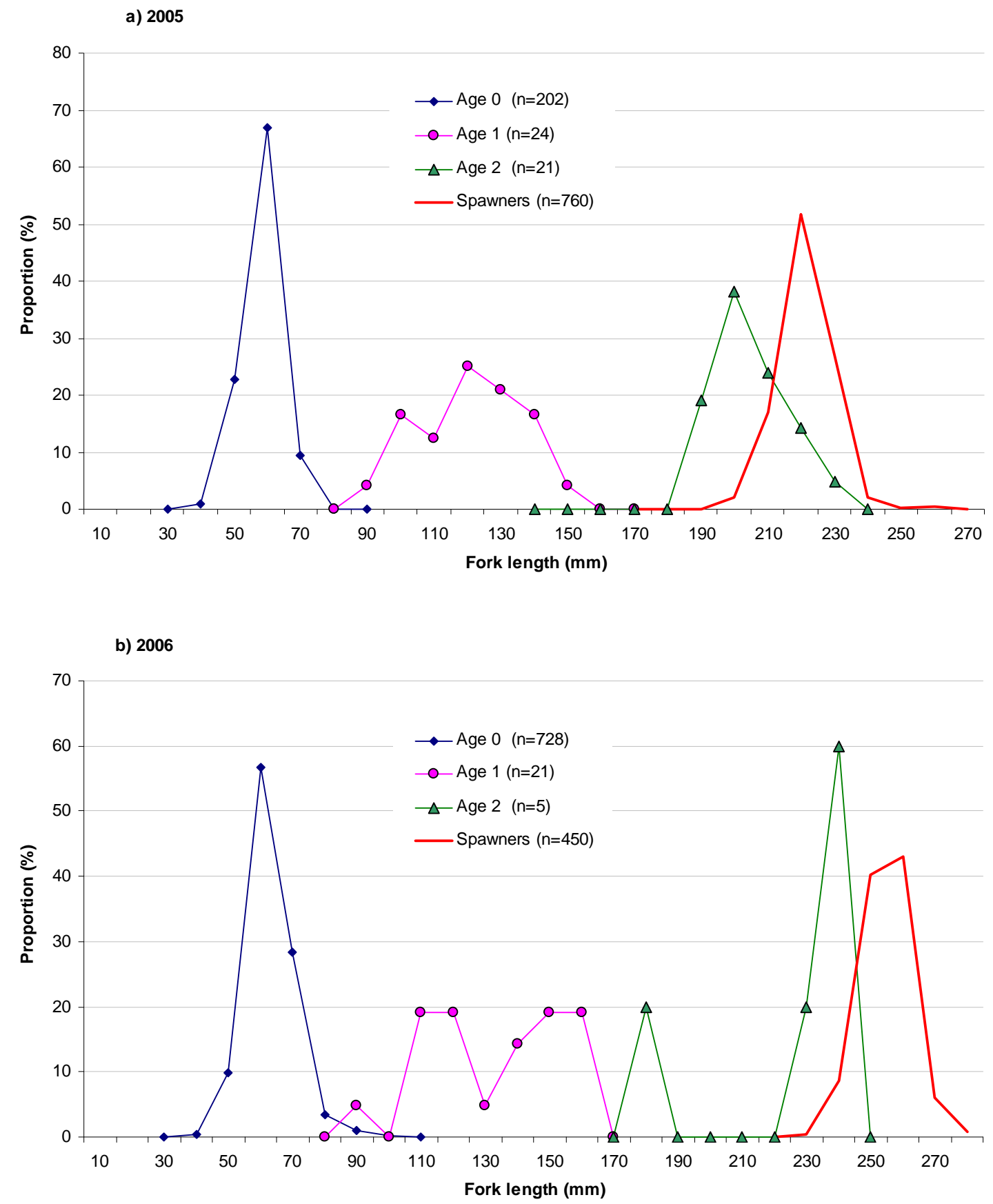

Figure 7.6. Kokanee length-frequency distributions by scale age for trawl-caught fish in Kootenay Lake and returning spawners to Meadow Creek in September 2005 and 2006.

Kootenay Lake Fertilization Experiment, Year 15 (North Arm) and Year 3 (South Arm) 199 (2006) Report 


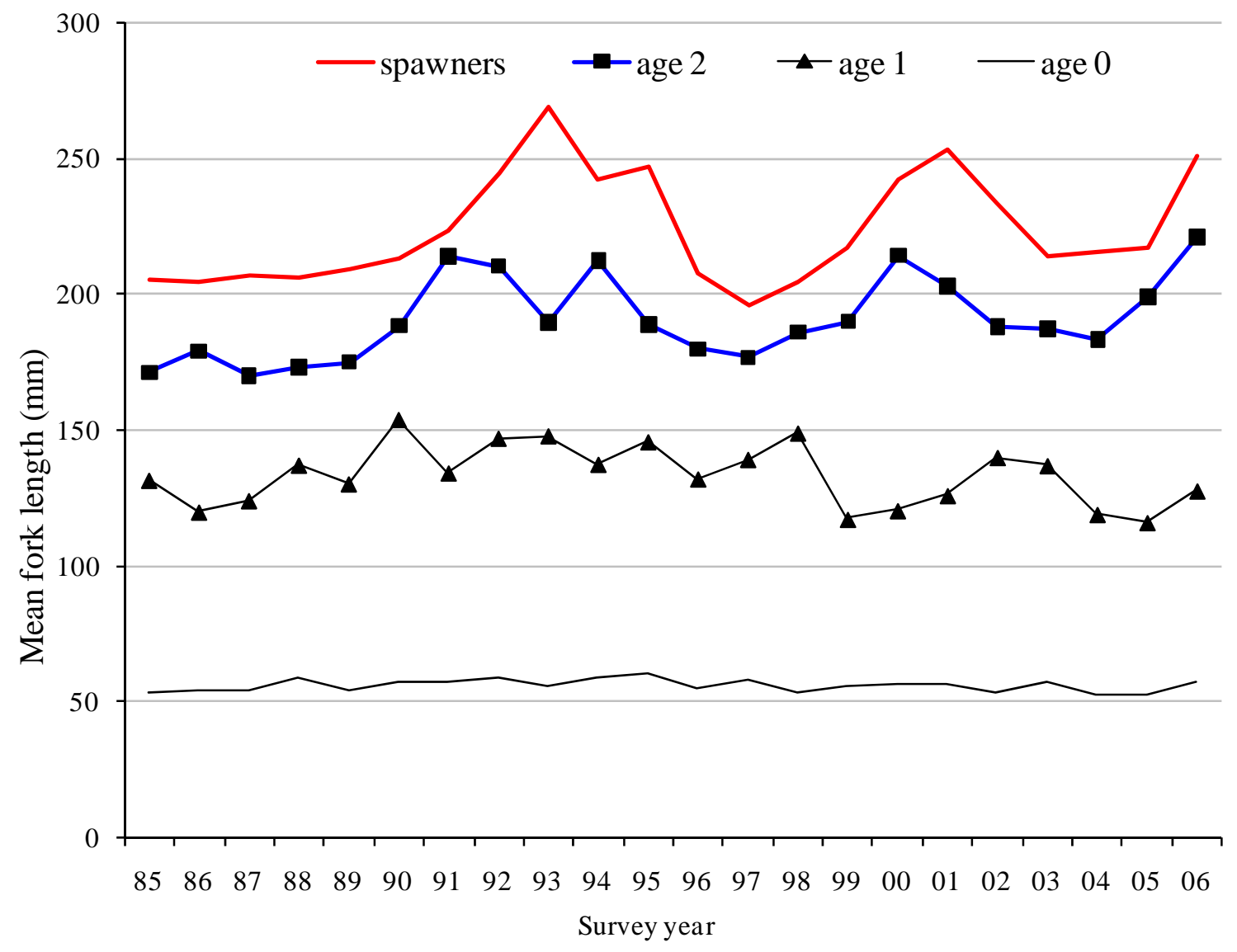

Figure 7.7. Comparisons of trends in kokanee mean length-at-age from trawl captures and Meadow Creek spawner samples.

Kootenay Lake Fertilization Experiment, Year 15 (North Arm) and Year 3 (South Arm) 


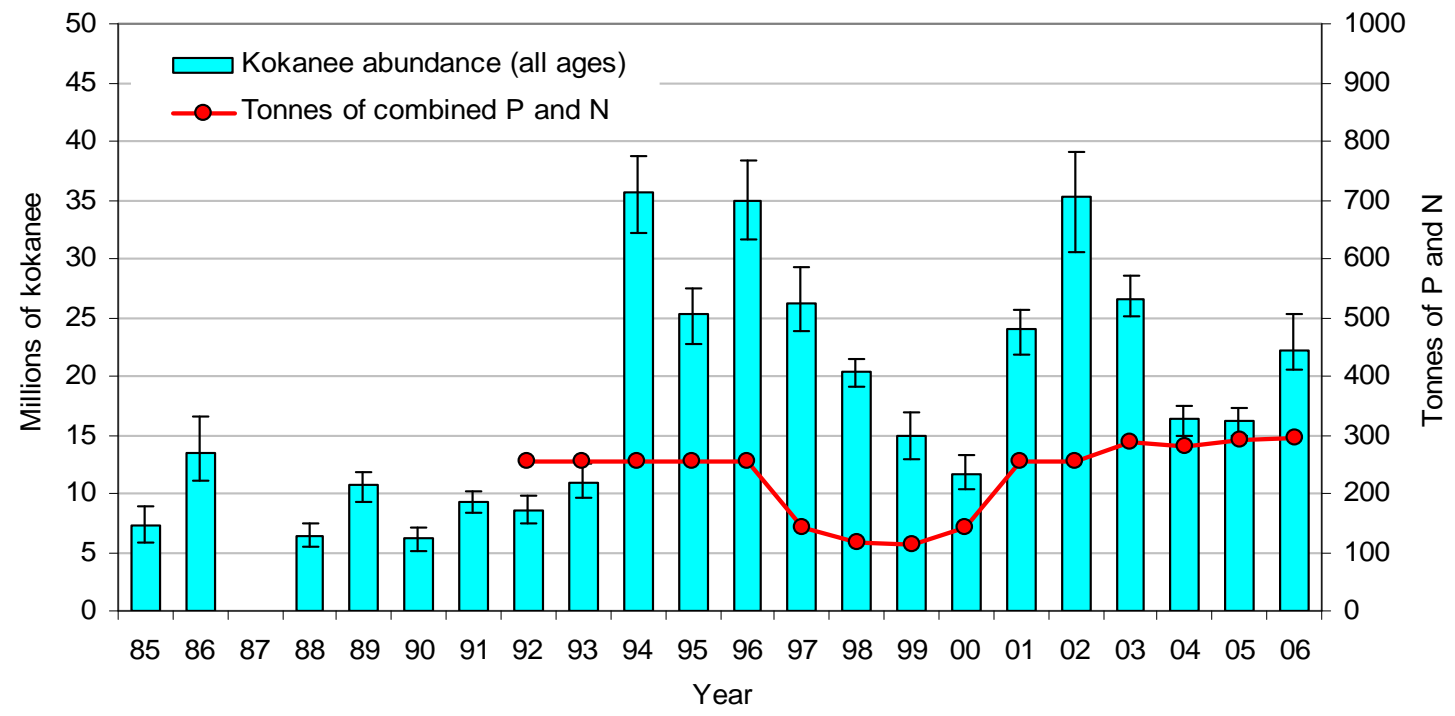

Figure 7.8. Response of in-lake kokanee populations (all ages) to nutrient enrichment, based on acoustic surveys. Error bars represent 95\% confidence limits.

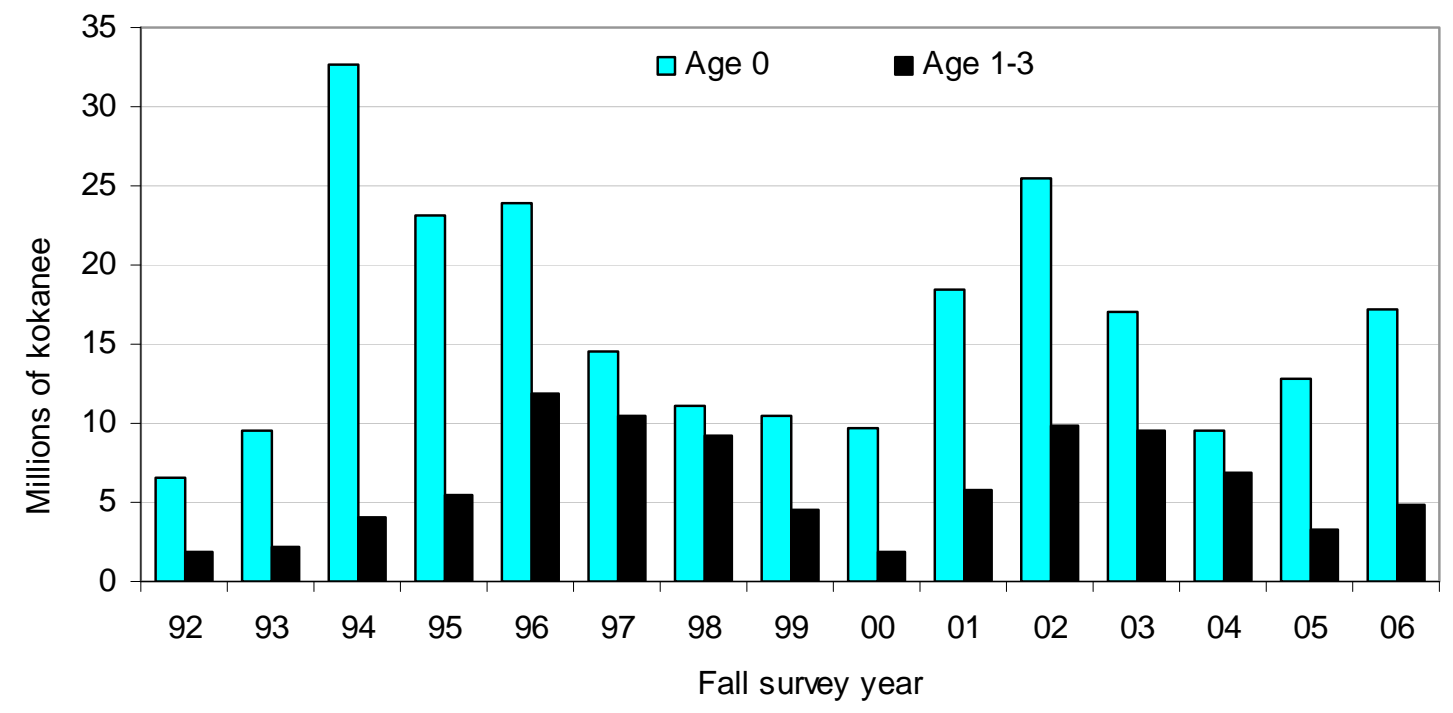

Figure 7.9. Kokanee abundance estimates for age 0 and ages 1-3 kokanee in Kootenay Lake based on fall acoustic sampling 1992-2006.

Kootenay Lake Fertilization Experiment, Year 15 (North Arm) and Year 3 (South Arm) 201 (2006) Report 


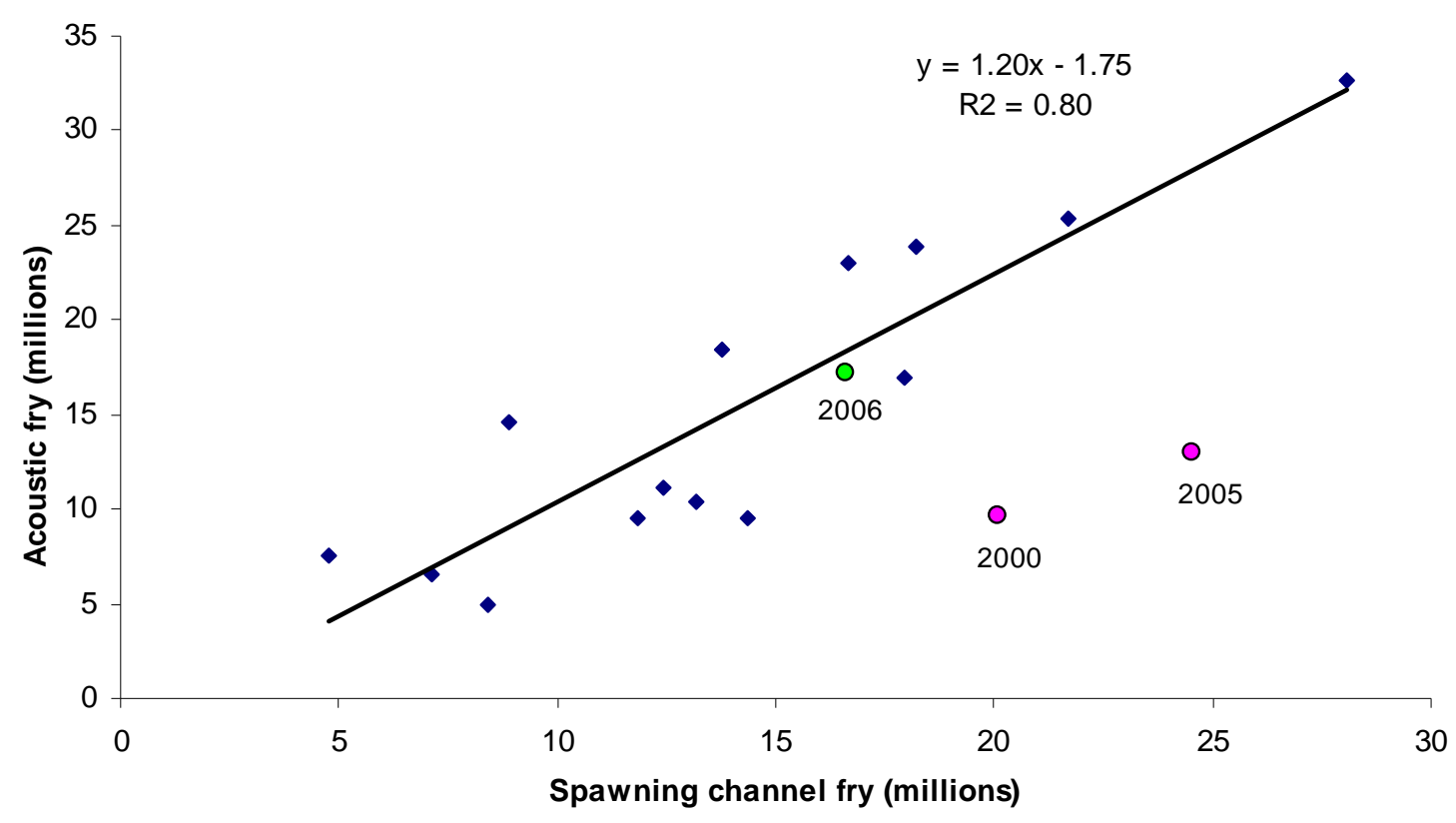

Figure 7.10. Relationship between numbers of kokanee fry produced from the Meadow Creek spawning channel and estimated numbers of fall fry determined by hydroacoustics.

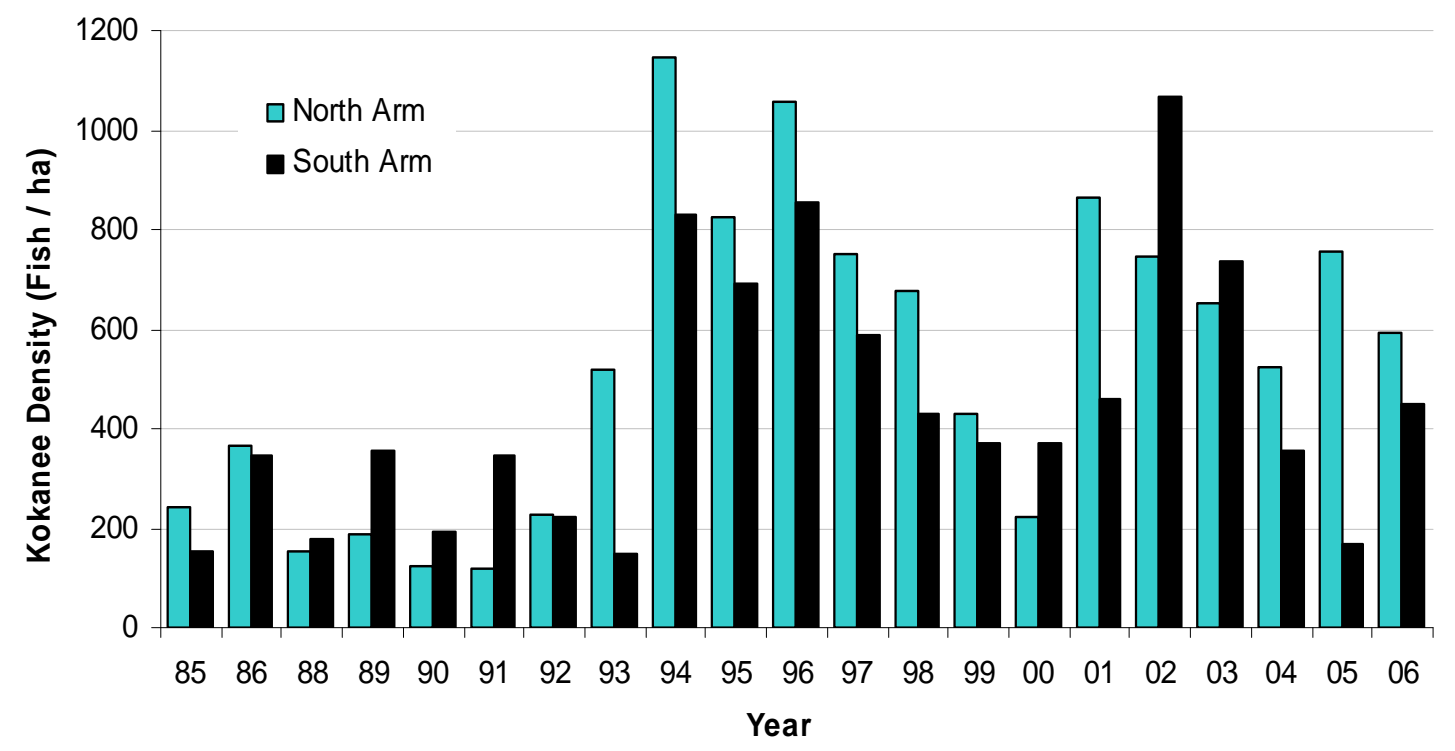

Figure 7.11. Comparison of kokanee density in North and South Arms of Kootenay Lake based on annual acoustic monitoring, 1985-2006.

Kootenay Lake Fertilization Experiment, Year 15 (North Arm) and Year 3 (South Arm) 202 (2006) Report 


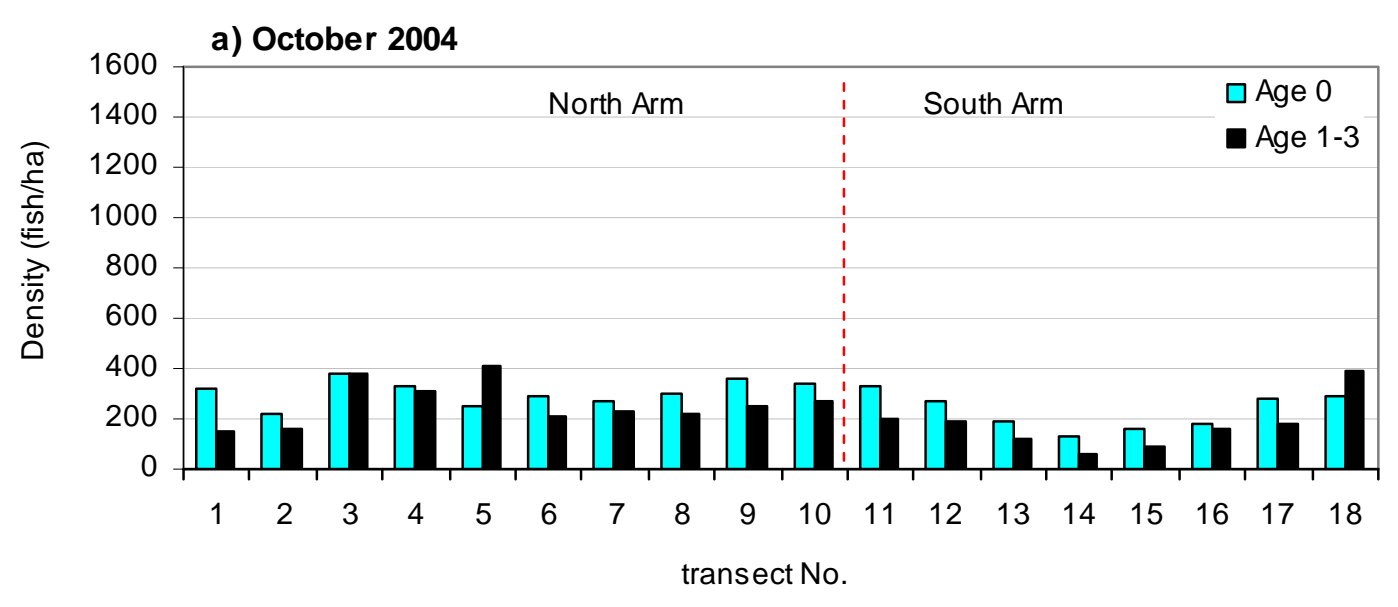

b) September 2005

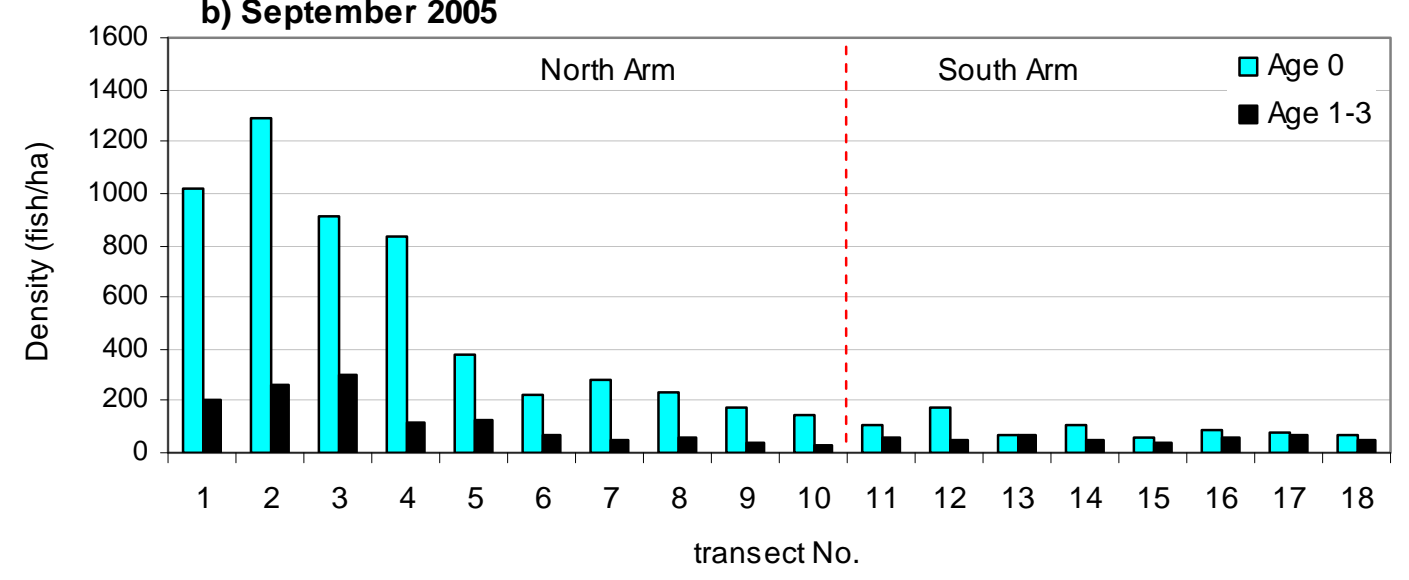

c) September 2006

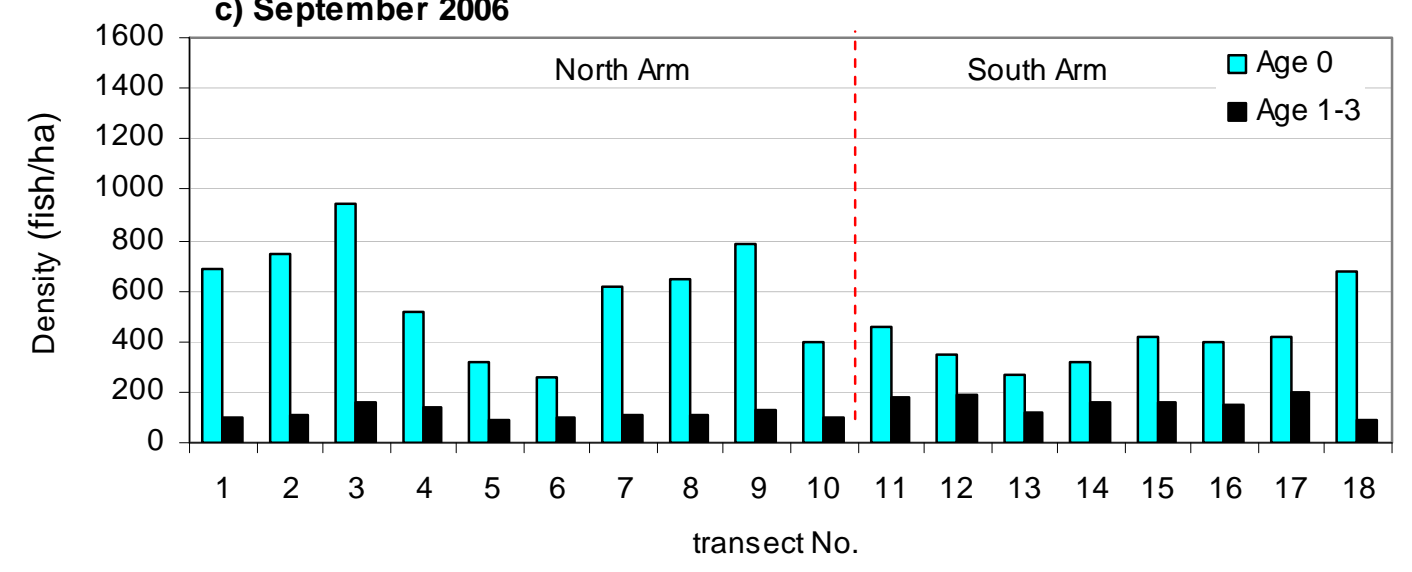

Figure 7.12 Longitudinal density distribution for age 0 and ages 1-3 kokanee in Kootenay Lake during a) October 2004 b) September 2005 and c) September 2006.

Kootenay Lake Fertilization Experiment, Year 15 (North Arm) and Year 3 (South Arm) 203 (2006) Report 


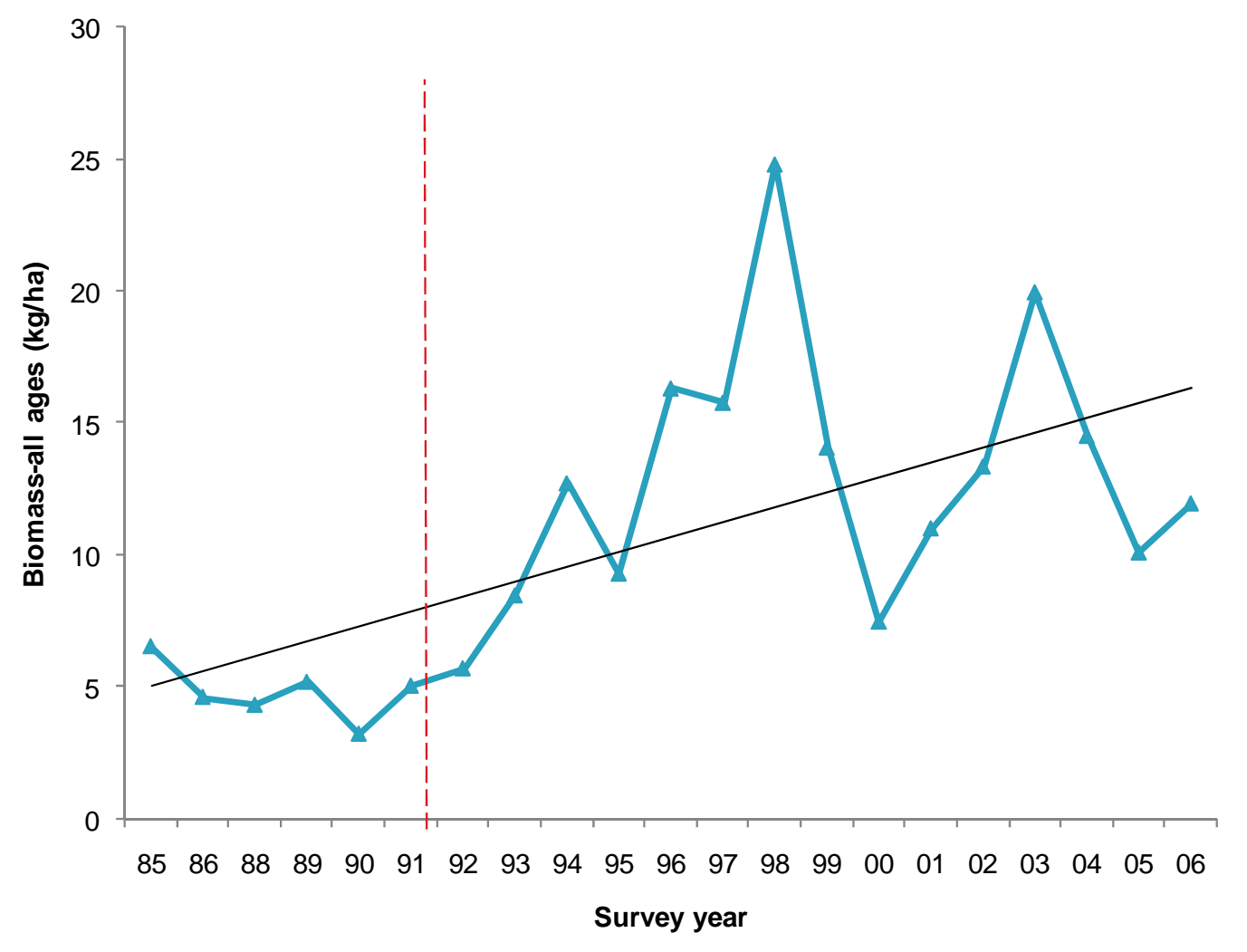

Figure 7.13 Biomass estimates ( $\mathrm{kg} / \mathrm{ha}$ ) for all ages of Kootenay Lake kokanee from trawl and hydroacoustic surveys and known weights of spawners. Dotted line indicateds commencement of fertilization; trendline shown as solid line.

Kootenay Lake Fertilization Experiment, Year 15 (North Arm) and Year 3 (South Arm) 204 (2006) Report 


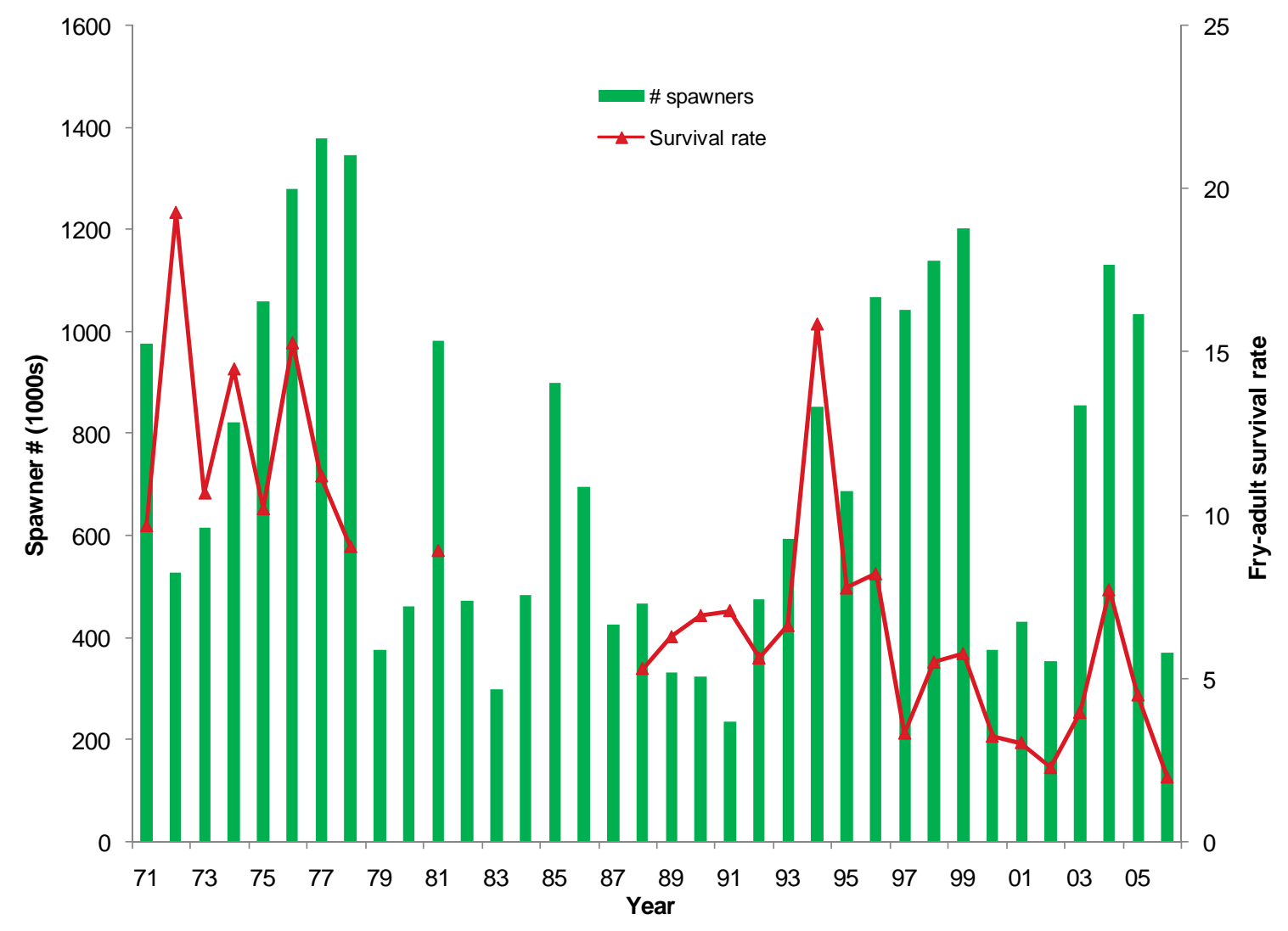

Figure 7.14. Kokanee fry-to-adult survival based on Meadow Creek Spawning Channel data. 


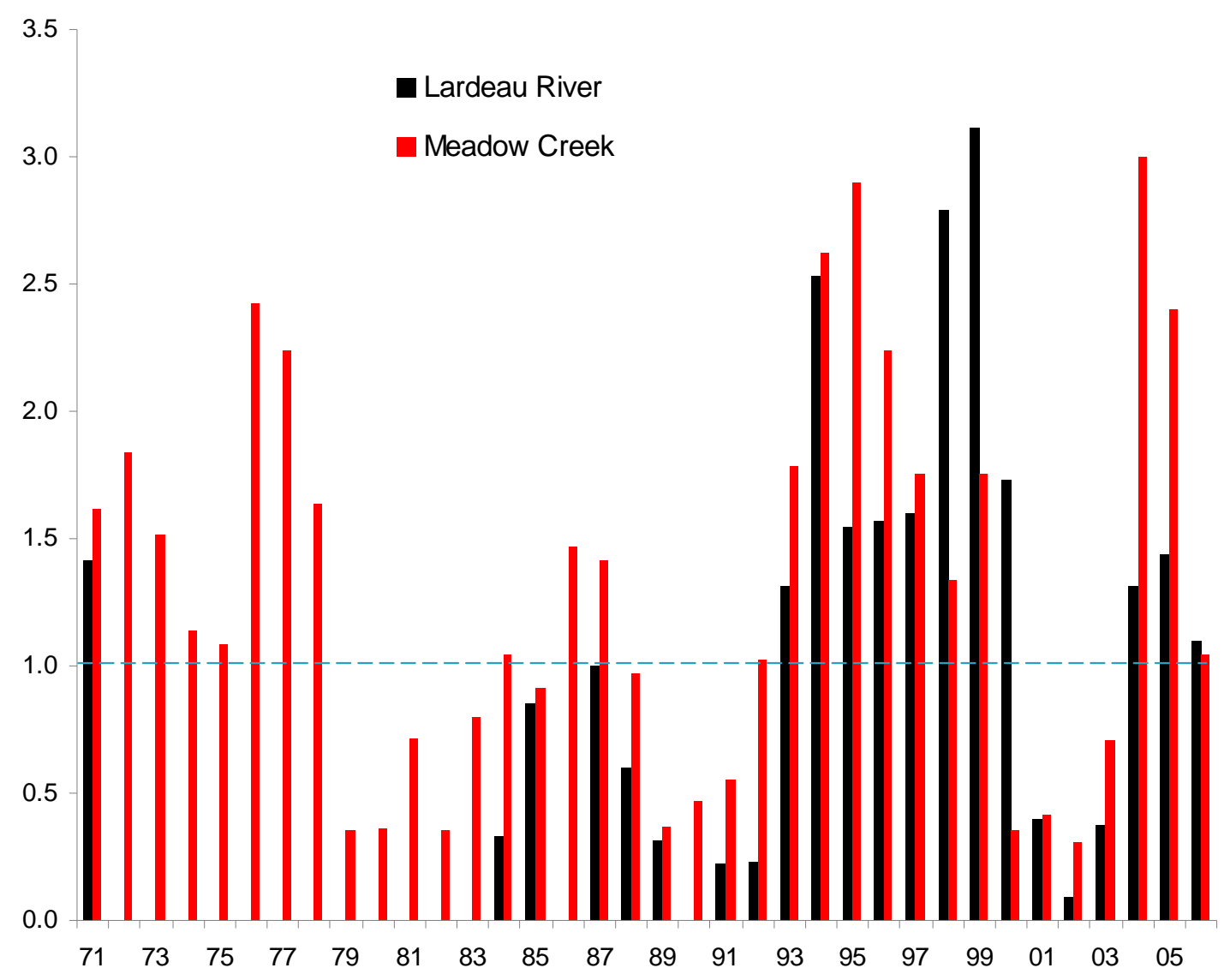

Figure 7.15. Recruit-spawner relationship for Lardeau River and Meadow Creek (19712006). Dotted line represents replacement level of 1.0. 
APPENDIX 7.1. Kokanee length correction factors for Kootenay Lake. Correction factors for $>180$-mm fish and for 100-180-mm fish are from Rieman and Myers (1992). Correction factors for $<100$-mm fish were derived from Okanagan Lake trawl samples collected during 1988-93.

\begin{tabular}{|c|c|c|c|c|c|c|c|}
\hline Date & $>180 \mathrm{~mm}$ & $100-180 \mathrm{~mm}$ & $<100 \mathrm{~mm}$ & Date & $>180 \mathrm{~mm}$ & $100-180 \mathrm{~mm}$ & $<100 \mathrm{~mm}$ \\
\hline 1-Sep & 1.025 & 1.064 & 1.090 & 7-Oct & 1.000 & 1.000 & 0.982 \\
\hline 2-Sep & 1.023 & 1.061 & 1.087 & 8-Oct & 1.000 & 1.000 & 0.979 \\
\hline 3-Sep & 1.021 & 1.058 & 1.084 & 9-Oct & 1.000 & 1.000 & 0.976 \\
\hline 4-Sep & 1.020 & 1.056 & 1.081 & 10-Oct & 1.000 & 1.000 & 0.973 \\
\hline 5-Sep & 1.018 & 1.053 & 1.078 & 11-Oct & 1.000 & 1.000 & 0.970 \\
\hline 6-Sep & 1.016 & 1.050 & 1.075 & $12-O c t$ & 1.000 & 1.000 & 0.967 \\
\hline 7-Sep & 1.014 & 1.047 & 1.072 & 13-Oct & 1.000 & 1.000 & 0.964 \\
\hline 8-Sep & 1.012 & 1.044 & 1.069 & 14-Oct & 1.000 & 1.000 & 0.961 \\
\hline 9-Sep & 1.011 & 1.042 & 1.066 & 15-Oct & 1.000 & 1.000 & 0.958 \\
\hline 10-Sep & 1.009 & 1.039 & 1.063 & 16-Oct & 1.000 & 1.000 & 0.955 \\
\hline 11-Sep & 1.007 & 1.036 & 1.060 & 17-Oct & 1.000 & 1.000 & 0.952 \\
\hline 12-Sep & 1.005 & 1.033 & 1.057 & 18-Oct & 1.000 & 1.000 & 0.949 \\
\hline 13-Sep & 1.003 & 1.030 & 1.054 & 19-Oct & 1.000 & 1.000 & 0.946 \\
\hline 14-Sep & 1.002 & 1.028 & 1.051 & 20-Oct & 1.000 & 1.000 & 0.943 \\
\hline 15-Sep & 1.000 & 1.025 & 1.048 & 21-Oct & 1.000 & 1.000 & 0.940 \\
\hline 16-Sep & 1.000 & 1.023 & 1.045 & 22-Oct & 1.000 & 1.000 & 0.936 \\
\hline 17-Sep & 1.000 & 1.022 & 1.042 & 23-Oct & 1.000 & 1.000 & 0.933 \\
\hline 18-Sep & 1.000 & 1.020 & 1.039 & 24-Oct & 1.000 & 1.000 & 0.930 \\
\hline 19-Sep & 1.000 & 1.018 & 1.036 & 25 -Oct & 1.000 & 1.000 & 0.927 \\
\hline 20-Sep & 1.000 & 1.017 & 1.033 & 26-Oct & 1.000 & 1.000 & 0.924 \\
\hline 21-Sep & 1.000 & 1.015 & 1.030 & 27-Oct & 1.000 & 1.000 & 0.921 \\
\hline 22-Sep & 1.000 & 1.013 & 1.027 & 28-Oct & 1.000 & 1.000 & 0.918 \\
\hline 23-Sep & 1.000 & 1.011 & 1.024 & 29-Oct & 1.000 & 1.000 & 0.915 \\
\hline 24-Sep & 1.000 & 1.010 & 1.021 & 30-Oct & 1.000 & 1.000 & 0.912 \\
\hline 25-Sep & 1.000 & 1.008 & 1.018 & 31-Oct & 1.000 & 1.000 & 0.909 \\
\hline 26-Sep & 1.000 & 1.006 & 1.015 & 1-Nov & 1.000 & 1.000 & 0.906 \\
\hline 27-Sep & 1.000 & 1.005 & 1.012 & 2-Nov & 1.000 & 1.000 & 0.903 \\
\hline 28-Sep & 1.000 & 1.003 & 1.009 & 3-Nov & 1.000 & 1.000 & 0.900 \\
\hline 29-Sep & 1.000 & 1.001 & 1.006 & 4-Nov & 1.000 & 1.000 & 0.897 \\
\hline 30-Sep & 1.000 & 1.000 & 1.003 & 5-Nov & 1.000 & 1.000 & 0.894 \\
\hline 1-Oct & 1.000 & 1.000 & 1.000 & 6-Nov & 1.000 & 1.000 & 0.891 \\
\hline 2-Oct & 1.000 & 1.000 & 0.997 & 7-Nov & 1.000 & 1.000 & 0.888 \\
\hline 3-Oct & 1.000 & 1.000 & 0.994 & 8-Nov & 1.000 & 1.000 & 0.885 \\
\hline 4-Oct & 1.000 & 1.000 & 0.991 & 9-Nov & 1.000 & 1.000 & 0.882 \\
\hline 5-Oct & 1.000 & 1.000 & 0.988 & $10-\mathrm{Nov}$ & 1.000 & 1.000 & 0.879 \\
\hline 6-Oct & 1.000 & 1.000 & 0.985 & $11-\mathrm{Nov}$ & 1.000 & 1.000 & 0.876 \\
\hline
\end{tabular}

Kootenay Lake Fertilization Experiment, Year 15 (North Arm) and Year 3 (South Arm) 
APPENDIX 7.2. Equipment and data processing specifications.

Echosounder Specifications and Field Settings

\begin{tabular}{ll}
\hline Description & SIMRAD EY200P-P \\
\hline Transducer type & Single beam $70 \mathrm{kHz}$ \\
Beam angle & 11.6 degree \\
Receiver gain & $3(0 \mathrm{~dB})$ \\
Pulse width $(\mathrm{msec})$ & 0.3 \\
Ping rate $(\mathrm{p} / \mathrm{sec})$ & Medium $(1.5)$ \\
Time varied gain & $40 \log \mathrm{r}$ \\
TVG range $(\mathrm{m})$ & 2 to 66 \\
Attenuation & $-15 \mathrm{~dB}$ \\
Power & $1 / 1$ \\
Calibration & 2 min. AC tone \\
Tape recorder & Sony TCD-D10 \\
Record volume & 3.5 fixed \\
\hline
\end{tabular}

\section{Data Processing Specifications}

\begin{tabular}{ll}
\hline Description & HADAS version 3.98 \\
\hline Interface gain & Calibration tone to intersect 2 volts at 50 milliseconds \\
Threshold & Minimum detectable target approximately $-65 \mathrm{~dB}$ \\
Field calibration & $\begin{array}{c}\text { September 9, 2005, Kootenay Lake; Peak sphere voltage }=4100 \mathrm{mV} \text {; Sphere depth } \\
=12 \mathrm{~m} \text {; Threshold used for survey }=240 \mathrm{mV}\end{array}$ \\
Lab calibration & July 8, 1998, Applied Physics Laboratory, UWA \\
\hline
\end{tabular}

\section{APPENDIX 7.3. Love's (1977) empirical relation of fish length to acoustic target strength.}

$$
\text { TS }=19.1 \log _{10}(\mathrm{~L})-0.9 \log _{10}(\mathrm{~F})-62
$$

where TS=target strength in decibels $(\mathrm{dB})$, $\mathrm{L}=$ =length in $\mathrm{cm}$, and $\mathrm{F}=$ frequency in $\mathrm{kHz}$.

\begin{tabular}{ccccc}
\hline $\begin{array}{c}\text { HADAS size class } \\
(\mathrm{db})^{1}\end{array}$ & $\begin{array}{c}\text { Acoustic size range } \\
(\mathrm{dB})\end{array}$ & \multicolumn{2}{c}{$\begin{array}{c}\text { Fish length range } \\
(\mathrm{mm})^{2}\end{array}$} \\
\hline-35 & -35 & -33.1 & 317 & $500+$ \\
-38 & -38 & -35.1 & 221 & 317 \\
-41 & -41 & -38.1 & 154 & 221 \\
-44 & -44 & -41.1 & 107 & 154 \\
-47 & -47 & -44.1 & 75 & 107 \\
-50 & -50 & -47.1 & 52 & 75 \\
-53 & -53 & -50.1 & 36 & 52 \\
-56 & -56 & -53.1 & 25 & 36 \\
-59 & -59 & -56.1 & 18 & 25 \\
-62 & -62 & -59.1 & 12 & 18 \\
\hline${ }^{2}$ HADAS was set up to view a 30dB range in 10 size classes of 3 dB. \\
From Love's (1977) empirical formula (Dorsal aspect).
\end{tabular}

Kootenay Lake Fertilization Experiment, Year 15 (North Arm) and Year 3 (South Arm) 208 (2006) Report 


\section{APPENDIX 7.4. Transect fish densities (number/ha) in Kootenay Lake, September}

2006.

\begin{tabular}{crrr}
\hline $\begin{array}{c}\text { Transect } \\
\text { Number }\end{array}$ & All Ages & Age 0 & Age 1-3 \\
\hline 1 & 778 & 682 & 96 \\
2 & 855 & 743 & 113 \\
3 & 1109 & 946 & 162 \\
4 & 655 & 520 & 135 \\
5 & 411 & 316 & 94 \\
6 & 353 & 257 & 96 \\
7 & 723 & 615 & 107 \\
8 & 756 & 647 & 108 \\
9 & 911 & 782 & 130 \\
10 & 496 & 401 & 95 \\
11 & 636 & 454 & 183 \\
12 & 534 & 345 & 189 \\
13 & 384 & 266 & 118 \\
14 & 477 & 315 & 162 \\
15 & 574 & 419 & 155 \\
16 & 548 & 396 & 152 \\
17 & 610 & 415 & 195 \\
18 & 768 & 680 & 89 \\
\hline
\end{tabular}

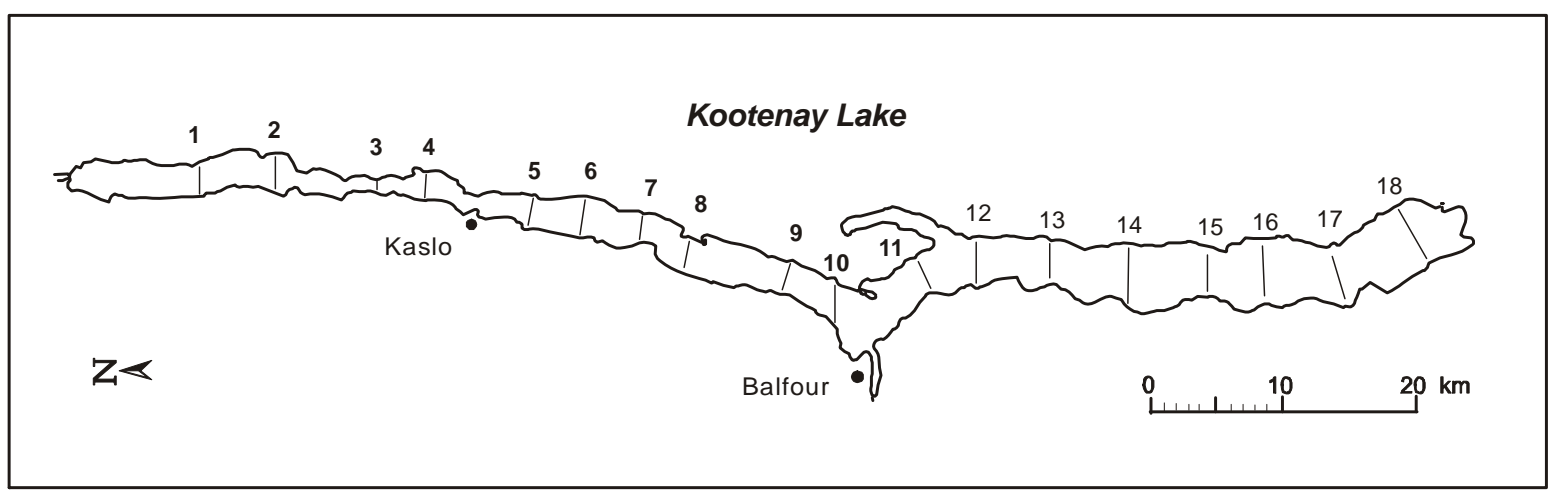

Kootenay Lake Fertilization Experiment, Year 15 (North Arm) and Year 3 (South Arm) 209 (2006) Report 


\section{APPENDIX 7.5. Maximum likelihood population estimates and bounds for (a) all ages of kokanee and (b) ages 1-3 kokanee in Kootenay Lake in September 2006.}

\section{a) Statistics for kokanee of all ages (>-62 dB) in two zones (transects 1-3 and 4-18)}

\begin{tabular}{|c|c|c|c|c|c|c|c|c|c|}
\hline Zone & Depth & $\mathbf{N}$ & $\mathbf{R}^{2}$ & Density & Std Error & Area & $\begin{array}{r}\begin{array}{r}\text { Stratum } \\
\text { Pop. }\end{array} \\
\end{array}$ & Statistic $^{1}$ & Abundance \\
\hline 1 & 5 & 3 & 0.997 & 21.300 & 0.837 & 5,320 & 113,316 & & \\
\hline 1 & 10 & 3 & 0.968 & 89.777 & 11.599 & 5,320 & 477,614 & & \\
\hline 1 & 15 & 3 & 0.966 & 485.285 & 64.151 & 5,320 & $2,581,716$ & & \\
\hline 1 & 20 & 3 & 0.829 & 192.879 & 61.884 & 5,267 & $1,015,855$ & & \\
\hline 1 & 25 & 2 & 0.899 & 29.016 & 9.704 & 5,211 & 151,211 & & \\
\hline 1 & 30 & 2 & 0.935 & 5.352 & 1.406 & 5,138 & 27,501 & $\mathrm{LB}=$ & $20,584,080$ \\
\hline 1 & 35 & 2 & 0.999 & 1.121 & 0.041 & 5,052 & 5,663 & MLE= & $22,103,300$ \\
\hline 1 & 40 & 2 & 0.761 & 0.533 & 0.298 & 4,965 & 2,646 & $\mathrm{UB}=$ & $25,210,766$ \\
\hline 2 & 5 & 14 & 0.400 & 3.230 & 1.098 & 32,880 & 106,202 & & \\
\hline 2 & 10 & 14 & 0.497 & 6.562 & 1.830 & 32,880 & 215,759 & & \\
\hline 2 & 15 & 14 & 0.664 & 10.006 & 1.973 & 32,880 & 328,997 & & \\
\hline 2 & 20 & 15 & 0.750 & 133.363 & 20.603 & 32,649 & $4,354,211$ & & \\
\hline 2 & 25 & 15 & 0.902 & 278.219 & 24.498 & 32,431 & $9,022,804$ & & \\
\hline 2 & 30 & 15 & 0.954 & 122.668 & 7.220 & 32,137 & $3,942,211$ & & \\
\hline 2 & 35 & 14 & 0.608 & 15.992 & 3.563 & 31,859 & 509,491 & & \\
\hline 2 & 40 & 14 & 0.673 & 1.802 & 0.349 & 31,644 & 57,022 & & \\
\hline 2 & 45 & 15 & 0.122 & 0.176 & 0.126 & 31,426 & 5,531 & & \\
\hline
\end{tabular}

${ }^{1} \mathrm{MLE}=$ maximum likelihood estimate, $\mathrm{LB}=$ lower bound, and UB = upper bound

b) Statistics for ages 1-3 kokanee (>-47 dB) in two zones (transects 1-3 and 4-18)

\begin{tabular}{|c|c|c|c|c|c|c|c|c|c|}
\hline Zone & Depth & $\mathbf{N}$ & $\mathbf{R}^{2}$ & Density & Std Error & Area & Stratum Pop. & Statistic $^{1}$ & Abundance \\
\hline 1 & 5 & 2 & 0.991 & 4.779 & 0.449 & 5,320 & 25,424 & & \\
\hline 1 & 10 & 2 & 0.862 & 2.136 & 0.853 & 5,320 & 11,364 & & \\
\hline 1 & 15 & 3 & 0.941 & 36.571 & 6.455 & 5,320 & 194,558 & & \\
\hline 1 & 20 & 3 & 0.985 & 48.128 & 4.157 & 5,267 & 253,481 & & \\
\hline 1 & 25 & 2 & 0.996 & 10.638 & 0.644 & 5,211 & 55,438 & & \\
\hline 1 & 30 & 2 & 0.930 & 3.611 & 0.992 & 5,138 & 18,555 & $\mathrm{LB}=$ & $4,549,936$ \\
\hline 1 & 35 & 2 & 0.931 & 0.770 & 0.210 & 5,052 & 3,890 & MLE= & $4,866,100$ \\
\hline 2 & 5 & 15 & 0.283 & 1.038 & 0.442 & 32,880 & 34,129 & $\mathrm{UB}=$ & $5,445,607$ \\
\hline 2 & 10 & 15 & 0.276 & 0.611 & 0.265 & 32,880 & 20,090 & & \\
\hline 2 & 15 & 14 & 0.503 & 1.243 & 0.342 & 32,880 & 40,870 & & \\
\hline 2 & 20 & 15 & 0.701 & 13.435 & 2.346 & 32,649 & 438,644 & & \\
\hline 2 & 25 & 15 & 0.934 & 57.440 & 4.088 & 32,431 & $1,862,813$ & & \\
\hline 2 & 30 & 15 & 0.900 & 55.354 & 4.935 & 32,137 & $1,778,925$ & & \\
\hline 2 & 35 & 14 & 0.588 & 6.659 & 1.546 & 31,859 & 212,150 & & \\
\hline 2 & 40 & 15 & 0.538 & 1.570 & 0.389 & 31,644 & 49,681 & & \\
\hline 2 & 45 & 15 & 0.11 & 0.022 & 0.017 & 31,426 & 691 & & \\
\hline
\end{tabular}

${ }^{1} \mathrm{MLE}=$ maximum likelihood estimate, $\mathrm{LB}=$ lower bound, and UB = upper bound

Kootenay Lake Fertilization Experiment, Year 15 (North Arm) and Year 3 (South Arm) 


\section{APPENDIX 7.6 Preliminary estimates of kokanee biomass for Kootenay Lake}

a) Estimated number of fish at each age based on acoustic abundance, trawl proportions and mean weights by year and age from trawl samples

\begin{tabular}{rrrrr|rrrr}
\hline & \multicolumn{3}{c}{ Estimated number of fish } & \multicolumn{4}{c}{ Mean weight (g) } \\
\cline { 2 - 9 } Year & \multicolumn{1}{c}{ Age 0 } & \multicolumn{1}{c}{ Age 1 } & \multicolumn{1}{c|}{ Age 2 } & Age 3 & Age 0 & Age 1 & Age 2 & Age 3 \\
\hline 1985 & $3,630,000$ & $1,334,103$ & $2,016,667$ & 279,231 & 1.6 & 24.9 & 53.5 & 66.0 \\
1986 & $11,603,512$ & 648,799 & $1,023,105$ & 224,584 & 1.9 & 17.9 & 60.4 & 69.3 \\
1988 & $3,400,660$ & $1,685,283$ & $1,294,057$ & - & 2.2 & 26.6 & 52.2 & \\
1989 & $7,423,643$ & $1,368,605$ & $1,700,388$ & 207,364 & 1.6 & 25.5 & 59.9 & 68.3 \\
1990 & $4,808,922$ & 732,788 & 480,892 & 137,398 & 2.2 & 39.9 & 75.4 & 89.2 \\
1991 & $7,479,751$ & 930,124 & 775,104 & 155,021 & 2.1 & 29.7 & 127.9 & 130.8 \\
1992 & $7,212,801$ & 390,618 & 908,413 & 18,168 & 2.1 & 36.3 & 120.6 & 180.9 \\
1993 & $8,790,000$ & $1,218,451$ & 460,634 & 430,915 & 1.5 & 36.5 & 76.4 & 108.9 \\
1994 & $31,780,000$ & $2,510,286$ & $1,287,886$ & 21,829 & 2.0 & 31.0 & 114.1 & 134.0 \\
1995 & $21,000,000$ & $3,721,029$ & 572,466 & 6,505 & 2.0 & 34.2 & 74.4 & 138.4 \\
1996 & $22,600,000$ & $6,181,282$ & $5,956,053$ & 162,665 & 1.4 & 21.4 & 57.2 & 62.8 \\
1997 & $14,270,000$ & $5,807,355$ & $5,840,165$ & 262,479 & 1.7 & 25.0 & 50.5 & 77.4 \\
1998 & $8,400,000$ & $2,248,680$ & $8,012,903$ & 538,416 & 1.4 & 36.8 & 73.4 & 97.4 \\
1999 & $10,360,000$ & $2,050,323$ & $2,489,677$ & - & 2.1 & 33.3 & 101.4 & \\
2000 & $9,690,000$ & 636,667 & $1,273,333$ & - & 2.0 & 32.2 & 123.0 & \\
2001 & $18,380,000$ & $4,967,368$ & 752,632 & - & 2.4 & 35.9 & 119.2 & \\
2002 & $25,430,000$ & $9,091,528$ & 542,778 & 135,694 & 1.8 & 37.0 & 84.9 & 111.4 \\
2003 & $17,049,000$ & $5,263,848$ & $4,187,152$ & - & 3.4 & 39.9 & 90.9 & 109.3 \\
2004 & $9,450,000$ & $3,692,578$ & $2,782,813$ & 374,609 & 2.5 & 23.1 & 90.6 & 137.7 \\
2005 & $12,830,000$ & $1,703,125$ & $1,021,875$ & 545,000 & 1.7 & 18.7 & 110.8 & 13.8 \\
2006 & $17,230,000$ & $3,933,462$ & 936,538 & - & 3.3 & 35.8 & 183.4 & \\
\hline
\end{tabular}

b) Calculation of inlake biomass (metric tonnes) and biomass density (kg/ha) of kokanee in Kootenay Lake

\begin{tabular}{lrrrrr|rrrrr}
\hline & \multicolumn{5}{c|}{ Biomass (metric tones) } & \multicolumn{5}{c}{ Biomass Density (kg/ha) } \\
\cline { 2 - 10 } Year & Age 0 & Age 1 & \multicolumn{1}{c}{ Age 2 } & Age 3 & Total & Age 0 & Age 1 & Age 2 & Age 3 & Total \\
\hline 1985 & 6 & 33 & 108 & 18 & 165 & 0.16 & 0.87 & 2.82 & 0.48 & 4.3 \\
1986 & 22 & 12 & 62 & 16 & 111 & 0.58 & 0.30 & 1.62 & 0.41 & 2.9 \\
1988 & 7 & 45 & 68 & - & 120 & 0.19 & 1.18 & 1.77 & - & 3.1 \\
1989 & 12 & 35 & 102 & 14 & 163 & 0.31 & 0.91 & 2.67 & 0.37 & 4.3 \\
1990 & 11 & 29 & 36 & 12 & 88 & 0.28 & 0.76 & 0.95 & 0.32 & 2.3 \\
1991 & 16 & 28 & 99 & 20 & 163 & 0.42 & 0.72 & 2.59 & 0.53 & 4.3 \\
1992 & 15 & 14 & 110 & 3 & 142 & 0.40 & 0.37 & 2.87 & 0.09 & 3.7 \\
1993 & 14 & 44 & 35 & 47 & 140 & 0.35 & 1.16 & 0.92 & 1.23 & 3.7 \\
1994 & 64 & 78 & 147 & 3 & 291 & 1.66 & 2.04 & 3.85 & 0.08 & 7.6 \\
1995 & 41 & 127 & 43 & 1 & 212 & 1.07 & 3.33 & 1.11 & 0.02 & 5.5 \\
1996 & 32 & 132 & 341 & 10 & 515 & 0.83 & 3.46 & 8.92 & 0.27 & 13.5 \\
1997 & 24 & 145 & 295 & 20 & 485 & 0.64 & 3.80 & 7.72 & 0.53 & 12.7 \\
1998 & 12 & 83 & 588 & 52 & 735 & 0.31 & 2.17 & 15.40 & 1.37 & 19.2 \\
1999 & 22 & 68 & 252 & - & 343 & 0.57 & 1.79 & 6.61 & - & 9.0 \\
2000 & 19 & 21 & 157 & - & 196 & 0.50 & 0.54 & 4.10 & - & 5.1 \\
2001 & 44 & 178 & 90 & - & 312 & 1.15 & 4.67 & 2.35 & - & 8.2 \\
2002 & 47 & 336 & 46 & 15 & 444 & 1.22 & 8.81 & 1.21 & 0.40 & 11.6 \\
2003 & 57 & 210 & 381 & - & 648 & 1.50 & 5.50 & 9.96 & - & 17.0 \\
2004 & 24 & 85 & 252 & 41 & 402 & 0.62 & 2.23 & 6.60 & 1.07 & 10.5 \\
2005 & 21 & 32 & 113 & 75 & 242 & 0.56 & 0.83 & 2.96 & 1.96 & 6.3 \\
2006 & 56 & 141 & 172 & - & 369 & 1.47 & 3.69 & 4.50 & - & 9.7 \\
\hline Pre & 12 & 30 & 79 & 13 & 135 & 0.3 & 0.8 & 2.1 & 0.4 & 3.5 \\
Fert & 33 & 113 & 201 & 18 & 365 & 0.9 & 3.0 & 5.3 & 0.5 & 9.6 \\
\hline
\end{tabular}

Kootenay Lake Fertilization Experiment, Year 15 (North Arm) and Year 3 (South Arm) 
c) Calculation of kokanee spawner biomass (metric tonnes) and biomass density (kg/ha) in Kootenay Lake. Note: bottom rows compare average biomass during prefertilization (1985-91) and fertilization years (1991-2006).

\begin{tabular}{rrrr|crr} 
Year & $\begin{array}{c}\text { Total } \\
\text { Spawners } \\
\text { (no) }\end{array}$ & $\begin{array}{c}\text { Mean } \\
\text { Weight } \\
\text { (g) }\end{array}$ & $\begin{array}{c}\text { Spawner } \\
\text { Biomass } \\
\text { (tonnes) }\end{array}$ & $\begin{array}{c}\text { Spawners } \\
\text { (kg/ha) }\end{array}$ & $\begin{array}{r}\text { Inlake } \\
\text { (kg/ha) }\end{array}$ & $\begin{array}{r}\text { Total } \\
\text { (kg/ha) }\end{array}$ \\
\hline 1985 & 901,100 & 93.7 & 84.4 & 2.2 & 4.3 & 6.5 \\
1986 & 697,600 & 93.7 & 65.4 & 1.7 & 2.9 & 4.6 \\
1988 & 467,900 & 96.5 & 45.2 & 1.2 & 3.1 & 4.3 \\
1989 & 333,000 & 106.7 & 35.5 & 0.9 & 4.3 & 5.2 \\
1990 & 325,000 & 107.1 & 34.8 & 0.9 & 2.3 & 3.2 \\
1991 & 237,100 & 125.7 & 29.8 & 0.8 & 4.3 & 5.0 \\
1992 & 477,200 & 158.5 & 75.6 & 2.0 & 3.7 & 5.7 \\
1993 & 840,000 & 218.2 & 183.3 & 4.8 & 3.7 & 8.5 \\
1994 & $1,230,000$ & 158.2 & 194.6 & 5.1 & 7.6 & 12.7 \\
1995 & 860,000 & 166.7 & 143.4 & 3.8 & 5.5 & 9.3 \\
1996 & $1,210,000$ & 89.4 & 108.2 & 2.8 & 13.5 & 16.3 \\
1997 & $1,440,000$ & 81.8 & 117.7 & 3.1 & 12.7 & 15.8 \\
1998 & $2,240,000$ & 94.9 & 212.5 & 5.6 & 19.2 & 24.8 \\
1999 & $1,730,000$ & 112.6 & 194.8 & 5.1 & 9.0 & 14.1 \\
2000 & 570,000 & 156.2 & 89.0 & 2.3 & 5.1 & 7.5 \\
2001 & 590,000 & 184.0 & 108.5 & 2.8 & 8.2 & 11.0 \\
2002 & 460,000 & 143.5 & 66.0 & 1.7 & 11.6 & 13.4 \\
2003 & $1,060,000$ & 108.2 & 114.7 & 3.0 & 17.0 & 20.0 \\
2004 & $1,367,600$ & 111.6 & 152.7 & 4.0 & 10.5 & 14.5 \\
2005 & $1,286,638$ & 112.0 & 144.1 & 3.8 & 6.3 & 10.1 \\
2006 & 480,000 & 180.0 & 86.4 & 2.3 & 9.7 & 11.9 \\
\hline Pre & 493,617 & 103.9 & 49 & 1.3 & 3.5 & 4.8 \\
Fert & $1,056,096$ & 138.4 & 133 & 3.5 & 9.6 & 13.0 \\
\hline
\end{tabular}

Kootenay Lake Fertilization Experiment, Year 15 (North Arm) and Year 3 (South Arm) 


\title{
CHAPTER 8
}

STATUS OF KOKANEE IN THE SOUTH ARM OF KOOTENAY LAKE AS A RESULT OF EXPERIMENTAL FERTILIZATION

\author{
by
}

\author{
Greg F. Andrusak \\ Redfish Consulting Ltd. \\ Nelson, BC
}

and

Dale Sebastian

Ministry of Environment

Victoria, BC 


\section{Introduction}

Kootenay Lake kokanee have undergone wide fluctuations in their numbers over the last six decades largely due to significant impacts caused by man (Northcote 1973). During the last decade the lake has undergone intensive restoration initiatives in response to a decline in lake productivity, primarily as a result of hydro-electric development and other man-made influences over the last four decades. As a result of lower productivity, main lake populations of kokanee (Oncorhynchus nerka), considered the keystone species within the Kootenay Lake ecosystem, declined below sustainable levels in the 1980s and early 1990s before nutrient addition was initiated. Declining productivity in lakes and reservoirs has a combined bottom up effect from nutrient dynamics and top down effect from cascading trophic interactions, primarily top predators and prey (Carpenter. et al. 2001, Hyatt et al. 2004, and Perrin et al. 2006). Restoration initiatives by means of experimental lake fertilization began on the North Arm of Kootenay Lake in 1992, presently funded by the Fish and Wildlife Compensation Program - Columbia Basin. The South Arm of Kootenay Lake has also experienced a major decline in overall productivity. Commencing in 2004, fertilization of a portion of the South Arm was undertaken, by means of funding from the Kootenai Tribe of Idaho (funded by Bonneville Power Authority [BPA]), to restore lake productivity impacted by the Libby Dam.

Most South Arm streams flowing into Kootenay Lake supported modest numbers of spawning kokanee at least since the 1950s when Vernon (1957) conducted the first formal kokanee assessment. Spawner numbers began to dwindle in the late 1970s and today virtually all South Arm tributaries are devoid of spawning kokanee. The same lack of spawners applies to Kootenai/y River tributaries in Idaho which also historically supported spawning populations of kokanee (Andrusak et al. 2004). The Kootenai/y River is the main tributary to Kootenay Lake, hence, is a very important system for spawning and rearing of most fish species that live all or part of their life in Kootenay Lake. A measurable response by kokanee to South Arm fertilization will take some time since they need to be re-established in South Arm (BC) and Kootenai/y River (Idaho) tributaries. The most recent results of trophic level responses indicate a positive response to lake fertilization (E. Schindler Limnologist, Ministry of Environment pers. comm.). As part of the South Arm fertilization experiment, a major emphasis is to restore kokanee populations by conducting kokanee eyed-egg plants within various South Arm and Kootenai/y River tributaries within BC and Idaho, respectively. On-going annual kokanee escapement estimates to South Arm (BC) and Kootenai/y River (Idaho) tributaries provide an important metric for nutrient addition in the South Arm of Kootenay Lake.

South Arm kokanee stocks should respond in a similar manner to lake fertilization as did the North Arm kokanee stocks. North Arm kokanee populations have recovered to near historic numbers as a result of overall increased in-lake survival attributed to lake fertilization (Ashley et al. 1997; Sebastian et al. 2007). This report summarizes annual estimates of South Arm kokanee spawners and documents the extent of kokanee eyed-egg plants (Meadow Creek stock, Kootenay Lake) to South Arm (BC) and Kootenai/y River (Idaho) tributaries in 2006. In addition, estimates of total kokanee lake abundance in 2006 are summarized and interactions between North and South stocks within Kootenay Lake are discussed. This project follows an overall international Kootenai/y River sub-basin plan (Anders et al. 2004) aimed at restoring the impacted fish species with particular emphasis on kokanee.

Kootenay Lake Fertilization Experiment, Year 15 (North Arm) and Year 3 (South Arm) 


\section{Project Objectives}

Relative to the sub-basin plan's goal and tasks outlined in Anders et al. (2004), the specific objectives of this report are:

1. summarize 2006 South Arm (BC) and Kootenai/y River (Idaho) tributary kokanee escapements;

2. summarize methods and locations of kokanee eyed-egg plants in South Arm (BC) and Kootenai/y River (Idaho) tributaries; and,

3. provide a summary report on total in-lake kokanee numbers and their distribution.

\section{Background}

The main lake populations of kokanee, the keystone species within Kootenay Lake, declined in throughout the 1980s and into the early 1990s to the lowest levels recorded in over four decades. Status and health of the kokanee population in Kootenay Lake have a direct influence on other species of fish, primarily piscivorous populations of white sturgeon (Acipenser transmontanus), bull trout (Salvelinus confluentus), burbot (Lota lota) and rainbow trout (Oncorhynchus mykiss). The primary reasons for the decline in kokanee numbers have been attributed to the overall nutrient reduction exacerbated by direct competition for selective zooplankton by freshwater opossum shrimp (Mysis relicta) (Northcote and Lorz 1966, Northcote 1991, Ashley et al. 1997, 1999, Whall and Lasenby 1998).

The success experienced through nutrient additions to the North Arm led to exploring similar options for South Arm restoration. Little attention had been paid to the status of kokanee that originate from South Arm tributaries and it was quite clear that these systems were virtually devoid of kokanee. In August 2004, restoration measures commenced on the South Arm of Kootenay Lake to increase lake productivity and restore impacted fish communities (see Chapter 2 in this report). Importantly, the fertilization project on the South Arm is coordinated and integrated through a sub-basin plan designed to restore impacted fish species with particular emphasis on kokanee in Kootenay Lake (BC) and the Kootenai/y River (Idaho) (Anders et al. 2004). The partnership includes cooperation with various agencies within Canada and the United States including: Kootenai Tribe of Idaho (KTOI); Bonneville Power Association (BPA); British Columbia Ministry of Environment (MoE); and, Idaho State Fish and Game.

Since the focus of South Arm fertilization is the recovery of fish stocks, monitoring annual kokanee escapements along with supplemental egg plants should provide a measure of success of the experiment. Little data on South arm tributaries exist except for periodic kokanee escapement data. Historic data for South Arm steams has been summarized by Andrusak and Fleck (2007). Kokanee eyed-egg plants (Meadow Creek stock, Kootenay Lake) in South Arm (BC) streams began in fall 2005 and again in 2006 while the Kootenai Tribe of Idaho began kokanee eyed-egg plants in Idaho tributaries as early as 1997 (Andrusak and Fleck 2007). 


\section{Site Description}

Kootenay Lake is located in the upper Columbia River drainage of Southeast British Columbia, and lies between the Selkirk and Purcell Mountain ranges (Fig.8.1). The main lake is $107 \mathrm{~km}$ long, approximately $4 \mathrm{~km}$ wide with a mean depth of $94 \mathrm{~m}$ and a maximum of $154 \mathrm{~m}$ (Daley et al. 1981). The lake is fed by two major river systems: the Lardeau/Duncan system at the north end (North Arm) and the Kootenai/y River that flows into the south end (South Arm). The outlet of the main lake, at Balfour, British Columbia, forms the upper end of the West Arm before becoming the lower Kootenai/y River which flows into the Columbia River at Castlegar, BC.

The South Arm of the lake receives 61\% of the entire inflow to the lake via the Kootenai/y River drainage and represents about two thirds of the entire lake surface and volume (Daley et al. 1981). The Kootenai/y River drainage originates on the western slopes of the Rocky Mountains in eastern BC and flows southwest to Canal Flats, BC where it enters the Rocky Mountain trench and flows south into Montana. Downstream of the Libby Dam in Montana there is a natural waterfall (Kootenai Falls) that represents a barrier to all upstream fish movement. Below the falls the river flows west through Northern Idaho to Bonners Ferry where it shortly thereafter swings north to flow into the South Arm of the lake near Creston, BC.

The primary streams flowing into the east side of the South Arm (BC) include the Goat River, Boulder Creek, Akokli Creek, Sanca Creek, Lockhart Creek, Grey Creek, and Crawford Creek, while Boundary, Corn, Summit, Next, Cultus, and Midge creeks flow into the west side of the lake (Fig. 8.1).

The focus of kokanee work in northern Idaho tributary streams flowing into the Kootenai/y River include: Boundary, Fisher, Smith, Parker, Long Canyon, Trout, and Myrtle creeks (Fig. 8.1).

\section{Methods}

\section{Kokanee Escapement Estimates}

South Arm streams located in BC were surveyed weekly from August 18, 2006 until September 19, 2006. Kokanee counts were conducted by an experienced fisheries technician who walked each stream and recorded daily counts for those sections of stream accessible to spawning kokanee. Frequency of stream counts increased during the first two weeks of September when peak spawning was anticipated.

In 2006 the Kootenai Tribe of Idaho (KTOI) staff conducted kokanee spawner surveys on six northern Idaho tributaries to the Kootenai/y River. The surveys were conducted from mid August to early October but frequency of surveys were reduced to five or less given the few fish observed in 2005.

\section{Kokanee Eyed-egg Plants}

Streams selected for eyed-egg plants were known to have historically supported spawning populations. Sites were chosen primarily based on accessibility and habitat stability. Site specific 
"redds" were developed based on likelihoods of adequate over-wintering water levels and velocities determined by experienced biologists and technicians.

Due to a shortfall in number of kokanee eggs collected from Meadow Creek during fall 2006 the number of eyed eggs available for planting in South Arm (BC) tributaries was quite limited. Redds were developed only in Summit and Boulder creeks on October 172006 and kokanee eyed-egg plants were conducted on October 21, 2006. A late fall freshet in Summit Creek after the egg plant places some doubt as to effectiveness of this particular plant. Five redds were developed at Boulder Creek while six redds were developed at Summit Creek.

In 2006 only three Northern Idaho tributaries were selected for egg plants owing to limited numbers available. Single sites in Fisher, Long Canyon and Trout creeks were selected for redd development and kokanee eyed-egg plants were conducted on October 25, 2006.

Prior to receiving eggs, redds were developed by excavating the stream substrate as deep as $0.5 \mathrm{~m}$ and $\sim .75 \mathrm{~m} \times 1.5 \mathrm{~m}$ in area. Size (area) of redds varied depending on ease of excavation. A $5 \mathrm{~cm}$ flexible PVC pipe was laid on the stream floor of the excavated area with one end at the downstream of the excavated area and the other end protruding out of the water upstream of the excavated area. The pipe was then held in place with nearby large rocks $(\sim 5-15 \mathrm{~cm})$. After securing the PVC pipe, smaller $(<3 \mathrm{~cm})$ screened gravels were then laid over the larger rocks and pipe to the level of the stream bed.

As in 2005 kokanee eggs from Meadow Creek were developed to the eyed stage at the Kootenay Trout Hatchery by the Freshwater Fisheries Society of BC, and were then transported to the redd sites for placement in October 2006. About 200,000 eggs were placed in redds in the BC streams while $<100,000$ were planted in the Idaho streams. This was done by pouring the eggs into the protruding pipe. As the pipe filled with eggs it was gradually pulled from the redd allowing the eggs to flow out the open end and disperse within the gravel. Occasionally eggs "leaked" out of the artificial redd and small gravel and fines were placed to hold the eggs in place.

\section{Kootenay Lake Kokanee In-lake Abundance}

In late June 2006 trawl and acoustic surveys were conducted to determine if fry were present in the South Arm prior to southward movement of Meadow Creek fry from the north end of the lake. The more conventional fall survey of the limnetic habitat in Kootenay Lake was conducted during September 2006 concurrent with the annual trawl survey. Both July and September acoustic surveys used a Simrad model EY200P scientific echosounder and each survey consisted of 18 transects evenly spaced from the north to the south end of Kootenay Lake following a standard survey design described by Sebastian et al. (1995). Details of methods and equipment are summarized in Andrusak et al. (2006).

Trawl gear consisted of a standard five by five meter beam trawl utilizing a $20 \mathrm{~m}$ long net of graduated mesh size (6 to $92 \mathrm{~mm}$ stretched), towed at $0.80-0.95 \mathrm{~m} \mathrm{~s}^{-1}$. The trawl net depth was estimated using cable length and angle and a Lowrance global positioning system (GPS) was used to estimate distances traveled for calculating sampled volumes. The July trawling was directed at the most concentrated part of the night-time fish layer in order to maximize the catch of age 0+ fish. A total of four trawls were done in the North Arm; two near Shutty Bench and two near 
Woodbury (Fig 1.1, Chapter 1). An additional 6 trawls were done in the South Arm; three at Rhino Point and three at Redmond Point. For the fall trawling, three standard stepped oblique trawls were conducted at each of the six standard trawl locations (for a total of 18 trawls) to ensure a representative sample was attained from all depths.

\section{Results}

\section{Kokanee Escapement Estimates}

Once again a number of streams tributary to the South Arm of Kootenay Lake were walked in an effort to determine numbers of kokanee spawners. Similar to recent years the surveys again confirmed virtually no returning kokanee spawners in 2006 (Table 8.1). The number of surveys leaves little doubt that if there were any spawners in these streams they would have been observed. Gray Creek in 2006 at least had a few spawners unlike in 2005 when no fish were observed. Select northern Idaho tributaries to the Kootenai/y River were surveyed by the KTOI survey crews for kokanee escapements in the fall of 2006. A total of five kokanee spawners were observed in Parker Creek in 2006 and six in Long Canyon Creek while the other streams yielded no returning kokanee (Table 8.1). It is reasonable to conclude that if kokanee spawners were present in any appreciable numbers they would have been observed.

Table 8.1. $\quad$ Peak counts of kokanee spawners during August to September 2006 stream surveys, South Arm (BC) of Kootenay Lake and tributaries to Kootenai River, Idaho.

\begin{tabular}{lcc}
\hline \multicolumn{1}{c}{ BC Streams } & Observations & Peak Count \\
\hline Crawford & 5 & $\mathbf{2 0 0 6}$ \\
Gray & 5 & 0 \\
Lafrance & 5 & 9 \\
Lockhart & 5 & 0 \\
Akokli (Goat) & 5 & 0 \\
Sanca & 5 & 2 \\
Boulder & 5 & 0 \\
Summit & 5 & 0 \\
Goat River & 5 & 1 \\
\hline \multicolumn{1}{c}{ Idaho Streams } & & 0 \\
\hline Boundary & 2 & 0 \\
Fisher & 2 & 0 \\
Long Canyon & 5 & 6 \\
Parker & 5 & 5 \\
Trout & 2 & 0 \\
Myrtle & 1 & 0 \\
\hline
\end{tabular}




\section{Kokanee Eyed-Egg Plants}

In October 2006, kokanee eyed-eggs were planted into only two South Arm (BC) tributary streams in anticipation of increased in-lake survivals as a result of nutrient addition. Lower spawner returns to Meadow Creek meant there were far fewer kokanee eggs available for planting in the South Arm streams as well as the northern Idaho streams. In BC, two streams, Summit and Boulder creeks, were each planted with 200,000 eyed-egg plants (Table 8.2). Three streams in Idaho - Long, Canyon, Fisher and Trout (north fork) creeks-were selected for egg plants. A total of only 150,000 eggs were planted in these three streams (Table 8.2).

Table 8.2. $\quad$ Development of redds and egg deposition for October 2006 kokanee eyed-egg plants in tributary streams, South Arm (BC) of Kootenay Lake and Kootenai River, Idaho .

\begin{tabular}{lcccc}
\hline \multicolumn{1}{c}{ BC Streams } & \# Sites & \# Redds & \#Eggs/Redd & $\sim$ Total \\
\hline Boulder Creek & 1 & 5 & $\sim 200,000$ & 200,000 \\
Summit Creek & 2 & 6 & $\sim 200,000$ & 200,000 \\
\hline \multicolumn{1}{c}{ Idaho Streams } & & & & \\
\hline Long Canyon Creek & 1 & 1 & 100,000 & 100,000 \\
\hline Fisher Creek & 1 & 1 & 25,000 & 25,000 \\
\hline Trout Creek (nf) & 1 & 1 & 25,000 & 25,000 \\
\hline
\end{tabular}

\section{Kootenay Lake Kokanee In-lake Abundance}

Hydroacoustic surveys conducted in the early summer and fall each year on Kootenay Lake provide estimates of total in-lake kokanee abundance. Trawl surveys were used to determine the species and age composition of the limnetic fish community. Kokanee abundance estimates and age 0 proportions were derived from acoustic data while abundance estimates of age 1, 2, and 3 fish typically relied on acoustic abundance and age proportions in the trawl. Estimates have been derived for both the South and the North Arm of Kootenay Lake. For the fall trawling, fish lengths were adjusted to October 1 to enable comparisons between years.

During the past three years acoustic surveys have been conducted in June in addition to the standard fall survey. The intent of the spring survey has been to ascertain if fry can be detected in the South Arm prior to the southward movement of North Arm origin kokanee. All three years of early season sampling indicated fry densities were very low throughout the South Arm compared with fry densities in the North Arm (Fig. 8.2). Slightly higher densities in 2004 and 2006 at the south end of the South Arm (i.e. Transect 18) (Fig 1.1, Chapter 1) likely indicates localized recruitment from the Kootenai River and tributaries. In 2004 the spring fry distribution ranged between 107-1346 fry ha ${ }^{-1}$ in the North Arm and 76-366 fry ha ${ }^{-1}$ the South Arm. In 2005 the fry distribution ranged between 89-4929 fryha $^{-1}$ in the North Arm and 55-83 fryha $^{-1}$ in the South Arm. In 2006 the fry distribution ranged between 193-1415 fryha ${ }^{-1}$ in the North Arm and 52-280 fry ha $^{-1}$ in the South Arm. 
During two of the three years, the fry densities evened out over the entire lake by the fall sampling time as is typical based on the last several years of fall sampling. The 2005 fall distributions showing low fish use in the South Arm were therefore quite unusual.

The fall 2006 survey results indicated total lake abundance of kokanee (all ages) within Kootenay Lake was 22.1 million (20.6-25.2 million) fish (Fig. 8.3). This estimate is higher than the previous two years but still lower than the 2001-2003 estimates that were $>24$ million. The trend in ages 1-3 abundance changed in 2006 with an increase observed for the first time since 2002. Fry abundance again increased for the second consecutive year (Fig. 8.4). South Arm kokanee densities in 2005 declined for the fourth consecutive year to 168 fish/ha compared to the North Arm at 747 fish ha $^{-1}$ (Fig. 8.5). As mentioned above, the 2005 distribution was very unusual since the vast majority of kokanee remained at the north end of the lake. i.e. in particular the fry did not move southward as in previous years and as noted by Thompson (1999). The 2006 distribution was more typical with a north arm density of 778 fish ha ${ }^{-1}$ while the South Arm densities increased to $\sim 423$ fish ha ${ }^{-1}$ (Fig. 8.5).

\section{Discussion}

The 2006 South Arm stream surveys and those conducted on Kootenai River tributaries in Idaho continue to show that virtually no kokanee spawn in any of these streams. The significant decline in kokanee numbers in the South Arm and Kootenai/y River tributary streams over the last three decades (Appendix 8.1) is believed to be due to the decline in lake productivity during that same period. Recent discussions with Idaho Fish and Game personnel indicate that hundreds of thousands of displaced kokanee from Libby Reservoir have been observed migrating upstream to spawn in the Kootenai River below the natural barrier downstream of Libby, Montana. These fish almost certainly reared in Kootenay Lake, quite possibly the majority in the South Arm where they competed directly with the few fish produced in South Arm streams. This strong "stock" of fish of Libby Reservoir origin and those from Meadow Creek and Lardeau River are all produced from productive spawning habitat. Most of the other South and North Arm tributaries do not have such productive spawning habitat. It is speculated that the "weak" stocks do not fare well in the lake compared to the "strong" stocks, especially when competition and predation are very high.

Historically, South and West Arm kokanee numbers have been dominated by the more abundant North Arm stock (Andrusak and Brown 1987). It is most likely that intra-specific competition between the dominant stock (North Arm) and subdominant (South Arm) stock played a role in phylogenetic differences of these two stocks of kokanee in Kootenay Lake over time (Vernon 1957). Today there are virtually no kokanee in South Arm streams, whereas North Arm kokanee numbers are near record levels returning to Meadow Creek and to a lesser extent to the Lardeau River (Figs. 8.6 and 8.7).

Because kokanee are considered the keystone species in Kootenay Lake, maintaining healthy populations of kokanee have a direct influence on many other species of fish, primarily piscivores (white sturgeon, burbot, bull trout, and rainbow trout). Increasing the lake's carry capacity through nutrient addition, considered a bottom up strategy, should be beneficial to most other fish species. A positive response to an increase in primary productivity due to nutrient addition is expected to ultimately impact higher trophic levels that will in turn exert a downward

Kootenay Lake Fertilization Experiment, Year 15 (North Arm) and Year 3 (South Arm) 220 
cascading effect within the system (Hyatt et al. 2004, Mazumder and Edmundson 2002, Perrin et al. 2006).

North Arm kokanee production was restored following construction of the Duncan Dam by means of a spawning channel at Meadow Creek constructed in 1967 (Redfish Consulting Ltd. 1999). North Arm fertilization commenced in 1992 after the lake underwent a major decline in productivity during the 1980s (Ashley 1997). Until 2004, no restoration efforts were attempted in the South Arm and consequently in-lake competition for food, particularly during the period of lower lake productivity (1980s), probably resulted in a disproportionate decline of South Arm stream spawners since egg-to-fry survival rates in the natural systems are far lower than in the spawning channel (Redfish Consulting Ltd. 1999). This theory is supported by Parkinson and Korman (1994) who used the Large Lakes Kokanee Model to show that most stream populations would eventually disappear in the face of competition from the more productive spawning channel stock. This imbalance was further exacerbated in 1992 with the fertilization experiment as nutrient addition provided further advantage to the more productive North Arm stock. North Arm fry numbers increased due to superior channel production and this combined with increased lake productivity (fertilization) resulted in a density dependent growth response in the mid 1990s that favoured the more productive Meadow Creek population. All of these factors combined have resulted in driving the natural stream populations to near extinction (Andrusak et al. 2004, 2006, Andrusak and Fleck 2007).

The survival of the remaining South Arm kokanee stock is highly doubtful as reflected in virtually no returns for several cycles. A lack of spawners has necessitated human intervention to “jump start” kokanee stocks through eyed-egg plants to tributary streams of the South Arm and Kootenai/y River in anticipation of a positive response to South Arm fertilization (Andrusak 2007). While results of eyed-egg plants are not expected to be reflected in kokanee spawners until 2007 in Idaho and 2009 in BC some rough estimates can be made to predict future escapements based on average survival rates (Table 8.4). It should be noted that spawning habitat is not considered a limiting factor for kokanee in the South Arm and Kootenai/y River tributaries.

The acoustic surveys conducted in June during the last three years indicate low densities of "South Arm" kokanee since most of the North Arm fry were present at the most northernly stations (peak fry migration at Meadow Creek is usually in late May-early June). Origin of the fry found in the South Arm early in the season is unknown. They could be entrained kokanee from the Libby Dam while some may be survivors from the 4.3 million eggs planted in BC and Idaho streams in 2005 (Table 8.2).

Although Kootenay Lake kokanee have experienced a positive response to fertilization of the North Arm, estimates of total in-lake abundance of kokanee (all ages) from fall acoustic surveys and trawl sampling indicate an unexpected decline to $<16$ million from 2004-2005 compared to $>24$ million from 2001-2003 (Fig. 8.3). The 2006 distribution of fry reverted back to a more even distribution throughout the lake from spring to fall after the unusual concentration recorded in 2005 (Fig. 8.2). It can only be speculated as to what factors have caused the decline in kokanee numbers in the last three years. Similar responses have been manifested in many sockeye salmon (Oncorhynchus nerka) populations in coastal British Columbia believed to be

Kootenay Lake Fertilization Experiment, Year 15 (North Arm) and Year 3 (South Arm) 221 
linked to the hypothesis of a delayed density-dependence mortality (or inter-cohort density dependence mortality) which were thought to drive cyclical patterns of dominance (Myers et al. 1997, Ricker 1997, Myers 2001). Various sources of delayed density-dependence mortality are what Levy and Wood (1992) referred to as "brood interactions" which cause survival of year class (es) that follow the most dominant line to be reduced. Proposed mechanisms for this reduction are competition, i.e., heavy predation on lake zooplankton by dominant year classes diminishes the food supply of successive broods; or predation, i.e., disease, parasites, or predators are built up by dominant year classes and inflict higher rates of mortality on the weak years (Myers et al. 1997). However they concluded that between-cohort interactions were not sufficient alone to cause the observed cycles in adult abundance. Interestingly, the 2004-2006 brood years follow three successive years of high fry production. Regardless, detecting intercohort density dependent mortality is difficult especially when time series data are relatively short.

Table 8.3. $\quad$ Predicted escapement levels to BC and Idaho streams resulting from eyed-egg plants 2003-2006. Biostandards of 25\% egg-to-fry survival rates and 5\% fry-to-adult survival rates were used.

\begin{tabular}{|c|c|c|c|c|c|}
\hline Streams & $\begin{array}{c}\text { Stocked } \\
\text { Year }\end{array}$ & \# Eyed Eggs & Fry@ 25\% & $\begin{array}{c}\text { Predicted } \\
\text { Adult Return } \\
\text { @ 5\% } \\
\text { Fry/Adult } \\
\end{array}$ & $\begin{array}{c}\text { Year Of } \\
\text { Return @ } \\
\text { Age 3+ } \\
\text { Spawners } \\
\end{array}$ \\
\hline Boulder Creek (BC) & 2005 & 300,000 & 75,000 & 3750 & 2009 \\
\hline Boulder Creek (BC) & 2006 & 200,000 & 50,000 & 2500 & 2010 \\
\hline Crawford Creek (BC) & 2005 & 200,000 & 50,000 & 2500 & 2009 \\
\hline Goat River (BC) & 2005 & $1,000,000$ & 25,000 & 1250 & 2009 \\
\hline Summit Creek (BC) & 2005 & 500,000 & 125,000 & 6250 & 2009 \\
\hline Summit Creek (BC) & 2006 & 200,000 & 25,000 & 1250 & 2009 \\
\hline Long Canyon Creek (ID) & 2006 & 100,000 & 25,000 & 1250 & 2010 \\
\hline \multirow[t]{3}{*}{ Long Canyon Creek (ID) } & 2003 & 125,000 & 31,250 & 1563 & 2007 \\
\hline & 2004 & 500,000 & 125,000 & 6250 & 2008 \\
\hline & 2005 & 420,000 & 105,000 & 5250 & 2009 \\
\hline \multirow[t]{3}{*}{ Parker Creek (ID) } & 2003 & 125,000 & 31,250 & 1563 & 2007 \\
\hline & 2004 & 500,000 & 125,000 & 6250 & 2008 \\
\hline & 2005 & 420,000 & 105,000 & 5250 & 2009 \\
\hline \multirow[t]{4}{*}{ Trout Creek (ID) } & 2003 & 125,000 & 31,250 & 1563 & 2007 \\
\hline & 2004 & 912,500 & 228,125 & 11406 & 2008 \\
\hline & 2005 & 620,000 & 155,000 & 7750 & 2009 \\
\hline & 2006 & 25,000 & 6,250 & 313 & 2010 \\
\hline \multirow[t]{3}{*}{ Myrtle Creek (ID) } & 2003 & 125,000 & 31,250 & 1563 & 2007 \\
\hline & 2004 & 587,500 & 146,875 & 7344 & 2008 \\
\hline & 2005 & 420,000 & 105,000 & 5250 & 2009 \\
\hline \multirow[t]{3}{*}{ Fisher Creek (ID) } & 2004 & 500,000 & 125,000 & 6250 & 2008 \\
\hline & 2005 & 420,000 & 105,000 & 5250 & 2009 \\
\hline & 2006 & 25,000 & 6,250 & 313 & 2010 \\
\hline
\end{tabular}


It should also be recognized that effects of kokanee abundance can be masked by interactions with Mysis relicta, which are considered competitors for selective zooplankton within Kootenay Lake. Mysis have the ability to significantly alter the zooplankton assemblages which have direct negative impacts to kokanee populations (Chipps and Bennett 2000). Moreover, the carry capacity for zooplanktivorous fish populations may decline as a result of the middle-out effects of mysids on lower and higher trophic levels (Almond et. al.1996). Caution should be exercised when trying to interpret complex interactions and their effects within Kootenay Lake.

In summary, the South Arm kokanee stocks are expected to have a positive response to the South Arm fertilization as the lake carry capacity is further restored. Increasing the egg-to-fry survival rates through eyed-egg plants and increased in-lake survivals of juvenile kokanee should assist the recovery of these stocks. Complex in-lake trophic interactions will ultimately balance the response kokanee will have to the South Arm fertilization experiment. Intensive escapement monitoring should continue to be used to evaluate the success of egg plants and provide valuable information on kokanee survival to assess the South Arm fertilization experiment.

\section{Recommendations}

1. Continued fertilization of the South Arm.

2. Eventual reduction of Meadow Creek fry production.

3. Increased stream production through eyed-egg plants, and/or,

4. South Arm stream restoration projects to increase stream productivity (i.e., egg-to-fry survival rates for kokanee).

\section{Acknowledgements}

The Kootenai Tribe of Idaho provided the financial support for this study and this assistance is much appreciated. The Fish and Wildlife Compensation Program - Columbia Basin provided the financial support for the North Arm Kootenay Lake project and the fall hydroacoustic surveys.

Sue Ireland from the Kootenai Tribe of Idaho has been the visionary working towards restoration of lower Kootenai/y River kokanee, as well as other fish species to their former abundance is she admired and respected- the author is grateful to be of assistance in her pursuit.

Assistance and advice from Eva Schindler of the Ministry of Environment in Nelson is acknowledged. In addition, George Scholten of the Ministry of Environment in Victoria is acknowledged for his tireless hours of collection and analysis of acoustic and trawl data. Les Fleck is thanked for collecting data on kokanee stream escapements on South Arm (BC) streams. Jeff Burrows Les Fleck and John Bell are acknowledged for their direction on the kokanee egg plants.

Marla Zarelli is thanked for her patience and assistance in report preparation.

Kootenay Lake Fertilization Experiment, Year 15 (North Arm) and Year 3 (South Arm) 
Thanks to the British Columbia Conservation Foundation for administering the Kootenai Tribe of Idaho funds for this report.

\section{References}

Acara, A.H. 1970. The Meadow Creek Spawning Channel. Unpublished MS Department of Recreation and Conservation, Fish and Wildlife Branch, Victoria, BC.

Almond, M.J.R., E. Bentaen and W.D. Taylor. 1996. Size Structure and Species Composition of Plankton Communities in Deep Ontario Lakes with and Without Mysis relicta and Planktivorous Fish. Canadian Journal of Fisheries and Aquatic Sciences 53:315-325.

Anders, P., H. Andrusak, K. Ashley and J. Hammond. 2004. Kokanee and Ecosystem Restoration in South Arm Kootenay Lake and the Arrow Lakes Reservoir, British Columbia. Pre-implementation Report and Work Plan-FY 2003. Contract report prepared for the Kootenai Tribe of Idaho.

Andrusak, G.F. 2007. Status of Kokanee in the South Arm of Kootenay Lake as a Result of Experimental Fertilization. 2005 Pages 215 - 235.In Schindler et al. Kootenay Lake Fertilization Experiment, Year 14 (North Arm) and Year 2 (South Arm) (2005) Report, Fisheries Project Report No. RD 122. Minsitry of Environment, Province of British Columbia.

Andrusak, H., and C. Brown. 1987. Kootenay Lake Fisheries Management Plan 1987-89. B.C. Ministry of Environment, 56 pp.

Andrusak, H., P. Slaney, and L. Fleck. 2004. Status of Kokanee in the South Arm of Kootenay Lake and Assessment of Select Tributary Streams with Restoration Potential for Spawning Kokanee and Rainbow Trout. Redfish Consulting Ltd. Contract Report for the Kootenai Tribe of Idaho, Bonners Ferry, Idaho.

Andrusak, H., D. Sebastian, G. Scholten, and P. Woodruff. 2006. Response of Kokanee and Gerrard Rainbow Trout to Experimental Fertilization of the North Arm of Kootenay Lake, 2002 and 2003 Pages 157 - 181. In Schindler et al. Kootenay Lake Fertilization Experiment, Years 11 and 12 (2002 and 2003), Fisheries Project Rerpot No. RD 114, Ministry of Environment, Province of British Columbia.

Andrusak, H., and L. Fleck. 2007. Status of Kokanee in the South Arm of Kootenay Lake prior to Experimental Fertilization 2004 Pages 251 - 272. In Schindler et al. Kootenay Lake Fertilization Experiment, Year 13 (North Arm) and Year 1 (South Arm) (2004) Report. Fisheries Project Report No. RD 117, Ministry of Environment, Province of British Columbia.

Ashley, Ken, Lisa C. Thompson, David C. Lasenby, Laurie McEachern, Karen E. Smokorowski and D. Sebastian. 1997. Restoration of an Interior Lake Ecosystem: the Kootenay Lake Fertilization Experiment. Water Qual. Res. J. Canada, 1997. Volume 32 No. 295-323. 
Ashley, K.I., L.C. Thompson, D. Sebastian, D.C. Lasenby, K.E. Smokorowski and H. Andrusak. 1999. Restoration of kokanee salmon in Kootenay Lake, a large intermontane lake, by controlled seasonal application of limiting nutrients. Pages 127 - 169. In T Murphy and M. Munawar, editors. Aquatic restoration in Canada. Backhuys, Leiden, Netherlands.

Carpenter, S.R., J.J. Cole, J.R. Hodson, J.F. Kitchell, M.L. Pace, D. Bade, K.I. Cottingham, T.E. Essington, J.N. Houser and D.E. Schindler. 2001. Trophic Cascades, Nutrients and Lake Productivity: Whole Lake Experiments. Ecol. Monogr. 71:163-186.

Chipps, S.R. and D.H. Bennett. 2000. Zooplanktivory and Nutrient Regeneration by Invertebrate (Mysis relicta) and Vertebrate (Oncorhynchus nerka) Planktivores: Implications for Trophic Interactions in Oligotrophic Lakes. Transactions of the American Fisheries Society 129:569-583.

Daley, R.J., E.C. Carmack, C.B.J. Gray, C.H. Pharo, S. Jasper, and R.C. Wiegand. 1981. The Effects of Upstream Impoundments on Kootenay Lake, BC Canada Inland Waters Directorate, Research Institute, Scientific Series, West Vancouver, British Columbia.

Hyatt, K.D., D.J. McQueen, K. S. Shortreed, and D. P. Rankin. 2004. Sockeye Salmon (Oncorhynchus nerka) Nursery Lake Fertilization: Review and Summary of Results. Environm. Rev. 12: 133-162 (2004)

Levy, D.A., and C.C. Wood. 1992. Review of Proposed Mechanisms for Sockeye Salmon Population Cycles in the Fraser River. Bull. Math. Biol. 54:241-261.

Mazumder, A. and J.A. Edmundson. 2002. Impact of fertilization and stocking on trophic interactions and growth of juvenile sockeye salmon (Onchorhynchus nerka). Can. J. Fish. Aquat. Sci. 59:1361-1373.

Myers, R.A, M. J. Bradford, J. M. Bridson, and G. Mertz. 1997. Estimating Delayed DensityDependent Mortality in Sockeye Salmon (Oncorhynchus nerka): A Meta-Analytic Approach. Can. J. Fish. Aquat. Sci. 54: 2449-2462 (1997)

Myers, R.A. 2001. Stock and Recruitment: Generalizations about Maximum Reproductive Rate, Density Dependence, and Variability Using Meta-Analytic Approaches. ICES Journal of Marine Science, 58: 937-951.

Northcote T. G. and H.W. Lorz. 1966. Seasonal and Diel Changes in Food of Adult Kokanee (Oncorhynchus nerka) in Nicola Lake, British Columbia. J. Fish. Res. Bd. Canada, 23(8): 1096-1106.

Northcote, T.G. 1973. Some Impacts of Man on Kootenay Lake and Its Salmonids. Great Lakes Fisheries Commission Tech. Rep. 25.

Northcote, T.G. 1991. Success, Problems and Control of Introduced Mysid Populations in Lake and Reservoirs. American Fisheries Society Symposium 9:5-16, 1991 
Parkinson, E. A. and J. Korman. 1994. Application of the Large Lakes Kokanee Model to Five Management Problems in British Columbia. BC Ministry of Environment, Lands and Parks. Fisheries Management Report No. 1031994.

Perrin, C., M. L. Rosenau, T. B. Stables, and K. Ashley. 2006. Restoration of a Montane Reservoir Fishery via Biomanipulation and Nutrient Addition. North American Journal of Fisheries Management.26:391-407, 2006.

Purcell Resources Inc. 2002. Reconnaissance (1:20,000) Fish and Fish Habitiat Inventory of Midge Creek. Contract report prepared for J.H. Huscroft Ltd. Creston, BC. In EcoCat: the Ecological Reports Catalogue, BC Ministry of Environment website.

Redfish Consulting Ltd. 1999. Performance Evaluation of Six Kokanee Spawning Channels in British Columbia. Unpubl. MS. Ministry of Fisheries, Province of British Columbia, Victoria, BC.

Ricker, W.E. 1997. Cycles of Abundance Among Fraser River Sockeye Salmon. Canadian Journal of Fisheries and Aquatic Sciences, 54: 950-968.

Sebastian, D., G. Scholten, D. Addison and D. Green. 1995. Results of the 1985-94 Acoustic and Trawl Surveys on Okanagan Lake, Unpubl. MS Stock Management Unit Report No. 2. Fisheries Branch, Ministry of Environment, Victoria, BC, 54 p.

Sebastian, D., H. Andrusak, G. Scholten, P. Woodruff and G.F. Andrusak. Response of kokanee to experimental fertilization of the North Arm of Kootenay Lake in 2005 Pages 179-214. In Schindler et al. Kootenay Lake Fertilization Experiment, Year 14 (North Arm) and Year 2 (South Arm) (2005) Fisheries Project Report No. Report, RD 122, Ministry of Environment, Province of British Columbia.

Thompson, L.C. 1999. Abundance and Production of Zooplankton and Kokanee Salmon (Oncorhynchus nerka) in Kootenay Lake, British Columbia during Artificial Fertilization. PHD Thesis University of British Columbia Vancouver BC. 252 p.

Vernon, E. H. 1957. Morphometric Comparison of Three Races of Kokanee (Oncorhynchus nerka) Within a Large British Columbia Lake. Journal of the Fisheries Research Board of Canada 27: 1239-1250.

Whall, J.D. and D. Lasenby. 1998. Comparison of the Trophic Role of the Freshwater Shrimp Mysis Relicta in Two Okanagan Valley Lakes, British Columbia. In:Ashley et. al. Okanagan Lake Action Plan Year 1 (1996-97) and Year 2 (1997-98) Report. Fisheries Project Report No. RD 73. British Columbia Ministry of Fisheries, Fisheries Management Branch. 


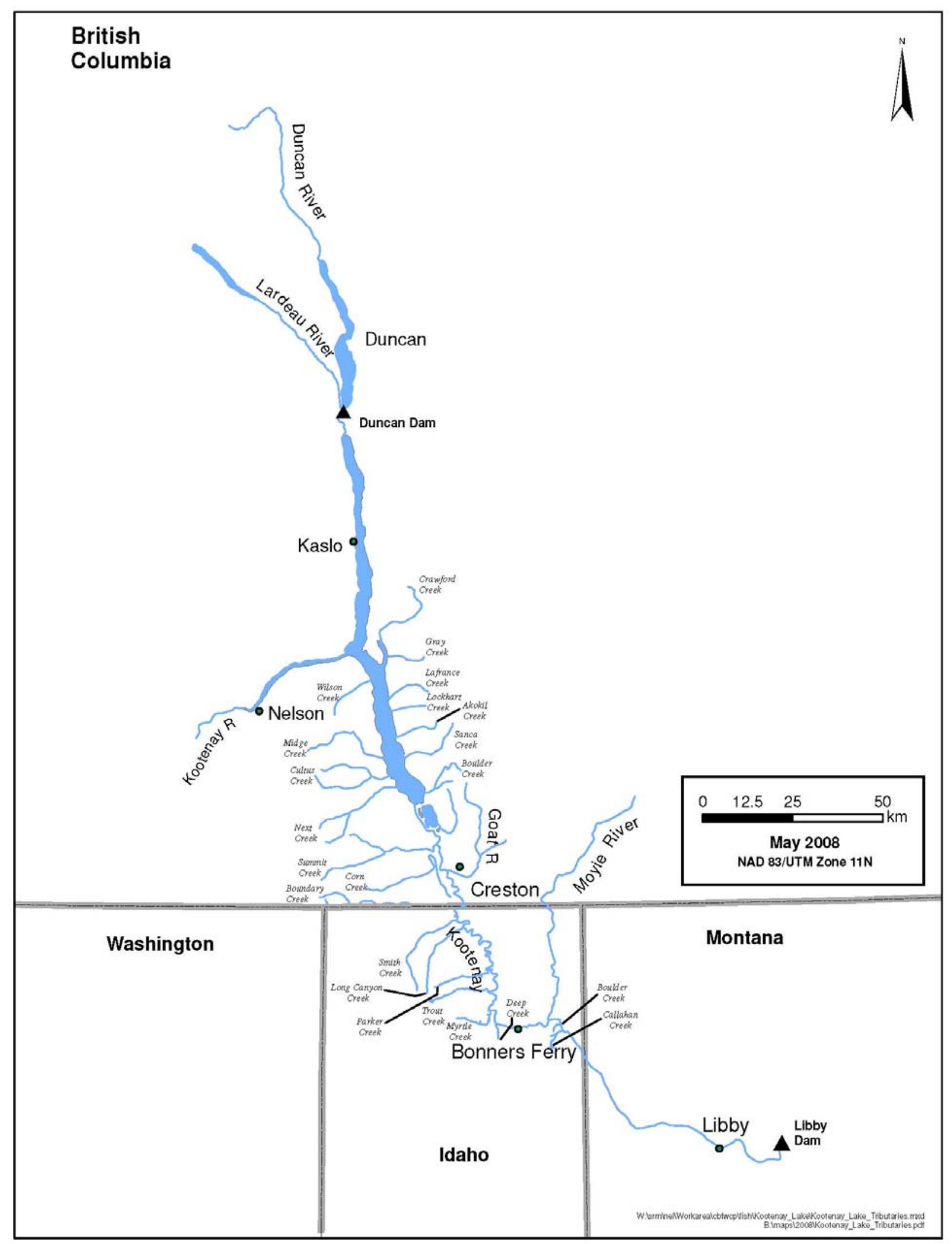

Figure 8.1. Kootenay Lake, Kootenai/y River and tributary streams.

Kootenay Lake Fertilization Experiment, Year 15 (North Arm) and Year 3 (South Arm) 

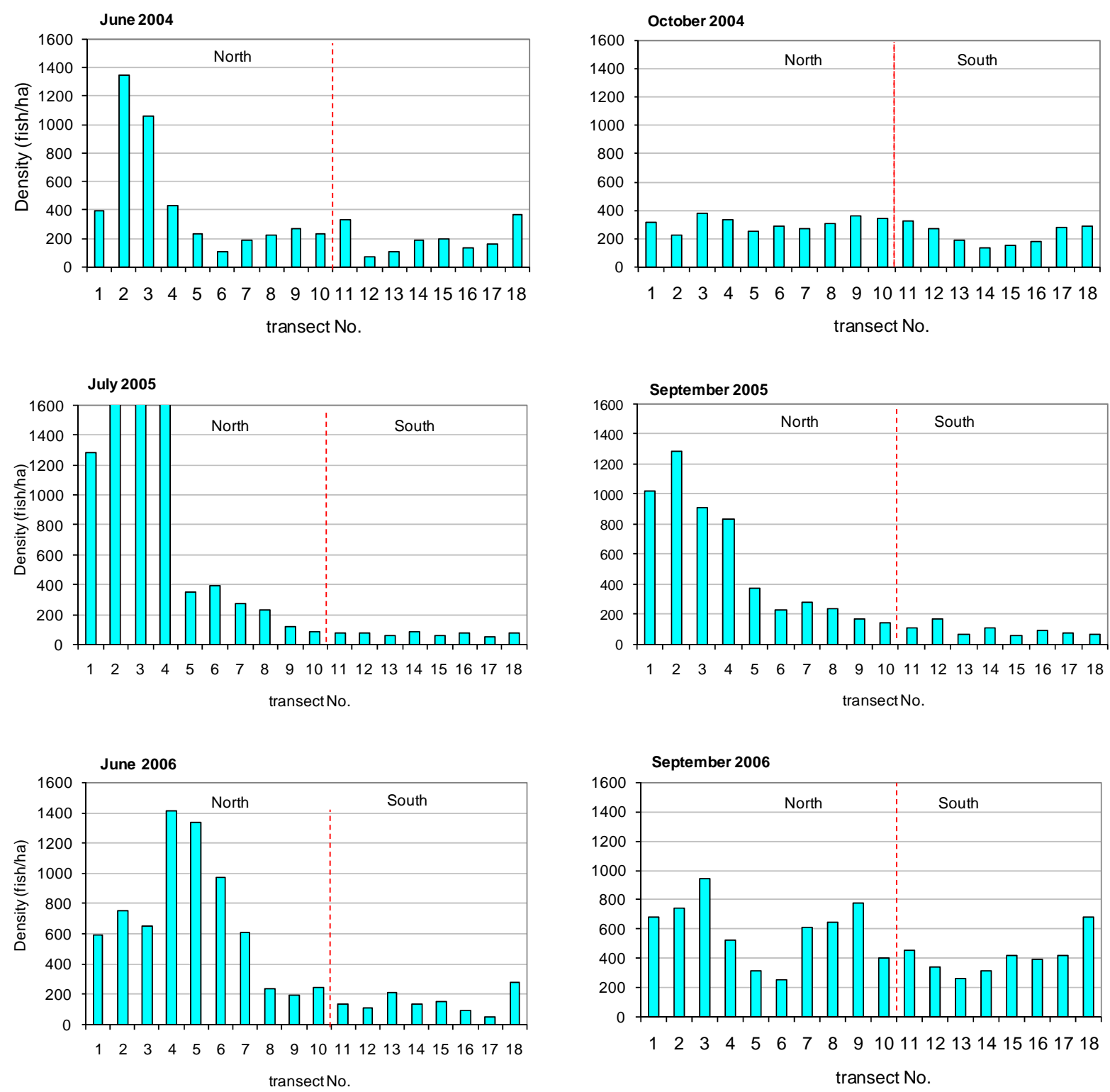

Figure 8.2. Longitudinal density distributions of age $0+$ kokanee in early summer and fall sampling in Kootneay Lake based on acoustic surveys in 2004-06.

Kootenay Lake Fertilization Experiment, Year 15 (North Arm) and Year 3 (South Arm) 


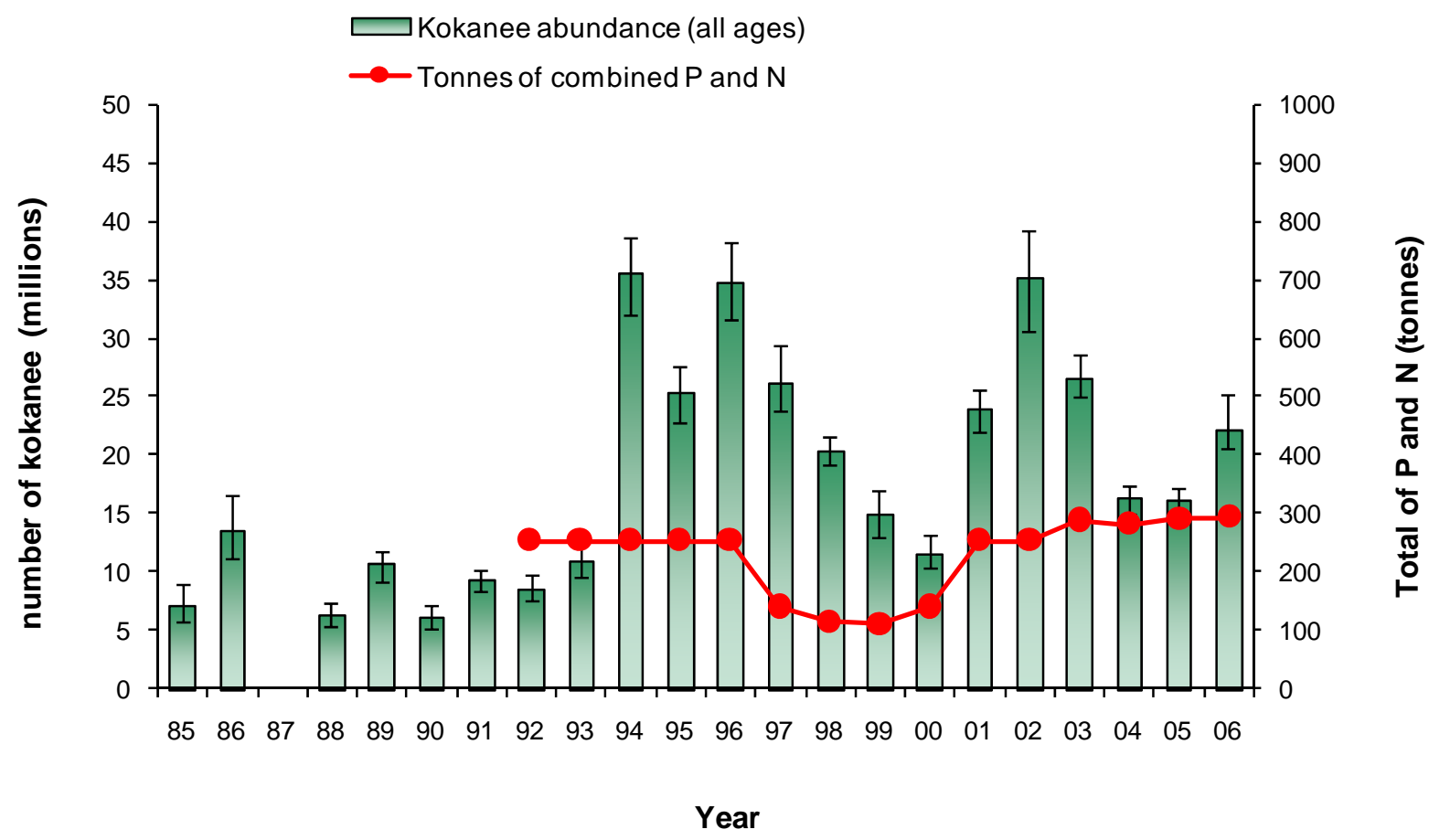

Figure 8.3. Response of fall in-lake kokanee population (all ages) to nutrient enrichment in the North Arm.

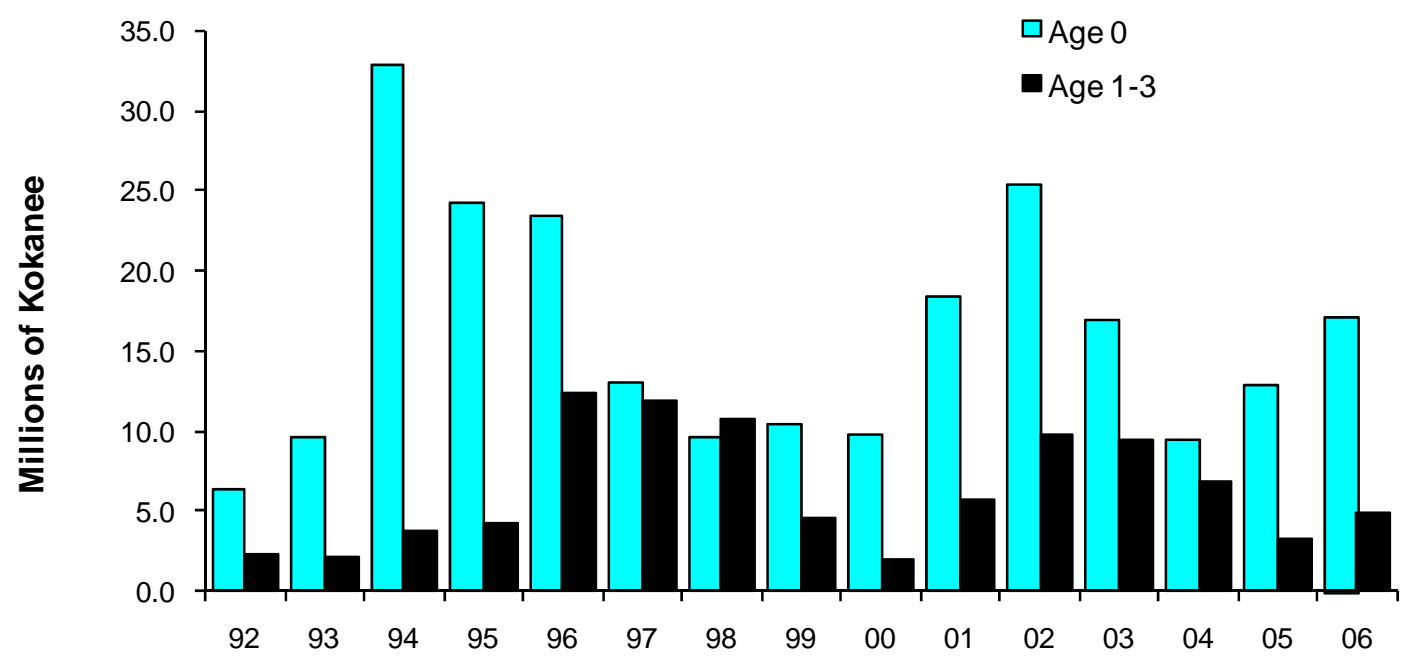

Fall Survey Year

Figure 8.4. Trends in fall kokanee abundance by age for Kootenay Lake, 1985-2006.

Kootenay Lake Fertilization Experiment, Year 15 (North Arm) and Year 3 (South Arm) 


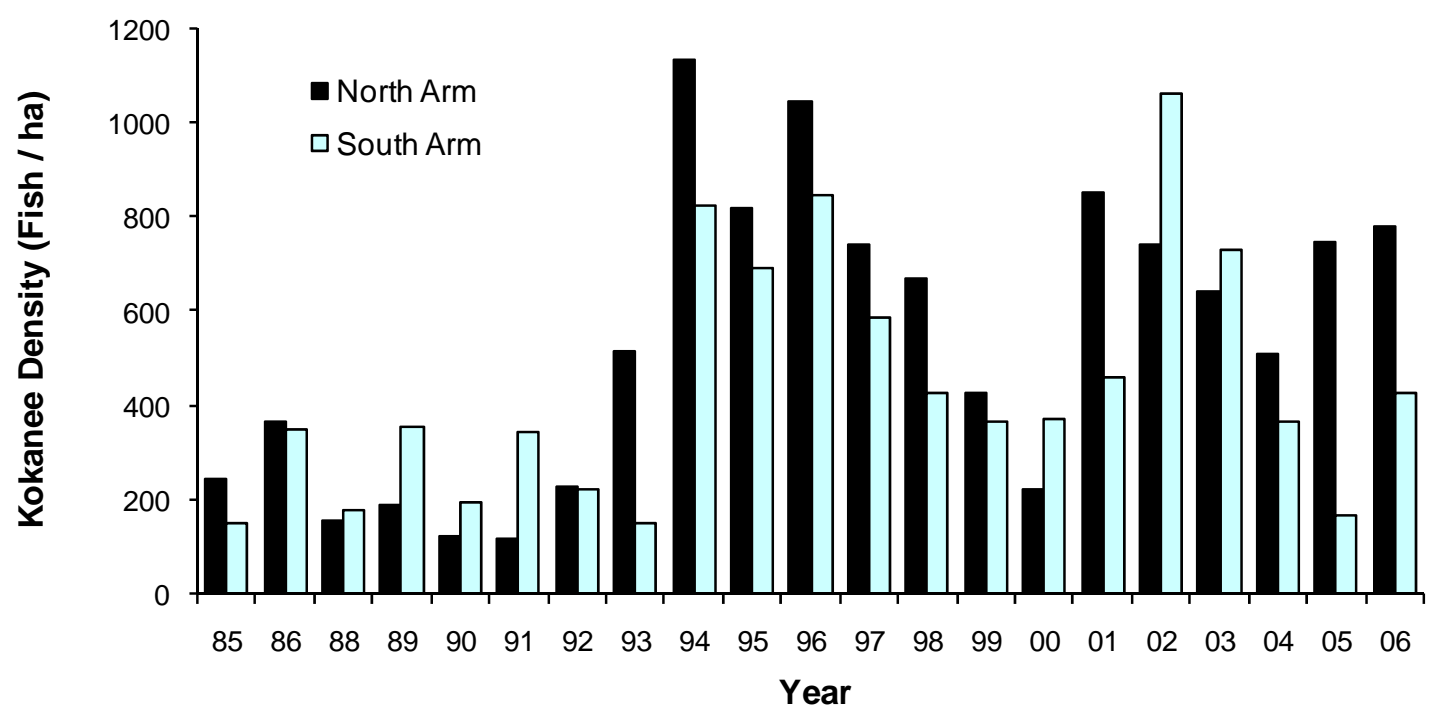

Figure 8.5. Comparison of kokanee density in North and South Arms of Kootenay Lake based on annual fall acoustic monitoring, 1985-2006. 


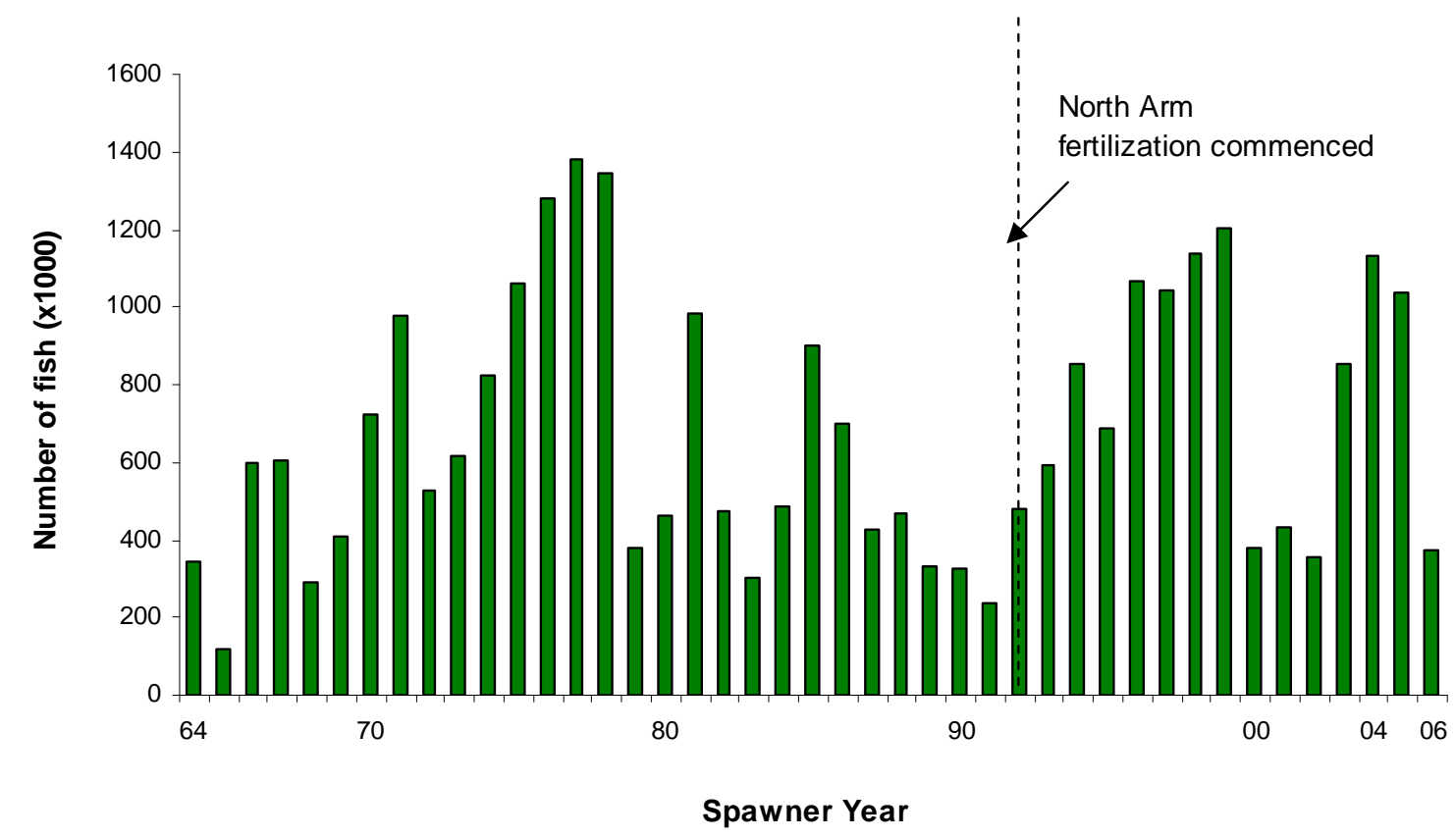

Figure 8.6. North Arm of Kootenay Lake kokanee escapements to Meadow Creek 1964-2006. Note: 1964-1968 data from Acara, unpublished MS.

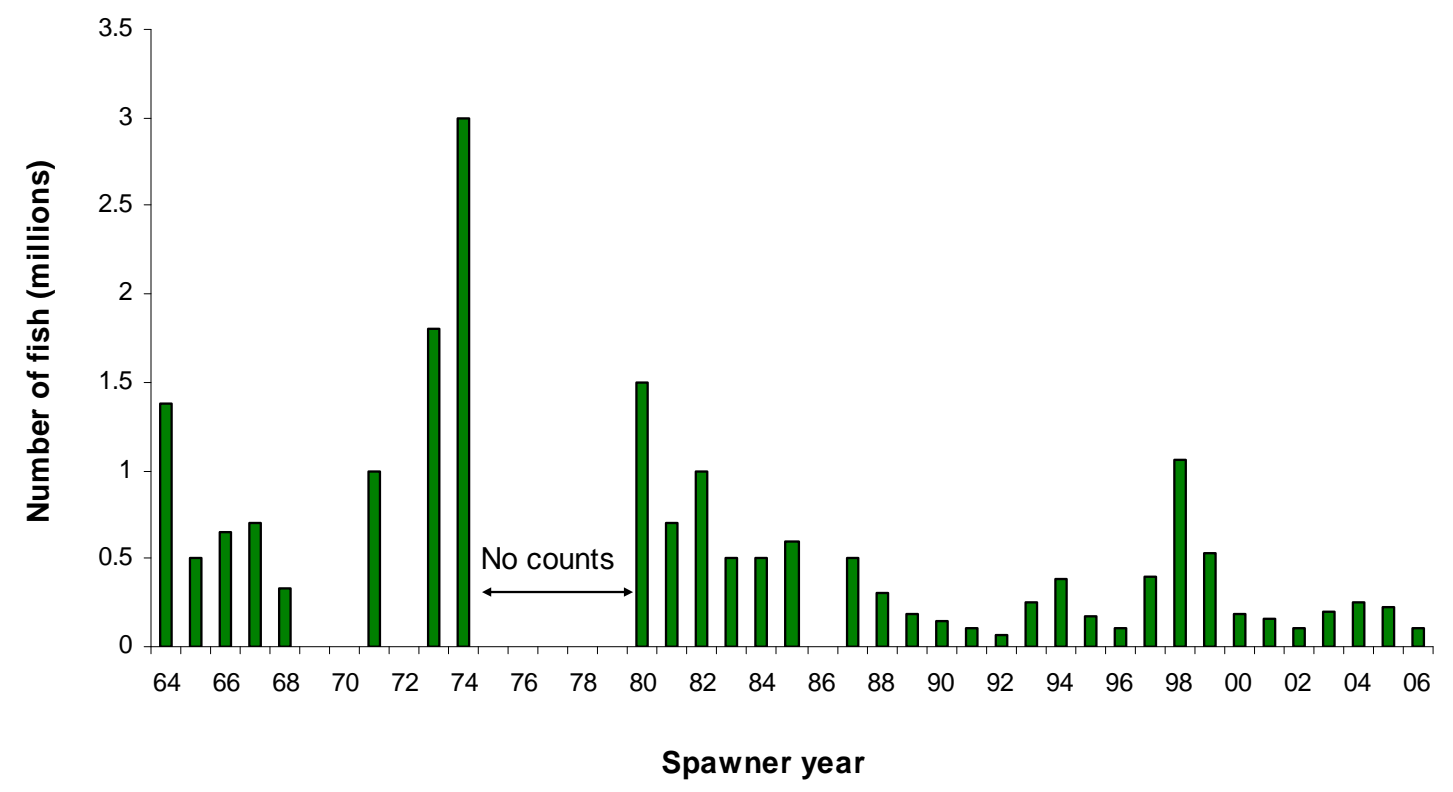

Figure 8.7. North Arm of Kootenay Lake kokanee escapements to Lardeau River 1964-2006. Note: 1964-1968 data from Acara, unpublished MS. 
APPENDIX 8.1 Kokanee counts to the South Arm of Kootenay Lake and lower Kootenai River in Northern Idaho.

\begin{tabular}{|c|c|c|c|c|c|c|c|c|c|c|c|c|c|c|c|}
\hline Stream & 1951 & 1952 & 1969 & 1970 & 1972 & 1973 & 1974 & 1975 & 1976 & 1978 & 1979 & 1980 & 1981 & 1986 & 1989 \\
\hline \multicolumn{16}{|l|}{ Crawford } \\
\hline Gray & & & & & & & & & & & & & & 204 & \\
\hline Lafrance & & & & & & & & & & & & & & 38 & \\
\hline Lockhart & & & & & & & & & & & & & & 128 & \\
\hline $\begin{array}{l}\text { Akokli } \\
\text { (Goat) }\end{array}$ & 354 & 172 & & & & & & & & & & & & 13 & \\
\hline Sanca & & & & & 650 & & & & & & & & & 40 & \\
\hline Boulder & & & & & 30 & & & & & & & & & 0 & \\
\hline \multicolumn{16}{|l|}{ Midge } \\
\hline Goat River & & & & & 17,500 & & & & & & & & & $3710^{\mathrm{a}}$ & \\
\hline Summit & & & 3,100 & 4,200 & 3,700 & 1,400 & 900 & 1,750 & 2,300 & 1,150 & 2,050 & 4,100 & $\mathrm{n} / \mathrm{a}$ & $2500^{\mathrm{b}}$ & 1,700 \\
\hline Corn & & & & & 0 & & & & & & & & & & \\
\hline \multicolumn{16}{|l|}{ Cultus } \\
\hline Boundary & 0 & & & & & & & & & & & 2,000 & 1,100 & & \\
\hline Smith & & & & & & & & & & & & 2,000 & 600 & & \\
\hline Long & & & & & & & & & & & & 2,000 & 1,600 & & \\
\hline \multicolumn{16}{|l|}{ Canyon } \\
\hline Parker & & & & & & & & & & & & 500 & 350 & & \\
\hline Trout & & & & & & & & & & & & 100 & 50 & & \\
\hline Myrtle & & & & & & & & & & & & 0 & 50 & & \\
\hline
\end{tabular}

Note: $\quad{ }^{\mathrm{a}}$ Corrected from Andrusak and Fleck 2007.

${ }^{\mathrm{b}}$ Corrected from Andrusak and Fleck 2007.

c Thirty-three adult kokanee were sampled in Midge Creek 2001 as part of a Fish Habitat Survey (Purcell Resource Inc. 2002). 
APPENDIX 8.1 continued.

\begin{tabular}{|c|c|c|c|c|c|c|c|c|c|c|c|c|c|c|c|c|c|}
\hline Stream & 1990 & 1991 & 1992 & 1993 & 1994 & 1995 & 1996 & 1997 & 1998 & 1999 & 2000 & 2001 & 2002 & 2003 & 2004 & 2005 & 2006 \\
\hline Crawford & & & & & 2 & 0 & 40 & 0 & 0 & 0 & 0 & 0 & 0 & 5 & 0 & 0 & 0 \\
\hline Gray & & & & & 0 & 0 & 30 & 100 & 5 & 20 & 2 & 8 & 10 & 35 & 8 & 0 & 9 \\
\hline Lafrance & & & & & 0 & 0 & 20 & 3 & 0 & 2 & 0 & 0 & 0 & 0 & 0 & 0 & 0 \\
\hline Lockhart & & & & & 0 & 0 & 20 & 1 & 0 & 0 & 0 & 0 & 0 & 0 & 0 & 0 & 0 \\
\hline $\begin{array}{l}\text { Akokli } \\
\text { (Goat) }\end{array}$ & & & & & 100 & 0 & 200 & 150 & 50 & 20 & 20 & 6 & 5 & 151 & 8 & 1 & 2 \\
\hline Sanca & & & 6 & & 4 & 0 & 0 & 7 & 2 & 2 & 0 & 0 & 0 & 5 & 0 & 0 & 0 \\
\hline Boulder & & & 3 & & 0 & 0 & 0 & 0 & 0 & 0 & 1 & 0 & 0 & 0 & 0 & 0 & 0 \\
\hline Midge & & & & & 0 & 0 & 50 & 0 & 5 & 0 & & $33^{c}$ & & 0 & 0 & ns & ns \\
\hline $\begin{array}{l}\text { Goat } \\
\text { River }\end{array}$ & & & 20 & & 0 & 0 & 4 & 0 & 2 & 0 & 0 & 0 & 0 & 2 & 0 & 0 & 0 \\
\hline Summit & 0 & 0 & 30 & & 0 & 0 & 0 & 0 & 0 & 0 & 0 & 0 & 0 & 1 & 0 & 0 & 1 \\
\hline Corn & & & & & & 0 & & & & & & & & & 0 & ns & ns \\
\hline Cultus & & & & & 0 & 0 & 50 & & & & & & & & 0 & ns & ns \\
\hline Boundary & & & & 0 & & & 0 & 0 & 8 & 38 & 15 & 31 & 0 & 0 & 9 & 0 & 0 \\
\hline Smith & & & & & & & 0 & 0 & 0 & 0 & ns & ns & 30 & ns & 0 & 0 & ns \\
\hline $\begin{array}{l}\text { Long } \\
\text { Canyon }\end{array}$ & & & & 17 & & & 0 & 3 & 0 & 0 & 30 & 25 & ns & 40 & 11 & 0 & 6 \\
\hline Parker & & & & 47 & & & 0 & 0 & 0 & 0 & 7 & 0 & 30 & 55 & 1 & 3 & 5 \\
\hline Trout & & & & 0 & & & 0 & 0 & 0 & 0 & 0 & 7 & 0 & 0 & 5 & 0 & 0 \\
\hline Myrtle & & & & 0 & & & & ns & ns & ns & ns & ns & ns & 0 & 0 & 0 & 0 \\
\hline
\end{tabular}

Kootenay Lake Fertilization Experiment, Year 15 (North Arm) and Year 3 (South Arm)

(2006) Report 